Portland State University

PDXScholar

\title{
An Historical Perspective of Oregon's and Portland's Political and Social Atmosphere in Relation to the Legal Justice System as it Pertained to Minorities: With Specific Reference to State Laws, City Ordinances, and Arrest and Court Records During the Period -- 1840-1895
}

Clarinèr Freeman Boston

Portland State University

Follow this and additional works at: https://pdxscholar.library.pdx.edu/open_access_etds

Part of the Criminology and Criminal Justice Commons, and the Public Administration Commons Let us know how access to this document benefits you.

Recommended Citation

Boston, Clarinèr Freeman, "An Historical Perspective of Oregon's and Portland's Political and Social Atmosphere in Relation to the Legal Justice System as it Pertained to Minorities: With Specific Reference to State Laws, City Ordinances, and Arrest and Court Records During the Period -- 1840-1895" (1997). Dissertations and Theses. Paper 4992.

https://doi.org/10.15760/etd.6868

This Thesis is brought to you for free and open access. It has been accepted for inclusion in Dissertations and Theses by an authorized administrator of PDXScholar. Please contact us if we can make this document more accessible: pdxscholar@pdx.edu. 


\section{THESIS APPROVAL}

The abstract and thesis of Clarinèr Freeman Boston for the Master of Science in Administration of Justice were presented March 14, 1997, and accepted by the thesis committee and the department.

COMMITTEE APPROVAL:
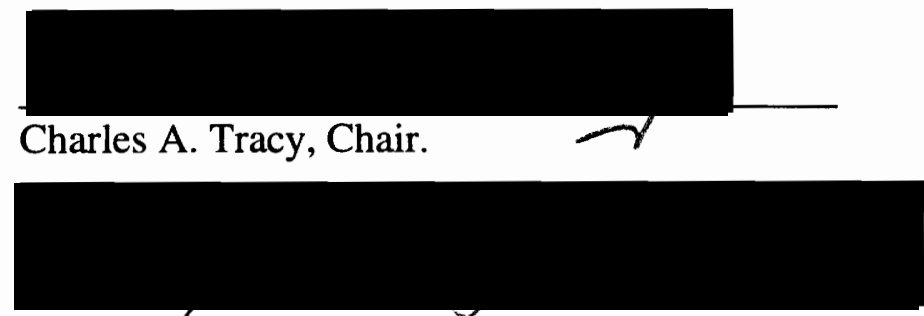

Robert W. Lockwood

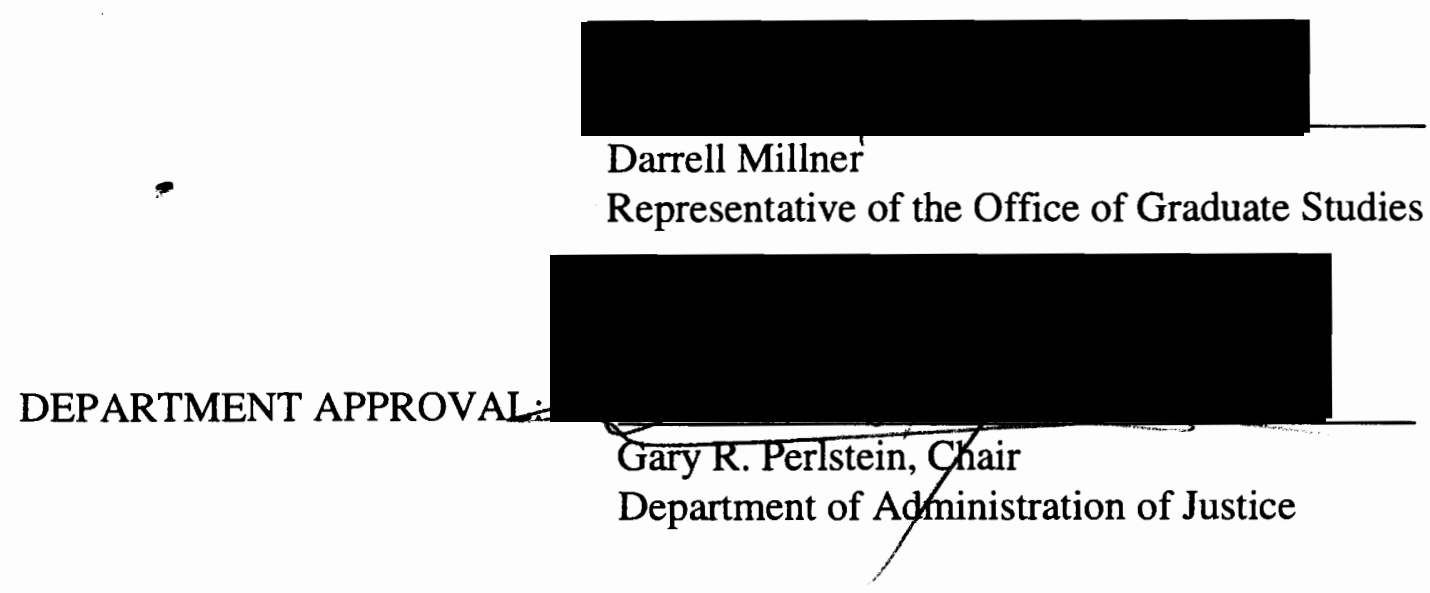

$* * * * * * * * * * * * * * * * * * * * * * * * * * * * * * * * * * * * * * * * * * * * * * * * * * * * * * * * * * * * * * * * * * *$

ACCEPTED FOR PORTLAND STATE UNIVERSITY BY THE LIBRARY

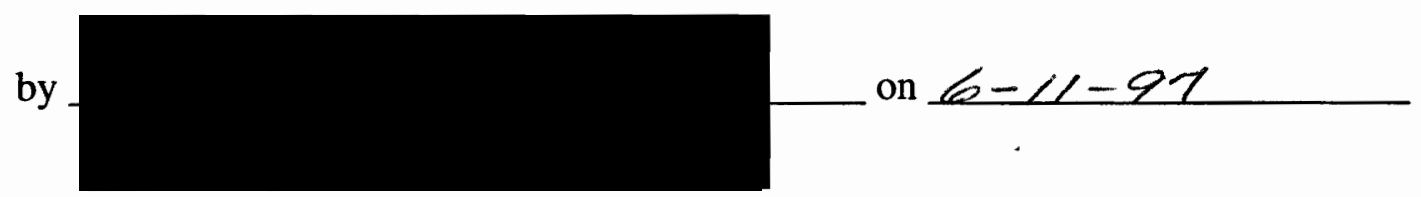




\begin{abstract}
An abstract of the thesis of Clarinèr Freeman Boston for the Master of Science in Administration of Justice, presented March 14, 1997.

Title: An Historical Perspective of Oregon's and Portland's Political and Social Atmosphere in Relation to the Legal Justice System as it Pertained to Minorities: With Specific Reference to State Laws, City Ordinances, and Arrest and Court Records During the Period-1840-1895.
\end{abstract}

Racial and ethnic minorities are disproportionately represented in Portland, Oregon's criminal justice system. Laws, legal procedures and practices that excessively target minorities are not new phenomena. This study focused on a history of political and social conditions in Oregon, and subsequently, Portland, from the 1840 's to 1895 , that created unjust state laws and city ordinances that adversely impacted Native Americans, African Americans, and Chinese Immigrants. Attention was also given to the Jewish population.

The approach was to examine available arrest and court records from Oregon's and Portland's early beginnings to ascertain what qualitative information records could provide regarding the treatment of minorities by the justice system. As an outgrowth of this observation, it was necessary to obtain an understanding of the legal environment related to arrests and dispositions of adjudications. Finally, a 
review of the political and social atmosphere during the time period provided a look at the framework that shaped public attitudes and civic actions.

Examination of available arrest records and court records recorded during the period were conducted at the City of Portland's Stanley Paar Archives. Observations were limited to the availability of archive records. Oregon's history, relative legislation, Portland's history and applicable ordinances were studied and extrapolated from valid secondary resources. Political and social conditions were reviewed through newspaper accounts during recorded history from that time period.

Research indicated that Native Americans, African Americans and Chinese Immigrants were: not legally afforded equal access to Oregon land provisions; denied equitable treatment under the law in comparison to their white counterparts; were unjustly targeted for criminal activities by the enactment and enforcement of laws based on racist views; and, negatively used as political ploys to the advantage of candidates seeking public office. Much of this research is akin to actions in many political, legal and justice arenas of the 1990's, that continue to adversely impact racial/ethnic minorities unfairly. Although members of the Jewish community were not negatively affected by law, they suffered social injustices. However, they were members of the legal and political fiber that shaped civic sentiments and legislative action in both positive and negative ways. 
AN HISTORICAL PERSPECTIVE OF OREGON'S AND PORTLAND'S POLITICAL AND SOCIAL ATMOSPHERE IN RELATION TO THE LEGAL JUSTICE SYSTEM AS IT PERTAINED TO MINORITIES: WITH SPECIFIC REFERENCE TO STATE LAWS, CITY ORDINANCES, AND ARREST AND COURT RECORDS DURING THE PERIOD-1840-1895.

\section{BY}

CLARINÈR FREEMAN BOSTON

A thesis submitted in partial fulfillment of the requirements for the degree of

MASTER OF SCIENCE

in

ADMINISTRATION OF JUSTICE

Portland State University

1997 


\section{ACKNOWLEDGEMENTS}

I would like to thank my family for their loyal support. I especially want to acknowledge my husband, Louie, for his personal effort and devoted assistance in helping me to complete this work. I must thank my daughter Cyreena, who had to endure my repeated absences from home during prolonged periods of research and writing. I want to thank Alvenice for keeping me on tract and Willa, who took the time to edit this text, and both together with Dorothy, for being a trusting sounding board.

My thanks also to my committee for their encouragement and patience during the lengthy effort of completing this work. My thanks to the staff at the City of Portland Stanley Paar Archives who endured my nine month stay and for allowing me to be part of their team. And finally, to all my relatives and friends who were continuous advocates of this effort, thank you.

To Louis Boston, Louis Boston II, Lowell and Linda Boston, Lyle Boston, and Cyreena Boston, my family and cheering gallery. 


\section{TABLE OF CONTENTS}

THESIS APPROVAL

ABSTRACT

TITLE PAGE

ACKNOWLEDGMENTS i

TABLE OF APPENDICES iv

INTRODUCTION

RESEARCH METHODOLOGY 12

CHAPTER I OREGON HISTORY - AN OVERVIEW 28

Acts of Congress Relating To Public Lands In Oregon $1859 \quad 28$

Articles of Compact - $1789 \quad 42$

Slavery Exclusionary Act - 1844

Oregon Provisional Government - Organic Law - 1845

Act to Establish Oregon Territorial Government - 1848

CHAPTER II PORTLAND HISTORY - AN OVERVIEW 57

City of Portland - Mayors $\quad 60$

City of Portland Officials

CHAPTER III OREGON, MULTNOMAH COUNTY

AND CITY OF PORTLAND -

HISTORY OF JUSTICE SYSTEMS

Provisional Government - Supreme Court $\quad 75$

Territorial Government - Supreme Court 76

Oregon Court Systems $\quad 77$

Multnomah County Courts $\quad 79$

$\begin{array}{lr}\text { Portland City Recorder } & 81\end{array}$

$\begin{array}{ll}\text { Portland City Attorney } & 81\end{array}$

Portland Police Judge - $\quad 82$

Qualifications, Duties \& Responsibilities $\quad 83$

Portland Justices of the Peace and Precincts $\quad 87$

Portland Police $\quad 90$ 
TABLE OF CONTENTS

CONT.

CHAPTER IV PORTLAND NATIVE AMERICANS

CHAPTER V NATIVE AMERICANS

PORTLAND ARREST RECORDS

112

CHAPTER VI NATIVE AMERICANS

STATE OF OREGON \&

CITY OF PORTLAND

COURT RECORDS

CHAPTER VII PORTLAND AFRICAN AMERICANS

183

CHAPTER VIII AFRICAN AMERICANS

204

PORTLAND ARREST RECORDS

CHAPTER IX AFRICAN AMERICANS

STATE OF OREGON \&

CITY OF PORTLAND

COURT RECORDS

CHAPTER X PORTLAND CHINESE IMMIGRANTS

228

CHAPTER XI CHINESE IMMIGRANTS

PORTLAND ARREST RECORDS

252

CHAPTER XII CHINESE IMMIGRANTS

STATE OF OREGON \&

CITY OF PORTLAND

COURT RECORDS

CHAPTER XIII PORTLAND JEWS

SUMMARY

BIBLIOGRAPHY 


\title{
APPENDICES
}

The following APPENDICES may be reviewed at the Administration of Justice Department, Portland State University, Portland, Oregon.

\author{
APPENDICES VIII - XII (arrest records), \\ APPENDICES XIII - XXI, (court records),
} APPENDIX XXII (State of Oregon - Legislation Germane To The Justice System in the Application of Oregon Law and Identified Inequitable Laws Contained in the Constitution of the State of Oregon 1843-1872, and

\author{
APPENDIX XXIII, City of Portland, General Ordinances Adversely \\ Affecting Minorities, Ordinances Pertaining to Criminal Violations, and \\ Ordinances Outlining the General Duties and Responsibilities of Justice \\ Officials 1854-1886,
}

Copies of APPENDICES, including any portion thereof, may be obtained through arrangements with the Department. 
OREGON SUPREME COURT TASK FORCE:

SUMMARY RESEARCH \& FINDINGS

APPENDIX II

ARTICLES IN OREGON NEWSPAPERS CITING

CRIMINAL, CIVIL RIGHTS VIOLATIONS AND

OTHER ARTICLES OF INTEREST INVOLVING

AFRICAN AMERICAN

APPENDIX III

OREGON, PORTLAND AND COUNTY

POPULATIONS-1850'S-1890'S

APPENDIX IV

CHARACTERISTICS OF PERSONS

ARRESTED BY YEAR-1868-1885

APPENDIX V

CITY DIRECTORY - NAMES, ETHNIC

DERIVATIONS, AND VOCATIONS OF

THE MINORITY RESIDENTS OF PORTLAND

IN 1870 AND 1872, INCLUDING WHITE CITY

OFFICIALS, ATTORNEYS AND THE CLERGY

APPENDIX VI

PORTLAND JEWISH RESIDENTS STARTING

IN 1854

APPENDIX VII

REPLICATED ARREST RECORDS

CITY OF PORTLAND \& STATE OF OREGON

FELONIES \& MISDEMEANORS

NOVEMBER 1870 - JANUARY 1875

APPENDIX VIII

CITY OF PORTLAND

FELONIES \& MISDEMEANORS

JANUARY 1875 - MARCH 1878

APPENDIX IX

CITY OF PORTLAND \& STATE OF OREGON

FELONIES \& MISDEMEANORS

APRIL 1878 - NOVEMBER 1879

APPENDIX $\mathrm{X}$ 
TABLE OF APPENDICES

CONT.

\section{REPLICATED ARREST RECORDS cont.}

CITY OF PORTLAND \& STATE OF OREGON

FELONIES \& MISDEMEANORS

DECEMBER 1879 - MARCH 1880

APPENDIX XI

CITY OF PORTLAND

FELONIES \& MISDEMEANORS

MAY 1894 - APRIL 1895

APPENDIX XII

REPLICATED COURT RECORDS STATE OF OREGON

STATE OF OREGON - COURT RECORDS

JUNE 1867-JULY 1868

APPENDIX XIII

STATE OF OREGON - COURT RECORDS

AUGUST 1868-JULY 1870

APPENDIX XIV

STATE OF OREGON - COURT RECORDS

DECEMBER 1874-MARCH 1880

APPENDIX XV

REPLICATED COURT RECORDS

CITY OF PORTLAND

CITY OF PORTLAND - COURT RECORDS

JUNE 1867-AUGUST 1870

APPENDIX XVI

CITY OF PORTLAND - COURT RECORDS

AUGUST 1870-JULY 1871

APPENDIX XVII

CITY OF PORTLAND - COURT RECORDS

JULY 1871-OCTOBER 1873

APPENDIX XVIII

CITY OF PORTLAND - COURT RECORDS

NOVEMBER 1873-JUNE 1877

APPENDIX XIX 
TABLE OF APPENDICES CONT.

REPLICATED COURT RECORDS

CITY OF PORTLAND

CITY OF PORTLAND - COURT RECORDS

AUGUST 1879-AUGUST 1881

APPENDIX XX

CITY OF PORTLAND - COURT RECORDS

SEPTEMBER 1881-AUGUST 1882

APPENDIX XXI

OREGON CONSTITUTION

1843-1872

STATE OF OREGON LEGISLATION

GERMANE TO THE JUSTICE SYSTEM

IN THE APPLICATION OF OREGON LAW

AND IDENTIFIED INEQUITABLE LAWS

CONTAINED IN THE CONSTITUTION

OF THE STATE OF OREGON 1843-1872

APPENDIX XXII

CITY OF PORTLAND ORDINANCES

1854-1886

CITY OF PORTLAND

GENERAL ORDINANCES ADVERSELY

AFFECTING MINORITIES, ORDINANCES

PERTAINING TO CRIMINAL VIOLATIONS,

AND ORDINANCES OUTLINING THE

GENERAL DUTIES AND RESPONSIBILITIES

OF JUSTICE OFFICIALS

1854-1886

APPENDIX XXIII 


\section{INTRODUCTION}

This study provides evidence that both the legal and justice systems of Oregon and Portland were political ploys manipulated by those in power. As such, the power monopolizers controlled and brought about changes that adversely impacted the powerless by rendering them inequitable legal treatment, disproportionate targeting practices and social and legal victimization. Such actions lead to catastrophic conditions among and within racial and ethnic minority groups.

Oscar Handlin, in his book, Race and Nationality in American Life, cites this abuse as being worldwide. Handlin stated that a tragic succession of horrors challenge the assumption, upon which modern civilization rests, that personal dignity was inherent in the condition of human beings (Handlin, p. ix). He referred to the Turks in Smyrna in 1922, the Soviet Union's extermination of millions in the Ukraine in the 1930's and the Nazis' annihilation of hundreds of thousands of Jews during the 1940's. Handlin published his book in 1957. The 1950's was not a decade recognized as a time in history in which most scholars were politically astute about other holocausts. If scholars were cognizant of such heinous crimes, the vast majority apparently chose to remain silent.

Handlin failed to mention the destruction of established Mexican societies that thrived on the very land on which much of the United States is built. Land that white men took for their own and in so doing wiped out not only the lives of hundreds of thousands of American natives but also much of their culture and 
heritage. He also did not include the illegal imprisonment of Japanese during World War II, or the abuse and misuse of Chinese in the early and later development of this country.

While Handlin did not specifically recount these historical developments, he did share that the horror beyond the human tragedy was that the men who led these holocausts ...were moved by ideas, preconceptions and emotions that negated the oneness of humankind and affirmed the ineradicable differences among peoples. He stated that we have ...accumulated such information concerning the nature and effect of the various divisive doctrines that have attempted to create different categories of men. Handlin assumed that we, thought to be a nation of civilized people, learned about the role of hatred in these brutal assaults upon our common heritage and benefited.

Handlin's book is a discussion regarding the plight of Negroes (the popular label during his research) in the United States. In this regard he wrote,

...the condition of the Negro, who, in American society, has been the most notable victim of racism. His degradation was clearly connected with his exploitation, although his exploitation did not altogether explain his degradation. The history of his settlement in America and the popular conceptions of his character may throw light on the judgments made by his race (Handlin, p. X). 
Handlin also stated that,

Serious students have approached the subject (racism) as a system by three different avenues. Some have treated racism as a system of ideas, and have tried to discover the origin and ...trace the formal development of such ideas in diverse times and place. Other scholars have taken as their point of departure an analysis of the types of personality susceptible to racist influences...Still a third group of investigators concentrates upon the nature of the background against which prejudice develops and seeks causes of prejudice in the structure of society (Handlin, pp. ix-x).

Finally, Handlin concluded,

It may be that the emotions which found one form of expression in race hatred are susceptible, under other conditions, of finding more positive and more creative forms. The indications in our past of the means of channeling these sentiments in constructive directions may have critical implications for the problems of the future (Handlin, p. xi).

The results of the study conducted by the Oregon Supreme Court Task Force, ${ }^{1}$ regarding racial and ethnic issues in the judicial system; special reports regarding the disproportionate number of minorities involved in the criminal legal system (see APPENDIX II) and the report from the Oregon Department of Corrections - Racial Disparities Studies ${ }^{2}$ acknowledging the need to investigate minority treatment by the system prompted my research into Portland's justice system. The intent was to examine Portland's early lawful treatment of minorities as one means of determining the origins of an unjust legal system.

It was not only the system of formal justice that required examination but systems, legal, political and social, that patronized the demise of civil rights for

1 Report of the Oregon Supreme Court Task Force on Racial/Ethnic Issues in the Judicial System, (May 1994), Office of the State Court Administrator, Oregon Judicial Department, Office of the Secretary of State, Archives Division, Territorial Document \#3666, pp. 181-182. See APPENDIX II.

2 Ireson, Randall, Ph.D., (February 1994), Racial Disparities In Parole Revocation: Identifying Patterns and Possible Causes, Oregon Department of Corrections - Planning and Development - Research and Evaluation Unit, Salem Oregon. 
minorities. Professionals on both sides of the judicial bench, such as police, lawyers, social workers, probation and parole officers, judges and correctional officers have each under separate report, acknowledged the failure of most public systems to deal with minorities, male and female, with justice.

For law and practice in the seventeenth century comprehended other forms of involuntary bondage. The essential attributes of villenage were fastened on many men not through heredity and ancient custom, as in the case of the vellein, but through poverty, crime, or mischance. Debtor in cases "where there was not sufficient distress of goods," could be "sold at an outcry." Conviction for vagrancy and vagabondage, even the mere absence of a fixed occupation, exposed the freeborn Englishman, at home or in the colonies, to the danger that he might be bound over to the highest bidder, his labor sold for a term. Miscreants who could not pay their fines for a wide range of offenses were punished by servitude on 'publick works or on the estates of individuals under conditions not far different from those of villenage' Such sentences, in the case of the graver felonies, sometimes for life (Handlin, p. 5).

Handlin used the literary works of various historians and writers to explain

reactions to different groups resorting in racism.

...the Indian, who was free yet colored. Untainted by the inferiority of the slave status, the red man was often endowed by the white with a reputation for primitive virtues--courage, love of freedom, and a concept of honor. For example, he enjoyed the same presumption of freedom as the whites, and contacts along the frontier had permitted some degree of marriage and miscegenation. Yet, the Southern defender of slavery could not conceive that the Indian would some day take a place in his own society. So long as the tribes held desirable lands east of the Mississippi they set an intolerable obstacle in the way of expansion and at the same time created a disruptive refuge for fugitive Negroes; only by a move to the Far West could they yet hope to save themselves. As important, their redness was a problem for those who argued that color was a trait indicative of the inferior of the group. In the 1830's T. R. Dew was already reasoning that the Indian should have been enslaved and that a greater number "would have been saved, had we rigidly persevered in enslaving them." As it was their future was dim' the further advance of settlement would ultimately lead to their extermination. Only slavery could save them from the consequences of their inferiority (Handlin, p. 34).

The majority of white settlers would under no circumstances yield their

position of perceived superiority. Acceptance of the equality of the Negro, Native

Americans and Chinese by the white population would have run counter to the 
complexity of beliefs and habits nurtured during four centuries of slavery, the annihilation of Native Americans, the expulsion of Chinese and the misuse and abuse of each group.

Acceptance of the immorality of these inequities would amount to an admission of guilt. Guilty not only for the injustices of slavery against Native Americans, African Americans and Chinese and other forms of bigotry, but for the warworn disasters of their induced battles and wars. That was intolerable. The inferiority of these groups was more than a habit of thought, more than a justification for privilege, it was an article of faith, made necessary by society's history (Handlin, p. 36):

The Chinese on the Pacific coast had, at first, been welcomed for their labor's sake. By contrast with the Negro they were "clean, orderly, and industrious," obedient, "affectionate and grateful." Such a race could fully blend with the "whites." After 1873, however, these model newcomers aroused the increasingly bitter antagonism of influential white groups and were stigmatized for their color. They too...were racially separate and unable to mingle in terms of equality with the Caucasians. Their low character, lack of moral sense, and criminal instincts made their exclusion imperative, or, at the very least, demanded that they be kept firmly subjected in an inferior status. The same accusations, later, would be leveled against the Japanese and other Orientals

(Handlin, p. 37)

In a variety of situations, identifiable racial differences signaled presumed value differences to justify the exploitation of, or discrimination against, minority groups. Often in the last decade of the nineteenth century Native Americans were denounced as skulking brutal savages pampered by sentimental humanitarians (Handlin, pp. 37-38). 
By the end of the nineteenth century the pattern of racist practice and ideas seemed fully developed: Orientals were to be totally excluded; Negroes were to live in a segregated enclave; Indians were to be confined to reservations and treated as permanent wards of the nation. All whites were expected to assimilate as rapidly as possible to a common standard. Only by then it had become clear that the racial lines could not be drawn simply on the basis of color. Some Americans had long wondered...that "although the Jewish race has been subjected...to every possible variety of ...moral and physical influences in the four quarters of the earth, yet, in no instance, has it lost its own type or approximated to that of other races...the influence of those who insisted that...the Jews, the Japanese, and the Negroes were fully Americans waned as racist ideas grew consistently stronger (Handlin, pp. 38-39).

Oregon State Senator, Avel Gordy, stated, There's an African Proverb that says, 'The ruin of a nation begins in the homes of its people' (Turnquist, p. A120).

An examination of Oregon's early history revealed the existence of a society of white settlers who feared not only minorities but foreign immigrants whom they perceived threatened American stability. ${ }^{3}$ Early on, Oregon settlers enacted Exclusionary Laws to prevent the inclusion of blacks, free or slave as residents of the region. In addition, these laws prevented minority ownership of land freely given to white settlers as an enticement to settle in the area. The right to claim free land eventually led to wealth and prosperity for many early white pioneers and their descendants. This Land Claim Act prohibited the offer of free land to full blooded Native Americans, ${ }^{4}$ free African Americans, and Asians.

The Chinese population grew from the 1860's on as a result of the need for labor on the railroad and in the mines. When Chinese laborers were no longer

\footnotetext{
3 During the early history of Oregon, white settlers included mostly Irish, English, Russian, Finish, Norwegian, French and Italian persons. While Protestants dominated the religious element, there were also Catholics and Jews.

4 A full blooded Native American was the direct descendant of a Native American father and mother.
} 
needed or wanted in northern California, many Chinese migrated to Oregon, especially Portland in search of employment. As a result of a growing population, housing in the Portland area was a premium. Perhaps, the lack of sufficient housing precipitated the refusal to allow Chinese (later extended to the Japanese) to purchase property. An explanation was not stipulated. However, while motive was not specifically indicated, the intent was clear. The employment of Chinese in menial labor positions was conveniently tolerated by white settlers. While the Chinese were hired to do work most whites debased, they had limited control over their living conditions as a result of inequitable laws and practices by the legal system and its enforcers.

White citizens, recognized as the majority, in the United States have historically registered their dissatisfaction with any fraction that appears to threaten or disrupt their comfort zone through political practices and strategically stated opinions. Crime, including most felonious acts, has been declining since the early 1980's in the majority of regions within the United States. Yet, in an effort to attract an audience for sponsors, the media continue to present negative images that mostly depict minorities as perpetrators in criminal situations (Schulberg, p. E14). As a result, many laws and public practices, legal, social and political, are proposed and enacted as a result of raw data based on emotion and not scientific research. More often than not, such laws and practices adversely and disproportionately target 
minority groups who are blamed for repugnant conditions related and unrelated to criminal activity (Cole, p. A20).

Laws such as Three Strikes and You're Out, in California, ${ }^{5}$ Measure Eleven ${ }^{6}$ in Oregon and federal mandatory sentencing guidelines ${ }^{7}$ leading to inefficiencies and ineffectiveness demonstrate the lack of validity and ultimate inequities inherent in such actions. Such laws were intended to deter the criminal activities of hardened career and murderous offenders. Yet, the arrest and incarceration of a multiplexity of individuals committing less heinous crimes have occurred (Cole, p. 120). As a result, law enforcement officers are often overworked, court systems have tremendous case backlogs, and prisons and jails are overcrowded. The citizenry votes for increased arrest, convictions and imprisonment. In conjunction, residents support the need for new buildings to house the increasing number of convicted offenders, but reject locating such facilities in their neighborhood.

While a major percentage of offenders are legally separated from society, the hard core criminal often remains at large, for example that 6 percent of offenders who commit 80 to 90 percent of felonious crimes are usually not arrested. In

$5 \quad$ Three strike laws have become a popular political ploy, but critics claim they are costly and ineffective. Supporters point out that by locking up career criminals, three strike laws can effectively target the small portion of the population who commit most of the crimes. Critics claim that the laws take away judicial discretion, will lead to more court congestion, cost too much and unfairly punish petty criminals (Meese, Edwin, p. 481).

A Multnomah County Judge refuses to impose Measure 11 penalty for the first-time robber. When voters overwhelmingly passed Measure 11, Oregon's tough mandatory sentencing law, last November (1994), it seemed that no judge would be willing to oppose that kind of public mandate. Until now. A Multnomah County Judge refused to sentence a convicted robber under Measure 11 last week, saying it violated Oregon's constitutional guarantees against disproportionate and cruel and unusual punishment (Manzano, Phil, p. C1).

7 The question...points up an ongoing struggle between federal judges and prosecutors and goes to the heat of a growing controversy about national sentencing policies (Biskupic, Joan, p. A5.). 
addition, studies ${ }^{8}$ indicate racial disparities in...legislation such as...three-strike convictions (Cole, p. A20).

Is there a history of tolerated inequitable legal and illegal treatment of racial and ethnic minorities lending support to adverse contemporary practices and applications within Oregon's justice system? Minorities are disproportionately present throughout Oregon's criminal justice system as clients and victims. Is there a correlation between present conditions and historical trends?

The extent to which treatment of racial and ethnic groups in the 1990's has evolved from a history of partisan practices, requires examination in an effort to provide current policy makers and social activists with an informed historical perspective in one formulating perception as to the origin of inequitable policies and practices.

Oregon's and subsequently, Portland's documented history of prejudiced attitudes and blatant discriminatory actions based on a presumption of superior customs and values evolved from the values of early white settlers. Research of this history reflects legal, and economic, injustices against Indians (Native Americans), Negroes (African Americans), Chinese Immigrants and social intolerance of Jews.

How did an atmosphere of intolerance affect the justice system's treatment of racial and ethnic minorities? What was the correlation between public perceptions and the justice system's treatment of racial and ethnic minorities? Does the report by

\footnotetext{
$8 \quad$ Two years after the three strike law passed, a study conducted by The Center On Juvenile and Criminal Justice indicated that 85 percent of those sentenced under the law were convicted of nonviolent crimes, including drug offenses, burglary and petty theft (Cole, p. A20).
} 
the Oregon Supreme Court Task Force on racial/ethnic issues in the justice system have origins in Oregon's and eventually Portland's early social, political and legal history?

The extent to which arrest, court appearances and dispositions of cases were influenced by social commentary and practice was a significant part of this research. Research of the history of minorities in the United States in the mid 1860's to the 1990's, offers documentation of social, political, civic and legal inequities. Racial and ethnic intolerance vibrated throughout the nation, including Oregon and subsequently, Portland. A review of the history of Oregon's legal justice system was originally considered necessary to the premise for this study to determine the extent of inequities within the state legal system.

However, during the historical period researched, while Native Americans may have inhabited various geographical areas throughout Oregon, Chinese, African Americans, ${ }^{9}$ and the largest population of Jews primarily resided in or near the city of Portland. As Oregon's largest city, Portland offered the best opportunity for minorities to work and maintain residence. When compared to other regions within the state, Portland's larger minority populations during the mid 1800's to mid 1890 's, provided the majority of available data for research on this subject.

Oregon history and law are included as a point of reference in understanding the emergence of inequitable laws and practices. An overview of the early history of

\footnotetext{
9 By $1870,47 \%$ of the black population of Oregon lived in Multnomah County (McLagan,
} p. 89). 
Oregon and Portland are included to provide the background on which laws, policies, procedures and practices were perpetrated, enacted, and conducted. Portland's history, Ordinances, and social context provide the dynamics of the setting in which arrest and court proceedings were recorded.

It must be recognized that while Native Americans, African Americans and Asians have not usually been favorably included in most accounts of the evolvement of the history of Oregon and Portland, they were present. Not only were they present but they contributed to the archives in the development of the Northwest region of North America and subsequently the United States, the Oregon region, the Oregon Territory, and eventually the state of Oregon and the city of Portland, against tremendous disadvantages and adversities. 


\section{RESEARCH METHODOLOGY}

Does a history of tolerated inequitable legal and illegal treatment of racial and ethnic minorities have adverse impact on contemporary practices and applications within Oregon's justice system? Racial and ethnic minorities are disproportionately represented throughout Oregon's criminal justice system. The extent to which Oregon's treatment of racial and ethnic groups has evolved from a history of partisan practices requires examination..

A history of prejudiced attitudes and blatant discriminatory actions coupled with a presumption of superior customs and values evolved from early Oregon and subsequently Portland white settlers. Consequently, intolerance for ethnic differences and nontraditional beliefs of diverse groups exemplified populace behavior starting from Oregon Territorial inception, through Oregon statehood to the emergence of the city of Portland with implications that have continued into the twentieth century.

These unjust practices had far reaching influences that negatively impact Oregon's and Portland's administration of justice. What does an examination of history contain that can provide additional insight regarding the inequitable treatment of minorities by Portland's criminal justice system? Was (and is) there a correlation between public perceptions and the justice systems' treatment of a disproportionate number of racial and ethnic minorities? 
My research provides historical data citing instances in which prevailing legal practices were antagonistic to the presence and activities of diverse ethnic groups. Oregon and Portland histories contains evidence of enacted laws, supported by legislative intent, dictating unjust judicial decisions directed toward minorities. After statehood several public officials, including key personnel within the justice system, continued to sanction unfair (legal and illegal) practices unjustly targeting minorities.

The influence of personnel within the justice system harboring intolerance for minorities had tremendous negative impact on Portland's treatment of minorities seeking resolutions to often unjust allegations. Capsuled insertions of Oregon's laws and Portland's Ordinances are provided to illustrate the pervasive intolerance of minorities and their diverse cultures by some public officials. In addition, arrest and court records available from this period were examined to get an understanding of the extent to which unjust laws and practices related to and regulated the lives of minorities.

As Oregon begins its transition into the twenty-first century, research indicates, while discrimination against minorities is not flagrant, its subtleties are pervasive. Contemporary studies show minorities are excessively represented at all levels within the criminal justice system. Minorities are more often: detained; arrested; brought before the courts; incarcerated; given longer sentencing, and; the target of legislation perceived to reduce crime, than their European-American counterparts. 
Racial and ethnic antagonists have mastered the technique of working within (or, on the boundaries of) the legal system to perpetuate divisive actions, views and attitudes. Oregon's historical legislative intolerance for differences among individuals, supported by the broader society, continues to haunt many aspects of the justice system. Current laws, seeking to reduce crime and control criminal activity, disproportionately target minorities, overload the justice system and do nothing to change misinformed attitudes.

A brief history of the United States Government's approach to land rights, including Oregon's legal framework involving minorities, and Portland's Ordinances, provide recorded genesis for the derivation of an influential intolerant atmosphere. This study provides evidence that legislative action in response to racist societal pressures to control and dictate minority behavior were (and are) unjust. Such actions continue to be reflected in many, if not all, legislation pertaining to crime in the 1990's.

The public responds to crime reports with emotional reflexes by seeking immediate change through legislative action. Many laws, designed to suppress crime, that have been enacted during this decade have been based on data derived from raw public opinion. Such laws have done little to relieve the justice system of criminal acts, but have served to congest and overload the criminal justice process. Such laws unjustly target the poor and disenfranchised members of society who are usually members of a racial/ethnic minority group. It is also hoped that this study 
sheds light on the disadvantages and lack of benefit to the public when criminal laws are allowed to evolve in this manner.

The method of science is to isolate variations in single causes and associated effects. These variations may be in time decade to decade or century to century thus becoming historic. Historiography is the written and oral past providing a genuine form of methodology to conduct research. My research involved the use of primary and secondary data to validate and authenticate my thesis statement by using aspects of historiography methodology, such as:

\begin{tabular}{ll|}
\hline 1. & Chronicles, public papers and records; annals, police and court archives; memoirs; \\
genealogies, census data; and, recorded historical remains. & 10 \\
2. & Critically analyzing researched materials and authenticating their originality and content \\
3. & Interpreting and grouping facts by relationships. \\
4. & Present documented results.
\end{tabular}

The human element drives individual perceptions that are inherently a part of qualitative studies and written histories. Qualitative data is often the result of subjective interpretation. Subjective interpretations are accepted by the new scientific community as providing value to the research process and are considered valid and credible. In the process of formulating this work, objectivity was primary, but some subjectivity could not be avoided. In some instances, it was necessary to make assumptions, form an opinion and/or arrive at a conclusion.

An established society creates laws to protect its community by resolving and minimizing conflict and other actions that threaten to disrupt the status quo. Usually such laws reflect the interests and values of the ruling class. Conflict results from

\footnotetext{
10 Historical remains refers to customs, habits, ceremonies and religious applications that continue to be practiced and/or celebrated.
} 
dissension regarding social norms which dictate, or at least influence, individual and group behaviors. The prevailing members of the society - the controlling class through law, subtlety and overtly influence what conduct is unacceptable and ultimately, what punishment (social and legal) should be utilized for behaviors not sanctioned.

As a result, laws are a reflection of society's temper, guided (or misguided) by the upper echelon, the wealthy, the politically astute... Policing duties involve enforcing laws resulting from this aligned temper. Usually, those members of the society whose values and actions deemed inferior or in conflict with society's temper, are often targeted for police action because they are perceived as being the law breakers. In support of this theory, my research involved:

- Analyzing the origins of Oregon and Portland's history and relevancy to the treatment of minority inhabitants.

- Critically analyzing researched materials including United States legislation, Oregon law, Portland Ordinances and other legal policies, procedures and practices impacting Portland's justice system and identified minorities residing within the community.

- Interpreting and grouping information by relationships, such as social, political, and civic movements and activities.

- Replicating documented results, such as laws, ordinances, names and positions of elected officials, appointed personnel, census/population data, judicial and corrections data and directories identifying Native Americans, African Americans, Chinese Immigrants, and Jews.

- Observing and replicating arrest and court records from the mid to late 1800 's, of identifiable Native Americans/Indians, African Americans/blacks, and Chinese Immigrants, while analyzing the extent of their treatment within Oregon and Portland's justice system..

- Identifying Jews and their relationships with Portland's justice system.

While my research involved quantitative data, my focus primarily involved analyzing such data from a qualitative perspective to determine what instructive information could be derived from the results. 
An overview of the history of Oregon and Portland and relationships to the presence and treatment of indicated minorities are included in this work. These annals provide background information essential to understanding Oregon's, but more significantly, Portland's early minority status. Much of this research was obtained from the written works of other researchers, noted authors of history and notes from relative lectures by professors at Portland State University

Particular attention was given to identifying legislation adversely affecting the presence of minorities in Oregon, but more particularly in the Portland area. My research entailed perusing and analyzing United States law pertaining to Oregon, Oregon legislation and finally Portland Ordinances just prior to the mid 1800's to the mid 1890's. See CHAPTERS I and II. These laws have been reproduced and inserted in this document as evidence of their existence. Oregon law and related U. S. law and Portland Ordinances were obtained from written works by researchers, books by authors of history and published legislation.

In addition, to providing an understanding of the social norms, customs, and legal practices prevalent during this historic period, other Oregon laws and Portland Ordinances relative to criminal violations have been included. See CHAPTER I and APPENDICES XXII and XXIII. Social, political and civic incidents in history associated with these legislative acts are also included to illustrate how such practices impacted prevailing legal and justice policies. 
In each reproduced documentation some words and/or phrases may appear to be misspelled and/or appear with inappropriate upper or lower case lettering. However, to maintain the integrity of the data, such words and/or phrases were replicated in their original form and format. The use of the adverb [sic] was not inserted in the interest of space and the essence of historical probity.

In addition, the names, political and public positions, dates of office, and where possible, brief biography of appointed, elected and hired public officials were also identified. These names and related information were included in this work as clarification of their political, social and/or civic connections to and influence on Portland's legal and justice system.

Census data and other population figures are included for reference. See APPENDICES IV. Also, included is a listing of the names of African Americans and Chinese merchants in contrast to census data. These names and related occupations were obtained from Portland City Directories and other reliable cited sources. See APPENDICES VI. A list providing the identity of some Jews residing in the Portland area was researched. The names of identified Jews were used to designate those who held public positions and other positions of authority during that time period. Attention was also given to the societal climate affecting Jewish social affiliations and religious freedoms in Portland. See CHAPTER XIII.

My research of arrest and court records was contained to the Portland Stanley Paar City Archives, Portland Oregon. While some records were unavailable, 
assessable data was extensive and examination of this information time consuming. Perusing arrest and court records was conducted for a period of approximately six months. Research was conducted between June 1995 and March 1996, Monday through Friday, usually from 8:30AM to 4:00PM.

The City Archives' limited availability of written documentation related to arrest and court proceedings directed the scope of much of my research. While the Portland Archives houses court and arrest records dating back from the mid to late 1800 s, some arrest records for that period were unavailable. As a result, there are some months and a few years for which arrest data was not reviewed. However, there was sufficient data to provide reasonable deductions relative to the essence of my research.

Preserved arrest and court records were maintained in books measuring approximately twenty-four inches by fifteen inches in length and width and about five inches in depth. The books were heavy, large and awkward to handle. To preserve the cover's leather finish, the integrity of recorded data, and the protection of fading ink, white gloves were required to be worn at all times.

The books' covers were moldy and musty and the deterioration of the bound leather left rust colored residue on anything (or anyone) touching the surface. Consequently, researchers also protect their hands and clothes by wearing the required gloves. In addition, the fragility of each historic volume required that the researcher maintain each book in a flat position when perusing the data. Researchers 
are cautioned to carefully turn each page one at a time to avoid tears to the often brittle and yellowed with age paper.

Records were handwritten and while Court Recorders presumably took pride in their penmanship, the use of a magnifying glass was often necessary to decipher and understand what was scribed. Letters were formed using scrip characteristics absent from most handwriting in the 1990's, but still formally used by calligraphers. However, the difficulty in deciphering the hand written data did not disrupt the validity of my research. The inability to accurately read some names and understand other pertinent information had minor impact on my findings.

Available court and arrest records and the recorded criminal activities of identifiable racial and ethnic minorities and case dispositions were reproduced. See APPENDICES VIII-XXI. My research approach in identifying racial and ethnic minorities was unscientific. However, utilizing an approach that any reasonable person would adopt, given the status of the data, certainly validated this effort. Identifying race/ethnicity based on the information provided was complex. City Archives Arrest and Court Records in the late 1860's and 1880's did not require the inclusion of a specific ethnic category. Most Arrest and Court Records required and provided the following: (See the following page) 
...set forth in appropriate columns the names of persons arrested and brought before the court,

the date thereof,

the offense charged,

whether for a violation of a city ordinance or a law of the State,

the amount of fine,

term of commitment, (sentencing in lieu of paying fine)

amount of costs,

amount of fines and fees collected,

amount due to witnesses and other persons,

and to whom payable,

and amount due the chief of Police

(Deady, p. 131)

Arrest and court records contained variations of the information required by

City Ordinance 899. Recorders or Police Judges recorded the prescribed information and often added ethnic descriptions of arrestees and defendants. My research relied on recognizing ethnic names and other recorded disparaging references to ethnicity used by arrest and court reporters when labeling members of a particular minority group. As a result, by using this technique I could only identify labeled Native Americans, specified African Americans, and Chinese by their ethnic names. Some Jews ${ }^{11}$ were identified through a listing (obtained through a cited source) identifying them as Portland residents prior to the mid 1850's. However, I did observe court records from the mid 1890's that specifically indicated ethnicity/race under the heading Nativity.

I compared the arrest data obtained through my research and replicated in this work to that of another research project numerically identifying total arrests in

11 Many Jews changed their names to avoid racist treatment. A list of the names of Jewish families living in the Oregon region as early as 1854 was compared to census data to identity Jews residing in Portland during this period (Scott, pp. 116-117). The list identifying Jewish merchants residing in the Oregon Territory prior to 1852, was developed by Portland Jewish residents, John M. Breck, George L. Story, Henry Failing and T. B. Trevett. See CHAPTER XII. 
Portland during this period. ${ }^{12}$ See APPENDIX V. The comparison was used to validate my findings while recognizing the limitations of my research.

My research was limited as a result of the unavailability of some arrest and court records. Also, in the absence of specific recorded ethnic identity, the ability to more accurately identify minorities, particularly, African Americans, was restricted. Native Americans and Chinese persons were readily identifiable. In recognition of these conditions, additional research is needed.

In addition, as a result of arrest and court records not being continuous, there were obvious gaps in the recorded data examined. As such, there was not an effort to relate arrest cases to court cases. Perhaps, an examination of that information is also basis for a research project.

12 Tracy, Charles Abbott, (1976), The Evolution of the Police Function in Portland, Oregon, 1811-1874, Dissertation, University of California, California State University campus, San Jose, California, See CHARACTERISTICS OF PERSONS ARRESTED BY YEAR - see APPENDIX V. 


\section{ARREST RECORDS}

Arrests records were observed for the following time periods, prosecuting jurisdictions, and status of charges:

\begin{tabular}{|c|c|c|}
\hline DATE & JURISDICTION & STATUS OF CHARGE \\
\hline November 1870 - January 1875 & City of Portland \& State of Oregon & Felonies \& Misdemeanors \\
\hline January 1875 - March 1878 & City of Portland & Felonies \& Misdemeanors \\
\hline August 1877 - October 1879 & City of Portland \& State of Oregon & Felonies \& Misdemeanors \\
\hline December 1879 - October 1881 & City of Portland \& State of Oregon & Felonies \& Misdemeanors \\
\hline May 1894 - April 1895 & City of Portland & Felonies \& Misdemeanors \\
\hline
\end{tabular}

When reviewing arrest records, my research involved analyzing the flowing data:

...date

attention to date in relation to corresponding events in history

$\ldots \mathrm{hr}$

attention to time to determine hour of night or day arrest occurred and compared to

like arrest for whites

...names of persons arrested (defendant)

descriptions of, remarks in reference to and/or names of race/ethnicity.

...arresting officers

to determine if a trend for any officer(s) was evident

...complainant

ethnicity of persons filing complaints against minorities to determine if unusual

pattern(s) existed

...the charges...charged with crime of

types of complaints filed against minorities/ethics compared to others

types of complaints filed by arresting officers toward minorities/ethics

...where arrested

to determine if one section of town was frequented than any other

...whether for a violation of City Ordinance/County Ordinance/Law of the State

or felonies types of complaints culminating in the arrest of minorities/ethics-- misdemeanors

...property/amount of money (coin) on prisoner

did minorities appear to have financial means to pay fines

...male (M) - female (F)

compared differences in the number of females $v$. males arrested within an ethnic

group and between ethnic groups

...bail

was the accused allowed to post bail - did the accuse post bail - amount of bail

...fines - paid (P) - unpaid (U)...

compared paying fine trends within ethnic groups and between ethnic groups

...number of davs works...

was any ethnic group required to work more or less than any other group

...number of days in dark cell... ...nativity

was any ethnic group remanded to a dark cell more than any other group

...Remarks...

to determine race/ethnicity when information provided

offering of bail to/amount of fines levied /length of sentencing given to minorities as a result of their arrests - court disposition of cases involving minorities 


\section{COURT RECORDS}

Court Records were observed for the following time periods, prosecuting

jurisdictions, status of charges, and the name of the presiding adjudicating official:

\begin{tabular}{|c|c|c|c|}
\hline DATE & $\begin{array}{c}\text { COURT } \\
\text { JURISDICTION }\end{array}$ & $\begin{array}{l}\text { STATUS OF } \\
\text { CHARGE }\end{array}$ & $\begin{array}{c}\text { *POLICE JUDGE } \\
\text { **JUSTICE OF THE } \\
\text { PEACE } \\
\text { *** RECORDER } \\
\end{array}$ \\
\hline June 1867 -July 1868 & State of Oregon & Felonies & ** J. J. Hoffman \\
\hline August 1868 -July 1870 & State of Oregon & Felonies & $* *$ J. J. Hoffman \\
\hline August 1870 -November 1874 & (not observed) & & \\
\hline December 1874-March 1880 & State of Oregon & Felonies & */** O. N. Denny \\
\hline June 1867 - August 1870 & City Of Portland & Misdemeanors & ** J. J. Hoffman \\
\hline August 1870-April 1871 & City of Portland & Misdemeanors & $* * / * * *$ Sin Anderson \\
\hline July $1871-$ October 1873 & City of Portland & Misdemeanors & * O. N. Denny \\
\hline November 1873-June 1877 & City of Portland & Misdemeanors & *O. N. Denny \\
\hline July $1877-$ July 1879 & (not observed) & & -- \\
\hline August 1879-August 1881 & City of Portland & Misdemeanors & *O. N. Denny \\
\hline September 1881-August 1882 & City of Portland & Misdemeanors & \\
\hline
\end{tabular}

When reviewing Court Records, my research involved analyzing:

\begin{tabular}{|ll|}
\hline \multicolumn{1}{|c|}{ Category } & \multicolumn{1}{c|}{ Data } \\
Case: & And determining if case involved a minority \\
Warrant & Date of warrant \\
Issued: & If an arrest was made - lapsed period of time between issuance of warrant and \\
Arrested & arrest \\
& Comparison of charges against racial/ethnic minorities compared to those of \\
Charge; & white defendants \\
& How did the accused plead \\
Plead: & Period of time between arrest and trial date \\
Trial Date: & Was the defendant allowed to post bail \\
Bail Set: & Did the defendant have witnesses \\
Witnesses: & Comparison of frequency of guilty verdicts \\
Verdict: & If found guilty, comparison of amount of fine compared to those of white \\
Fine:: & defendants \\
Tax: & If found guilty, comparison of amount of taxes (court costs) compared to those \\
& of white defendants \\
In Lieu of & If found guilty, in lieu of payment ,comparison of sentencing compared to that \\
Payment of fine & of white defendants \\
$\begin{array}{l}\text { Disposition of } \\
\text { case }\end{array}$ & How did the offender/non-offender resolve his/her case \\
\hline
\end{tabular}


Court records at the Portland City Archives began in June 1867, with J. J. Hoffman, Recorder, presiding. ${ }^{13}$ Cases were recorded as State of Oregon v. (name of the defendant) in one record, or City of Portland $v$. (name of the defendant) The overall judicial process remain fairly constant only the Recorder and eventually the presiding Police Judge or the Justice of the Peace changed. As indicated, cases tried for the state of Oregon were usually felonies and cases tried for the City of Portland were mainly misdemeanors. Portland was divided into precincts, however, designating a specific precinct was not specified in the arrest or court records observed. See JUSTICES OF THE PEACE, CHAPTER III.

While the Recorder or Police Judge or eventually the Court Recorder, were required to record particular data for each court case, records of briefs and court proceedings, if used, were not retained. As a result, precise facts related to court proceedings were not available. The lack of the specificity of this form of data necessitated conclusions based on (by judicial standards in the 1990's) inconclusive information. As a result, my research is presented with commentary as a reflection of obvious actions and subtle reactions. However, in an effort to remain objective, I offered limited opinions except in instances where some comment was necessary.

As stated, court records provided data that rendered limited insightful information regarding the adjudication process. Initially, a warrant was issued by the court and served by the Marshal. In the vast majority of cases an arrest was designation of Justice of the Peace. See Court Records APPENDICES XIII-XXI. 
immediately made. ${ }^{14}$ Upon arrest, the defendant was brought before the Recorder, charged and required to enter a plea of guilty or not guilty. Most defendants plead guilty and paid their fine and/or failing to pay, served a jail sentence. Those who plead not guilty, were adjudicated, received a verdict and if found guilty, paid a fine and/or was sentenced. Defendants and the State of Oregon, plaintiff, often used the testimony of witnesses to strengthen their case. In a few cases minorities were summoned as witnesses. In such instances, witnesses, especially minority witnesses and specifically Chinese, were jailed until trial.

Defendants found guilty were usually fined and required to pay court costs. Court costs included Justice's fees, Marshal fees, Prosecuting Attorney's fees and when used, witnesses' fees. If the defendant was unable to pay, or refused to pay, a jail, or prison, if appropriate, sentence was imposed. In rare instances, regarding a felony, defendants were sentenced to the State Penitentiary or San Quentin, in California. Few arrestees were sentenced to prison, including minorities. The number of offenders sentenced to Oregon prison is provided. See APPENDIX I.

There was an abundance of data and other appropriate information selected for inclusion in the research of this project. In order to have an informed understanding as to how custom, social practices, political action and subsequent law

\footnotetext{
14 In those few cases were the Marshal was unable to locate the accused, if the charge was a misdemeanor, the complaint was not resolved and according to record, no attempt was made to locate the party. Felony charges were given more attention by the Marshal/Sheriff/Police Chief and his deputies/policemen.
} 
interacted and impacted minorities, it was necessary to identify and present information related to the civic atmosphere surrounding these community forums. An educated interpretation of the arrest and court records of minorities required a basic awareness of the influences of these forums adjacent to which violations were cited. An informed view of the origins of criminal laws leading to arrest warrants, subsequent adjudications and final dispositions of charges was essential in understanding how minorities were disproportionately represented in Portland's criminal justice system.

I offer this work as a perspective of that process. 


\title{
CHAPTER I \\ OREGON HISTORY
}

\author{
An Overview
}

Several white American settlers started arriving in the Oregon region during

the 1830's. This immigration was followed by rapid migration of additional white

settlers during the 1840 's. During the 1850's, the United States Congress enacted a

land claim act granting married white American males 640 acres of land (Deady, p. 65).

\begin{abstract}
September 27, 1850 GRANTS OF PUBLIC LAND.

\$4. There shall be, and hereby is granted to every white settler or occupant $f$ the public lands, American half-breed Indians included, above the age of eighteen years, being a citizen of the United States, or having made a declaration according to law, of his intention to become a citizen, or who shall make such declaration on or before the first day of December, Eighteen hundred and fifty-one, now residing in said territory, or who shall become a resident thereof, on or before first day of December, eighteen hundred and fifty, and who shall have resided upon and cultivated the same for four successive years, and shall otherwise confirm to the provisions of this act, the quality of one half sections, or three hundred and twenty acres of land, if a single man and if a married ${ }^{3}$ man, or if he shall become married within one year from the first day of December, eighteen hundred and fifty, the quantity of one section, or six hundred and forty acres, one half himself, and the other half to his wife, to be held by her in her own right;...(p. 65)

GRANTS OF LAND TO WHITE PERSONS EMIGRATING BETWEEN DECEMBER 1, 1850 AND DECEMBER 1, 1853.

85. To all white male citizens of the United States, or persons who shall made a declaration of intention to become such, above the age of twenty-one years, emigrating to and settling in said territory, between the first day of December, eighteen hundred and fifty, and the first day of December, eighteen hundred and fifty-three; and to all white male American citizens, not hereinafter provided for, becoming one and twenty years of age, in said territory, and settling there between the time last afore said, who shall in other respects comply with the foregoing section and the provisions of this law, there shall be, and hereby is granted the quantity of one quarter section, or one hundred and sixty acres of land, if a single man; or if married, or if he shall become married within one year from the time of arriving in said territory, or within one year after becoming twenty-one years of age as aforesaid, then the quantity of one half section, or three hundred and twenty acres, one half to the husband, and the other half to the wife in her own right...(p. 66).

Julv 17, 1854. 10 State. 306.

$\$ 25 . \quad$...That the period of two years' occupancy required of settlers before they can purchase the land claimed by them under the provisions of the first section of the act of February fourteen, eighteen hundred and fifty-three, above mentioned, shall be, and the same is hereby, reduced to one year (p. 74).

September 27, 1850 Act of July 17, 1854

$\$ 26 . \quad$ Repealed. (see above)
\end{abstract}

ACTS OF CONGRESS ${ }^{1}$ RELATING TO PUBLIC LANDS IN OREGON (TERRITORY)

1 Deady, Matthew P. and Lafayette Lane, Organic and Other General Laws of Oregon: 18431872 .

2 Ibid., Criminal Code, footnote, p. 65. The words "single man" include an unmarred woman, 77 Wall., 219.

3 Ibid. A settler is married within the meaning of this act, without reference to the color or race of his wife. The wife takes an account of her "wifeship," and no other qualification is required (footnote, p. 65). 
The promise of free land lured a large influx of European Americans (whites)

to the area. This migration inevitably brought disease and other sociological problems to the Northwest region that had been previously inhabited by nations of Native American tribes. While diseases such as malaria, tuberculosis, smallpox and measles were devastating to settlers, such plagues had catastrophic effect on Oregon Native Americans. Native Americans had never been exposed to such communicable diseases. The following is a capsule of these events.

Oregon's history emerges from movements that prompted white settlers to seek settlement in the Northwestern region of the United States. White settlers gradually took possession of land previously occupied and governed by Native Americans forced to abandon their sovereign state.

Captains Meriwether Lewis and William Clark commanded an exploring expedition at the request of President Thomas Jefferson in 1804 from Missouri westward to the Northwest region. York, a black slave, served as an interpreter for the expedition. ${ }^{4}$ Lewis and Clark's expedition generated international interest that

$4 \quad$ York, born in Virginia, was William Clark's slave. York was a hunter, spoke French and his presence often excited Native Americans unaccustomed to his unusual appearance. York has been estimated to have been over six feet in height, with jet black skin and thick curly hair; a stark contrast to Native American features.

York, although a slave, was permitted a voice in camping decisions, such as camp site selections and food provisions. In 1811, York was given his freedom upon returning to St. Louis. White members of the expedition received 320 acres. York, denied the right to free land by the federal government, received six horses and a wagon.

York's later adventures are somewhat mysterious. There are several theories regarding his life but most cannot be collaborated. Yet, York's presence in the Northwest created many legends retold by Native Americans impressed with his hunting abilities and leadership (McLagan, pp. 3-4). 
eventually led to a vigorous fight from the French $^{5}$ and the English to prevent this proclaimed virgin territory from any rightful claim by the United States government. The struggle for possession and subsequent ownership persevered for several decades.

Simon Fraser, an English subject and agent of the Northwest Fur Company, established a trading posts in 1805 at Fraser Lake (Scott, p. 19). In 1808, an American, Henry, founded Fort Henry, located at the origin of the (later named) Snake River (Scott, p. 19). Following this period, other Americans arrived and laid claim to land.

In 1810, Nathan Winship and William Smith, agents of the Boston Company, attempted to establish a settlement on the south bank of the Columbia River (Scott, p. 19). However, unpredictable weather compelled the settlement to move to higher ground which was not receptive to Native Americans (Indians) living in the area. The hostile atmosphere forced the duo to abandon their plans and return to the East Coast. However, while their presence created antagonism among Native Americans, their departure did not lessen animosity toward other newcomers, including capitalistic businessmen.

Yet, despite the hostile environment, John Jacob Astor, ${ }^{6}$ an American, authorized the establishment of a trading post at the entrance to the Columbia River.

$5 \quad$ The United States purchased the Louisiana Territory from France. This possession provided the opportunity for the U. S. to expand its holdings to the Pacific Ocean. However, this did little to diminish French interest in the Pacific Coastal region (McLagan, p. 3).

6 John Astor established the trading post with the approval of President Jefferson and Congress in an effort to countermand the transactions of independent traders and gain control of the thriving business location (Scott, p. 20). 
Astor commissioned an expedition led by Wilson Price Hunt on the ship Tonquin, captained by Jonathan Torn (McLagan, p. 6). The ship's crew included a black cook, ${ }^{7}$ and two other black men, Edward Rose ${ }^{8}$ and Françoise Duchouquette ${ }^{9}$ (McLagan, p. 6). The trading post operated under the name, Pacific Fur Company and Astor named the location, Fort Astoria Scott, p. 21).

Astor's diplomatic tactics initially enabled him to negotiate and establish a trading business with Native Americans. However, on one of his crews' expeditions to the Vancouver area, the men became entangled in a battle with Native Americans. There was a horrendous gun powder explosion killing several Native Americans and crew members. This incident ultimately isolated Astor's business connections (McLagan, p. 7).

Initially, the War of $1812^{10}$ weakened American influence in the Oregon region by giving control to the British (Scott, p. 22). Fort Astoria was captured by

Name not indicated (McLagan, p. 6).

$8 \quad$ Edward Rose, born in Kentucky, was the son of a white trader; his mother was black and Cherokee. Rose was acquainted with native American traditions and customs having lived much of his life in their midst. His often worked as a guide, hunter and interpreter for expeditions. Rose later met Wilson Price Hunt, who eventually objected to Rose's troubled personality.

Hunt dismissed his services, gave him a year's provisions and forced him to leave the expedition. It is reported that Hunt's party, without an experienced guide, became lost along the Snake River. Several men in the party died before they reached the mouth of the Columbia and established Fort Astoria.

Rose served as a guide for other expeditions included those led by Jedediah Smith (passage through the Rockies) and General Henry Atkinson (Native American treaty negotiator). Rose died during the 1830's (McLagan, pp. 6-7).

$9 \quad$ A Canadian, François Duchouquette descended from French and black ancestry. Douchouquette worked at Fort Astoria as a blacksmith until 1814. when he traveled to Lake Superior to work at Fort Williams. During his time in the Oregon region, he fathered a son, his namesake, by an Okanogan Native American woman (McLagan, p. 6).

${ }_{10}$ The War of 1812 was a conflict between the United States and Great Britain, when the U.S. attempted to take control of the vulnerability of feuding European nations' neglect of neutral countries and other unclaimed territories and Britain sought to regain the U. S. - a sovereignty once claimed and governed by Britain (World Almanac and Book of Facts, The) 
British forces and renamed Fort George. Subsequently, Astor sold his vested stock to the Canadian Northwest Fur Company. The Treaty of Ghent, at the end of the war, decreed that previous claimed land be restored to former occupants While this Treaty superficially returned portions of the Oregon region to the U. S., it did not assist in restoring American trading in the area.

In 1815, the British were informed that the United States' would reclaim Fort George. However, reclamation efforts were not put forth until 1817, when the United States claimed such rights based on four legalities:

1) as a portion of the Louisiana, purchased from France in 1803;

2) by right of discovery by the Spanish explorers Ferrelo in 1543 and by Perez, Aguilar, Hectar, Abdega, Quadra, among several others, the benefit of whose discoveries accrued to the United States by the Florida purchase in 1819;

3) by the discovery of the Columbia River by Captain Gray, in 1792; and, 4) by reason of the exploration of Lewis and Clark and the establishment of forts at Astoria and two other points by the Pacific Fur Company (Scott, p. 22).

Britain disputed these legal contentions. ${ }^{11}$ Since the two countries could not agree, joint ownership was granted for a ten year period starting in 1818. After this ten year interval, nominal possession of Fort George/Astoria was given to the U. S., but actual possession remained with the Northwest Company (Scott, p. 23). However, the presiding judge cautioned that neither country had legal right to the region.

$11 \quad$ Britain claimed rights as a result of Francis Drakes' discoveries in 1578, thus de-emphasizing explorations of Ferrelo, Cook, Vancouver, Meares and other British traders between 1775 and 1793. Britain's claim was also based on the establishment of a fort on Fraser Lake by an agent of the Northwest Company who purchased the property of the Pacific Fur Company (Scott, P. 23). 
The Northwest Fur Company (an enterprise operated by British agents) became quite profitable as a result of their progressively captivating trading power in the region. ${ }^{12}$ The Hudson's Bay Company (also a British business) also thrived financially (Scott, p. 24). However, the two companies' contentions for exclusive trading rights in the region and ambition to be the authoritative governing body, often resulted in bloody feuds. Finally, in 1821, the British Parliament merged the two companies under one name, The Honorable Hudson's Bay Company (Scott, p. 24). This joint venture advanced Britain's position of control over the Oregon region. The newly organized Honorable Hudson's Bay Company, fortified by merged financial drive, exerted unrelenting power. The Company was uncompromising in its hostility toward anyone interfering with the Company's trading traffic and the exclusive right to trade with Native Americans in the area.

From 1823 to 1845, Dr. John McLoughlin, commanded the Hudson's Bay Company (Scott,, p. 25). Under his guidance there was organization, harmony and good will in what was primarily a lawless area. He settled all disputes and punished all offenders under the jurisdiction of the Hudson's Bay Company and extended that rule to include others residing within the region. Although, considered to be compassionate and fair, McLoughlin was challenged in the British Courts by his adversaries who felt he was too humane to American settlers (McLagan, p. 14). McLoughlin assisted Americans during their hardships when attempting to settle new

12 During this period, 1813-1821, the Northwest Fur Company employed two thousand voyagers and was unrelenting in the search for fur pelts (Scott, p. 24). 
communities. As a result of complaints about his favoritism toward Americans, McLoughlin was subsequently forced to resign (Scott, $\mathrm{p} 26$ ).

During McLoughlin's sojourn in the Oregon region, he used the services of George Washington, a black cook. At McLoughlin's request, Washington often transported food to missionaries located south of Vancouver. ${ }^{13}$ Despite his freedom of movement, Washington refused to live in the Oregon region and be subjected to unequal racial treatment (McLagan, p.27). In recognition of his willingness to work, several Oregon residents petitioned to repeal Oregon law prohibiting blacks from relocating to the Oregon region, and ultimately Oregon Territory (McLagan, p. 27). Their efforts were futile. In the absence of McLoughlin, Washington ultimately moved north of Vancouver and established Centralia, Washington (McLagan, p. 27).

Despite McLoughlin's departure, by the end of the ten year moratorium, British rule continued to advance and regional rights of the United States appeared to be diminishing. New commissioners were appointed by both countries in an effort to settle ownership of the Oregon region. During this period neither country was inclined to abandoned their claim. In 1827 , a new treaty extended joint occupation for an indefinite period (Scott, p. 28). However, Britain, through the business efforts of the Honorable Hudson's Bay Company, retained powerful control over the region.

13 It is reported that George Washington, known for his cooking ability, often attempted to pilot the ship used to transport food, but was usually unsuccessful. Unable to purchase land and live in the Oregon Territory, Washington founded Centralia, Washington, still a thriving community in the 1990's. See APPENDIX III, Articles involving African Americans: 1846, August 6, Oregon Spectator Negro Living at Cape Disappointment Attempts To Pilot Shark To Astoriap. 2, col. 3 
Several American traders attempted to challenge the Hudson's Bay

Company's enterprising presence. However, without organization and lacking useful affiliations with other traders, they were unable to launch a successful contention. Recognizing their beneficial business connections, regional Native Americans felt obliged to defend their interest with the Hudson's Bay Company (Scott, p. 29).

During its operation, the Hudson's Bay Company employed persons of mixed racial heritage. In 1831, James Douglas, ${ }^{14}$ a West Indian, was chief accountant promoted to Chief Trader. During McLoughlin's absence, Douglas managed Fort Vancouver from 1838 to 1839 . In 1840 , he was given the highest rank in the Company, Chief Factor. Douglas relocated to Fort Victoria, Canada, ${ }^{15}$ eventually becoming the first governor of British Columbia (McLagan, p. 12).

The Unites States Congress, occupied with other issues, did little to support any interest in contesting the Hudson's Bay Company's earlier control of the region (Scott, p. 31). White settlers in the region, excluding missionaries, did not sense the necessity to change the status quo. Conversely, missionaries, challenged by their desire to share religious beliefs with area Native Americans and other white settlers, wanted to create a permanent colony and therefore sought legal change and a means to protect their civil and religious rights.

14 James Douglas, a British subject, was born in British Guiana in 1803 of a Scottish father and a Creole mother. During his management of Fort Vancouver, cognizant of McLoughlin's precarious position, changed business practices, by denying America settler's credit for supplies. When the Company closed, Douglas relocated north to Fort Victoria and eventually became the first governor of the British Columbia (McLagan, pp. 14-15).

15 The Hudson Bay Company established Fort Victoria Canada in 1843 (Champagne, 1994, p. $x v i$.$) .$ 
Missionary settlements, located in the Willamette Valley, about ten miles below what was to become Salem, prospered by producing goods in demand. They expanded their presence through the increased emergence of emigration populations (Scott, p. 32). By 1840, the arrival of other religious leaders and their families assisted in transforming the settlement into a vast religious community determined to teach the Gospel to local heathens.

Initially, missionaries concentrated on convincing other white settlers to migrate to the Oregon region and subsequently they sought to infuse their religious beliefs on newcomers. As a result, they ultimately erected schools and churches, infiltrating the area between Salem and Portland. Methodist missionaries were followed by Presbyterian missionaries. From these missionaries emerged a group of men determined to secure Oregon as a possession of the United States against the claims of Great Britain.

Concurrently, ministers from both denominations settled among Native American tribes such as the Cayuse at Wailatpu, in the Walla Walla Valley, the Nez Perce, at Lapwai among the Flatheads at Alpona, and the Spokane in the area of Fort Colville in an effort to instill religious conversion (Scott, pp. 33-34).

In 1838, Roman Catholics started migrating to the Oregon region. Protestant missionaries were skeptical, they felt Catholics were sympathetic to British interests and became increasing disturbed by their expanding occupancy (Scott, p. 34). Catholics supported the Hudson's Bay Company and for that reason established their 
religious headquarters at Vancouver close to the Company's headquarters. Catholics, initially discouraged any local establishment of a government influenced by American interest. Nonetheless, they eventually acquiesced to rule by self-selected Protestant missionaries when it became clear they would and could govern (Scott, p. 35).

However, the divisiveness between Catholics and Protestants grew more apparent and Native Americans felt split between the two religions. ${ }^{16}$ Most white established settlers in the Oregon region were either Protestant or Catholic. Newcomers, however, felt no obligation to associate with any religion and were comprised mostly of three diverse groups. Many new settlers were from the Rocky Mountains, where they led lives filled with danger and excitement and religion was not part of their former life style (Scott, p. 35). Other new arrivals included sailors, who left life at sea to try their luck on land. Finally, a third class consisted of restless, roaming immigrants looking for places offering new adventure and challenge (Scott, p. 35). A diversity in values eventually created conflict in what had been a mostly homogeneous community of white settlers.

Until 1839, the Hudson's Bay Company's laws prevailed. Nevertheless, acting out of a need for an authority that all settler's could respect, Methodist Missionaries appointed two persons to act as magistrates. Although, the independent

16 Native Americans were led to believe the rival for their souls was the basis for the harsh differences between the two groups. Ultimately, however, Catholics were the best at proselytizing. As a result, for the next ten years, Protestants discontinued their attempts to convert Native Americans to their religious beliefs (Scott, p. 34). 
settlers had not been consulted, they agreed to honor the Methodist Missionary's decision (Scott, p. 36).

Prior to this period, American independent settlers, due to Congress's inattentiveness and neglect, had existed without a governing body of law.

Missionaries, on the other hand, had rules and regulations which governed their interactions with each other uniting them in a common bond for mutual protection. However, the independent settlers had no such agreement which made them and the American independents vulnerable to lawless predators (Scott, p. 36). Perhaps, it was in recognition of the lack of civil and property laws that persuaded the two groups to readily accept the authority of the Methodist Missionary's appointed magistrates.

Residents of the Oregon region seemed destined to determine their future. Congress continued to ignore the region and those residing there. In an effort to gain Territorial recognition, on January 28, 1839, Lewis F. Linn, a United States Senator from Missouri, ${ }^{17}$ presented a petition to the U. S. Senate (Scott, p. 36). The petition had been signed by thirty-six settlers of the Oregon region in which they stated the importance of accepting Oregon as a Territory of the United States, citing its natural resources and the need for a civil government to guide its residents. The petition failed to generate Congressional response.

17 Senator Linn was an avid champion of the settlers in Oregon and the claims of the United States to the Oregon Territory. Senator Linn did not live to see Oregon become a state. However, Linn County was named in his honor for his untiring efforts to obtain United States Territorial recognition for Oregon (Scott, pp. 37-38). 
In 1840, another petition was again presented by Senator Linn (Scott, 37). This petition was signed by seventy Oregon inhabitants. Again, the Senate failed to act. By 1840 , it was estimated that 137 white Americans resided in the Oregon region: 29 percent, about forty, were connected with one of the religious missions in some capacity; 44 percent, about sixty, were Canadian settlers and former employees of the Hudson's Bay Company; The remaining 27 percent were American independents. The Canadian settlers joined with the American independents to form a politically influential group (Scott, p. 36).

In 1841 , the first of many parties of immigrants (111 persons) came to Oregon (Scott, p. 40). Hudson's Bay Company associates continued to enter the region, but were incessantly out-numbered by the arrival of additional American settlers. The area became composed of two distinct divisions: Americans and subjects of the British sovereign (Scott, p. 41). These two groups were further splintered into three groups: officers of the Hudson's Bay Company, considered to be members of the aristocratic English class; missionaries, regarded as American aristocrats, and; the designated common people, both American and British, who deeply resented their socially ascribed position.

In 1842 , another wagon train of immigrants (109 in the party) arrived in Oregon. It was becoming obvious that law and law enforcement would be necessary to maintain order. During that year, the Methodist Mission attempted to establish a formal civil government. Methodist leaders encouraged foreign born settlers to 
support their political endeavors. However, the Methodist were unable to gain any significant advocacy. Methodist Missionaries were unaware that there was also a movement among independent settlers to also deal officially with local issues.

In February of 1843 , behind closed doors, independent settlers met to consider the formation of a public government; discussion continued at a March meeting. The independent settlers expended great effort to ensure that the missionaries were unaware of their efforts to colonize. ${ }^{18}$ During the March meeting, they created and adopted resolutions to appoint a committee to develop the foundation for a formal civil government and provisions for military protection (Scott, p. 43).

In May of 1843, the committee presented its report which was passed by a vote of fifty-two to fifty. During this meeting the following elected offices were recognized: Supreme Judge; Sundry Subordinate Officers, and; a Legislative Committee of nine persons ${ }^{19}$ to prepare and report necessary laws to be under the control of the new government.

Despite their clandestine meetings, on July 5, 1843, proposed officials and the Legislative Committee's proposed laws were publicly voted on and accepted by the majority of voting settlers in the region (Scott, p. 43). These laws were referred

18 The settlers met under the guise of developing maneuvers that would be useful in protecting their herd from attacks by wild animals. Behaving as clandestine Machiavellians, the independents felt compelled to announce a cause for their second meeting. They used the same deceptive theme the need to further develop plans to protect their livestock from untamed beasts (Scott, p.42). 19 The Legislative Committee of nine persons consisted of: Robert Moore, Robert Shortess, Alanson Beers, Thomas J. Hubbard, William H. Gray, James A. O'Neil, Robert Newell, David Hill and William P. Dougherty (Deady, p.80). 
to as the Organic Code. ${ }^{20}$ The Organic Code was a reflection of...the adoption of the

Ordinance of 1787. As a reflection of the provisions contained in the 1789

Ordinance, a preamble to law was adopted, as well as a bill of rights. There was commitment to religion, schools, and initially, respect for the rights of Native Americans.

20 Organic code/law - ...made up of many parts, but being a unit; coordinated, the United States is an organic unit made up of 50 states...that is part of the structure or constitution of a person or thing; fundamental: The Constitution is the organic law of the United States...(World Book Dictionary, p. 1464). 


\section{ARTICLES OF COMPACT ${ }^{21}$}

\section{CONTAINED IN THE ORDINANCE OF 1787, FOR THE GOVERNMENT OF THE NORTH- WEST TERRITORY ${ }^{22}$}

\section{JULY 13, 1789 \\ Compact between states and the people and states and the territory.}

Right of religious worship guaranteed.

Rights of person and property.

Schools to be encouraged Good faith to be observed to the Indians; their rights and property to be respected.
...For extending the fundamental principles of civil and religious liberty, which forms the basis whereon these republics, their laws, and constitutions are erected; to fix and establish those principles as the basis of all laws, constitutions and government, which forever, also, for the establishment of states, and permanent government therein, and for their admission to a share in the federal councils on an equal footing with the original states, at as early periods as may be consistent with the general interest: (p. 80).

It is hereby ordained and declared, by the authority aforesaid, That the following articles shall be considered as articles of compact between the original states and the people, and states in the said territory, and forever remain unalterable, unless by common consent, to wit:(p.80).-

\section{ARTICLE I}

No person demeaning himself in a peaceable and orderly manner, shall ever be molested on account of his mode of worship or religious sentiments, in said territory.

\section{ARTICLE II}

The inhabitants of said territory shall always be entitled to the benefits of the writ habeas corpus, and of the trial by jury; of a proportionate representation of the people in the legislature, and of judicial proceedings according to the course of the common law. All persons shall be liable, unless for capital offenses, where the proof shall be evident, of the presumption great. All fines shall be moderate, and no cruel or unusual punishments shall be inflicted. No man shall be deprived of his liberty or property, but by the judgment of his peers, or the law of the land. and, should the public exigencies make it necessary, for the common preservation, to take any person's property, or to demand his particular services, full compensation shall be made for the same. And, in the just preservation of rights and property, or have force in the said territory, that shall, in any manner whatever, interfere, or affect private contracts or engagements, bona fide, and without fraud previously formed. (p. 81).

\section{ARTICLE III}

Religion, morality, and knowledge, being necessary to good government and the happiness of mankind, schools and the means of education shall be forever encouraged. The utmost good faith shall always be observed towards the Indians; their lands and property shall never be taken from them without their consent; and in their property, rights and liberty, they shall never be invaded or disturbed, unless unjust and lawful wars, authorized by congress; but laws founded in justice and humanity, shall from time to time, be made for preventing wrongs being done to them and for preserving peace and friendship with them (P. 81). 


\section{ARTICLES OF COMPACT}

\section{CONTAINED IN THE ORDINANCE OF 1787, FOR THE GOVERNMENT OF THE NORTH- WEST TERRITORY}

\begin{tabular}{|c|c|}
\hline $\begin{array}{r}\text { Slavery nor } \\
\text { involuntary servitude } \\
\text { not to exist in the } \\
\text { territory other than } \\
\text { for crimes. } \\
\text { What fugitives from } \\
\text { labor or service may } \\
\text { be reclaimed in } \\
\text { another state. } \\
\text { Resolution of April } 23, \\
1784, \text { repealed. }\end{array}$ & $\begin{array}{l}\text { ARTICLE VI } \\
\text { There shall be neither slavery nor otherwise than in the punishment of } \\
\text { crimes, whereof the party shall have been duly convicted; Provided, always } \\
\text { That any person escaping in the same, from whom labor or services is } \\
\text { lawfully claimed in any one of the original states, such fugitive may be } \\
\text { lawfully reclaimed, and conveyed involuntary servitude in the aaid territory, } \\
\text { to the person claiming his or her labor or service as aforesaid (P. 83). } \\
\text {... Be it ordained by the authority aforesaid, That the resolutions of the } 23 r d \text { of } \\
\text { April, I784, relative to the subject of this ordinance, be, and the same are } \\
\text { hereby repealed, and declared null and void. } \\
\text { Done by the United States in congress assembled, the 13th day of July, in } \\
\text { the year of our Lord } 1787, \text { and of their sovereignty and independence the } 12 \text { th } \\
\text { CHARLES THOMPSON, sec'y }\end{array}$ \\
\hline
\end{tabular}

Yet, included in the Organic Code were laws prohibiting slavery and restricting voting rights to free male descendants of white men twenty-one years of age or older, thereby excluding free black and full blooded Native American men (McLagan, pp. 23-25).

Oregon white residents did not favor the presence of slaves in their region. Settlers lured to the Pacific coast by the promise of free land and an opportunity for prosperity, did not welcome the competition of free labor. In addition, a large percentage of settlers were uncomfortable with the idea of fraternizing with blacks, as slaves or free persons.

The Oregon governing body was comprised of a Legislative Committee of nine, a Judiciary consisting of a Supreme Court, Probate Court and Justices of the Peace. 


\begin{tabular}{|c|c|c|c|c|c|}
\hline YEAR & OFFICE & JUDGE & SEAT & TERM & COMMENTS \\
\hline 1844 & Circuit Judge & I. L Babcock* & & May 1844 & $\begin{array}{c}\text { Resigned Nov. } 11,1844 \\
\text { position remained vacant }\end{array}$ \\
\hline 1844 & District Judge & A. L. Lovejoy\# & Clackamas & $1844-1845$ & \\
\hline 1845 & Circuit Judge & J. W. Nesmith & & April 1845 & \\
\hline 1845 & Supreme Judge & Nathaniel Ford & Oregon City & (Not Indicated) & Ford declined \\
\hline 1845 & Supreme Judge & Peter H. Burnett & & $\begin{array}{c}\text { Aug., } 1845- \\
\text { Dec. } 29,1846\end{array}$ & Elected to replace Ford \\
\hline 1848 & Supreme Judge & Columbia Lancaster & & $\begin{array}{l}\text { June } 1848 \text { - } \\
\text { Sept. } 1848\end{array}$ & \\
\hline 1849 & Chief Justice & Wm. P. Bryant & 1st District. & 1849 & Resigned \\
\hline 1849 & Chief Justice & Thomas Nelson & & 1849 & Replaced Bryant \\
\hline 1849 & Justice & Peter G. Bumett & & (Not Indicated) & \\
\hline 1849 & District Judge & Orville C. Pratt & Tualitin County & $1849-1852$ & Pratt replaced Turney \\
\hline 1849 & Supreme Judge & J. Quinn Thornton & & Feb. $9,1847-$ & \\
\hline 1849 & District Judges & $\begin{array}{c}\text { B. O. Tucker } \\
\text { H. Higgins } \\
\text { Wm. Burris }\end{array}$ & Tuality & Not Indicated & \\
\hline 1850 & Justice & William Strong & 3d District. & Aug., 1850 & Replaced Bumett \\
\hline 1850 & Justice & James Turney & & (Not Indicated) & Turney did not accept \\
\hline \multicolumn{6}{|c|}{$\begin{array}{l}\text { \#I. L. Babcock, MD ran for office against the following: J W. Nesmith, P. H. Burnett, P. G. Stewart, Osborn Russell, and O. } \\
\text { Johnson. } \\
\text { \#A. L. Lovejoy, one of the founders of Portland, Oregon. }\end{array}$} \\
\hline
\end{tabular}

An entire system of law was enacted, parts of which were adopted from the State of Iowa (Scott, p. 43).

This action by white settlers in the Oregon region depleted British rule and subsequently, Great Britain's business claims in the area. Having lost its formidable controlling presence, Britain did not attempt to revive trading power. Most residents, British subjects included, accepted the authority of the new government. This form of solidarity among settlers, should have prompted the United States Congress to recognize its obligation to Northwest residents and the need to claim the Oregon region as property of the United States (Scott, p. 44). Yet, Congress failed to appropriately respond.

By the end of 1843 , the population of the Oregon region had increased to over 800 white residents (Scott, p. 44). See POPULATIONS, APPENDIX IV. With this 
growth and recognizing the need for stronger government, the laws of 1843 were amended in 1844 by the Oregon Legislative Committee and included exclusionary laws (Scott, p. 46).

\section{AN ACT PASSED \\ BY THE \\ PROVISIONAL LEGISLATURE \\ 1844 \\ AND \\ SPONSORED BY \\ PETER H. BURNETT ${ }^{23}$}

\section{An Act Regard to Slavery and Free negroes and Mulattoes.}

Section 1. That slavery and involuntary servitude shall be forever prohibited in Oregon. Section 2. That in all cases where slaves have been or shall hereafter be brought into Oregon, the Owners of such slaves shall have the term of three years from the introduction of such slaves to remove them from the (Oregon) Country.

Section 3. That if such owners of slaves shall neglect or refuse to remove such slaves from the (Oregon) country within the time specified in the preceding section, such slaves shall be free.

Section 4. That when any free Negro or Mulatto shall have come to Oregon, he or she, as the case may be, if of the age of eighteen or upward, shall remove from and leave the country within the term of two years for males and three years for females from the passage of this act - . - -

Section 5. That if such free Negro or Mulatto be under the age aforesaid, the terms of time specified in the preceding section shall begin to run when he or she shall arrive at such age.

Section 6. That if any such free Negro or Mulatto shall fail to quit the (Oregon) country as required by this act, he or she may be arrested upon the warrant issued by some justice of the peace, and if guilty upon trial before such justice, shall receive upon his or her bare back not less than twenty not more than thirty-nine stripes, to be inflicted by the constable of the proper county.

Section 7. That if any free Negro or Mulatto shall fail to quit the country within the term of six months after receiving such stripes, he or she shall again receive the same punishment once in every six months until he or she shall quit the (Oregon) country.

Section $8 . \quad$ That when any slave shall obtain his or her freedom the time specified in the fourth section shall begin to run from the time when such freedom shall be obtained.

However, when the Committee convened, two members recommended that

the Exclusionary Laws be conditional if black individuals posted a bond under

promise of proper behavior (McLagan, p. 26). The recommendation was adopted

and amended to include penalties. ${ }^{24}$ The law was to take effect in 1846 , but was

23 Hill, Daniel G., Jr., (1932), The Negro In Oregon: A Survey, a Thesis, University of Oregon, Eugene, Oregon, pp. 19-23.

24 Initially, penalty referred to hard labor, later changed to whip lashing (McLagan, p. 26). 
repealed in $1845 .^{25}$ Some white settlers were agitated by local incidents which increased their intolerance for people of color.

The Cockstock Affair ${ }^{26}$ is reported to have provoked consideration of increased inequitable laws regarding the exclusion of black residents in the Oregon region (Oregon Spectator, p. 2) ${ }^{27}$ Although such laws were not initially adopted, within five days of the incident, the Legislative Committee met and out of fear, formulated a military organization (McLagan, p. 25).

25 Exclusionary Laws were finally formally adopted by 1850 (McLagan, p. 26).

26 The Cockstock Affair occurred in Oregon City in 1844. James Saules, an Oregon black settler and Cockstock, a Wasco native American, were involved in a dispute regarding the ownership of a horse. To exploit local prejudice of Native Americans, Saules accused Cockstock of threatening the lives of white settlers in the area. Cockstock angered by the false accusation, recruited several members of his tribe and traveled to Willamette Falls to confront Saules.

During the struggle, George LeBreton (a clerk and recorder for the Oregon Provisional Government) was fatally wounded. Cockstock was killed by Winslow Anderson (also referred to as George Winslow, another African American. See CHAPTER VII. Area residents blamed Saules and Anderson (Winslow) for the incident, threatened their lives and encouraged them to leave the area. Saules issued a counter threat, stating he could provoke local Native Americans into attacking area white settlers. The fatal fight is considered to have been the first major confrontation between Native Americans and white settlers. Cognizant of Saules threat, white settlers and law makers became anxious about the possibility of a Black and Native American up-rising (Moreland, et al., pp. 4-5). See APPENDIX III: 1851, September 2, Oregon Spectator, Winslow Anderson Declared Notorious, Ordered From Oregon Territory, and also, 1851, September 2, Oregon Spectator, Winslow Anderson Said To Be Mulatto reported Responsible For Brave Among Oregon City Indians.

Another version: George Winslow (Winslow Anderson), a black man, hired Cockstock, a Native American, to clear a tract of land on his farm. He promised to pay him with a horse in return for his work. Winslow sold the horse and the farm to James D. Saules. Upon completion of his job, Cockstock asked for payment. Saules refused to give him the horse. Cockstock took the horse he felt he had earned.

Elijah White, the local Indian agent, ordered Cockstock to return the horse. Cockstock complied but promised revenge against both Winslow and Saules. White offered a $\$ 100$ reward for Cockstock's peaceful capture. This led to a bloody feud, killing Cockstock and two other men including George Le Breton and wounding several others.

White reported the incident to the U. S. Secretary of War fearing an Indian War. Oregon Legislator reacted to this perceived crisis (McLagan, pp. 25-26).

An article featuring the following headline appeared in the newspaper, the Oregon Spectator in 1851: Winslow Anderson Declared Notorious, Ordered From Oregon Territory p. 2, (Davis, p. ). 27 Davis, Oregon Spectator., Winslow Anderson Said To be Mulatto Reported Responsible For Brave Among Oregon City Indians, p. 2. 
Legislative amendments provided for the office of Governor, ${ }^{28}$ having veto power and the replacing the Legislative Committee of nine with that of a house of representatives, to be comprised of not less than thirteen and not more than sixty-one members (Scott, p. 46). Having formulated a governing body with power to enact and enforce laws as the region continued to grow, white settlers felt efficient, prosperous and somewhat protected. Missionaries, who occupied most governing positions were respected by the majority of local settlers and revered by a few others. Yet, during this period of residential growth among white settlers, Native Americans were increasingly frustrated by their inability to regain control of their land and its natural resources. In 1846, Texas was annexed to the U. S. adding more than 100,000 Native Americans to the nation's population. However, this did not diminish Indian animosities. Most Native Americans felt hopelessly caught in a losing battle. They were surrounded with hostile neighbors and disastrously burdened with catastrophic diseases.

In 1847 , the demise of missionaries, Dr. and Mrs. Whitman during what became known as the Whitman Massacre, reputedly led to Oregon Territorial recognition by Congress and the subsequent lost of control and ownership of the Oregon region by Native Americans. ${ }^{29}$ In retaliation, white settlers took legal action

$28 \quad$ George Abernethy was the first Governor of the Oregon Territory. As governor he lobbied for the passage of the Congressional Oregon Bill that provided the donation of public land to attract new settlers to the area. This bill aided in the rapid rise of Oregon's white population (Scott, p. 46). 29 Dr. Marcus and Mrs. Narcissa Whitman were missionaries who established the Waiilatpu Mission in 1836, within the Cayuse (Native American tribe) Territory. The mission served as a way station. The Cayuses were not especially receptive to the placement of the station in their territory and resented its attraction to strangers. As a means of pacifying their complaints, Dr. Whitman befriended the tribe becoming their teacher. However, each season hundreds of white men and their families 
to restrict the rights of Northwest Native Americans including any righteous claims

to their land. This action provided white settlers with their established legal right to claim land.

Provisional Governor George Abernathy sent State Supreme Court Judge J. Quinn Thornton to Washington, D. C., as ambassador representing Oregon regional white settlers and their struggle for Territorial recognition and rights and eventually, statehood (Scott, p. 49).

continued to pass through the Cayuse country eyeing the area as potential land for a settlement (Baxter, p. 20).

In 1847, a group of arriving settlers spread an epidemic of measles, ultimately killing hundreds of members of the Cayuse tribe (Clark, p. 159). On November 29, not understanding the disease or its effects, the Cayuses in retaliation attacked the mission killing Dr. Whitman, his wife and twelve to fifteen other white settlers. They held the remaining settlers as captives, who were subsequently rescued by Peter Skene Ogden, chief factor of the Hudson Bay Company. This event was cited by most historians as the Whitman Massacre and eventually led to the Cayuse War of 1848 (Clark, p. 159).

As a result of revolt, authorities deemed it necessary to punish Native Americans promptly to avert any other threat of uprisings. At the urgency of Governor Abernethy and escalating hatred for Indians, Captain H. A. G. Lee, assembled fifty men armed with rifles (Clark, p. 248). On December 21,1947 , with additional organized troops in pursuit, the army attacked the Cayuse and their recruited allies, the Palouse tribe. The Cayuse were driven from the Oregon Territory (Clark, p. 249).

In 1850, after peace had been re-established, the Cayuse were told they could return but only after surrendering five of the guilty ring-leaders. The five were tried, testifying that they believed the Whitman's were poisoning their people as a means of confiscating their land. In 1850, despite their plea, the five were convicted and executed (hanged) at Oregon City, to avenge the "murders" of American citizens (Scott, p. 48).

With the increasing migration of American whites to the northwest territory, tribes such as Bannock, Chinook, Klamath, Modoc and Nez Perce, eventually loss their land and were ultimately forced to live as second class residents with out authority and often restricted to particular jurisdictions such as reservations (Baxter, p. 12). Native American populations originally thought to have numbered in the hundreds of thousands were diminished to mere thousands and in some geographic locations, much less (Champagne, p. xvii).

After the massacre, efforts were increased to obtain statehood for the Oregon Territory. Settlers felt the need for protection by the United States government from Native Americans and other threats to the stability of their settlements (Scott, p. 49). 


\section{ORGANIC LAW ${ }^{30}$ \\ OF THE PROVISIONAL GOVERNMENT OF OREGON ${ }^{31}$}

\begin{tabular}{|c|c|}
\hline $\begin{array}{r}\text { July } 5,1845 \\
\text { Preamble }\end{array}$ & $\begin{array}{l}\text { We, the people of Oregon territory, for the purposes of mutual } \\
\text { protection, and to secure peace and prosperity among ourselves agree to } \\
\text { adopt the following laws and regulations, until such time as the United } \\
\text { States of America extend their jurisdiction over us:(p. 58). }\end{array}$ \\
\hline $\begin{array}{r}\text { Division of territory into } \\
\text { districts }\end{array}$ & $\begin{array}{l}\text { Be it enacted, therefore, by the free citizens of Oregon territory, That the } \\
\text { said territory, for the purposes of temporary government, be divided into } \\
\text { not less than three nor more than five districts, subject to be extended to a } \\
\text { greater number when an increase of population shall require (p. 58). }\end{array}$ \\
\hline Basis of government & $\begin{array}{l}\text { For purposes of fixing the principles of civil and religious liberty, as the } \\
\text { basis of all laws and constitution of government that may hereafter be } \\
\text { adopted, - }\end{array}$ \\
\hline Articles of compact & $\begin{array}{l}\text { Be it enacted, -That the following articles be consider articles of } \\
\text { compact among the free citizens of this territory: (p. } 58 \text { ) }\end{array}$ \\
\hline & ARTICLE I \\
\hline $\begin{array}{l}\text { Freedom of religious } \\
\text { worship and sentiment }\end{array}$ & $\begin{array}{l}\text { Sec. 1. No person demeaning himself in a peaceable and orderly manner, } \\
\text { shall ever be molested upon account of his mode of worship, or religious } \\
\text { sentiments ...(p. } 58) \text {. }\end{array}$ \\
\hline $\begin{array}{r}\text { Habeas corpus, trial by } \\
\text { jury, representation, and } \\
\text { the common law } \\
\text { Bail } \\
\text { Fines and punishment } \\
\text { liberty of person }\end{array}$ & $\begin{array}{l}\text { Sec. } 2 . \text { The inhabitants of said territory shall always be entitled to the } \\
\text { benefits of habeas corpus and trial by jury, of a proportionate } \\
\text { representation of the people in the legislature, and of judicial proceedings, } \\
\text { according to the course of common law. All persons shall be bailable, } \\
\text { unless for capital offenses, where the proof shall be evident, or the } \\
\text { presumption great. All fines shall be moderate, and no cruel or unusual } \\
\text { punishment inflicted. No man shall be deprived of his liberty, but by the } \\
\text { judgment of his peers or the law of the land; and should the public } \\
\text { exigencies make it necessary for the common preservation, to take any } \\
\text { person's property, or to demand his particular services, full compensation } \\
\text { shall be made for the same; and in the just preservation of rights and } \\
\text { property, it is understood and declared, that no law ought ever to be made, } \\
\text { or have force in said territory, that shall, in nay manner whatever, interfere } \\
\text { with or affect private contracts or engagements, bona fide and without } \\
\text { fraud, previously formed (p. 59). }\end{array}$ \\
\hline $\begin{array}{l}\text { Religion, morality and } \\
\text { schools. } \\
\text { Faith towards the Indians. } \\
\text { Property not to be taken } \\
\text { from them without their } \\
\text { consent. } \\
\text { Not to be disturbed except } \\
\text { in lawful war } \\
\text { Laws to be passed from } \\
\text { time to time to prevent } \\
\text { injustice being done them }\end{array}$ & $\begin{array}{l}\text { Sec. 3. Religion, morality, and knowledge, being necessary to good } \\
\text { government and the happiness of mankind, schools and the means of } \\
\text { education shall be forever encouraged. The utmost good faith shall always } \\
\text { be observed towards the Indians; their lands and property shall never be } \\
\text { taken from them without their consent; and in their property, rights and } \\
\text { liberty, they shall never be invaded or disturbed, unless unjust and lawful } \\
\text { wars, authorized by the representatives of the people, but laws founded in } \\
\text { justice and humanity, shall from time to time, be made for preventing } \\
\text { injustice being done to them, and for preserving peace and friendship with } \\
\text { them (p. 59). }\end{array}$ \\
\hline
\end{tabular}

30 Deady, M. P., compiler and annotator, (1866), The Organic and Other General laws of Oregon Together With the National Constitution and Other Pubic Acts and Statues of the United States: $1845-1864$, Henry L. Pittock, State Printer, Portland, Oregon, pp. 58-63.

$31 \quad$ Ibid., the Organic Law was prepared by Messrs. Lee, Newell, Applegate(Jesse), Smith and McClure, a subcommittee of the legislative committee at its session, 24 June 1845, Oregon City, Oregon (footnote 1, p. 58) 


\section{ORGANIC LAW}

\section{OF THE PROVISIONAL GOVERNMENT OF OREGON}

\begin{tabular}{|c|c|}
\hline Inhibition of slavery & $\begin{array}{l}\text { Sec. 4. There shall be neither slavery nor involuntary servitude in said } \\
\text { territory, otherwise than for the punishment of crimes, whereof the party } \\
\text { shall have duly convicted...(p. 59). }\end{array}$ \\
\hline $\begin{array}{l}\text { Right to bear arms. } \\
\text { Unreasonable searches and } \\
\text { seizures. Freedom of the } \\
\text { press. Person not to be } \\
\text { twice tried. Right of } \\
\text { peaceful assemblage and } \\
\text { discussion. }\end{array}$ & $\begin{array}{l}\text { Sec. } 5 . \text { No person shall be deprived of the right of bearing arms in his own } \\
\text { defense; no unreasonable searches or seizures shall be granted; the freedom } \\
\text { of the press shall not be restrained; no person shall be twice tried for the } \\
\text { same offense; nor the people deprived of the right of peaceably assembling } \\
\text { and discussing any matter they may think proper; nor shall the right of } \\
\text { petition ever be denied. }\end{array}$ \\
\hline \multirow[t]{2}{*}{$\begin{array}{r}\text { Right of petition. } \\
\text { Powers of government to be } \\
\text { divided into three } \\
\text { departments. No person } \\
\text { belonging to one } \\
\text { department to exercise } \\
\text { powers of the other. }\end{array}$} & $\begin{array}{l}\text { Sec. 6. The power of the government shall be divided into three distinct } \\
\text { departments:- the legislative, executive and judicial; and no person or } \\
\text { persons belonging to one of these departments, shall exercise any of the } \\
\text { powers properly belonging to either of the others, except in cases herein } \\
\text { directed or permitted. }\end{array}$ \\
\hline & $\mathbf{A R}$ \\
\hline $\begin{array}{r}\text { Legislative power, how } \\
\text { vested. } \\
\text { Number of representatives } \\
\text { and how chosen. }\end{array}$ & $\begin{array}{l}\text { Sec. } 1 . \text { The legislative power shall be vested in a house of representatives, } \\
\text { which shall consist of not less than thirteen nor more than sixty-one members, } \\
\text { whose numbers shall not be increased more than five at any one session, to } \\
\text { be elected by the qualified electors at the annual election, to giving to each } \\
\text { district a representative in the ration of its population (excluding Indians) } \\
\text { and the said members shall reside in the district for which they shall be } \\
\text { chosen; and in case of vacancy by death, resignation, or otherwise, the } \\
\text { executive shall issue his writ to the district where such vacancy has occurred, } \\
\text { and cause a new election to be held...(p.60)... }\end{array}$ \\
\hline $\begin{array}{r}\text { shall give opinions to } \\
\text { legislation } \\
\text { Supreme court given } \\
\text { original jurisdiction in } \\
\text { criminal cases }\end{array}$ & $\begin{array}{l}\text { Sec. 8. The judicial power shall be vested in a supreme court, and such } \\
\text { inferior courts of law, equity and arbitration, as may by law from time to time } \\
\text { be established. The Supreme Court shall consist of one judge, who shall be } \\
\text { elected by the house of representatives, ...the supreme court shall have } \\
\text { appellate jurisdiction only...shall hold two sessions annually...first Mondays } \\
\text { of June and September, and at such Iplaces as by law directed. The supreme } \\
\text { court shall have a general superintending control over all inferior courts of } \\
\text { law...The supreme court shall have power to decide upon and annual any } \\
\text { laws contrary to the provisions of these articles of compact, and whenever } \\
\text { called upon by the house of representatives, the supreme judge shall give his } \\
\text { opinion, touching the validity of any pending measure. The house of } \\
\text { representatives may, hereafter, provide by law for the supreme court having } \\
\text { original jurisdiction in criminal cases (pp. 62-63). }\end{array}$ \\
\hline $\begin{array}{l}\text { What persons qualified to } \\
\text { vote and eligible to office }\end{array}$ & $\begin{array}{l}\text { Sec. } 10 \text { Every free male descendant of a white man, inhabitant of this } \\
\text { territory, of the age of twenty-one years and upwards, who shall have been } \\
\text { an inhabitant of this territory at the time of its organization, shall be } \\
\text { entitled to vote at the election of officers, civil and military, and be eligible } \\
\text { to any office in the territory; Provided, That all persons of the description } \\
\text { entitled to vote by the provisions of this section, who shall emigrate to this } \\
\text { territory after organization, shall be entitled to the rights of citizens, after } \\
\text { having resided six months in the territory. }\end{array}$ \\
\hline
\end{tabular}


Senator Benton, an avid supporter of American interest in the Pacific Coast, assisted Judge Thornton in drafting the Bill that would formally entitle Oregon to become recognized as a Territory of the United States (Scott, p. 49). However, this Bill contained a clause prohibiting slavery and a resistance to the slave-holding power of Congress (Scott, p. 49). ${ }^{32}$

Jefferson Davis and John C. Calhoun, objected to the anti-slavery wording expressed in the Bill. ${ }^{33}$ Nevertheless, the Senate managed to pass the Bill on August 13, 1848, which was signed immediately by President Polk (Scott, p. 49). The Oregon Territory was comprised of what would later be the states of Oregon, Washington and parts of Idaho and Montana west of the Rocky Mountains. It should be noted, there were no provisions for the living arrangements of Native Americans to whom the land belonged originally (Scott, p. 49). The gold rush in California attracted additional settlers to the Pacific West Coast. Oregon was also inundated, further diminishing any chance for Native Americans to regain control of their land. President Polk appointed General Joseph Lane as Territorial Governor ${ }^{34}$ of the new system of administration, thereby relieving Provisional Governor

32 It has been suggested, that settlers in the Oregon region objected to slavery out of respect for the liberty and the rights of all men regardless of color or race (Scott, p. 51). However, contemporary historians submit that white settlers had more selfish motives for refuting the admittance of slavery to the new land. There were few jobs and fewer resources - settlers wanted to ensure that their needs would and could be met without competing with free labor (Clark, p. ??).

This form of respect for freedom was not granted to Native Americans nor African Americans migrating to the region.

33 Thomas B. Benton's letter provided specific reasons for Jefferson Davis' and John C. Calhoun' objections. See APPENDIX VII.

34 General Joseph Lane (December 14, 1801-April, 1881), a democrat, the first Territorial Governor, was a delegate to 32nd and 33d Congress and a United States Senator (1859-1861). He was in command when the Mrs. Whitman was slain by the Cayuse Indians. See this CHAPTER, pp. 


\begin{abstract}
Abernathy ${ }^{35}$ from his temporary duties. Under the new government, the Oregon Territory prospered. ${ }^{36}$ In 1849 , Congress finally granted American settlers residing in the Oregon Territory official military protection (Scott, p. 38). ${ }^{37}$
\end{abstract}

19-20. He lost his prominence in public office presumably because of his pro-slavery position (Corning, p. 142).

35 George Abernathy, (October 7, 1807-May 2, 1877), first and only Provisional Governor of Oregon (1845-1849), came to Oregon as a Methodist missionary, experienced financial loss as a result of the Willamette flood of 1861, and eventually faded from public life (Corning, p. 1) 3616,000 square miles of land was allotted for public schools, and 26,000,000 acres to be divided among nine states, including Oregon, admitted to the Union since 1848 (Scott, p. 51). 37 Historians cite Oregon's distance from Washington D. C., as one reason early federal statesmen did not have an immediate interest in the land or its residents. However, a letter from Thomas B. Benton disputes this assertion, the delay was prompted by Oregon's decision on the slavery issue. This issue was discussed at length in this document. See Benton APPENDIX VII. 


\section{TERRITORIAL GOVERNMENT ${ }^{38}$}

\section{AN ACT \\ TO ESTABLISH THE TERRITORIAL GOVERNMENT OF OREGON}

\section{AUGUST 14, 1848 \\ Temporary government for territory of Oregon established.}

Proviso as to Indians in said territory.

Executive power to be vested in a government in a governor; his tenure of office, power, duties and emoluments.
Be it enacted by the senate and house of representatives of the United States of America in congress assembled. That from and after the passage of this act, all that part of the territory of the United States which lies west of the summit of the Rocky mountains, north of the forty-second degree of north latitude known as the territory of Oregon shall be organized into, and constitute a temporary government, by the name of the territory of Oregon: Provided, That nothing in this act contained shall be construed to impair the right of person or property now pertaining to the Indians in said territory, so long as such rights shall remain unextinguished by treaty between the United States and such Indians, or to affect the authority of the government of the United States, to make any regulation respecting such Indians, their lands, property, or other rights, by treaty, law or otherwise, which it would have been competent to the government to make if this act had never passed: and Provided also, That the title to the land, not exceeding six hundred and forty acres, now occupied as missionary stations among the Indian tribes in said territory, together with the improvements thereon, be confirmed and established in the several religious societies to which said missionary stations respectively belong; and Provided further, That nothing in this act contained shall be construed to inhibit the government of the United States from dividing said territory into two or more territories, in such manner and at such times as congress shall deem convenient and proper, or from attaching any portion of said territory to any other state or territory of the United States (p. 66). ${ }^{39}$

Sec. 2. And be it further enacted, That the executive power and authority, in and ever said territory of Oregon, shall be vested in a government, who shall hold his office for four years,...The governor shall reside within said territory,... and receive the emoluments of superintendent of Indian Affairs, ${ }^{40}$ he may grant pardons and respites for offenses against the laws of said territory, and reproves for offenses against the laws of the United States, under the decision of the president can be made known thereon; he shall commission all officers who shall be appointed to office under the laws of the said territory, where, by law, such commissions shall be required, and shall take care that the laws be faithfully executed (p. 67)...

Sec. 4. And be it further enacted, That the legislative power and authority of said territory, shall be vested in a legislative assembly. The Legislative assembly shall consist of a council and a house of representatives. The council shall consist of nine members...(pp. 67-68)...

38 Deady, M. P., compiler and annotator, (1866), The Organic and Other General Laws of Oregon Together With the National Constitution and Other Pubic Acts and Statues of the United States: $1845-1864$, Henry L. Pittock, State Printer, Portland, Oregon, (pp. 66-76).

39 Ibid., by an act dated 2 March 1853 , the Territory of Washington was created out of that portion of the Territory of Oregon lying north of the mouth of the Columbia River to $46^{\circ}$ north latitude and eastward to the summit of the Rocky Mountains (footnote 1, p. 66).

40 Ibid., by an act dated 5 June 1850, the duties of superintendent of Indian Affairs were passed to a separate officer (footnote 1, p. 67). 


\section{TERRITORIAL GOVERNMENT}

\section{AN ACT \\ TO ESTABLISH THE TERRITORIAL GOVERNMENT OF OREGON}

\begin{tabular}{|c|c|}
\hline $\begin{array}{r}\text { AUGUST 14, 1848 } \\
\text { Qualifications of } \\
\text { voters. }\end{array}$ & $\begin{array}{l}\text { Sec. 5. And be it further enacted, That every white male inhabitant, above } \\
\text { the age of twenty-one years, who shall have been a resident of said territory at } \\
\text { the time of the passage of this act, shall be entitled to vote...Provided, That the } \\
\text { right of suffrage and holding office, shall be exercised only by citizens of the } \\
\text { United States above the age of twenty-one...(p. 69). }\end{array}$ \\
\hline $\begin{array}{r}\text { Judicial power; how } \\
\text { vested }\end{array}$ & $\begin{array}{l}\text { Sec. 9. And be it further enacted, That the judicial power of said territory } \\
\text { shall be vested in a supreme court, district courts, probate courts, and in } \\
\text { justices of the peace. The supreme court shall consist of a chief justice and two }\end{array}$ \\
\hline$\frac{\text { AUGUST 18, } 1848}{\text { District court. }}$ & $\begin{array}{l}\text { associates justices, any two of whom shall constitute a quorum,...the said } \\
\text { territory shall be divided into three judicial districts, and a district court shall } \\
\text { be held in each of said districts, by one of the justices of the supreme court, at } \\
\text { such times and places as may be prescribed by law....Provided, That justices of } \\
\text { the peace shall not have jurisdictions in any case in which the title to land shall }\end{array}$ \\
\hline $\begin{array}{r}\text { Each district court to } \\
\text { appoint its clerk. } \\
\text { Marshal. }\end{array}$ & $\begin{array}{l}\text { in any wise come in question, or where the debt or damages claimed, shall } \\
\text { exceed one hundred dollars...Each district court or the judge thereof, shall } \\
\text { appoint its clerk....There shall also be a Marshal for the territory } \\
\text { appointed...(pp. 71-73). }\end{array}$ \\
\hline $\begin{array}{r}\text { Governor, secretary } \\
\text { chief justice associate } \\
\text { justice, attorney and } \\
\text { Marshal to be } \\
\text { appointed by the } \\
\text { president }\end{array}$ & $\begin{array}{l}\text { Sec. 11. And be it further enacted, That the governor, secretary, chief justice, } \\
\text { and associate justices, attorney, and Marshal, shall be nominated, and by and } \\
\text { with the advice and consent of the senate, appointed by the president of the } \\
\text { United States...(p. 73). }\end{array}$ \\
\hline $\begin{array}{r}\text { AUGUST 14, } 1848 \\
\text { And for presents to } \\
\text { Indians. }\end{array}$ & $\begin{array}{l}\text { Sec. 13. And be it further enacted, That the sum of ten thousand dollars be, } \\
\text { and is hereby appropriated, to be expended under the direction of the } \\
\text { president of the United States, in payment for the services and expenses of } \\
\text { such persons as have been engaged by the provisional government of Oregon, } \\
\text { in conveying communications to and from the United States, and the } \\
\text { purchase of presents for such of the Indian tribes as the peace and quietude } \\
\text { of the country requires (p. 75). }\end{array}$ \\
\hline $\begin{array}{l}\text { Ordinance of } 1787 \\
\text { extended over Oregon. }\end{array}$ & $\begin{array}{l}\text { Sec. 14. And be it further enacted, That the inhabitants of said territory shall } \\
\text { be entitled to enjoy all and singular, the rights, privileges, and advantages } \\
\text { granted and secured to the people of the territory of the United States } \\
\text { northwest of the river Ohio, by the articles of compact contained in the } \\
\text { ordinance for the government of said territory, on the thirteenth day of July, } \\
\text { seventeen hundred and eighty-seven; and shall be subject to all the conditions, } \\
\text { and restrictions, and prohibitions in said articles of compact imposed upon the } \\
\text { people in said territory; and the existing laws now in force in the territory of } \\
\text { Oregon, under the authority of the provisional government established by the } \\
\text { people...(p. 76). }\end{array}$ \\
\hline
\end{tabular}


However by 1849 , settlers felt the need to exclude all blacks from residing in Oregon territory. As such, they demanded and received a law disallowing any black residents from remaining in Oregon while prohibiting the inclusion of any new black families. ${ }^{41}$ The Oregon Spectator featured the article, Act Preventing Negroes or Mulatoes Coming To or Residing In Oregon Passed By Territory Legislature in 1849 (Oregon Spectator, p. 3). However, laws were often inconsistently enforced.

Excluding Native Americans, the population of Oregon grew from 12,000 during the 1850 's to over 300,000 in the 1890 's. In 1850 , Oregon's black population is reported to have been fifty-four. The Chinese population was reported to be zero. However, there is sufficient evidence that Chinese did reside and work in Oregon as early as the 1850 's. See CHAPTER X.

Also starting in 1850, Californians began committing genocide by killing and terrorizing Indians dwelling in that state (Champagne (1994) p. xvii). Intimidation and physical assaults against Chinese immigrants soon followed. Many California Native Americans and freed African Americans, also not welcomed in California, escaped to the Oregon region, followed by Chinese immigrants. However, each group eventually resided in Oregon under the threat of Exclusionary Laws. While African Americans, freed or slave, were officially denied residence, Native

$41 \quad$ Black Exclusion Law stipulated a penalty of $\$ 500$ for violators, including employers. The law remained in forced for five years and was repealed due to the efforts of local residents petitioning on behalf of several black citizens. Efforts were made to revive the law, suggesting the earlier repeal was unintentional (McLagan, pp. 26-28). 
Americans and Chinese immigrants residing in California were also not expected to migrate to Oregon.

White settlers owning slaves, guilty of ignoring the law, were fined and their slaves subjected sporadically to physical punishment, and/or banished from residence in the Territory. After Statehood, Chinese residents were excluded from owning land based on their foreign status. Chinese residents able to prove birth in the United States were also denied real-estate rights. In 1859, Oregon became the thirty-third state to be admitted to the Union.

Also, during that year the silver rush in Nevada, Arizona, Idaho, California and western Oregon brought prospectors, miners and explorers to the Pacific region. These mostly lawless adventurers entered Native American territory with ruthless determination to strike it rich, thereby further flaming Native American resentments.

Oregon enacted anti-black, anti-Indian and anti-Chinese laws as a means of controlling who could live and prosper in Oregon and who could not. See APPENDIX XXII. These legislative acts involving inequitable laws have been replicated for insertion in this document as reference to legal, although unjust, statutes. In addition, are laws citing and governing criminal violations and also the duties and responsibilities of legal and justice officials. 


\section{CHAPTER II \\ PORTLAND HISTORY \\ An Overview}

In 1843 , William Overton ${ }^{1}$ was credited with claiming the first property ${ }^{2}$ of what would become the heart of downtown Portland (Merriam, p. 14). A newcomer to the area, Overton became acquainted with General Amos Lawrence (A. L.) Lovejoy, ${ }^{3}$ an attorney and resident of Oregon City (Scott, p. 81 ). Overton offered to share his claim with Lovejoy if in return he (Lovejoy) would assist him in improving the land. Lovejoy accepted the offer. Lovejoy and Overton recognized that the site's topography distinguished the area as the most acceptable location for the positioning of a town (Scott, p. 81). Eventually, however, Overton turned his property interest over to Francis W. (F. W.) Pettygroove, ${ }^{4}$ a local businessman, in return for an outfit reported to be worth about $\$ 50$ (Scott, p. 82). This ended Overton's link to the emergence of the city of Portland.

\footnotetext{
1 William Overton came from Tennessee to Oregon in 1843. After claiming the Portland property, he ventured to the Sandwich Islands, but returned in poor health. Overton decided to go to Texas to care for his ailing mother. His need to move prompted the need to sell his property. Initially, he offered his share to Lovejoy, but changed to mind and ultimately sold his property to F. W. Pettygroove (Merriam, p. 14)..

2 Overton obtained his property as a result of the Donation Land Law. To compensate settlers for making any sacrifices necessary to migrate West, The United States Congress enacted the Donation Land Law. The law granted 320 acres to every white man and Indian half-breed (one parent white, the other Indian) who was a citizen of the United States, who became a resident of the territory by December 1, 1850. A Married woman was given a half-section of her own. Settlers migrating to Oregon after December 1, 1850 and before December 1, 1851, received half as much land (Clark, pp. 236-237)

A. L. Lovejoy, was from Groton, Massachusetts, educated at Cambridge and Amherst. His mother was a Lawrence, an east coast wealthy family. despite his affinity to labor, it was though that Lovejoy axed the first tree in Portland, thus paving the way for Oregon's timber industry (Scott, p.81.

4 F. W. Pettygroove was from Calawis, Maine, educated by the public school system and became a businessman. His ill heath eventually forced him to sell his property rights to Portland to relocate to the coast (Scott, p. 82).

5 The term outfit was not defined but concluded as reference to a team of horses (Chen, $p$. 114).
} 
In 1844, Pettygroove and Lovejoy had the property surveyed to establish boundaries; originally, the undeveloped property was less than two square miles in scope. The property was overgrown with trees which were cleared to make room for prospective buildings. Pettygroove and Lovejoy eventually erected a building in the midst of the small, by comparison to other towns, but ample plat. ${ }^{6}$ The building housed an employee during the winter who operated a make-shift store. They agreed, ultimately, to name the town, Portland. ${ }^{7}$

Although the presence of minorities in Portland during its development is not routinely recognized, a few black families resided in nearby communities (McLagan, pp. $80-85 .^{8}$ Few Native Americans resided within the Portland community. Chinese immigrants did not arrive in any significant numbers until the early 1850 's.

The city prospered financially and geographically as a result of business ventures led by John H. Couch, ${ }^{9}$ James Terwllliger, ${ }^{10}$ John Waymire, ${ }^{11}$ D. H.

6 The original claim was 640 acres (Merriam, p. 30).

7 Francis W. Pettygroove was originally from Maine and Asa Lovejoy was from Massachusetts. Pettygroove chose the name Portland, for Portland, Maine, and Lovejoy selected Boston, for Boston, Massachusetts. The toss of a coin decided the name Portland (Merriam, p. 15).

In 1845, after additional surveying, four streets were laid off making a plat of sixteen blocks Front Street followed by Water Street. Some streets were intended for private use while others were ear marked for public use. Streets were sixth feet wide; lots were fifty by one hundred feet (White, p. 85).

$8 \quad$ For example: Robin and Polly Holmes - 1844 - Son Lon accused of theft and almost hanged - dying a short time later (McLagan, $\mathrm{p}, 80$ ).

Reuben Shipley - 1850's - slave who bought freedom (McLagan, p. 81).

Lou Southworth - 1850's - slave who bought freedom (McLagan, p. 83).

Richard A. Bogle (ancestor of Richard Bogle - former Portland City Commissioner during 1980's and early 1990's), - 1851 - free man (McLagan, p. 84)

Rachel Beldon- 1843 - slave (McLagan, p. 85).

Jackson Berry - 1852 - slave - later freed (McLagan, p. 87).

Samuel Vose - 1850's or 1860's free man (McLagan, p. 87)

John Couch, for who Couch Street was named, was from Newburyport, Massachusetts, sailed to the West Indies. He developed a cargo merchandise business by buying goods from one area and selling them in another (White, p. 86). 
Lownsdale, ${ }^{12}$ and Dr. Ralph Wilcox. ${ }^{13}$ Formally incorporated in April 1851, Portland ${ }^{14}$ expanded to become the largest city in the state of Oregon. ${ }^{15}$ Portland was located in Multnomah County and during the period researched, was the residence of a major percentage of racial and ethnic minorities living within Oregon. As a result of this minority population concentration, research for this project was narrowed to the city of Portland.

Research for this project involved reading and applying Portland Ordinances that may have adversely affected racial and ethnic minorities. See APPENDIX XXIII. This document contains Ordinances passed by Portland City Council over the period from 1854-1886. Several Ordinances are cited to illustrate legislation related to criminal acts prevalent during the period of study. Other Ordinances are inserted to illustrate acts used to control the social practices and living arrangements of Chinese residing within the Portland community.

The names and positions of various members of Portland's administrative and legal systems during the time period of study are indicated to provide a historical and political perspective of individuals in power during that era (Scott, pp. 181-183).

10 James Terwilliger, for whom Terwilliger Boulevard was named, was from New York City, hunted buffalo and wild turkeys in Illinois and claimed to have built the first cabin, according to him in Portland (White, p. 86).

11 D. H. Lownsdale and business colleagues established a shingle company in Oregon (White, p. 87).

D. H. Lownsdale, grandfather of Harry Lownsdale, Multnomah County politician and businessman (White, p. 87).

13 Dr. Ralph Wilcox, was the first physician and school teacher in Portland (White, p. 87).

14 Named for Portland, Maine.

15 Portland was located in the northwestern section of the state straddling the Willamette River and its confluence with the Columbia River. 


\section{CITY OF PORTLAND OFFICERS 1851-1888 ${ }^{16}$}

1851 - Hugh D. O'Bryan. O'Bryan was born in 1813, Franklin County, Georgia, he grew upon among Cherokee Indians where his father was a missionary. Arrived in Oregon City in 1843. Participated in the Whitman Massacre against the Cayuses in 1847.

1852 - A. C. Bonnell. Bonnell was born in 1801, near Chathem, Morris County, New Jersey. Father was a soldier in the Revolution.

1853 - Simon B. Marye. Marye was an attorney by education. He was born in Marye Heights, Virginia.

1854 - Josiah Failing. Failing died in office. Failing was born in 1806, Fort Plain, Montgomery County, New York. Failing came to Oregon in 1851. A fatherly figure, known as Conscript Father was conservatively religious, a Baptist. He had an extreme interest in public schools. His father came to this country by way of New York, living in the Mahawk Valley among a nation of six American Native tribes.

1854 W. S. Ladd. Ladd was born in New Hampshire but arrived in Portland in 1850.

1855 - Fifth Mayor, George W. Vaughn. Vaughn was born in New jersey, came to Portland in 1850 . He ran a hardware business.

18656, 1857, 1858 - James O' Neil. O'Neil was a three term mayor. O'Neil was born in the Duanesburg, Schenectady County, New York. He served as an Indian Agent at Fort Lapwai, and also at the Colville reservation. (Merchant).

1858 - A. M. Starr. Starr was born in New York State and came to Portland in 1850.

1859 - S. J. McCormick. McCormick was born in Ireland. His company printed McCormick's Almanac - City Directory - Indian History.

1860 - George C. Robbins. A jeweler. Robbins moved to Nevada.

1861 - John M. Breck. Breck was born in Philadelphia, Pennsylvania in 1828. (Businessman).

1862, 1863 - W. H. Farrar. Farrar was born in Massachusetts. Farrar served two terms as mayor.

1864 - David Logan. Logan was an attorney. He ran for Congress three times.

1864, 1865 - Henry Failing. A Republican, Failing, the son of Josiah Failing - see 1854, was a banker. He was born in New York, New York. He was a public school trustee in the Portland system.

16 Scott, pp. 191-197. 


\section{CITY OF PORTLAND OFFICERS 1851-1888}

cont.

1866 - Mayor, T. J. Holmes. Died in office. Vacancy completed by Hamilton Boyd until election of Dr. J. A. Chapman.

1866, 1867, 1868 - Dr. J. A. Chapman. Dr. Chapman was born in Allegheny County, New York, in 1821. Served in the army in the South. Practiced medicine in Portland.

1968 - Hamilton Boyd. Boyd was an accountant. Served two years as county commissioner.

1869 - B. Goldsmith. Came to Portland by way of California. Goldsmith was also involved in mining property in Idaho.

1871 - Philip Wassermann. Wassermann was born in Germany in 1827 . He served two terms in the Oregon legislature.

1873 - Henry Failing. See Henry Failing 1864.

1877,1878 - W. S. Newbury. Newbury was born in Ripley, New York in 1834 . he lived in Chicago, Wisconsin, Sioux City, Iowa, and Iola, Kansas. He served in the Union army and was provost Marshall of Kansas and secretary of the State senate. He was a lawyer and owned a farm machinery business.

1879, 1880, 1881 - David P. Thompson. Thompson was born in Harrison county, Ohio, in 1834. He also served as governor of the Idaho Territory in 1875 .

1882, 183, 1884 - Dr. J. A. Chapman. See 1866.

$1885,1886,1887$ - John Gates. Gates was born in Maine. He was an engineer and an inventor.

1888 - Van B. DeLashmutt. DeLashmutt a banker and business man. 
City of Portland Officers 1851-1889 ${ }^{17}$

\begin{tabular}{|c|c|c|c|c|c|c|c|c|}
\hline Year & Mayor & Recorder & Marshal & $\begin{array}{l}\text { Police } \\
\text { Judge }\end{array}$ & Councilmen & First Ward & Second Ward & Third Ward \\
\hline 1851 & $\begin{array}{l}\text { Hugh D } \\
\text { O'Bryant* } \\
\text { (b. 1803) } \\
\text { (Georgia) }\end{array}$ & WS Caldwell* & - & - & $\begin{array}{c}\text { Robert Thompson* } \\
\text { Shubrick Norris* } \\
\text { George A Barnes* } \\
\text { Thomas G } \\
\text { Robinson* } \\
\text { LB Hastings* }\end{array}$ & - & - & - \\
\hline 1852 & $\begin{array}{c}\text { AC Bonell* } \\
\text { (b. 1801) } \\
\text { (New Jersey) } \\
\text { Simon B Marye* } \\
\text { (Virginia) } \\
\end{array}$ & SS Slater* & Wm Grooms & - & $\begin{array}{c}\text { WP Abrams* } \\
\text { AP Dennison* } \\
\text { Thomas Pritchard* } \\
\text { Abel G Tripp } \\
\text { Hiram Smith* }\end{array}$ & - & - & - \\
\hline 1853 & $\begin{array}{c}\text { Josiah Failing } \\
\text { (b. 1806) } \\
\text { (New York) }\end{array}$ & AC Bonnell* & $\begin{array}{l}\text { William } \\
\text { Grooms }\end{array}$ & - & $\begin{array}{c}\text { Robert Thompson* } \\
\text { WS Ladd* } \\
\text { John H Couch* } \\
\text { WP Abrams* } \\
\text { RN McLaren* } \\
\text { RN Field } \\
\text { Charles P Pillow* } \\
\text { HW Davis } \\
\text { Jonas Williams }\end{array}$ & - & - & - \\
\hline
\end{tabular}




\section{City of Portland Officers 1851-1889}

\begin{tabular}{|c|c|c|c|c|c|c|c|c|}
\hline Year & Mayor & Recorder & Marshal & $\begin{array}{l}\text { Police } \\
\text { Judge }\end{array}$ & Councilmen & First Ward & Second Ward & Third Ward \\
\hline 1854 & $\begin{array}{c}\text { WS Ladd* } \\
\text { (New Hampshire) }\end{array}$ & AP Dennison* & WL Higgins* & - & $\begin{array}{c}\text { AM Starr* } \\
\text { James Field, Jr. } \\
\text { Shubrick Norris* } \\
\text { Thomas Carter* } \\
\text { Willia McMillan } \\
\text { AD Fitch* } \\
\text { OJ Backus } \\
\text { AR Shipley } \\
\text { James Turnbull }\end{array}$ & - & - & - \\
\hline 1855 & $\begin{array}{c}\text { George W. } \\
\text { Vaughn* } \\
\text { (New Jersey) }\end{array}$ & $\begin{array}{c}\text { L Limerick } \\
\text { (resigned) } \\
\text { (replaced by) } \\
\text { Anthony L. } \\
\text { Davis* }\end{array}$ & $\begin{array}{l}\text { Thomas J } \\
\text { Holmes* }\end{array}$ & - & $\begin{array}{c}\text { George Kittridge* } \\
\text { John Green } \\
\text { HS Jacobs } \\
\text { Matthew Patton } \\
\text { Lewis Love* } \\
\text { John C Carson } \\
\text { Thomas Hartness* } \\
\text { EB Calhoun } \\
\text { George C Robbins* }\end{array}$ & - & - & - \\
\hline
\end{tabular}


City of Portland Officers 1851-1889

\begin{tabular}{|c|c|c|c|c|c|c|c|c|}
\hline Year & Mayor & Recorder & Marshal & Port Warden & Councilmen & First Ward & $\begin{array}{c}\text { Councilmen } \\
\text { Second Ward }\end{array}$ & Third Ward \\
\hline 1856 & $\begin{array}{c}\text { James O'Neill } \\
\text { (b. 1824) } \\
\text { (Schenectady, } \\
\text { New York) }\end{array}$ & AL Davis & $\begin{array}{l}\text { Thomas S. } \\
\text { Holmes* }\end{array}$ & - & $\begin{array}{l}\text { Robert Porter } \\
\text { AD Shelby } \\
\text { AB Elfedt } \\
\text { LM Starr* } \\
\text { WS Ladd* } \\
\text { William Beck } \\
\text { W Davis } \\
\text { SM Smith } \\
\text { James Burke }\end{array}$ & - & - & - \\
\hline 1857 & $\begin{array}{l}\text { James O'Neill } \\
\text { (see above) }\end{array}$ & Al Davis & SR Holcomb* & - & $\begin{array}{c}\text { JH Couch* } \\
\text { TJ Holmes* } \\
\text { AB Hallock* } \\
\text { Charles Hutchins } \\
\text { P Hardenburg } \\
\text { NS Coon } \\
\text { BF Goodwin } \\
\text { SG Reed } \\
\text { James M Blossom }\end{array}$ & - & - & - \\
\hline 1858 & $\begin{array}{l}\text { LM Starr* } \\
\text { (New York) }\end{array}$ & Alonzo Leland & SR Holcomb* & ZN Stanbury & $\begin{array}{c}\text { George C Robbins* } \\
\text { AP Ankeny } \\
\text { CP Bacon } \\
\text { TN Lakin } \\
\text { R Porter } \\
\text { TJ Holmes* } \\
\text { JC Carson* } \\
\text { William King } \\
\text { CS Kingsley*** } \\
\end{array}$ & & & \\
\hline
\end{tabular}




\section{City of Portland Officers 1851-1889}

\begin{tabular}{|c|c|c|c|c|c|c|c|}
\hline Year & Mayor & Recorder & Marshal & Port Warden & Councilmen & \multicolumn{2}{|c|}{$\begin{array}{c}\text { Councilmen } \\
\text { Second Ward }\end{array}$ Third Ward } \\
\hline 1859 & SJ McCormick & Noah Huber & JH Lappeus & & AB Hallock & & - \\
& (Ireland) & & & & JM Vansycke & & \\
& & & & & J Davidson & & \\
& & & & & AD Shelby & & \\
& & & & & MM Lucas & & \\
& & & & & JC Hawthorne & & \\
& & & & ACR Shattuck & & \\
& & & John Blanchard & & \\
\end{tabular}




\section{City of Portland Officers 1851-1889}

\begin{tabular}{|c|c|c|c|c|c|c|c|c|c|c|}
\hline Year & Mayor & Recorder & Marshal & Deputies & $\begin{array}{c}\text { Street } \\
\text { Commissione } \\
\mathbf{r} \\
\end{array}$ & $\begin{array}{l}\text { President of } \\
\text { City Council }\end{array}$ & Councilmen & $\begin{array}{l}\text { First Ward } \\
\text { Ward }\end{array}$ & $\begin{array}{l}\text { Councilmen } \\
\text { Second } \mathrm{W}\end{array}$ & rd Third \\
\hline 1860 & $\begin{array}{c}\text { George C } \\
\text { Robbins } \\
\text { (?) }\end{array}$ & O Risley & $\begin{array}{l}\text { James H } \\
\text { Lappeus }\end{array}$ & & & & $\begin{array}{l}\text { JC Ainsworth } \\
\text { J Davidson } \\
\text { AB Hallock* } \\
\text { AD Shelby } \\
\text { MM Lucas } \\
\text { WL Higgins* } \\
\text { ACR Shaw } \\
\text { ED Shattuck } \\
\text { Jacob Stitzel }\end{array}$ & - & - & - \\
\hline 1861 & $\begin{array}{c}\text { JM Breck* } \\
\text { (Philadelphia, } \\
\text { Pennsylvania) }\end{array}$ & O Riskley & $\begin{array}{l}\text { William } \\
\text { Grooms* }\end{array}$ & & & & $\begin{array}{c}\text { John McCraken } \\
\text { AB Hallock* } \\
\text { F Harbaugh } \\
\text { WL Higgins* } \\
\text { W C Hull } \\
\text { William M King } \\
\text { ER Scott } \\
\text { William Masters } \\
\text { John S White }\end{array}$ & Scott resigned - $v$ & acancy filled by & E Barr \\
\hline 1862 & $\begin{array}{c}\text { WH Farrar } \\
\text { (Massachusett } \\
\text { s) }\end{array}$ & JF McCoy & $\begin{array}{l}\text { William } \\
\text { Grooms* }\end{array}$ & & & & - & $\begin{array}{c}\text { Thomas A } \\
\text { Davis* } \\
\text { Thomas J } \\
\text { Holmes* } \\
\text { AB Hallock* }\end{array}$ & $\begin{array}{c}\text { O Risley } \\
\text { JM Breck } \\
\text { AP } \\
\text { Dennison* }\end{array}$ & $\begin{array}{c}\text { S Coffin* } \\
\text { CS Silvers } \\
\text { AG Walling }\end{array}$ \\
\hline 1863 & $\begin{array}{l}\text { WH Farrar } \\
\text { (see above) }\end{array}$ & JF Mc Coy & $\begin{array}{l}\text { William } \\
\text { Grooms }\end{array}$ & $\begin{array}{l}\text { AB Brannan } \\
\text { FM Arnold }\end{array}$ & AB Stewart & O Risley & - & $\begin{array}{l}\text { TJ Holmes* } \\
\text { AB Hallock* } \\
\text { N Williams }\end{array}$ & $\begin{array}{c}\text { O Risley } \\
\text { AP Dennison }\end{array}$ & $\begin{array}{c}\text { S Coffin } \\
\text { CS Silvers } \\
\text { AG Walling }\end{array}$ \\
\hline $\begin{array}{l}1863- \\
64^{18}\end{array}$ & $\begin{array}{c}\text { David Logan } \\
\text { (?) }\end{array}$ & JF McCoy & WB Clark & $\begin{array}{c}\text { TC Foreman } \\
\text { JN Skidmore* }\end{array}$ & Daniel Wright & $\begin{array}{l}\text { John M } \\
\text { Sutton }\end{array}$ & - & $\begin{array}{c}\text { Al Zieber } \\
\text { H Saxer } \\
\text { Alex Dodge }\end{array}$ & $\begin{array}{c}\text { John W. } \\
\text { Sutton } \\
\text { lA Austin } \\
\text { PS Watson }\end{array}$ & $\begin{array}{l}\text { MM Lucas } \\
\text { Joseph Knott } \\
\text { David } \\
\text { Monastes }\end{array}$ \\
\hline
\end{tabular}


City of Portland Officers 1851-1889

\begin{tabular}{|c|c|c|c|c|c|c|c|c|c|c|}
\hline Year & Mayor & Recorder & Marshal & Deputies & $\begin{array}{c}\text { Street } \\
\text { Commissione } \\
\mathbf{r}\end{array}$ & $\begin{array}{l}\text { President of } \\
\text { City Council }\end{array}$ & Councilmen & $\begin{array}{l}\text { First Ward } \\
\text { Ward }\end{array}$ & $\begin{array}{l}\text { Councilmen } \\
\text { Second }\end{array}$ & ard Third \\
\hline $1864-65$ & $\begin{array}{c}\text { Henry } \\
\text { Failing* } \\
\text { (b. 1834) } \\
\text { (New York) }\end{array}$ & JF McCoy & Henry Hoyt & - & $\begin{array}{c}\text { Nelson } \\
\text { Northrump }\end{array}$ & - & - & $\begin{array}{c}\text { James W } \\
\text { Cook } \\
\text { John } \\
\text { McCraken } \\
\text { AM Starr* } \\
\end{array}$ & $\begin{array}{c}\mathrm{Wm} \mathrm{H} \\
\text { Bennett* } \\
\text { JJ Hoffman } \\
\text { Thos } \\
\text { Robertson } \\
\end{array}$ & $\begin{array}{l}\text { Thoa Frazer* } \\
\text { SN Gilmore } \\
\text { Israel Graden }\end{array}$ \\
\hline $1865-66$ & $\begin{array}{c}\text { Henry } \\
\text { Failing* (see } \\
\text { above) }\end{array}$ & JJ Hoffman & HL Hoyt & - & $\begin{array}{c}\text { Samuel } \\
\text { Simmons }\end{array}$ & - & & $\begin{array}{c}\text { John } \\
\text { McCraken } \\
\text { PC Schuyler } \\
\text { RR } \\
\text { Thompson }\end{array}$ & $\begin{array}{c}\text { ES Morgan } \\
\text { SA Clarke } \\
\text { A Rosenheim }\end{array}$ & $\begin{array}{c}\text { JPO } \\
\text { Lownsdale* } \\
\text { OPS Plummer } \\
\text { SM Gilmore }\end{array}$ \\
\hline $1866-67$ & $\begin{array}{c}\text { Thomas J } \\
\text { Holmes } \\
\text { (b. 1819) } \\
\text { (England) }\end{array}$ & JJ Hoffman & $\begin{array}{l}\text { Henry L Hoyt } \\
\text { attempt to } \\
\text { unseat by } \\
\text { A. } \\
\text { Rosenheim }^{19}\end{array}$ & - & HW Davis & - & & $\begin{array}{c}\text { John } \\
\text { McCraken } \\
\text { AB Hallock* } \\
\text { AL Zieber }\end{array}$ & $\begin{array}{c}\text { A Rosenheim } \\
\text { M O'Connor } \\
\text { CH } \\
\text { Fechheimer }\end{array}$ & $\begin{array}{c}\text { JPO } \\
\text { Lownsdale* } \\
\text { TJ Carter* } \\
\text { JC Carson* }\end{array}$ \\
\hline $1867-68$ & $\begin{array}{l}\text { JA Chapman } \\
\text { (b. 1821) } \\
\text { (New York) }\end{array}$ & JJ Hoffman & D Jacobi ${ }^{20}$ & - & $\begin{array}{c}\text { MN } \\
\text { McMillan }\end{array}$ & - & & $\begin{array}{c}\text { AB Hallock* } \\
\text { J McCraken } \\
\text { AC Ripley }\end{array}$ & $\begin{array}{c}\text { CS } \\
\text { Fechheimer } \\
\text { R Porter } \\
\text { A Rosenheim }\end{array}$ & $\begin{array}{l}\text { L Besser } \\
\text { CD Burch } \\
\text { MF Mulky }\end{array}$ \\
\hline
\end{tabular}

19 A. Rosenheim was elected Marshall on July 31, 1868 by the Portland City Council. Henry Hoyt, who held the position refuse to surrender his office. Hoyt felt Rosenheim's election was illegal. Eventually, the Oregon Supreme Court ruled against Hoyt, but Rosenheim failed to take office (Cline, p. 87).

Identified as Jewish (Cline, p. 87) 
City of Portland Officers 1851-1889

\begin{tabular}{|c|c|c|c|c|c|c|c|c|}
\hline Year & Mayor & Recorder & Marshal & $\begin{array}{l}\text { Police } \\
\text { Judge } \\
\end{array}$ & $\begin{array}{c}\text { Street } \\
\text { Commissioner } \\
\end{array}$ & First Ward & $\begin{array}{l}\text { Councilmen } \\
\text { Second Ward } \\
\end{array}$ & Third Ward \\
\hline $1868-69$ & $\begin{array}{l}\text { Hamilton Boyd } \\
\text { (?) }\end{array}$ & O Risley & $\begin{array}{c}\text { WH } \\
\text { Weed }\end{array}$ & - & Joseph Tucker* & $\begin{array}{l}\text { AB Hallock* } \\
\text { Wm Cree } \\
\text { AC Ripley }\end{array}$ & $\begin{array}{c}\text { JM Breck } \\
\text { R Porter } \\
- \\
\end{array}$ & $\begin{array}{c}\text { CD Burch } \\
\text { L Besser } \\
\text { Chas Hopkins } \\
\end{array}$ \\
\hline $1869-70$ & $\begin{array}{l}\text { B Goldsmith } \\
\text { (b. 1832) } \\
\text { (Germany) }\end{array}$ & $\begin{array}{c}\text { Levi } \\
\text { Anderson }\end{array}$ & $\begin{array}{c}\text { Joseph } \\
\text { Saunders }\end{array}$ & - & Jacob Startle & $\begin{array}{c}\text { C Bills } \\
\text { Wm Cree } \\
\text { AC Ripley } \\
\end{array}$ & $\begin{array}{l}\text { JM Breck } \\
\text { W Moffett } \\
\text { JB Congle } \\
\end{array}$ & $\begin{array}{l}\text { W Lair Hill } \\
\text { JM Drake } \\
\text { L Besser } \\
\end{array}$ \\
\hline Year & Mayor & Attorney & Marshal & $\begin{array}{l}\text { Police } \\
\text { Judge } \\
\end{array}$ & $\begin{array}{c}\text { Street } \\
\text { Commissioner }\end{array}$ & \multicolumn{3}{|c|}{$\begin{array}{l}\text { Councilmen } \\
\text { Second Ward }\end{array}$} \\
\hline $1870-71$ & $\begin{array}{l}\text { B Goldsmith } \\
\text { (see above) }\end{array}$ & $\begin{array}{c}\text { CA } \\
\text { Dolph }\end{array}$ & - & $\begin{array}{c}\text { DC } \\
\text { Lewis }\end{array}$ & JF Shartle & $\begin{array}{c}\text { George L. Story* } \\
\text { AB Halleck } \\
\text { EM Burton }\end{array}$ & $\begin{array}{c}\text { W Moffett } \\
\text { JB Congle } \\
\text { JM Caywood }\end{array}$ & $\begin{array}{l}\text { RG Combs } \\
\text { L Besser } \\
\text { W Lair Hill } \\
\end{array}$ \\
\hline $1871-72$ & $\begin{array}{c}\text { Phillip } \\
\text { Wassermann } \\
\text { (b. 1827) } \\
\end{array}$ & $\begin{array}{l}\text { CA } \\
\text { Ball }\end{array}$ & - & $\begin{array}{c}\text { ON } \\
\text { Denny }\end{array}$ & AJ Marshal & $\begin{array}{c}\text { George L Story* } \\
\text { AH Halleck } \\
\text { EM Burton }\end{array}$ & $\begin{array}{c}\text { M Moffett } \\
\text { JB Congle } \\
\text { JM Caywood }\end{array}$ & $\begin{array}{l}\text { RG Combs } \\
\text { L Besser } \\
\text { W Lair Hill } \\
\end{array}$ \\
\hline Year & Mayor & Attorney & $\begin{array}{c}\text { Chief of } \\
\text { Police } \\
\end{array}$ & $\begin{array}{l}\text { Police } \\
\text { Judge } \\
\end{array}$ & $\begin{array}{c}\text { Street } \\
\text { Commissioner } \\
\end{array}$ & \multicolumn{3}{|c|}{$\begin{array}{l}\text { Councilmen } \\
\text { Second Ward }\end{array}$} \\
\hline $1872-73$ & $\begin{array}{c}\text { Phillip } \\
\text { Wassermann } \\
\text { (Germany) }\end{array}$ & $\begin{array}{c}\text { MF } \\
\text { Mulky }\end{array}$ & $\begin{array}{c}\mathrm{JH} \\
\text { Lappens }\end{array}$ & $\begin{array}{c}\text { ON } \\
\text { Denny }\end{array}$ & AJ Marshal & $\begin{array}{c}\text { AB Halleck } \\
\text { EM Burton } \\
\text { George L Story* }\end{array}$ & $\begin{array}{c}\text { JB Congle } \\
\text { JM Caywood } \\
\text { EF Russell }\end{array}$ & $\begin{array}{c}\text { L Besser } \\
\text { W Lair Hill } \\
\text { JC Moreland }\end{array}$ \\
\hline Year & Mayor & Attorney & $\begin{array}{l}\text { Chief of } \\
\text { Police } \\
\end{array}$ & $\begin{array}{l}\text { Police } \\
\text { Judge }\end{array}$ & $\begin{array}{c}\text { Superintendent } \\
\text { of Streets }\end{array}$ & \multicolumn{3}{|c|}{$\begin{array}{l}\text { Councilmen } \\
\text { Second Ward }\end{array}$} \\
\hline $1873-74$ & $\begin{array}{c}\text { H Failing* } \\
\text { (see 1864-65) }\end{array}$ & $\begin{array}{c}\text { MF } \\
\text { Mulky }\end{array}$ & $\begin{array}{c}\mathrm{JH} \\
\text { Lappens }\end{array}$ & $\begin{array}{c}\text { ON } \\
\text { Denny }\end{array}$ & RA Habersham & $\begin{array}{c}\text { EM Burton } \\
\text { George L Story* } \\
\text { GW Hoyt }\end{array}$ & $\begin{array}{l}\text { JM Caywood } \\
\text { EF Russell } \\
\text { JH Lyon }\end{array}$ & $\begin{array}{l}\text { W Lair Hill } \\
\text { JH Lyon } \\
\text { JC Moreland }\end{array}$ \\
\hline $1874-75$ & $\begin{array}{l}\text { Henry Failing* } \\
\text { (see 1864-65) }\end{array}$ & $\begin{array}{c}\mathrm{AC} \\
\text { Gibbs }\end{array}$ & - & $\begin{array}{c}\text { ON } \\
\text { Denny }\end{array}$ & Perry W. Davis & $\begin{array}{l}\text { RR Thompson* } \\
\text { George L Story* } \\
\text { GW Hoyt }\end{array}$ & $\begin{array}{c}\text { John Catlin } \\
\text { ET Russell } \\
\text { JH Lyon }\end{array}$ & $\begin{array}{c}\text { E Corbett* } \\
\text { JH Lyon } \\
\text { JC Moreland }\end{array}$ \\
\hline
\end{tabular}


City of Portland Officers 1851-1889

\begin{tabular}{|c|c|c|c|c|c|c|c|c|}
\hline Year & Mayor & Attorney & $\begin{array}{l}\text { Chief of } \\
\text { Police }\end{array}$ & $\begin{array}{l}\text { Police } \\
\text { Judge }\end{array}$ & $\begin{array}{c}\text { Superintendent } \\
\text { of Streets }\end{array}$ & First Ward & $\begin{array}{l}\text { Councilmen } \\
\text { Second Ward }\end{array}$ & Third Ward \\
\hline $1875-76$ & $\begin{array}{l}\text { JA Chapman } \\
\text { (see 1867-68) }\end{array}$ & $\begin{array}{c}\text { John } \\
\text { M } \\
\text { Gearin }\end{array}$ & $\begin{array}{c}\mathrm{JH} \\
\text { Lappens }\end{array}$ & $\begin{array}{c}\text { WH } \\
\text { Adams }\end{array}$ & Perry W Davis & $\begin{array}{l}\text { GW Hoyt } \\
\text { HD Sandborn } \\
\text { JR Wiley* }\end{array}$ & \begin{tabular}{|c|} 
Wm H Audrus \\
John Catlin \\
SG Skidmore*
\end{tabular} & \begin{tabular}{|c|} 
L Besser \\
Elijah Corbett* \\
EJW Stemme
\end{tabular} \\
\hline $1876-77$ & $\begin{array}{l}\text { JA Chapman } \\
\text { (see 1867-68) }\end{array}$ & $\begin{array}{l}\text { John } \\
\text { Gearin }\end{array}$ & - & $\begin{array}{c}\text { WH } \\
\text { Adams }\end{array}$ & $\begin{array}{l}\text { William } \\
\text { Showers }\end{array}$ & $\begin{array}{l}\text { Thomas Stephens* } \\
\text { DF Harrington } \\
\text { JR Wiley* }\end{array}$ & $\begin{array}{l}\text { Wm H Audrus } \\
\text { S Blumauer* } \\
\text { SG Skidmore }\end{array}$ & $\begin{array}{c}\text { Noah Lambert } \\
\text { Elijah Corbett* } \\
\text { EJW Stemme }\end{array}$ \\
\hline $1877-78$ & $\begin{array}{l}\text { WS Newberry } \\
\text { (b. 1834) } \\
\text { (Ripley, NY) }\end{array}$ & $\begin{array}{c}\mathrm{JC} \\
\text { Moreland }\end{array}$ & $\begin{array}{c}\mathrm{L} \\
\text { Besser }\end{array}$ & $\begin{array}{c}\text { WH } \\
\text { Adams }\end{array}$ & DE Budd & $\begin{array}{c}\text { Thomas Stephens* } \\
\text { F Opitz } \\
\text { JR Wiley* }\end{array}$ & $\begin{array}{l}\text { Wm H Audrus } \\
\text { Joseph Simon } \\
\text { SG Skidmore }\end{array}$ & $\begin{array}{l}\text { Noah Lambert } \\
\text { GW Yocum } \\
\text { EJW Stemme }\end{array}$ \\
\hline $1878-79$ & $\begin{array}{l}\text { WS Newbury } \\
\text { (see above) }\end{array}$ & $\begin{array}{c}\text { JC } \\
\text { Moreland }\end{array}$ & $\begin{array}{c}\text { L. } \\
\text { Besser }\end{array}$ & $\begin{array}{c}\text { WH } \\
\text { Adams }\end{array}$ & W Braden & $\begin{array}{c}\text { Thomas Stephens* } \\
\text { F Opitz } \\
\text { JW Payne }\end{array}$ & $\begin{array}{l}\text { Wm H Audrus } \\
\text { Joseph Simon } \\
\text { EH Stolte }\end{array}$ & $\begin{array}{c}\text { Noah Lambert } \\
\text { GW Yocum } \\
\text { H Weber }\end{array}$ \\
\hline $1879-80$ & $\begin{array}{l}\text { DP Thompson } \\
\text { (b. 1834) } \\
\text { (Ohio) }\end{array}$ & $\begin{array}{c}\text { JC } \\
\text { Moreland }\end{array}$ & $\begin{array}{c}\mathrm{JH} \\
\text { Lappens }\end{array}$ & $\begin{array}{c}\text { LB } \\
\text { Stearns }\end{array}$ & - & $\begin{array}{c}\text { F Opitz } \\
\text { JW Payne } \\
\text { R Gerdes }\end{array}$ & $\begin{array}{c}\text { Joseph Simon } \\
\text { EH Stoltze ? } \\
\text { TL Nicklin }\end{array}$ & $\begin{array}{l}\text { JF Watson } \\
\text { JS Keller } \\
\text { H Weber }\end{array}$ \\
\hline
\end{tabular}


City of Portland Officers 1851-1889

\begin{tabular}{|c|c|c|c|c|c|c|c|c|c|c|}
\hline Year & Mayor & Attorney & $\begin{array}{l}\text { Chief } \\
\text { of } \\
\text { Police }\end{array}$ & $\begin{array}{l}\text { Police } \\
\text { Judge }\end{array}$ & $\begin{array}{c}\text { Deputy } \\
\text { Super- } \\
\text { intendent of } \\
\text { Streets } \\
\end{array}$ & $\begin{array}{c}\text { Super- } \\
\text { intendent } \\
\text { of Streets }\end{array}$ & $\begin{array}{l}\text { President } \\
\text { of } \\
\text { Council }\end{array}$ & First Ward & $\begin{array}{l}\text { Councilmen } \\
\text { Second Ward }\end{array}$ & Third Ward \\
\hline $\begin{array}{c}1880- \\
81\end{array}$ & $\begin{array}{c}\text { DP } \\
\text { Thompson } \\
\text { (b. 1834) } \\
\text { (Ohio) }\end{array}$ & $\begin{array}{c}\mathrm{JC} \\
\text { Moreland }\end{array}$ & - & $\begin{array}{c}\text { LB } \\
\text { Stearns }\end{array}$ & - & $\begin{array}{l}\text { William } \\
\text { Braden }\end{array}$ & - & $\begin{array}{c}\text { JS Raleigh } \\
\text { R Gerdes } \\
\text { Henry Hewett }\end{array}$ & $\begin{array}{l}\text { EH Stolte } \\
\text { TL Nickin } \\
\text { WA Andus }\end{array}$ & $\begin{array}{l}\text { H Weber } \\
\text { JS Keller } \\
\text { JB Kellogg }\end{array}$ \\
\hline $\begin{array}{c}1881- \\
82\end{array}$ & $\begin{array}{c}\text { DP } \\
\text { Thompson } \\
\text { (see above) }\end{array}$ & $\begin{array}{c}\mathrm{JC} \\
\text { Moreland }\end{array}$ & $\begin{array}{c}\text { JH } \\
\text { Lappens }\end{array}$ & $\begin{array}{c}\text { LB } \\
\text { Stearns }\end{array}$ & $\begin{array}{c}\text { JH } \\
\text { Phirman }\end{array}$ & $\begin{array}{l}\text { William } \\
\text { Braden }\end{array}$ & $\begin{array}{c}\text { WB } \\
\text { Honeyman }\end{array}$ & $\begin{array}{l}\text { Henry Hewett } \\
\text { JS Raleigh } \\
\text { Richard Gerdes }\end{array}$ & $\begin{array}{c}\text { TL Nickin } \\
\text { Charles } \\
\text { Holman } \\
\text { WL Chittenden }\end{array}$ & $\begin{array}{l}\text { JB Kellogg } \\
\text { JS Keller } \\
\text { WB } \\
\text { Honeyman }\end{array}$ \\
\hline $\begin{array}{c}1882- \\
83\end{array}$ & $\begin{array}{c}\text { JA } \\
\text { Chapman } \\
\text { (see 1867- } \\
68)\end{array}$ & SW Rice & $\begin{array}{c}\mathrm{JH} \\
\text { Lappens }\end{array}$ & $\begin{array}{c}\text { SA } \\
\text { Moreland }\end{array}$ & $\begin{array}{c}\text { WF } \\
\text { Matthews }\end{array}$ & $\begin{array}{l}\text { William } \\
\text { Braden }\end{array}$ & $\begin{array}{c}\text { WB } \\
\text { Honeyman }\end{array}$ & $\begin{array}{c}\text { Henry Hewett } \\
\text { D Mackay } \\
\text { JE Smith }\end{array}$ & $\begin{array}{l}\text { WS Scoggin } \\
\text { Charles } \\
\text { Holman } \\
\text { WL Chittenden }\end{array}$ & $\begin{array}{c}\text { JB Kellogg } \\
\text { WH Adams } \\
\text { WB } \\
\text { Honeyman }\end{array}$ \\
\hline $\begin{array}{c}1883- \\
84\end{array}$ & $\begin{array}{c}\text { JA } \\
\text { Chapman } \\
\text { (see 1867- } \\
68) \\
\end{array}$ & $\begin{array}{c}\text { RM } \\
\text { Dement }\end{array}$ & $\begin{array}{c}\text { WH } \\
\text { Watkinds }\end{array}$ & $\begin{array}{c}\text { SA } \\
\text { Moreland }\end{array}$ & $\begin{array}{c}\text { WF } \\
\text { Burke }\end{array}$ & $\begin{array}{c}\mathrm{AF} \\
\text { Sears }\end{array}$ & $\begin{array}{c}\text { WH } \\
\text { Adams }\end{array}$ & $\begin{array}{l}\text { R Gerdes } \\
\text { JB Hailey } \\
\text { JE Smith }\end{array}$ & $\begin{array}{l}\text { WA Scoggin } \\
\text { WH Andus } \\
\text { WL Chittenden }\end{array}$ & $\begin{array}{c}\text { AF Sears, Jr. } \\
\text { WH Adams } \\
\text { WB } \\
\text { Honeyman }\end{array}$ \\
\hline $\begin{array}{c}1884- \\
85\end{array}$ & $\begin{array}{c}\text { JA Chapman } \\
\text { (see 1867- } \\
68) \\
\end{array}$ & $\begin{array}{c}\mathrm{AH} \\
\text { Tanner }\end{array}$ & $\begin{array}{c}\text { SB } \\
\text { Parrish* }\end{array}$ & $\begin{array}{c}\text { SA } \\
\text { Moreland }\end{array}$ & $\begin{array}{c}\text { WS } \\
\text { Broocke }\end{array}$ & $\begin{array}{c}\text { FE } \\
\text { Vaughn }\end{array}$ & $\begin{array}{c}\text { WH } \\
\text { Adams }\end{array}$ & $\begin{array}{l}\text { R Gerdes } \\
\text { JJ Holland } \\
\text { JE Smith }\end{array}$ & $\begin{array}{l}\text { WA Scoggin } \\
\text { WH Adams } \\
\text { CM Forbes }\end{array}$ & $\begin{array}{l}\text { AF Sears, Jr. } \\
\text { WH Adams } \\
\text { Wm Fliedner }\end{array}$ \\
\hline Year & Mayor & Attorney & $\begin{array}{l}\text { Chief of } \\
\text { Police }\end{array}$ & $\begin{array}{l}\text { Police } \\
\text { Judge }\end{array}$ & $\begin{array}{l}\text { Street } \\
\text { Comm- } \\
\text { issioner }\end{array}$ & $\begin{array}{c}\text { City } \\
\text { Physician }\end{array}$ & $\begin{array}{c}\text { President } \\
\text { of } \\
\text { Council }\end{array}$ & First Ward & $\begin{array}{l}\text { Councilmen } \\
\text { Second Ward }\end{array}$ & Third Ward \\
\hline $\begin{array}{c}1885- \\
86\end{array}$ & $\begin{array}{c}\text { John Gates } \\
\text { (b. 1827) } \\
\text { (Maine) }\end{array}$ & $\begin{array}{c}\text { AH } \\
\text { Tanner }\end{array}$ & $\begin{array}{c}\text { SB } \\
\text { Parrish* }\end{array}$ & $\begin{array}{c}\text { RM } \\
\text { Dement }\end{array}$ & $\begin{array}{c}\text { FE } \\
\text { Vaughn }\end{array}$ & - & $\begin{array}{c}\text { Wm } \\
\text { Fliedner }\end{array}$ & $\begin{array}{l}\text { R Gerdes } \\
\text { JJ Holland } \\
\text { JJ Gallagher }\end{array}$ & $\begin{array}{c}\text { S Farrell } \\
\text { WH Andrus } \\
\text { CM Forbes }\end{array}$ & $\begin{array}{l}\text { AF Sears, Jr. } \\
\text { F Hacheny } \\
\text { Wm Fliedner }\end{array}$ \\
\hline
\end{tabular}


City of Portland Officers 1851-1889

\begin{tabular}{|c|c|c|c|c|c|c|c|c|c|c|}
\hline Year & Mayor & $\begin{array}{c}\text { Attor- } \\
\text { ney }\end{array}$ & $\begin{array}{c}\text { Chief } \\
\text { of } \\
\text { Police }\end{array}$ & $\begin{array}{l}\text { Police } \\
\text { Judge }\end{array}$ & $\begin{array}{c}\text { Street } \\
\text { Commiss- } \\
\text { ioner }\end{array}$ & $\begin{array}{c}\text { City } \\
\text { Physi- } \\
\text { cian }\end{array}$ & $\begin{array}{l}\text { President } \\
\text { of Council }\end{array}$ & First Ward & $\begin{array}{l}\text { Councilmen } \\
\text { Second Ward }\end{array}$ & Third Ward \\
\hline $\begin{array}{l}1886- \\
87\end{array}$ & $\begin{array}{l}\text { John } \\
\text { Gates } \\
\text { (see } \\
\text { above) }\end{array}$ & $\begin{array}{c}\mathrm{AH} \\
\text { Tanner }\end{array}$ & $\begin{array}{c}\text { SB } \\
\text { Parrish } \\
*\end{array}$ & $\begin{array}{c}\text { Ralph } \\
\text { Dement }\end{array}$ & $\begin{array}{c}\text { WS } \\
\text { Chapman }\end{array}$ & - & $\begin{array}{l}\text { Sylvester } \\
\text { Farrell }\end{array}$ & $\begin{array}{l}\text { R Gerdes } \\
\text { JJ Holland } \\
\text { JJ Gallagher }\end{array}$ & $\begin{array}{c}\text { S Farrell } \\
\text { RH Schwab } \\
\text { CM Forbes }\end{array}$ & $\begin{array}{l}\text { Tyler Woodward } \\
\text { F Hacheny } \\
\text { Wm Fliedner }\end{array}$ \\
\hline $\begin{array}{l}1887- \\
88\end{array}$ & $\begin{array}{l}\text { John } \\
\text { Gates } \\
\text { (see } \\
\text { above) }\end{array}$ & $\begin{array}{c}\text { WH } \\
\text { Adams } \\
*\end{array}$ & $\begin{array}{c}\text { SB } \\
\text { Parrish } \\
*\end{array}$ & $\begin{array}{c}\text { Ralph } \\
\text { M } \\
\text { Dement }\end{array}$ & $\begin{array}{c}\text { WS } \\
\text { Chapman }\end{array}$ & $\begin{array}{c}\text { FB } \\
\text { Perry }\end{array}$ & $\begin{array}{c}\mathrm{CM} \\
\text { Forbes }\end{array}$ & $\begin{array}{c}\text { R Gerdes } \\
\text { C Castendieck } \\
\text { JJ Gallagher }\end{array}$ & $\begin{array}{c}\text { S Farrell } \\
\text { RH Schwab } \\
\text { CM Forbes }\end{array}$ & $\begin{array}{l}\text { Tyler Woodward } \\
\text { F Hacheney } \\
\text { Wm Fliedner }\end{array}$ \\
\hline & & & & & $\begin{array}{c}\text { Deputy } \\
\text { Super- } \\
\text { intendents } \\
\text { of Streets }\end{array}$ & & & & & \\
\hline $\begin{array}{l}1888- \\
89\end{array}$ & $\begin{array}{c}\text { Van B. } \\
\text { De- } \\
\text { Lashmutt }\end{array}$ & $\begin{array}{l}\text { WH } \\
\text { Adams }\end{array}$ & $\begin{array}{c}\text { SB } \\
\text { Parrish }\end{array}$ & $\begin{array}{c}\mathrm{AH} \\
\text { Tanner }\end{array}$ & $\begin{array}{c}\text { WE } \\
\text { Mulhollam } \\
\text { Wm } \\
\text { E Braden } \\
\text { William } \\
\text { Conner } \\
\end{array}$ & $\begin{array}{c}\text { FA } \\
\text { Meyer }\end{array}$ & $\begin{array}{c}\text { Tyler } \\
\text { Woodward }\end{array}$ & $\begin{array}{c}\text { C Castendieck } \\
\text { R Gerdes } \\
\text { Richard Hoyt }\end{array}$ & $\begin{array}{l}\text { S Farrell } \\
\text { RH Schwab } \\
\text { CM Forbes }\end{array}$ & $\begin{array}{l}\text { T Woodward } \\
\text { Wm Showers } \\
\text { Wm Fliedner }\end{array}$ \\
\hline & & \multicolumn{3}{|c|}{$\begin{array}{l}\text { Overseer of Street Cleaning } \\
\text { and Sprinkling }\end{array}$} & $\begin{array}{c}\text { Superin- } \\
\text { tendent } \\
\text { of Streets }\end{array}$ & & & & & \\
\hline $\begin{array}{l}1888- \\
89\end{array}$ & cont. & \multicolumn{3}{|c|}{ SB Matthews } & $\begin{array}{c}\text { WS } \\
\text { Chapmen }\end{array}$ & & & & & \\
\hline
\end{tabular}




\section{CHAPTER III \\ OREGON, MULTNOMAH COUNTY AND PORTLAND \\ HISTORY OF JUSTICE SYSTEMS}

Early in the history of the Oregon region, English law governed English subjects residing in the region. American missionaries shared a code of honor which governed their daily lives. Population of the region was sparse and scattered and the need for court systems was limited. A judiciary system was not organized until 1841, at the insistence of American settlers seeking an organized and authoritative system (Scott, p. 308).

Independent settlers operating without a system of formal law were vulnerable to the acts of lawless individuals. American missionaries, increasingly cognizant of the need for an authority that all inhabitants could respect, urged the appointments of three Justices of the Peace. Three justices were commissioned, one of whom was James Douglas. ${ }^{1}$ The Justices, while providing the appearance of authority, initially rarely heard cases and those brought before them were usually insignificant. (Scott, p. 308).

This commission prevailed until local American missionaries appointed a Provisional Government to govern the Oregon region. The gradual increase in population signal a need to adopt a code of formal law. While French and Canadian settlers did not readily accept American intervention, the establishment of local laws

\footnotetext{
(Scott, p. 310).

James Douglas was elected by the 1845 Legislature as a Judge of the Vancouver District
} 
and regulations forced the need for a formal judiciary body to adjudicate violators and other legal matters (Scott, p. 308).

The death of a local citizen alerted settlers to the need of a probate court to settle his estate and subsequent estates of others. As a result, settlers met in the deceased home, drafted a code of laws and recommended creating specific judicial offices and included a slate of nominees. On February 18, 1841, I. L. Babcock was elected Supreme Judge and given probate powers (Scott, p. 309).

Initially, in the absence of a formal set of governing laws and regulations, the court followed the laws of New York State. Judge Babcock was a physician connected to the Methodist Mission and not familiar with formal law. Yet, Dr. Babcock was subsequently elected as Circuit Judge, holding sessions in Clackamas County and what would eventually become Multnomah County (Scott, p.310).

In May of 1843 at Champoeg, A. E. Wilson was elected to act as Supreme Judge, with probate powers and several magistrates were also selected. During this meeting, white settlers also adopted provisions for a future election to take place the following year on May 2, 1844. In addition, in 1843, Organic Law was adopted by local settlers during a public meeting on July 5 .

For judicial purposes, the region was divided into four (4) districts. The most significant of the four was District One, Tuality District, comprised of the following geographical boundaries (Scott, p. 310):

south of the northern tip boundary of the United States west of the Willamette or Multnomah River north of Yamhill River east of the Pacific Ocean 
The judicial system was altered by the first Legislative body under provisions of the Organic Act of June 1844. Judicial power rested in the Circuit Court and Justices of the Peace. One Circuit Judge having probate powers, was to be elected holding two court sessions per county each year. However, few cases were adjudicated by the Court.

\begin{tabular}{|c|c|c|c|c|c|c|}
\hline Year & Office & \multicolumn{2}{|c|}{ Candidates } & Elected & Term & Comments \\
\hline 1844 & $\begin{array}{l}\text { Circuit } \\
\text { Judge }\end{array}$ & $\begin{array}{l}\text { I. L. Babcock, MD } \\
\text { J. W. Nesmith } \\
\text { P. H. Burnett } \\
\end{array}$ & $\begin{array}{l}\text { P. G. Stewart } \\
\text { Osborn } \\
\text { O. Johnson }\end{array}$ & $\begin{array}{c}\text { I. L. } \\
\text { Babcock, } \\
\text { MD }\end{array}$ & $\begin{array}{l}\text { May } 1844- \\
\text { April } 1845\end{array}$ & $\begin{array}{c}\text { Resigned Nov. 11, 1844 } \\
\text { (position remained } \\
\text { vacant) }\end{array}$ \\
\hline 1845 & $\begin{array}{c}\text { Circuit } \\
\text { Judge }\end{array}$ & \multicolumn{2}{|c|}{ J. W. Nesmith } & $\begin{array}{c}\text { J. W. } \\
\text { Nesmith }\end{array}$ & $\begin{array}{c}\text { April, } 1845- \\
?\end{array}$ & \\
\hline
\end{tabular}

Justices of the Peace were elected and their duties defined accordingly. The vast majority of cases were heard by the Justice of the Peace and no (official) record (of those cases) remains (Scott, p. 311). ${ }^{2}$

The Legislature, elected in 1845, under the Provisional Government, appointed a committee to revise Organic Law, which in turn produced the Constitution of the Oregon Region, adopted by voters on July 26, 1845. According to the eighth section of Article II, judicial power was vested in the Oregon Supreme Court, allowing inferior courts to be established by law (Scott, p. 311-312).

The Oregon Supreme Court, consisted of one judge, elected by the House of Representatives, for a four year term, having appellate (appeal process) jurisdiction only, with control over inferior Courts and power to issue remedial writs, to hear and

2 The earliest record of any case brought before the Supreme Court involved two farmers, Ninevah Ford and Abi Smith, who immigrated to the area in 1843. The farmers, as had others settlers, brought many heads of cattle with them, many of which were lost during the migration. As a result, ownership of the remaining cattle was often unclear. Ford and Smith claimed ownership of a particular pair of oxen that survived the rugged trip. Ford had possession of the oxen and Smith filed suit claiming ownership. In April of 1844, two Justices of the Peace, sitting as a Supreme Court, ruled in favor of the plaintiff (Scott, p. 311). 
determine such cases involving the same (Scott, p. 312). The Oregon Supreme Court also had jurisdiction over criminal cases. ${ }^{3}$

The Oregon Provisional Legislature elected judges and created courts:

\section{Provisional Government - Supreme Court}

\begin{tabular}{|c|l|l|c|c|l|}
\hline Year & \multicolumn{1}{|c|}{ Office } & \multicolumn{1}{c|}{ Judge } & Seat & \multicolumn{1}{c|}{ Term } & \multicolumn{1}{c|}{ Comments } \\
\hline 1841 & Supreme Judge & I. L. Babcock & Not Indicated & Not Indicated & (given probate powers) \\
\hline 1843 & Supreme Judge & $\begin{array}{l}\text { Champoeg A. E. } \\
\text { Wilson }\end{array}$ & $\begin{array}{c}\text { Not } \\
\text { Indicated }\end{array}$ & $\begin{array}{c}\text { Not } \\
\text { Indicated }\end{array}$ & $\begin{array}{l}\text { (Elected by settlers) } \\
\text { (given probate powers) }\end{array}$ \\
\hline 1845 & Supreme Judge & Nathaniel Ford & Oregon City & Not Indicated & Ford declined \\
\hline 1845 & Supreme Judge & Peter H. Burnett & Not Indicated & $\begin{array}{l}\text { Aug. 1845 - } \\
\text { Dec. 29, 1846 }\end{array}$ & $\begin{array}{l}\text { Elected to replace } \\
\text { Ford - Resigned 1846 }\end{array}$ \\
\hline 1847 & Supreme Judge & J. Quinn Thornton & Not Indicated & Feb. 9, 1847 & Replaced Burnett \\
\hline 1848 & Supreme Judge & Columbia Lancaster & Not Indicated & June-Sept. 1848 & Replaced Thornton \\
\hline
\end{tabular}

The Oregon Legislature also created Probate, Criminal and Justice Courts.

The names of the judges appointed to these courts were not observed during my

research. On June 2, 1846, three attorneys were admitted to the Oregon Regional

Bar, W. G. T. Vault, A. L. Lovejoy ${ }^{4}$ and Cyruds Olney. Vault, Lovejoy and Olney ${ }^{5}$

were the first to be allowed to present a case before the Oregon Supreme Court. ${ }^{6}$

Again, under Oregon Codified Law, the Legislative Committee appointed a committee of three to consider adopting portions of Iowa's Laws. ${ }^{7}$ However, the absence of a printing press fostered 'ignorance of the law,' since only one copy of

\footnotetext{
3 Research for this work did not include observing Oregon Supreme Court cases..

4 A. L. Lovejoy, became the Prosecuting Attorney (Scott, p. 313).

5 A. A. Skinner also became an attorney of the Court, as did Judge Bennect upon his resignation from the bench. Samuel R. Thurston, Aaron E. Wait and Milton Elliott joined this elite group of attorneys in 1848 (Scott, p. 314).

Under the revised Supreme Court system the first case heard concerned James B. Stephen regarding his application for a license to conduct a ferry business across the Willamette River at Portland. He was denied a license on the grounds that the Supreme Court lacked standing to issue the permit under the Organic Law (Scott, p. 322)

The Laws were modified and adopted at a subsequent meeting. The Laws were brought to Oregon in 1843, bound in blue boards and referred to as the blue book. The Legislative Committee, under Article II, Section 1, officially enacted the modified Laws of Iowa with stipulations that said laws could not conflict with English Common Law (Scott, p 315).
} 
Iowa Law existed in the Oregon Region. In addition, there continued to be questions regarding specificity of legality and rights of authority in the region because existing government jurisdiction rights had not been resolved.

However, on March 3, 1849, Oregon became an official Territory of the United States. Governor Joseph Lane, appointed by the President, issued a proclamation dismissing the current District and Supreme Court officers, thereby, paving the way for new Judges of the Supreme Court to be appointed by the President.

SUPREME COURT - OREGON TERRITORIAL

\begin{tabular}{|l|l|l|l|l|l|}
\hline 1849 & Chief Justice & Wm. P. Bryant & 1st District & 1849 & Resigned appointment \\
\hline 1849 & Chief Justice & Thomas Nelson & Not Indicated & 1849 & Replaced Bryant \\
\hline 1849 & Justice & Peter G. Burnett & Not Indicated & 1849 & Resigned appointment \\
\hline 1849 & Justice & William Strong & 3d District & Aug., 1850 & Replaced Burnett ${ }^{*}$ \\
\hline 1849 & Justice & James Turney & Not Indicated & Not Indicated & Resigned appointment \\
\hline 1849 & Justice & Orville C. Pratt & Not Indicated & $1849-1852$ & Replaced Turney \\
\hline
\end{tabular}

The newly appointed Oregon Supreme Court presided over by Chief Justice

Bryant and District Judge Pratt Russell heard one case at Oregon City ${ }^{8}$. Subsequent cases tried before the Supreme Court were heard at a court room at Salem.

"...the early history of The Bench and Bar of Portland was closely identified with that of the whole State. There were few Court Houses, and the accommodations at the hotels were often rude. One term of Court at Eugene City... was held under an umbrageous oak tree... At the county seats the lawyers, judges, litigants and witnesses boarded around at different houses...(Scott, pp. 323-324).

The Supreme Court lacking a specified location, held court on the Circuit until the Marshall received a directive to obtain an official seal to be adhered to formal stationary indicating a room in the Capital at Salem as the official seat (Scott, p. 323). 
TERRITORY OF OREGON - Under new officers -

\begin{tabular}{|c|c|c|c|l|}
\hline YR. & OFFICE & JUDGE & DISTRICT & GEOGRAPHIC LOCATION \\
\hline 1847 & Associate Justice & Cyrus Olney & West of Willamette River & Appointed by President Pierce \\
\hline 1852 & Chief Justice & Wm. P. Pratt & & Pratt's name was withdrawn \\
\hline 1852 & Chief Justice & George H. Williams & East of Willamette River & Appointed by President Pierce \\
\hline & Associate Justice & Matthew P. Deady & & Removed from Judgeship \\
\hline & Associate Justice & Obadiah B. McFadden & Territory of Washington & Replaced Deadly - \\
\hline & Associate Justice & Matthew P. Deady & Southern Oregon & Reinstated - McFadden reassigned \\
\hline
\end{tabular}

DISTRICT COURT OF UNITED STATES FOR THE DISTRICT COURT OF OREGON ${ }^{10}$

\begin{tabular}{|c|c|c|c|c|}
\hline Year & District & Judge & Term & Geographic Location \\
\hline 1849 & First & Wm. P. Bryant & $1849-1851$ & $\begin{array}{c}\text { Vancouver } \\
\text { counties south of Columbia }\end{array}$ \\
\hline 1849 & Second & Orville C. Pratt & $1849-1852$ & $\begin{array}{c}\text { Remaining counties in } \\
\text { Willamette Valley }\end{array}$ \\
\hline 1849 & Third & $\begin{array}{c}\text { Wm. P. Bryant } \\
\text { (for five months only) }\end{array}$ & $\begin{array}{c}\text { Remainder of what was } \\
\text { currently } \\
\text { State of Washington }\end{array}$ \\
\hline 1850 & Third & William Strong & & $\begin{array}{c}\text { State of Washington } \\
\text { Area reduced to } \\
\text { Clackamas County }\end{array}$ \\
\hline 1851 & First & $\begin{array}{c}\text { Thomas Nelson } \\
\text { (Chief Justice) }\end{array}$ & $1851-1853$ & $\begin{array}{c}\text { Appointed by President } \\
\text { but never arrived in Oregon }\end{array}$ \\
\hline
\end{tabular}

DISTRICT COURT OF UNITED STATES FOR THE DISTRICT COURT OF OREGON ${ }^{12}$

\begin{tabular}{|c|c|c|c|c|}
\hline Year & Office & Judge & Term & Comments \\
\hline 1859 & District Court of US & Matthew P. Deady & & Appointed by the President \\
\hline 1859 & District Attorney & J. K. Kelly & & Appointed by the President \\
\hline 1859 & Marshal & Walter Forward & & Appointed by the President \\
\hline
\end{tabular}

OREGON SUPREME COURT - (CIRCUIT COURT) ${ }^{13} 1859$

\begin{tabular}{|c|l|c|c|c|}
\hline Year & Office & Judge & Term & Geographical Location \\
\hline 1859 & Justice & R. E. Stratton & 6 years & \\
\hline 1859 & Justice & R. P. Boise & 6 years & \\
\hline 1859 & Chief Justice & A. E. Wait & & \\
\hline & & P. P. Prim & & \\
\hline & & William P. Page $^{15}$ & & \\
\hline & & E. D. Shattuck & & \\
\hline 1868 & & W. W. Upton & & \\
\hline 1874 & & E. D. Shattuck & $1878^{17}$ & \\
\hline
\end{tabular}

9 Deady, originally a democrat, was a major advocate of slavery and had little regard for Negroes. He eventually became a Republican and supported Abraham Lincoln for United States President in 1864. Whether his views on blacks changed was not clear (Woodward, p. 235).

$10 \quad$ Federal Court convened on the third floor of a building located at 63 Front Street (near Stark Street until 1871, when the federal Court House was built (Scott, p. 333)

11 When Judge Bryant resigned January 1, 1851, Judge Pratt became the only Judge in the Oregon Court (Woodward, p. 36).

12 Federal Court convened on the third floor of a building located at 63 Front Street (near Stark Street until 1871, when the federal Court House was built (Scott, p. 333)

13 The Act of June 3, 1859 directed the Supreme Court to be held as Salem on the first and second Monday in December, and on the second Monday in July in Portland on an annual basis.

The Act of October 17, 1862 stipulated that Court be held in Salem on the first Monday of September. These dates were changed in 1872, 1878, 1880, and 1889 (Scott, p. 332, footnote).

$14 \quad$ Matthew P. Deady was initially selected to be a Supreme Court Judge, but as a result of his appointed to the District Court of the United States at Oregon, A. E. Wait replace him (Scott, p. 333). 15 William P. Page replaced A. E. Wait upon his resignation to run for Congress (Scott, p. 333). 16 In an election E. D. Shattuck defeated William P. Page (Scott, p. 333). 
OREGON CIRCUIT COURT - FOURTH DISTRICT

\begin{tabular}{|c|c|c|c|c|}
\hline Year & Office & Judge & Term & Comments \\
\hline 1878 & & C. B. Bellinger & & First Judge of Fourth District \\
\hline 1880 & & Raleigh Stott & 6 years & $\begin{array}{c}\text { Replaced Belliger upon his } \\
\text { retirement -resigned }\end{array}$ \\
\hline 1884 & & Seneca Smith & 2 years & $\begin{array}{c}\text { Petition bar for appointment to } \\
\text { finish term }\end{array}$ \\
\hline
\end{tabular}

The justice system...was interfered with by violent political controversies and partisan warfare that divided the judges as well as the body of the people (Scott, $\mathrm{p}$. 325). The District Attorney of the Second District, Amory Holbrook, was absent in what was regarded as the State of Oregon. As a result, the Legislature attempted to appoint Reuben P. Boise. However, Chief Justice Nelson, appointed by the president, refused to acknowledge their appointment and appointed S. B. Marye (Scott, p. 334).

When his term expired, Judge Pratt was replaced by C. F. Train, appointed by the President. However, Train never came to Oregon. Changes in the federal administration resulted in changes in judicial appointments.

In 1853, the Legislative Committee established two terms of the Supreme Court yearly; one held at Salem (the first Monday in December), the other in Portland (the first Monday of June). On June 20, in 1853, the first Supreme Court was held in Portland, presided over by Judges M. P. Deady and C. Olney. ${ }^{18}$

17 In 1878 The Oregon Legislature provided for the election of Judges to the Oregon Supreme Court and for the Circuit Courts which were separated (Scott, p. 333).

18 In the absence of Allan P. Millar, Court Clerk, Ralph Wilcox was appointed in his stead. Not having any records, books, or papers of the Court, Judges Deady and Olney, sent Marshal J. W.

Nesmith, with a written note to M. Seymour, Deputy Clerk under Millar, at Oregon City to turn over the records. Marshal Nesmith returned without the books reporting that Seymour refused to produce the books (Scott, p. 335) 


\section{DISTRICT COURTS}

Districts were subdivided into counties, however, there were District Courts.

\begin{tabular}{|c|c|c|c|c|c|}
\hline Year & Office & Judge & District & Term & Comments \\
\hline$?$ & District Judge & $\begin{array}{l}\text { B. O. Tucker } \\
\text { H. Higgins } \\
\text { Wm. Burris }\end{array}$ & Tualitin & $\begin{array}{c}\text { Not } \\
\text { Indicated }\end{array}$ & $\begin{array}{c}\text { Not } \\
\text { Indicated }\end{array}$ \\
\hline 1844 & District Judge & A. L. Lovejoy & Clackamas & $1844-1845$ & Resigned 1845 \\
\hline
\end{tabular}

\section{MULTNOMAH COUNTY COURTS}

Tualitin District contained what would become Washington County, ${ }^{19}$ with Hillsboro as the County seat. Tualitin District also contained what is presently Multnomah County. Multnomah County was segregated (separated from) in 1854, when Portland became the County seat (Scott, p. 321). The first County Court in Multnomah County began January 17, 1855. After Oregon statehood, the first County Court opened July 4, 1855 (Scott, p. 328).

\begin{tabular}{|c|c|c|c|c|c|c|}
\hline Date & County Judge & Commissioner & & Date & County Judge & Commissioner \\
\hline $1855-1858$ & G. W. Vaughn & Ainslie R. Scott & & $1875-1878$ & J. H. Woodward & \\
\hline $1855-1858$ & & James Bybee & & $1879-1882$ & S. W. Rice & \\
\hline $1858-1862$ & E. Hamilton & & & $1883-1885$ & L. B. Stearns & \\
\hline $1862-1870$ & P. A. Marquam & & & $1885-1886$ & J. C. Moreland & \\
\hline $1871-1874$ & E. Hamilton & & & $1186-1890$ & John Catlin & \\
\hline
\end{tabular}

In 1885, the Oregon Legislature divided the Circuit Court of the Fourth

District into two departments:

1. MULTNOMAH COUNTY - FOURTH DISTRICT

\begin{tabular}{|l|l|l|l|l|}
\hline Year & Office & Judge & Term & Comments \\
\hline 1885 & Circuit & Loyal B. Stearns & & appointed until regular election \\
\hline 1885 & County & Julius C. Moreland & & \\
\hline
\end{tabular}

\footnotetext{
19 The Oregon Legislature changed Tualitin District to Washington County in July 1849 (Scott, p. 321).
} 


\section{SUBDIVIDED - CIRCUIT COURT \& COUNTY COURT}

\section{a. $\quad$ Circuit Court - $\mathbf{1 8 8 6}$}

\begin{tabular}{|l|l|l|l|l|}
\hline Year & Office & Judge & Term & Comments \\
\hline 1886 & Circuit & Loyal B. Stearns & 6 years & \\
\hline 1886 & Circuit & E. D. Shattuck & 6 years & \\
\hline
\end{tabular}

\section{b. County Court $\mathbf{- 1 8 8 6}$}

\begin{tabular}{|l|l|l|l|l|}
\hline Year & Office & Judge & Term & Comments \\
\hline 1886 & County & John Catlin & 4 years & \\
\hline
\end{tabular}

\section{PORTLAND - RECORDER - CITY ATTORNEY - POLICE JUDGE JUSTICE OF THE PEACE - POLICE COURTS}

Even though Portland was not under the protection and authority of the

United States, all settlers put forth great effort to honor prevailing laws and regulations. Under the Provisional Government there were not official Courts in Portland only Justices of the Peace (Scott, p. 318 \& 328). However, In December of 1845, The Legislative Committee provided for the election of an additional Justice of the Peace to serve the Eastern District of the Tuality District, as of October 1846. As such, this was considered by some historians to be the first judicial officer to serve the City of Portland.

During this period court sessions were conducted in the meeting house, a public gathering place also used for school and religious assemblies. Initially, The City Recorder had the same authority as the Justice of the Peace. The Recorder could try and decide cases involving violations of City Ordinances, offenses committed within City limits and the collection of debts. The position of Recorder 
was abolished and replaced by a Police Judge, having the same authority, who presided over the Police Court (Scott, p. 319).

\section{CITY RECORDER}

The city of Portland was incorporated in 1851. In January of that year, the office of Recorder was established. The Recorder officiated over the same jurisdiction as a District Justice of the Peace regarding offenses committed within Portland in violation of Oregon law, and exclusive jurisdiction in cases involving violations of City Ordinances (Scott, p. 319).

\begin{tabular}{|l|l|l|l|l|}
\hline \multicolumn{1}{|c|}{ CITY RECORDER } & \multicolumn{1}{|c|}{ YEAR } & & CITY RECORDER & \multicolumn{1}{c|}{ YEAR } \\
\hline WS Caldwell & 1851 & & Noah Huber & 1859 \\
\hline SS Slater & 1852 & & O Risley & 1861 \\
\hline AC Bonnell & 1853 & JF McCoy & $1862-65$ \\
\hline AP Dennison & 1854 & JH (JJ) Hoffman & $1866-68$ \\
\hline L Limerick & 1855 & O Risley & 1869 \\
\hline AL Davis & $1856-57$ & Levi Anderson & 1870 \\
\hline Alonzo Leland & 1858 & & \\
\hline
\end{tabular}

\section{CITY ATTORNEY}

In 1852, the Portland City Charter was amended to include the office of City Attorney. However, names of those who held this office are not known until 1865 (Scott, p. 319)

\begin{tabular}{|c|c|c|c|}
\hline CITY ATTORNEY & YEAR & CITY ATTORNEY & YEAR \\
\hline JN Dolph & $1865-66$ & AC Gibbs & 1875 \\
\hline WW Upton & 1867 & John M Gearin & $1876-77$ \\
\hline D Fredenrich & 1868 & JC Moreland & $1878-82$ \\
\hline WF Trimble & 1869 & SW Rice & 1883 \\
\hline CA Dolph & $1870-71$ & RM Dement & 1884 \\
\hline CA Ball & 1872 & AH Tanner & $1885-87$ \\
\hline MF Kulkey & $1873-74$ & WH Adams & $1887-$ \\
\hline
\end{tabular}




\section{POLICE JUDGE}

In 1870, the office of Recorder was abolished and the office of Police Judge assumed responsibilities as Judicial Officer presiding over the Police Court, with authority over the same jurisdiction (violation of Oregon law and Portland City Ordinances) as the Recorder - see above.

\begin{tabular}{|l|l|l|l|l|}
\hline \multicolumn{1}{|c|}{ Police Judge } & \multicolumn{1}{c|}{ Year } & \multicolumn{1}{c|}{ Police Judge } & Year \\
\hline DC Lewis & 1871 & \multicolumn{1}{|l|}{ SA Moreland } & $1883-85$ \\
\hline ON Denny & $1872-75$ \\
\hline WH Adams & $1876-79$ \\
\hline LB Stearns & $1880-82$ & \\
\hline
\end{tabular}

Police Judges were recruited to conduct Police Court. The following pages contain Portland Ordinances regarding the establishment of the office of Police Judge, qualifications, duties and responsibilities. 
An Act

\section{To Incorporate \\ The City Of Portland \\ Approved October 14, 1864; \\ And Acts Amendatory Thereof. ${ }^{20}$}

Chapter X.

Miscellaneous provisions.

Police Judge - To hold a Court.

Sec. 153. The Police Judge was the judicial officer of the corporation, and shall hold court therein, at such place as the council shall provide, which shall be known as the Police Court;...(pp. 38-39)

Qualifications for office of.

Sec. 153. $\quad$...he shall be an attorney of the degree of attorney of the Supreme Court of the State, and appointed by the Mayor, with the consent of a majority of the members of the council, and shall hold his office the term of two years and until his successor was appointed and qualified (p. 39). Amended by Act of October 29, 1874.

Term of office of Police Judge.

Sec. 154. The term of the first Police Judge appointed under this act shall commerce July 1, 1875, and end December 31,1876, and the appointment of Police Judge shall in no case be made to exceed twenty days before the time when the term of such appointee shall commence: Provided, That the Mayor to be elected at the general election of said city to be held in June, 1875, shall appoint the first Police Judge under this act...(p. 39)

\section{When vacancy in office.}

Sec. 154. cont. ...The office of Police Judge shall be deemed vacant whenever he shall be absent from the city for a period of more than ten days, without the consent of the Council first had and obtained, except in case of sickness, or whenever the person appointed thereto shall fail to qualify thereof within ten days from such appointments; and any vacancy in such office shall be filled by appointment for the remainder of the term, in the manner herein provided for making an appointment to a full term (p. 39). ${ }^{21}$

Approved October 14, 1864.

Jurisdiction of Police Judge.

Sec. 155. The Police Judge has jurisdiction of all crimes defines by an ordinance of the City of Portland, and all actions brought to enforce or recover any forfeiture or penalty declared or given by any such ordinance (p. 39).

Amended by Act of October 29, 1874.

Same as Justice of the Peace.

Sec. 156. The Police Judge has the jurisdiction and authority of a justice of the peace within the limits of the City of Portland, in both civil and criminal matters, and shall be subject to all general laws of the State prescribing the duties of a justice of the peace and the mode of performing them (p. 39). ${ }^{22}$

$20 \quad$ Portland, Charter of the City of, General Ordinances, In Force September, 1886, Together With Rules of Order of the Common Council and Police and Fire Department Laws and Table of City Grades with Chronological Index of Ordinances, Passed by the Common Council of the City of Portland, from 1854 to 1886, R. H. Schwab \& Bro., Portland, Oregon.

21 Ibid., Portland, Charter of, The, Amended October 21, 1870 and October 29, 1874, footnote, p. 39.

Ibid., Amended October 29, 1874, footnote, p. 39. 
An Act

\author{
To Incorporate \\ The City Of Portland \\ Approved October 14, 1864; \\ And Acts Amendatory Thereof. ${ }^{23}$
}

\title{
General laws to govern in Police Court.
}

Sec. 157. All civil or criminal proceedings before the Police Judge or in the Police Court, including all proceedings for the violation of any city ordinance, are governed and regulated by the general laws of the State applicable to justices of the peace or justices' courts in like or similar cases; but in a proceeding for the violation of a city ordinance the trial shall be without a jury...(p. 40)

Police Judge to collect fees as Justice of the Peace and pay them to City Treasurer.

Sec. 173. The Police Judge, when acting as a Justice of the Peace, must tax and collect the same fees and compensations as are allowed to such Justices for like services, and after July 1, 1875, he shall pay the same over to the City Treasurer, as provided in section 158...(p. 44)

\section{Chapter X.}

Miscellaneous provisions.

Amended by Act of October 29, 1874.

\section{Chief of Police same as to his fees.}

Sec. 173. cont. ...The Chief of Police, when acting under or enforcing any law or statute other than a city ordinance, was entitled to collect and receive the same fees and compensation as are allowed to a Constable for like services, and he shall pay the same over to the City Treasurer as provided in the case of fees received by the Police Judge...(pp. 44-45)

Amended by Act of October 26, 1870.

Chief to keep book of arrests.

Sec. 173. cont. ...The Chief of Police shall keep in his office a book of arrests, in which shall be entered by him or under his direction the name of every person arrested, the cause or such arrest, by whom arrested, and the date thereof (p. 45).

\section{relating to the duties of the "police judge."}

No. 899.- approved November 25, 1870.

The City of Portland does ordain as follows:

Section 1. The Police Judge shall make and file with the Auditor of the first day of the months of January, April, July and October, or within five days thereafter, a full and complete report of the business transacted in his court for the quarter preceding, in which said report shall be set forth in appropriate columns the names of persons arrested and brought before the court, the date thereof, the offense charged, whether for a violation of a city ordinance or a law of the State, the amount of fine, term of commitment, amount of costs, amount of fines and fees collected, amount due to witnesses and other persons, and to whom payable, and amount due the chief of Police (p. 131).

$23 \quad$ Portland, Charter of the City of, General Ordinances, In Force September, 1886, Together With Rules of Order of the Common Council and Police and Fire Department Laws and Table of City Grades with Chronological Index of Ordinances, Passed by the Common Council of the City of Portland, from 1854 to 1886, R. H. Schwab \& Bro., Portland, Oregon. 


\section{CHAPTER VIII.}

of the police department—police judge

Police Judge-qualifications of.

Section 61. There shall be appointed by the Mayor, with the consent of s majority of the members of the Common Council, a Police judge, who shall be the judicial official of the corporation, who shall hold a court therein, at such place as the Common Council shall provide, which shall be known as the Police Court;

\section{An attorney of the Supreme Court.}

Sec. 61. cont. he shall possess the qualifications of $a$ voter of the City $f$ Portland and shall be an attorney of the degree of attorney of the Supreme Court of the State (p. 25).

Must qualify-Term of office.

Sec. 62. The Police Judge shall qualify within ten days after his appointment, and hold his office until his successor was appointed and qualified (p. 25).

Absent more than 10 days-Office vacant to possess qualifications.

Sec. 63. The office of Police Judge shall be deemed vacant whenever he shall be absent from the City for a period of more than ten days without the consent of the Council first had and obtained, or whenever he shall cease to possess the qualifications prescribed in Section 61 (p. 25).

\section{Jurisdiction of.}

Sec. 64. The Police Judge has jurisdiction of all crimes defined by ordinance of the City of Portland, and all actions brought to enforce or recover any forfeiture or penalty declared or given by such ordinance, and the jurisdiction and authority of a Justice of the Peace within the limits of the City of Portland, in both civil and criminal matters, and shall be subject to all the general laws of the State prescribing the duties of a Justice of the Peace and the mode of performing them (p. 26).

Proceedings similar to - before a Justice of the peace.

Sec. 65. All civil and criminal proceedings before the Police Judge or in the Police Curt, including al proceedings for the violation of any city ordinance, are governed and regulated by the general laws of the State applicable to the Justices of the Peace or Justices' Courts in like or similar cases;...

\section{Police Judge-qualifications of.}

Section 61. There shall be appointed by the Mayor, with the consent of s majority of the members of the Common Council, a Police judge, who shall be the judicial official of the corporation, who shall hold a court therein, at such place as the Common Council shall provide, which shall be known as the Police Court;

An attorney of the Supreme Court.

Sec. 61. cont. he shall possess the qualifications of a voter of the City $f$ Portland and shall be an attorney of the degree of attorney of the Supreme Court of the State (p. 25).

Must qualify-Term of office.

Sec. 62. The Police Judge shall qualify within ten days after his appointment, and hold his office until his successor was appointed and qualified (p. 25).

Absent more than 10 days - Office vacant to possess qualifications.

Sec. 63. The office of Police Judge shall be deemed vacant whenever he shall be absent from the City for a period of more than ten days without the consent of the Council first had and obtained, or whenever he shall cease to possess the qualifications prescribed in Section 61 (p. 25).

Jurisdiction of.

Sec. 64. The Police Judge has jurisdiction of all crimes defined by ordinance of the City of Portland, and all actions brought to enforce or recover any forfeiture or penalty declared or given by such ordinance, and the jurisdiction and authority of a Justice of the Peace within the limits of the City of Portland, in both civil and criminal matters, and shall be subject to all the general laws of the State prescribing the duties of a Justice of the Peace and the mode of performing them (p. 26). 


\section{CHAPTER VIII.}

of the police department-police judge

\section{Proceedings-similar to-before a Justice of the peace.}

Sec. 65. All civil and criminal proceedings before the Police Judge or in the Police Curt, including al proceedings for the violation of any city ordinance, are governed and regulated by the general laws of the State applicable to the Justices of the Peace or Justices' Courts in like or similar cases;...

Police Judge-qualifications of.

Section 61. There shall be appointed by the Mayor, with the consent of s majority of the members of the Common Council, a Police judge, who shall be the judicial official of the corporation, who shall hold a court therein, at such place as the Common Council shall provide, which shall be known as the Police Court;

\section{An attorney of the Supreme Court.}

Sec. 61. cont. he shall possess the qualifications of $a$ voter of the City $f$ Portland and shall be an attorney of the degree of attorney of the Supreme Court of the State (p. 25).

\section{Must qualify-Term of office.}

Sec. 62. The Police Judge shall qualify within ten days after his appointment, and hold his office until his successor was appointed and qualified (p. 25).

\section{Absent more than 10 days-Office vacant to possess qualifications.}

Sec. 63. The office of Police Judge shall be deemed vacant whenever he shall be absent from the City for a period of more than ten days without the consent of the Council first had and obtained, or whenever he shall cease to possess the qualifications prescribed in Section 61 (p. 25).

\section{Jurisdiction of.}

Sec. 64. The Police Judge has jurisdiction of all crimes defined by ordinance of the City of Portland, and all actions brought to enforce or recover any forfeiture or penalty declared or given by such ordinance, and the jurisdiction and authority of a Justice of the Peace within the limits of the City of Portland, in both civil and criminal matters, and shall be subject to all the general laws of the State prescribing the duties of a Justice of the Peace and the mode of performing them (p. 26).

\section{Proceedings-similar to-before a Justice of the peace.}

Sec. 65. All civil and criminal proceedings before the Police Judge or in the Police Curt, including al proceedings for the violation of any city ordinance, are governed and regulated by the general laws of the State applicable to the Justices of the Peace or Justices' Courts in like or similar cases;... 


\section{JUSTICES OF THE PEACE \& PRECINCTS}

Portland was separated into precincts, presided over by Justices of the Peace elected by their constituents. The first precincts were North Portland and South Portland, which were subdivided and expanded. Portland established six Courts under the title of either Police Court or Court of Record. However, in 1885, most of these Courts were abolished, leaving the North and South Portland precincts only (Scott, p. 319). 


\section{PORTLAND \\ JUSTICES OF THE PEACE \& PRECINCTS ${ }^{24}$}

\begin{tabular}{|c|c|c|c|c|c|}
\hline & North Precinct & South Precinct & Central Precinct & Western Precinct & $\begin{array}{c}\text { Washington } \\
\text { Precinct }\end{array}$ \\
\hline Year & Justice of the Peace & Justice of the Peace & Justice of the Peace & Justice of the Peace & Justice of the Peace \\
\hline $1863-64$ & L Anderson & DW Lichenthaler & menty & 2. & 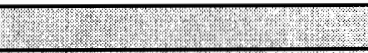 \\
\hline $1865-66$ & L Anderson & Geo B Gray & 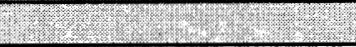 & 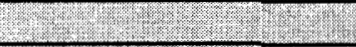 & Tl: \\
\hline 1867 & L Anderson & Jno Corey & I Graden & 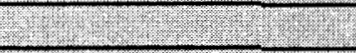 & 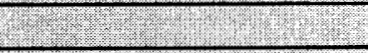 \\
\hline 1868 & L. Anderson & & SA Moreland & 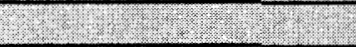 & (2) \\
\hline $1869-70$ & JO Waterman & & Jno C Work & 10 & MP Bull \\
\hline $1871-72$ & Those J Dryer & C Crich & AM Snyder & 2.0 .0 .02 & SA Moreland \\
\hline Year & North Precinct & South Precinct & (Discontinue) & Western Precinct & - As Stated - \\
\hline 1873 & Alex. Dodge & C Crich & 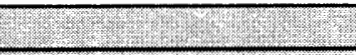 & Those J Dryer & EW Ryan (Morrison)) \\
\hline 1873 & & & (1:- & & HW Davis (Madison) \\
\hline 1873 & & & 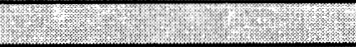 & & L Anderson (Couch \\
\hline 1874 & E Russell & C Crich & 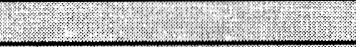 & J Dryer & EW Ryan (Morrison)) \\
\hline 1874 & & & F" & & HW Davis (Madison) \\
\hline 1874 & & & 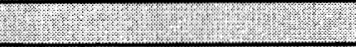 & & L Anderson (Couch \\
\hline 1875 & J Reilly & OS Phelps & 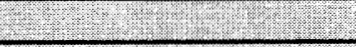 & Those J Dryer & A Bushwiler (Morrison) \\
\hline 1875 & & & (T). & & HW Davis (Madison) \\
\hline 1875 & & & (3) & & L Anderson (Couch \\
\hline $1876-77$ & CS Clark & OS Phelps & 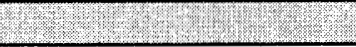 & Those J Dryer & RE Bybee (Morrison) \\
\hline
\end{tabular}

24 Scott, H. W., Editor, (1890), History of Portland Oregon: With Illustrations and Biographical Sketches of Prominent Citizens and Pioneers, D. Mason \& Co., Syracuse, New York, p. 319. 


\section{PORTLAND \\ JUSTICES OF THE PEACE}

\begin{tabular}{l|l|l|l|l|l|l}
\hline \multicolumn{1}{|c|}{ Year } & North Precinct & \multicolumn{1}{c|}{ South Precinct } & (Discontinue) & Western Precinct & - As Stated - \\
\hline $1876-77$ & & C Crich & & & HW Davis (Madison) \\
\hline $1876-77$ & & & & & L Anderson (Couch \\
\hline $1878-79$ & JE Evans & C Crich & & & Those J Dryer \\
\hline $1878-79$ & JR Wiley & & & & HW Davis (Madison) \\
\hline $1878-79$ & & & & & L Anderson (Couch \\
\hline $1878-79$ & & & & J Phelan & A Bushwiler (Couch) \\
\hline $1880-81$ & C Petrain & SS White & & & RE Bybee (Morrison) \\
\hline $1880-81$ & & & & & HW Davis (Madison) \\
\hline $1880-81$ & & & & & A Bushwiler (Couch) \\
\hline $1882-83$ & SH Greene & SS White & & & RE Bybee (Morrison) \\
\hline $1882-83$ & & & & & HW Davis (Madison) \\
\hline $1882-83$ & & & & CC Redman & A Bushwiler (Couch) \\
\hline $1884-85$ & SH Greene & SS White & & RE Bybee (Morrison) \\
\hline $1884-85$ & & & & & HW Davis (Madison) \\
\hline $1884-85$ & & & & & A Bushwiler (Couch) \\
\hline $1886-87$ & A Bushwiler & BB Turtle & & & \\
\hline $1888-89$ & J Phelan & BB Turtle & & & \\
\hline 1890 & John J Biles & WH Wood & & & \\
\hline
\end{tabular}




\section{PORTLAND POLICE}

1872 is the year cited as the official beginning of a formal policing system in the City of Portland. The Health Department was connected to the Police Department; every police officer was also a health officer. A City Physician inspected all buildings, ships and trains. Quarantines were enforced by the City Council (Scott, pp. 181-182).

There was a City Hospital, Poor House and Poor Farm for the indigent, incompetent and those unable to provide for themselves. The Poor Farm was also used to house Chinese lepers. A pest house was also owned and operated by the City of Portland (Scott, pp. 181-183).

The following police officers served the City of Portland: 
PORTLAND POLICE OFFICERS 1872-1889

\begin{tabular}{|c|c|c|c|c|c|c|c|}
\hline YEAR & POLICE & OFFICE & \multicolumn{2}{|c|}{ POLICE } & RANK & SPECIALS & POUNDMASTER \\
\hline 1872 & $\begin{array}{l}\text { A. B. Hallock } \\
\text { W. P. Burke } \\
\text { Eugene Semple }\end{array}$ & President & $\begin{array}{l}\text { J. H. Lappens } \\
\text { J. R. Wiley } \\
\text { A. B. Brannan } \\
\text { H. M. Hudson } \\
\text { W. M. Ward } \\
\text { D. Norton }\end{array}$ & $\begin{array}{l}\text { D. Walton } \\
\text { B. P. Collins } \\
\text { J. W. Kelly } \\
\text { C. F. Schoope } \\
\text { T. Burke } \\
\text { Thos. Gale }\end{array}$ & $\begin{array}{l}\text { Chief } \\
\text { First Capt. } \\
\text { Sec. Capt. }\end{array}$ & $\begin{array}{l}\text { W. M. Hickey } \\
\text { B. O. Hara } \\
\text { J. M. McCoy } \\
\text { M. F. } \\
\text { Sherwood } \\
\text { Paul Marten }\end{array}$ & Charles Lawrence \\
\hline 1873 & $\begin{array}{l}\text { A. B. Hallock } \\
\text { W. P. Burke } \\
\text { O. Risley }\end{array}$ & & $\begin{array}{l}\text { J. H. Lappens } \\
\text { J. R. Wiley } \\
\text { A. B. Brannan } \\
\text { Thos. Burk } \\
\text { J. W. Kelly } \\
\text { C. F. Cheppe } \\
\text { D. Norton } \\
\text { J. Corcoran } \\
\text { H. M. Hudson } \\
\text { J. K. Mercer } \\
\text { B. P. Collins }\end{array}$ & $\begin{array}{l}\text { J. D. Yates } \\
\text { O. D. Buck } \\
\text { A. J. Barlow } \\
\text { F. Reardon } \\
\text { M. T. Shhehan } \\
\text { B. O'Hara } \\
\text { J. McCoy } \\
\text { J. Sloan } \\
\text { P. Shea } \\
\text { J. O'Neil } \\
\text { P. Martin }\end{array}$ & $\begin{array}{l}\text { Chief } \\
\text { Captain } \\
\text { Captain }\end{array}$ & & \\
\hline $1874-1875$ & Not Indicated & & & & & & \\
\hline $1875-1876$ & $\begin{array}{l}\text { Shubrick Norris } \\
\text { J. R. Foster } \\
\text { M. S. Burrell }\end{array}$ & & $\begin{array}{l}\text { J. H. Lappens } \\
\text { B. P. Collins } \\
\text { J. Sloan } \\
\text { Thos. Burke } \\
\text { A. B. Brannan } \\
\text { B. T. Belcher }\end{array}$ & $\begin{array}{l}\text { Chas. Gritmacher } \\
\text { J. W. Kelly } \\
\text { J. T. Watson } \\
\text { J. W. Hain } \\
\text { H. M. Hobson } \\
\text { J. S. Hamilton }\end{array}$ & $\begin{array}{l}\text { Chief } \\
\text { Captain } \\
\text { Captain }\end{array}$ & $\begin{array}{l}\text { J. McCoy } \\
\text { B. O'Hara } \\
\text { M. T. Sheehan }\end{array}$ & Charles Lawrence \\
\hline $1877-1878$ & $\begin{array}{l}\text { R. R. Riley } \\
\text { Wm. Connell } \\
\text { E. W. Connell }\end{array}$ & & $\begin{array}{l}\text { L. Besser } \\
\text { H. S. Allen } \\
\text { J. W. Kelly }\end{array}$ & $\begin{array}{l}\text { C. P. Elwanger } \\
\text { H. M. Hudson } \\
\text { J. W. Kelly }\end{array}$ & $\begin{array}{l}\text { Chief } \\
\text { Captain } \\
\text { Captain }\end{array}$ & $\begin{array}{l}\text { J. McCoy } \\
\text { Barney O'Hara } \\
\text { M. F. Sheehan } \\
\text { C. W. Howard }\end{array}$ & M. B. Wallace \\
\hline
\end{tabular}


PORTLAND POLICE OFFICERS 1872-1889

\begin{tabular}{|c|c|c|c|c|c|c|c|}
\hline YEAR & $\begin{array}{c}\text { POLICE } \\
\text { COMMISSIONERS }\end{array}$ & OFFICE & \multicolumn{2}{|c|}{ POLICE } & $\overline{\text { RANK }}$ & SPECIALS & POUNDMASTER \\
\hline 1879 & $\begin{array}{l}\text { R. R. Riley } \\
\text { Wm. Connell } \\
\text { P. Taylor }\end{array}$ & & $\begin{array}{l}\text { L. Besser } \\
\text { J. Sloan } \\
\text { J. W. Kelly } \\
\text { H.M. Hudson } \\
\text { J. Jaskallar } \\
\text { P.G. Martin } \\
\text { P. Coakley } \\
\text { W. B. Daniels }\end{array}$ & $\begin{array}{l}\text { J. W. Ryan } \\
\text { Richard Collins } \\
\text { Andrew Henline } \\
\text { C. Gritmacher } \\
\text { James Stephens } \\
\text { Terry Mcmanus } \\
\text { T. P. Luther }\end{array}$ & $\begin{array}{l}\text { Chief } \\
\text { Captain } \\
\text { Captain }\end{array}$ & $\begin{array}{l}\text { M. F. Sheehan } \\
\text { B. Branch } \\
\text { F. M. Arnold } \\
\text { Wm Hickey } \\
\text { S. C. Barton }\end{array}$ & S. H. Reed \\
\hline 1880 & $\begin{array}{l}\text { Peter Taylor } \\
\text { E. Cvorbett } \\
\text { S. G. Skidmore }\end{array}$ & & $\begin{array}{l}\text { J. H. Lappens } \\
\text { James Sloan } \\
\text { C. Gritzmacher } \\
\text { Benj. F. Goodwin } \\
\text { H. M. Hudson } \\
\text { J. Jaskalla } \\
\text { D. J. Gillies } \\
\text { P. Coakley } \\
\text { C. S. Silver }\end{array}$ & $\begin{array}{l}\text { S. C. Mattieu } \\
\text { R. Collins } \\
\text { J. P. Luther } \\
\text { A. Henline } \\
\text { James Stephenson } \\
\text { J. I. Watson } \\
\text { J. W. Sloan } \\
\text { John Burk }\end{array}$ & $\begin{array}{l}\text { Chief } \\
\text { Captain } \\
\text { Captain } \\
\text { Clerk } \\
\text { Detective }\end{array}$ & $\begin{array}{l}\text { A. B. Brannan } \\
\text { Wm. Hickey } \\
\text { S. C. Barton } \\
\text { Benj. Branch } \\
\text { P. Saunders } \\
\text { Joseph day } \\
\text { J. W. Ryan } \\
\text { C. P. Elwanger }\end{array}$ & S. H. Reed \\
\hline 1881 & (not observed) & & & & & & \\
\hline
\end{tabular}


PORTLAND POLICE OFFICERS 1872-1889

\begin{tabular}{|c|c|c|c|c|c|c|c|}
\hline & HEALTH \& & POLICE & \multicolumn{2}{|c|}{ POLICE } & RANK & SPECIALS & POUNDMASTER \\
\hline 1882 & $\begin{array}{l}\text { T. L. Nicklin } \\
\text { J. B. Kellogg } \\
\text { Henry Hewitt }\end{array}$ & $\begin{array}{c}\text { S. B. } \\
\text { Stearns }\end{array}$ & $\begin{array}{l}\text { J. H. Lappeus } \\
\text { C. Gritzmacher } \\
\text { C. T. Belcher } \\
\text { B. F. Goodwin } \\
\text { H. M. Hudson } \\
\text { James Mott } \\
\text { Arthur M. Putnam } \\
\text { Peter Schulderman } \\
\text { Levi Wing } \\
\text { T. P. Luther } \\
\text { Alex Johnson } \\
\text { James T. Watson } \\
\text { Chris Emig }\end{array}$ & $\begin{array}{l}\text { Richard Collins } \\
\text { D. W. Dobbins } \\
\text { Andrew Holmberg } \\
\text { Felix Martin } \\
\text { Simeon C. Barton } \\
\text { A. B. Brannan } \\
\text { Wm. Meyers } \\
\text { James Barry } \\
\text { John Ring } \\
\text { S. C. Matthieu } \\
\text { Orrin H. Smith } \\
\text { Andrew Henline } \\
\text { Benj. Branch }\end{array}$ & $\begin{array}{l}\text { Chief } \\
\text { Captain } \\
\text { Captain } \\
\text { Clerk }\end{array}$ & & \\
\hline
\end{tabular}


PORTLAND POLICE OFFICERS 1872-1889

\begin{tabular}{|c|c|c|c|c|c|c|c|}
\hline & HEALTH \& & POLICE & \multicolumn{2}{|c|}{ POLICE } & RANK & SPECIALS & POUNDMASTER \\
\hline 1883 & $\begin{array}{l}\text { W. S. Scroggin } \\
\text { W. H. Adams } \\
\text { D. Mackay }\end{array}$ & $\begin{array}{c}\text { S. A. } \\
\text { Moreland }\end{array}$ & $\begin{array}{l}\text { J. H. Lappens } \\
\text { C. Gritzmacher } \\
\text { T.P. Luther } \\
\text { H.M. Hudson } \\
\text { John Ring } \\
\text { Alex. Johnson } \\
\text { W.A. Beaumont } \\
\text { Levi Wing } \\
\text { Wm Meyers } \\
\text { D. W. Dobbins } \\
\text { Benj. Branch } \\
\text { J. T., Watson' }\end{array}$ & $\begin{array}{l}\text { W. B. Bumpus } \\
\text { S. C. Barton } \\
\text { A. M. Putnam } \\
\text { Andrtew Henline } \\
\text { Chris Emig } \\
\text { Orrin H. Smith } \\
\text { James A Mott } \\
\text { J. N. James } \\
\text { Andrew Holmberg } \\
\text { J. F. Hair } \\
\text { James Barry }\end{array}$ & \begin{tabular}{|l|} 
Chief \\
Captain \\
Captain
\end{tabular} & & \\
\hline 1884 & $\begin{array}{l}\text { R. Gerdes } \\
\text { A. F. Sears, Jr. } \\
\text { W.H. Andrus }\end{array}$ & $\begin{array}{c}\text { S. A. } \\
\text { Moreland }\end{array}$ & $\begin{array}{l}\text { W. H. Watkinds } \\
\text { John Neale } \\
\text { A. F. Turner } \\
\text { J. F. Hair } \\
\text { A. M. Cornelius } \\
\text { Chas A. Christie } \\
\text { F. D. Love } \\
\text { A. Henline } \\
\text { Geo H. Ward } \\
\text { A. Johnson } \\
\text { S. S. Young } \\
\text { Levi Wing } \\
\text { E. C. Lyon } \\
\text { Abdrew Holmberg } \\
\text { Pat Keegan } \\
\text { J.N. James } \\
\text { A. B. Brannan } \\
\end{array}$ & $\begin{array}{l}\text { H. M. Hudson } \\
\text { Wm. Myers } \\
\text { F. M. Arnold } \\
\text { Richard Collins } \\
\text { J. E. Cramer } \\
\text { S. C. Barston } \\
\text { W.A. Hart } \\
\text { W. A. Beaumont } \\
\text { J. T. Watson } \\
\text { J. R. E. Selby } \\
\text { James Barry } \\
\text { R.M. Stuart } \\
\text { A. M. Putnam } \\
\text { W.L. Higgins } \\
\text { O. H. Smith } \\
\text { J. T. Flynn } \\
\text { C. T. Belcher } \\
\end{array}$ & $\begin{array}{l}\text { Chief } \\
\text { Clerk } \\
\text { Captain } \\
\text { Captain } \\
\text { Captain } \\
\text { Clerk of Police } \\
\text { Deputy }\end{array}$ & & \\
\hline
\end{tabular}


PORTLAND POLICE OFFICERS 1872-1889

\begin{tabular}{|c|c|c|c|c|c|c|c|}
\hline & HEALTH \& & POLICE & \multicolumn{2}{|c|}{ POLICE } & RANK & SPEICIALS & POUNDMASTER \\
\hline 1886 & $\begin{array}{l}\text { B. P. Cardwell } \\
\text { Johnathan } \\
\text { Bourne, Jr. } \\
\text { Joseph Smith }\end{array}$ & $\begin{array}{l}\text { R.W. } \\
\text { Dement }\end{array}$ & $\begin{array}{l}\text { S.B. Parrish } \\
\text { S. P. Lee } \\
\text { C. Gritzmacher } \\
\text { J. F. Farrell } \\
\text { A. Henline } \\
\text { Felix Martin } \\
\text { C. W. Holsapple } \\
\text { R. H. Austin } \\
\text { H. D. Griffin } \\
\text { J. M. Harkleroad } \\
\text { Henry Holland } \\
\text { J. H. Cunningham } \\
\text { Chris Emig } \\
\text { Daniel Maher } \\
\text { A. Tichenor } \\
\text { W. M. Beach } \\
\text { Andrew Holmberg } \\
\text { J. N. James } \\
\text { H. M. Hudson } \\
\text { F. M. Arnold } \\
\text { W. A. Hart } \\
\text { J. H. Beyer } \\
\text { J. H. Molt }\end{array}$ & $\begin{array}{l}\text { Ben Branch } \\
\text { J. J. Byrne } \\
\text { J. T. Watson } \\
\text { James Barry } \\
\text { A.M. Putnam } \\
\text { O. M. Smith } \\
\text { C. L. Belcher } \\
\text { S. S. Young } \\
\text { J. H. Nash } \\
\text { Pat Keegan } \\
\text { Samuel Simmons } \\
\text { A. B. Brannan } \\
\text { Wm Myers } \\
\text { Richard B. } \\
\text { Colllins } \\
\text { S.C. Barton } \\
\text { R. M. Stuart } \\
\text { P.J. MaCabe } \\
\text { FelixMartin } \\
\text { Wm. Hickey } \\
\text { C. P. Elwanger } \\
\text { J. A. Kelly } \\
\text { G. C. Morgan }\end{array}$ & $\begin{array}{l}\text { Chief } \\
\text { Clerk } \\
\text { Captain } \\
\text { Captain } \\
\text { Captain } \\
\text { Health Officer }\end{array}$ & & $\begin{array}{r}\text { Henry Wilmer } \\
\text { (Deputy) }\end{array}$ \\
\hline 1887 & (not observed) & & & & & & \\
\hline 1888 & (not observed) & & & & & & \\
\hline
\end{tabular}


PORTLAND POLICE OFFICERS 1872-1889

\begin{tabular}{|c|c|c|c|c|c|c|c|}
\hline & HEALTH \& & POLICE & \multicolumn{2}{|c|}{ POLICE } & RANK & SPECIALS & POUNDMASTER \\
\hline 1889 & $\begin{array}{l}\text { Joseph Simon } \\
\text { B. P. Cardwell }\end{array}$ & $\begin{array}{l}\text { A. H. } \\
\text { Tanner }\end{array}$ & $\begin{array}{l}\text { S. B. Parrish } \\
\text { C. Gritzmacher } \\
\text { R. H. Cardwell } \\
\text { Felix Martin } \\
\text { S. B. Parrish } \\
\text { R. H. Austin } \\
\text { James Barry } \\
\text { Ben Banch } \\
\text { J. J. Byrne } \\
\text { M. P. Charles } \\
\text { R. Z Collins } \\
\text { Jos. Day } \\
\text { Chris. Emig } \\
\text { J. F. Farrell } \\
\text { George Foss } \\
\text { H.D. Griffin } \\
\text { W. A. Hait } \\
\text { Wm. Hickie } \\
\text { C. E. Hoxsie } \\
\text { A. Holmberg } \\
\text { C. W. Holsapple }\end{array}$ & $\begin{array}{l}\text { H. M. Hudson } \\
\text { J. H. James } \\
\text { J. F. Kerrigan } \\
\text { Dan Maher } \\
\text { Felix Martin } \\
\text { Sam Miller } \\
\text { J. A. Mott } \\
\text { G. C. Morgan } \\
\text { Wm. Myers } \\
\text { N. M. Putnam } \\
\text { F. W. Robinson } \\
\text { Thos. Ryan } \\
\text { Abe Tichenor } \\
\text { J. T. Watson } \\
\text { H. S. Wood } \\
\text { Levi Wing } \\
\text { H. Wilmer } \\
\text { W. H. Warren } \\
\text { S.S. Young } \\
\text { S. P. Lee }\end{array}$ & $\begin{array}{l}\text { Chief } \\
\text { Captain } \\
\text { Captain } \\
\text { Humane Ofc.* } \\
\text { Health Officer }\end{array}$ & Henry Wilmer & \\
\hline
\end{tabular}

* Human Society - prevention of cruelty in city prison

Children's Aid Society - also known as Benevolent Society housed in the city of Portland's prison, (Scott, p. 183). 


\section{CHAPTER IV NATIVE AMERICANS}

Native Americans were the first people recognized as inhabitants of the Oregon country. It has been stated that many centuries ago tribes made their way from Asia by following the coast of Siberia, crossing the Bering Strait and from Alaska descended southward eventually making their homes along the Western coast of what would become the United States (Clark, p. 16).

Other historians believe earlier tribes probably came by ships/boats across the Pacific. Whatever the origin of their arrival, Native Americans have occupied the Western region of the U. S. for at least hundreds, but most likely, thousands of years prior to the arrival of white explorers and white settlers.

Tribes varied in their living arrangements and social and political structure. Some Native Americans were ultimately considered barbaric by white American standards, while others were accepted as civilized (Clark, p. 16). The Incas of Peru, the Mayas of Central America, and the Aztecs of Mexico were considered to be fully immersed in white contemporary living. While eastern tribes such as the Iroquois of New York, were respected for their form of government, most western tribes were considered barbaric and uncultivated, or as labeled by white settlers, savage (Clark, p. 17)

Native Americans were held to a white man's authoritative ideals of what civilized embraced. The tribes appeared to share no evidence of a written language, considered by westerners as a sign of intellect. Most tribes migrated with the change 
in seasons and therefore, labeled wanderers. The Native American diet consisted of wild fruits, berries and when necessary, insects, alien to the palates of most white settlers (Clark, p. 18). Native Americans were nomadic hunters -- and for that reason, considered closer to the cave man era than nineteenth century living. White men thought the Indians' use of bows and arrows as dated when compared to their use of gun powder and fire arms. White frontiersmen had no direct appreciation for the Native American's ability to make tools and utensils. They viewed Native American's craved pictures and inscribed engravings upon rocks, on their canoes and on the walls of their homes as uncultured and primitive (Clark, p. 18). Yet, despite these alleged inadequacies, Native Americans were recognized as prolific and resilient. White explorers and settlers were forced to accept that Native Americans fully occupied the western region of North America and were willing to resist intrusions into their homeland. Native Americans generally occupied four areas in the Oregon region (Clark, pp. 18-20):

1) the valley of the Columbia River - home to the Chinook and Clatsop tribes - on the Washington side of the river, home to the Cowlitz tribe;

2) the Willamette Valley - home to the Calapooias, the Molalas, the Santiams, the Lakmiuts, The Yamells (Yamhills) and the Tualati (Tualatins);

3) the coast county lying between the Coast Range and the sea -- home to the Tillammok, the Nehalems, the Nestucca, the Umpqua, and the Coquille tribes. Along the Rogue River the Tututni resided;

4) eastern Oregon - home to the Cayuses, Nez Perce, the Klamaths, the Modocs and the Yakimas

It has been estimated that hundreds of thousands of Native Americans complacently co-existed in the Northwest and western coastal region of North America prior to the arrival of white immigrants (Reddy, pp. 1-9). The arrival of 
settlers and explorers brought contagious, catastrophic diseases, which the immune system of Native Americans could not survive.

It has been calculated that tens of thousands of Native Americans residing in the Oregon region lost their lives to the spread of measles and smallpox between 1820 and 1850 (Clark, p. 20). Epidemic wars, the exposure to white man's whiskey, population dissipation and the continuing inflow of additional debilitating diseases such as tuberculosis, sapped the strength and the spirit of tribesmen throughout the region into the late 1800's (Clark, p. 35).

As a result, Native American military strength dissipated. Native American once distinguished as warriors, gradually became vulnerable and hence forced to accept the presence of white settlers and troops as each moved in and took control and ownership of what was once tribal land. There were laws enacted by the United States government and sanctioned by the white residents of Oregon and ultimately, the City of Portland, that adversely affected the lives and of Native Americans and jeopardized ownership of their land. ${ }^{1}$

Oregon lawmakers enacted laws during the provisional period many of which transferred into statehood controlling the daily lives of Native American residing in Oregon. The following commentary contains acts and these laws as examples of legal inequities.

\footnotetext{
1 During the 1840's white settlers in Willamette Valley, established a code of law under the direction of Dr. Elijah White, appointed by President Polk as a sub-Indian agent (Tracy, p. 54). The laws, entitled White Code, while designed to use Native American chiefs to control the activities of tribes, also enabled White to police the social movements of the white settlers (Tracy, p. 55) - See White Code, this CHAPTER, p. 156.
} 
Initially, in 1845, under Article I of the Organic Law of the Provisional

Government, Native Americans were accorded civil rights with respect to their land and other property.

\begin{tabular}{|c|c|}
\hline \multicolumn{2}{|r|}{$\begin{array}{c}\text { ORGANIC LAW } \\
\text { OF THE PROVISIONAL GOVERNMENT OF OREGON }\end{array}$} \\
\hline & ARTICLE I \\
\hline $\begin{array}{r}\text { Religion, morality and } \\
\text { schools. } \\
\text { Faith towards the Indians. } \\
\text { Property not to be taken } \\
\text { from them without their } \\
\text { consent. } \\
\text { Not to be disturbed except } \\
\text { in lawful war } \\
\text { Laws to be passed from } \\
\text { time to time to prevent } \\
\text { injustice being done them }\end{array}$ & $\begin{array}{l}\text { Sec. 3. Religion, morality, and knowledge, being necessary to good } \\
\text { government and the happiness of mankind, schools and the means of } \\
\text { education shall be forever encouraged. The utmost good faith shall always } \\
\text { be observed towards the Indians; their lands and property shall never be } \\
\text { taken from them without their consent; and in their property, rights and } \\
\text { liberty, they shall never be invaded or disturbed, unless unjust and lawful } \\
\text { wars, authorized by the representatives of the people, but laws founded in } \\
\text { justice and humanity, shall from time to time, be made for preventing } \\
\text { injustice being done to them, and for preserving peace and friendship with } \\
\text { them (p. 59). }\end{array}$ \\
\hline
\end{tabular}

Yet, within the same document, their right to government representation was denied. Native Americans were afforded civil rights they could not legislatively protect.

\begin{tabular}{|c|c|}
\hline \multicolumn{2}{|r|}{$\begin{array}{c}\text { ORGANIC LAW } \\
\text { OF THE PROVISIONAL GOVERNMENT OF OREGON }\end{array}$} \\
\hline & ARTICLE II \\
\hline $\begin{array}{r}\text { Legislative power, how } \\
\text { vested. } \\
\text { Number of representatives } \\
\text { and how chosen. }\end{array}$ & $\begin{array}{l}\text { Sec. } 1 . \text { The legislative power shall be vested in a house of representatives, } \\
\text { which shall consist of not less than thirteen nor more than sixty-one members, } \\
\text { whose numbers shall not be increased more than five at any one session, to } \\
\text { be elected by the qualified electors at the annual election, to giving to each } \\
\text { district a representative in the ration of its population (excluding Indians) } \\
\text { and the said members shall reside in the district for which they shall be } \\
\text { chosen; and in case of vacancy by death, resignation, or otherwise, the } \\
\text { executive shall issue his writ to the district where such vacancy has occurred, } \\
\text { and cause a new election to be held...(p.60)... }\end{array}$ \\
\hline
\end{tabular}

2 Deady, M. P., compiler and annotator, (1866), The Organic and Other General laws of Oregon Together With the National Constitution and Other Pubic Acts and Statues of the United States: $1845-1864$, Henry L. Pittock, State Printer, Portland, Oregon, pp. 59-76. 
In 1848 , the Oregon region was granted territorial rights by the United States government. ${ }^{3}$ Under territorial government, legislative sentiments changed. The U. S. government provided for the protection of property rights of white settlers claiming land in the Oregon Territory without direct consent from Native Americans. Native American treaties were either signed under duress or without agreement among all parties involved. Provisions were included in the Territorial Act ${ }^{4}$ to ensure that the federal government had final authority regarding land ownership and allocation.

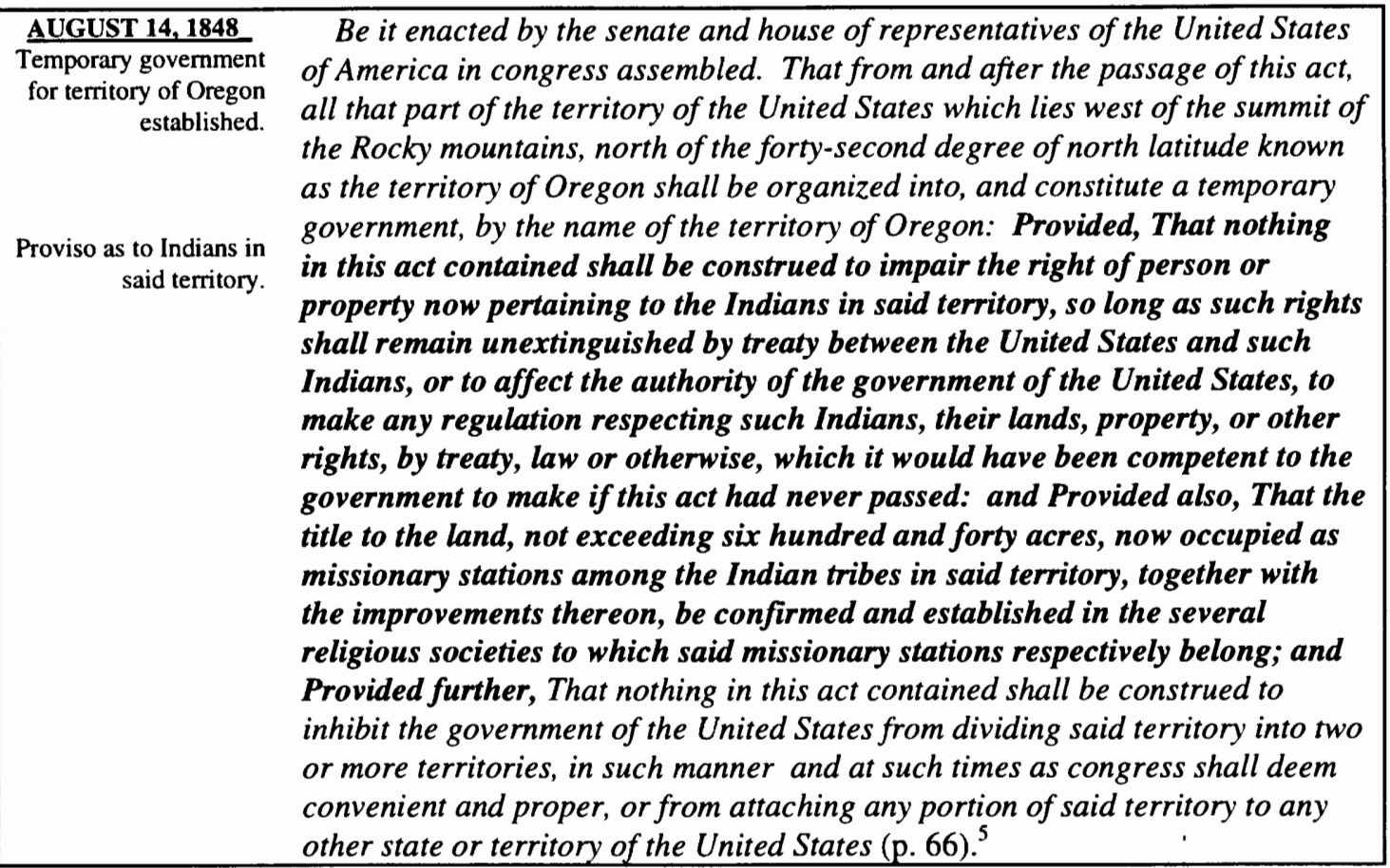

3 The Oregon Territory was comprised of what would eventually become the states of Oregon, Washington and parts of Idaho and Montana west of the Rocky Mountains. The Territory, under white men's rule was controlled with strict provisions for living arrangements for Native Americans to whom the land had originally belonged...(Scott, p. ). See Reservations this CHAPTER.

4 See TERRITORIAL GOVERNMENT - AN ACT - TO ESTABLISH THE TERRITORIAL GOVERNMENT OF OREGON, CHAPTER I, pp. 28-29.

$5 \quad$ Op. Cit., Deady, (1866), by an act dated 2 March 1853, the Territory of Washington was created out of that portion of the Territory of Oregon lying north of the mouth of the Columbia River to $46^{\circ}$ north latitude and eastward to the summit of the Rocky Mountains (footnote 1, p. 66). 
The territorial governor was given authority over Native American

transactions. Chiefs and tribes who once controlled their destiny were subjected to government rule.

Executive power to be vested in a government in a governor; his tenure of office, power, duties and emoluments.
Sec. 2. And be it further enacted, That the executive power and authority, in and ever said territory of Oregon, shall be vested in a government, who shall hold his office for four years,...The governor shall reside within said territory,... and receive the emoluments of superintendent of Indian Affairs, ${ }^{6}$ he may grant pardons and respites for offenses against the laws of said territory, and reproves for offenses against the laws of the United States, under the decision of the president can be made known thereon; he shall commission all officers who shall be appointed to office under the laws of the said territory, where, by law, such commissions shall be required, and shall take care that the laws be faithfully executed (p. 67)...

Under the same Act, provisions were made to provide gifts to Native Americans as a means of keeping the peace. It was assumed Native Americans would be satisfied in accepting trivial peace offerings in exchange for the occupation of their land, disturbance and interruption of their customs and traditions and control of their daily activities.

\begin{aligned} & \hline AUGUST 14, 1848 $\begin{array}{r}\text { Sec. 13. And be it further enacted, That the sum of ten thousand dollars be, } \\ \text { And for prests to } \\ \text { Indians. }\end{array} \\ &$ of is hereby appropriated, to be expended under the direction of the president \\ & as have been engaged by the provisional government of Oregon, in conveying \\ & communications to and from the United States, and the purchase of presents \\ & for such of the Indian tribes as the peace and quietude of the country \\ & requires (p. 75). \end{aligned}

6 Ibid., by an act dated 5 June 1850, the duties of superintendent of Indian Affairs were passed to a separate officer (footnote 1, p. 67). 
However, this Act implied that while Native Americans were present in the

territory, they were not considered as inhabitants worthy of civil rights and government protections of those rights.

Ordinance of 1787 Sec. 14. And be it further enacted, That the inhabitants of said territory shall extended over Oregon. be entitled to enjoy all and singular, the rights, privileges, and advantages granted and secured to the people of the territory of the United States northwest of the river Ohio, by the articles of compact contained in the ordinance for the government of said territory, on the thirteenth day of July, seventeen hundred and eighty-seven; and shall be subject to all the conditions, and restrictions, and prohibitions in said articles of compact imposed upon the people in said territory; and the existing laws now in force in the territory of Oregon, under the authority of the provisional government established by the people...(p. 76).

\section{Donation Land Law ${ }^{7}$}

In an effort to attract white settlers to the northwestern region of the United States, Congress enacted the Donation Land Law stipulating the following previsions:

\section{ACTS OF CONGRESS \\ RELATING TO PUBLIC LANDS IN OREGON (TERRITORY)}

September 27, 1850

Grants of public land.

$\$ 4$. There shall be, and hereby was granted to every white settler or occupant f the public lands, American half-breed Indians included, above the age of eighteen years, being a citizen of the United States, or having made a declaration according to law, of his intention to become a citizen, or who shall make such declaration on or before the first day of December, Eighteen hundred and fiftyone, now residing in said territory, or who shall become a resident thereof, on or before first day of December, eighteen hundred and fifty, and who shall have resided upon and cultivated the same for four successive years, and shall otherwise confirm to the provisions of this act, the quality of one half sections, or three hundred and twenty acres of land, if a single man ${ }^{8}$ and if a married man, or if he shall become married within one year from the first day of December, eighteen hundred and fifty, the quantity of one section, or six hundred and forty acres, one half himself, and the other half to his wife, to be held by her in her own right;...(p. 65).

7 Deady, Matthew P. and Lafayette Lane, Organic and Other General Laws of Oregon: 18431872, Criminal Code, p. 66.

$8 \quad$ Ibid., The words "single man" include an unmarred woman, 77 Wall., 219, (footnote 1,p. $65)$.

9 Ibid. A settler was married within the meaning of this act, without reference to the color or race of his wife. The wife takes an account of her "wifeship," and no other qualification was required as to her (footnote 2, p. 65). 
The land rights of Native Americans became null and void unless an Indian was the offspring of a white man. The Land Donation Act played a dominate role in attracting white settlers to the Oregon Territory while diminishing the occupancy of Native Americans. Although ultimately offering less acreage to white settlers, the deadline for claim incentives was nevertheless extended from December 1850 until

\section{December 1853.}

Grants of land to white persons emigrating between December 1,1850 and December 1,1853 .

$\$ 5$. To all white male citizens of the United States, or persons who shall made a declaration of intention to become such, above the age of twenty-one years, emigrating to and settling in said territory, between the first day of December, eighteen hundred and fifty, and the first day of December, eighteen hundred and fifty-three; and to all white male American citizens, not hereinafter provided for, becoming one and twenty years of age, in said territory, and settling there between the time last afore said, who shall in other respects comply with the foregoing section and the provisions of this law, there shall be, and hereby was granted the quantity of one quarter section, or one hundred and sixty acres of land, if a single man; or if married, or if he shall become married within one year from the time of arriving in said territory, or within one year after becoming twenty-one years of age as aforesaid, then the quantity of one half section, or three hundred and twenty acres, one half to the husband, and the other half to the wife in her own right... (p. 66).

The four year rule of occupancy was reduced to two years and even further reduced to one year as an additional incentive for white settlers to seek residence in Oregon Territory.

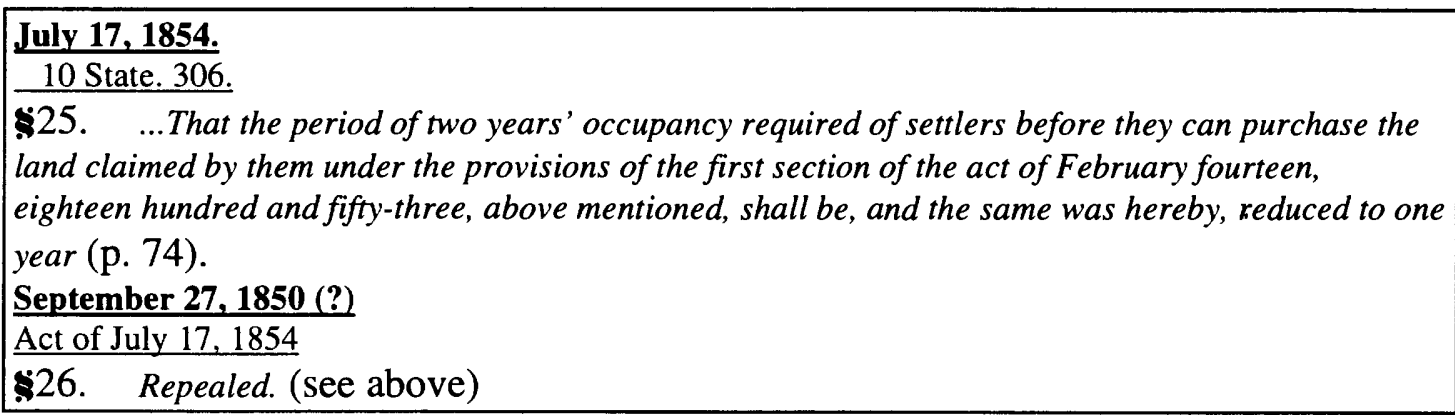

Other Oregon laws enabled the Native American wife of a white man to be accepted as a married woman under the definition of the Donation Land Act. This 
interpretation entitled her to one half of 160 acres, the section of land owned by both her and her husband, totaling 320 acres (Deady, p. 66). ${ }^{10}$

However, a full-blooded Indian (both parents Native American) could not claim land under this provision. Yet, if a Native American's male parent was white, subsequently labeling him as a half-breed, he was entitled to 160 acres as a single man, or 320 acres as a married man.

Most Native Americans were denied rights of full citizenship and not considered as identifiable residents of Oregon. The difficulty for Native Americans was expressed as having

...derived from their position of wardship and dependency, which discouraged initiative and thrift and deprived them of individual title to their lands "the chief incentive to labor and exertion--the very mainspring on which prosperity of a people depends (Handlin, p. 35).

\section{Census Taking}

It cannot be denied that Native Americans were not acknowledged as citizens within the Oregon Territory.

\section{ARTICLE IV. LEGISLATIVE DEPARTMENT.}

September 18, 1857

Census.

\$5. The legislative assembly shall, in the year eighteen hundred and sixty-five, and every ten years after, cause an enumeration to be made of all the white population of the state (p. 81).

However, the 1870 census (see the following page) does indicate that the presence of some Native Americans was acknowledged during that national survey. The aggregate census of 1892 , of the previous four decades indicated that Native

10 See CHAPTER I, footnote 1 of this document. 
Americans, while not appearing ${ }^{11}$ to be present in significant numbers within the city of Portland, were members of the community. See POPULATIONS - APPENDIX IV.

\section{UNITED STATES CENSUS OF THE CITY OF PORTLAND, OREGON $1870^{12}$ IDENTIFIABLE NATIVE AMERICANS}

\begin{tabular}{|c|c|c|c|c|c|c|c|c|}
\hline \multirow[t]{2}{*}{$\begin{array}{c}* \text { NO } \\
. \\
\end{array}$} & \multirow[t]{2}{*}{$\begin{array}{c}* * \\
\text { HOUSE } \\
\text { HOLD }\end{array}$} & \multicolumn{2}{|c|}{ NAME } & \multirow[t]{2}{*}{ AGE } & \multirow[t]{2}{*}{$\begin{array}{l}\text { GEN } \\
\text { DER }\end{array}$} & \multirow[t]{2}{*}{$\begin{array}{l}\text { BIRTH } \\
\text { PLACE }\end{array}$} & \multirow[t]{2}{*}{ VOCATION } & \multirow[t]{2}{*}{ ETHNICITY } \\
\hline & & LAST & FIRST & & & & & \\
\hline 1. & 1285 & Alupin, & Mary & 27 & $f$ & Ore & $\begin{array}{l}\text { washing } \\
\text { by day }\end{array}$ & Indian \\
\hline 2. & & & Sally Ann & 12 & f & Ore & & Indian \\
\hline 3. & & & Amelia & 25 & f & Ore & $\begin{array}{l}\text { washing } \\
\text { by day }\end{array}$ & \\
\hline 4. & 656 & Itta, & Clothilde & 12 & $\mathrm{f}$ & Ore & domestic & Indian \\
\hline 5. & 1450 & Delora, & Mary & 45 & f & W. T. & keeps house & Indian \\
\hline 6. & & & Celia & 18 & f & Ore & doubtful & Indian \\
\hline 7. & & & Margaret & 13 & f & Ore & school & white \\
\hline 8. & 1289 & Jansen & Otto & 26 & $\mathrm{~m}$ & Idaho & fishing & Indian \\
\hline 9. & & & Amelia & 22 & f & Ore & keeps house & Indian \\
\hline 10. & & & Lucy & 15 & f & Ore & & Indian \\
\hline 11. & & & Mary A. & 1 & f & Ore & & Indian \\
\hline 12. & 1286 & Kenley & Charles & 28 & $m$ & Idaho & laborer & Indian \\
\hline 13. & & & Catherine & 25 & f & B. C. & keeps house & Indian \\
\hline 14. & & & Louisa & 2 & f & Ore & & Indian \\
\hline 15. & & & Mary & 1 & $\mathrm{f}$ & Ore & & Indian \\
\hline 16. & 1287 & Ketsman & John & 26 & $\mathrm{~m}$ & Rupertland & laborer & Indian \\
\hline 17. & 1288 & Kimsah & Mary & 28 & $\bar{f}$ & Ore & keeps house & Indian \\
\hline 18. & & & Amelia & 12 & f & Ore & & Indian \\
\hline 19. & & & Jane & 10 & f & Ore & & Indian \\
\hline 20. & & & John & 5 & $\mathrm{~m}$ & Ore & & Indian \\
\hline 21. & 1287 & Komas & Jim & 26 & $\mathrm{f}(?)$ & Rupertland & laborer & Indian \\
\hline 22. & 1449 & Marshall & Wm. H. & 29 & $\mathrm{~m}$ & N. Y. & $\begin{array}{l}\text { saloon } \\
\text { keeper }\end{array}$ & white \\
\hline 23. & & & Maggie & 21 & F & Ore & keeps house & Indian \\
\hline 24. & 126 & Raney & Sophia & 18 & $\mathrm{f}$ & Ore & domestic & Indian \\
\hline 25. & 1287 & Sheppard & Joseph & 18 & $m$ & Idaho & laborer & Indian \\
\hline
\end{tabular}

*Count as per this research

** System used - but not explained

11 Some historians assert that most Native Americans were not counted and therefore the extent of their Portland population from the 1850's to the late nineteenth century was not accurate - see POPULATIONS - APPENDIX IV.

12 Hiday, Mrs. Harry I, Compiler, (1872). The data has been replicated and condensed from the entire census report of 1870 for the city of Portland. 


\section{$\underline{\text { Education }}$}

My research did not indicate that there was a specific legal provisions denying Indian children not living on reservations, the right, or opportunity, to attend public schools. However, such rules were, if not legally, at least socially, enforced. ${ }^{13}$ Records observed did not suggest that Native American children attended public schools or any school. ${ }^{14}$

\section{Liquor Laws}

The daily movements and the fraternization of Native Americans were legally suppressed and manipulated.

\section{December 8, 1865}

CHAPTER VIII.

Of crimes against public policy.

\section{Selling liquor or fire-arms to Indians.}

$\$ 669$. If any person, without the authority of the United States, or some authorized officer thereof, sell, barter or give to any Indian or half breed, who lives and associates with Indians, any fire-arms or ammunition thereof, what ever or any spirituous, malt or vinous liquor, such person, upon conviction thereof, shall be punished by imprisonment in the county jail not less than one, nor more than five hundred dollars (p. 437).

Oregon law denied Native Americans the same civil and legal rights as white residents. This intolerant atmosphere encouraged non-Native Americans to

13 In 1819, Congress established the Indian Civilization Fund, which promised annuities for education including teachers and physical facilities (Szasz, p.214). However, my research did not indicate that schools existed in Oregon. The Bureau of Indian Affairs did not become active in educational endeavors until the late 1800's (Wood, p. 1).

14 In the early 1800 's the U. S. government initially made provisions for Native American education through legislation and treaties. However, the form of education was to civilize Native Americans by instructing Indians how to adopt white customs (Szasz, pp. 9-10). 
infantilize Indians, especially Native American males. Native Americans were subjected to status offense violations ${ }^{15}$ usually applied to youth in a open society.

An examination of the data extracted from the 1870 census (see APPENDIX IV) appears to indicate that a Native American population comprised of mostly females resided in Portland. Occupations of Native American males registered by the census denoted non-traditional vocations not usually inherent in Indian culture.

\section{Intermarriage}

The following laws provide additional examples of Oregon's disregard for Native Americans and total neglect of any semblance of civil rights or human dignity.

\section{October 24, $1866 \$ 1$. Intermarriage with negro, etc., declared void. (p. 440) \\ $\$ 689$. Hereafter it shall not be lawful within this state for any white person, male or female, to intermarry with any Negro, Chinese or any person having one fourth or ore Negro, Chinese or Kanaka blood, or any person having more than one half Indian blood; and all such marriages or attempted marriages, shall be absolutely null and void ( p. 440). \\ Punishment for the same (see \$689). \\ $\$ 690$. If any white person, Negro, Chinese, Kanaka or Indian, within the degrees forbidden in section 689, shall knowingly intermarry, or attempt the same, by procuring a solemnization of marriage, under any of the forms or ceremonies legalized in this state, such person or persons, upon conviction thereof, shall be punished by imprisonment in the penitentiary or county jail, not less than three months, not more than one year (p. 440).}

While Oregon law prohibited miscegenation, intermarriage between white males and Native American females was informally tolerated. A closer look at the

15 Status Offense violations refers to offenses committed by youth that usually are not considered in violation of law if committed by an adult, i.e. breaking curfew, loitering, frequenting certain establishments, and/or truancy from certain required gatherings (Champion, p. 35). 
1870 census report suggests that the head of household was an unemployed Native American female with one Indian and one white child.

\begin{tabular}{|c|c|c|c|c|c|c|c|}
\hline $\begin{array}{l}\text { *House } \\
\text { Hold }\end{array}$ & $\begin{array}{c}\text { Last } \\
\text { Name }\end{array}$ & $\begin{array}{l}\text { First } \\
\text { Name }\end{array}$ & Age & $\begin{array}{c}\bar{M} \\
\mathbf{F}\end{array}$ & $\begin{array}{l}\text { Birth } \\
\text { Place }\end{array}$ & Vocation & Ethnicity \\
\hline 1450 & Delora, & $\begin{array}{c}\text { Mary } \\
\text { Celia } \\
\text { Margaret }\end{array}$ & $\begin{array}{l}45 \\
18 \\
13\end{array}$ & $\begin{array}{l}\mathrm{f} \\
\mathrm{f} \\
\mathrm{f}\end{array}$ & $\begin{array}{l}\text { W. T. } \\
\text { Ore } \\
\text { Ore }\end{array}$ & $\begin{array}{c}\text { keeps house } \\
\text { doubtful } \\
\text { school }\end{array}$ & $\begin{array}{l}\text { Indian } \\
\text { Indian } \\
\text { white }\end{array}$ \\
\hline
\end{tabular}

*System used - but not explained

It seems logical to presume that Mary Delora was probably married to, or residing with, a white male. As a result of Oregon law prohibiting interracial marriages, it is suggested that perhaps Mary Delora and her mate sought to formally conceal their marital status ${ }^{16}$ or living arrangements, while informally ignoring Oregon 's discriminatory laws.

\section{Reservations $^{17}$}

Provisions were made for surviving Native Americans and their descendants to live on reservations and anyone seeking to interrupt this arrangement was considered in violation of Oregon law.

\section{CHAPTER XXV. ${ }^{18}$}

OF INDIANS AND HALF-BREEDS BELONGING TO THE RESERVATION. Indians or half breed, unlawful to entice from reservation or harbor.

$\$ 1$. It shall be unlawful for any person to entice, induce or persuade any Indian or half-breed, who habitually resides with Indians, to leave the Indian reservation or territory, where such Indian or half-breed belongs, or to harbor or conceal such Indian or half-breed or to countenance or encourage, or in any way assist such Indian or half/breed to escape from, elude or evade the agent or superintendent having charge of the tribe...

16 In order to circumvent Oregon law, historians report that residents seeking interracial relationships eloped to Washington Territory, later becoming the State of Washington, to get married (Hill, p. 30).

17 In 1887, the U. S. government passed the Dawes Act, or Allotment Act which provided for land provisions to Native Americans residing on reservations (Szasz, p. 8)

18 see Oregon Constitution October 26, 1864 and APPENDIX XXII. 
Yet, having restricted Native Americans to reservations, Oregon law makers still sought to control Native American socialization by assigning white agents to monitor their movements, thus removing the obligations from the territorial governor.

\section{Written consent of agent.}

$\$ 1$. cont....unless such Indian or half-breed was absent by the written consent of the superintendent or agent aforesaid (p. 619).

Oregon laws were also enacted to ensure that any form of public-spirited interference did not occur.

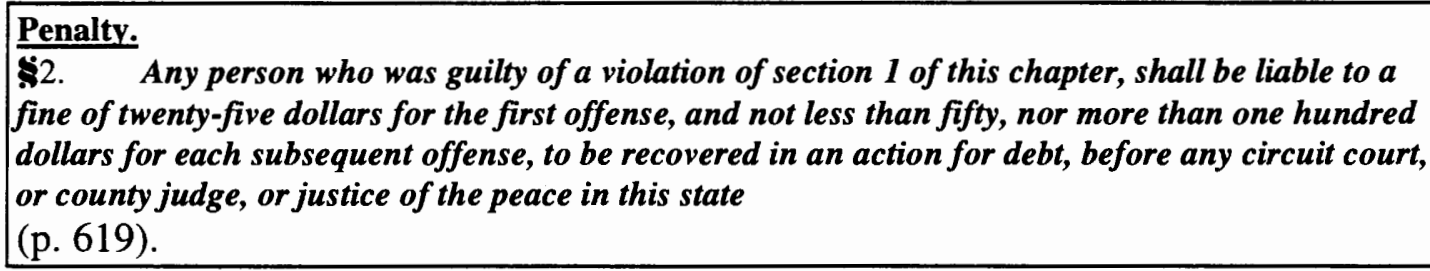
fine of twenty-five dollars for the first offense, and not less than fifty, nor more than one hundred dollars for each subsequent offense, to be recovered in an action for debt, before any circuit court, or county judge, or justice of the peace in this state (p. 619).

\section{Portland Ordinances}

An examination of significant Portland Ordinances enacted from 1854 to 1886, does not disclose specific animosities toward Native Americans per se. See APPENDIX XXIII. However, the City was bound to observe and enforce the laws of the State of Oregon and the United States government.

Within the perimeters of the legally influenced and socially intolerant climate that existed in Portland, what does an examination of the Arrest and Court Records of cases involving Native Americans divulge? In addition, what other legal and social influences impacted the lives of Native Americans during the historical periods observed? 
The race/ethnicity of arrestees (defendants) was not specifically indicated under a designated heading until 1894. In cases involving arrests of Native Americans, first names only were recorded with the accompanied description of 'Indian. ${ }^{19}$ The City Ordinance it did not specify that both a first and last name had to be recorded; other criterion were also stipulated.

\section{RELATING TO THE DUTIES OF THE “POLICE JUDGE.”}

No. 899.-APPROVED NOVEMBER 25, 1870.

\section{The City of Portland does ordain as follows:}

Section 1. The Police Judge shall make and file with the Auditor of the first day of the months of January, April, July and October, or within five days thereafter, a full and complete report of the business transacted in his court for the quarter preceding, in which said report shall be set forth in appropriate columns the names of persons arrested and brought before the court, the date thereof, the offense charged, whether for a violation of a city ordinance or a law of the State, the amount of fine, term of commitment, amount of costs, amount of fines and fees collected, amount due to

19 H. S. Lyman in his article, Indian Names, stated,... white men always like to change the original Indian somewhat...such a disposition arises partly from the white man's egotism, which rejoices in showing that he can make a thing wrong if he pleases, and especially that an Indian name has no rights which he (the white man) was bound to respect...(p. 316). 


\section{CHAPTER V \\ NATIVE AMERICANS \\ PORTLAND ARREST RECORDS}

Information regarding the arrests of Native Americans was extrapolated from the arrest data inserted from arrest records observed during my research. See PORTLAND ARREST RECORDS, APPENICES VIII-XII. Most cases involving the arrests of Native Americans have been included in this section because there were few incidents observed per year. Most Native Americans appeared to have been policed and adjudicated by special forces formed from within their ranks.

Native Americans residing on reservations were policed by their elected officials and adjudicated by authority of the Indian agent appointed to the region (Hagan, p.25).

During the 1860 's and 1870 's, without formal approval from the federal government, including the President, several Native American agents decided that circumstances (such as horse thefts) on reservations required law enforcement and judicial services other than that provided by government at any level.

Native American agents insisted on the establishment of a police force and court for each reservation (Hagan, p. 25). Pawnees, Klamaths, Modocs, Navajos, Apaches, Blackfeet, Chippewas and Sioux were several of the tribes required to adhere to this new form of governance. Agents selected warriors, respected within their ranks, from each tribe, provided uniforms, and ordered that they end larceny and 
other activity deemed criminal or unacceptable to Anglo Saxon ${ }^{1}$ society (Hagan, p. 25).

The selected Native American authorities were alleged to have been flattered and yet challenged by their distinction and delegated responsibility (Hagan, p. 25). This group of Native Americans successfully curbed one of the most popular and prestigious customs among Native Americans.

For generations, one of the methods used by young Native American braves to demonstrate their right to become warriors was to raid the horse herds of their enemies. However, Native Americans, assigned policing duties, seized and restored any stolen property. Their actions all but eliminated a traditional custom accepted as a demonstration of Native American manhood (Hagan, p. 25). This form of policing was enforced for several years despite objections by tribal members. The following account is an example of disruptions to the centuries of customs central to Native Americans' life style.

As a result of the tolerated but objectionable policing, the Klamath Reservation in Oregon experienced a difficult situation. John B. Meacham was appointed as agent of the Klamath and Modoes Reservations. Meacham became aware that the Modoes were returning to their ancestral, deemed criminal, customs. As a result, he arranged for the election of chiefs more receptive to change, introduced a new code of laws and a court preceded over by the newly elected chiefs (Hagan, p. 26).

The new code of law was formerly known as the White Code - suggesting such laws reflected the white man's view of authority. The White Code has been inserted to illustrate the inequities contained within its provisions. Not only were the

\footnotetext{
Thesaurus)

Anglo -English - Saxon - German (American Heritage Dictionary, Roget's II: The New
} 
majority of these laws unjust, they were alien to Native American culture. Such laws were designed to command Native American assimilation into white culture.

\section{WHITE CODE ${ }^{2}$}

Article 1. Whoever willfully takes a life shall be hung.

Article 2. Whoever burns a dwelling-house shall be hung.

Article 3. Who ever burns an outbuilding shall be imprisoned six months, receive fifty lashes and pay all damages.

Article 4. Whoever carelessly burns a house or any property shall pay damages.

Article 5. If any one enters a house without the permission of the owner the chiefs (Native American) shall punish him as they think proper. Public rooms are excepted.

Article 6. If anyone steals, he shall pay back twofold. And if it be of the value of a beaver skin, or less, he shall receive twenty-five lashes; and if the value is over a beaver skin, he shall pay back twofold and receive fifty lashes.

Article 7. If any one take a horse and ride it without permission, or take any article and use it without liberty, he shall pay for the use of it and receive from twenty-five to fifty lashes, as the chiefs shall direct.

Article 8. If any one enter a field and injure the crops, or throw down the fence so that cattle or horses enter and do damage, he shall pay all damage and receive twenty-five lashes for every offense.

Article 9. Those only may keep dogs who travel or live among game. If a dog kill a lamb, calf or any domestic animal, the owner shall pay the damage and kill the dog.

Article 10. If any Indian raise a gun or other weapon against a white man, it shall be reported to the chiefs and they shall punish him, it shall be reported to Dr. White, and he shall punish or redress.

Article 11. If an Indian break these laws he shall be punished by the chiefs, and if a white man break them he shall be reported to Dr. White and he shall punish or redress.

The code, based on Anglo-Saxon legal traditions, created mass

hostility as such laws adversely affected Klamath-Mood sex mores and family

2 Tracy, Charles Abbott, (1976), The Evolution of the Police Function in Portland, Oregon, 1811-1874, Dissertation, University of California, California State University campus, San Jose, California, pp. 55-56. Also see:

A. J. Allen (ed.), (1848), Ten Years in Oregon: Travels and Adventures of Doctor E. White and Lady, Mack, Andrus and Company, Ithaca, New York, pp. 189-190. 
orientations (Hagan, p. 26). Although the code forced what appeared to be a more humanitarian life style, such laws did not consider that a change in attitudes often required education and time rather than forced unfamiliar and uncomfortable discipline. For example, the new laws enforced monogamy and interfered with a Native American husband's traditional right to lodge pole $^{3}$ his wife if she proved to be uncontrollable (Hagan, p. 29).

Nevertheless, but perhaps to demonstrate their objections, Native American judges cognizant of their position, made arrest for trivial offenses or no offenses, a mockery of the system (Hagan, p. 30). The results of their laced, but often inappropriately zealous, attitude is thought to have put Meacham life's in jeopardy. He was wounded and reportedly almost slain by a group of Native American conspirators not only acting out their anguish against the new laws, but against the presence and control of white authority. They despised the new laws and compliance that forced Native Americans to capture and kill other Native Americans fighting to retain civil and human rights, dignity and tribal traditions (Hagan, pp. 30-38).

Yet, the special policing movement took momentum under the direction of Special Indian Commissioner, General O. O. Howard. He recruited additional Native Americans from various tribes to control Indian activities. Policing by Native Americans of Native Americans continued, but

3 Lodge pole - a tree trunk that serves as the central support of a tent or tepee. Sioux woman hung their children's cradleboards on the ledge pole (Patterson, p. 129). 
not without continued disruptions. There was dissatisfaction with uniforms, wages, and an ongoing discontent with the government's total disregard for Native American traditions and practices (Hagan, p. 27). Government effort to contain Native American strife was a continuing process. However, there were legal areas not defined, or explained.

Judges conducting court at various levels of judicial jurisdictions often did not understand if they had authority over Native Americans violating laws against another Native American. The Trade and Intercourse Act of 1834 was general and did not provide specifics regarding the arrest and adjudication of Native Americans who violated laws within their designated regions and against other Native Americans (Hagan, pp. 25-45). The following statement illustrates how United States officials regarded Native Americans:

Indians were to be kept as remotely as possible from all settlements, to be assisted as hunters, to be forcibly precluded from an undue supply of gunpowder and rum, and to be kept as peaceable as possible by the presence of an agent and the distribution of a few annuities in cash and blankets (Smith, p.521). ${ }^{4}$

Native Americans were arrested and adjudicated by special Native American police and tried by special courts. Perhaps, this explains the few arrests and court cases conducted by Portland criminals justice authorities. ${ }^{5}$ However few, there were arrests observed.

4 Smith, Edward P., Annual Report, 1875, Annual Reports of the Secretary of the Interior, ser. 1680 , p. 521).

$5 \quad$ Native Americans agents were not authorized to establish Indian police forces until 1878. Prior to this time, an Indian agent established Native American police to aid in his ability to control 
The following commentary is an explanation of the categories observed in most arrest books. These categories are explained as each pertained to Native Americans placed under arrest. ...names of persons arrested...

Native Americans were not acknowledged as having first and last name, as was customary for most white settlers. It was unclear if the recorded name of the defendant was assigned by the Court Recorder, if the same few Native Americans were charged with repeated violations, or, if Indians adopted names common to Anglo culture. ${ }^{6}$ Native American defendants were identified as 'Jim, Dick, Charley,' or 'Tom,' typically, non-traditional names not normally associated with Indian culture in the 1800 's.

The Anglo name Indian Jim (see the following inserted cases) was an Anglo name commonly used, or assigned to Native Americans during that period. Records did not indicate if the Native American arrested on July 6,1871, was the same Indian Jim arrested April 20,1872. Also, there was no indication if other Native Americans shared the same name, were the same individual, or if such names were arbitrarily assigned by the arresting officer or recorder. Refer to the cases inserted on the following page.

their behavior. In 1883, the Secretary of Interior approved of Courts of Indian Offenses. During the interim, agents used their discretion. Often Native American Agents acted as judges, delegated authority to a white subordinate, or to a trusted Native American (Patterson, p. 104).

$6 \quad$ Ibid., An Indian name...that might have been rendered into very good English fifty years ago, may now, (circa 1900) having become subject to the mutations of our fads of pronunciation, be spoken (and written) quite differently from the original tongue (Lyman, p. 317). 


\begin{tabular}{|l|l|l|l|l|l|l|l|l|}
1871 & NI & $\begin{array}{l}\text { Indian } \\
\text { Jim }\end{array}$ & $\begin{array}{l}\text { J. W. } \\
\text { Kelley }\end{array}$ & Indian Tom & 51 & $\begin{array}{l}\text { Assault with a } \\
\text { knife }\end{array}$ & State \\
\hline July & 6 & \multicolumn{18}{|l|}{} & $\begin{array}{l}\text { S. F. } \\
\text { Schapple }\end{array}$ & Indian & 66 & $\begin{array}{l}\text { Assault with a } \\
\text { knife }\end{array}$ & State \\
\hline April & 20 & NI & $\begin{array}{l}\text { Indian } \\
\text { Jim }\end{array}$ &
\end{tabular}

...the date thereof...

Across all race and ethnic lines, in the majority of instances in which criminal complaints were filed, most arrests occurred instantaneously. In most misdemeanor cases if the trial date was on a day later than the arrest, the defendant was allowed to deposit bail and return for trial.

In most cases involving Native Americans, bail money was not deposited. Native Americans were routinely detained over night as a result of the delay in their trial date. Most trails involving charges of a misdemeanor were heard the same day of the arrest.

During the period observed, the vast majority of complaints filed against Native Americans were charges of intoxication. Most, if not all, Native Americans arrested for this charge were remanded to jail for a minimum of one night. Perhaps overnight detention was to provide a period for detoxification.

...the offense charges...charged with crime of...

Most complaints were filed by the arresting officer. An examination of the arrest records during this period, indicated that Native Americans seldom had criminal complaints lodged against them resulting in an arrest. ${ }^{7}$ During the period researched and of the arrest records observed, there were few instances in which a

7 Tracy, Charles Abbott, (1976), The Evolution of the Police Function in Portland, Oregon, 1811-1874, Dissertation, University of California, California State University campus, San Jose, California, See CHARACTERISTICS OF PERSONS ARRESTED BY YEAR - see APPENDIX V. 
Native American (that could be identified) filed a complaint against any other individual. While, it was common for other racial/ethnic groups to file complaints against each other, seldom were charges by one minority racial/ethnic group filed against another minority racial/ethnic group, including Native Americans.

Consistent with arrest charges filed against Indian males, the type of complaint filed against Native American females was typically drunk and disorderly. However, any criminal charge against a Native American female was unusual. The charge of larceny, a felony, was most unusual. Generally, Native American women

\begin{tabular}{|c|c|c|c|c|c|c|c|c|}
\hline Mon & Day & Page & Defendant & $\begin{array}{c}\text { Officer } \\
\text { Making } \\
\text { Arrest }\end{array}$ & Complainant & No. & Charged With & $\begin{array}{l}\text { Juris- } \\
\text { diction }\end{array}$ \\
\hline \multicolumn{9}{|l|}{1870} \\
\hline Nov. & 14 & 6 & $\begin{array}{c}\text { Indian } \\
\text { Girl }\end{array}$ & $\begin{array}{l}\text { J. M. } \\
\text { McCoy }\end{array}$ & $\begin{array}{c}\text { Miss } \\
\text { Gan Yok }\end{array}$ & 45 & Larceny & State \\
\hline
\end{tabular}

were seldom arrested and certainly not for larceny. The reference to Girl does not necessarily denote age, but could have been the Recorder's demeaning description of a Native American 'woman.' The word girl or boy has often been used to devalue the adult status of minority men and women by the white majority. It should be noted however, there were no cases observed involving charges of prostitution against Native American females.

...whether for a violation of a city ordinance or a law of the State...

Violations were coded as ' $\mathrm{C}$,' for a Portland City Ordinance violation, or 'S,' for an Oregon State Law violation. A violation of a City Ordinance was usually a misdemeanor; a violation of State Law was usually a felony. In those instances 
where Native Americans were arrested, the complaint was usually drunk \& disorderly Conduct, a violation of a City Ordinance, a misdemeanor.

...amount of coin (money) on prisoner...

When a Native American was arrested, it was rare if he (she) had coin(s) (money) on their person. It was not clear if Native Americans lacked money, or purposely did not carry coins. ${ }^{8}$ There were exceptions to this statement observed during the years 1873 and 1874. During those years, when arrested, several Native Americans had coins in their possession. However, after 1874, Native Americans appeared to have ceased carrying money, or, at least failed to pay fines.

...Male (M) - Female $(F) \ldots$

The defendant's gender was usually recorded. Most Native Americans that were arrested were male. Arrest cases involving a female Native American were exceptions.

\begin{tabular}{|l|l|l|l|l|l|l|l|l|}
\hline Mo. & Day & Page & Defendant & $\begin{array}{l}\text { Officer } \\
\text { Making } \\
\text { Arrest }\end{array}$ & Complainant & No. & Charged With & $\begin{array}{l}\text { Juris- } \\
\text { diction }\end{array}$ \\
\hline $\begin{array}{l}1870 \\
\text { Nov. }\end{array}$ & 14 & 6 & $\begin{array}{l}\text { Indian } \\
\text { Girl }\end{array}$ & $\begin{array}{l}\text { J. M. } \\
\text { McCoy }\end{array}$ & $\begin{array}{l}\text { Miss Gan } \\
\text { Yok }\end{array}$ & 45 & Larceny & State \\
\hline $\begin{array}{l}1872 \\
\text { July }\end{array}$ & 11 & NI & $\begin{array}{l}\text { Indian } \\
\text { Girl }\end{array}$ & Wiley & Wiley & 34 & Vagrant & City \\
\hline $\begin{array}{l}1872 \\
\text { July }\end{array}$ & 11 & NI & $\begin{array}{l}\text { Indian } \\
\text { Kate }\end{array}$ & Wiley & Wiley & 35 & Vagrant & City \\
\hline
\end{tabular}

For example, arrest cases such as: Indian Girl, November 14, 1870, charged with larceny; Indian Girl ${ }^{9}$, July 11, 1872, charged with vagrancy, and perhaps a companion, Indian Kate on the same date (also charged with vagrancy - see

8 In February of 1869, the Recorder stipulated that fines be paid in ...United States gold coin. See p. 357-358 of court book, 8090-1 ,or 21-05-38/3, Multnomah County Court Dockets, July 1867August 1870, City of Portland Stanley Paar Archives, Columbia Blvd., Portland, Oregon.

9 See Indian Girl, this Chapter, p. 166, for a discussion on the usage of the term Girl. 
APPENDIX VIII, pp. 1 \& 9), and; Emma Indian, November 29, 1975, charged with being drunk, p. 4 - were unusual. See APPENDIX IX.

...fines - paid (P) - unpaid $(U) \ldots$

In addition, there were as stated, few cases observed in which a Native American paid his (her) fine. It was not clear if Native Americans were financially unable to pay, since fines had to be paid in silver or gold coins (see footnote 7), or if they refused to pay, for example, as a matter of principle. Native Americans usually served a sentence due to failing to pay fines and/or court costs.

For instance, in the case of Indian Dick (inserted for clarification), the fine was $\$ 5.00$ for the violation and $\$ 1.70$ for Court costs. ${ }^{10}$ The defendant failed to pay the fine and was sentenced to three (3) days in the County (Multnomah) Jail. His period of confinement included the day he was arrested, August 2, at which time he was remanded overnight until his trial date, August 3. Indian Dick, found guilty, was sentenced and finally discharged on August 5 .

10 When a defendant was found guilty of the charge he (she) was required to pay court costs which could include any or all of the following: Justice fees; Marshall fees; Prosecuting Attorney fees, and ; Witness fees. See APPENDIX XXIII, POLICE FORCE, Sec. 78, this document, p. 74. 
August 1880

\begin{tabular}{|c|c|c|c|c|c|c|c|c|c|c|c|c|c|c|c|c|}
\hline $\begin{array}{c}\text { Mo. } \\
\text { \& } \\
\text { Day }\end{array}$ & $\begin{array}{l}\text { Name } \\
\text { of } \\
\text { Defend }\end{array}$ & $\begin{array}{l}\text { Arrest } \\
\text { Ofc }\end{array}$ & $\begin{array}{c}\text { Witnes } \\
\text { s }\end{array}$ & $\begin{array}{c}\text { Date } \\
\text { of } \\
\text { Trial }\end{array}$ & $\begin{array}{c}\text { Charged } \\
\text { with } \\
\text { crime } \\
\text { of }\end{array}$ & $\begin{array}{c}\text { Fine } \\
\text { paid } \\
\text { (P) } \\
\text { unpaid } \\
\text { (U) }\end{array}$ & $\begin{array}{l}\mathbf{A} \\
\mathbf{1}\end{array}$ & $\begin{array}{l}\mathbf{B} \\
12\end{array}$ & $\begin{array}{l}\mathrm{C} \\
\mathbf{1 3}\end{array}$ & $\begin{array}{l}D \\
14\end{array}$ & $\begin{array}{l}E \\
15\end{array}$ & $\begin{array}{l}\text { F } \\
16\end{array}$ & $\begin{array}{l}\mathbf{G} \\
17\end{array}$ & $\begin{array}{l}\mathrm{H} \\
\mathbf{1 8}\end{array}$ & I' & $\mathbf{2 0}_{20}^{\mathbf{J}}$ \\
\hline $\begin{array}{c}\text { Aug } \\
2\end{array}$ & $\begin{array}{c}\text { Indian } \\
\text { Dick }\end{array}$ & $\begin{array}{c}\mathrm{LC} \\
\text { Barton }\end{array}$ & $\begin{array}{c}\text { LC } \\
\text { Barto } \\
\text { n }\end{array}$ & $\begin{array}{c}\text { Aug } \\
3\end{array}$ & $\begin{array}{l}\text { Drunk \& } \\
\text { Disorder }\end{array}$ & $\begin{array}{c}5.00- \\
-U-\end{array}$ & & 1.70 & 3 & 4 & & & $\mathrm{C}$ & $\begin{array}{c}\text { Aug } \\
5\end{array}$ & $\mathbf{M}$ & \\
\hline
\end{tabular}

...number of days worked...

The City Council enacted Ordinance No. 922, allowing the use of offenders

for work on City projects.

AN ORDINANCE TO PROVIDE FOR THE WORKING OF CITY PRISONERS. No. 922. The City of Portland does ordain as follows:

Liable to work on city property.

Section 1. That hereafter all city prisoners, during the term of their imprisonment or commitment, after conviction, shall be liable to work upon the public square, lots, blocks, engine houses, streets, cisterns, sewers and other property of the city or property of which the city has direct charge or control, and in cleaning all crossings of streets in the city, and upon any and all streets of the city when so required by the Superintendent of Streets and the Chief Engineer of the Fire Department, or either of them (p. 82).

Who to designate where work to be done.

Sec. $2^{21}$ Whenever the Chief of police shall have prisoners in his custody, the Superintendent of Streets or Chief Engineer of the Fire department shall designate the place or places where the labor of such prisoners may be required, and the kind of work necessary to be done, and thereupon the Chief of Police shall have such work performed by the prisoners in his custody as far as practicable (p. 83).

Power to punish prisoners who refuse to work.

4. cont. ...And may provide for the working of the prisoners and punishment of prisoners who shall refuse to work (p. 42).

To punish by fine or imprisonment.

37. To provide for the punishment of a violation of any ordinance of the city by fine or imprisonment not exceeding three hundred dollars, or ninety days, or both, or by a forfeiture as penalty not exceeding three hundred dollars, and for working any person sentenced to such imprisonment upon the streets, public squares, work-house or house f correction during the term thereof, and to provide for the punishment of any person sentenced to imprisonment who shall refuse to work when ordered (p. 19).

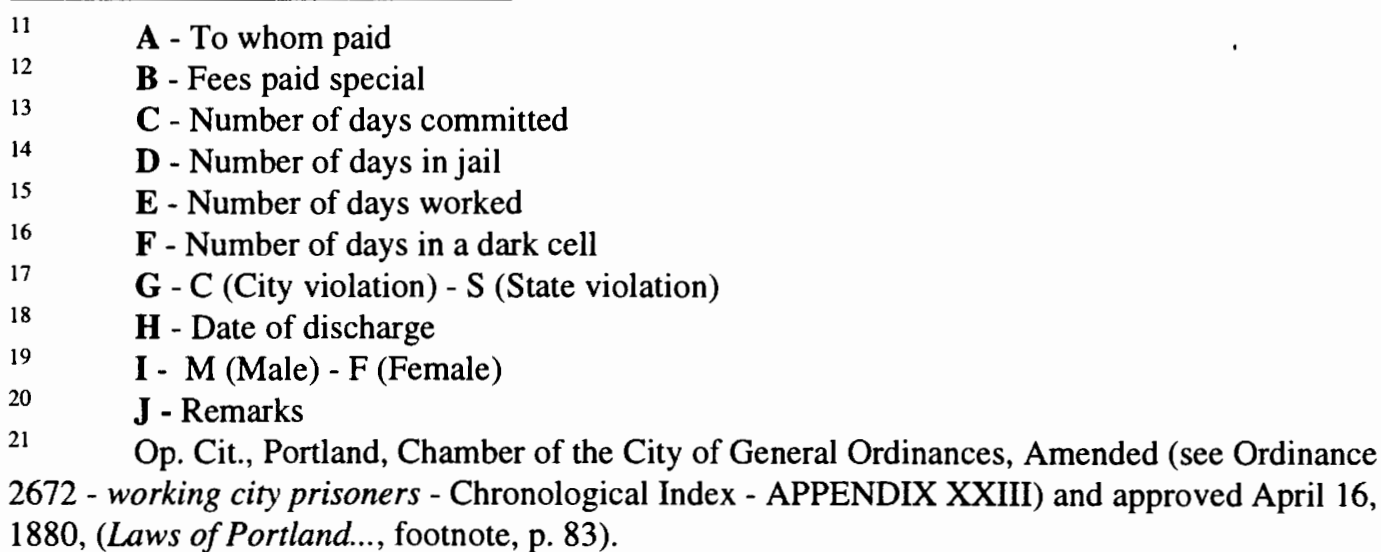


Work houses were used to allow debtors to work off their debts and for sentenced offenders.

To provide city jail and house of corrections.

18. To provide for the erection of a city jail, house of correction and work-house, and government and management of the same (p. 16).

However, although provisions for prisoners to work was legally allowed, arrest records rarely indicated that this form of punishment was applied to Native Americans.

...number of days in a dark cell...

Records did not indicate instances where spending days in a dark cell was applied as a form of punishment against Native Americans, or any other offender ...Remarks...

The 'Remarks' column rarely contained any additional information regarding cases involving Native Americans.

The following pages include all cases involving the arrests of Native Americans during the years observed as per arrest records observed during the time periods indicated. 


\section{ARREST BOOK}

Recorded

November 1870 - January 1875

\begin{tabular}{|c|c|c|c|c|c|c|c|c|}
\hline Mon & Day & Page & Defendant & $\begin{array}{l}\text { Officer } \\
\text { Making } \\
\text { Arrest } \\
\end{array}$ & Complainant & No. & Charged With & $\begin{array}{l}\text { Juris- } \\
\text { diction }\end{array}$ \\
\hline \multicolumn{9}{|l|}{1870} \\
\hline \multirow[t]{2}{*}{ Nov. } & 14 & 6 & $\begin{array}{l}\text { Indian } \\
\text { Girl }\end{array}$ & $\begin{array}{l}\text { J. M. } \\
\text { McCoy }\end{array}$ & $\begin{array}{l}\text { Miss } \\
\text { Gan Yok }\end{array}$ & 45 & Larceny & State \\
\hline & 15 & 6 & $\begin{array}{l}\text { Indian } \\
\text { Charley } \\
\end{array}$ & $\begin{array}{l}\text { W. M. } \\
\text { Ward }\end{array}$ & $\begin{array}{l}\text { John } \\
\text { Wesley }\end{array}$ & 48 & $\begin{array}{l}\text { Assault } \\
\text { and Battery }\end{array}$ & State \\
\hline \multicolumn{9}{|l|}{1871} \\
\hline \multirow[t]{6}{*}{ Feb. } & 4 & NI & $\begin{array}{l}\text { Indian } \\
\text { Joseph }\end{array}$ & $\begin{array}{l}\text { D. } \\
\text { Jacobi }\end{array}$ & D. Jacobi & 42 & $\begin{array}{l}\text { Disorderly } \\
\text { Conduct }\end{array}$ & City \\
\hline & 4 & NI & Indian & $\begin{array}{l}\text { D. } \\
\text { Jacobi }\end{array}$ & D. Jacobi & 43 & $\begin{array}{l}\text { Disorderly } \\
\text { Conduct }\end{array}$ & City \\
\hline & 10 & NI & $\begin{array}{l}\text { Indian } \\
\text { Tom }\end{array}$ & $\begin{array}{l}\text { J. R. } \\
\text { Wiley }\end{array}$ & $\mathrm{NI}$ & 68 & $\begin{array}{l}\text { Murderers } \\
\text { sent to } \\
\text { Yamhill } \\
\text { County } \\
\end{array}$ & $\mathrm{NI}$ \\
\hline & 10 & NI & Indian & $\begin{array}{l}\text { J.R. } \\
\text { Wiley }\end{array}$ & NI & 69 & $\begin{array}{l}\text { Murderers } \\
\text { sent to } \\
\text { Yamhill } \\
\text { County } \\
\end{array}$ & NI \\
\hline & 16 & NI & $\begin{array}{l}\text { Spokane } \\
\text { Indian }\end{array}$ & $\begin{array}{l}\text { W. M. } \\
\text { Ward }\end{array}$ & $\begin{array}{l}\text { Mary } \\
\text { Hagan }\end{array}$ & 105 & $\begin{array}{l}\text { Assault } \\
\text { and Battery }\end{array}$ & State \\
\hline & 17 & NI & Indian & $\begin{array}{l}\text { J. H. } \\
\text { Lappers }\end{array}$ & $\begin{array}{l}\text { Chas. } \\
\text { Lawrence } \\
\end{array}$ & 110 & $\begin{array}{l}\text { Lying drunk } \\
\text { upon 6th Street }\end{array}$ & City \\
\hline \multirow[t]{3}{*}{ July } & 3 & $\overline{\mathrm{NI}}$ & $\begin{array}{l}\text { Indian } \\
\text { John }\end{array}$ & $\begin{array}{l}\text { D. } \\
\text { Norton }\end{array}$ & $\begin{array}{l}\text { John } \\
\text { Wesley }\end{array}$ & 33 & $\begin{array}{l}\text { Breaking glass } \\
\text { in a building } \\
\text { not his own }\end{array}$ & State \\
\hline & 6 & NI & $\begin{array}{l}\text { Indian } \\
\text { Jim } \\
\end{array}$ & $\begin{array}{l}\text { J. W. } \\
\text { Kelley }\end{array}$ & Indian Tom & 51 & $\begin{array}{l}\text { Assault with a } \\
\text { knife }\end{array}$ & State \\
\hline & 6 & NI & $\begin{array}{l}\text { Indian } \\
\text { Davidson }\end{array}$ & $\begin{array}{l}\text { J. W. } \\
\text { Kelley }\end{array}$ & Jon Wesly & 52 & $\begin{array}{l}\text { Assault with a } \\
\text { pistol }\end{array}$ & State \\
\hline Oct & 30 & NI & $\begin{array}{l}\text { Indian } \\
\text { Lucy }\end{array}$ & $\begin{array}{l}\text { D. } \\
\text { Walton }\end{array}$ & $\begin{array}{l}\text { D. } \\
\text { Walton }\end{array}$ & 174 & $\begin{array}{l}\text { Drunk and } \\
\text { Disorderly }\end{array}$ & City \\
\hline \multicolumn{9}{|l|}{1872} \\
\hline \multirow[t]{3}{*}{ April } & 20 & NI & $\begin{array}{l}\text { Indian } \\
\text { Jim } \\
\end{array}$ & $\begin{array}{l}\text { S. F. } \\
\text { Schapple }\end{array}$ & Indian & 66 & $\begin{array}{l}\text { Assault with a } \\
\text { knife }\end{array}$ & State \\
\hline & 20 & NI & $\begin{array}{l}\text { Indian } \\
\text { Jim } \\
\end{array}$ & $\begin{array}{l}\text { S. F. } \\
\text { Schapple }\end{array}$ & Schapple & 67 & $\begin{array}{l}\text { Assault } \\
\text { and Battery }\end{array}$ & State \\
\hline & 20 & NI & $\begin{array}{l}\text { Indian } \\
\text { Tom }\end{array}$ & $\begin{array}{l}\text { (J. D. } \\
\text { Yates) } \\
\text { Schapple }\end{array}$ & Schapple & 68 & $\begin{array}{l}\text { Assault } \\
\text { and Battery }\end{array}$ & State \\
\hline
\end{tabular}


ARREST BOOK

Recorded

November 1870 - January 1875

\begin{tabular}{|c|c|c|c|c|c|c|c|c|}
\hline Mon & Day & Page & Defendant & $\begin{array}{l}\text { Officer } \\
\text { Making } \\
\text { Arrest } \\
\end{array}$ & Complainant & No. & Charged With & $\begin{array}{l}\text { Juris- } \\
\text { diction }\end{array}$ \\
\hline \multicolumn{9}{|l|}{1872} \\
\hline \multirow[t]{7}{*}{ July } & 7 & NI & Indian & $\begin{array}{l}\text { C. F. } \\
\text { Schappe }\end{array}$ & $\begin{array}{l}\text { C. F. } \\
\text { Schappe }\end{array}$ & 22 & $\begin{array}{l}\text { Drunk } \\
\text { disorderly on } \\
\text { 1st Street }\end{array}$ & City \\
\hline & 11 & NI & $\begin{array}{l}\text { Indian } \\
\text { Girl } \\
\end{array}$ & Wiley & Wiley & 34 & Vagrant & City \\
\hline & 11 & NI & $\begin{array}{l}\text { Indian } \\
\text { Kate } \\
\end{array}$ & Wiley & Wiley & 35 & Vagrant & City \\
\hline & 14 & NI & Indian & $\begin{array}{l}\text { C. F. } \\
\text { Schappe }\end{array}$ & Schappe & 44 & $\begin{array}{l}\text { Disorderly } \\
\text { and drunk }\end{array}$ & City \\
\hline & 15 & $\mathrm{NI}$ & Indian & Thar gale & Gale & 50 & Drunk & City \\
\hline & 27 & NI & Indian & $\begin{array}{l}\text { D. } \\
\text { Norton }\end{array}$ & $\begin{array}{l}\text { D. Norton } \\
\text { Discharged }\end{array}$ & 113 & Discharged & \\
\hline & 31 & NI & $\begin{array}{l}\text { Sewash } \\
\text { Jim }\end{array}$ & Sheehan & Sheehan & 141 & $\begin{array}{l}\text { Prowling } \\
\text { round the } \\
\text { back yard of } \\
\text { the Waesae } \\
\text { Dorce (??) }\end{array}$ & City \\
\hline Aug. & 29 & $\mathrm{NI}$ & $\begin{array}{l}\text { Indian } \\
\text { Jim }\end{array}$ & $\begin{array}{l}\text { C. } \\
\text { Lawrence }\end{array}$ & $\begin{array}{l}\text { A. B. } \\
\text { Brannon }\end{array}$ & 147 & Murder & State \\
\hline \multirow[t]{4}{*}{ Sept. } & 2 & 267 & $\begin{array}{l}\text { Indian } \\
\text { Warcene }\end{array}$ & $\begin{array}{l}\mathrm{C} . \\
\text { Lawrence } \\
\end{array}$ & $\begin{array}{l}\text { I. H. } \\
\text { Lappers }\end{array}$ & 12 & Murder & State \\
\hline & 14 & NI & $\begin{array}{l}\text { Indian } \\
\text { Jim }\end{array}$ & Kelley & Kelley & 77 & $\begin{array}{l}\text { Indecent } \\
\text { exposure } \\
\text { on Wash. St. }\end{array}$ & City \\
\hline & 24 & NI & $\begin{array}{l}\text { Indian } \\
\text { Mary }\end{array}$ & Mercer & Mercer & 133 & $\begin{array}{l}\text { Drunk on } \\
4 \text { th Street }\end{array}$ & City \\
\hline & 26 & NI & $\begin{array}{c}\text { Indian } \\
\text { Jack }\end{array}$ & Kelley & Kelley & 144 & $\begin{array}{l}\text { Drunk and } \\
\text { disorderly on } \\
\text { Front St. } \\
\end{array}$ & City \\
\hline Nov. & 3 & NI & $\begin{array}{l}\text { Indian } \\
\text { Jim }\end{array}$ & $\begin{array}{l}\text { D. } \\
\text { Norton }\end{array}$ & $\begin{array}{l}\text { D. } \\
\text { Norton }\end{array}$ & 12 & $\begin{array}{l}\text { Abusive } \\
\text { Language on } \\
\text { first Street } \\
\end{array}$ & City \\
\hline Nov. & 20 & NI & Indian & $\begin{array}{l}\text { O. D. } \\
\text { Buck }\end{array}$ & $\begin{array}{l}\text { O. D. } \\
\text { Buck }\end{array}$ & 84 & $\begin{array}{l}\text { Drunk and } \\
\text { disorderly on } \\
\text { 1st Street } \\
\text { Knife, } \\
\text { Tobacco, } \\
\text { bottle Cologne } \\
(\$ 30.95)\end{array}$ & City \\
\hline Dec. & 9 & NI & $\begin{array}{l}\text { Indian } \\
\text { Jim } \\
\end{array}$ & Schappe & & 53 & $\begin{array}{l}\text { Threatening } \\
\text { to kill } \\
\end{array}$ & State \\
\hline
\end{tabular}


ARREST BOOK

Recorded

November 1870 - January 1875

\begin{tabular}{|c|c|c|c|c|c|c|c|c|}
\hline Mon & Day & Page & Defendant & $\begin{array}{c}\text { Officer } \\
\text { Making } \\
\text { Arrest }\end{array}$ & Complainant & No. & Charged With & $\begin{array}{l}\text { Juris- } \\
\text { diction }\end{array}$ \\
\hline \multicolumn{9}{|l|}{1872} \\
\hline \multirow[t]{2}{*}{ Dec. } & 23 & NI & $\begin{array}{l}\text { Indian } \\
\text { Dick }\end{array}$ & $\begin{array}{l}\text { I. W. } \\
\text { Kelley }\end{array}$ & $\begin{array}{l}\text { I. W. } \\
\text { Kelley }\end{array}$ & 130 & $\begin{array}{l}\text { Drunk and } \\
\text { disorderly on } \\
\text { Wash. St. } 3 \& \\
4\end{array}$ & City \\
\hline & 23 & $\overline{\mathrm{NI}}$ & Indian & I. Martin & $\begin{array}{l}\text { I. R. } \\
\text { Wiley }\end{array}$ & 132 & $\begin{array}{l}\text { Drunk on 3rd } \\
\text { Street }\end{array}$ & City \\
\hline \multicolumn{9}{|l|}{1873} \\
\hline \multirow[t]{3}{*}{ Jan. } & 10 & NI & $\begin{array}{l}\text { Indian } \\
\text { Jack }\end{array}$ & Mercer & $\begin{array}{l}\text { J K. } \\
\text { Mercer }\end{array}$ & 57 & $\begin{array}{l}\text { Indecent } \\
\text { exposure } \$ 3.50\end{array}$ & City \\
\hline & 10 & NI & $\begin{array}{l}\text { Indian } \\
\text { Jim }\end{array}$ & Mercer & $\begin{array}{l}\text { J. K. } \\
\text { Mercer }\end{array}$ & 58 & $\begin{array}{l}\text { Indecent } \\
\text { exposure }\end{array}$ & City \\
\hline & 12 & $\overline{\mathrm{NI}}$ & $\begin{array}{l}\text { Indian } \\
\text { Jim }\end{array}$ & $\begin{array}{l}\text { O. D. } \\
\text { Buck }\end{array}$ & $\begin{array}{l}\text { O. D. } \\
\text { Buck }\end{array}$ & 72 & $\begin{array}{l}\text { Obscene } \\
\text { language on } \\
\text { Taylor St. }\end{array}$ & City \\
\hline \multirow[t]{3}{*}{ Feb. } & 2 & $\mathrm{NI}$ & $\begin{array}{l}\text { (Half } \\
\text { breed) } \\
\text { Jennie }\end{array}$ & $\begin{array}{l}\text { J. W. } \\
\text { Kelley }\end{array}$ & $\begin{array}{l}\text { J.W. } \\
\text { Kelley }\end{array}$ & 4 & $\begin{array}{l}\text { Wandering the } \\
\text { street after } \\
\text { one o'clock } \\
\text { at night }\end{array}$ & City \\
\hline & 5 & NI & $\begin{array}{l}\text { Indian } \\
\text { Woman } \\
\text { Matilda }\end{array}$ & $\begin{array}{l}\text { B. } \\
\text { O'Hara }\end{array}$ & $\begin{array}{l}\text { Andrew } \\
\text { Soches }\end{array}$ & 24 & $\begin{array}{l}\text { Drunk upon } \\
\text { Front Street }\end{array}$ & City \\
\hline & 10 & NI & M. Marsh & $\begin{array}{l}\text { D. } \\
\text { Norton }\end{array}$ & $\begin{array}{l}\text { Indian } \\
\text { Dick }\end{array}$ & 43 & $\begin{array}{l}\text { selling liquor } \\
\text { to an Indian }\end{array}$ & State \\
\hline \multirow[t]{3}{*}{ Mar. } & 9 & $\overline{\mathrm{NI}}$ & $\begin{array}{l}\text { Indian } \\
\text { Dick }\end{array}$ & $\begin{array}{l}\text { M. F. } \\
\text { Sheehan }\end{array}$ & $\begin{array}{l}\text { M. F. } \\
\text { Sheehan }\end{array}$ & 38 & $\begin{array}{l}\text { Indecent } \\
\text { exposure } \\
\text { Front St. }\end{array}$ & City \\
\hline & 11 & NI & $\begin{array}{l}\text { Indian } \\
\text { Mary }\end{array}$ & $\begin{array}{l}\text { O. D. } \\
\text { Buck }\end{array}$ & $\begin{array}{l}\text { O. D. } \\
\text { Buck }\end{array}$ & 51 & $\begin{array}{l}\text { Drunk and } \\
\text { disorderly }\end{array}$ & City \\
\hline & 14 & NI & $\begin{array}{l}\text { Half- } \\
\text { breed }\end{array}$ & $\begin{array}{l}\text { Hickey } \\
\text { \& Buck }\end{array}$ & $\begin{array}{l}\text { O. D. } \\
\text { Buck }\end{array}$ & 64 & $\begin{array}{l}\text { Lying asleep } \\
\text { in the hay on } \\
\text { the wharf at the } \\
\text { foot Taylor St. }\end{array}$ & City \\
\hline \multirow[t]{2}{*}{ Apr. } & 11 & NI & $\begin{array}{l}\text { Indian } \\
\text { Mary }\end{array}$ & $\begin{array}{l}\text { O. D. } \\
\text { Buck }\end{array}$ & $\begin{array}{l}\text { O. D. } \\
\text { Buck }\end{array}$ & 51 & $\begin{array}{l}\text { Drunk and } \\
\text { disorderly }\end{array}$ & $\overline{\text { City }}$ \\
\hline & 14 & $\mathrm{NI}$ & $\begin{array}{l}\text { Half- } \\
\text { breed }\end{array}$ & $\begin{array}{l}\text { Hickey } \\
\text { \& Buck }\end{array}$ & $\begin{array}{l}\text { O. D. } \\
\text { Buck }\end{array}$ & 64 & $\begin{array}{l}\text { Lying asleep } \\
\text { in the hay on } \\
\text { the wharf at } \\
\text { the } \\
\text { foot Taylor St. }\end{array}$ & City \\
\hline
\end{tabular}


ARREST BOOK

Recorded

November 1870 - January 1875

\begin{tabular}{|c|c|c|c|c|c|c|c|c|}
\hline Mon & Day & Page & Defendant & $\begin{array}{l}\text { Officer } \\
\text { Making } \\
\text { Arrest } \\
\end{array}$ & Complainant & No. & Charged With & \begin{tabular}{|l|}
$\begin{array}{l}\text { Juris- } \\
\text { diction }\end{array}$ \\
\end{tabular} \\
\hline \multicolumn{9}{|l|}{1873} \\
\hline \multirow[t]{4}{*}{ June } & 7 & $\overline{\mathrm{NI}}$ & $\begin{array}{l}\text { Indian } \\
\text { Dick }\end{array}$ & $\begin{array}{l}\text { E. M. } \\
\text { Bearden }\end{array}$ & $\begin{array}{l}\text { E. M. } \\
\text { Bearden }\end{array}$ & 35 & $\begin{array}{l}\text { Disorderly and } \\
\text { drunk }\end{array}$ & City \\
\hline & 8 & $\overline{\mathrm{NI}}$ & $\begin{array}{l}\text { Jennie } \\
\text { Indian }\end{array}$ & J. O'Neil & $\begin{array}{l}\text { J. } \\
\text { O'Neil }\end{array}$ & 40 & $\begin{array}{l}\begin{array}{l}\text { Held as } \\
\text { witness }\end{array} \\
\end{array}$ & City \\
\hline & 8 & NI & $\begin{array}{l}\text { Mary } \\
\text { Indian }\end{array}$ & $\begin{array}{l}\text { J. } \\
\text { O'Neil }\end{array}$ & $\begin{array}{l}\text { J. } \\
\text { O'Neil }\end{array}$ & 41 & $\begin{array}{l}\text { Held as } \\
\text { witness }\end{array}$ & City \\
\hline & 29 & NI & $\begin{array}{l}\text { Indian } \\
\text { Tom }\end{array}$ & $\begin{array}{l}\text { B.P. } \\
\text { Collins }\end{array}$ & $\begin{array}{l}\text { B. P. } \\
\text { Collins }\end{array}$ & 201 & $\begin{array}{l}\text { Drunk \& } \\
\text { Disorderly } \\
\text { Oak St. bet 5th } \\
\text { \& 6th } 51 / 2 \text { o.c. } \\
\text { PM (5:30PM) }\end{array}$ & City \\
\hline \multirow[t]{3}{*}{ July } & 4 & NI & Indian & L. Burke & L. Burke & 17 & $\begin{array}{l}\text { Drunk at foot } \\
\text { of Pine St. - } \\
\text { time } 9 \text { o.c.am }\end{array}$ & City \\
\hline & 4 & NI & $\begin{array}{l}\text { Indian } \\
\text { Dick }\end{array}$ & L. Burke & L. Burke & 19 & $\begin{array}{l}\text { Drunk on } \\
1 \mathrm{st} \mathrm{St.} \mathrm{-c} \mathrm{coin} \\
60 \mathrm{cts} \text {. Ret } \\
\text { time } 91 / 2 \text { o.c.pm } \\
(9: 30 \mathrm{pm})\end{array}$ & City \\
\hline & 4 & NI & Indian & $\begin{array}{l}\text { C. F. } \\
\text { Schappe }\end{array}$ & $\begin{array}{l}\text { C. F. } \\
\text { Schappe }\end{array}$ & 21 & $\begin{array}{l}\text { Lying drunk } \\
\text { on Front St. - } \\
\text { time } 3 \text { o.c.pm }\end{array}$ & City \\
\hline \multirow[t]{2}{*}{ Aug. } & 4 & NI & $\begin{array}{l}\text { Indian } \\
\text { Shawanessy }\end{array}$ & $\begin{array}{l}\text { P. } \\
\text { Martin }\end{array}$ & $\begin{array}{l}\text { John } \\
\text { Wesley }\end{array}$ & 32 & $\begin{array}{l}\text { Drunk - time } \\
3.50 \mathrm{pm}\end{array}$ & City \\
\hline & 18 & $\overline{\mathrm{NI}}$ & Indian & $\begin{array}{l}\text { J.W. } \\
\text { Kelley }\end{array}$ & $\begin{array}{l}\text { J.W. } \\
\text { Kelley }\end{array}$ & 109 & $\begin{array}{l}\text { Drunk \& } \\
\text { disorderly } \\
\text { cor 2nd \& } \\
\text { Yamhill time } \\
10 \text { am - coin } \\
50 \not \text { pocket } \\
\text { book \& knife } \\
\text { (Ret) }\end{array}$ & City \\
\hline \multicolumn{9}{|l|}{1874} \\
\hline Mar.. & 30 & $\overline{\mathrm{NI}}$ & $\begin{array}{l}\text { Indian } \\
\text { Charley }\end{array}$ & $\begin{array}{l}\text { J. W. } \\
\text { Kelley }\end{array}$ & $\begin{array}{l}\text { J. W. } \\
\text { Kelley }\end{array}$ & 106 & $\begin{array}{l}\text { Drunk and } \\
\text { Disorderly } \\
\text { 1st \& B St. } 3 \\
\text { p.m. }\end{array}$ & City \\
\hline Apr. & 11 & NI & Charley & $\begin{array}{l}\text { J. W. } \\
\text { Ham }\end{array}$ & $\begin{array}{l}\text { J. W. } \\
\text { Ham }\end{array}$ & 45 & $\begin{array}{l}\text { Drunk \& } \\
\text { disorderly } \\
\text { cor Oak and } \\
2 \text { nd st } 2 \text { am } \\
\text { coin } \$ 1.75 \\
\text { (Ret) } \\
\end{array}$ & City \\
\hline
\end{tabular}




\section{ARREST BOOK \\ Recorded \\ November 1870 - January 1875}

\begin{tabular}{|c|c|c|c|c|c|c|c|c|}
\hline Mon & Day & Page & Defendant & $\begin{array}{c}\text { Officer } \\
\text { Making } \\
\text { Arrest }\end{array}$ & Complainant & No. & Charged With & $\begin{array}{l}\text { Juris- } \\
\text { diction }\end{array}$ \\
\hline \multicolumn{9}{|l|}{1874} \\
\hline \multirow[t]{4}{*}{ May } & 2 & NI & $\begin{array}{l}\text { Sitka } \\
\text { (Alaska) } \\
\text { Jim }\end{array}$ & D. Shea & D. Shea & 8 & $\begin{array}{l}\text { Wandreing } \\
\text { about back } \\
\text { streets after } \\
\text { hours } \\
\text { Coin } \$ 5.00 \\
\text { Ret } 11 \mathrm{PM} \\
\end{array}$ & City \\
\hline & 2 & $\mathrm{NI}$ & $\begin{array}{l}\text { Indian } \\
\text { Tom }\end{array}$ & D. Shea & D. Shea & 9 & $\begin{array}{l}\text { Wandreing } \\
\text { about back } \\
\text { streets after } \\
\text { hours Coin } \\
\$ 5.00 \text { Ret } \\
11 \mathrm{PM}\end{array}$ & City \\
\hline & 2 & $\overline{\mathrm{Ni}}$ & $\begin{array}{l}\text { Indian } \\
\text { Jake }\end{array}$ & D. Shea & D. Shea & 9 & $\begin{array}{l}\text { Wandreing } \\
\text { about back } \\
\text { streets } \\
\text { after hours } \\
\text { Coin } \$ 5.00 \\
\text { Ret } 11 \mathrm{PM}\end{array}$ & City \\
\hline & 29 & $\mathrm{NI}$ & $\begin{array}{l}\text { Indian } \\
\text { Tom }\end{array}$ & $\begin{array}{l}\text { B. P. } \\
\text { Collins }\end{array}$ & $\begin{array}{l}\text { B. P. } \\
\text { Collins }\end{array}$ & 102 & $\begin{array}{l}\text { Drunk lying } \\
\text { on sidewalk } \\
\text { cor Front. \& } \\
\text { C St } 101 / 2 \\
(10: 30) \text { PM } \\
\end{array}$ & City \\
\hline \multirow[t]{3}{*}{ July } & 3 & $\mathrm{NI}$ & $\begin{array}{l}\text { Indian } \\
\text { Tom }\end{array}$ & $\begin{array}{l}\text { A. J. } \\
\text { Barlow }\end{array}$ & $\begin{array}{l}\text { A. J. } \\
\text { Barlow }\end{array}$ & 10 & $\begin{array}{l}\text { Drunk on } \\
\text { Fourth \& } \\
\text { Taylor Sts. } \\
10-20 \text { PM }\end{array}$ & City \\
\hline & 3 & $\mathrm{NI}$ & $\begin{array}{l}\text { Indian } \\
\text { Jim }\end{array}$ & $\begin{array}{l}\mathrm{C} . \\
\text { Gritamache } \\
\mathrm{r}\end{array}$ & $\begin{array}{l}\text { C. } \\
\text { Gritamache } \\
r\end{array}$ & 11 & $\begin{array}{l}\text { Lying drunk } \\
\text { on Front St } \\
\& \text { Washington } \\
\text { St } 10-3 \mathrm{pm}\end{array}$ & City \\
\hline & 11 & $\mathrm{NI}$ & $\begin{array}{l}\text { Indian } \\
\text { Jim }\end{array}$ & $\begin{array}{l}\text { Sheehan } \\
\text { \& Collins }\end{array}$ & $\begin{array}{l}\text { B. P. } \\
\text { Collins }\end{array}$ & 38 & $\begin{array}{l}\text { Drunk on } \\
\text { Pine St. Coin } \\
\$ 1.00 \mathrm{Ret} \\
1-20 \mathrm{PM} \\
\end{array}$ & City \\
\hline Oct. & 10 & NI & $\begin{array}{l}\text { Indian } \\
\text { Tom }\end{array}$ & $\begin{array}{l}\text { Beardent } \\
\text { \& Barlow }\end{array}$ & $\begin{array}{l}\text { E.W. } \\
\text { Bearden }\end{array}$ & 33 & $\begin{array}{l}\text { Drunk on } 4 \text { th } \\
\& \text { A St } 5 \mathrm{pm}\end{array}$ & City \\
\hline \multirow[t]{2}{*}{ Dec. } & 4 & $\mathrm{NI}$ & $\begin{array}{l}\text { Indian } \\
\text { Bayley }\end{array}$ & $\begin{array}{l}\text { J. H. } \\
\text { Lappers }\end{array}$ & $\begin{array}{l}\text { J. H. } \\
\text { Lappers }\end{array}$ & 19 & $\begin{array}{l}\text { Drunk on 4th } \\
\text { and Oak St }\end{array}$ & City \\
\hline & 4 & NI & $\begin{array}{l}\text { Indian } \\
\text { Johnson }\end{array}$ & $\begin{array}{l}\text { J. H. } \\
\text { Lappers }\end{array}$ & $\begin{array}{l}\text { J. H. } \\
\text { Lappers }\end{array}$ & 19 & $\begin{array}{l}\text { Drunk on 4th } \\
\text { and Oak } \mathrm{St}\end{array}$ & City \\
\hline
\end{tabular}


Arrest made during the early years of this period involved several felony charges filed against Native Americans. For example, there was a charge of larceny filed against Indian Girl, November 14, 1870. Native American women were seldom arrested.

However, as an observation, to be accused of a felony was not indicative of Native American behavior according to the arrest records reviewed after the summer of 1872 .

\begin{tabular}{|l|l|l|l|l|l|l|l|l|}
\hline Mon & Day & Page & Defendant & $\begin{array}{l}\text { Officer } \\
\text { Making } \\
\text { Arrest }\end{array}$ & Complainant & No. & Charged With & $\begin{array}{l}\text { Juris- } \\
\text { diction }\end{array}$ \\
\hline & 15 & 6 & $\begin{array}{l}\text { Indian } \\
\text { Charley }\end{array}$ & $\begin{array}{l}\text { W. M. } \\
\text { Ward }\end{array}$ & $\begin{array}{l}\text { John } \\
\text { Wesley }\end{array}$ & 48 & $\begin{array}{l}\text { Assault } \\
\text { and Battery }\end{array}$ & State \\
\hline
\end{tabular}

The assault and battery charge against Indian Charley, November 4, 1870, was again unusual when compared to the arrests of most Native Americans during ensuing years. Assault and battery charges against Native Americans appeared to be prevalent during the early 1870 's. This circumstance was not explained. Native Americans appear to have gotten less aggressive when viewing charges for arrest during subsequent years. See APPENDICES VIII-XI. 


\begin{tabular}{|l|l|l|l|l|l|l|l|l|l|}
\hline Mon & Day & Page & $\begin{array}{c}\text { De } \\
\text { fendant }\end{array}$ & $\begin{array}{l}\text { Officer } \\
\text { Making } \\
\text { Arrest }\end{array}$ & Complainant & No. & Charged With & $\begin{array}{l}\text { Juris- } \\
\text { diction }\end{array}$ \\
\hline \begin{tabular}{|l|l|l|l|l|l|l|l|l|}
\hline 10 \\
\hline 10
\end{tabular} & 10 & NI & $\begin{array}{l}\text { Indian } \\
\text { Tom }\end{array}$ & $\begin{array}{l}\text { J. R. } \\
\text { Wiley }\end{array}$ & NI & 68 & $\begin{array}{l}\text { Murderers } \\
\text { sent to Yamhill } \\
\text { County }\end{array}$ & NI \\
\hline 10 & 10 & NI & Indian & $\begin{array}{l}\text { J. R. } \\
\text { Wiley }\end{array}$ & Nl & 69 & $\begin{array}{l}\text { Murderers } \\
\text { sent to } \\
\text { Yamhill County }\end{array}$ & NI \\
\hline
\end{tabular}

The arrest of Indian Tom and Indian for murder on February 10, 1871, was one of only three cases observed in which Native Americans were charged with such an heinous crime.

\begin{tabular}{|c|c|c|c|c|c|c|c|c|}
\hline Mon & Day & Page & Defendant & $\begin{array}{c}\text { Officer } \\
\text { Making } \\
\text { Arrest }\end{array}$ & Complainant & No. & Charged With & $\begin{array}{l}\text { Juris- } \\
\text { diction }\end{array}$ \\
\hline \multicolumn{9}{|l|}{1871} \\
\hline Aug. & 29 & $\mathrm{NI}$ & $\begin{array}{l}\text { Indian } \\
\text { Jim }\end{array}$ & $\begin{array}{l}\text { C. } \\
\text { Lawrence }\end{array}$ & $\begin{array}{l}\text { A. B. } \\
\text { Brannon }\end{array}$ & 147 & Murder & State \\
\hline Sept. & 2 & 267 & $\begin{array}{l}\text { Indian } \\
\text { Warcene }\end{array}$ & $\begin{array}{l}\text { C. } \\
\text { Lawrence }\end{array}$ & $\begin{array}{l}\text { I. H. } \\
\text { Lappers }\end{array}$ & 12 & Murder & State \\
\hline
\end{tabular}

The other two cases involved Indian Jim on August 10, 1871 and Indian

Warcene, on September 2, 1871. See APPENDIX VIII, pp. 1 \& 4.

\begin{tabular}{|l|l|l|l|l|l|l|l|l|}
\hline Mon & Day & Page & Defendant & $\begin{array}{l}\text { Officer } \\
\text { Making } \\
\text { Arrest }\end{array}$ & Complainant & No. & Charged With & $\begin{array}{l}\text { Juris- } \\
\text { diction }\end{array}$ \\
\hline $\mathbf{1 8 7 1}$
\end{tabular}

The arrest of Indian Jim, July 6, 1871, charged with assault with a knife, against Indian Tom, and related cases of April 20, 1872, ${ }^{22}$ were exceptions.

22 It was unclear if the Native Americans indicated with a common Anglo name was the same individual arrested on a later date, or if several Native Americans shared common Anglo names or had them assigned by the arresting officer or by the recorder. 


\begin{tabular}{|c|c|c|c|c|c|c|c|c|}
\hline Mon & Day & Page & Defendant & $\begin{array}{c}\text { Officer } \\
\text { Making } \\
\text { Arrest } \\
\end{array}$ & Complainant & No. & Charged With & $\begin{array}{l}\text { Juris- } \\
\text { diction }\end{array}$ \\
\hline \multicolumn{9}{|l|}{1872} \\
\hline \multirow[t]{3}{*}{ April } & 20 & NI & $\begin{array}{l}\text { Indian } \\
\text { Jim }\end{array}$ & S. F. Schapple & Indian & 66 & $\begin{array}{l}\text { Assault with a } \\
\text { knife }\end{array}$ & State \\
\hline & 20 & NI & $\begin{array}{l}\text { Indian } \\
\text { Jim }\end{array}$ & S. F. Schapple & Schapple & 67 & $\begin{array}{l}\text { Assault and } \\
\text { Battery }\end{array}$ & State \\
\hline & 20 & NI & $\begin{array}{l}\text { Indian } \\
\text { Tom }\end{array}$ & $\begin{array}{l}\text { (J. D. Yates) } \\
\text { Schapple }\end{array}$ & Schapple & 68 & $\begin{array}{l}\text { Assault } \\
\text { and Battery }\end{array}$ & State \\
\hline
\end{tabular}

There were no explanations for the unusual number of felonies charged against Native Americans during the years of 1870,1871 and ending as of the summer in 1872 . It was interesting to note that after of the summer of 1872 , Native Americans were increasingly cited for misdemeanor violations only. Native Americans, in the majority of the following cases, were overwhelmingly arrested for being drunk and disorderly. 
ARREST BOOK

Recorded

January 1, 1875 - March 1878

\begin{tabular}{|c|c|c|c|c|c|c|c|c|c|c|c|c|}
\hline$\frac{\mathrm{A}}{\underline{\underline{3}}}$ & $\begin{array}{l}\text { Defend } \\
\text { Name }\end{array}$ & 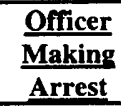 & $\underset{\text { plainant }}{\text { Com: }}$ & $\underline{\mathrm{B}^{24}}$ & $\begin{array}{l}\text { Charged } \\
\text { with } \\
\text { crime of }\end{array}$ & $\begin{array}{c}\text { Date } \\
\text { Trial } \\
\end{array}$ & $\begin{array}{l}\text { Arrest } \\
\text { Time }\end{array}$ & $\frac{\mathbf{C}}{\underline{2 S}}$ & $\underline{D^{26}}$ & $\underline{E^{27}}$ & $\frac{\mathrm{M}}{\mathrm{or}}$ & $\begin{array}{l}\text { Re- } \\
\text { marks }\end{array}$ \\
\hline \multicolumn{13}{|c|}{ April 1875} \\
\hline 21 & $\begin{array}{l}\text { Indian } \\
\text { Boy }\end{array}$ & & & 51 & $\begin{array}{l}\text { Brought to } \\
\text { City Jail by } \\
\text { Rev. W. C. } \\
\text { Chatten with } \\
\text { request that } \\
\text { he be given } \\
\text { lodging } \\
\text { and meals }\end{array}$ & & $8: 00 p$ & C & & & $\bar{M}$ & $\begin{array}{l}\text { Dis- } \\
\text { charge } \\
\text { Apr } \\
22\end{array}$ \\
\hline \multicolumn{13}{|c|}{ July 1875} \\
\hline 31 & $\begin{array}{l}\text { Indian } \\
\text { Tom }\end{array}$ & $\begin{array}{l}\text { John } \\
\text { W. Hain }\end{array}$ & $\begin{array}{l}\text { John W. } \\
\text { Hain }\end{array}$ & 60 & $\begin{array}{l}\text { drunk and } \\
\text { disorderly } \\
\text { on } U \text { and } \\
\text { lst St }\end{array}$ & & $\begin{array}{r}11: 30 \\
a\end{array}$ & $\bar{C}$ & & & $\bar{M}$ & \\
\hline
\end{tabular}

\begin{tabular}{|c|c|c|c|c|c|c|c|c|}
\hline 13 & $\begin{array}{l}\text { Indian } \\
\text { Tom }\end{array}$ & $\begin{array}{l}\mathrm{JL} \\
\text { Hamilton }\end{array}$ & Hamilton & 54 & $\begin{array}{l}\text { drunk on 5th } \\
\text { bet } \\
\text { Taylor \& } \\
\text { Salmon St. }\end{array}$ & $9: 25 a$ & $\mathrm{C}$ & $\mathbf{M}$ \\
\hline 29 & $\begin{array}{l}\text { Emma } \\
\text { Indian }\end{array}$ & $\begin{array}{l}\text { C. } \\
\text { Gritz- } \\
\text { macher }\end{array}$ & $\begin{array}{l}\text { Gritz- } \\
\text { macher }\end{array}$ & 105 & $\begin{array}{l}\text { drunk corner } \\
\text { 2nd \& } \\
\text { Salmon Sts }\end{array}$ & $9: 00 p$ & $\mathrm{C}$ & $\bar{F}$ \\
\hline
\end{tabular}

\begin{tabular}{|l} 
December 1875 \\
\begin{tabular}{|l|l|l|l|l|l|l|l|l|l|l|l|l|}
\hline 14 & $\begin{array}{l}\text { Indian } \\
\text { Tom }\end{array}$ & $\begin{array}{l}\text { Hain \& } \\
\text { Hamilton }\end{array}$ & Hain & 61 & $\begin{array}{l}\text { drunk \& } \\
\text { disorderly on } \\
\text { Front \& E St }\end{array}$ & 8:00p & C & & & M & \\
\hline 13 & $\begin{array}{l}\text { February 1876 } \\
\text { Charley }\end{array}$ & $\begin{array}{l}\text { Brannon } \\
\text { Belcher }\end{array}$ & Brannon & 39 & $\begin{array}{l}\text { drunk \& } \\
\text { disorderly on } \\
\text { 1st \& Lincoln } \\
\text { St }\end{array}$ & & $\begin{array}{c}10: 00 \\
\text { p }\end{array}$ & C & & & M & \\
\hline
\end{tabular}
\end{tabular}

\begin{tabular}{l} 
July 1877 \\
\begin{tabular}{|l|l|l|l|l|l|l|l|l|l|l|l|l|}
\hline 19 & $\begin{array}{l}\text { Indian } \\
\text { Charley }\end{array}$ & $\begin{array}{l}\text { PM } \\
\text { McCoy }\end{array}$ & $\begin{array}{l}\text { PM } \\
\text { McCoy }\end{array}$ & 79 & $\begin{array}{l}\text { Violation } \\
\text { of Ord 822 } \\
\text { (concerning } \\
\text { bathing in the } \\
\text { Willamette } \\
\text { River) }\end{array}$ & $\begin{array}{l}\text { July } \\
19\end{array}$ & $1: 55 \mathrm{p}$ & C & & & M & \\
\hline 16 & $\begin{array}{l}\text { Indian } \\
\text { Charley }\end{array}$ & $\begin{array}{l}\text { CW } \\
\text { Howard }\end{array}$ & $\begin{array}{l}\text { CW } \\
\text { Howard }\end{array}$ & 120 & $\begin{array}{l}\text { drunk and } \\
\text { disorderly }\end{array}$ & $\begin{array}{l}\text { Oct } \\
16\end{array}$ & $12: 00$ & C & & $\begin{array}{c}\text { Aug } \\
20\end{array}$ & M & \\
\hline 17 & $\begin{array}{l}\text { Indian } \\
\text { Dick }\end{array}$ & $\begin{array}{l}\text { Ben } \\
\text { Branek }\end{array}$ & $\begin{array}{l}\text { Ben } \\
\text { Branek }\end{array}$ & 132 & $\begin{array}{l}\text { Lying on the } \\
\text { street drunk }\end{array}$ & $\begin{array}{c}\text { Oct } \\
18\end{array}$ & $8: 40$ p & C & & & M & \\
\hline
\end{tabular} \\
\hline
\end{tabular}

\begin{tabular}{|l|l|l|l|l|l|c|c|c|c|c|c|c|}
\hline December 1877 & $\begin{array}{l}\text { Indian } \\
\text { Charlie }\end{array}$ & $\begin{array}{l}\text { Daniel } \\
\text { Shea }\end{array}$ & $\begin{array}{l}\text { Daniel } \\
\text { Shea }\end{array}$ & 29 & $\begin{array}{l}\text { drunk and } \\
\text { disorderly }\end{array}$ & $\begin{array}{c}\text { Dec } \\
5\end{array}$ & $6: 10 \mathrm{a}$ & $\mathrm{C}$ & 3.00 & $\begin{array}{c}\text { Dec } \\
9\end{array}$ & $\mathrm{M}$ & \\
\hline 5 & $\begin{array}{l}\text { Indian } \\
\text { Johnson }\end{array}$ & $\begin{array}{l}\text { Daniel } \\
\text { Shea }\end{array}$ & $\begin{array}{l}\text { Daniel } \\
\text { Shea }\end{array}$ & 30 & $\begin{array}{l}\text { drunk and } \\
\text { disorderly }\end{array}$ & $\begin{array}{c}\text { Dec } \\
5\end{array}$ & $8: 30 \mathrm{a}$ & $\mathrm{C}$ & 1.75 & $\begin{array}{c}\text { Dec } \\
9\end{array}$ & $\mathrm{M}$ & \\
\hline
\end{tabular}
23
A - Date of arrest
24
B - Number of arrests for the month - (ongoing tally of police arrests)
25 C - C - City -... S - State
26 D - Amount of coin (money) on prisoner
$27 \quad$ E - Date of return for trial as a result of bail deposit 
A practice related to the arrest of Native Americans and Chinese (see

CHAPTER v) was observed during all time periods . Although criminal complaints resulting in an arrest were seldom filed against Native American, when an Indian was arrested, it was not uncommon for another Native American to also be arrested by the same arresting officer for the same violation (refer to all cited cases). In such instances, fines or sentencing were usually the same for both defendants.

\section{Forsaken and Neglected Children}

An unusual case involved a Native American child in which no criminal charges were filed, but the individual was jailed, presumably, for his own protection and care.

\begin{tabular}{|c|c|c|c|c|c|c|c|c|c|c|c|c|}
\hline$\frac{\mathrm{A}}{28 \mathrm{~g}}$ & $\frac{\text { Defend }}{\text { Name }}$ & $\begin{array}{l}\frac{\text { Officer }}{\text { Making }} \\
\text { Arrest }\end{array}$ & $\begin{array}{c}\text { Com: } \\
\text { plainant }\end{array}$ & $\underline{\mathbf{B}^{29}}$ & 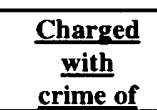 & $\begin{array}{c}\frac{\text { Date }}{\text { of }} \\
\text { Trial }\end{array}$ & $\begin{array}{l}\text { Arrest } \\
\text { Time }\end{array}$ & $\frac{C}{30}$ & $\underline{D}^{31}$ & ${\underline{\mathbf{E}^{32}}}$ & $\frac{\underline{M}}{\frac{\text { or }}{F}}$ & $\begin{array}{l}\text { Re- } \\
\text { marks }\end{array}$ \\
\hline \multicolumn{13}{|c|}{ April 1875 } \\
\hline 21 & $\begin{array}{l}\text { Indian } \\
\text { Boy }\end{array}$ & & & 51 & $\begin{array}{l}\text { Brought to } \\
\text { City Jail by } \\
\text { Rev. W. C. } \\
\text { Chatten with } \\
\text { request that } \\
\text { he be given } \\
\text { lodging } \\
\text { and meals }\end{array}$ & & $8: 00 p$ & $\mathrm{C}$ & & & $\bar{M}$ & $\begin{array}{l}\text { Dis- } \\
\text { charge } \\
\text { Apr } \\
22\end{array}$ \\
\hline
\end{tabular}

During Portland's early history, arrangements were made for abandoned and neglected children to be cared for by the Ladies Relief Society. ${ }^{33}$ However, in the

\footnotetext{
$28 \quad$ A - Date of arrest

29 B - Number of arrests for the month - (ongoing tally of police arrests)

30 C - C - City -.-- S - State

$31 \quad$ D - Amount of coin (money) on prisoner

$32 \quad$ E - Date of return for trial as a result of bail deposit
}

33 The Ladies Relief Society was organized March, 1867, and included the following members: Mmes: G. H. Atkinson, E. Ainsworth, J. C. Ainsworth, M. S. Burrell, J. H. Couch, J. B. Congle, T. L. Eliot, Thos. Frazer, A. Holbrook, C. H. Lewis, Donald Macleay, and S. G. Reed. (It was customary for married women to use their husband name in any formal situation).

A Home was built for forsaken and neglected children on F. and 14th Streets for $\$ 2,000$. The Home was incorporated in July 1871 . The Home provided for girls, ages three to twelve years old and 
case involving a Native American child, who appeared to be homeless, or at the very least lost, it does not appear that he was cared for by the Ladies Relief Society.

Without evidence of an alternative resource, the child was apparently remanded to jail where he remained over night and was released the following day. ${ }^{34}$ Criminal charges were not recorded. Rev. Chatten requested food and lodging on behalf of the 'Indian boy.' Without any information in the remarks column, the child's custodial care beyond his discharge date was uncertain.

boys, ages three to ten years old. The children were given clothing, food, and provisions were made for them to attend public school (Scott, p. 365).

Benevolent Societies were established to care for the poor and destitute members of the community (Scott, p. 364).

The Boys and Girls Aid Society was organized in 1885. The Society was created to improve conditions of homeless and abused children. The Society also received juvenile offenders endangered of being imprisoned. The organization sought suitable homes for displaced individuals and systematically attended to their treatment and condition (Scott, p. 367).

In 1887 a special officer of the City Police was assigned to service this society. The police officer investigated cases, visited families, completed reports regarding boys at the police station, attended court trial, looked after children in the streets, and maintained records of all cases. He actually worked to fulfill the needs of the society.

34 It should be noted that a child (of any age) housed in a jail, unless there was a cell not in use, shared a cell with an adult prisoner. 
ARREST BOOK

Recorded

July 1, 1877 - January 30, 1879

The following arrest was the only case observed during this time period involving the arrest of an identifiable Native American. Consistent with prior charges, the complaint was, drunk \& disorderly conduct, a misdemeanor.

October $\mathbf{- 1 8 7 7}$

\begin{tabular}{|c|c|c|l|c|c|c|c|c|c|c|c|c|c|c|c|}
\hline Oct & $\begin{array}{c}\text { Name } \\
\text { of } \\
\text { Defen } \\
\mathbf{d}\end{array}$ & $\begin{array}{c}\text { Arrest. } \\
\text { Officer }\end{array}$ & Witness & $\begin{array}{c}\text { Date } \\
\text { of } \\
\text { Trial }\end{array}$ & $\begin{array}{c}\text { Charged } \\
\text { with } \\
\text { crime } \\
\text { of }\end{array}$ & $\begin{array}{c}\text { Fine } \\
\text { Paid-P } \\
\text { Unpaid } \\
-\mathbf{U}\end{array}$ & $\begin{array}{c}\text { To } \\
\text { Who } \\
\mathbf{m} \\
\text { Paid }\end{array}$ & $\begin{array}{c}\mathbf{A} \\
\mathbf{3 5}\end{array}$ & $\begin{array}{c}\mathbf{B} \\
\mathbf{3 6}\end{array}$ & $\begin{array}{c}\mathbf{C} \\
\mathbf{3 7}\end{array}$ & $\begin{array}{c}\mathbf{D} \\
\mathbf{3 8}\end{array}$ & $\begin{array}{c}\mathbf{E} \\
\mathbf{3 9}\end{array}$ & $\begin{array}{c}\mathbf{F} \\
\mathbf{4 0}\end{array}$ & $\begin{array}{c}\mathbf{G} \\
\mathbf{4 1}\end{array}$ & $\begin{array}{c}\mathbf{H} \\
\mathbf{4 2}\end{array}$ \\
\hline 17 & $\begin{array}{c}\text { Indian } \\
\text { Jim }\end{array}$ & $\begin{array}{l}\text { CW } \\
\text { Howard }\end{array}$ & $\begin{array}{l}\text { CW } \\
\text { Howard }\end{array}$ & $\begin{array}{c}\text { Oct } \\
17\end{array}$ & $\begin{array}{c}\text { Drunk } \\
\text { \& Dis } \\
\text { (disorderly }\end{array}$ & $\begin{array}{c}9.00- \\
\text { U } \\
6.00-\mathrm{P}\end{array}$ & Allen & 7 & 4 & & & $\mathrm{C}$ & $\begin{array}{l}\text { Oct } \\
20\end{array}$ & $\mathrm{M}$ & \\
\hline
\end{tabular}

Number of days committed

Number of days in jail

Number of days worked

Number of days in solitary confinement

'C' Portland City Ordinance violation - 'S,' Oregon State Law violation

Date of discharge

Male (M) - Female (F)

Remarks 


\section{ARREST BOOK \\ Recorded \\ December 1, 1879 - October 31, 1881}

The following arrest was the only case observed during this time period involving the arrest of an identifiable Native American. Consistent with prior charges, the complaint was, drunk \& disorderly conduct, a misdemeanor.

\begin{tabular}{|c|c|c|c|c|c|c|c|c|c|c|c|c|c|c|c|c|}
\hline $\begin{array}{c}\text { Mo. } \\
\& \\
\text { Day }\end{array}$ & $\begin{array}{l}\text { Name } \\
\text { of } \\
\text { Defend }\end{array}$ & $\begin{array}{c}\text { Arrest } \\
\text { Off }\end{array}$ & Witness & $\begin{array}{c}\text { Date } \\
\text { of } \\
\text { Trial }\end{array}$ & $\begin{array}{c}\text { Charged } \\
\text { with } \\
\text { crime } \\
\text { of }\end{array}$ & $\begin{array}{c}\text { Fine } \\
\text { paid } \\
\text { (P) } \\
\text { unpaid } \\
\text { (U) }\end{array}$ & $\begin{array}{l}A \\
43\end{array}$ & $\begin{array}{l}B \\
44\end{array}$ & $\begin{array}{l}\mathrm{C} \\
45\end{array}$ & $\begin{array}{l}\mathrm{D} \\
46\end{array}$ & $\begin{array}{l}E \\
47\end{array}$ & $\begin{array}{l}\mathbf{F} \\
48\end{array}$ & $\begin{array}{l}\text { G } \\
49\end{array}$ & $\underset{50}{\mathbf{H}}$ & $\begin{array}{l} \\
51\end{array}$ & $\begin{array}{l}\mathrm{J}_{52} \\
\end{array}$ \\
\hline $\begin{array}{c}\text { Aug } \\
2\end{array}$ & $\begin{array}{c}\text { Indian } \\
\text { Dick }\end{array}$ & $\begin{array}{c}\text { LC } \\
\text { Barton }\end{array}$ & $\begin{array}{c}\text { LC } \\
\text { Barton }\end{array}$ & $\begin{array}{c}\text { Aug } \\
3\end{array}$ & $\begin{array}{l}\text { Drunk \& } \\
\text { Disorder }\end{array}$ & $\begin{array}{l}5.00 \\
-U-\end{array}$ & & 1.70 & 3 & 4 & & & $\mathrm{C}$ & $\begin{array}{c}\text { Aug } \\
5\end{array}$ & $\mathbf{M}$ & \\
\hline
\end{tabular}

\footnotetext{
$43 \quad$ A - To whom paid

$44 \quad$ B - Fees paid special

45 C - Number of days committed

46 D - Number of days in jail

$47 \quad$ E - Number of days worked

48 F - Number of days in a dark cell

$49 \quad \mathbf{G}-\mathbf{C}$ (City violation) - S (State violation)

so $\quad \mathbf{H}$ - Date of discharge

51 I - M (Male) - F (Female)

$52 \quad$ J - Remarks
} 


\section{ARREST BOOK \\ Recorded}

May 1894 - April 1895

This time period was observed because information in the arrest records contained the category, Nativity, or race/ethnicity. This category was not required in prior records. The availability of this criteria enabled me to specifically identify minorities arrested. The following cases involved the arrest of Native Americans and were inserted to exhibit several factors:

1. Some Native Americans adopted Anglo names.

2. In the year 1894, Oregon law continued to be enforced prohibiting the sell of liquor to Native Americans.

3. In 1894, Native Americans had money in their possession.

4. In 1894, as previously noted, few charges/complaints are filed against Native Americans.

5. In 1894, charges/complaints filed against Native Americans continued to be misdemeanors, mostly drunk/disorderly .

6. In 1894, it was still unusual for a complaint/charged to be filed against Native American females.

\begin{tabular}{|c|l|l|l|l|l|l|l|l|l|l|l|l|}
\hline Mo hr & $\begin{array}{l}\text { defend- } \\
\text { ant }\end{array}$ & $\begin{array}{l}\text { arrestin } \\
\text { g officer }\end{array}$ & $\begin{array}{l}\text { com- } \\
\text { plainant }\end{array}$ & charge & $\begin{array}{l}\text { where } \\
\text { arrest } \\
\text { ed }\end{array}$ & $\begin{array}{l}\text { pro- } \\
\text { per- } \\
\text { ty }\end{array}$ & $\begin{array}{l}\text { m } \\
\text { o } \\
\text { n } \\
\text { e } \\
\text { ys- }\end{array}$ & $\begin{array}{l}\text { charg } \\
\text { ed } \\
\text { Mo. } \\
\text { day }\end{array}$ & & age & $\begin{array}{l}\text { nativity } \\
*\end{array}$ & $\begin{array}{l}\text { remark } \\
\text { s }\end{array}$ \\
\hline
\end{tabular}

\begin{tabular}{|c|c|c|c|c|c|c|c|c|c|c|c|}
\hline $\begin{array}{l}\text { Jun } \\
30\end{array}$ & $\begin{array}{l}\text { 6:30 } \\
\text { PM }\end{array}$ & $\begin{array}{l}\text { Paul } \\
\text { Lumber }\end{array}$ & $\begin{array}{l}\text { Chas. } \\
\text { Benabl } \\
\text { e }\end{array}$ & $\begin{array}{l}\mathrm{CP} \\
\text { Holly }\end{array}$ & $\begin{array}{l}\text { Held } \\
\text { as } \\
\text { witness } \\
\text { selling } \\
\text { wine } \\
\text { to } \\
\text { Indian }\end{array}$ & $\begin{array}{l}\text { Front/ } \\
\text { Morri- } \\
\text { son }\end{array}$ & $\begin{array}{l}\text { Sun- } \\
\text { dries } \\
\text { bag } \\
25\end{array}$ & 2 & 50 & Indian & $\begin{array}{l}\text { Released } \\
\text { per order } \\
\text { Marshall } \\
\text { Grady } \\
\text { Prop } \\
\text { Ret. }\end{array}$ \\
\hline $\begin{array}{c}\text { Jul. } \\
1\end{array}$ & $\begin{array}{l}12: 30 \\
\text { am }\end{array}$ & $\begin{array}{l}\text { Sam } \\
\text { Jackson }\end{array}$ & $\begin{array}{l}\text { SS } \\
\text { Young }\end{array}$ & $\begin{array}{l}\text { SS } \\
\text { Young }\end{array}$ & $\begin{array}{l}\text { drunk - } \\
\text { held } \\
\text { as a } \\
\text { witness } \\
\text { w/ } \\
\text { Lumber }\end{array}$ & $\begin{array}{l}\text { 1st \& } \\
\text { Burn- } \\
\text { side }\end{array}$ & $\begin{array}{l}\text { Sun- } \\
\text { dries } \\
\text { bag } \\
4\end{array}$ & 2 & 24 & Indian & $\begin{array}{l}\text { Released } \\
\text { per order } \\
\text { Marshall }\end{array}$ \\
\hline
\end{tabular}

Paul Lumber, a Native American was held as a witness in the charge of selling wine to an Indian. It was not clear who the charge was being levied against. In addition, Sam Jackson, also a Native American, was also held as a witness. It was 
unclear as to who purchased the wine. It is also unclear, as to whether Lumber and Jackson were held as witnesses against themselves - clearly a violation of the United States Constitution. Refer to the Bill of Rights, the Fifth Amendment: No person shall be...compelled in any criminal case to be a witness against himself,...(World Book Encyclopedia, p. 1012).

\begin{tabular}{|c|c|c|c|c|c|c|c|c|c|c|c|c|}
\hline $\begin{array}{l}\text { Mo } \\
\text { da }\end{array}$ & $\mathbf{h r}$ & $\begin{array}{l}\text { defend- } \\
\text { anf }\end{array}$ & $\begin{array}{l}\text { arrestin } \\
\mathrm{g} \text { officer }\end{array}$ & $\begin{array}{l}\text { com- } \\
\text { plainant }\end{array}$ & charge & $\begin{array}{l}\text { where } \\
\text { arrest } \\
\text { ed }\end{array}$ & $\begin{array}{l}\text { pro- } \\
\text { per- } \\
\text { ty }\end{array}$ & $\begin{array}{l}\mathbf{m} \\
\mathbf{o} \\
\mathbf{n} \\
\mathbf{e} \\
\mathbf{y}\end{array}$ & $\begin{array}{l}\text { dis } \\
\text { charg } \\
\text { ed } \\
\text { Mo. } \\
\text { day } \\
\end{array}$ & age & $\begin{array}{c}\text { nativity } \\
*\end{array}$ & remarks \\
\hline \multicolumn{13}{|c|}{1894} \\
\hline $\begin{array}{l}\text { Jul. } \\
28\end{array}$ & $4: 00 \mathrm{a}$ & $\begin{array}{l}\text { Frank } \\
\text { Cooke }\end{array}$ & $\begin{array}{l}\text { HA } \\
\text { Parker }\end{array}$ & $\begin{array}{l}\text { HA } \\
\text { Parker }\end{array}$ & Drunk & $\begin{array}{l}\text { rrd } \\
\& \\
\text { Oak }\end{array}$ & $\begin{array}{l}\text { bag } \\
75\end{array}$ & $\begin{array}{l}2 \\
0\end{array}$ & 28 & 32 & Indian & $\begin{array}{l}\text { Release } \\
\text { by Chief }\end{array}$ \\
\hline
\end{tabular}

The arrest of Frank Cooke, a Native American, on July 28, 1894, on charges of being drunk and released by Chief (assumed in reference to the Chief of Police) was unusual. Cook was either not guilty of being drunk, or the charges were dropped.

\begin{tabular}{|c|c|c|c|c|c|c|c|c|c|c|c|c|}
\hline $\begin{array}{l}\text { Mo } \\
\text { da }\end{array}$ & $\mathbf{h r}$ & $\begin{array}{l}\text { defend- } \\
\text { ant }\end{array}$ & $\begin{array}{l}\text { arrestin } \\
\text { g officer }\end{array}$ & $\begin{array}{l}\text { com- } \\
\text { plainant }\end{array}$ & charge & $\begin{array}{l}\text { where } \\
\text { arrest } \\
- \\
\text { ed }\end{array}$ & $\begin{array}{l}\text { pro- } \\
\text { per- } \\
\text { ty }\end{array}$ & $\begin{array}{l}\mathbf{m} \\
\mathbf{o} \\
\mathbf{n} \\
\mathbf{e} \\
\mathbf{y}\end{array}$ & $\begin{array}{l}\text { dis } \\
\text { charg } \\
\text { ed } \\
\text { Mo. } \\
\text { day }\end{array}$ & age & $\begin{array}{c}\text { nativity } \\
*\end{array}$ & remarks \\
\hline \multicolumn{13}{|c|}{1894} \\
\hline $\begin{array}{l}\text { Oct } \\
13\end{array}$ & 9:30a & $\begin{array}{l}\text { Billy } \\
\text { Indian }\end{array}$ & $\begin{array}{l}\text { Sheriff } \\
\text { Houser }\end{array}$ & $\begin{array}{l}\text { Sheriff } \\
\text { Houser }\end{array}$ & Safety & & & & 13 & 20 & Indian & \\
\hline
\end{tabular}

There was no recorded explanation for the arrest of Billy Indian, taken into custody October 13, 1894. The charge was recorded as 'Safety.' However, it was unclear if the arrest was in the interest of Billy Indian's safety, or to ensure the safety of the community by his absence. He was released the same day. 


\begin{tabular}{|c|c|c|c|c|c|c|c|c|c|c|c|c|}
\hline $\begin{array}{l}\text { Mo } \\
\text { da }\end{array}$ & hr & $\begin{array}{l}\text { defend- } \\
\text { ant }\end{array}$ & $\begin{array}{l}\text { arrestin } \\
\mathbf{g} \text { officer }\end{array}$ & $\begin{array}{l}\text { com- } \\
\text { plainant }\end{array}$ & charge & $\begin{array}{l}\text { where } \\
\text { arrest } \\
\text { - } \\
\text { ed }\end{array}$ & $\begin{array}{l}\text { pro- } \\
\text { per- } \\
\text { ty }\end{array}$ & \begin{tabular}{|l|}
$\mathbf{m}$ \\
$\mathbf{o}$ \\
$\mathrm{n}$ \\
$\mathrm{e}$ \\
$\mathrm{y}$
\end{tabular} & $\begin{array}{l}\text { dis } \\
\text { charg } \\
\text { ed } \\
\text { Mo. } \\
\text { day }\end{array}$ & age & $\begin{array}{c}\text { nativity } \\
*\end{array}$ & remarks \\
\hline \multicolumn{13}{|l|}{1894} \\
\hline $\begin{array}{l}\text { Oct } \\
19\end{array}$ & $\begin{array}{l}\text { 12:00 } \\
\text { a }\end{array}$ & $\begin{array}{l}\text { Homer } \\
\text { Hoffner }\end{array}$ & $\begin{array}{l}\text { GF } \\
\text { Johnso } \\
\text { n }\end{array}$ & $\begin{array}{l}\text { BM } \\
\text { Smith }\end{array}$ & $\begin{array}{l}\text { Witnes } \\
\mathrm{s}\end{array}$ & $\begin{array}{l}\text { Stati } \\
\text { on }\end{array}$ & & & 18 & 40 & Indian & \\
\hline
\end{tabular}

Hommer Hoffner, a Native American, taken into custody October 19, 1894, was held as a witness. It was not unusual for an individual to be jailed to ensure that he/she would appear as a witness at trial.

\begin{tabular}{|c|c|c|c|c|c|c|c|c|c|c|c|c|}
\hline $\begin{array}{l}\text { Mo } \\
\text { da }\end{array}$ & hr & $\begin{array}{l}\text { defend- } \\
\text { ant }\end{array}$ & $\begin{array}{l}\text { arrestin } \\
\mathbf{g} \text { officer }\end{array}$ & $\begin{array}{l}\text { com- } \\
\text { plainant }\end{array}$ & charge & $\begin{array}{l}\text { where } \\
\text { arrest } \\
\text { ed }\end{array}$ & $\begin{array}{l}\text { pro- } \\
\text { per- } \\
\text { ty }\end{array}$ & $\begin{array}{l}\mathrm{m} \\
\mathbf{o} \\
\mathrm{n} \\
\mathrm{e} \\
\mathrm{y}\end{array}$ & $\begin{array}{l}\text { disc- } \\
\text { harg- } \\
\text { ed } \\
\text { Mo. } \\
\text { day } \\
\end{array}$ & age & $\begin{array}{c}\text { nativity } \\
*\end{array}$ & remarks \\
\hline \multicolumn{13}{|c|}{1895} \\
\hline $\begin{array}{l}\text { Jan } \\
18\end{array}$ & $4: 00 p$ & $\begin{array}{l}\text { Ben } \\
\text { Jenning } \\
\text { s }\end{array}$ & Hudson & $\begin{array}{l}\text { HW } \\
\text { Hudson }\end{array}$ & Drunk & $\begin{array}{l}\text { E } \\
\text { Side }\end{array}$ & B. 6 & $\begin{array}{l}\$ \\
2\end{array}$ & 20 & 45 & Indian & \\
\hline
\end{tabular}

The arrest of Ben Jenning (a Native American) on January 18, 1895, for being drunk, was not unusual. However, what was unusual was that when observing arrest records stating in 1894, Native American names were recorded with the use of both first and last Anglo names. The denotation of Indian, except under the category, Nativity, appeared to have ceased. The use of Anglo names is unclear, but it was evident, Native Americans were no longer labeled by just their ethnicity. 


\section{CHAPTER VI \\ NATIVE AMERICANS \\ STATE OF OREGON \& CITY OF PORTLAND \\ COURTS OF RECORD - POLICE COURTS ${ }^{1}$}

\section{Background 1866-1874}

From 1866 through 1874, the Montana Gold Rush attracted additional white settlers to the western region who came to explore new territory and seek their fortune (Champagne, pp. 44-45). In 1867, the U. S. purchased Alaska without treaties or recognition of land ownership by Alaskan Natives. In addition, the Treaty of Fort Laramie in 1868, pushed Sioux and Cheyenne tribes into Montana, Wyoming and the Dakotas (Champagne, pp. 44-45). Although not involved with these Indian nations, west coast Native Americans also experienced estrangement from their land. The U.S. government used troops and Marshals to control or oust tribes who failed to recognize various treaties (Champagne, p. 45). The Arrest Records of Native Americans by Portland Police during this time period did not indicate overt adverse political influence.

While arrest records observed from the mid 1800's to the mid 1890's, indicated Native Americans were seldom arrested or involved in the criminal justice process, court records from that time period, provided different information. Native Americans were actively involved in the court process either as defendants, as prosecutors (complainant), or as witnesses.

1 Portland was divided into several Precincts. However, which Precinct was involved in the a court case was not indicated in court records observed - see PRECINCTS, CHAPTER III, pp. 36-137 


\section{COURT DOCKET RECORDS \\ STATE OF OREGON \\ June 1867 to July 1870 \\ J. J. Hoffman - Recorder \\ FELONIES}

\section{Background - 1867}

In 1867, the US government purchased Alaska from the Russian government. The Natives residing in Alaska gained no advantage. The Aleuts, Eskimos and Indians living in Alaska were not involved in any treaty negotiations with the US government, or was land ownership determined (Champagne, p. 45).

During the period of 1867 to 1870 , Native Americans were increasingly involved in the criminal justice process as a result of felonious acts. Court cases will be discussed after insertion.

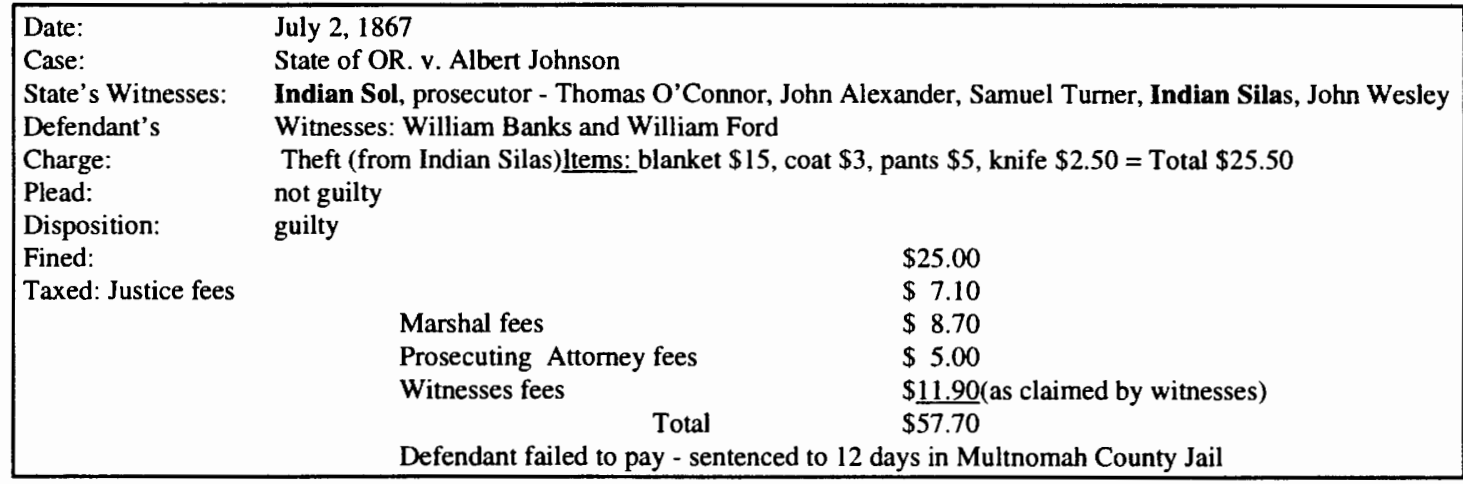

The case of State of OR v. Albert Johnson, July 2, 1867, indicated that Indian Sol was the complainant and Indian Silas was his own witness. Indian Sol filed a complaint on behalf of Indian Silas, the victim, accusing one Albett Johnson of theft. The defendant plead not guilty, was found guilty, fined $\$ 25.00$, plus court costs of $\$ 32.70$, for a total of $\$ 57.70$. The defendant failed to pay, was sentenced and served twelve days in Multnomah County Jail. Indian Silas appears to have received equal treatment under the law. He accused a white settler, Albert Johnson (nothing 
indicated that Johnson was of any other race/ethnicity), of a crime, was allowed to provide witnesses to support his charge and ultimately won his case.

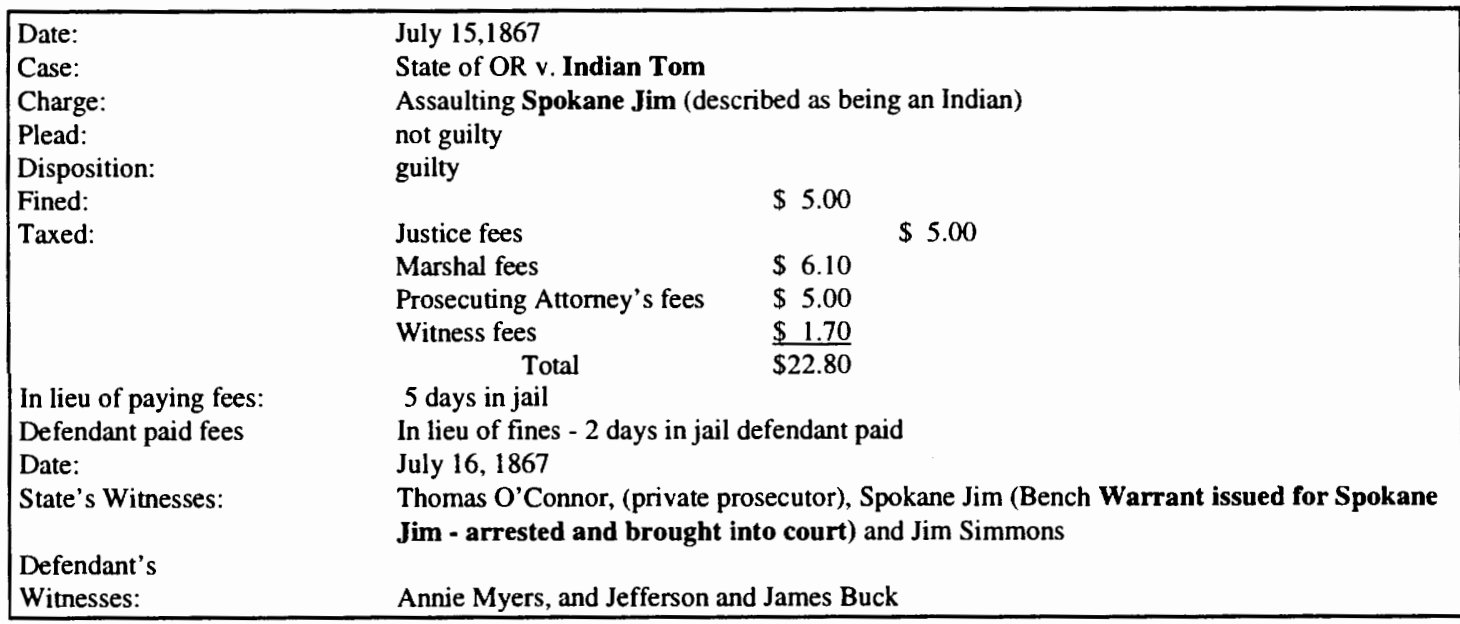

In a another case, State of Oregon v. Indian Tom, July 15, 1867, the defendant was accused of assaulting Spokane Jim (also described as an Indian). The defendant, Indian Tom, entered a plea of not guilty, was found guilty, fined $\$ 5$ and court costs of $\$ 17.80$, for a total of $\$ 22.80$. In lieu of payment, the defendant could have spent five days in Multnomah County Jail, but opted instead to pay the fine. This act in itself was different than that recorded in most arrest records where Native Americans seldom paid fines.

\begin{tabular}{|c|c|}
\hline $\begin{array}{l}\text { Date: } \\
\text { Case: } \\
\text { State's } \\
\text { Witnesses: } \\
\text { Jim- } \\
\text { Defendant's } \\
\text { Witnesses: }\end{array}$ & $\begin{array}{l}\text { July 16, } 1867 \\
\text { State of OR v. William Smith } \\
\text { Thomas O'Connor, (private prosecutor), Spokane Jim (Bench Warrant issued for Spokane } \\
\text { arrested and brought into court) and Jim Simmons } \\
\text { Annie Myers, and Jefferson and James Buck }\end{array}$ \\
\hline $\begin{array}{l}\text { Case: } \\
\text { Charge: } \\
\text { Plead: } \\
\text { Disposition: }\end{array}$ & $\begin{array}{l}\text { State of OR v. William Smith } \\
\text { Selling liquor to an Indian w/o authority of US or authorized officer } \\
\text { not guilty } \\
\text { not guilty and discharged }\end{array}$ \\
\hline
\end{tabular}

Note: Commentary to follow 
In the case of the State of Oregon v. William Smith, July 16, 1867, the defendant was accused of selling liquor to a Native American without the authority of an authorized U. S. officer. In this case Thomas O'Connor, private prosecutor (the complainant) and Spokane Jim were used as witnesses against the defendant, despite the latter's criminal involvement (see testifying against oneself, footnote 6). In addition, Spokane Jim was brought in on a bench warrant. It could be assumed he did not freely testify under his volition. The defendant, William Smith, used three witnesses, plead not guilty, was found not guilty and discharged.

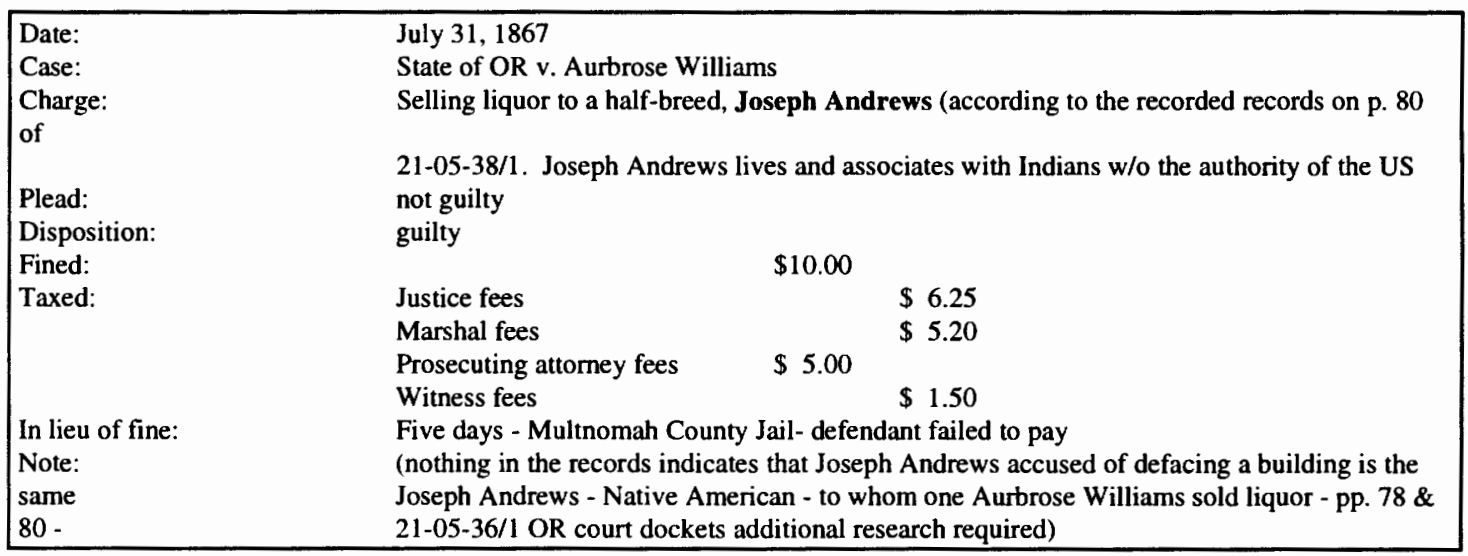

However, in the case of the State of Oregon v. Aurbrose Williams, July 31, 1867 , the disposition of the case was guilty. Williams was accused of selling liquor to a half-breed Native American, Joseph Andrews ${ }^{2}$ The fine and court costs in this case totaled seventeen dollars and ninety-five cents. Fines were inconsistently applied regardless of race or ethnicity. Portland City Ordinances provided for a

2 See COURT RECORDS, APPENDIX XIII-XXI. Joseph Andrews lived and associated with Native Americans without the authority of the United States government. It was not clear if Andrews had bi-racial parents, or if he was considered a half-breed as a result of his living arrangements. 
range of fines for violations. Recorders, and subsequently, Justices of the Peace and Police Judges used personal discretion when assigning fines.

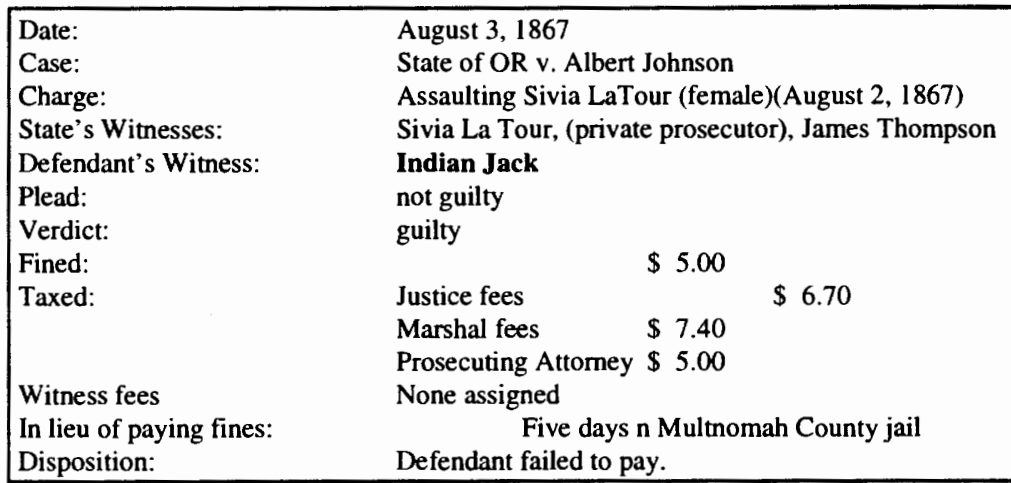

In the case of the State of Oregon v. Albert Johnson, August 3, 1867, it was recorded that Indian Jack was the defendant's witness. The defendant was found not guilty, witness fees were not charged and Indian Jack did not receive a witness fee. Witness fees were applied sporadically in most court cases and while the recorder specifically noted when white settlers were paid, there were not any indications that minorities were paid.

\begin{tabular}{|c|c|c|}
\hline Date: & \multicolumn{2}{|l|}{ October 18,1867} \\
\hline Case: & \multicolumn{2}{|l|}{ State of OR v. Indian Joe } \\
\hline Charge: & \multicolumn{2}{|c|}{ Feloniously taking and carrying away from a Mrs. Cotton: } \\
\hline & Item & Value \\
\hline & cloak & $\$ 8.00$ \\
\hline & three (3) gold studs & $\$ 5.00$ \\
\hline & Total & $\$ 13.00$ \\
\hline Warrant Issued: & \multicolumn{2}{|l|}{ October 17,1867} \\
\hline Bail set: & \\
\hline Defendant's witnesses subpoenaed: & \multicolumn{2}{|c|}{ (October 16,1867 (date given ???) - John Doran } \\
\hline $\begin{array}{l}\text { State's witnesses: } \\
\text { Plead: }\end{array}$ & \multicolumn{2}{|c|}{$\begin{array}{l}\text { Francis Brown (private prosecutor), Mrs. Cotton, P. Saunders, and Philip Doran. } \\
\text { guilty }\end{array}$} \\
\hline Disposition: & \multicolumn{2}{|c|}{ Convicted } \\
\hline Fined: & \multicolumn{2}{|l|}{$\$ 60.00$} \\
\hline \multirow{5}{*}{ Taxed: } & Justice fees & $\$ 10.00$ \\
\hline & Marshal fees & $\$ 7.60$ \\
\hline & Prosecuting Attorney fees & $\$ 5.00$ \\
\hline & Witness fees & $\$ 1.50$ \\
\hline & Total & $\$ 24.10$ \\
\hline In lieu of fine: & \multirow{3}{*}{\multicolumn{2}{|c|}{$\begin{array}{l}\text { Thirty (30) days in Multnomah County Jail } \\
\text { Defendant paid justice's fees (\$10), but failed (words used by } \\
\text { the Peace - JJ Hoffman) to pay the fine and taxed costs, and was } \\
\text { mandated to the Multnomah County Jail for the full } 30 \text { days - no } \\
\text { indicated for having paid the } \$ 10.00 \text { ) }\end{array}$}} \\
\hline Note: & & \\
\hline $\begin{array}{l}\text { Recorded/Justice of } \\
\text { therefore } \\
\text { reduction was }\end{array}$ & & \\
\hline
\end{tabular}


In the case of the State of Oregon v. Indian Joe, October 17, 1867, the defendant was accused of stealing a cloak, valued at eight dollars, and three gold studs, valued at thirteen dollars, a felony. The defendant did not post bail and as a result, was committed to jail until his trial date. Indian Joe plead guilty, was convicted, fined ten dollars and court costs of fourteen dollars and ten cents, for a total of twenty-four dollars and ten cents. The defendant failed $d^{3}$ to pay and was sentenced to Multnomah County Jail for thirty days. He did pay ten dollars towards his total court costs, but his jail sentence was not reduced. Comparing the results of this case to that of State of Or v. Albert Johnson, July 2, 1867, while the charges and conviction were the same, punishment for failing to pay the fine was not the same.

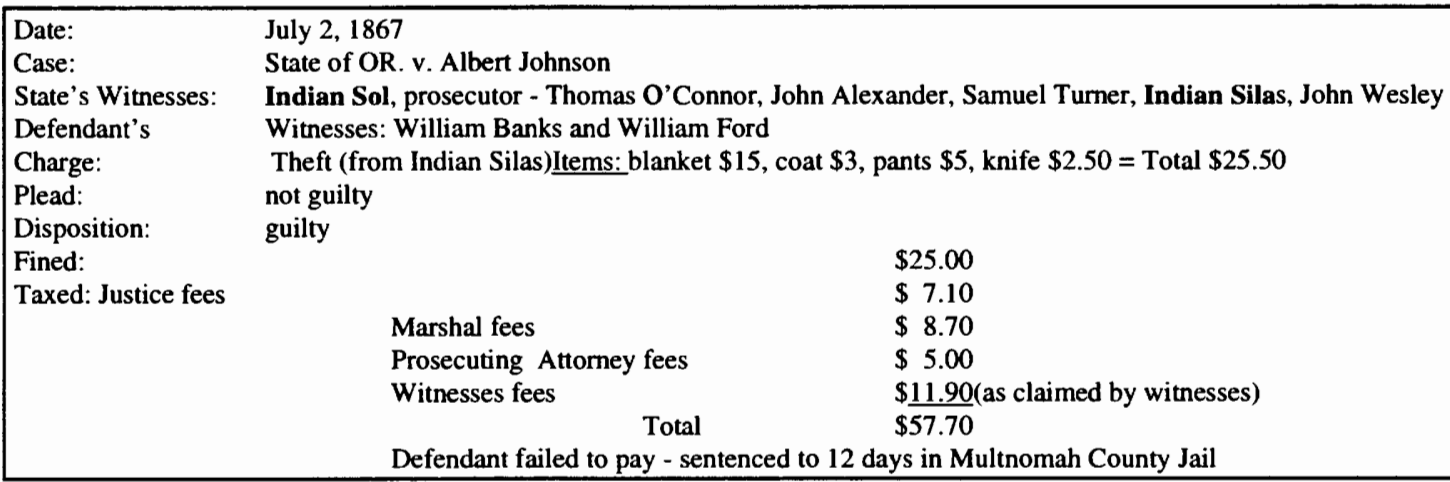

Indian Joe was convicted of feloniously taking personal items valued at thirteen dollars from a Mrs. Cotton, presumed to be white since records do not indicate otherwise. He was fined, including court costs, a total of twenty-four dollars and ten cents, of which he paid ten dollars. Failing to pay the entire amount he was sentenced to jail for thirty days.

3 Most judges used the word 'failed' to pay indicating the fine and/or court costs were not paid. However, it was not clear if the defendant was unable to pay or failed to pay. 
In the case of Albert Johnson, he was charged with theft, of items valued at

- twenty-five dollars and fifty cents, property of Indian Silas. Johnson was convicted, and failed to pay his fine including court costs. He was expected to pay a total of fifty-seven dollars and seventy cents. Despite failing to pay any portion of his fine, he was only sentenced to twelve days in Multnomah County Jail. The final disposition of similar cases were often inconsistent.

A city Ordinances authorized that witnesses be paid a fee for testifying.

However, the Recorder's notations did not indicate if during this period Native Americans were paid for their court appearances. Usually, the Recorder noted that a witness $\mathrm{fee}^{4}$ was charged and paid.

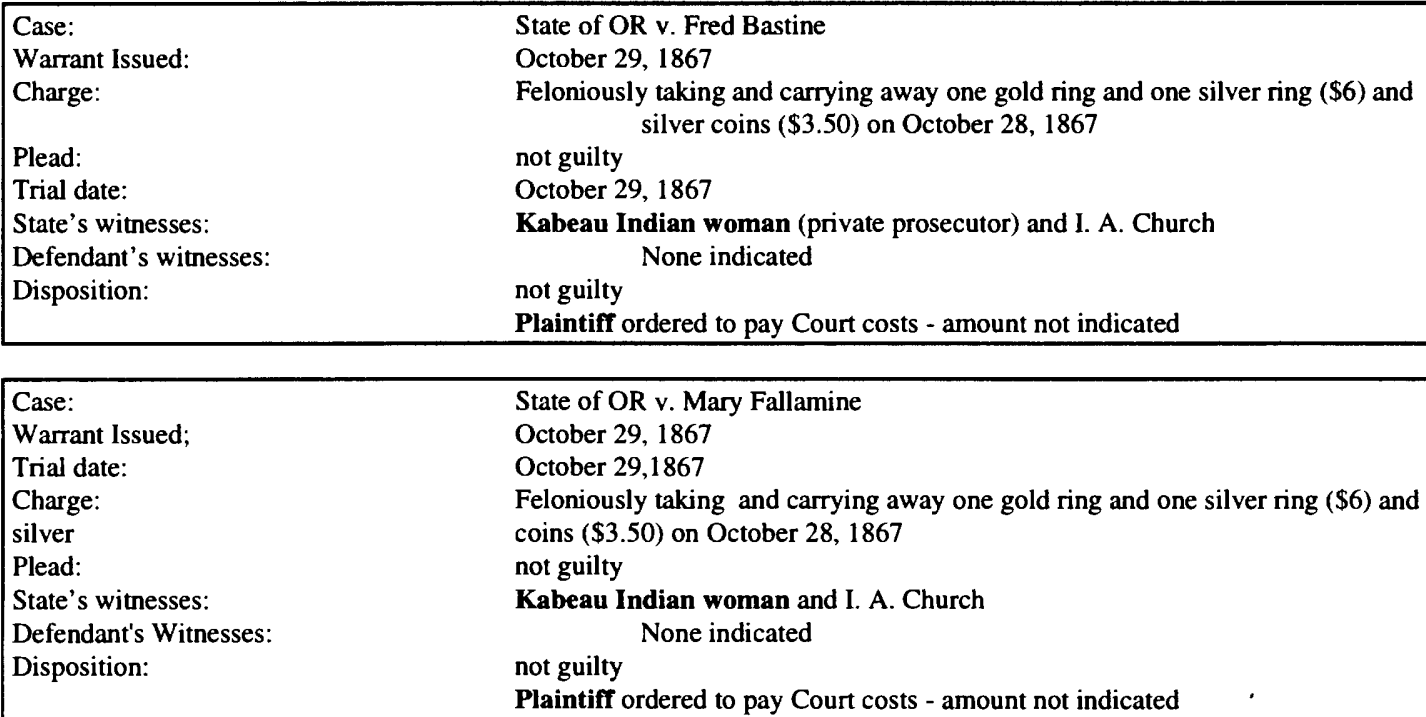

Commentary relative to the above cases will follow the next four cited cases

4 Witness fees were paid as a part of court costs by a convicted defendant. If there was more than one witness, then an additional fee was charged per witness to the convicted offender. If the defendant was found Not Guilty, the complainant/plaintiff, was responsible for court costs. The plaintiff included the City Attorney and the Marshall if they files charges on behalf of the State or the City. See COURT RECORDS - APPENDIX XIII-XXI. 
Case:

Warrant Issued:

Charge:

Plead:

State's witnesses:

Defendant's Witnesses:

Disposition:
State of OR v. Fred Bastine

October 29, 1867 (again)

Assault and battery on October 28, 1867

not guilty

Kabeau Indian woman and I. A. Church

None indicated

not guilty

Plaintiff ordered to pay Court costs - amount not indicated

See the following related cases.

\begin{tabular}{|c|c|}
\hline $\begin{array}{l}\text { Case: } \\
\text { Warrant lssued; } \\
\text { Trial date: } \\
\text { Charge: } \\
\text { Plead: } \\
\text { State's witnesses: } \\
\text { Defendant's Witnesses: } \\
\text { Disposition: }\end{array}$ & $\begin{array}{l}\text { State of OR v. Mary Fallamine } \\
\text { October } 29,1867 \\
\text { October } 29,1867 \\
\text { Assault and battery on October } 28,1867 \\
\text { not guilty } \\
\text { Kabeau Indian woman and I. A. Church } \\
\text { None indicated } \\
\text { not guilty } \\
\text { Plaintiff ordered to pay Court costs - amount not indicated }\end{array}$ \\
\hline $\begin{array}{l}\text { Case: } \\
\text { Warrant lssued: } \\
\text { Charge: } \\
\text { Plead: } \\
\text { State's witnesses: } \\
\text { Defendant's Witnesses: } \\
\text { Disposition: } \\
\text { Fined: } \\
\text { Taxed: } \\
\text { Defendant paid: } \\
\text { Disposition: } \\
\text { fine }\end{array}$ & $\begin{array}{l}\text { State of OR v. Fred Bastine } \\
\text { October 29, } 1867 \text { (again) } \\
\text { Feloniously taking and carrying away } \$ 11 \text { on October } 28,1867 \\
\text { not guilty } \\
\text { Kabeau Indian woman and I. A. Church } \\
\quad \text { None indicated } \\
\text { guilty } \\
\$ 25 \\
\text { Court costs - costs not indicated } \\
\$ 17 \\
\text { Defendant remanded to Multnomah County Jail for one day for every } \$ 2 \text { of unpaid } \\
\text { and tax (Court costs) not to exceed } 7 \text { days. }\end{array}$ \\
\hline
\end{tabular}

Case repeated with complete information.

Case:

Warrant Issued;

Trial date:

Charge:

Plead:

State's witnesses:

Defendant's Witnesses:

Disposition:

Fined:

Taxed:

Disposition:
State of OR v. Mary Fallamine

October 29, 1867

October 29,1867

Assault and battery on October 28, 1867

not guilty

Kabeau Indian woman and I. A. Church None indicated

guilty

Justices fees

$\$ 50.00$

Marshal fees

$\$ 6.70$

Prosecuting Attomey fees

Witness fees

$\$ 5.00$

$\$ 5.75$

Total

in lieu of fines and taxes:

Total $\quad \$ 1.50$

25 days in Multnomah County Jail Defendant failed to pay - jailed for 25 days

A Kabeau Indian woman, October 29, 1867 (a given name was not

indicated), the private prosecutor, filed charges of larceny and assault and battery 
against two white (race not otherwise indicated) defendants. The nature of the complaints filed by the Native American woman was highly unusual. Fred Bastine was found guilty of larceny in one instance but not guilty in the other. He was also found not guilty of assault and battery. Mary Fallamine, on the other hand, was found guilty of assault and battery and one instance of larceny, but not guilty on the other charge of larceny.

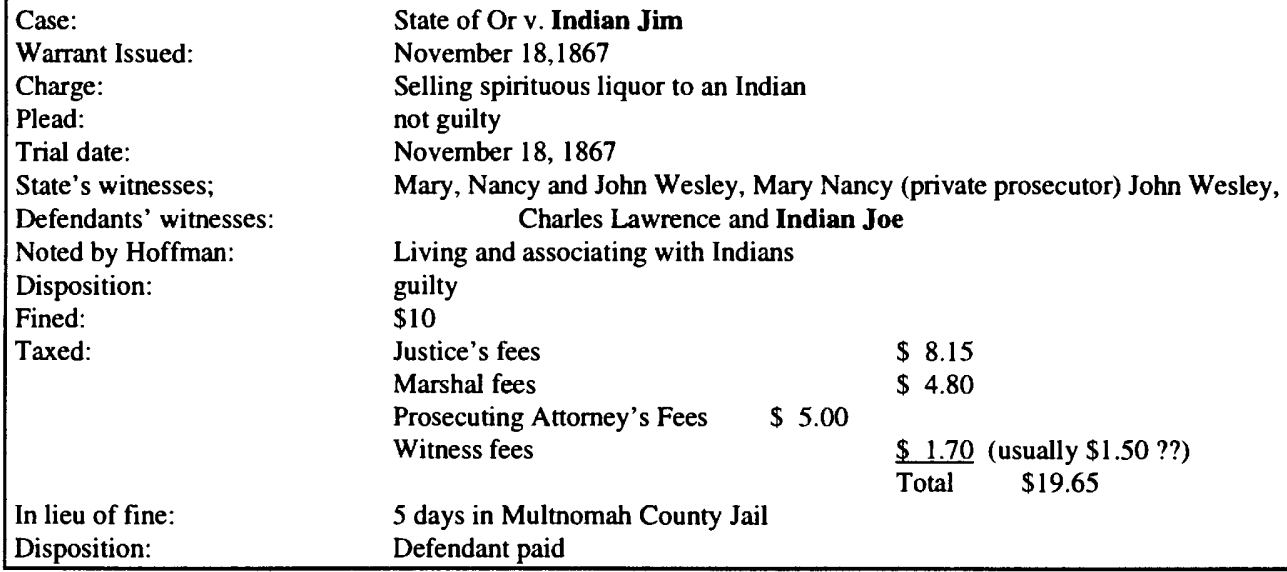

In the above case, Indian Jim, November 18, 1867, was charged and found guilty of selling spirituous liquor to another Native American. It is not clear if Indian Joe, appearing as a witness for the State, was the Native American to whom Indian Jim sold the liquor. Selling liquor to a Native American was a state violation. As such, it would seem, that the Native American to whom the liquor was sold would also have been in violation of Oregon law. 


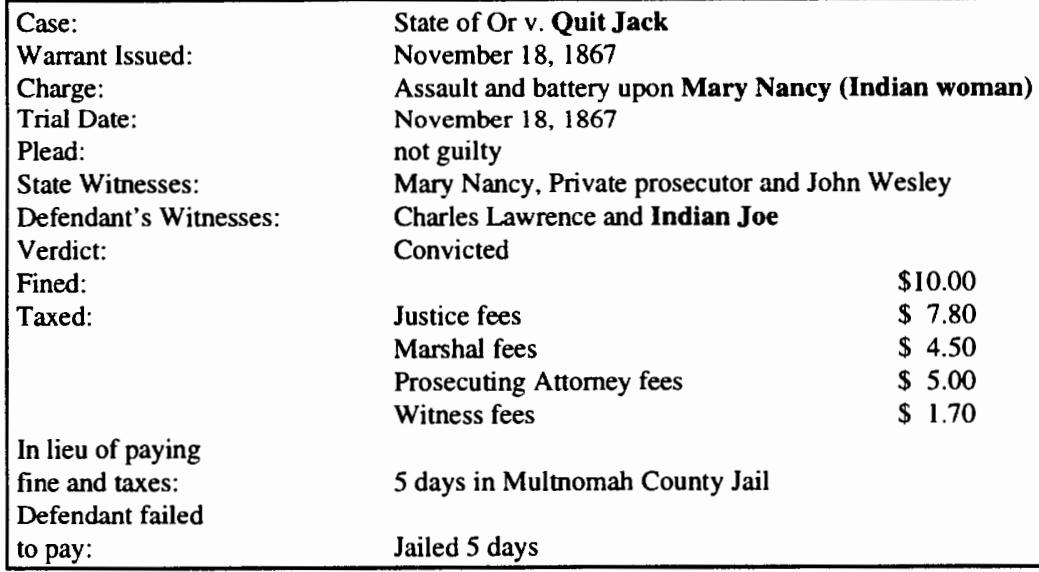

Mary Nancy, a Native American, November 18, 1867, filed charges of assault and battery against a Quit Jack. It is not clear if Quit Jack was Native American. In this case, Quit Jack was convicted, fined, and in lieu of payment, sentenced to five days in Multnomah County Jail.

\begin{tabular}{|ll|}
\hline Case: & State of OR v. Mrs. Madison \\
Warrant Issued: & November 20,1867 \\
Charge: & Selling Spirituous Liquor to an Indian w/o authority of the US or any authorized officer on \\
& November 12, 1867 \\
Plead: & not guilty \\
$\begin{array}{l}\text { State's Witnesses: } \\
\text { defendant's Witnesses: }\end{array}$ & Indian Jim, private prosecutor \\
$\begin{array}{l}\text { Verdict: } \\
\text { Plaintiff ordered to }\end{array}$ & not guilty \\
pay court fees: & Amount not indicated \\
\hline
\end{tabular}

Indian Jim, was used as a witness in the case of State of Or v. Mrs. Madison. Again, as in the previous cited case, it is not clear to whom the liquor was sold. If Indian Jim was the purchaser, then it appeared that he was required to testify against himself - a United States Constitutional violation. ${ }^{5}$ See footnote 6 this CHAPTER.

$5 \quad$ The Fifth Amendment to the United States Constitution states: No person shall...compelled in any criminal case to be a witness against himself,... (World Almanac, Bill of Rights, Constitution of the United States, p. 519). 


\begin{tabular}{|ll|}
\hline Case: & State of OR v. Indian George \\
Warrant Issued: & December 7, 1867 \\
Charge: & Feloniously taking and carrying away one stove (\$5), personal property of E. Eckles \\
Plead: & not guilty \\
Trial date: & December 9, 1867 \\
Bail Set: & None set \\
State's witnesses: & W. H. Harrison, private prosecutor, E. Eckles \\
Defendant's witnesses:: & Mr. Dryer \\
Verdict: & not guilty \\
Disposition: & Plaintiff ordered to pay court costs \\
\hline
\end{tabular}

Indian George, December 7, 1867, charged with theft, was found not guilty.

The plaintiff, the complainant, was required to pay court cost. The defendant, a

Native American, was found not guilty, despite having two white men (no notations

to indicate the contrary) testify against him.

\begin{tabular}{|ll|}
\hline Case: & State of OR v. Mary Fellamine \\
Warrant Issued; & January 31,1868 \\
Charge: & Selling spirituous liquor to an Indian (Indian Peter) w/o authority of the US or \\
any & authorized officer thereof. \\
Plead: & not guilty \\
Trial date: & January 31,1867 \\
Bail Set: & None \\
State's witnesses: & D. Jacobi, private prosecutor, Bastine, Indian Peter, Frederick Bastine, J. Channcy \\
& and James Parkow \\
Defendant's Witnesses: & None indicated \\
Verdict: & Convicted \\
Fined: & None \\
Bail set: & \$100 - defendant failed to pay \\
Disposition: & Defendant jailed “..until he be legally discharged..." \\
\hline
\end{tabular}

In the above case, a Mary Fellamine, January 31, 1868, was charged with selling spirituous liquor to Indian Peter, without authorization. However, in the closing statement, having been convicted, a 'he' was ordered to be jailed until legally discharged. It was unclear if the 'he' referred to, was a recording error, or if the purchaser, a Native American, was remanded to jail. In addition, the $\$ 100$ fine was highly unusual when compared to other cases with like charges resulting in convictions. 


\title{
COURT DOCKET RECORDS \\ STATE OF OREGON \\ June 1867 to July 1870 \\ J. J. Hoffman - Recorder \\ FELONIES \\ cont.
}

\begin{abstract}
Background - 1868
The Montana Gold Rush since 1866 continues to attack increasing numbers of non-Native Americans in their pursuit of gold. In an effort to protect miners from attacks by Sioux, and Cheyenne tribes, the government attempts to establish several forest along the trial. However, persistent attacks by Native Americans forces the government to abandon this tactic and negotiate the Treaty of Fort Laramie in 1868. As a result, some Sioux and Cheyenne leaders agree to relocate their reservations to Montana, Wyoming and the Dakotas. Nevertheless, incursion into Native American Territory persists, as miners, hunters and railroad employees continue to trespass on Sioux and Cheyenne county

(Champagne, pp. 44-45)
\end{abstract}

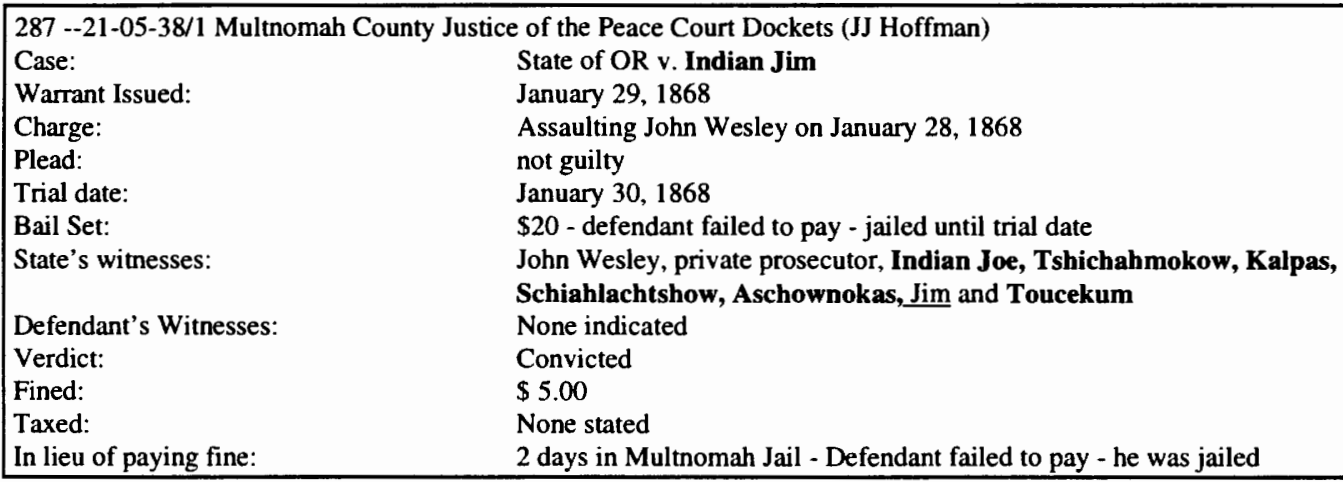

In the case of the State of Oregon v. Indian Jim, January 29, 1868, John

Wesley, a white settler, charged the defendant with assault. Six other Native

Americans, Indian Joe, Tshichahmokow, Kalpas, Schiahlachtshow, Aschownokas,

Jim and Toucekum testified against Indian Jim. ${ }^{6}$ It was unclear, if witnesses were

forced to testify or did so willingly. The U.S. Constitution protects individual's

from having to testify against him/herself. ${ }^{7}$ It was indeterminate if Jim was Indian

6 The spelling of Native American names involved in this case may be incorrect due to the difficulty in deciphering the clerk's handwriting.

$7 \quad$ Op. Cit., footnote 5. 
Jim, the defendant, or another witness. The only record of any portion of the proceedings were recorded in the Court Docket. Most recorded procedures did not offer or provide any explanations for actions that appeared to be unusual. The defendant, Indian Jim, did not have witnesses.

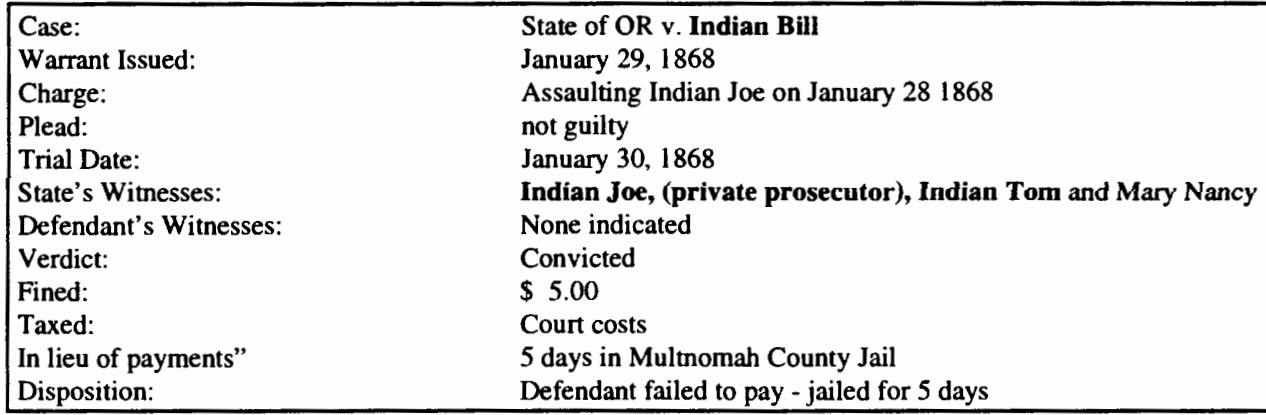

In the case, the State of Oregon v. Indian Bill, January 29, 1868, the defendant was charged with assaulting another Native American, Indian Joe. Again, Indian Tom failed to pay and was sentenced to Multnomah County jail for five days.

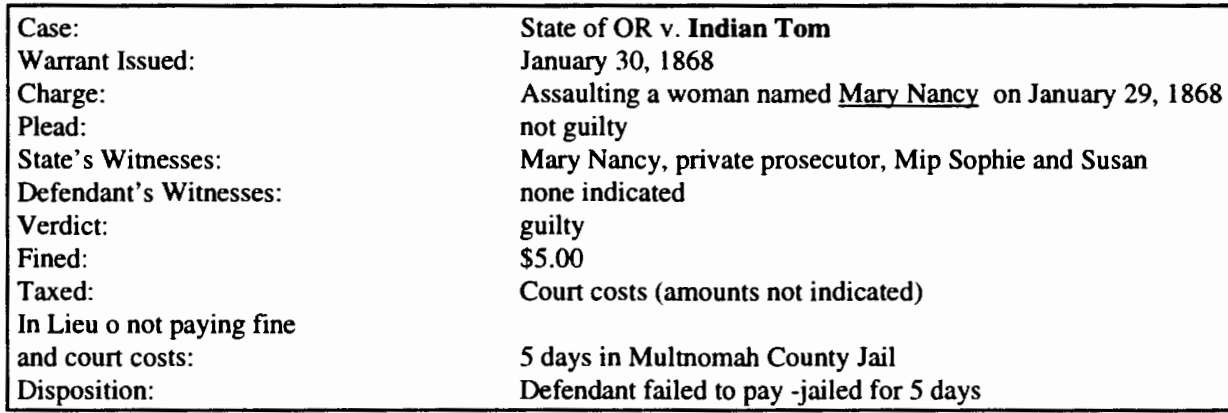

Another case involved the State of Oregon v. Indian Tom, January 30, 1868.

The defendant was charged with assaulting a woman, Mary Nancy. Mary Nancy's race/ethnicity was not indicated, suggesting she may have been white. The defendant plead not guilty, was found guilty, fined $\$ 5$, court costs were not indicated. Indian Tom failed to pay his fine and was jailed for five days. Neither the amount of the 
fine nor the length of sentence were unusual for the crime. The physical abuse of women was not especially punished as a deterrent to the act.

There are numerous Court cases involving Native Americans. While Native Americans filed charges of assault against white settlers, (no indication of any other ethnicity/race), during this period, white defendants were seldom found guilty.

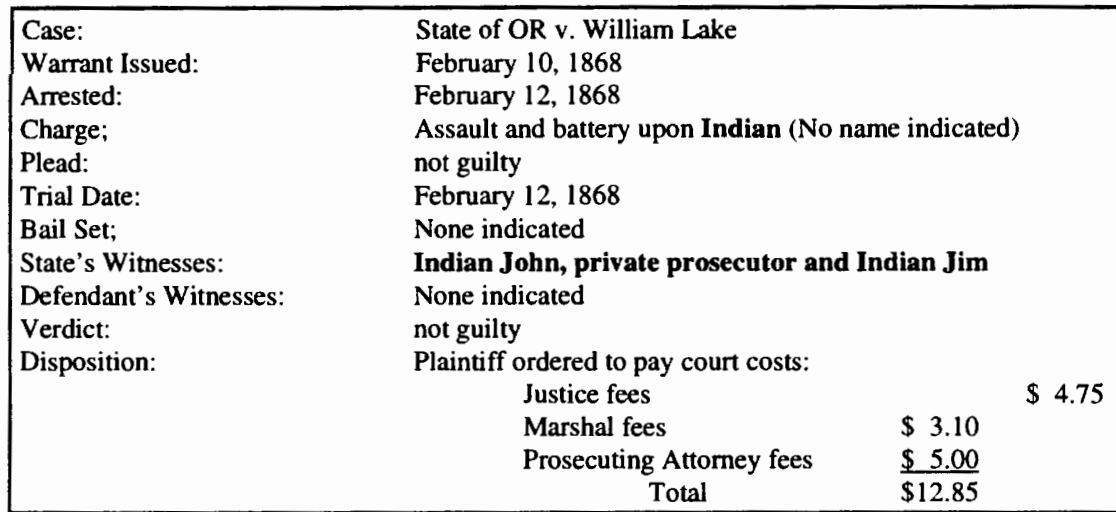

In the case of the State of Oregon v. William Lake, February 10, 1868, the complainant (and probably the victim), Indian Joe, private prosecutor, filed charges of assault against the defendant. Indian John had a witness, Indian Jim. William Lake was found not guilty.

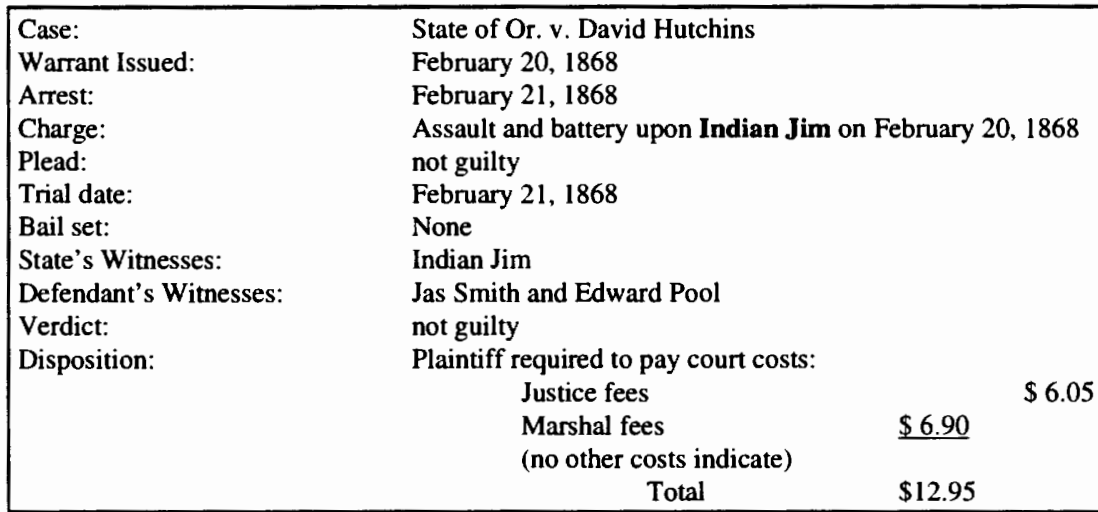


A verdict of not guilty, was also rendered in the State of Oregon v. David Hutchins, February 20, 1868. In this case, Indian Jim (there was no way of determining if this Indian Jim was the same Indian Jim cited in the preceding case as a witness) filed assault charges against David Hutchins - against the defendant was found not guilty. In each of these cases the plaintiff, complainant, was required to pay court costs.

Without records of court proceedings, there was no way to determine the guilt or innocence of defendants. It seems obvious, however, that Native Americans did file charges of assault and were mostly unsuccessful in getting a guilty verdict against a white defendant. Charges of false allegations did not appear to have been filed against either of the plaintiffs.

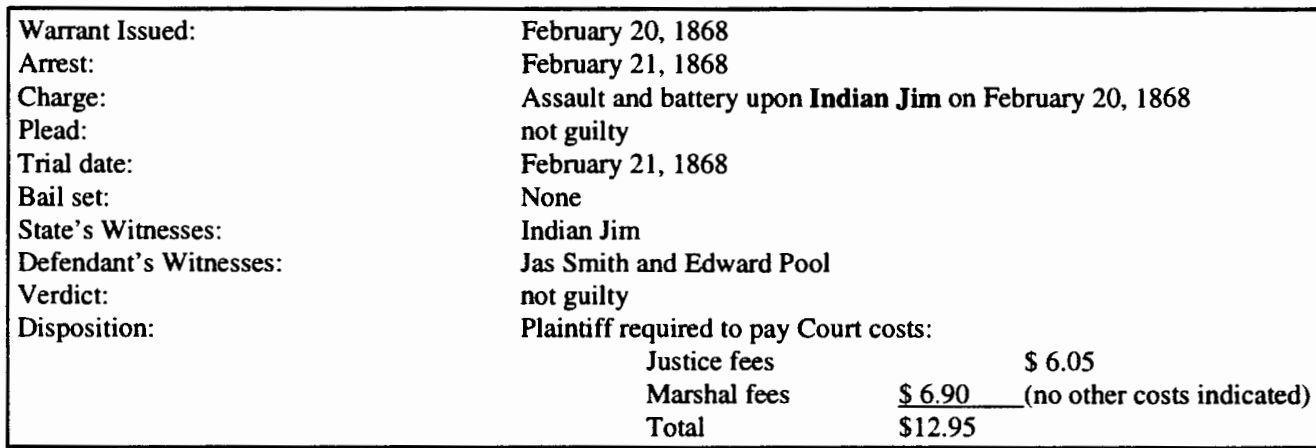

In a case involving the assault by a Native American against another Native American, there was a verdict of guilty - see the State of Oregon v. Indian Jim, March 17, 1868. 
In the following case, State of Or v. Indian Charlie, May 26, 1868, a white settler filed charges of assault against a Native American. Yet, Indian Charlie, the defendant, was found not guilty.

\begin{tabular}{|c|c|}
\hline $411-21-05-38 / 1$ & \\
\hline Case: & State of OR v. Indian Charlie \\
\hline Warrant Issued: & May 26,1868 \\
\hline $\begin{array}{l}\text { Charge; } \\
\text { Plead: }\end{array}$ & $\begin{array}{l}\text { Assault and battery upon James Simmons, May } 25,1868 \\
\text { not guilty }\end{array}$ \\
\hline Trial Date: & May 27,1868 \\
\hline Bail Set: & $\$ 50$ - Defendant failed to pay - defendant jailed until trial date \\
\hline $\begin{array}{l}\text { State's Witnesses: } \\
\text { Defendant's Witnesses: } \\
\text { Verdict: }\end{array}$ & $\begin{array}{l}\text { James Simmons, private prosecutor, Narcesse Joseph, Jenny Mary Ann, and Mary Nancy } \\
\text { None Indicated } \\
\text { not guilty }\end{array}$ \\
\hline Disposition: & 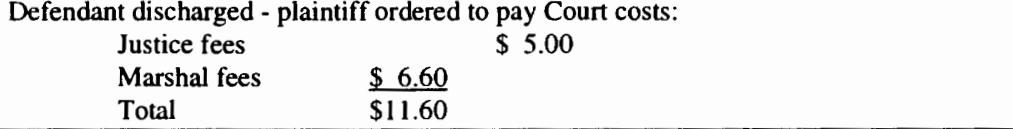 \\
\hline
\end{tabular}

p. $413 \cdot 21-05-38 / 1$

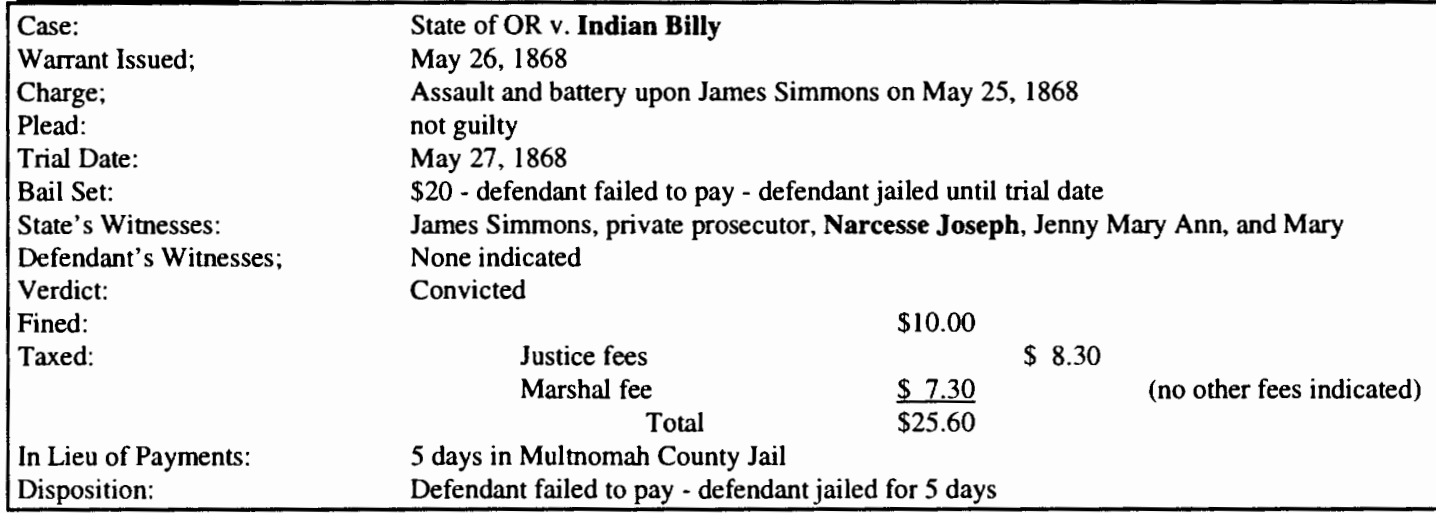

In the above case, the State of Oregon v. Indian Billy, May 26, 1868, the defendant was charged with assault and battery by the same complainant as in the State of OR v. Indian Charlie, case. See the previous case. However, Indian Billy was found guilty. The complainant in each case had the same name, James Simmons, and was assumed to be the same person. 


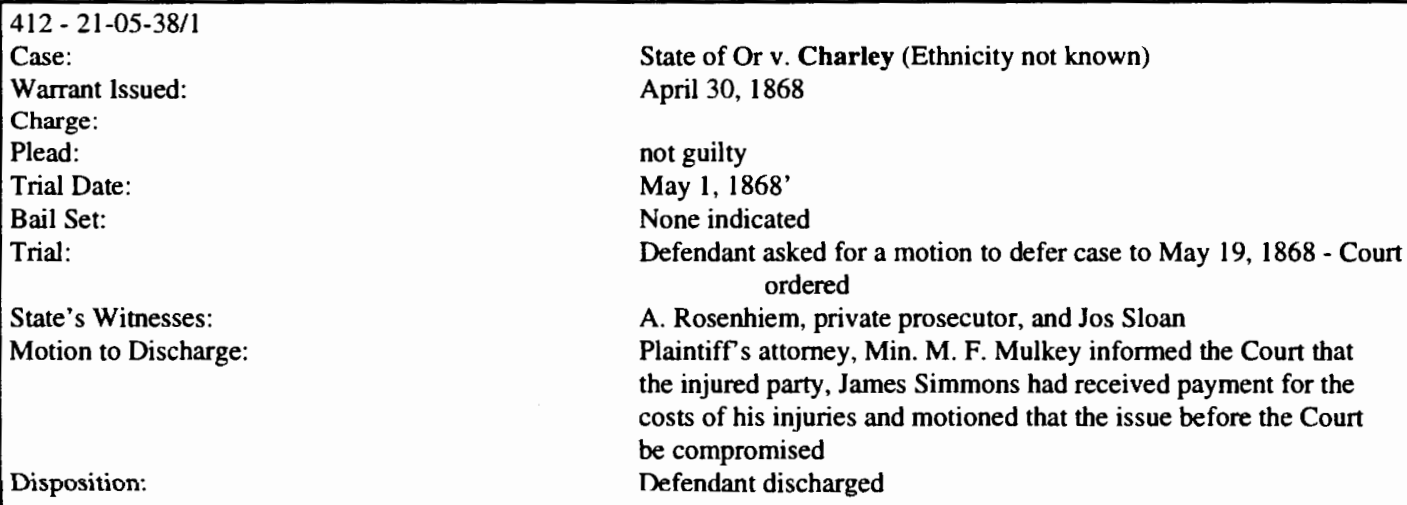
the injured party, James Simmons had received payment for the costs of his injuries and motioned that the issue before the Court be compromised Defendant discharged

In the case of the State of Oregon v. Charley, April 30, 1868 (there was no reference to race or ethnicity - there was nothing to indicate that Charley was the same person as Indian Charlie), the defendant (assuming that Charley was Native American $)^{8}$ requested a motion to defer his case for approximately three week, to May 19, 1868. The Court complied, but on May 26, (the case was entered in the Court Docket between two cases recorded on that date and discussed herein) the plaintiff's attorney informed the Court that the defendant, Charley, had paid the victim/plaintiff for the costs of his injuries; having done so, the case was discharged. If, indeed Charley, was Native American, the circumstances surround this case were highly unusual.

8 The name Charley, without a given last name, usually indicated that the individual was a Native American. See NATIVE AMERICAN ARREST RECORDS ...name of persons arrested... CHAPTER V, p. 159. 


\begin{tabular}{|c|c|c|}
\hline \multicolumn{3}{|l|}{$410-21-05-38 / 1$} \\
\hline Case: & \multicolumn{2}{|l|}{ State of OR v. Indian Thomas } \\
\hline Warrant Issued: & \multicolumn{2}{|l|}{ May 26,1868} \\
\hline Charge: & \multicolumn{2}{|c|}{$\begin{array}{l}\text { Assault and battery upon James Simmons on } \\
\text { May } 25,1868\end{array}$} \\
\hline Plead: & \multicolumn{2}{|l|}{ not guilty } \\
\hline Trial Date: & \multicolumn{2}{|l|}{ May 27,1868} \\
\hline Bail Set: & \multicolumn{2}{|c|}{$\$ 20$ - Defendant failed to pay - defendant jailed until trail date } \\
\hline State's Witnesses: & \multicolumn{2}{|c|}{ James Simmons, private prosecutor, Narcisse Joseph, Jenny Mar Ann } \\
\hline and & \multicolumn{2}{|l|}{ Mary } \\
\hline Defendant's Witnesses: & \multicolumn{2}{|l|}{ None indicated } \\
\hline Verdict: & \multicolumn{2}{|l|}{ Convicted } \\
\hline Fined: & & $\$ 50.00$ \\
\hline \multirow[t]{4}{*}{ Taxed: } & Justice fees & $\$ 8.30$ \\
\hline & Marshal fees & $\$ 7.30$ \\
\hline & Prosecuring Altomey fees & (none indicated) \\
\hline & Total & $\$ 65.60$ \\
\hline In Lieu of Payments: & \multirow{2}{*}{\multicolumn{2}{|c|}{$\begin{array}{l}35 \text { days in Multnomah County Jail } \\
\text { Defendant failed to pay - defendant jailed for } 25 \text { days }\end{array}$}} \\
\hline Disposition: & & \\
\hline
\end{tabular}

Indian Thomas was charged with assault and battery upon a James Simmons

on May 25, 1868. Thomas plead not guilty and was offered bail of twenty dollars.

Failing to post bail, Thomas was jailed until his trial date, May 27. Indian Thomas, the defendant had no witnesses to testify in his behalf. However, the State had several witnesses including Narcisse Joseph. Thomas was convicted, fined fifty dollars, an extreme fine when compared to the amount of other fines for the same charge. In lieu of payment, Indian Thomas was sentenced to thirty-five days in jail. There were no remarks to explain the unusual amount of the fine. 


\section{COURT DOCKET RECORDS \\ STATE OF OREGON \\ June 1868 to July 1870 \\ J. J. Hoffman - Recorder \\ FELONIES}

\begin{tabular}{|ll|}
\hline C. 8 & \\
\hline Warre: & State of OR v. Indian Tom \\
Arrested: & August 4, 1868 \\
Charge: & (same) \\
Plead: & Assault upon Indian Dick on August 2, 1868 \\
Trial Date: & not guilty \\
Bail Set: & (same) \\
State's Witnesses:: & None indicated \\
Defendant's Witnesses: & Indian Dick, private prosecutor, John Wesley and Big Indian \\
Verdict: & Indian Mary, Indian Nancy and Big Indian \\
Fined: & Convicted \\
Taxed: & \$10.00 \\
In Lieu of Payments: & Court costs - amount not stipulated \\
Disposition: & Max. 5 days in Multnomah County Jail (MCJ) \\
& Defendant paid \$12 in gold coins - defendant jailed for 2 days - defendant was \\
\hline
\end{tabular}

In the above case, State of Oregon v. Indian Tom, August 4, 1868, the defendant was charged with assault on another Native American, Indian Dick. The State had three witnesses including Indian Dick, a John Wesley (presumably a white male), and 'Big Indian.' The defendant, Indian Tom, also had witnesses, Indian Mary, Indian Nancy and 'Big Indian.' Records did not indicate whether Big Indian, testifying for the prosecution, was the same Big Indian testifying for the defense. Indian Tom was convicted and fined ten dollars; court costs were not stipulated. In lieu of payment, the defendant was sentenced to five days in the Multnomah County Jail.

However, the defendant paid twelve dollars in gold coins and his sentenced was reduced to two days. It was assumed the difference in the amount of the fine and the defendant's payment represents court costs, the amount of which was not 
indicated in the record. The payment of a fine was rare for Native Americans and to have paid in gold coins, even more unusual.

\begin{tabular}{|c|c|}
\hline Case: & State of OR v. Indian Tom \\
\hline Warrant Issued: & August 3,1868 \\
\hline Arrested: & (same) \\
\hline Charge: & Assault upon Indian Joseph on August 2, 1868 \\
\hline Plead: & not guilty \\
\hline Trial Date: & August 4,1868 \\
\hline Bail Set: & $\begin{array}{l}\$ 20 \text { - defendant failed to give bail - defendant jailed until time } \\
\text { of trial }\end{array}$ \\
\hline State's Witnesses:: & $\begin{array}{l}\text { Indian Joseph, private prosecutor, John Wesley, Jim Wesley, } \\
\text { and Big Indian }\end{array}$ \\
\hline Defendant's Witnesses: & Indian Nancy and Indian Mary \\
\hline Verdict: & Convicted \\
\hline Fined: & $\$ 10.00$ \\
\hline Taxed: & Court costs - amount not stipulated \\
\hline In Lieu of Payments: & Max. 5 days in MCJ \\
\hline Disposition: & Defendant failed to pay - defendant jailed for 5 days \\
\hline
\end{tabular}

In the case, State of Oregon v. Indian Tom, August 3, 1868, the defendant was also charged with assault, but upon an Indian Joseph. In the cited case, Indian Tom was allowed to deposit twenty dollars bail, but failing to do so, was jailed until the date of his trial. Records did not provide an explanation for cases being recorded out of sequence. See Sate of OR v. Indian Tom, August 4, 1868, and the above case Oregon v. Indian Tom, August 3, 1868.

The prosecution used the same witnesses, Indian Joseph, John Wesley and Big Indian. However, in the case of August 4, 1868, the defense used only two witnesses, Indian Mary and Indian Nancy. Big Indian was not used as a witness for the defense.

Again, Indian Tom was convicted, fined ten dollars, but failing to pay, was jailed for five days. Indian Tom, assaulted Indian Joseph and Indian Dick, perhaps during the same confrontation. 
Case:

Warrant Issued:

Arrested:

Charge:

Plead:

Trial Date:

Bail Set:

State's Witnesses:

Defendant's Witnesses:

Verdict:

Fined:

Taxed:

In Lieu of Payments:

Disposition:
State of OR v. Joe (a half breed) (as written)

August 4, 1868

(same)

Selling liquor to an Indian named Dick who lives and associates with Indians on

August 2, 1868

not guilty

August 5, 1868

$\$ 200$ - defendant failed to make bail - defendant jailed until time of trial Indian Joseph private prosecutor, John Wesley, Jim Wesley, and Big Indian Indian Nancy and Indian Mary

Convicted

Defendant held to answer the crime and be admitted to bail for $\$ 200$ - defendant jailed until he was legally discharged

In the above case, the State of Oregon v. Joe, a half-bred, August 4, 1868,

bail was offered for the defendant, at an unusual rate of $\$ 200$. The defendant was

charged with selling liquor to a Native American, Dick. The defendant was

convicted and jailed until discharged. The length of sentencing was not stipulated, indeterminate sentencing seemingly, was applied.

p. 94

Case:

Warrant Issued:

Arrested:

Charge:

Plead:

Trial Date:

Bail Set:

State's Witnesses::

Defendant's Witnesses:

Verdict:

Fined:

Taxed:

In Lieu of Payments:

Disposition:

State of OR v. Indian Jim
November 10,1868
(same)
Assault - being armed with a dangerous weapon committed on Little Indian Jim
on November 9,1868
not guilty
November 10,1868
None indicated
Little Indian Jim, private prosecutor, John Wesley and Chickum Cun
None indicated
Convicted
Court costs - amount no indicated
Max. 25 days in MCJ
Defendant failed to pay fine and/or costs - defendant jailed for 25 days

In an unusual case, the State of Oregon v. Indian Jim, November 10, 1868,

the defendant was charged with assaulting his son, Little Indian Jim, with a

dangerous weapon. The prosecution, presented three witnesses, including Little

Indian Jim and Chickum Cun, presumed to be another Native American. Indian Jim 
was convicted, fined $\$ 50$, failing to pay, he was sentenced to twenty-five days in Multnomah County Jail. The fine for physically assaulting a child was more stringent than most other fines. It should be noted that the usual fine for assaulting a female was usually ten dollars or less.

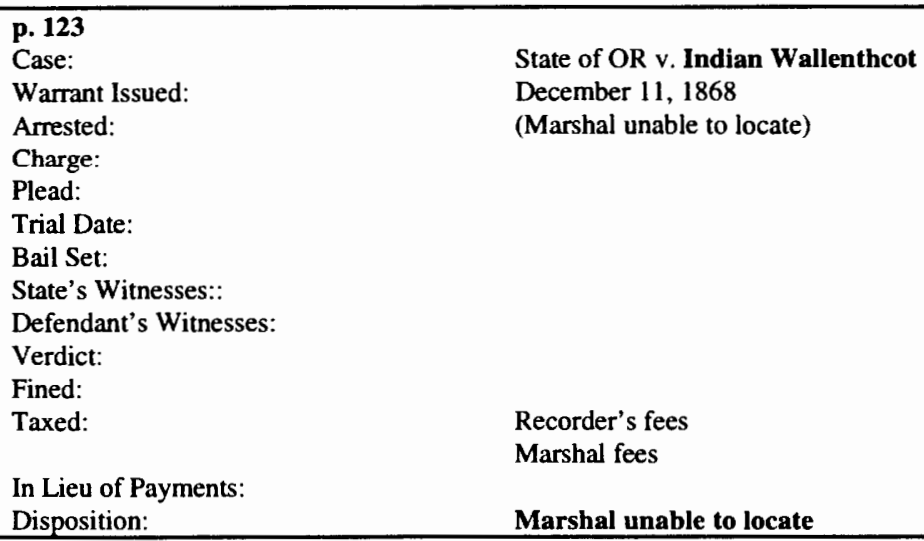

In the case, the State of Oregon v. Indian Wallenthcott, December 11, 1868, the Marshal was unable to locate the defendant. The charge was not indicated, nor was there any effort recorded to locate the accused. 


\section{COURT DOCKET RECORDS \\ STATE OF OREGON \\ June 1868 to July 1870 \\ J. J. Hoffman - Recorder \\ FELONIES \\ cont.}

\section{Background - 1869}

In 1869 and continuing into 1871, an Indian Commissioner of Indian Affairs, Brigadier General Ely Parker, a Seneca Indian, was appointed by President Ulysses S. Grant. The was a move to appease Native American tribes and their members into reconciling themselves to accept their displacement to reservations in exchange for food and clothing (Champagne, p. 45). Many tribes resented the treatment and the continued infusion by outsiders onto what was previously their land. A few Native Americans attempted to assimilate into white society, but many more were unacceptable to the new government and its intrusion. They resented the use of reservations, government handouts and control of their presence (Champagne, p. 45)

\section{The Arrest and Crime Data report, indicated that twenty Native Americans}

were arrested in $1869 .{ }^{9}$ Twelve cases were observed to have been heard by the

Portland Police Court, inserted here for discussion.

1. State of Oregon v. Indian Jim, February 1, 1869, charged with assault and battery upon Andres F. Delin, a white victim (no indication of any other race or ethnicity), convicted, fined $\$ 10$, failed to pay, jailed for five days.

2. State of Oregon v. Indian Jim, March 26, 1869, charged with defacing a building not his own, convicted, fined \$30, failed to pay, jailed for fifteen days in Multnomah County Jail (MCJ).

3. State of Oregon v. Indian Norris and Indian John Doe, March 29, 1869 (John Doe presumed to be an alias), charged with arson in burning the dwelling of Charles Adams (assumed to be white, no indication of any other race or ethnicity), Indian Norris was convicted and Indian John Doe was discharged, Indian Norris was required to answer in Circuit Court and held in MCJ until trial.

4. State of Oregon v. Indian Tom, May 31, 1869, charged with assault and battery upon Hugh Kearns, convicted, fined $\$ 5$, failed to pay, jailed for three days in MCJ.

5. State of Oregon v. Indian Jack, June 22, 1869, charged with assault and battery upon No Sabe (thought to be Chinese), plead not guilty, found guilty, Fined $\$ 5$, failed to pay, jailed in MCJ for three days.

6. State of Oregon v. Indian Jack, June 30, 1869, charged with assault and battery upon a chinaman, plead not guilty, Found guilty, fines $\mathbf{\$ 1 0}$, failed to pay, jail in MCJ for five days.

7. State of Oregon v. Indian Joe, October 20,1869 , charged with larceny, plead guilty, Fine not indicated but was assessed Court costs of $\$ 15.60$, failed to pay sentenced to MCJ for thirty days.

9 Tracy, Charles Abbott, (1976), The Evolution of the Police Function In Portland, Oregon, 1811-1874, Dissertation, University of California, California State University campus, San Jose, California, pp. 55-56 and CHARACTERISTICS OF PERSONS ARRESTED BY YEAR APPENDIX V. 
Cases No. 1, 4, 5 and 6, on the preceding page involved charges of assault and battery perpetrated by a Native American against white men and Chinese men. These incidents were unusual. Perhaps, the resentment of the presence of outsiders onto Native American land was taking its toll. 


\section{COURT DOCKET RECORDS \\ STATE OF OREGON \\ June 1868 to July 1870 \\ J. J. Hoffman - Recorder \\ FELONIES}

\section{Background 1870}

Canada acquires the Hudson's Bay Company lands fro the British government with the understanding that it will negotiate land cession treaties with Native Americas.

Most of the area becomes the Northwest Territories, governed by the federal government. Metis

Leader Louis Riel obtained Manitoba, but the federal government controls the land and its natural resources (Champagne, p. 111).

Note: In $1868 \mathrm{~J}$. J. Hoffman, was the Justice of the Peace. However, as of August, 1870, his title was changed to Ex-Officio Justice of the Peace. Hoffman continued to serve the Police Court.

In 1870, two court cases involving Native Americans dealt with charges of assault and battery perpetrated against them by white men (no indication of any other racial/ethnic group). Gender is assumed in the absence of that information. One case involved assault and battery by one Native America against another Native American. In each case a verdict of guilty was rendered and either defendants paid their assessments, or were jailed.

1. State of Oregon v. Tre Thomas, February 9, 1870, charged with selling spirituous liquid to Frank, an Indian, plead not guilty, found not guilty, Bail of $\$ 100$ returned.

2. State of Oregon v. Isaac Love, April 14, 1870, charged with assault and battery upon Indian Jim, plead guilty, fine not indicated, assessed Court costs of $\$ 11.65$, paid assessment and was discharged.

3. State of Oregon v. Henry Samatt, June 7, 1870, charged with assault and battery upon Indian Sam, plead guilty, fined $\$ 20$, and court costs of $\$ 14.60$ for a total of $\$ 34.60$, paid $\$ 30.30$, jailed for two days in lieu of $\$ 4.00$ not paid.

4. State of Oregon v. Indian Charles, June 20,1870, charged with assault and battery upon Indian Louezo, plead guilty, fined $\$ 20$, and Court costs of $\$ 15.50$, failed to pay, jailed for ten days. 
COURT DOCKET RECORDS

STATE OF OREGON

December 1874 to March 1880

O. N. Hoffman - Recorder

FELONIES

There were no cases observed during this time period that involved an identifiable Native American. 


\section{COURT DOCKET RECORDS \\ CITY OF PORTLAND \\ June 1867 to August 1870 \\ J. J. Hoffman- Police Judge \\ MISDEMEANORS}

\section{Background 1870}

Cree and Backfoot (Blackfeet ?) fight the last plains war in Canada near Woop-up. The conflict was an outgrowth of rights to diminishing buffalo herds (Champagne, p. 111). Also see 1870 under the previous section FELONIES

Cases observed during this time period and in the Court Docket book,

dealt with misdemeanors, City of Portland $v$. (the name of the defendant). Court

cases citing Native Americans, involved charges of drunk and disorderly conduct.

As observed in arrest records, Native Americans adjudicated in 1870 did not pay

their fines. Again, it was unclear if they failed to pay or were unable to pay. Refer to

the following for cases that occurred during the noted time period of this section:

1. City of Portland v. Indian John, August 27, 1870, charged with being drunk and disorderly, convicted, fined $\$ 5$ and taxed $^{10} \$ 10.90$, failed to pay, jailed for five days.

2. City of Portland v. Indian Joseph, February 6, 1871, charged with being drunk and disorderly, convicted, fined $\$ 20$ - based on five previous convicted - however, record of charges not observed, tax not indicated, ordered to work or leave town within twenty-four hours - defendant discharged.

3. City of Portland v. Indian (no name indicated), February 17, 1871, charged with being drunk and disorderly, convicted, fined $\$ 5$, tax not indicated, failed to pay, jailed for five days.

4. City of Portland v. Clicital Charley (an Indian), April 20, 1871, charged with being drunk and disorderly, convicted, fined $\$ 5$, tax not indicated, failed to pay, jailed for three days.'

5. City of Portland v. Pedro Jack an Indian, April 20, 1871, charged with being drunk and disorderly, convicted, fine and tax not indicated, held in City Jail for twenty-two hours, departed on Rioes Steamer for his home in Montecello.

$10 \quad$ Taxed refers to court costs - Recorder's fees, Marshall fees, Witness(es) fees, Prosecutor's fees, and Police Judge's fees. 


\section{COURT DOCKET RECORDS \\ CITY OF PORTLAND \\ July 1871 to May 1875 \\ O. N. Denny - Police Judge \\ MISDEMEANORS/FELONIES}

\section{Background - 1871}

In 1871 , Congress passed an act signaling the end to treaty negotiations with Native American nations. While treaties signed between 1778 and 1871 were to be enforced, tribes wishing to re-negotiate agreements could no longer seek changes (Champagne, p. 46). Many Native

Americans felt betrayed and remanded to the life of an outsider on land that was once familiar and life supporting.

According to the records reflecting Arrest and Crime Data for $1871,{ }^{11}$ only ten Native Americans were arrested during that year. Records observed and available at the Portland City Archives start in July of 1871. The following drunk and disorderly Conduct case, was the only trial observed for that year involving an identifiable Native American.

City of Portland v. Indian Tom, December 21, 1871, charged with being drunk and disorderly, convicted, fined $\$ 5$, tax not indicated, failed to pay, jailed for three days.

" Op. Cit., Tracy, CHARACTERISTICS OF PERSONS ARRESTED BY YEAR APPENDIX V. 


\section{COURT DOCKET RECORDS \\ CITY OF PORTLAND \\ July 1871 to May 1875 \\ O. N. Denny - Police Judge \\ MISDEMEANORS/FELONIES}

\section{Background - 1872}

Stating 1870 and continuing into 1890 , the use of peyote ${ }^{12}$ by Native Americans during their religious ceremonies was recognized by the U.S. government. Years later, the Office of Indian Affairs launched a movement to limit the use of peyote and disband the Native American Church. Their attempts were unsuccessful (Champagne, p. 46).

Arrest and Crime Data records indicated that the Portland Police arrested sixteen Native American in $1872^{13}$ and sixteen court cases were observed. See the following cases. In each case, with the exception of one, the charge was drunk and disorderly or disorderly conduct.

12 Peyote - a plant, imported from northern Mexico, used in religious ceremonies by Native Americans that produces a mild hallucinatory state, thought to bring the user closer to the spirit world. In the late nineteenth century, its use spread throughout several North American Native American tribes as part of their songs, symbolism, dreams, visions and prayers (Champagne, p. 46).

13 Ibid. 
1. City of Portland v. Jim (again, the use of a first name only usually refers to a Native American), May 21,1872 , charged with lying drunk, convicted, fined $\$ 10$, tax not indicated, failed to pay ${ }^{14}$, jailed for five days.

2. City of Portland v. Indian John, July 8, 1872, charged with being drunk and disorderly, convicted, fined $\$ \$ 10$, failed to pay, jailed for five days.

3-4. City of Portland v. Lucy and Jane (Indians - indicated), July 12, 1872, charged with being violent and disorderly, fined $\$ 10$ each, paid fine and were discharged.

5. City of Portland v. Indian Joe, July 15, 1872, charged with being drunk and disorderly, convicted, fined $\$ 10$, failed to pay, jailed for five days.

6. City of Portland v. Indian Jim, July 15, 1872, charged with being drunk and disorderly, convicted, fined $\$ 5$, paid fine and was discharged.

7. City of Portland v. Siwash ${ }^{15}$ Jim v. August 1, 1872, charged with being disorderly, convicted, fined $\$ 10$, failed to pay, jailed for five days.

8. City of Portland v. Jack (again, first name only usually indicates a Native American), September 13, 1872, charged with being drunk, verdict not indicated, but presumed convicted since the defendant was fined $\$ 10$, failed to pay, jailed for five days.

9. City of Portland v. Indian Jim, October 16, 1872, charged with indecent exposure of his person, convicted fined $\$ 10$ - failed to pay - jailed for five days).

10. City of Portland v. Indian Mary, October 25, 1872, charged with being drunk, convicted, fined $\$ 5$, failed to pay, jailed for three days.

11. City of Portland v. Indian Jack, October 28, 1872, charged with being drunk, convicted, fined $\$ 10$, paid fine and was discharged.

12. City of Portland v. Indian Jim, November 4, 1872, charged with using abusive language, convicted, fined $\$ 10$, failed to pay, jailed for five days.

13. City of Portland v. Charley, November 13, 1872, charged with being drunk and disorderly, convicted, fined $\$ 5$, failed to pay, jailed for three days.

14. City of Portland v. Indian Williams, November 21, 1872, charged with being drunk and disorderly, convicted, fined $\$ 10$, paid fine and was discharged.

15. City of Portland v. Indian Joe, December 24, 1972, charged with being drunk and disorderly, convicted, fined $\$ 10$, failed to pay, jailed for five days.

16. City of Portland v. Indian Dick, December 24, 1872, charged with being drunk, convicted, fined $\$ 15$, failed to pay, jailed for seven days. No reason given for increase in amount of fine, nor for increase in number of days served in jail in absence of paying fine.

14 Starting with the Denny Court in 1851 , Tax, or court costs were sporadically indicated

15 Siwash - A North American Indian of the northern Pacific coast (used in an unfriendly

way)... (World Book Dictionary, pp. 1952-1953). 
Native American females were charged with being violent and disorderly.

See Lucy and Jane, above. Not only were the charges uncharacteristic of Native American women, the defendants paid their fines and were discharged. In most other cases, Native Americans continued to fail to pay their fines and as usual, were jailed. However, in 1872, a few Native Americans started to reverse this trend by paying their fines and getting discharged.

Arrest and Crime Data records indicate sixteen Native Americans were arrested by Portland Police in 1872, however, only fifteen Court cases were observed. ${ }^{16}$ Criminal charges filed against Native Americans during this time period expanded from merely drunk and/or disorderly to more inflammatory complaints. It was unclear if when arresting Native Americans on drunk and/or disorderly charges, if they are intoxicated from liquor or any other drug, including peyote.

16 Op. Cit., Tracy, CHARACTERISTICS OF PERSONS ARRESTED BY YEAR APPENDIX V. 


\section{COURT DOCKET RECORDS \\ CITY OF PORTLAND \\ July 1871 to May 1875 \\ O. N. Denny - Police Judge \\ MISDEMEANORS/FELONIES}

\section{Background - 1873}

The United States Department of Interior is given responsibility over Indian affairs. Ten Americans and Canadians killed at least thirty Assiniboine ${ }^{17}$ in the Cypress Hills Massacre. The Cypress Hills are located in Canada's southwestern prairies (Champagne, p. 111).

In the following cases Indian Dick, was either a popular Native American name, or the defendant appeared to have a drinking problem. He was finally confined to jail for twenty days, a rather lengthy sentence. However, Indian Chas Sprenger also charged with being drunk, was convicted and sentenced to jail for twenty days without indications of a levied fine. See the following cases.

17 Assiniboine - A member of a Siouan tribe of northeastern Montana and adjacent parts of Canada (World Book Dictionary, p. 124). 


\section{COURT DOCKET RECORDS \\ CITY OF PORTLAND \\ July 1871 to May 1875 \\ O. N. Denny - Police Judge \\ MISDEMEANORS/FELONIES}

2.

3. City of Portland v. Jack and Jim, January 11, 1873 - charged with Indecent Exposure, convicted, fined $\$ 20$, failed to pay, jailed for ten days.

4. City of Portland v. Indian Jim, January 13, 1873, charged with Using Obscene Language, convicted, fined $\$ 15$, failed to pay, jailed for seven days.

5. City of Portland v. Indian Dick, Mach 10, 1873, charged with Indecent Exposure, convicted, fined $\$ 20$, failed to pay, jailed for ten days.

6. City of Portland v. Indian Mary, April 12, 1873, drunk and disorderly...(usual charge)

7. City of Portland v. Indian Dick, April 15, 1873, Being a Vagrant, convicted, jailed for five days.

8. City of Portland v. Lee (probably Chinese) and Jim (possibly Native American), May 5, 1873, charged with Indecent Acts of Conduct, (not explained), convicted, fined \$5, jailed for three days.

9. City of Portland v. Indian Dick, June 9, 1873, charged with being drunk and disorderly, convicted, fined $\$ 5$, failed to pay, jailed three days.

10. City of Portland v. Indian Tom, June 30,1873 , charged with being drunk and disorderly, convicted, fined (amount not indicated), failed to pay, jailed seven days.

11. City of Portland v. Indian (name not indicated), July 5, 1873, charged with being drunk, convicted, fined $\$ 5$, failed to pay, jailed for five days.

12. City of Portland v. Indian Dick, July 5, 1873, charged with being drunk, not fined, committed to jail for twenty days, (no explanation provided). See prior cases - perhaps, the Court was intolerant.

13. City f Portland v. Indian (Chas.) Sprenger, July 5, 1873, charged with bring drunk, no fine indicated, jailed for twenty days.

14. City of Portland v. Indian (name not indicated), August 5, 1873, charged with being drunk, convicted, fined $\$ 10$, failed to pay, jailed for ten days.

15. City of Portland v. Indian (name not indicated), September 19, 1873, Charged with being drunk and disorderly, convicted, fined $\$ 10$, failed to pay, jailed for five days.

16. City of Portland v. Charley ${ }^{18}$ (possibly Native American), October 24, 1873, charged with being drunk and disorderly, convicted, fined $\$ 5$, failed to day, jailed for three days.

18 There are instances in this research where Native Americans use the name "Charley, Charlie, or Chas., as did Chinese residents. For example, refer to this case and City of Portland v. Ah Faug, Lee Fau, Su Fou, Ah Bon and Charley, June 27, 1873, APPENDICES XVIII and XIX. 


\section{COURT DOCKET RECORDS \\ CITY OF PORTLAND \\ November 1873 to May 1875 \\ O. N. Denny - Police Judge \\ MISDEMEANORS/FELONIES}

\section{Background - 1874}

During the early 1870's, The first Ghost Dance movement spread through Native American tribes. ${ }^{19}$ The movement supported the belief that those who failed to follow the practice would disappear in the ruins of an earthquake (Champagne, p. 44).

In 1874 , Arrest and Crime Dada records indicate only eleven Native

Americans were arrested by the Portland Police. ${ }^{20}$ However, only five cases were recorded as adjudicated by the Denny Police Court. Charges, again, routinely were drunk and/or disorderly conduct.

1. City of Portland v. Indian Charley, March 30, 1874, charged with being drunk, convicted, no fine indicated, ${ }^{21}$ jailed for two days.

2. City of Portland v. Indian Tom, May 30,1874 , charged with being drunk, convicted, fined $\$ 10$, failed to pay, jailed for five days.

3. City of Portland v. Indian Jim, July 6, 1874, charged with being drunk, convicted, no fine indicated, jailed for twenty days (no explanation provided for length of sentence).

4. City of Portland v. Indian Tom, October 12, 1874, charged with being drunk and disorderly, convicted, no fine indicated, jailed for three days.

5. City of Portland v. Indian Jack, October 24, 1874, charged with being drunk and disorderly, convicted, fined $\$ 5$, failed to pay, jailed for three days.

19 The Ghost Dance was part of an effort to revitalize Native American religion. Wodziwob, Paiute Native American residing on the California/Nevada border was believed to have started this form of religion in the early 1870's (Champagne, p. 47).

20 Op. Cit., Tracy, CHARACTERISTICS OF PERSONS ARRESTED BY YEAR APPENDIX V.

${ }_{21} \quad$ No fine indicated, could have been inefficient record keeping, or the discretion of the Police Judge not to fine but to confine. 


\title{
COURT DOCKET RECORDS \\ CITY OF PORTLAND \\ May 19 - July 25, 1875 \\ S. A. Moreland \\ July 26, 1875 to January 16,1879 \\ W. H. Adams \\ MISDEMEANORS/FELONIES
}

\begin{abstract}
Background - 1875
The Nez Perce Native Americans of Oregon strive to remain faithful to their treaty with the US government signed in 1863 (Champagne, p. 44). However, the discovery of gold on the Nez Perce Idaho reservation and the government's intervention to reduce their land holdings with the introduction of a new treaty creates an atmosphere of animosity and distrust. Most chiefs failed to sign the new agreement including Chief Joseph (Champagne, p. 44).
\end{abstract}

According to Arrest and Crime Data records, there were six arrests by Portland Police of Native Americans in $1875 .^{22}$ However, only three Court cases were observed. In this section, cases involving white settlers (no information to indicate otherwise) have been included to provide an example of their treatment for similar charges during the same time period. The examples do not indicate that white defendants compared to Native American defendants for charges involving being drunk unfairly differ by rate of conviction, amount of fine or length of sentencing. See cases inserted:

1. City of Portland v. Indian Tom, August 2, 1875, charged with being drunk and disorderly, convicted, fined $\$ 5$, failed to pay, jailed for three days.

2. City of Portland v. Indian Tom, November 15, 1875, charged with being Dunk, convicted, fined $\$ 15$, failed to pay, jailed for seven days.

3. City of Portland v. Indian Tom, December 18 1875, charged with being drunk, convicted, no fine indicated, jailed for ten days. (Perhaps, the Court had grown intolerant.

22 Op. Cit., Tracy, CHARACTERISTICS OF PERSONS ARRESTED BY YEAR APPENDIX V. 


\title{
COURT DOCKET RECORDS \\ CITY OF PORTLAND
}

July 26,1875 to January 16,1879

W. H. Adams

MISDEMEANORS/FELONIES

\begin{abstract}
Background - 1876
The Sioux nation led by Chief Crazy Horse of the Oglala tribe and Sitting Bull of the Hunkpapa, a group of Teton's, seek to protect the Black Hills from miners seeking their fortune. The Cheyenne and Arapaho Native American nations join the Sioux in this effort against American troops protecting the miners. Colonel George Armstrong Cluster and his forces, using Crow and Arikara scouts, are attacked and slain by the Sioux and the Cheyenne at Little Big Horn Valley, current known as Montana (Champagne. p. 47).
\end{abstract}

In 1876, Arrest and Crime Data records indicated only two Native Americans were arrested by Portland Police. ${ }^{23}$ However, only one court case was observed. City of Portland v. Indian Charley, February 14, 1876, charged with being drunk and disorderly, convicted, fined $\$ 10$, failed to pay, jailed for five days

Ibid. 


\title{
COURT DOCKET RECORDS \\ CITY OF PORTLAND \\ July 26, 1875 to January 16,1879 \\ W. H. Adams \\ MISDEMEANORS/FELONIES
}

\begin{abstract}
Background - 1877
Between 1863 and 1876, the Wallowa ${ }^{24}$ Nez Percé continued to refuse to sign the Thief Treaty of 1773. As a result of Cluster's defeat at Little Big Horn in 1876 and Chief Crazy Horse's attempted escape and subsequent death in 1877, the U. S. government, leery of Native American attacks, increased their efforts to mandate Indians to reservations. By 1977 , Chiefs Joseph ${ }^{25}$ Ollikut, ${ }^{26}$ Looking Glass, Rainbow, White Bird and Toohoolhoolzote of the Nez Percé nation, agreed to sign the new treaty and move their people to reservations. However, in route a skirmish occurred involving young Nez Percé ultimately resulting in the Nez Perce War. After losing several; battles, Chief Joseph conceded with the understanding that the Nez Perce nation not be punished for their resistance and be allowed to reside on the reservation in Idaho. General Oliver O. Howard and Colonel Nelson A. Miles accepted the terms of the agreement. However, General William Tecumseh Sherman failed to accept the deal and exiled the Nez Perce and their fighting allies, the Palouse, to Fort Leavenworth in Kansas. They were treated as prisoners of war and eventually forced to move to Oklahoma (Champagne, p. 47).
\end{abstract}

See commentary and only case indicated involving an identifiable Native American during this time period on the following page.

24 The Nez Perce Nation was comprised of tribes designated by their geographical locations. The Wallowa Nez Perce of the Wallowa Valley, under the leadership of Chief Joseph, were notoriously unrentlentless in their struggle to retain their land and rights in the late 1870's. However, the Lapwai Nez Perce (near Lewiston, Idaho) were resented by Chief Joseph's followers for their seemingly accommodating response to U. S. government orders to sign and comply with the 1863 treaty (Nukes, p. C1).

${ }_{25}$ Chief Joseph's Native American name was Hinmahtooyahlatkekt, or Thunder Coming From Water Overland (Champagne, p. 47).

26 There are variations on the spelling of Chief Ollikut's name. Chief Ollikut is reported to have been the brother of Chief Joseph. Chief Ollikut's grandson, Chief Joseph Earl 'Taz' Conner (1938- ), spells his grandfather's name as Ollokot (Nokes, p. C1). 


\section{COURT DOCKET RECORDS \\ CITY OF PORTLAND \\ July 26, 1875 to January 16,1879 \\ W. H. Adams \\ MISDEMEANORS/FELONIES}

In 1877, according to Arrest and Crime Data records, the number of arrests

involving Native Americans increased to nine during that year. ${ }^{27}$ However, only one case was observed to have been heard by the Portland Police Court. In the following case, while the race of the defendant was not clear, the name Blackhawk, has historical significance in Native American lineage and for this reason was cited. ${ }^{28}$

- State of Oregon v. Blackhawk Mason, (date not indicated - Case \#107 - case appeared in the records between Court cases dated in the year 1877), charged with Larceny of Property - totaling $\$ 27$, acquitted and discharged. The Plaintiff, JH Way, was required to pay court costs of $\$ 15.20$.

27 Op. Cit., Tracy, CHARACTERISTICS OF PERSONS ARRESTED BY YEAR APPENDIX V.

$28 \quad$ Black Hawk - Indian Name. Makataemwashkiakiak, 1767-1838, leader of the Fox (tribe of Agonquian-speaking Indians of southwestern Wisconsin who merged with the Sauk in 1760) and Sauk (tribe of Native Americans living in Michigan, Wisconsin and lllinois, who settled in Iowa and Oklahoma) Indians in the Black Hawk War of 1832. (American Heritage Dictionary, pp. 137, 520, \& 1155 ). 


\title{
COURT DOCKET RECORDS \\ CITY OF PORTLAND \\ July 26, 1875 to January 16,1879 \\ W. H. Adams \\ MISDEMEANORS/FELONIES
}

\begin{abstract}
Background $\mathbf{- 1 8 7 8}$
During 1878, Chief Joseph, Chief of the Wallowa Nez Perce Nation, increasingly became disillusioned with the U. S. government's rescission of the Howard -Miles agreement under which the Native American nation agreed to surrender. Chief Joseph promotes a movement to take their grievance to Washington DC (Champagne, p.47).
\end{abstract}

In 1878, Arrest and Crime Data records indicated that two Native Americans were taken into custody by the Portland Police. ${ }^{29}$ However, Portland Court records observed during this time period did not cite any cases involving Native Americans. 


\section{COURT DOCKET RECORDS \\ CITY OF PORTLAND \\ July 26, 1875 to January 16,1879 \\ W. H. Adams \\ August 1879 \\ O. N. Denny \\ MISDEMEANORS/FELONIES}

\section{Background - 1879}

In 1879, Chief Joseph traveled to Washington, D. C., where he was interviewed by the editor of the North American Review. As a result of his published essay explicating the injustices by the federal government on the Nez Perce nation, several Americans initiated action demanding the return of these Native Americans to the northwest, their homeland (Champagne, p. 47).

In 1879, according to Arrest and rime Data records, seven Native Americans were arrested. ${ }^{30}$ There were only two Court cases adjudicated in the City Police Court observed during this period involving identifiable Native Americans.

1. City of Portland v. Dick Indian, charged with being drunk and disorderly, convicted, fined \$5, failed to pay, jailed for three days.

2. City of Portland v. Indian Charley, charged with being drunk and disorderly, convicted, fined $\$ 5$ and fined Court costs of $\$ 1.70$, failed to pay, jailed for three days. 


\section{COURT DOCKET RECORDS \\ CITY OF PORTLAND \\ January 17,1879 to 1882 \\ L. B. Stearns \\ MISDEMEANORS/FELONIES}

\section{Background - 1880}

Stating in 1879 and continuing until 1890, the Carlisle Indian School in Pennsylvania was founded to demonstrate that Native Americans could be educated to adapt American culture. Other schools were established in California, Oregon, Oklahoma, New Mexico and Arizona, and on reservations. U. S. reformers removed Native American children from their homes, as early as age five, with the intent of destroying their Native culture. Children were forced to learn English and if they deviated from the curriculum by speaking their Native language or exhibiting any of their Native customs, they were whipped and deprived of food (Champagne, p. 48).

In 1880, Arrest and Crime Data records indicated that fourteen Native

Americans were arrested. ${ }^{31}$ Only one case involving the adjudication of two identifiable Native Americans was observed. It was unusual for a Native American to be arrested with members of a different race. It was also unusual for a Native American to deposit bail.

1-2. City of Portland v. Indian Dick, David Irving, Wm. Flynn, Indian Peter and SW Jackson, charged with being drunk and disorderly, Irving and Indian Peter having paid \$5, failed to appear at trial, Indian Dick, Flynn and Jackson, wee convicted, fined $\$ 5$, failed to pay, jailed for three days.

$31 \quad$ Ibid. 


\section{COURT DOCKET RECORDS \\ CITY OF PORTLAND \\ January 17,1879 to 1882 \\ L. B. Stearns \\ MISDEMEANORS/FELONIES}

\section{Background - 1881}

In 1881, Helen Hunt Jackson, in her book, Century of Dishonor, indicts the U. S. government for its Native American policy and the treatment of Indians by American society. As a result of the attention given to Jackson's research and publication, a special commission was appointed to investigate and recommend reforms for Native American affairs. In response to the commissions findings, Jackson writes Ramona, a biographical novel about the life of a California Native American female (Champagne, pp. 48-49).

In 1881, Arrest and crime Data records indicated that fifteen Native

Americans were apprehended. ${ }^{32}$ Only one case was observed to have been

adjudicated during this period for an identifiable Native American.

- City of Portland v. Wm. Alexander, Indian Tom, J. Westlake, John Westlake W, Myers, and Thos. Frazer, charged with being drunk and disorderly, deposited $\$ 10$ each, failed to appear at trial, forfeited amount of bail to City. 


\section{COURT DOCKET RECORDS \\ CITY OF PORTLAND \\ January 17,1879 to 1882 \\ L. B. Stearns \\ MISDEMEANORS/FELONIES}

\section{Background -1882}

The book, Ramona, by Helen Hunt Jackson, a biography of a California Native American woman was published. It was thought to have attracted interest in the United States regarding the struggles and life of Native Americans (Champagne, p. 49) In 1882, the Cree ${ }^{33}$ tribes seeking adjacent reserves decide to abandon the Cypress Hills after being told they will not be given food aid if they remain (Champagne, p. 113).

The following case is the only incident observed involving an identifiable Native American in 1882. Indian Dick plead guilty, was fined $\$ 20$, failed to pay his fine and was therefore jailed for three days. The exhibit, Arrest and Crime Data Records, indicates twenty-one Native Americans were arrested in 1882. Arrest records for 1882 were not observed as part of this research.

\begin{tabular}{ll}
\hline p. 628 & \\
Case: & City of Portland v. Indian Dick \\
Ordinance No: & Not indicated \\
Complaint Filed By: & JM James \\
No.: & \\
Plead: & guilty \\
Trial Date: & $5 / 12 / 1882$ \\
Charge: & Sleeping on premises without the permission of the \\
& owners \\
City's Witnesses: & None indicated \\
Defendant's Witnesses: & Defendant in person \\
Verdict: & Convicted \\
Fined: & \$20 \\
Taxed: & None indicated \\
In Lieu of Payments: & 2 days in City Jail \\
Disposition: & Defendant failed to pay fine - jailed for 2 days \\
\hline &
\end{tabular}

33 A member of a tribe of American Indians living in Montana and in central and southern Canada (World Book Dictionary, p. 487). 


\section{CHAPTER VII \\ PORTLAND \\ AFRICAN AMERICANS}

On December 21, 1787, Captain Robert Gray set sail on the ship, Lady

Washington, from the Cape Verde Islands to explore the west coast of North

America. On board his ship, serving as cabin boy, was Marcus Lopez, historically

recognized as the first black man to visit the Oregon region (McLagan, p.1). ${ }^{1}$

It was not until 1805 , that recorded history recognized the arrival of another

black man, York, to the Northwest region. York was a slave and member of the

Lewis and Clark Expedition. ${ }^{2}$ York served as personal servant to Captain Lewis and

as interpreter of the expedition. ${ }^{3}$

\footnotetext{
1 On August 14, 1788, the ship anchored near Tillamook, Oregon, to allow members of the crew to obtain food and water. Native Americans, living in the area, while appearing to be hospitable in trading their goods, were suspicious of strangers. On August 15, Lopez went ashore using a cutlass ${ }^{1}$ to mow grass for the ship's livestock. He left the cutlass lying on the sand to carry a lode (load) of grass to the ship. A Native American seized the opportunity to abscond with the tool. Lopez having been appraised of the situation by another crew member, took pursuit. Suddenly, Lopez found himself surrounded by other Indians, who slain him. Members of the ship's crew attempted to rescue Lopez, but recognizing the jeopardy to their welfare, hastily returned to the safety of the ship (McLagan, p. 2). ${ }_{2}$ The Lewis and Clark Expedition, was an expedition, sanctioned and financed by the United States government by authority of President Jefferson, to explore lands west of the region known as the United States (Hill, pp. 2-3)

3 He was feared and yet admired by local Native Americans (Hill, p. 2). Indians Consider Negro Slave Accompanying Lewis and Clark Expedition 'Big medicine' (Davis, p. 43). However, upon receiving his freedom York reportedly disappeared (McLagan, p. 5).

One description of York was stated as, I crossed the river in about an hour after the arrival of the Indian express with 23 men including the interpreters-- a mulatto, who spoke bad French and worse English, served as interpreter to the Captains, so that a simple word to be understood by the party required to pass from the natives to the woman (Sacajawea (Sacagawea)- an Indian woman, serving as a guide and an interpreter of the Lewis \& Clark expedition), Indian wife of Charboneau, who could not speak English) from the woman to the husband, from the husband to the mulatto, from the mulatto to the captains (Hill, p. 3).

Another description, York was the slave of William Clark, and was born at his master's home in Virginia. He was a man of impressive size; six feet two inches tall, of large built with jet black skin and thick curly hair. He was a skilled hunter, and had some knowledge of French, which proved essential in translating for the guide Charbonneau, who spoke no English. He was adept in living off the land... Clark observed in his diary...(McLagan, p. 3).
} 
In 1844, another black settler, George Bush of Pennsylvania, ${ }^{4}$ son of Matthew Bush who was born in India, and an Irish mother, also settled in the Oregon region (McLargan, p. 20). It is interesting to note that Bush was considered a black man because he was a person of color. However, his ancestral roots did not necessarily trace back to Africa.

Bush was a wealthy man known for his generous financial aid to other families (McLagan, p, 20). However, racial animosities directed toward him and his white wife and black exclusion laws, prompted Bush to move north. Bush settled in Tumwater, Washington (McLagan, p.19). Under the Donation Land provision, Bush could not claim 640 acres of land he had farmed for almost ten years because of his color/race. However, as a result of a petition signed and presented to the United States Congress, Bush was granted his land (McLagan, p. 20).

Some historians theorize that blacks were probably crew members for explorers and traders who bartered their wares along the western coast of North America from the early fifteenth through the sixteenth centuries. Free black scouts, known as mountainmen, ${ }^{5}$ sold their services by leading westward bound wagon trains through treacherous mountain passes leading to western regions (Millner, lecture). Other black free men, many of whom were fur trappers, bartered their

$4 \quad$ Despite difficulties directed toward his interracial marriage, Bush was respected for his efforts in creating wagon roads throughout the Oregon region. It was reported that Michael Simons, a white resident, introduced a bill to exempt Bush from the law prohibiting Negroes owning property. Although there was no record of the passage of this bill, Bush did squatter 640 acres in the Olympia area and no argument was presented denying him ownership rights to the property (Hill, pp. 4-5). $5 \quad$ Mountainmen were a multiracial group of scouts serving as guides to settlers unfamiliar with mountain passages through the Rocky Mountains leading to the far western frontiers (Hafen, Grolier Electronic Publishing, Inc.). 
merchandise to Native American traders and white settlers. There is recorded

evidence that several blacks journeyed by wagon train to the Oregon area as slaves

and free persons employed as servants

The personal diaries and daily journals written by members of westward bound caravans in the 1830 's through 1860's, cite negro slaves as members of these processions (Hill, p. 5). Missionaries also brought black workers including free black servants and slaves into the Oregon region.

It has been asserted that the minority Exclusionary Act of 1844 (following) resulted from an incident known as the Cockstock Affair. White settlers felt threatened by the possibility of black residents and Native Americans jointly instigating uprisings. ${ }^{6}$ With the removal of free blacks, came questions regarding the institution of slavery.

$6 \quad$ In 1834, George Anderson Winslow, a black man, came to Oregon with Ewing Younger ( a trapper) and Hall Jackson Kelly (an Oregon promoter). Winslow settled in Clackamas Prairie, married a native American and settle in to raise a family. Winslow was familiar with the appropriate use of medicine. He used this knowledge to develop a business which he used to supported his family. However, the arrival of Dr. Forber of the Hudson Bat Company diminished the need for his services. Recognizing his financial dilemma, Winslow chose to relocate and became a potato farmer. Historians indicate that Winslow resided in Clatsop County near the mouth of the Columbia River. It was here that Winslow became involved in an incident that prompted a spontaneous movement to enact the 1844 Exclusionary Act. See EXCLUSIONARY LAW 1844 this section) This incident was known as the Cockstock Affair (Moreland, pp. 4-5).

James Saules, another Oregon black settler and Cockstock, a Wasco Native American, were involved in a dispute regarding the ownership of a horse. To exploit local prejudice against Native Americans, Saules accused Cockstock of threatening the lives of white settlers in the area. Cockstock, angered by the false accusation, recruited several members of his tribe and rode to Willamette Falls to confront Saule (Baxter, p. 26).

During the brawl, George LeBreton (a clerk and recorder for the Oregon Provision Government) was fatally shot and Winslow killed Cockstock. Area residents...blamed Saules and Anderson (Winslow) for the incident, threatened their lives and encouraged them to leave the area. Saules cautioned with a counter threat, stating that he would arouse local Native Americans into attacking white settlers. Subsequently, frightened white settlers took serious any confrontation by Native Americans. As a result, settlers became anxious about the possibility of a black-Native 


\section{AN ACT PASSED \\ BY THE \\ PROVISIONAL LEGISLATURE \\ 1844 \\ AND \\ SPONSORED BY \\ PETER H. BURNETT ${ }^{7}$}

\section{An Act Regard to Slavery and Free negroes and Mulattoes.}

Section 1. That slavery and involuntary servitude shall be forever prohibited in Oregon.

Section 2. That in all cases where slaves have been or shall hereafter be brought into Oregon, the Owners of such slaves shall have the term of three years from the introduction of such slaves to remove them from the (Oregon) Country.

Section 3. That if such owners of slaves shall neglect or refuse to remove such slaves from the (Oregon) country within the time specified in the preceding section, such slaves shall be free.

Section 4. That when any free Negro or Mulatto shall have come to Oregon, he or she, as the case may be, if of the age of eighteen or upward, shall remove from and leave the country within the term of two years for males and three years for females from the passage of this act . . . .

Section 5. That if such free Negro or Mulatto be under the age aforesaid, the terms of time specified in the preceding section shall begin to run when he or she shall arrive at such age.

Section 6. That if any such free Negro or Mulatto shall fail to quit the (Oregon) country as required by this act, he or she may be arrested upon the warrant issued by some justice of the peace, and if guilty upon trial before such justice, shall receive upon his or her bare back not less than twenty not more than thirty-nine stripes, to be inflicted by the constable of the proper county.

Section 7. That if any free Negro or Mulatto shall fail to quit the country within the term of six months after receiving such stripes, he or she shall again receive the same punishment once in every six months until he or she shall quit the (Oregon) country.

Section 8. That when any slave shall obtain his or her freedom the time specified in the fourth section shall begin to run from the time when such freedom shall be obtained.

Most documented records refer to Dutch ships during the early 1600 's, as

bringing shipments of blacks as slaves to North America on the east coast to colonies

such as Virginia. Although, the institution of slavery became entrenched in southern

American upraising. The result of this action was believed to have led to the 1844 Exclusionary Act (Baxter, p. 26).

Hill, Daniel G., Jr., (1932), The Negro In Oregon: A Survey, an unpublished thesis,

University of Oregon, Eugene, Oregon, pp. 19-23. 
tradition, many northerners did not respect the civil rights nor the human dignity of

African men, women and children. African Americans were regarded as chattel.

Inequalities before the law existed in the Northeast, but they were far more pervasive in the Old Northwest, where many white Southerners had settled.

The Blacks Laws regulating the behavior of free Negroes in the Old Northwest were in fact based upon the slave codes of the southern states (Bracey, p. 1).

In addition, the system of slavery was used to resist the presence of immigrants considered to be beneath the social status of Southern white aristocrats.

Slavery was a profitable business and afforded leisure for southern aristocracy much after the fashion of the Greek city states. Slavery was a self-sufficient system that kept successive waves of European immigration from overflowing into the south... (Hill, p. 6)..

However, the westward spread of the institution of slavery gradually became a national issue that fueled divisiveness within the nation. Northern states, attempting to compete through the use of costly factories, resented Southern states occupied by slave owners who were pocketing higher profits as a result of free labor. Territories aspiring for statehood were also divided on the issue.

Settlers residing in the Oregon region sought to obtain United States territorial recognition and eventually statehood. Yet, they too were splintered on the question of slavery. Many residents were European immigrants seeking work and a sense of job security in their new found homeland. White settlers traveled westward in search of the adventures of a new frontier, free land and dreams of prosperity. Some settlers saw slavery as a threat to their livelihood while others saw slavery as a means to their livelihood. ${ }^{8}$

8 An examination of the regional composition of settlers who migrated to Oregon prior to 1859, indicates the following: out of approximately 7444 pioneers, $56 \%$ were born in northern states, 


\section{Some residents}

...argued that cheaper labor was necessary to develop agricultural resources....and that Oregon's salubrious climate would beneficial to Negro slaves (Hill, p. 12). ${ }^{9}$

There was also divisiveness among churches. The Baptists, the Methodists, the Presbyterians, and the Catholics were splintered on the question of slavery and the civil rights of free blacks. ${ }^{10}$ Each religion formed separate congregations within their denominations, one group for slavery - the other against (Hill, p. 8).

The census of 1850 indicates that 207 blacks resided in Oregon. See POPULATIONS - APPENDIX IV. The black population of Portland and surrounding communities had tremendous impact on issues about slavery and the socialization of Negroes.

Oregon, and Portland, politicians took a stand on one side of the issue or the other. ${ }^{11}$ The question as to whether Oregon should be a slave state or free state was a question, but only secondary to whether black persons should be admitted to the state at all. The most effective argument in opposition to slavery was an open letter written by Chief Justice George H. Williams. On July 18, 1857 Williams wrote the

$33 \%$ in southern states and $21 \%$ for foreign born. It was estimated that these ratios remained fairly constant as of the 1860 census (Hill, p 9, from an interview with G. H. Hines, Curator, Oregon Historical Society, 1932). see POPULATIONS - APPENDIX IV.

9 Statement made by F. B. Martin of Yamhill County in The Statesman newspaper, August 4, 1857.

10 The Roman Catholic parish established separate seating arrangements in addition to separate churches for white and colored communicants (Hill, p. 8).

11 Dryer, a legislator in Salem, opposed slavery - Governor Lane (Oregon Territory), a democrat, supported slavery to the extent that he imported Hibben, from the east coast, to edit the Portland Times as a pro-slavery newspaper., Supreme Court Associate Justice Matthew Deady, and a contributor to the Oregon Constitution, favored slavery (Hill, p. 14). 
following statement which while encouraging many voters to vote against slavery, also ended Williams political career. ${ }^{12}$

\section{Judge William's open letter to Oregonians regarding the institution of slavery}

In the first place, there is no ambition - no enterprise - no energy in slavery. One white man is worth more than two Negro slaves - slave labor is "demonstrably the dearest on any." Second, Negro slaves other than house servants would be perfect leeches upon the farmers during the long, rainy winters. Third, the risk and expense in transporting slaves to distant Oregon, and the ease of escape in the sparsely settled, wooded and mountainous country, would render investment in slave property altogether too hazardous. Fourth, the escaped Negroes would find refuge and consort with Oregon's Indian enemies and become an added menace to the people. Fifth, slavery can no more stand as a paying institution with one-half of public sentiment arrayed against than a house can stand with one corner stone. Sixth, introduce slavery and free white labor become degraded, if not impossible to secure altogether. To mix slave labor and free labor aggravates the evils of each and subtracts from the benefits of each. Finally, can Oregon afford to throw away the friendship of the North -.overruling the power of the nation--for the sake of slavery?

The Statesman printed Williams" letter. The following are his specific

points and concluding statement.(Hill, p. 15):

1. ultimate benefits of slavery were in doubt even in the south. There was no ambition, no enterprise in such labor. Oregon, because of geographical conditions, does not favor the slave system.

2. Negro slaves, other than house servants, would be leeches upon the families of farmers during the long, rainy winters.

3. Risk and expense of transporting slaves to distant Oregon would be too great.

4. Escaped Negroes would find refuge and consprt with Oregon's Indian enemies.

5. Oregon could not foster such institution with one half of public sentiment arrayed against it.

6. Introduction of slave labor degrades free white labor.

Oregon cannot afford to throw away the friendship of the north for the sake of slavery.

In 1857 , settlers voted on the adoption of the Constitution and the resolution of the slavery question. Not only did the majority vote against the admission of slaves to the State, they also voted against the admission of free Negroes in general.

12 Justice Williams', a democrat, was appointed Chief Justice to the Oregon Territory by President Pierce. Seeking election to the United States Senate, Williams loss his bid for the Congressional seat as a result of being the only democrat to take a stand against the institution of slavery in Oregon (Hill, p. 14). 
The Vote on the Adoption of the Oregon Constitution November 9, $1857^{13}$

\begin{tabular}{|c|c|c|c|c|c|c|}
\hline & \multicolumn{2}{|c|}{ CONSTITUTION } & \multicolumn{2}{|c|}{$\begin{array}{l}\text { SLAVERY } \\
\end{array}$} & \multicolumn{2}{|c|}{ FREE NEGROES } \\
\hline COUNTIES & YES & NO & YES & No & YES & No \\
\hline Benton & 440 & 225 & 283 & 368 & 132 & 459 \\
\hline Clackamas & $\mathbf{5 3 0}$ & 216 & 98 & 655 & 113 & 594 \\
\hline Clatsop & 69 & 37 & 225 & 71 & 25 & 65 \\
\hline Columbia & 30 & 66 & 11 & 84 & 24 & 66 \\
\hline Coos & 68 & 26 & 19 & 72 & 10 & 79 \\
\hline Curry & 117 & 14 & 35 & 95 & 8 & $\overline{121}$ \\
\hline Douglas & 419 & 203 & 248 & 377 & 23 & 560 \\
\hline Jackson & 465 & 372 & 405 & 426 & 46 & 710 \\
\hline Josephine & 445 & 139 & 155 & 435 & 41 & 534 \\
\hline Lane & 591 & 362 & 356 & 602 & 97 & 783 \\
\hline Linn & 1111 & 176 & 198 & 1092 & 113 & 1095 \\
\hline Marion & 1024 & 252 & 214 & 1055 & 76 & 1115 \\
\hline Multnomah & 496 & 255 & 96 & 653 & 112 & 587 \\
\hline Polk & 528 & 188 & 231 & 484 & 53 & 584 \\
\hline Tillamook & 23 & 1 & 6 & 22 & 1 & 25 \\
\hline Umpqua & 155 & 84 & 32 & 201 & 24 & 181 \\
\hline Wasco & 55 & 89 & 58 & 85 & 18 & 122 \\
\hline Washington & 265 & 226 & 68 & 428 & 80 & 393 \\
\hline Yamhill & 371 & 274 & 107 & 522 & 85 & 521 \\
\hline Total & 7195 & 3215 & 2645 & 7727 & 1081 & 8640 \\
\hline & $a$ & $\mathrm{~b}$ & 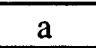 & $\mathrm{b}$ & $\bar{a}$ & $\mathrm{~b}$ \\
\hline Majorities & 3980 & $(a-b)$ & (b-a) & 5082 & (b-a) & 7559 \\
\hline & & & & Woo & APPEN & DIX I) \\
\hline
\end{tabular}

The Oregon constitution while denouncing the presence of slavery, expressed opposition to the presence of African Americans including those individuals who were racially mixed, referred to as Mulattos.

13 Published in the Oregon Statesman, December 22, 1857 (Woodward, Appendix I). 


\section{September 18, 1857}

\section{CONSTITUTION \\ OF THE STATE OF OREGON ${ }^{14}$ \\ ARTICLE I. \\ BILL OF RIGHTS}

Prohibition of slavery.

$\$ 34$. There shall be neither slavery not involuntary servitude in the state, otherwise than a s a punishment for crime, whereof the party shall have been duly convicted (p. 78).

Free Negroes and Mulattoes.

$\$ 35$. No free negro or mulatto, not residing in this state at the time of the adoption of this constitution, shall come, reside or be within this state, or hold any real estate, or make any contracts, or maintain any suit therein; and the legislative assembly shall provide by penal laws for the removal by public officers of all such negroes and mulattoes, and for their effectual exclusion from the state, and for the punishment of persons who shall bring them into the state, or employ or harbor them (p. 78). ${ }^{15}$

The question regarding Negro (including free men) suffrage was also decided

perhaps as a precaution, since nationally most blacks were unable to vote.

September 18, 1857.

Negro, Chinamen, \&c.

\$6. No negro, chinaman, or mulatto shall have the right of suffrage (p. 79). ${ }^{16}$

However, while prohibition of Negro suffrage was upheld, the exclusion of

blacks from Oregon was not consistently applied. Slavery existed in several Oregon

14 Deady, M. P., compiler and annotator, (1866), The Organic and Other General laws of Oregon Together With the national Constitution and Other Pubic Acts and Statues of the United States: 1845-1864, Henry L. Pittock State Printer, Portland Oregon, pp. 66-76...constitution was framed by a convention of delegates. 60 in number, chosen at the general election on the first Monday in June, 1857, ...(adopted) November 9,1857...On February 14, 1859,...(admitted) Oregon into the Union.

15 Ibid., This clause was superseded and annulled by the XIV Amendment to the national Constitution. Ante p. 32.

16 Ibid., Negroes and mulattoes born or naturalized in the United States and subject to the jurisdiction thereof, by virtue of the XIV amendment are now citizens of the United States, and the state wherein they reside, and therefore by virtue of the $X V$ amendment are entitled to the right of suffrage in this state, the same as white citizens; and the same was true of all persons, born or naturalized in the United States, and subject to the jurisdiction thereof. See the Slaughter House Cases, 16 Wall. 36 (p. 79). 
counties (Hill, p.16). ${ }^{17}$ There are instances where penalties were applied or slaves were released from involuntary servitude. ${ }^{18}$ Yet, arguments regarding the presence of blacks prevailed.

At the end of the Civil War, ${ }^{19}$ the slavery issue was discussed daily in Oregon newspapers, and among residents at political and social gatherings (Hill, pp. 21-23). States had to amend or reject the proposed thirteenth Amendment to the U. S. Constitution legally removing the existence of the institution of slavery throughout the nation. There were two major views published by local editors through their respective newspapers. Two newspapers, The Statesman (a Salem newspaper) and The Oregonian (a Portland newspaper), were in opposition on the question of slavery and reconstruction (Hill, p. 10). Neither paper welcomed the inclusion of black residents in Oregon, but each approached the subject from different political perspectives.

17 Black slaves resided in Benton, Lane, Polk, and Yamhil Counties and several others (Hill, p. 16). Information provided by William Allen, a democrat from Yamhill County in a statement to The Oregonian, December 26, 1857 (Hill, p. 16). following:

In addition, there are personal letters confirming the presence of blacks in Oregon - see the

Judge R. P. Boise, Oregon Supreme Court to T. W. Davenport, Oregon Historical Society XVIII: 108-9 (Hill, p. 17);

Llewellyn Jones, Captain, USA, see Oregon historical Society, XVIII: 108-10 (ill, p. 18); U. s. Caldwell, Auditor \& Recorder Washington County, Oregon Territory, see Oregon Historical Society, XVII: 108-10 (Hill, p. 19).

18 Case involving colored family - Polk County - 1853:

A colored (Negro/black) man and his wife brought before Judge Williams" under a writ of habeas corpus. They had been brought as slaves from Missouri by Nathaniel Ford and held by him on his property in Oregon. After careful inquiry the Court ruled there could be no slavery in Oregon and as such the slaves were freed (Scott, p. 331).

19 Civil War 1861-1865, (Encyclopedia Americana, pp. 739-740). 
There were two points to be resolved: the acceptance of the thirteenth amended abolishing slavery; Negro suffrage, more specifically, suffrage for black males. ${ }^{20}$ The editors of the two newspapers published daily commentary on the subject fueled by local politics.

The views of the two journals as to the proper status of the Negroes by the war, were almost as antithetical as on the general question of reconstruction. Governor Gibbs called a special session of the legislature to meet December 5, 1865, to consider the Thirteenth Amendment which had been presented by Congress to the various states. The Amendment passed the senate by $a$ vote of 13 to 3 and the house by a vote of 30 to 4 . The seven Democrats of the assembly vigorously opposed it. The Statesman was almost alone opposing the call of the special session. arguing that the settling of the question at that time would rob the Union party of a good issue in the approaching campaign, and that it would entail useless expense. Emancipation suggested, almost immediately, other vital issues anent the future of the Negro, which began at once to receive attention. The chief of these issues was naturally the negro suffrage (Woodward, p. 243).

The Statesman projected an image of dissatisfaction with the problems associated with slavery, while The Oregonian hailed its benefits (Hill, pp. 22-23).

The Statesman, October 2,1865, “...came out squarely against the issue and was inclined to ridicule those Union men, and especially the office-seekers for their delicacy in discussing the subject or avoidance of it altogether...its, objection to the enfranchisement of the Negro was this: "We do not believe that any democratic or republican form of government can successfully govern two separate and distinct races of people in large numbers with equal political rights to both races." The Oregonian did not yet give an explicit expression on the issue, satisfying itself with giving space to a few innuendoes at the position of the

States..."The Statesman has expressed its opinion plainly upon this, the most important question of the day, while the Oregonian, with its usual want of manly frankness, is waiting to see which way it will be prudent to jump" ...(Woodward p. 243).

The Oregonian, and white residents of Oregon, equated the subject of negro

suffrage with negro equality (Woodward, p. 244).

One cannot pick up any Democratic newspaper without finding these terrible words (Negro quality) staring at him from all parts of the page...Bom of the slavery interest, nurtured by the profits of human bondage, hoisted to and kept in power by the slave trade and the protagonist and now dying of an overdose of nigger and self-administered treason, the Democratic party will have no consolation not derived from recollections of the 'nigger' and strongly objects to being buried in anything but a 'nigger shroud. a 'nigger' coffin and a 'nigger' grave. It will expire with 'negro equality' last on its mortal tongue (Woodward, p. 244). 
The Ku Klux Klan first appeared in Pulaski, Tennessee in 1865

(Geschwender, p. 161). This night-riding organization of white men attempted to revert the position of blacks to being subservient and exploitable. There was a national agenda to end congressional Reconstruction and return the South to white planters most, if not all, of whom were members of the Democratic political party. The philosophy of the Democrats permeated the nation moving Democrats to anti black positions and the return to the institution of slavery (Geschwender, p. 161).

Oregon Democrats were adamant in their appeal to reject the presence of free blacks and re-institutionalized slavery. The presidential election of 1876 with Rutherford B. Hayes, a Republican, opposing Samuel J. Tilden, a Democrat, was scandalous. There were questions as to whether black men were freely allowed to vote (Geschwender, p. 161). Tilden received a majority of the popular vote, $4,285,992$, to Hayes' $4,033,768$, and the electoral college vote of 202 to 166 . However, the election returns were contested by Republicans. Republicans in South Carolina, Florida, Louisiana, and Oregon charged that blacks voters were intimidated and kept from the voting polls (Geschwender, pp. 161-162). A Congressional investigation resulted in Haynes receiving all disputed votes and the presidency of the U. S (Geschwender, p. 162).

Once it became evident that blacks would be permanently freed under the provisions of the Thirteenth Amendment to the U. S. Constitution, unrelinquishing whites in Oregon were unwilling to allow free blacks to reside in the state and 
refused to grant black men the right to vote. In 1866, Senator Stephen A. Douglas state, ...the Government was made on a white basis for white men, hence we are opposed to extending the right of suffrage to any other" in his attempt to persuade Democrats to vote against voting rights for black men (Woodward, p. 248).

Democrats were vehemently opposed to the presence of blacks and publicly voiced their sentiments. The following statements are examples of excerpts taken from various speeches and newspaper articles expressing Democratic viewpoints.

"Do you want your daughter to marry a nigger?"

"Would you allow a nigger to force himself into a seat at church between you and your wife?' and "D----n a nigger!" denouncing niggers and taxes (Woodward, p. 244)

Democrats favored the institution of slavery, while Republicans, in the shadow of President Lincoln, objected (Hill, p. 10). Neither group accept blacks as equals in Oregon, nor other geographic locations throughout the nation. ${ }^{21}$

Nowhere in the Old Northwest or in the newer states beyond the Mississippi River could blacks exercise the right to vote or serve on juries; and in many of these states they could not testify in cases involving whites. These states also attempted to discourage black settlers by requiring them to present bonds of $\$ 500$ or $\$ 1000$ guaranteeing that they would not disturb the peace or become public charges. Toward the end of the ante-bellum period, Illinois, Indiana, and Oregon excluded negro migrants entirely (Bracey, p. 1). ${ }^{22}$

Yet, African Americans in Portland were a part of the working and civic community despite the hostile legal and social climate resulting in their isolation. In

21 There were a few Oregon residents who viewed slavery as immoral. In 1868, a group of thirty-nine men held an Anti-slavery Convention at Albany, Oregon. They created a document espousing their sentiments and sought to have it published in The Statesman, but Asahel Bush, the editor refused, calling the convention a collection of old grannies (Hill p. 26)

22 Bracey refers to periods prior to and during the ante-bellum era, 1830's through the late 1850's (pp. 1-4). 
1932, Daniel G. Hill's research for his master's thesis included several interviews with black residents who lived in the Portland area as early as the 1860 's. ${ }^{23}$ One interviewee stated:

At this time colored people were not allowed to own property. They were not allowed to go into any kind of business and they were not allowed to vote. Every Negro had to pay $\$ 10.00$ head tax. The colored people had no civil rights. It was very difficult to get jobs of any kind except as a menial (Hill, p. 29).

Black residents lived in one section of Portland and the white population resided in another. Initially, there was only a school for black adults. Eventually, black children attended public school although their facility was separate from the building used for white students (Hill, pp. 29-30). ${ }^{24}$

Soon after the end of the Civil War, in reaction to legislation in California requiring Negroes to wear a collar around their neck with a tag attached, several black inhabitants of Portland organized The Working Men's Joint Stock Association (Hill, p. 30). Through the efforts of this organization, black activists stood ready to legally withstand any action by Oregon legislators to reduce black Oregonians to subhuman roles.

23 Daniel G. Hill interviewed George B. Hardin, A E. Flowers (house cleaner, and janitor, Custom House, res 128 College st. bet. 6th and 7th, and I. Fuller during his research. Oregon State Directory 1881, p. 311). See PORTLAND CITY DIRECTORY 1872, this document - APPENDIX VI

24 In 1862, prior to the end of the national institution of slavery, there were four teachers in the colored school. Up until the Fourteenth and Fifteenth Amendments to the United States Constitution, there were two colored teachers and two white (Hill, p. 30).

At a yearly meeting in 1867 , a group of Negro residents petitioned for black children to attend public school. Observing public opinion the petition was denied, but a separate school was opened for 'colored' children opened in the fall of 1867. By 1871, public opinion became more accepting allowing black children and white children to attend the same school (Merriam, p. 103). 
By the 1870 census, 346 black residents in Oregon, the majority of whom resided in Portland. See POPULATIONS, APPENDIX IV. It was unclear if this number was an actual indication of Oregon's black population in view of Oregon's exclusionary law, or a reflection of the desire for some free blacks, slaves, and their owners not to be enumerated to avoid legal and perhaps social consequences.

With the end of slavery and the increased availability of menial jobs, Oregon's black population increased from 346 in 1870 to 1886 in 1890. During this period, black workers were employed by the railroad as porters and brakemen's helpers, by shipping yards, as waiters in flourishing hotels, as cooks, as janitors, as barbers, as livery drivers and as hack drivers. Black entrepreneurs owned and managed many different businesses (Hill, p. 31). See PORTLAND CITY

\section{DIRECTORY, APPENDIX VI.}

Enoch Newsome ${ }^{25}$ and another black businessman, Peter Sykes had contracts with Portland to clean city streets. Sykes, also owned and operated a restaurant (1870 Census, p. 131). Black farmers sold produce and poultry in the Portland marketplace (Hill, p. 32). Several black businessmen owned and operated shoemaker stores.

Brady (no second name indicated), a black clothing maker, owned and operated a successful tailoring shop catering to white clientele only (Hill,

25 Enoch Newsome, street cleaner, res. cr. S. Second and Wood - see Oregon State directory 1881, p. 189. Also, see POPULATIONS - APPENDIX IV - Blacks in Census of 1870, and Hiday, p. 101. 
p. 33). Black employees worked in the timber industry and at various summer resorts along the coast. Another black, Rueben Crawford had the reputation of being the best ship corker in the Northwest. ${ }^{26}$

As blacks moved into Portland, they were increasingly employed to perform jobs most white workers refused to do. As a result, while black separatism was socially enforced, Oregon Laws adversely affecting black inhabitants were at times conveniently ignored.

Some black entrepreneurs operated in Portland's Under World. ${ }^{27}$ There was a red-light district ${ }^{28}$ on the west side of the Willamette River up to Broadway and Glisan Streets and from Glisan to Burnside (Hill, p. 34). This section of the City was not racially segregated and Saturday night brawls often occurred including incidents of shootings (Hill, p. 35). However, there was not a record indicating that such incidents involved only African Americans. Many white men and some white women patronized these facilities. Although not recorded as a part of my research, arrest of European Americans in this area of the city were observed in arrest records. Most were arrested for drunk and disorderly conduct and a few were arrested for illegal gambling.

26 Crawford, Rueben, (colored) jobber, re s e cor North Third C, Samuel's Directory of Portland 1873, p. 137 and calker, 425 Sixth st., bet. hall and College, (Oregon State Directory 1881, p. 292) vice (World Book, p. 2276).

${ }_{28}$ Red Light District - Characterized by many brothels and disorderly places (World Book, $\mathrm{p}$. $1751)$. 
Saloons operated late into the night and gambling was common place (Hill, $\mathrm{p}$.

35). Frank Webb and Mark Burnett were black businessmen who operated saloons

in the restricted area. Portland's under-world was notorious and although not

sanctioned by City government, did openly operate under certain understood

guidelines. These business establishments were required under City Ordinances to

be licensed thus providing municipal revenue.

The City of Portland does ordain as follows:

Bawdy house unlawful.

Section 1. That was shall be unlawful for any person or persons to open, set up on or keep within the corporate limits of the City of Portland, any bawdy house, or reside in or become an inmate thereof (p. 71).

Keepers of inmates, how punished

Sec. 2. Any person who shall open, set up, or keep, within he corporate limits of the city of Portland, any bawdy house, or who shall knowingly aid or assist in setting up or keeping any bawdy house, or who shall reside in or become an inmate of any bawdy house or house of ill fame,...(p. 71) Penalty.

Sec. 2. cont. $\quad$...shall, upon conviction thereof before the Police Judge be punished by a fine of not less than fifty nor more than one hundred dollars, or by imprisonment not less than twenty-five days nor more than fifty days, and in all cases shall be adjudged to pay the costs of the prosecution, and in default of the payment of fine and costs shall be imprisoned at the rate of one day for every two dollars of fine and costs, but in no case for more than ninety days (p. 71).

\section{Chief of Police to prosecute.}

Sec. $4 . \quad$ It shall be the duty of the Chief of Police to institute prosecutions for the violation of this Ordinance whenever he shall have reasonable cause to believe that any person or persons have been guilty of a violation of the same (p. 72).

Ordinance repealed.

Sec. $5 . \quad$ Ordinance No. 957, entitled, "Ordinance to suppress bawdy houses," approved March 4, 1871, was hereby repealed (p. 72).

Ordinance No. 2996. Suppressing bawdy houses. Approved Feb. 4,1881. ${ }^{29}$

Portland's under-world also provided revenue to the city in the form of taxes and when violations were cited (inconsistently), fines provided another source of income. To be legally licensed, bawdy houses were listed as legitimate rooming houses. In addition, despite its illegality, prostitution operated under strict scrutiny.

29 Chronological Index of Ordinances Passed By the Common Council of the City of Portland, 1854-1886. See APPENDIX XXIII, this document. 
Inmates (prostitutes) had to be periodically examined by a physician (Hill, p.37). ${ }^{30}$ The following City Ordinances were enacted to prevent the spread of sexually transmitted diseases.

\begin{tabular}{l|l}
\hline 2069. & $\begin{array}{l}\text { Physician's report, infectious diseases. Approved Oct. } 19,1877^{31} \\
\text { Protect the public health and prevent spread of dangerous or contagious } \\
\text { diseases. Approved Feb. } 23,1881.32\end{array}$ \\
\hline
\end{tabular}

While the Portland's under-world implicated the lives of some African Americans, most blacks were involved in respectable activities. Blacks, largely shunned by most white residents, were an intricate part of the larger Portland community. The names of city public officials were readily provided through innumerable secondary sources. However, while race and/or ethnicity were not indicated, there is evidence that minorities were elected and/or appointed to public positions.

During the 1880's, Charlie Green was elected the first black councilman (Hill, p. 38). ${ }^{33}$ However, it was purported that Green never took his seat, ...for he was bought out (Hill, p. 38). There was no other information regarding Green's public election. Starting in the early 1890's, blacks became the target of increased separatism and bigotry. Yet, George Hardin, whom Hill interviewed for his thesis,

30 Reportedly, these houses provided Portland with revenue through licensing and taxes (Hill, pp. 36-37).

Op. Cit., Chronological Index of Ordinances Passed By the Common Council of the City of Portland, 1854-1886.

32 Ibid.

33 Green, Charles W., carpenter, 292 Market st., res. s. w. cor. Fourth and Yamhill Sts. (Oregon Statue Directory 1881, p. 321). 
was reported to be the first black Portland policemen, hired in 1894 (Hill, p. 39). ${ }^{34}$ Also, in 1894, Gus Waterford was reportedly accepted as a volunteer fireman (Hill, p. 32).

Julius Sevier and an African American named Webb (no first name indicated), were politicians in the black community who allegedly solicited funds from elected officials ${ }^{35}$ in return for their voting allegiance and a promise of political support from the black community (Hill, 38).

There was also mention of an African American political organization, the Bed Rock Republican Club. ${ }^{36}$ The membership of this organization was entirely black and also directed the political interest of the black community.

\begin{tabular}{|l|l|l|l|}
\hline The Oregonian & $\begin{array}{l}\text { Organization of Colored } \\
\text { Immigration Society }\end{array}$ & $\begin{array}{l}\text { December } \\
17,1879\end{array}$ & $\begin{array}{l}\text { p. 3, } \\
\text { col. } 3\end{array}$ \\
\hline The Oregonian & $\begin{array}{l}\text { Portland Colored Citizens Have A Public } \\
\text { Meeting Pass Resolution Urging Greater } \\
\text { Union At The Polls }\end{array}$ & $\begin{array}{l}\text { April 24, } \\
1884\end{array}$ & $\begin{array}{l}\text { p. 3, } \\
\text { col. } 6\end{array}$ \\
\hline
\end{tabular}

Up until 1890, although there were separate public facilities, a few black children attended schools with white children in some parochial school situations(Hill, p. 39)., Initially, black and white worshipers attended the same church of their denomination and ministers made no great effort to keep worshippers separated by race. Yet, in the 1890's, as stated, the social structure changed.

$34 \quad$ An organization, The Bed Rock Republican Club, organized in 1878 or 1880 , with a membership of about forty black political activists, used political persuasion to pressure the Portland police force into hiring a black policeman (Hill, p. 38).

The names of Brown, (a saloon keeper, perhaps Francis Brown, see 1870 Census, p. 15), St. Clair, (James St. Clair, teamster, res. s. w. cor. N. 20th and C sts. (see Oregon State Directory, p. 419), Harding, the Clark brothers, John Clark, No. 130 First (Samuel's, Directory, p. 365), and Geffart (Hill, p. 38).

Op. Cit., footnote 34 . 
Catholics and Protestants vying for the attention of local residents, were antagonistic towards each other. In addition, like the know-nothing party in the 1850's and the Ku Klux Klan starting in the 1860's, the American Protestant Association (APA) initiated a formal religious indoctrination struggle against Catholics. The APA also feared Catholics were attempting to gain social and religious control of their children (Mecklin, pp. 164-165)..

The APA attempted to solicit support from black and Jewish communities to alienate Catholics by dismissing them and their religious beliefs (Hill, p. 42). Failing to attract sufficient numbers of supporters from either group, perhaps members of the APA felt threatened. At any rate, social changes gradually emerged, the religious practices of Catholics were increasingly challenged and social relationships with blacks were mostly absent and those with Jews became less tolerable (Hill, p. 42).

During this decade, theaters were the first to establish separate seating. ${ }^{37}$ Laws that had been mostly ignored were gradually enforced and blacks were even more socially isolated, separated and denied entry to not only affluent but also common place establishments such as restaurants and corner eateries.

Jim Crow laws mostly associated with the South gradually emerged and became socially and legally enforced. Black residents began to see their civil and other legal rights diminished. Inequitable laws that had been largely supported throughout the nation, but inconsistently ignored in Oregon gradually were regularly enforced.

37 When a Negro minstrel show came to Portland, Negro waiters requested a reserved section. As a result of their request for separatism, this protocol became the rule rather than the exception (Hill, p. 410. 
An informed perspective of Oregon's inequitable social and legal system, provided an historical setting used in examining arrests and court records of African Americans in an effort to determine their treatment by the justice system during that time period. 


\title{
CHAPTER VIII \\ AFRICAN AMERICANS \\ CITY OF PORTLAND \\ ARREST RECORDS - POLICE COURTS
}

\begin{abstract}
Background - 1857 - 1890's
The U. S. Supreme Court in Dred Scott v. Stanford in 1857, declaring the Missouri Compromise unconstitutional because it failed to provide provisions allowing slave owners to protect their slave propriety without due process. The Court declared that under the Constitution a slave was property to be treated as any other merchandise or property and as such, slaves were inferior and had no rights which the white man was bound to respect (Carson, p. 641).

On May 9, 1862, General David Hunter issued a proclamation emancipating slaves in Georgia, Florida, and South Carolina as contrabands of war. President Abraham Lincoln overruled the order. However, on June 19, of the same year, President Lincoln signed a bill abolishing slavery in federal territories. On July 17, Congress enacted legislation allowing blacks to serve in the Union Army, but blacks received less pay than their white counterparts. ${ }^{1}$

In August of 1862, Lincoln summoned several blacks to his office to discuss public policy and to encourage Negroes to emigrate to Africa or Latin America. In September of that year, Lincoln issued a preliminary Emancipation Proclamation, threatening to free slaves in those states considering seceding from statehood. On January 1, 1863, Lincoln made good his threat.

During the following two years the Civil War continued to negatively impact most of the U.S. Perhaps, in opposition to U. S. policies, or pending political strategies, on April 14, 1865, President Lincoln was assassinated. On December 18, the Thirteenth Amendment, prohibiting slavery, or involuntary servitude, except as punishment for a crime, was adopted.

In 1867, black men residing in Washington D. C., were giving the right to vote. On April 1, of that year, the Ku Klux Klan held their first national convention in Nashville, Tennessee. By 1868 , under Reconstruction, several blacks were U. S. Congressmen. Some blacks in Louisiana, Mississippi and South Carolina ${ }^{2}$ held high ranking state positions.
\end{abstract}

1 A white private received $\$ 13$ a month and $\$ 3.50$ for clothing; blacks of the same rank were paid $\$ 7$ and $\$ 3$ respectively. Over 186,000 African Americans served in the Union Army. Of the 38,000 who died, most died as a result of poor medical care and slave working conditions (Horndby, p. 25).

The Confederate Congress passed a resolution declaring negro troops and their officers criminals, permitting captured black soldiers to be murdered or enslaved. Despite warnings by President Lincoln, the practice continued. On April 12, 1864, Union black troops were captured and massacred at Fort Pillow Tennessee. Congress reacted by enacting legislation equalizing salaries and supplies for all Union soldiers. Recognizing the need for additional troops, General Robert E. Lee insisted that blacks be employed as troops in the Confederate Army. The bill authorizing the use of Black troops in the Confederate Army was signed into law by President Jefferson Davis, on March 13 (Hornsby, p. 26).

2 When the South Carolina Legislature met on July 6, 1867, over half the delegation was black. The eventually changed as whites gradually gained control of the house and the senate. 
Background - 1860's - 1890's cont.

On July 28,1868 , the Fourteenth Amendment to the U. S. Constitution granted black persons citizenship thereby guaranteeing their civil rights was enacted. As such, this law also automatically granted blacks citizenship in their home states, thus ensuring equal protection of the law throughout the nation. Yet, equality for African Americans was not realized. In 1875, Congress enacted Civil Rights legislation prohibiting discrimination in public places. ${ }^{3}$ However, the U. S. Supreme Court over turned the law in $1883 .^{4}$

Yet, throughout this period several black colleges were established. Under Reconstruction blacks continued to be elected to the U.S. Congress and to various state positions. Racial disturbances and civil unrest dominated the south and some midwestern states.

Starting in the late 1870 's, frustrated with life in the south, many blacks emigrated to the western region of the United States hoping to find a more tolerant atmosphere. However, these pioneering blacks were met with social hostility and legal barriers.

By the late 1890's, it was evident that although armed with formal written laws declaring that blacks receive equal treatment, African Americans were perhaps more ostracized by white society than they had been during slavery. Stating in the early 1890 's, literacy test were used as one criteria for voting. Blacks, not allowed to be educated for most of the century, now found themselves eagerly seeking to be informed (or, having to prove they were educated) for their personal improvement and to socially qualify for basic civil rights and human dignity granted freest to most white Americans (Hornsby, pp. 26-40).

In 1896, the Supreme Court in Plessy v. Furguson, mandated that separate facilities for black citizens did not violate the equal protection clause of the U. S. Constitution. As a result, the separate but equal doctrine was established (Carson, p. 4).

From 1870 to the 1890 's, arrest records observed did not reflect proportionately

Portland's population of African Americans. Up until the mid 1890's, of the arrest records observed, few blacks, that could be identified, were arrested. In addition, in researching African American arrests, the data used to analyze the treatment of Native Americans, could not appropriately be used to analyze African American arrests. See the INTRODUCTION, RESEARCH METHODOLOGY section of this document.

3 The provisions of the bill granted prohibition of discrimination in public accommodations including inns, public conveyances on land or water, theaters, and other places of public amusement (Hornsby, pp. 34-35).

4 On October 15, 1883, the U. S. Supreme Court declared the Civil Rights Act of 1875 as unconstitutional. The Court reasoned that Reconstruction Amendments did not extend into the area of public accommodations (Hornsby, p. 38). The Supreme Court's actions nullified the effects of the Fourteenth Amendment as it pertained to the rights of African Americans (Encyclopedia Americana, pp. 773-774). 
The system used in attempting to identify Native Americans was also used in identifying African Americans. My research depended on racial remarks used by Court Recorders when describing blacks by the usage of such identifying terms as, race, color and/or national origin. The following remarks were observed: Africa; African; colored, or; negro. Based on the use of those written designations and lacking any other valid means of identifying African Americans, there were few instances of arrests involving identifiable blacks during the period observed until the years 1894 and 1895 , when this category became part of arrest and court records.

According to Arrest and Crime Data, ${ }^{5}$ an African American was not recorded as being arrested in the City of Portland until 1873. Arrest records observed at the Portland City Archives were available starting in the year 1870. On March 13, 1870, one Negro Jack, was arrested and charged with being drunk. There were no identifiable arrest in 1872.

In 1873, one Negro Jim was arrested May 2, and charged with assault with intent to kill, a felony. Also arrested with him, was a Negro Jack, charged with the same violation, assault with intent to kill. Arrest records provide a minimum of information related any case.

It was not until November 8, 1873, that the arrest of another African American was observed. Negro Steward was arrested for lying drunk on Yamhill and 2nd street,

\footnotetext{
5 Tracy, Charles Abbott, (1976), The Evolution of the Police Function In Portland, Oregon, 1811-1874, Dissertation, University of California, California State University campus, San Jose, California, pp. 55-56 and CHARACTERISTICS OF PERSONS ARRESTED BY YEAR APPENDIX V.
} 
a misdemeanor. There were no identifiable African Americans arrested in 1874, 1875, $1876,1877,1878$, or 1879 .

Arrest and Crime Data did not indicate any additional arrests until 1880, when twenty-three blacks were reportedto have been arrested. In addition, in 1881, twentyseven African Americans were also reported to have been arrested. However, arrest records observed for the years 1880 and 1881 did not indicate that any identifiable African Americans were arrested. The differences between the data derived from each study may be attributed to information obtained from each research location. Data for the Arrest and Crime Data Report, (see APPENDIX IV) were obtained at the Portland Police Records Archives. Data for this study was obtained from the Portland City Stanley Paar Archives. However, quantitative data were not an essential part of those examinations.

Arrest records observed from May 1894 through January 1895, which list race/ethnicity, indicated several blacks were taken into custody during that time period. Arrest and Crime Data indicated that in 1884, two African Americans were arrested and in 1885 , fourteen blacks were reportedly arrested. ${ }^{6}$ Yet, according to arrest records observed, sixteen American Colored/Negroes (blacks) were arrested in 1894 and one was observed as being arrested in 1895 . However, research for the year 1895 was limited to January only of that year.

Included in the arrest tallies for 1894 and limited to January of 1895 , were six defendants designated as Africans. It was unclear if those individuals were from the 
continent of Africa or were African Americans assigned the nativity of Africa. However, Blacks, assumed to have been native born to the United States, were designated as American Colored. Charges filed against African Americans and Africans bore a wide range of complaints, from drunk, a misdemeanor, to assault and battery, a felony.

Lenwood G. Davis in his unpublished thesis, Blacks In The State of Oregon 1788-1971, provides an extensive bibliography of newspaper articles citing specific criminal and civil rights violation cases involving African Americans. Records of the following cases were not observed during my research but are included here as examples of incidents for which there are no formal legal records. See APPENDIX III, for additional newspapers articles regarding African American during this period. 


\section{ARTICLES IN NEWSPAPERS CITING CRIMINAL OR CIVIL RIGHTS VIOLATIONS INVOLVING AFRICAN AMERICANS ${ }^{7}$}

\begin{tabular}{|c|c|c|c|}
\hline Newspaper & Article & Date & Page(s) \\
\hline Oregon Statesman $^{8}$ & $\begin{array}{l}\text { Habeas Corpus Proceedings In Oregon } \\
\text { Supreme Court To Release Negroes At } \\
\text { Dalles, Polk County Who Were Once 'Held } \\
\text { As Slaves In Mo.' }\end{array}$ & July 5,1853 & p. 2 , col. 2 \\
\hline Oregon Spectator & $\begin{array}{l}\text { J. D. Saul Charged With Murder of Indian } \\
\text { Wife }\end{array}$ & $\begin{array}{l}\text { December 24, } \\
1846\end{array}$ & p. 2, col. 1 \\
\hline Oregon Statesman & $\begin{array}{l}\text { Luteshio Ceusar, Woman Slave In Missour } \\
\text { Brought To Oregon, Sues Estate of Master } \\
\text { For Back Wages }\end{array}$ & October 17,185 & p. 3 , col. 1 \\
\hline Oregon Spectator & $\begin{array}{l}\text { Negro brought To Oregon By Mr. } \\
\text { Vanderpool To Be banished For (From??) } \\
\text { Territory }\end{array}$ & $\begin{array}{l}\text { September } 12 \text {, } \\
1850\end{array}$ & p. 2 , col. 6 \\
\hline Oregon Spectator & $\begin{array}{l}\text { Negro Burglary Suspects In Oregon City } \\
\text { Dismissed By S. W. Moss, Justice }\end{array}$ & $\begin{array}{l}\text { September } 12 \text {, } \\
1850\end{array}$ & p. 2, col. 6 \\
\hline Oregon Spectator & $\begin{array}{l}\text { One of Three Negroes Charged With Sellin } \\
\text { Liquor To Indians Drowns While being tak } \\
\text { To Magistrates; Other Two Discharged Fo } \\
\text { Lack of Evidence; } \\
\quad \text { (cited in same article) } \\
\text { Negroes Reported Employed By Oregon Ci } \\
\text { White Man }\end{array}$ & $\begin{array}{l}\text { December 30, } \\
1851\end{array}$ & p. 2 , col. 2 \\
\hline Oregon Spectator & $\begin{array}{l}\text { Oregon Territory Council Adopts } \\
\text { Amendment To Witness Bill Preventing } \\
\text { negroes (Including Mulattoes) From } \\
\text { Testifying Against Whites } \\
\end{array}$ & January 7,1854 & p. 1 , col. 1 \\
\hline Oregon Spectator & $\begin{array}{l}\text { Winslow Anderson Declared Notorious, } \\
\text { Ordered From Oregon Territory }\end{array}$ & $\begin{array}{l}\text { September 2, } \\
2851\end{array}$ & p. 2, col. 2 \\
\hline
\end{tabular}

The following cases, however, were examined and inserted for reference after related commentary.

Wm. Logan, May 13, 1894, was charged with Assault and Battery against, presumably, Frank Garramini, the complainant. The Nativity (race/ethnicity) of the complainant was unclear. It was assumed from information contained within the arrest report that Logan was convicted, fined $\$ 10$, either paid or did not pay the fine, and sent

\footnotetext{
$7 \quad$ Bibliography - see Davis, p. 29

8 Oregon Spectator, Oregon first newspaper, established 1845, Oregon City, Oregon (Scott, footnote 19, p. 317.
} 
to Multnomah County Jail. The length of Logan's sentence was not reflected in the arrest record.

John Freeman, August 28, 1994, was also arrested and charged with Assault and Battery. The alleged victim was not specified, unless Freeman assaulted the officers who filed the complaint for his arrest. Presumably Freeman was convicted, fined $\$ 20$, sent to the County Jail. The length of his sentence was not specified.

Julius Caesar, arrested May 29, 1894, on charges of being drunk, a misdemeanor, was released May 30, the following day. Caesar was listed under Nativity as being an American Colored. However, a Julius Caesar was arrested December 21, 1894 for Vagrancy, and listed in the Nativity column as 'African.' He was discharged December 27, the following day. It was unclear if the two Caesars are the same person. It was possible that given the black population in Portland during 1894 and 1895, that two individuals could have identical names, but most unlikely. Therefore, assuming Caesar and Caesar were the same person, then blacks were classified as either American Colored or African. Under this assumption, perhaps the Clerk selected the choice of terms.

John Smith was arrested September 5, 1894, also on charges of being drunk, and released September 6, the following day. Records did not indicate that either Caesar or Smith were offered the opportunity to pay a fine or be jailed under the drunk charge. 
As (A) Thomas, taken into custody July 14, 1894, was declared insane (by whom was unclear), and sent to the Asylum for the mentally insane at Salem, Oregon. There were specific laws regarding the treatment of individuals legally declared insane.

December 15, 1853

\section{CHAPTER XIII.}

OF THE DOMESTIC RELATIONS.

TITLE II.

Of guardians and wards.

Guardian for insane person.

$\$ 13$. When the relations or friends of any insane person, or any other persons, inhabitants of the county in which such insane person resides, shall apply to the county by petition in writing, to have a guardian appointed for him, the judge shall cause notice, to have a guardian appointed for him, the judge shall cause notice to be given to the supposed insane person, of the time and place appointed for hearing the case, not less than ten days before the time so appointed; and if, after a full hearing, it shall appear to the judge that the person in question is incapable of taking care of himself, the judge shall appoint a guardian of his person and estate, with the powers and duties hereinafter specified (p. 555).

Specific procedure were to be followed regarding the placement of those legally declared to be mentally ill.

\section{September 27, 1862}

\section{CHAPTER XXVI.}

OF THE CUSTODY AND TREATMENT OF THE INSANE.

Who not to be sent to asylum.

$\$ 4$...That no insane or idiotic person shall be sent to an insane asylum, under the provisions of this act, who has friends that can, or desire to provide for their safe keeping and medical treatment...(p. 621).

According to Oregon Law, the Court when attending to the needs of an individual declared insane would normally seek the services of a friend of the person.

This did not appear to the action indicated in the case of As, or A Thomas, July 14,

1894. In addition, there was an ascribed period in which the person's demeanor was to be observed in order to determine if the individual had mental incapacity. Thomas was not afforded this time period from information provided with the record. 
John Patterson, arrested July 17, 1894, on charges of disorderly Conduct, was held for ten days. There was no indication that Patterson was offered the choice of paying a fine or being confined. John Snell, July 26, 1894 and Bert Jacobs, August 20, 1894, were both arrested on charges of Suspicious Character. The term, Suspicious Character, was not defined. Research did not disclose an Oregon Law or a Portland City Ordinance that specified provisions for a Suspicious Character violation. Snell and Jacobs were both released from custody the same day of their arrests.

As (A) Williams, ascribed under Nativity as African, arrested October 13, 1894, was charged with Trespassing, usually a misdemeanor, convicted and sentenced to thirty days in the County Jail. Fred Suy, also designated as being an African, was arrested October 23, 1894, charged with Disturbing By Fighting, a misdemeanor, assumed to have been convicted, fined $\$ 10$, no indication of the fine being paid, presumably jailed and released October 28, 1894.

Jesse Davenport, designated as African, was arrested on November 26, 1894 and charged with using Abusive Language, a misdemeanor, presumably convicted, fined $\$ 10$, and discharged November 27, the following day. John Lynch, also purportedly an African, was arrested on January 26, 1895 and charged with Vagrancy, a misdemeanor. Presumably, Lynch was convicted, while a fine was not indicated, ${ }^{9}$ he was sentenced to thirty days, but released after serving nineteen days ...on order of the court for good behavior.

$9 \quad$ Fines were not stipulated in cases involving Vagrancy, presumably, based on the assumption that defendants were financially unable to pay as a result of their itinerancy - transient lifestyle. 
While the vast majority of African Americans arrested were males, two females were observed as being taken into custody. Jennie Hatch, July 8, 1894, was arrested on charges of Soliciting Prostitution, a misdemeanor and Eva Emory, July 28, 1894, for allegedly committing Larceny (stealing) From A Person, a felony.

A child, reportedly an African, Raymond Johnson, was taken into custody December 12,1894, on the complaint of being a Runaway filed by a Mr. Johnson, presumably his father. He was held overnight and released the following day, December 13.

The following arrest records reflect information discussed in the former commentary. 
AFRICAN AMERICAN ARREST RECORDS

\begin{tabular}{|c|c|c|c|c|c|c|c|c|c|c|c|c|c|c|c|}
\hline $\mathbf{D a}$ & Hour & No & $\mathbf{P g}$ & $\begin{array}{l}\text { Defend } \\
\text {. }\end{array}$ & $\begin{array}{l}\text { Arrest } \\
\text { Officer }\end{array}$ & $\begin{array}{c}\mathbf{A} \\
10\end{array}$ & Charge & $\begin{array}{l}\text { Arrest } \\
\text { Loc. }\end{array}$ & $\begin{array}{c}\mathbf{B} \\
\mathbf{1 1}\end{array}$ & $\begin{array}{l}\mathrm{C} \\
12\end{array}$ & $\begin{array}{l}\mathrm{D} \\
13\end{array}$ & $\underset{14}{E}$ & $\begin{array}{l}\mathbf{F} \\
15\end{array}$ & $\begin{array}{c}\text { Nativity } \\
\text { Age }\end{array}$ & Remarks \\
\hline \multicolumn{16}{|c|}{1894} \\
\hline 13 & $\begin{array}{l}\text { 4:00 } \\
\text { pm }\end{array}$ & 101 & 8 & $\begin{array}{l}\text { Wm. } \\
\text { Logan }\end{array}$ & $\begin{array}{l}\text { Tom } \\
\text { Cole- } \\
\text { man }\end{array}$ & $\begin{array}{l}\text { Frank } \\
\text { Garr- } \\
\text { amini }\end{array}$ & $\begin{array}{l}\text { Assault } \\
\& \\
\text { Battery }\end{array}$ & $\begin{array}{l}\text { 3rd } \\
\text { \& D }\end{array}$ & $\begin{array}{c}\text { bag } \\
39\end{array}$ & - & - & $\$ 10$ & $\begin{array}{l}\text { May } \\
14\end{array}$ & $\begin{array}{l}\text { Amer. } \\
\text { Colored } \\
\text { Age 35 }\end{array}$ & $\begin{array}{l}\text { Sent to } \\
\text { County } \\
\text { Prop } \\
\text { Ret. }\end{array}$ \\
\hline 29 & $\begin{array}{l}\text { p:45 } \\
\text { pm }\end{array}$ & 207 & 15 & $\begin{array}{l}\text { Julius } \\
\text { Caesar }\end{array}$ & $\begin{array}{c}\text { Adams } \\
\& \\
\text { Cole- } \\
\text { man }\end{array}$ & $\begin{array}{l}\text { Tim } \\
\text { Cole- } \\
\text { man }\end{array}$ & drunk & $\begin{array}{c}\text { 3rd } \\
\& \\
\text { D }\end{array}$ & $\begin{array}{c}\text { bag } \\
21\end{array}$ & & & & $\begin{array}{l}\text { May } \\
\mathbf{3 0}\end{array}$ & $\begin{array}{l}\text { Amer. } \\
\text { Negro } \\
\text { Age } 50\end{array}$ & $\begin{array}{l}\text { Releas- } \\
\text { ed } \\
\text { by } \\
\text { Capt. } \\
\text { Nuden }\end{array}$ \\
\hline \multicolumn{16}{|c|}{ July } \\
\hline 8 & $\begin{array}{l}9: 30 \\
\text { pm }\end{array}$ & 128 & 42 & $\begin{array}{l}\text { Jennie } \\
\text { Hatch }\end{array}$ & $\begin{array}{c}\text { WB } \\
\text { John- } \\
\text { ston }\end{array}$ & $\begin{array}{c}\text { WB } \\
\text { John- } \\
\text { ston }\end{array}$ & $\begin{array}{l}\text { Solicit- } \\
\text { ing } \\
\text { Prosti- } \\
\text { tution }\end{array}$ & $\begin{array}{c}81 \mathrm{~N} . \\
\text { 3rd }\end{array}$ & & & & $\begin{array}{l}\mathbf{R O} \\
\mathbf{R}\end{array}$ & $\begin{array}{c}\text { Jul } \\
9\end{array}$ & $\begin{array}{l}\text { Amer. } \\
\text { Negro } \\
\text { Age } 28\end{array}$ & $\begin{array}{l}\text { Released } \\
\text { by } \\
\text { Chief } \\
\text { (police) }\end{array}$ \\
\hline 14 & $\begin{array}{c}7: 15 \\
\text { am }\end{array}$ & 225 & 49 & $\begin{array}{l}\text { As } \\
\text { Thomas }\end{array}$ & $\begin{array}{c}\text { JA } \\
\text { Davis }\end{array}$ & $\begin{array}{c}\text { JA } \\
\text { Davis }\end{array}$ & Insane & $\begin{array}{c}\text { Burn- } \\
\text { side } \\
\text { btw } \\
\text { 1st \& } \\
\text { 2nd } \\
\end{array}$ & $\begin{array}{c}\text { bag } \\
66\end{array}$ & .90 & & & $\begin{array}{l}\text { Jul } \\
14\end{array}$ & $\begin{array}{c}\text { Amer } \\
\text { Colored } \\
\text { Age } 30\end{array}$ & $\begin{array}{l}\text { Sent to } \\
\text { Asylum } \\
\text { Salem }\end{array}$ \\
\hline 17 & $\begin{array}{c}11: 00 \\
\text { pm }\end{array}$ & 217 & 52 & $\begin{array}{l}\text { John } \\
\text { Patter- } \\
\text { son }\end{array}$ & $\begin{array}{c}\text { Davi- } \\
\text { son \& } \\
\text { Endi- } \\
\text { cott }\end{array}$ & $\begin{array}{c}\text { John } \\
\text { Fitz- } \\
\text { gerald }\end{array}$ & $\begin{array}{l}\text { Larceny } \\
\text { from } \\
\text { person }\end{array}$ & $\begin{array}{c}\text { 2nd } \\
\text { btw } \\
\text { 3rd \& } \\
\text { 4th }\end{array}$ & & $\begin{array}{c}\$ 11 \\
\& \\
.15\end{array}$ & $\begin{array}{l}\text { B } \\
\mathbf{o} \\
\mathbf{n} \\
\mathbf{d}\end{array}$ & $\begin{array}{l}60 \\
\text { da } \\
M \\
C \\
J\end{array}$ & $\begin{array}{l}\text { Jul } \\
27\end{array}$ & $\begin{array}{c}\text { Amer. } \\
\text { Colored } \\
\text { Age } \mathbf{3 4}\end{array}$ & $\begin{array}{l}\text { Pro- } \\
\text { perty } \\
\text { Return- } \\
\text { ed }\end{array}$ \\
\hline
\end{tabular}

10 Complainant

Property on person arrested

Money

Bail

Judgment - Fine/Amount/Unpaid/Paid

Discharged 
AFRICAN AMERICAN ARREST RECORDS

1894

\begin{tabular}{|c|c|c|c|c|c|c|c|c|c|c|c|c|c|c|c|}
\hline $\mathrm{Da}$ & Hour & No & $\overline{\mathbf{P g}}$ & Defend & $\begin{array}{l}\text { Arrest } \\
\text { Officer }\end{array}$ & $\begin{array}{l}\mathbf{A} \\
16\end{array}$ & Charge & $\begin{array}{c}\text { Arrest } \\
\text { Loc. }\end{array}$ & $\begin{array}{c}\text { B } \\
17\end{array}$ & $\begin{array}{l}\mathrm{C} \\
18\end{array}$ & $\begin{array}{l}\text { D } \\
19\end{array}$ & \begin{tabular}{|c|}
$\mathbf{E}$ \\
$\mathbf{2 0}$
\end{tabular} & $\begin{array}{l}\mathbf{F} \\
21\end{array}$ & $\begin{array}{c}\text { Nativity } \\
\text { Age }\end{array}$ & Remarks \\
\hline 26 & $\begin{array}{c}5: 00 \\
\text { pm }\end{array}$ & 378 & 60 & $\begin{array}{l}\text { John } \\
\text { Snell }\end{array}$ & $\begin{array}{l}\text { Tom } \\
\text { Cole- } \\
\text { man }\end{array}$ & $\begin{array}{l}\text { Tom } \\
\text { Cole- } \\
\text { man }\end{array}$ & $\begin{array}{l}\text { Suspic- } \\
\text { ious } \\
\text { char- } \\
\text { acter }\end{array}$ & $\begin{array}{c}\text { 2nd } \\
\& \\
\text { B }\end{array}$ & & & & & $\begin{array}{l}\text { Jul } \\
26\end{array}$ & $\begin{array}{c}\text { Amer. } \\
\text { Colored } \\
\text { Age } 30\end{array}$ & $\begin{array}{l}\text { Releas- } \\
\text { ed } \\
\text { by } \\
\text { Chief } \\
\text { shuen to } \\
\text { officers } \\
\text { ?? }\end{array}$ \\
\hline 28 & $\begin{array}{c}12: 45 \\
\text { am }\end{array}$ & 397 & 61 & $\begin{array}{l}\text { Eva } \\
\text { Emory }\end{array}$ & $\underset{\text { Roberts }}{\text { JM }}$ & $\underset{\text { Roberts }}{\text { JM }}$ & $\begin{array}{l}\text { Larceny } \\
\text { from } \\
\text { person }\end{array}$ & $\begin{array}{c}\text { 2nd } \\
\text { btw } \\
\text { E \& F }\end{array}$ & $\begin{array}{c}\text { bag } \\
38\end{array}$ & $\begin{array}{c}\$ 3 \\
\& \\
.05 \\
\text { used } \\
\text { as } \\
\text { evi- } \\
\text { dence } \\
\end{array}$ & $\begin{array}{l}\$ 200 \\
\text { Bond }\end{array}$ & \begin{tabular}{|l|}
$\$ 2$ \\
5 fine
\end{tabular} & $\begin{array}{l}\text { Jul } \\
31\end{array}$ & $\begin{array}{c}\text { Amer. } \\
\text { Colored } \\
\text { Age } \mathbf{3 0}\end{array}$ & \\
\hline \multicolumn{16}{|c|}{ August } \\
\hline 20 & $\begin{array}{c}12: 15 \\
\text { pm }\end{array}$ & 260 & 84 & $\begin{array}{l}\text { Bert } \\
\text { Jacobs }\end{array}$ & $\begin{array}{l}\text { Tom } \\
\text { Cole- } \\
\text { man }\end{array}$ & $\begin{array}{l}\text { Tom } \\
\text { Cole- } \\
\text { man }\end{array}$ & $\begin{array}{l}\text { Suspic- } \\
\text { ious } \\
\text { char- } \\
\text { acter }\end{array}$ & $\begin{array}{c}\text { 3rd } \\
\& \\
\text { B }\end{array}$ & & & & & $\begin{array}{l}\text { Aug } \\
30\end{array}$ & $\begin{array}{l}\text { Amer. } \\
\text { Colored } \\
\text { Age } 25\end{array}$ & $\begin{array}{l}\text { Released } \\
\text { by } \\
\text { Chief } \\
\text { Holly }\end{array}$ \\
\hline 28 & $\begin{array}{c}10: 20 \\
\text { pm }\end{array}$ & 349 & 90 & $\begin{array}{l}\text { John } \\
\text { Free- } \\
\text { man }\end{array}$ & $\begin{array}{l}\text { D } \\
\text { Endi- } \\
\text { cott }\end{array}$ & $\begin{array}{l}\text { D } \\
\text { Endi } \\
\text { cott \& } \\
\text { John } \\
\text { Brown } \\
\end{array}$ & $\begin{array}{l}\text { Assault } \\
\& \\
\text { Battery }\end{array}$ & $\begin{array}{c}\text { 2nd } \\
\text { btw } \\
\text { E } \\
\& \\
\text { F } \\
\end{array}$ & $\begin{array}{c}\text { bag } \\
56\end{array}$ & $\begin{array}{c}\$ 4 \\
\& \\
.75\end{array}$ & & \$20fine & $\begin{array}{l}\text { Aug } \\
30\end{array}$ & $\begin{array}{c}\text { Amer. } \\
\text { Colored } \\
\text { Age } 53\end{array}$ & $\begin{array}{l}\text { Sent to } \\
\text { County } \\
\text { Property } \\
\text { Returned }\end{array}$ \\
\hline
\end{tabular}

Complainant

Property on person arrested

Money

Bail

Judgment - Fine/Amount/Unpaid/Paid

Discharged 
AFRICAN AMERICAN ARREST RECORDS

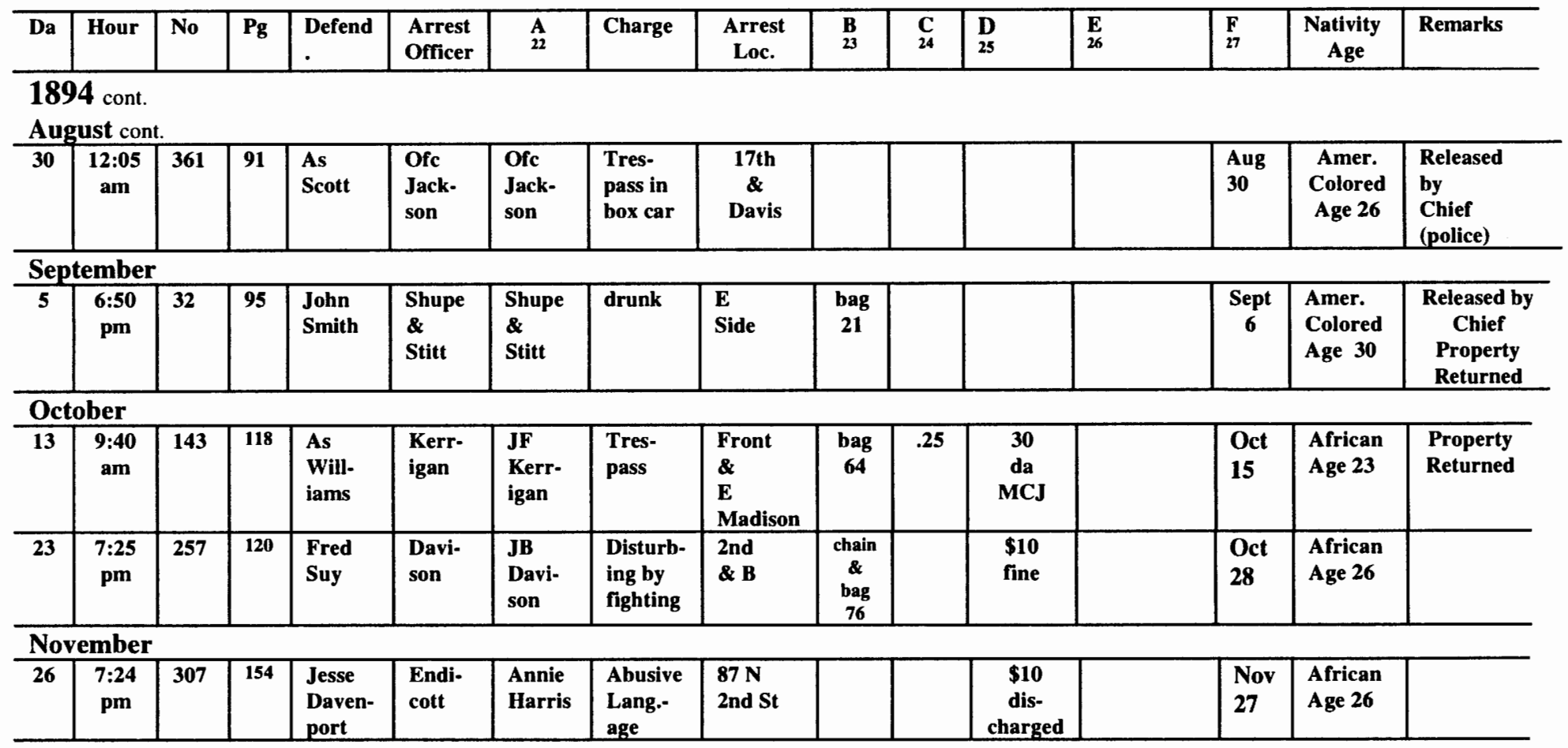

Complainant

Property on person arrested

Money

Bail

Judgment - Fine/Amount/Unpaid/Paid

Discharged 
AFRICAN AMERICAN ARREST RECORDS

\begin{tabular}{|c|c|c|c|c|c|c|c|c|c|c|c|c|c|c|c|}
\hline Da & Hour & No & $\mathbf{P g}$ & $\begin{array}{l}\text { Defend } \\
.\end{array}$ & $\begin{array}{l}\text { Arrest } \\
\text { Officer }\end{array}$ & $\overrightarrow{28}$ & Charge & $\begin{array}{l}\text { Arrest } \\
\text { Loc. }\end{array}$ & $\begin{array}{l}\text { B } \\
2\end{array}$ & $\underset{310}{C}$ & $\begin{array}{l}\text { D } \\
\mathbf{3 1}\end{array}$ & $\begin{array}{l}\mathbf{E 2} \\
\mathbf{3 2}\end{array}$ & $\begin{array}{l}\mathbf{F} \\
\mathbf{3 3}\end{array}$ & $\begin{array}{c}\text { Nativity } \\
\text { Age }\end{array}$ & Remarks \\
\hline \multicolumn{16}{|c|}{ December } \\
\hline 12 & $\begin{array}{c}12: 22 \\
\text { am }\end{array}$ & 110 & 164 & $\begin{array}{l}\text { Peter } \\
\text { Mc- } \\
\text { Neal }\end{array}$ & $\begin{array}{l}\text { John- } \\
\text { son }\end{array}$ & $\begin{array}{l}\text { A } \\
\text { John- } \\
\text { son }\end{array}$ & $\begin{array}{l}\text { Roam-ing } \\
\text { streets }\end{array}$ & $\begin{array}{l}\text { 3rd } \\
\& \\
D\end{array}$ & $\begin{array}{c}\text { bag } \\
7\end{array}$ & .25 & $\begin{array}{l}\$ 5 \\
\text { pd }\end{array}$ & $\begin{array}{l}10 \\
\text { fine }\end{array}$ & $\begin{array}{l}\text { Dec } \\
12\end{array}$ & $\begin{array}{l}\text { Amer. } \\
\text { Colored } \\
\text { Age 35 }\end{array}$ & \\
\hline 12 & $\begin{array}{l}630 \\
\text { pm }\end{array}$ & 122 & 165 & $\begin{array}{l}\text { Ray- } \\
\text { mond } \\
\text { John- } \\
\text { son }\end{array}$ & $\begin{array}{l}\text { Vener- } \\
\text { able }\end{array}$ & $\begin{array}{l}\text { Mr. } \\
\text { John- } \\
\text { son } \\
\text { father } \\
?\end{array}$ & Runa-way & $\begin{array}{l}\text { 1st \& } \\
\text { Wash }\end{array}$ & & & & & $\begin{array}{l}\text { Dec } \\
13\end{array}$ & $\begin{array}{l}\text { African } \\
\text { Age 11 }\end{array}$ & \\
\hline 26 & $\begin{array}{c}7: 00 \\
\text { pm }\end{array}$ & 304 & 178 & $\begin{array}{l}\text { Julius } \\
\text { Caesar }\end{array}$ & $\begin{array}{l}\text { GF } \\
\text { John- } \\
\text { son }\end{array}$ & $\begin{array}{l}\text { GF } \\
\text { John- } \\
\text { son }\end{array}$ & Vagrancy & $\begin{array}{l}\text { 2nd } \\
\& \\
\text { Oak }\end{array}$ & & & & disc & $\begin{array}{l}\text { Dec } \\
27\end{array}$ & $\begin{array}{l}\text { African } \\
\text { Age 60 }\end{array}$ & \\
\hline \multicolumn{16}{|c|}{$\begin{array}{l}1895 \\
\text { January }\end{array}$} \\
\hline 26 & $\begin{array}{c}7: 05 \\
\mathrm{pm}\end{array}$ & 279 & 201 & $\begin{array}{l}\text { John } \\
\text { Lynch }\end{array}$ & $\begin{array}{l}\text { Davi- } \\
\text { son } \\
\& \\
\text { Endi- } \\
\text { cott }\end{array}$ & $\begin{array}{l}\text { Davi- } \\
\text { son } \\
\& \\
\text { Endi- } \\
\text { cott }\end{array}$ & $\begin{array}{l}\text { Vag- } \\
\text { rancy }\end{array}$ & $\begin{array}{l}\text { 3rd \& } \\
\text { D }\end{array}$ & $\begin{array}{l}\text { bag } \\
17\end{array}$ & & & $\begin{array}{c}30 \\
\text { days }\end{array}$ & $\begin{array}{c}\text { Feb } \\
15\end{array}$ & $\begin{array}{l}\text { African } \\
\text { Age } 52\end{array}$ & $\begin{array}{l}\text { Releas- } \\
\text { ed on } \\
\text { order } \\
\text { of court } \\
\text { for good } \\
\text { behavior }\end{array}$ \\
\hline
\end{tabular}

\begin{tabular}{ll}
\hline 28 & Complainant \\
29 & Property on person arrested \\
30 & Money \\
31 & Bail \\
32 & Judgment - Fine/Amount/Unpaid/Paid \\
33 & Discharged
\end{tabular}




\section{CHAPTER IX \\ STATE OF OREGON \& CITY OF PORTLAND \\ COURTS OF RECORD \& POLICE COURTS ${ }^{1}$ \\ AFRICAN AMERICANS}

As indicated in the INTRODUCTION - RESEARCH METHODOLOGY section, the following court records were observed:

\begin{tabular}{|c|c|c|}
\hline Date & Court Jurisdiction & Status of Charge \\
\hline June 1867-July 1868 & State of Oregon & Felonies \\
\hline August 1868-July 1870 & State of Oregon & Felonies \\
\hline August 1870-November 1874 & (not observed) & -- \\
\hline December 1874-March 1880 & State of Oregon & Felonies \\
\hline August 1870-April 1871 & City of Portland & Misdemeanors \\
\hline July 1871-October 1873 & City of Portland & Misdemeanors \\
\hline November 1873-June 1877 & City of Portland & Misdemeanors \\
\hline July 1877-July 1879 & (not observed) & -- \\
\hline August 1879-August 1881 & City of Portland & Misdemeanors \\
\hline September 1881-August 1882 & City of Portland & Misdemeanors \\
\hline
\end{tabular}

There were date breaks in available court records. However, while the absence of this data did not disrupt my research, available records provided limited information regarding the treatment of African Americans by Oregon's and Portland's court systems during the time periods observed. Few African Americans were identified as being involved in the adjudication process during the indicated time periods.

\footnotetext{
I Although other precincts existence for a period of time - see Precincts - CHAPTER III records of Court proceedings were not observed.
} 


\section{COURT DOCKET RECORDS \\ STATE OF OREGON \\ June 1867 to July 1868 \\ FELONIES}

J. J. Hoffman - Justice of the Peace \& Court Recorder

\section{Background}

On January 8,1868 , Congress enacted a bill giving suffrage to black men residing in Washington, D. C. On May 1, of that year, Howard University, a black college, opened in the nation's capital. However, also in 1868, the National Association of Baseball denied admission of black ball players to any affiliated baseball club, offering the following statement:

It is not presumed by your committee that any clubs who have applied are composed of persons of color, or any portion of them; and the recommendations of your committee in this report are based upon this view...If colored were admitted, there would be in all probability some division of feeling — whereas by excluding them, no injury could result to anybody (Hornsby, p. 41)

African Americans, who could be identified, appeared as witnesses for the prosecution and the defense. The following case involves an African American identified by the first name only of Bill. Bill appeared as a witness for the prosecution in a case involving charges of assault and battery. Annie Kauer was found guilty of assaulting Mary Perry. Witness fees were paid to those testifying in court. There was not any indication as to whether Bill receive a witness fee or not. The date of the case was not indicated but the record of the proceedings appeared between cases dated July 1, 1867 and July 15,1867 . It seems valid to assume the defendant appeared before the court sometime during that period.

According to a newspaper article in the January 7,1854 , edition of the Oregon Spectator, The Oregon Territory amended the Witness Bill to prevent Negroes, including Mulattoes, from testifying against whites (Davis, p. 40). A review of Oregon law enforced in as of 1862 did not indicate this prohibition under 
neither the Criminal Code, nor the Civil Code of the Oregon constitution (Deady, 1874, p. $381 \&$ p. 251 ). The record indicated that Bill provided testimony for the prosecution which would have been against Mary Petty; while she, the defendant, had three witnesses who appeared in her behalf. Nevertheless, Mary Petty lost her case. It was assumed that Mary Petty was white - there was not a notation indicating she was a person of color.

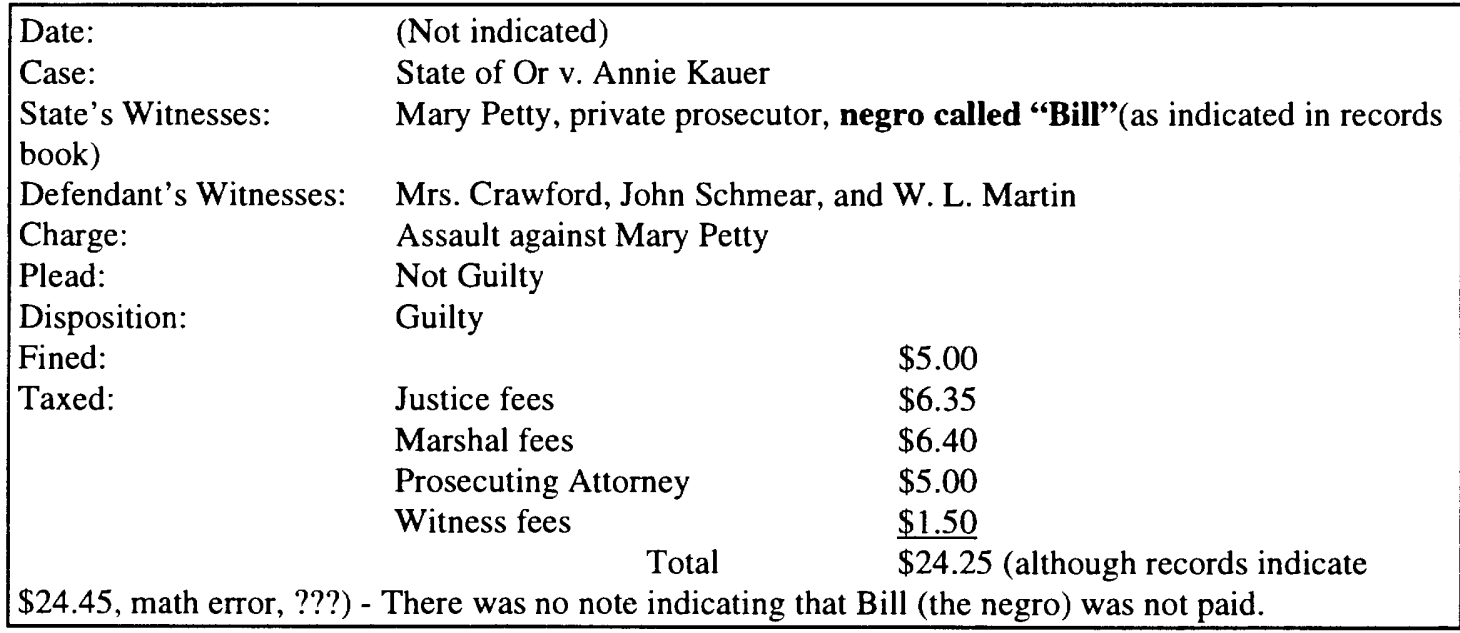

The indicated case was the only trial involving an identifiable African American during the specified time period. 


\section{COURT DOCKET RECORDS}

STATE OF OREGON

August 1868 to July 1870

J. J. Hoffman - Ex Officio Justice of the Peace

FELONIES

There were no court cases involving an identifiable African American during this time period. 


\section{POLICE COURT STATE OF OREGON \\ December 1874 to March 1880}

O. N. Denny - Police Judge \& Justice of the Peace FELONIES

There were no court cases involving an identifiable African American during this time period. 


\section{COURT DOCKET RECORDS}

CITY OF PORTLAND

August 1870 to April 1871

Sin Anderson - Ex Officio Justice of the Peace

MISDEMEANORS

There were no court cases involving an identifiable African American during this time period. 


\section{COURT DOCKET RECORDS \\ CITY OF PORTLAND \\ July 1871 to October 1873 \\ O. N. Denny - Police Judge \\ MISDEMEANORS}

There were no court cases involving an identifiable African American during this time period 


\section{COURT DOCKET RECORDS}

CITY OF PORTLAND

November 1873 to June 1877

J. J. Hoffman - Justice of the Peace \& Court Recorder

O. N. Denny - Police Judge MISDEMEANORS

There were no court cases involving an identifiable African American during this time period. 


\section{COURT DOCKET RECORDS}

CITY OF PORTLAND

\section{August 1879 to august 1881 \\ O. N. Denny - Police Judge \\ MISDEMEANORS}

There were no court cases involving an identifiable African American during this time period. 


\section{COURT DOCKET RECORDS \\ CITY OF PORTLAND \\ September 1881 to August 1882 \\ MISDEMEANORS}

There were no court cases involving an identifiable African American during this time period.

Examinations did not denote that any identifiable African Americans were involved in the court system during the indicated time periods. The population of African Americans in the Portland area reportedly increased from a purported four in 1850 to 1185 by 1890 . These figures have been disputed by other reports that indicate a larger black population existed during that period than has been formally acknowledged. See POPULATIONS - APPENDIX IV and also articles regarding Blacks residing in the Portland area, APPENDIX III. 


\section{CHAPTER X CHINESE IMMIGRANTS}

The quest for gold and the advantages of its wealth brought thousands of prospectors to the shores of California. News regarding the discovery of gold in California, spread throughout Europe and Asia. In China, gold was a rare mineral and its value held promise of a luxurious life style for any peasant. The Chinese, aware of gold strikes in the United States, referred to the country as Gold Mountains, geographically out of reach and therefore only a dream (Chen, p. 25).

The availability of passage by ship from China to the U. S., was limited. In addition, when passage was available, the costs of fares were not affordable to poor Chinese citizens. However, shipmasters eager to make a profit, went to China to lure Chinese workers to California. Crewmen distributed placards promising riches from the discovery of gold. They also gave out maps pin-pointing prospecting sites and pamphlets describing the Gold Mountains (Chen, p. 25). Railroad companies (Central Pacific, Union Pacific and later Southern Pacific), in need of workers, agreed to prepay ship passage and other expenses for Chinese peasants willing to come to California to work on the rail lines (Chen, p. 26).

Chinese laborers were welcomed initially and viewed as an asset in building western railroads (Chen, p. 26). The availability of new rail lines made it possible for eastern and mid western U.S. inhabitants to migrate to western shores. The gold rush and the opening of new frontiers were attractive to newcomers desiring a change and fresh beginnings. The increase in California's population created a need for 
additional public and private services and as a result, jobs became plentiful.

However, most white Californians wanted jobs that paid top wages. They were not interested in doing menial work that offered wages unable to support a decent means of living.

Chinese immigrants eager to escape the harsh life of their country, fled to the United States in search of work and the promise of riches. Chinese workers took whatever jobs were available regardless of the pay level. Any amount of pay was more than they could earn in China (Chen, pp. 14-23)..

By 1869 , thousands of Chinese newcomers were employed in various capacities throughout the major populated areas of California. Chinese workers were employed as cooks, laundrymen, farm hands, fruit pickers, land drainers and as laborers in factories (Chen, p. 26). White employers labeled the work of Chinese laborers as efficient and their wages as cheap. However, the vast majority of Chinese worked for the railroads. As planned, the railroads, with the aid of Chinese labor, opened the west to an onslaught of settlers seeking California gold and the hopes of new frontiers.

In the beginning, records indicate that Chinese immigrants were welcomed participants in California's celebration of statehood in 1850 and declared adopted citizens (Chen, p. 26). ${ }^{1}$ However, the honeymoon between Chinese workers and their host region lasted only until job opportunities began to fade.

\footnotetext{
1 California's first two governors, Peter H. Burnett, former judge in Oregon, and John McDougal often referred to the Chinese as a class of adopted citizens (Chen, p. 26).
} 
Early on, railroad companies were the major employers offering thousands of jobs. With vast numbers of Californians employed, the need for various other goods and services increased. Therefore, as rail sections were completed and railroad companies gradually laid off unneeded workers, their unemployment affected other industries. Other employment opportunities diminished for all workers. Ultimately, as work opportunities decreased for white westerners, Chinese workers gradually found themselves surrounded by hostility (Chen, p. 27). Unemployed white inhabitants blamed Chinese workers for their lack of viable jobs.

Chinese laborers, especially those lacking protection from American sympathizers, became predators to lawless individuals, immoral spectators, shrewd politicians and abusive European immigrants (Chen, p. 27). ${ }^{2}$ A significant number of Anti-coolie clubs $^{3}$ were established adversely targeting areas where Chinese resided and/or worked. The political, social and civil climate became extremely hostile and dangerous to Chinese inhabitants. Recognizing that their lives were in danger, Chinese emigrants began to filter to other areas within the United States. They were seeking friendlier territory, but mostly they wanted employment (Chen, p. 28).

2 Years after their initial arrival into the United States, and/or U. S. Territories, many Chinese were protected by the Burlington Treaty of 1868 . The Treaty stipulated that Chinese were to be afforded protection similar to that extended to American citizens (Chen, p. 80). The Treaty further allowed for free and unrestricted immigration between China and the U. S. Pacific Coast whites were angered by the provisions of The Treaty and on several occasions petitioned to limit Oriental (Asian) immigration (Maddux, p. 80).

3 In 1862 and continuing into 1867, Anti-coolie clubs were established throughout California, unionizing in 1867 (Chen, p. 28). Coolie was a disparaging term used to describe Chinese labor, perceived to be unskilled, willing to work for low or subsistence wages (Merriam-Webster, p. 255). 
The lack of viable employment created severe commercial conditions - a depressed economy. The depression of the 1870's was in part blamed on the presence of Chinese and their willingness to work for reduced wages by the white majority. In addition, unemployed Chinese were unacceptable competitors in an already frustrated labor market (Chen, p. 29). The Chinese increasingly became targets of crime and death. ${ }^{4}$ Increased adverse incidents forced the Chinese to seek residency in Oregon, Washington, and other seemingly less hostile regions.

Hostilities towards the Chinese continued to penetrate the United States prompting Congress to enact the Chinese Exclusion Act of $1882 .^{5}$ In 1883, The Pacific Railroad was completed, forcing additional unemployment. As Chinese racial persecution continued to spread, thousands of Chinese migrated to Oregon. ${ }^{6}$ As California's gold explorations became overflowing, many prospectors channeled their expeditions to other geographic areas. Gold was soon discovered in various sections of Oregon bringing a flood of prospectors and adventure seekers into the state. ${ }^{7}$ Chinese labor was initially welcomed to accommodate the service needs

4 In 1872, twenty-one Chinese were killed (fifteen hanged and others burned) in Los Angeles, California. A grand jury indicted 150 men, but only six were sentenced to a short jail term (Chen, p. 29)

The Chinese Exclusion Act was not repealed until 1944 (Maddux, p. 94).

In 1877, In San Francisco, Dennis Kearney, an Irishman, led the Workingmen's Party, an organization establishes to oust Chinese at any cost and by any means. Chinese immigrants were physically attacked with clubs, stones and potatoes until their scalps were bloody (Chen, pp. 30-31).

Chinese fled to the mountains of Oregon and Washington as places of refuge (Chen, p. 31).

On September 2, 1885, at Rock Springs, Wyoming, an entire village of Chinese were shot and burned. It is estimated that over forty-two Chinese were massacred before the dogs and wild boars ate their remains (Chen, p. 32).

7 In 1862, gold was discovered near Canyon City..., Oregon. As one mine dried up, prospectors moved on to other potentially richer districts (Chen, p. 75) 
of this rapidly growing population (Maddux, p. 78). ${ }^{8}$ Chinese also worked in the rich, yielding mines ${ }^{9}$. However, the vast majority of Chinese settled mostly in Portland, Oregon.

Chinese migration to Oregon actually staring in the early 1850 's. Chinese entrepreneurs opened businesses providing services such as laundries, shoemakers, cooks, barbers, gardeners, and shepherds ${ }^{10}$ (Chen. p.54). Many Chinese also worked in private service as domestics. Chinese owned thriving businesses. ${ }^{11}$ There were Chinese physicians, merchants and blacksmiths. Chinese physicians ${ }^{12}$ mainly treated Chinese patients and were not considered a threat to their white counterparts (Chen, p. 53). However, white patients often sought the services of Chinese doctors (Chen, pp. 121-123).

In a new country and wanting to earn the riches they had been promised, Chinese workers were willing to pursue jobs most whites were unwilling to do. Many whites felt threatened by the presence of Chinese. Oregon white settlers also felt Chinese workers would reduce their job opportunities.

\footnotetext{
8 Chinese workers were employed as cooks in restaurants or private homes, laundry workers, and gardeners and servants for wealthy Portland residents (Maddux, p. 78).

9 By 1872, $\$ 26,000,000$ worth of gold had been mined. Chinese miners earned a share (Chen, p. 80). However, the Oregon legislature enacted a law levying up to $\$ 50$ per month tax against Chinese mining in Oregon (Chen, p. 116). It was purported that Chinese were taxed whether they actually engaged in mining or not - any business venture warranted the tax (Chen, p. 116)

10 Sheep herding, difficult and lonely work, was one of the main jobs open to Chinese. Grant County, alone, had over 200,000 sheep I any year during this period (Chen, p. 117).

11 In 1851, the owner of the Tong Sung House, advertised in The Oregonian as a boarding house and restaurant. The Tong Sung House, was located on Second Street, the center of China Town, and offered first rate China cooks and lodging (Maddux, p. 77)

12 Chinese physicians were exceptionally skilled in using pulse diagnosis and practiced herb medicine (Chen, pp. 121-123).
} 
The Chinese worked in Oregon mines located at the eastern end of the state. ${ }^{13}$ However, Chinese laborers and their capacity to save money and create partnerships with other Chinese men, prompted an anonymous letter to the editor of the Portland Oregonian. The letter cautioned American miners to be cautious of Chinese seeking to buy their mineral and land claims (Chen. p. 34). It was stated that Chinese prospectors were attempting to take over the region by purchasing land and mineral claims owners wanted to turn into cash. Although such accusations eventually faded, Chinese were continually viewed with a jaundiced eye.

A practice prevailed that overtly signaled the arrival of Chinese passengers arriving by ship into Portland. In 1853, as incoming passengers arrived, area newspapers published the names and/or ethnicity of the list of passengers. Under the designation of race/ethnicity, Chinese were referred to as Celestials ${ }^{14}$ (Maddux, p. 47). This list while providing a service, alerted white residents to the arrival of Chinese and blacks ${ }^{15}$ moving into the Portland area (Chen, p. 33). Years later this service still prevailed, as noted by the following:

13 The Oregon State census indicates over 400 Chinese worked in Oregon mines in the year 1860 (Chen, p. 51). Mining communities where Chinese resided included: Jackson, Josephine, Elk Creek, Granite, Marysville, Olive Creek, Union, Canyon and John Day (Chen, p. 51).

${ }_{14}$ The term Celestials referenced the Celestial Empire of 1644, marking the finding of the Manchu dynasty that influenced Chinese dress, style and practices during the mid to late 1800's (Maddux, p. 84). The Manchus were overthrown in 1911, the demise of that dynasty gradually changed Chinese dress and practice in the U. S. (Maddux, p. 85).

15 While Chinese were listed as Celestials, blacks were listed as niggers (Maddux, p. 47). 
The Committee on Health and Police appointed by the mayor of the city of Portland July 21, 1869 .

Letter send to the Common Council of the City of Portland and signed by the mayor, signed by Philip Saunders, City Marshal:

Appointed: Dennis Murphy, William Clark, P. Owens and James Lanegen as Special officials and deputy City Marshal with authority and injunctions to keep watch alternately both day and night of the Chinese Passengers of the Bark ${ }^{16}$ Onward $^{17}$ to prevent any of the said Passengers from visiting the City of Portland within 10 days or until permitted by said July 21, 1869

Mayor Committee That P. Owens and James (Dennis) Murphy were actually engaged seven days each That James Lannigan and William Clark by their watch coming on Sunday nights were engaged eight days each That the services of each of the above named was (paid??) five dollars per day. wherefore I could most respectfully petition your Hon.. Body to make a special appropriation form the moneys in the General fund of the sum of $\$ 150.00$ and that the same be applied to the payment of said officers and that a warrant be drawn on favor of P. Owens for $\$ 35.00$ of Dennis Murphy for $\# 35.00$ of James for $\$ 40.00$ and of William Clark for $\$ 40.00$.

Upon their arrival, the differences observed in Chinese physical characteristics and manner of dress made them conspicuous (Maddux, p. 78). ${ }^{18}$ In addition, they spoke little English and therefore, tended to mingle only with themselves. ${ }^{19}$ The Chinese were immediately resented as they were perceived as posing a threat to the values and customs of white society. As a result they were blamed for any actions deemed socially unacceptable and or criminal. ${ }^{20}$

The Chinese population in Oregon progressively increased, estimated to have been over 900 in 1861 growing to between five to ten thousand during the 1880 's

16 Bark - any small sailing ship 2. a three mast vessel with her foremast and mainmast squarerigged and her mizzenmast fore-and-aft rigged. 3. a craft of any size or character propelled by any sails or oars (Webster's Third New International Dictionary, p. 177).

17 Onward, Barque, see 1870 City of Portland Directory p. 25 under Steamboats.

18 The sight of Chinese with their yellowed skin and almond eyes carrying their worldly possessions under one arm, dressed in dark-colored loose flowing pantaloons with lose fitting blouses, wearing sandals and a broad-brimmed hat made of bamboo with his hair in a queue was not accepting to whites unaccustomed to Asian culture (Maddux, p. 78).

19 While it was true the Chinese were clannish, Chinatown was primarily formed due to segregation by Portland's white residents (Chen, p. 66). Chinese were not socially permitted to reside in a white community without their permission (Chen, p. 67).

20 On August 9, 1872, a dozen chickens were reported stolen from a hennery and the thieves escaped. The Oregonian stated that the perpetrators were supposedly Chinese, tired of eating beef and bacon, looking for a change in their diet (Maddux, p. 79). 
(Chen, p. 34 and Maddux, p. 83). See POPULATIONS, APPENDIX IV. Portland housed the second largest population of Chinese in the United States from the 1860's through 1870's (Chen, p. 35). ${ }^{21}$

Although hesitantly welcomed for their work in the service industries, during the 1870 's and into the 1880's, Oregon's racial tolerance towards Chinese residence dwindled. During this economically depressed era in Oregon, as in California, Chinese were also blamed for the lack of full employment among white settlers. However, The Oregonian, in recognizing the acceptable utilization of Chinese labor, used its editorial page to chide whites who refused to do the work that Chinese welcomed. Never-the-less, politicians exploited anti-Chinese animosities to obtain votes for public office (Chen, p. 39). ${ }^{22}$

Chinese increasingly became the butt of racist jokes and ridicule (Maddux, p. 78). ${ }^{23}$ In 1873, an Oregon Anti-Chinese Association was established in Portland (Chen, p. 39). ${ }^{24}$ In that year, a great fire destroyed nineteen blocks in the commercial section of Portland (Chen, p. 39). The fire was purported to have connections to the presence of Chinese workers. ${ }^{25}$ Anti-Chinese sentiments continued into the 1880's.

\footnotetext{
21 The Chinese population of San Francisco was the largest in the United States during this period (Chen p. 35).

22 Lafayette Grover seeking the governorship in 1870 as a Democrat used Chinese antisentiments to appeal to voters; In 1878, William Thayer was elected governor as a result of denouncing Chinese labor: In addition, Sylvester Pennoyer, was also elected governor in 1887 as a result of his successful two year attack against the presence of Chinese (Chen, p. 39).

23 The Chinese were called Chink, Chink Chinaman by young boys, had stones thrown at them and were viewed as heathens by the larger population of white settlers (Maddux, pp. 78-79).

24 The Oregon Anti-Chinese Association organization was formed July 15, 1873 in Oregon City with F. R. Niale, as chairman. Members of the group discouraged Chinese immigration, employment and the election of any politician supporting Chinese causes.

25 It is believed that the fire was instigated by members of the Anti-Chinese Association organization as a warning to other merchants regarding the consequences of employing Chinese
} 
On February 12, 1886, the Anti-Chinese Congress was established with 173

delegates in attendance (Chen, p. 41). Following the move of anti-Chinese beliefs in the state of Washington, lead by Governor Squire, Oregon members issued a statement giving Chinese inhabitants forty days to vacant the state (Chen, p. 41$){ }^{26}$

This group also petitioned Congress to adopt exclusion laws targeting Chinese.

During the ensuing weeks, anti-Chinese support grew to included thousands of white residents. ${ }^{27}$ Chinese were forced from their jobs and their businesses were physically attacked by stone throwing and the use of dynamite (Maddux, pp. 8182). ${ }^{28}$ While the antagonists' intimidating attacks did not drive Chinese away, an undercurrent of opposition to their presence continued persistently. ${ }^{29}$

workers (Chen, p. 39). It was reported that the fire started in the back of a furniture store. Buildings loss included: The Multnomah Hotel; Schade's Saloon, Smith Brothers' Foundry and Clark Brothers (second hand furniture store); Occidental Hotel; The entire block of First and Morrison; the Portland Hotel on Taylor,; the Fashion Stables; the Veto Saloon, and ; the Franklin Hotel on First Street. The fire consumed twenty-two blocks (there are differing opinions on the exact number of blocks destroyed), between Morrison and Clay and Second and the River. The loss was estimated at over \$2 million. (Maddux, pp. 70-72).

However, there was a great fire the year before, in 1872. Reportedly, the fire started in the back of a Chinese laundry where pitch was being boiled. Supposedly, coals dropped under the house, landed on dry wood starting a blaze of fire. The fire rapidly spread to other buildings in the area including a few homes. Buildings loss: McCormick; W Currier \& Company, C. H. Woodward, and ; American Exchange Hotel - estimated loss was placed at \$500,000 (Maddux, pp. 69-70).

26 The Anti-Congress delegation was lead by Californian, Burnette A. Haskell, who espoused forcible extrication including 'shedding blood,' if necessary (Chen, p. 41).

27 The News, an Anti-Chinese newspaper, fueled the agenda of white suppressers by featuring antagonistic news articles denouncing the contributions and presence of Chinese workers and their families (Maddux, p. 81).

28 White men wearing mask or blackened faced ascended on Chinese work camps forcing occupants to leave by ferry and often paying their way. These vigilantes also robbed the Chinese victims. This group robe from camp to camp and ranch to ranch during the night, firing shots in their attempt to terrify and threaten the Chinese (Maddux, pp. 82-83).

29 Politics was dominated by Chinese issues. Sylvester Pennoyer, a Democratic candidate for governor, ran on an Anti-Chinese platform defeating the Republican candidate, Thomas R. Cornelius, propertied to have patronized a Chinese laundry (Maddux, p. 83).

Burnette A. Haskell, a Californian was the riot-breeder who attempted to lead a revolt ousting the Chinese from Portland (Chen, p. 41). However, Oregon Governor Zenas F. Moody, Sheriff 
The Chinese were mostly peaceful and not any more criminal than their white counterparts, yet members of their community repeatedly got into legal trouble that was quickly reported by newspapers (Chen, p. 79). Besides public ridicule, authorities within the justice system devised means to punish those considered guilty of criminal actions beyond fine and/or jail or imprisonment. They rendered them unacceptable to their own people by cutting off their queues (Maddux, p. 79). ${ }^{30}$

Chinese were charged with trespassing and other acts deemed indiscriminately as criminal. In similar situations whites were not as likely to be cited for violating City Ordinances or state laws. Chinese were repeatedly charged with operating opium dens often frequented by white patrons. ${ }^{31}$

Thomas A. Jordan, Mayor Jogan Gates and Chief of Police Samuel B. Parrish were instrumental in preventing the execution of that riot.

30 Queues are long braided hair worn singularly streaming from the nape of the neck (Maddux, p. 78).

During the 1860's a Chinese from Baker, Oregon serving his tree year sentence for receiving stolen property also had his queue cut off as part of his punishment. Upon his release, out of shame, he pretended to be a naturalized citizen thereby separating himself from his culture and his people (Maddux, p. 79). This act was thought to have alienated Chinese from the justice system and infused disrespect for American laws (Maddux, p. 84).

Chinese dress dates back to he Celestial Empire in 1644. the queue was considered as a sign of loyalty to the new ruling house (Maddux, p. 84).

31 There is later evidence to support that opium was smuggled into the U.S. on American ships such as Manchuria (an American steam ship built in 1804) and Siberia (built in 1902), belonging to the Pacific Mail S. S. Co. It was thought such practices were not particular to just that era, but dated back to the 19 th century.

In addition, it was discovered in 1903, that in addition to sales by Chinese merchants, opium was also purchased from American stores, for example, a Spokane Drug Co., a wholesale druggist sent a shipment to a Chinese merchant, Kam-Wah-Chung \& Co., in John Day, Oregon. The following message is an excerpt from that letter dated, November 13, 1903: We send you $2 \mathrm{lbs}$. Gum opium today registered mail at the price we quoted you, $\$ 3.90$ per pound (Chen, p. 88 - Letter -Appendix B).

During a particular Chinese New Year's celebration, white settlers as habit, brought their families to view the fire works. See this CHAPTER, pp. 22-23. During this particular celebration, white settlers were invited to share personally in Chinese festivities. A newspaper reported attended the inner circle of the celebration and was offered cigars. The Chinese, in a hospitable mood, also offered .... pull at their opium pipe...to a near-by nine year old white boy. The child imbibed and became intoxicated to the amusement of Chinese on-lookers. However, while the Chinese viewed their offering as being hospitable, an attempt to court the acceptance of white people, the reporter in 


\section{The City of Portland does ordain as follows: Keeping opium house.}

Sec. 25. That any person or persons who shall set up, open, cause to be opened, or keep any house as a resort for the purpose of smoking opium, or who shall sell or furnish opium for the purpose of being smoked upon the premises, shall be guilty of a misdemeanor,... (pp. 62-63).

\section{Penalty.}

Sec. 25. ... and upon conviction thereof before the Police Judge, shall be fined in a sum not less than twenty dollars not more than two hundred dollars, or imprisoned in the City Jail not exceeding ninety days, and it shall be the duty of the Police Judge to pay to the informer in such case one-third of the money collected as fine, and whenever any pipes or other utensils used in smoking opium shall be captured by the Police they shall be destroyed, upon the order of the Police Judge (p. 63). Buying opium to be smoked on premises.

Sec. 26. That any person persons who shall bargain for or buy any opium in any house or place, to be smoked upon the premises, shall be guilty of a misdemeanor, and upon conviction thereof before the Police Judge,..(p. 63)

Penalty.

Sec. 26. cont. ...shall be fined not less than twenty dollars nor more than one hundred dollars, or imprisoned in the City Jail not exceeding twenty days (p. 63).

\section{Smoking opium in house not occupied as residence.}

Sec. 27. That any person or person who shall smoke opium in any house not occupied by them as $a$ residence, or who shall be fund in any house or place kept as a resort for the purpose of smoking opium, without any lawful business, shall be deemed guilty of a misdemeanor,...(p. 63)

Penalty.

Sec. 27. cont. ....and upon conviction thereof before the Police Judge, shall be punished by a fine or not less than twenty dollars not more than one hundred dollars, or imprisonment in the City Jail not exceeding twenty days (p. 63).

Chinese were guilty of committing their share of crime but not to the extent of the disproportionate number of arrests and subsequent adjudications based on the size of their population (Maddux, pp. 79-80). See POPULATIONS, APPENDIX IV and ARREST RECORDS - APPENDICES VII - XI and COURT RECORDS APPENDICES XII-XXI.

During the winter the population of Chinatown would increase due to the arrival of Chinese seasonal laborers from surrounding farming communities.

his article took the Chinese to task. He reported the incident (as he saw it) and cautioned readers to beware of Chinese who could sow the seeds of a life of dissipation and disgrace (Chen, p. 207). It should be added that Chen (author) felt poor Chinese workers could not afford frequent free offerings of opium to anyone (p. 108). 
Chinese workers employed by near-by canneries and hop field farmers were laid off during winter months (Maddux, p. 83). Most, if not all, of these workers were men without the benefits of a family unit. Lacking income and forced to leave their seasonal residences, these workers sought refuge with their Portland Chinese bachelor friends (Maddux, p. 83).

The Chinese men residing in Portland's Chinatown, out of financial necessity, lived together. Most of these men held menial jobs paying substandard wages (Chen, p. 73). Living together enabled them to save money thereby, sharing expenses for food, lodging and other essential necessities. Sleeping arrangements required the use of bunk beds with several Chinese males sharing the same room (Maddux, p. 83).

Chinese were ineligible to own property and therefore rented from white landlords at enormous rates (Maddux, p. 83). When Chinese displaced workers were welcomed by their Portland relatives and friends to stay with them during the winter, white landlords felt they should benefit financially from that arrangement. White landlords wanted to charge additional moneys to renters seeking to accommodate the housing needs of unemployed friends even though they did not use any additional quarters or space (Maddux, p. 84).

Proving that Chinese renters were guilty of housing additional relatives and/or friends was difficult to establish (Maddux, p. 84). Most Chinese admitted that they had house guests who would only be present for a few nights. Yet, the Portland 
Common Council was prompted to respond to this problem. As a result, under the leadership of Mayor Wassermann, a City Ordinance was enacted restricting the number of occupants that could sleep in a given room based on supposedly health related concerns.

FOR PRESERVATION OF HEALTH
AND THE PREVENTION OF DISEASE.
No. 1347.-APPROVED JUNE 19, 1878.

The City of Portland does ordain as follows:

Space to each person.

Section 1. That for the purpose of preventing disease and preserving health, it shall be unlawful for any person or persons to use any tenement house or other building used as a sleeping apartment within the City of Portland, which contains less than five hundred and fifty cubic feet of air or space for each and every person lodging in such house or apartment (Charter of City of Portland, pp. 158-159).

\section{Penalty.}

Sec. 2. Every person violating section 1 of this ordinance shall be deemed guilty of a misdemeanor, and upon conviction thereof shall be punished by a fine of not less than five nor more than fifty dollars for each offence, or by imprisonment in the city jail not exceeding ten days (p. 159). Police to make examination.

Sec. 3. It shall be the duty of the Chief of Police and the members of the police force to make examination of premises, where they have reason to believe that persons are living in overcrowded houses, in violation of this ordinance; and, upon examination, if persons should be found violating this ordinance to arrest any person violating the same and take the person or persons before the Police Judge for trial (Charter of the City of Portland, p. 159).

The Ordinance (as stated) stipulated that specific dimensions be observed per occupant in a given sleeping area. To enforce this law, rental properties housing Chinese residents were raided randomly at odd hours during the night. However, this same enforcement was not applied to white residence. See CHINESE ARREST and

\section{RECORDS, CHAPTER XI.}

Chinese were also criminally cited for operating a business, outside a building

- usually on the open sidewalk, without obtaining a license from the City. These merchants did not meet the required definition of a peddler and therefore were 
required to purchase a license. Most Chinese were reluctant to do business outside of

Chinatown for fear of becoming victims of adverse racial incidents (Maddux, p. 83).

The City of Portland does ordain as follows:

Exemptions in peddlers' license.

Sec. 25. ...Any person except persons peddling newspapers, bibles and religious tracts, and farmers or persons peddling the products of their own farms, gardens or milk ranches, who offer to sell at retail goods, wares, merchandise or other commodities as traveling from place to place in the City of Portland shall be regarded as a peddler under this Ordinance (Charter of the City of Portland, p 56).

Chinese were required to be licensed if they operated from their place of residence. This ordinance included laundries and wash houses.

\section{Laundries and wash houses $-\$ 5$ per quarter.}

Sec. 28. Public laundries and wash houses shall pay a quarterly license of five dollars...(Charter of the City of Portland, p. 56)

What are.

Sec. 28. cont. Every house, building or place which is open to the public as a wash house or laundry shall be deemed a public laundry and wash house under this Ordinance (Charter of the City of Portland, p. 56).

Penalties for doing business without license.

Sec. 36. That if any person or persons exercise or carry on any trade, business or profession, or do any act for the exercising carrying on or doing of which (trade, business or profession) a license is required by this Ordinance, without taking out such license as in that behalf required; or violate any of the provisions of this Ordinance, he she or they shall, on conviction thereof before the Police Judge, for every such offense, besides being liable to the payment of the tax, be subjected to imprisonment for the term not exceeding fifty days, or fine not exceeding one hundred dollars, , or both. Provided, this section shall not apply to cases in which penalties or punishment are specifically provided for in this Ordinance (Charter of the City of Portland, p. 57).

City Ordinance 2958 was later changed to include licensing of peddlers. The amended Ordinance not only specifically defined peddler, it also stipulated mode of operation.

\section{AN ORDINANCE TO IMPOSE AND REGULATE LICENSES, AND REGULATE THE MANNER OF ISSUING LICENSES. No. 2958.}

The City of Portland does ordain as follows: Persons required to take out license.

Section 1. That no person, firm, company or corporation shall engage in, prosecute or carry on any trade, business or profession within the limits of the City of Portland, for which a license may be required by this ordinance, until he or they shall have obtained such a license (p. 92).

Sec. $3 . \quad \quad$...If by a peddler, such license shall state whether authorized to travel by foot, or with one, two or more animals,... 
In addition, peddlers were required to have their license present when They were conducting business. Chinese residents practiced customs unfamiliar to white culture. Chinese merchants and housewives carried goods in baskets attached to a yeo-ho pole propped across their shoulders; a traditional practice and efficient means of transporting goods in China and other Asian countries.

However, in San Francisco, California and Portland, this practice, considered to be a menace to pedestrian traffic, was banned by law (Maddux, p. 84). Portland City Council passed an ordinance banning this practice (Chen, p. 47).

The City of Portland does ordain as follows:

Carrying baskets, buckets, \&c. on poles; and rubbish, filth, \&c., on side walks.

Sec. 34. If any person or persons shall carry any basket or baskets, bucket or buckets, bag or bags, or any other things for carrying articles in, suspended from or attached to poles across or upon the shoulders, or shall carry any rubbish, garbage, swill or filth so as to be offensive to pedestrians upon any sidewalk, they shall be deemed guilty of a misdemeanor,...(p. 65) Penalty.

Sec. 34. cont. ...and upon conviction thereof before the Police Court, shall be punished by a fine of not less than five dollars not more than fifty dollars (p. 65).

The term peddler was often transferred to Chinese transporting personal goods using yeo-ho poles who often were not in private business. They would be stopped, searched and arrested. They were allowed to enter a plea and at times had their cases dismissed, but usually they were fined. In cases where they were convicted they were required to purchase a license for a business they were not operating (Maddux, p. 84). See ARREST RECORDS - APPENDICES VIII - XI and COURT RECORDS - APPENDICES XII-XXII. 


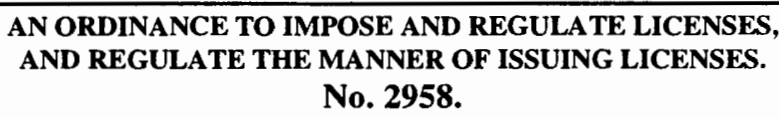

The City of Portland does ordain as follows:

...Person holding license, when to produce them.

Sec. 3. cont. ...in case any peddler shall refuse to produce his or her license when demanded by any city officer, said officer may seize the animals, wagon and contents, or pack, bundle or basket of any person so refusing, and hold the same until the license is produced (p. 93).

To be paid for in coin.

Sec. $6 . \quad$ All licenses required by this ordinance shall be paid in advance in gold or silver coin (Charter of City of Portland, p. 94).

Lacking sanitation services available to most in the 1990's, Portland

residents, in the late 1800 's, had to dump their own garbage, called swill. A Portland ordinance specified when and under what conditions swill could be transported through public streets. Failure to adhere to public law resulted in arrest and usually a fine, or if not paying the fine, a jail sentence. The schedule changed depending on the season of the year. Chinese, perhaps not aware of time and seasonal changes, or unable to read and/or understand City law were cited more than any other group for violating Sec. 38 of the following ordinance. 
The City of Portland does ordain as follows:

Hauling swill and garbage in streets must be in tightly covered box.

Sec. 38. If any person or persons shall remove, transfer or transport through any of the public streets of the City of Portland any swill or garbage, except it be in a tightly covered box or apparatus, or in such manner as will prevent the contents thereof from being deposited in the public streets, or from being exposed in the open air during such process of transportation, he shall be guilty of a misdemeanor,...(p. 66)

\section{Penalty.}

Sec. 38. cont. ....and upon conviction thereof, shall be fined not less than five (\$5) nor more than (\$25) twenty-five dollars (p. 66).

Hauling swill through the streets within certain hours.

Sec. 39. If any person or persons shall remove, transfer or transport any swill or garbage through any public street of the city north of Columbia street, east of Third street and North Third street, and south of $H$ street, except between the hours of $9 o^{\prime}$ 'clock forenoon during the months of April, May, June, July, August and September, and between the hours of $7 o^{\prime}$ 'clock evening and 10 o'clock forenoon during the months of October, November, December, January, February and March, or on a Sunday before $9 o^{\prime}$ 'clock in the evening and after sunrise, during the year, they shall be deemed guilty of a misdemeanor,...(pp. 66-67).

Penalty.

Sec. 39. cont. ....and on conviction thereof before the Police Court, shall be punished by fine not less than five dollars not more than fifty dollars (p. 67).

Defendant convicted to pay costs.

Sec. 42. In all cases of conviction for any of the offences mentioned in this Ordinance, the Court shall adjudge the offender to pay the costs of prosecution, and shall,...(p. 67)

\section{In default of paying fine to be committed.}

Sec. 42. cont. in default of payment of fine and costs, commit the offender to the City Jail for a term of imprisonment not exceeding ninety days, and in all cases where the term of punishment in the City Jail in lieu of a fine shall not be fixed by the Police Judge, the offender shall be imprisoned in default of payment of fine one day for every two dollars of such fine (p. 67).

As an outcome of their history, Chinese often settled individual differences among themselves. They did not trust United States court systems because they spoke limited English or no English and often interpreters were unavailable, dishonest and/or inaccurate (Maddux, p. 91). Chinese used trade associations called tongs $^{32}$ to mediate problems. Tong activities both legal and illicit were mostly either

32 Tong is defined as a society, club or association (Maddux, p. 91).

Tongs sometimes negotiated by using unorthodox means to settle differences. It has been purported that such groups destroyed rivals and enemies and then offered rewards for the murder of persons wanted out of the way (Maddux, p. 91).

It is thought that because tong activities went unsupervised by City authorities, the organization gradually gained power and corruptive influence which members used to extort 
unnoticed by City criminal authorities or ignored (Maddux, p. 93). It has been suggested that tong activities were the catalyst of Asian gangs prevalent in the 1990 's. ${ }^{33}$

Members of tong unions often forced Chinese workers and businesspersons to join their organization. Failure to join brought threats of violence and extortion and warnings not to inform the police. The members of one tong group would rival members of any other tong organization. Often such rivalries led to bloodshed and criminal accusations. When observing arrest and court records, there were several cases involving charges of assault and battery by one Chinese against the person of another Chinese (Maddux, p. 92). There are recorded incidents of tong/gang warfare (Maddux, pp. 92-93). ${ }^{34}$

protection money from merchants, and when necessary other residents, of Chinatown (Maddux, p. 91). The names of tongs association included: Hip Sing; Hup Sing, Suey Sing; Hoo Leong, and; Hung Sing (Maddux, p. 92). Each group protected their 'turf,' similar to gang activity in the 1990's. 33 Tong in Chinese is the word for 'party, ' clique,' or 'a gang' and indicates that it is an organization for the purpose of political strife or rebellion. The greatest rebellion in Ching dynasty was the Taiping Rebellion, 1850-1864. After being defeated, its remainders scattered as many underground Masonic organizations (Chen, p. 77).

Many Chinese laborers in America perhaps were the members of the Taipings, and carried Tong organizations to this country. But as the oreginal (original) goal of throwing over the Manchu regime no longer existed, the Tong societies thus gradually modified to be either associations of defferent (different) region or district, or of tiny groups of a few persons. Consequently, the conflicts or wars between different groups in the Chinese communities were called Tong wars (Chen, p. 77). 34 On December 2, 1888, three men of Chinese ethnicity emerged from Frank Woon's restaurant. AT the same time Mah Bing, also Chinese, came out of a gambling house. Upon seeing Bing the three Chinese men began shooting at him. What ensued was the Hup Sing against the Hoo Leong. Several shots were fired and ultimately, four men were killed. The Portland police investigated the incident prompting Chinatown residents to hope their presence would end the activities of the tong organizations. Law-abiding Chinese residents met with the police in an effort to solve the case and dislodge tong groups from their hideouts. The following day nine tong headquarters were closed, their signs dismantled and ornaments and other implements seized and locked up (Maddux, p. 93).

However, it was not until the Chinese Peace League and Chinese Benevolent Association were organized that tong activities in Portland dramatically subsided (Maddux, p. 94). 
Portland's Chinatown had three Chinese theaters, the first opened in 1879.

All three were located upstairs, none had street level entrances (Maddux, p. 89). The theaters had no scenery, curtains or stage lights. Performers acted out Chinese plays. Similar to European operas, actors sang their parts and pantomimed. Women did not perform; men played female roles and an orchestra provided music from behind the stage (Maddux, pp. 89-90). These theaters were not racially integrated which was not intentional on the part of the Chinese. In additioon, mostly Chinese men attended performances. ${ }^{35}$ The Chinese community consisted mostly of males. Initially, there were few Chinese women residing in the Portland area.

Chinese men came to the United States seeking work that could afford them the opportunity to send money home, to their country, to aid their often poor and malnourished families. Aware of the demand for male workers in the United States and its territories, mostly Chinese men migrated to this country. ${ }^{36}$ The few Chinese women brought here were brought especially to serve the needs of men, especially in the mining communities (Chen, p 55). Gradually, the need for women changed. As many Chinese men (perhaps without a choice due to lack of sufficient money to return to China) remained in this country, in Oregon and in Portland, Chinese women

35 During a performance on November 6, 1887, Lee Yek was attacked by Chinese assailants. A Portland police officer was called to the scene. Officer Nash, arrived and barred the doors to prevent ant attendees from leaving the scene of the crime. No weapon was found on any Chinese but later found lying on the stair case. Never-the-less, because Fong Long Dick and Chee Fong were unable to establish their innocence, they were convicted and sentenced to death (Maddux, pp. 90-91). 36 Chinese men night leave home to earn a living in other places, but not Chinese women. They were expected, mostly required, to remain at home and perform duties, including waiting on her inlaws. While their son was away, the in-laws would gain more compensation from their daughter-inlaw (Chen, p. 4). 
became a premium for those Chinese men seeking wives. It should be noted that Chinese were not legally permitted to intermarry under Oregon law. Therefore, they were restricted to marrying mostly within their own ethnic group. See the following law.

CHAPTER VIII.
Of crimes against public policy.
Intermarriage with negro, etc., declared void. (p. 440)
$\$ 689 . \quad$ Hereafter it shall not be lawful within this state for any white person, male or female, to
intermarry with any Negro, Chinese or any person having one fourth or ore Negro, Chinese or
Kanaka 37 blood, or any person having more than one half Indian blood; and all such marriages or
attempted marriages, shall be absolutely null and void ( $\mathrm{p}$. 440).
Punishment for the same (see $\$ 689$ ).
$\$ 690 . \quad$ If any white person, Negro, Chinese, Kanaka or Indian, within the degrees forbidden in
section 689, shall knowingly intermarry, or attempt the same, by procuring a solemnization of
marriage, under any of the forms or ceremonies legalized in this state, such person or persons, upon
conviction thereof, shall be punished by imprisonment in the penitentiary or county jail, not less than
three months, not more than one year (p. 440.)

In addition to the absence of Chinese women was the absence of Chinese children. Chinese children who were present were not accorded the privileges of childhood. Of the records and data observed, there was no indication that Chinese children attended school. Census data ${ }^{38}$ indicated that a nine year old Chinese child was employed as a miner (Chen, p. 55). According to the census data, this child was not associated with any family (Chen, p. 55). Yet, despite the absence of Chinese children, there was an abundance of older Chinese individuals, some as old as seventy. Despite their age, several older Chinese worked in the mines (Chen, p. 55).

37 Kanaka - A native of Hawaii; A plantation worker on many Pacific Islands; coolie (World Book Dictionary, p. 1145).

38 Source: The Compendium of the Tenth Census of the U.S. , 1880, Washington Government Printing Office, Table XXII, p. 334 (Chen, p. 57) 
The Chinese Exclusionary Acts of 1880, 1882 1888, and 1892, led to the decrease in Portland's Chinese population. While many Chinese residents returned to China, some remained in Portland. Efforts by many Chinese inhabitants to save Portland and the property of many white residents during the fires of 1872 and 1873 and eventually, the flood of 1894 , endeared the Chinese to many white residents and policemen. Consequently, their presence, while unjustly illegal, was tolerated by influential members of the white citizenry including public officials.

Wherever a Chinese community existed a Chinese temple would be erected (Chen, p. 100). Traditionally, there should have been a shrine of a throne with an idol placed on a middle shelf against a wall (Chen, p. 100). In front of this shrine should have been a table filled with religious articles such as a round box of bamboo containing ninety-one bamboo tallies, an incense burner, joss sticks, ${ }^{39}$ fire crackers and a bear claw in a wooden box. The shrine was to be decorated with ribbons, colored stripes of paper, surrounded by lamps, mysterious red and yellow papers, dried fruit and candles (Chen, p. 100).

There was a commercial sense to worship for Chinese in America away from their homeland. Often such shrines were erected in Chinese stores. Worshippers paid homage by buying incense and other supplies essential to their worship from the Chinese merchant. If they wished to be blessed or when an omen came true, they offered donations in gratitude (Chen, p. 101). They would post small red papers on

39 Joss stick - a slender stick of dried, fragrant paste, burned as incense (World Book Dictionary, p. 1136). 
which they inscribed their name and the amount of their donation and adhere it to the wall around the shrine. These donations were to be used to restore and maintain the shrine as need be. By Chinese standards, worshippers were viewed as heathens in need of religious leniency.

While shrines were located adjacent to mining communities, ${ }^{40}$ surprisingly, there were no shrines in Portland's Chinatown (Chen, p. 105). ${ }^{41}$ It was felt that perhaps Chinese inhabitants took solace in having a place in which they saw and mingled with people who looked, spoke and acted like them. Their need for religious worship was tempered (Chen, p. 104).

Most Chinese religious activities were scheduled around the New Year because most workers could get back from their work camps to Chinatown during that holiday time. The religious festival lasted several days and often attracted the curiosity of white residents (Chen, p. 106). The use of fire crackers was an essential part of these festivities.

Initially, the Portland City Council prohibited the use of fire crackers by enacting Ordinance 2530, prohibiting firing of fire crackers - Approved October 2, 1879. See CHAPTER II, p. 32. However, because the fire works delighted many

40 It was thought Chinese needed the presence of their make shift shrines to pray for luck and, surrounded by hostilities, mercy (Chen, pp. 104-105). Chinese did not worship as a congregation, they went separately to the joss house ( joss is a Portuguese word for God - Deos) when they felt the need to pray or worship (Maddux, pp. 86-87).

41 Chinese immigrants did not arrived from China practicing one religion; Chinese practiced Buddhism, Confucianism and Taoism (Maddux, p. 86). Viewed as heathens, in their zeal to appease white Christians, a few Chinese converted to Christianity; Chinese became Baptist and Presbyterian (Maddux, p. 86). 
white residents—especially their children, through the enactment of special

ordinances provisions were made to allow limited use of fire crackers.

The following Ordinances are the results of those actions.

\begin{tabular}{|l|l|}
\hline 3377. & Granting Chinese certain privileges. Approved Feb. $3,1882$. \\
\hline 3640. & Granting Chinese certain privileges. Approved Dec. 8, 1882. \\
\hline 4129. & Granting Chinese residents certain privileges. Approved Jan. $25,1884$. \\
\hline 4486. & Granting certain privileges to Chinese residents. Approved Jan. $10,1885$. \\
\hline 4766. & Granting Chinese residents certain privileges. Approved Jan. $21,1886$. \\
\hline
\end{tabular}

The following information was obtained from the minutes of the City of

Portland's City Council meetings per the indicated dates.

\section{City of Portland Stanley Paar Archives \\ General Index - Council Minutes \\ $1892-1894$}

General Information: Petition to have stores and houses numbered Ord. \# 7685 - March 10, 1892

(Vol. 13, p. 773)

Chinese applied for and received permission to celebrate (occasion not indicated) -

see Ord. \#7305 - approved January 16, 1892

General Information: Ord. 7996 - prohibiting sale of cigarettes to minors - (Date not indicated just the year, 1892)

Researched February 8, 1996

The following information relative to applicable ordinances were observed

within the minutes of the City Council.

\begin{tabular}{|c|c|c|c|c|c|c|}
\hline SUBJECT & OBJECT & ORD.\# & ACTION & DATE & \multicolumn{2}{|c|}{ PROCEEDINGS } \\
\hline & & & & & Vol. & Page \\
\hline Licenses & $\begin{array}{l}\text { Granted Wing Yuen Co. } \\
\text { (liquor) }\end{array}$ & $\begin{array}{l}\text { (box } 1 \\
\text { B10 }\end{array}$ & adopted & $\begin{array}{l}4 / 20 / 189 \\
2\end{array}$ & 13 & 80 \\
\hline $\begin{array}{l}\text { Chinese New } \\
\text { Year }\end{array}$ & $\begin{array}{l}\text { Granting privilege to } \\
\text { celebrate }\end{array}$ & 7305 & approved & $\begin{array}{l}1 / 16 / 189 \\
2\end{array}$ & & \\
\hline County Hospital & bldg. at poor farm & Gen. Info. & $\mathrm{H} \& \mathrm{P}$ & $2 / 1 / 1892$ & 14 & 153 \\
\hline $\begin{array}{l}\text { Chinese New } \\
\text { Year }\end{array}$ & $\begin{array}{l}\text { Ord. granted authority to } \\
\text { celebrate }\end{array}$ & 8711 & $\begin{array}{l}\text { (not } \\
\text { indicated) }\end{array}$ & $\begin{array}{l}\text { not } \\
\text { indicated }\end{array}$ & $\begin{array}{l}\text { not } \\
\text { indicated }\end{array}$ & $\begin{array}{l}\text { not } \\
\text { indicated }\end{array}$ \\
\hline $\begin{array}{l}\text { Chinese } \\
\text { Theater }\end{array}$ & $\begin{array}{l}\text { Chief of Police re: } \\
\text { employed women }\end{array}$ & & Rep. L. C. & $3 / 7 / 1894$ & 15 & 116 \\
\hline $\begin{array}{l}\text { Chinese New } \\
\text { Year }\end{array}$ & $\begin{array}{l}\text { Ord. authorized } \\
\text { celebration of }\end{array}$ & 9084 & approved & $1 / 2 / 1894$ & & \\
\hline Chun Sing & $\begin{array}{l}\text { Claimed damages from } \\
\text { Tanner Creek sewer } \\
\text { overflow }\end{array}$ & - & S \&D & $\begin{array}{l}1 / 30 / 189 \\
4\end{array}$ & 16 & 42 \\
\hline $\begin{array}{l}\text { Chinese New } \\
\text { Year }\end{array}$ & $\begin{array}{l}\text { Ord. granted permission } \\
\text { to celebrate }\end{array}$ & 9620 & approved & $\begin{array}{l}1 / 20 / 189 \\
5\end{array}$ & & \\
\hline $\begin{array}{l}\text { House of } \\
\text { Corrections }\end{array}$ & $\begin{array}{l}\text { Ord. prohibited erection } \\
\text { within } 15600 \text { feet of pubic } \\
\text { school house }\end{array}$ & 8541 & $\begin{array}{l}\text { general } \\
\text { information }\end{array}$ & & & \\
\hline Laundries & & 7385 & & & & \\
\hline
\end{tabular}


There were numerous arrests and court cases involving Chinese immigrants.

However, because of the enormity of cases involving Chinese persons, the commentary in CHAPTER XI cites only a fragment of those cases. Additional cases observed involving an identifiable Chinese, are available in the arrest and court records replicated for inclusion in this document. See APPENDICES VIII-XXII. 


\section{CHAPTER XI \\ CHINESE IMMIGRANTS \\ POLICE ARREST RECORDS}

Throughout their residency in Portland, Chinese inhabitants were monitored by enforcement authorities looking for signs of criminal behavior. Many cited violations were inequitable. As a result, in many instances, the justice system's treatment of Chinese could have been considered at the very least, harassment. While a number of incidents resulted in arrests, in some situations, cases were dismissed, or if convicted, fines were leveled at the minimum rate, consistent with treatment of most defendants.

Prejudice(s) against Chinese were not found upon any criminal acts of that race (Maddux, p. 80). Adverse white public sentiment aimed at Chinese immigrants prompted inequitable legislation and enforcement at federal, state and local levels. The following cases demonstrate both justified and unjustified enforcement and in some cases, adjudication.

The exact spelling of Chinese names was often difficult to decipher. As indicated in the INTRODUCTION - RESEARCH METHODOLOGY section of this document, the use of a magnifying glass was often useful. However, it was unclear if Recorders, Justices of the Peace or Court Recorders spelled Chinese names phonetically, were supplied with formal identification from which names were extracted, or developed an understanding for spelling the unusual names (by western 
standards) of Chinese immigrants. Referring to census data in his thesis, Chia-Lin Chen ${ }^{1}$ stated:

The state census is more detailed but is not a complete source (referring to identifying and accurately accounting for the presence of every Chinese immigrant and Chinese Americans), and particularly fails in recording correctly the names of Chinese. Spelling names in English makes the attempt to identify the same person appearing in different censuses utterly impossible. (And in arrest and courts' cases also.) A Chinese name rendered into English cannot carry any meaning contained in the Chinese language, except to sound strange to American ears, and to distort the Chinese connotations. A name like "Hsing" which means "new" or "happy" in Chinese, would appear...as "Sin" or "Sing." Since the word "Sin"...was more suitable to describe a degraded race, many "Ah Sins" showed up...as "Ah Sings." Furthermore, eighty percent of the names were incomplete, which made the situation more confused. For example, "Chen Hsien," "Lee Hsin," and "Wang Hsing," could all appear ...as "Ah Sin," as their family names were left out... Without family names, the relationships, or kinships, such as clans, families, brothers, cousins, and generations could not be detected (Chen, p. 50).

For example, several cases were observed where a Chinese person was identified as Sin or Sing. However, it should be noted that my research was not to specifically identify Chinese families but simply to identify Chinese as members of their ethnic group. Chinese were often identified as Chinaman, or the designation of Chinaman followed by a single name, e.g., Chinaman Jim, or Tom Chinaman.

Chinese women might be referred to as China woman. For an example, see APPENDIX VIII, page 1. It is not clear if the Recorders designated these names, or if the arrestee used stereotypical aliases.

1 Chia-Lin Chen is the researcher and author of, $A$ Gold Dream In The Blue Mountains, a thesis, recounting Oregon's early treatment of Chinese immigrants. See Bibliography. 


\section{November 1870 - January 1875 MISDEMEANORS AND FELONIES}

Chinese arrest records were extensive when compared to the number of arrests of Native and African Americans. As such, cases will not be discussed individually. See APPENDIX VIII-XII, to review arrest records. Chinese were arrested for allegedly committing numerous violations. The following are examples of charges filed against Chinese during this time period:

\begin{tabular}{|c|c|}
\hline $\begin{array}{l}\text { - } \text { drunk and disorderly conduct } \\
\text { - } \text { being loud and boisterous } \\
\text { or, disturbing the peace } \\
\text { - } \text { abusive language } \\
\text { - } \text { peddling without a license } \\
\text { - vagrancy } \\
\text { - disorderly by breaking windows } \\
\text { - fighting } \\
\text { - flaughtering within City limits } \\
\text { - depositing filth in street }\end{array}$ & $\begin{array}{l}\text { - } \text { roaming about after hours } \\
\text { - } \text { keeping a bawdy house } \\
\text { - } \text { burglary } \\
\text { - } \text { larceny } \\
\text { - } \text { carrying concealed weapons } \\
\text { - } \text { assault and battery; } \\
\text { - } \text { threatening to kill } \\
\text { - } \text { sleeping in a room having less than } 550 \text { cubic } \\
\text { feet of air per person }\end{array}$ \\
\hline
\end{tabular}

Most violations were common charges filed against all racial/ethnic groups. There were, however, a few that specifically affected only Chinese. There were particular Ordinances ${ }^{2}$ enacted targeting Chinese customs, practices and daily actions.

Public intoxication was a violation of Portland Ordinance. Chinese were arrested for violating this law, but not at any rate out of proportion to any other racial/ethnic group. It was unclear however, as to how an Ordinance approved in 1885 was enforced from 1870 through 1875.

2 Laws of Portland, City of Portland City Charter, An Act To Incorporate The City of Portland Approved October 24, 1882 - And Acts Amendatory Thereof. Of the organization and powers of the council - See CHAPTER II, this document. 
racial/ethnic group. It was unclear however, as to how an Ordinance approved in 1885 was enforced from 1870 through 1875.

4706. Restrain and punish intoxication. Approved Oct. 22, 1885.

See the following Ordinance.

\section{APPROVED SEPTEMBER 19, 1885. \\ AN ORDINANCE TO RESTRAIN AND PUNISH INTOXICATION. \\ 4706.}

The City of Portland does ordain as follows:

Intoxication unlawful.

Section 1. That it shall be unlawful for any person to be intoxicated upon any street or within any public place within the corporate limits of the city of Portland (p. 343).

Penalty.

Sec.2. Any person who shall violate any of the provisions of this ordinance shall be punished by a fine of not less than two dollars not more than two hundred dollars, or by

imprisonment in the City Jail not less than one day nor more than ninety days (p. 344).

Being loud and boisterous, and disturbing the peace were not unusual

violations and members of all ethnic groups were from time to time arrested for contributing to inappropriate volumes of noise at odd hours during the day.

However, the vast majority of complaints were filed against Chinese.

The absence of additional information associated with the arrests for these charges made it difficult to analyze the underlying cause of the disproportionate number of arrests of Chinese. Complaints in most instances were filed by the arresting officer. Deciding if an individual was disturbing the peace was often subjective. The arresting officer made the determination. 
The following Ordinance was observed.

\begin{tabular}{|c|c|}
\hline $\begin{array}{l}\text { AN ORD } \\
\text { The City of Porth } \\
\text { Violent, riotous, }\end{array}$ & $\begin{array}{l}\text { INANCE CONCERNING OFFENSES AND DISORDERLY CONDUCT. } \\
\text { No. } 3983 \text {. } \\
\text { and does ordain as follows: } \\
\text { or disorderly conduct. }\end{array}$ \\
\hline $\begin{array}{l}\text { Section } 1 . \\
\text { conduct,...(p. } 325 \\
\text { Profane, abusive }\end{array}$ & $\begin{array}{l}\text { That any person or persons who shall be guilty of any violent, riotous or disorderly } \\
\text { or obscene language. }\end{array}$ \\
\hline $\begin{array}{l}\text { Sec. } 1 . \text { cont. } \\
\text { or place within th } \\
\text { disturbed,...(p. } 32 \\
\text { Indecent or imm }\end{array}$ & $\begin{array}{l}\text { or who shall use any profane, abusive or obscene language in any street, house } \\
\text { he City of Portland, whereby the peace or quiet of the city is or may be } \\
\text { 25) } \\
\text { loral act or practice. }\end{array}$ \\
\hline $\begin{array}{l}\text { Sec. 1. cont. } \\
\text { shall,...(p. } 325) \\
\text { Penalty }\end{array}$ & ...or who shall be guilty of any indecent or immoral act or practice in said city, \\
\hline $\begin{array}{l}\text { Sec. } 1 \text { cont. } \\
\text { nor more than } t \\
\text { then }(90) \text { ninety }\end{array}$ & $\begin{array}{l}\text {... upon conviction thereof in the Police Court, pay a fine of not less than ten dollars } \\
\text { o hundred dollars, or be imprisoned in the City Jail not less than five days nor more } \\
\text { lays, or both, at the discretion of the Court (pp. 325-326). }{ }^{3}\end{array}$ \\
\hline
\end{tabular}

Chinese were either bilingual or, spoke only Chinese. As such, it is assumed that if a Chinese person wanted to use vile language, they would use their native tongue, especially, if such an act was illegal. Therefore, arresting a Chinese person for violating this Ordinance was often probably arbitrary.

Chinese diet and food taste differed from that of most Americans, especially white settlers. Whites, and other Americans, probably favored beef, milk butter and cheese (Chen, p. 81). In China, oxen and cows were essential to farming and therefore not used as food. The smell of cooked beef was intolerable to many Chinese who were farmers in their country (Chen, p. 81). Chinese preferred poultry, eggs, small pigs and other diary products (Chen, p. 82). Chinese cooks often slaughtered poultry and pigs, but butchering was not allowed within the City of Portland.

3 Ibid., Ordinance 2959, Section 1, Violent, riotous, or disorderly conduct. Profane, abusive or obscene language. 
The following Ordinance was observed.

111 To prevent butchering and other nuisances within certain limits. Approved May 22, 1862. Repealed by Ordinance No. 928.

$928 \quad$ For the prevention and removal of nuisances. Approved February 10, 1871.

Chinese were significantly cited for violation of this Ordinance, often to the exclusion of any other racial/ethnic group, including whites. For an example, see APPENDIX VIII, p. 8.

To tax and license slaughter and wash houses.
To license, tax, control and regulate slaughter houses, wash houses and public laundries,
and to provide for their exclusion from the city limits or any part thereof (p. 17).
To punish by fine or imprisonment.
37. To provide for the punishment of a violation of any ordinance of the city by fine or
imprisonment not exceeding three hundred dollars, or ninety days, or both, or by a forfeiture as
penalty not exceeding three hundred dollars, and for working any person sentenced to such
imprisonment upon the streets, public squares, work-house or house f correction during the term
thereof, and to provide for the punishment of any person sentenced to imprisonment who shall refuse
to work when ordered (p. 19).
Sec. 37. The Council has power and authority within the City of Portland-

It should also be noted that Chinese merchants owned and operated most, if not all of Portland's laundries. Refer to the above Ordinance to observe that it was illegal for those businesses to be located within City limits. However, when observing arrest records, there were no instances in which a Chinese launderer was cited for operating his business within City limits during this period of study.

Chinese were also cited for violating City Ordinance 1431. See APPENDIX VIII, p. 30, for examples. There were over thirty arrests, over a period of one week. It was not clear what the Chinese were doing. If several Chinese were obstructing the sidewalk, perhaps they were on strike, or protesting, the reason was unclear. 
Ordinance No. 1465, was essentially the same as Ordinance No. 1431. See the following:

1431 Prevent obstruction and injury sidewalks. Approved February 5, 1874.

1465 Prevent nuisances and obstruction streets. Approved April 6,1874.

Yet, given similar circumstances, a group of white women were treated differently when breaking essentially the same Ordinance. See Chapter XI, p. 288.

Note: See APPENDIX VII, p. 35. On April 7, 1874, in Portland, Oregon, fifteen European American women were arrested for praying on a public street - 1st and Morrision. These women were members of the Women's Temperance Prayer League. Their purpose was to rid the town of saloons (Tracy, pp. 252-154).

Chinese were rarely cited as vagrants. See APPENDIX VIII, pp. 4, 10. 12 and 14, for unusual examples. However, they were often arrested for their alleged association with a bawdy house. ${ }^{4}$ Anyone residing in or frequenting a house of ill repute could have been considered a vagrant. Defining the meaning of vagrancy was essential to enforcing the Ordinance prohibiting the practice.

907. Defining vagrancy and providing for its punishment. Approved December 2, 1870.

Again, the enforcement of this Ordinance was left to the discretion of the patrolling officer.

\section{Definition of a vagrant.}

Section. 1. Any habitually idle or dissolute person who has no visible means of living, or lawful occupations or employment by which to earn a living; or any person who shall be found begging the means of support; or who not having other lawful means of living refuses to work, or who shall habitually wander about the streets without any lawful business; or who lives in or about any houses of ill fame or bawdy house; is hereby defined to be a vagrant (p. 340).

Penalty on conviction of vagrancy. officer.

$4 \quad$ Bawd - ...a person, especially a woman who keeps a brothel... a prostitute...(World Book Dictionary, The, p. 173).

Ibid., Bawdy - ...the practice or occupation of a bawd...(p. 173). 


AN ORDINANCE TO DEFINE AND PUNISH VAGRANCY.
NO. 4549.
The City of Portland does ordain as follows:
Sec. $2 . \quad$ Any person who shall be convicted before the Police Judge of being a vagrant as
defined in section one of this ordinance, shall be fined not less than twenty-five dollars nor more
than one hundred dollars, or imprisonment in the city jail not less than ten days nor more than
ninety days (p. 340$){ }^{5}$
Chief of Police and all policemen to prosecute vagrants.
$\begin{aligned} & \text { Sec. } 3 . \quad \text { It shall be the duty of the Chief of Police and all policemen to prosecute any person } \\ & \text { whom they shall know of their own knowledge or reliable information to be a vagrant as defined in } \\ & \text { section one of this ordinance (p. } 340){ }^{6} \\ & \text { APPROVED MARCH } 28,1885 .\end{aligned}$

Chinese, as were other racial/ethnic groups, were arrested for wandering around aimlessly after midnight. Examples of the enforcement of this Ordinance maybe perused throughout all arrest records - see APPENDICES VIII-XII.

\section{AN ORDINANCE CONCERNING OFFENSES AND DISORDERLY CONDUCT. No. 3983.}

The City of Portland does ordain as follows:

Roaming about the streets after 12 o'clock at night without business prohibited.

Sec. 21. If any person or persons shall be found roaming about the streets at night, after the hours of 12 'clock, without having any lawful business upon the streets at that time, they shall be deemed guilty of a misdemeanor, and upon conviction thereof before the Police Court,...(p. 331) Penalty.

Sec. 21. ...shall be punished by fine of not less than ten dollars nor more than one hundred dollars (p. $331)$.

Chinese women and men were arrested on a variety of other charges

including operating a bawdy house. It has been purported that Chinese women were brought to the United States especially for the purpose of prostitution as a means of earning money to send home to their families (Chen, p. 55).

5 Op cit., City of Portland City Charter, see DEFINING VAGRANCY AND PROVIDING FOR THE PUNISHMENT THEREOF. No. 2995. APPROVED FEBRUARY 4, 1881, Vagrants, who are. $6 \quad$ Ibid., Approved March 28, 1885. 
AN ORDINANCE TO PREVENT AND SUPPRESS BAWDY HOUSES AND PLACES WHERE FORNICATION IS ENACTED, AND TO PUNISH KEEPERS, INMATES AND FREQUENTERS THEREOF. 4710.

The City of Portland does ordain as follows:

Bawdy houses unlawful.

Section 1. That is shall be unlawful for any person or persons to open, set up or keep within the corporate limits of the city of Portland, any bawdy house or place where fornication is enacted, or to frequent, reside in, or become an inmate thereof (p. 344).

Keepers of, how punished.

Sec. 2. Any person who shall open, set up, keep or maintain within the corporate limits of the city of Portland any bawdy house, or house or place where fornication is enacted, or knowingly aid or assist in setting up, keeping or maintaining the same, shall, upon conviction thereof before the Police Judge, be punished by a fine of not less than twenty-five dollars not ore than two hundred dollars, or in default of the payment of such fine, by imprisonment in the City Jail not less than ten days nor more than ninety days (p. 344).

Frequenters or inmates of-how punished.

Sec. 3. Any person who shall, within the corporate limits of the city of Portland, frequent, reside nor become an inmate of any bawdy house, or house where fornication is enacted, shall, upon conviction thereof before the Police Judge, be punished by a fine of not less than ten dollars not more than one hundred dollars, or in default of the payment of such fine, by imprisonment in the City Jail not less then five days nor more than fifty days (p. 345).

In all cases of prosecution common fame competent evidence.

Sec. 4. In all cases of prosecution under this ordinance common fame shall be competent evidence in support of the complaint, and every house or place used or occupied for the purposes of prostitution, fornication or lewdness, shall be taken an deemed to be a bawdy house within the meaning of this ordinance, in any prosecution against any person or persons for violating any of the provisions of this ordinance (p. 345).

Any person endeavoring to entice attract attention of passers-by, or who shall be, remain at, sit or stand by, in or near any door, window or place in any bawdy house, in any manner offensive to the public how punished.

Sec. 5. Any person who shall, within the corporate limits of the city of Portland, stand, or sit at, or in or near any door, window or place in any such bawdy house or place so as to be observed by passers-by, or who shall, by any sign, token or motion, while in any such house or place, attract the attention of passers-by, or who shall remain at or in any door or window or place in any such bawdy house or place in such condition as to attract the attention of persons passing along the street, or shall be or remain at or in any door, window or place in any such bawdy house or place in such condition, attitude, or dress as to be or become offensive to public decency, shall upon conviction thereof, before the Police Judge, be punished by a fine of not less than ten dollars, not more than one hundred dollars, or in default of the payment of such fine by imprisonment in the City jail not less than five days nor more than fifty days (p. 345).

\section{Chief of Police to enforce.}

Sec. 6. It shall be the duty of the Chief of Police and all policemen to institute prosecutions for the violation of this ordinance whenever he shall have reasonable cause to believe that any person or persons have been guilty of a violation of the same (p. 345).

Repeal.

Sec. 7.

Ordinance No. 2996 , entitled "An ordinance to suppress bawdy houses and for the punishment of the inmates thereof, approved February 4,1881," is hereby repealed (p. 346).

7 Ibid., see Ordinance 2996, Chronological Index, Charter of the City of Portland, p. 510, and the Chronological Index. 
The Portland Weekly Herald reported ...If it will rid the city of the filthy Chinese huts along second street, as a hygienic measure, it is one of the best (ordinances) ever framed by the city (Merriam, p. 69).

In addition to arresting Chinese women for prostitution, the Portland Police often arrested their customers. However, upon conviction, the rates of fines were substantially different. The female prostitute was fined from twenty-five dollars to fifty dollars or more; whereas, her customer was fined five to ten dollars.

The arrests of Chinese women for acts of prostitution were not consistently enforced. While several arrests were made on the same day, usually by the same officers, repeated arrest would not occur for several months, often not until the following year. It was unclear if prostitution ceased, enforcement of the Ordinance was ignored, or if prostitutes conducted business in a more discriminate manner.

The Chinese were treated with disdain and total lack of respect. Adult Chinese men and women were often subjected to taunting by children. In addition, they were also physically attacked (Maddux, p. 78). When reviewing arrest records during this time period, there were instances observed in which the perpetrators of these acts were arrested. However, the race/ethnicity of such individuals was difficult to decipher. See APPENDIX VIII, p. 8, May 1, 1872, the arrests of Chas Wamslaf, Yee Brown (probably Chinese) and Billy O'Regan. 
Perhaps, in response to their inability to always defend themselves against such attacks, there were several incidents in which Chinese were arrested for carrying a concealed weapon. How a concealed weapon was found on the

\section{Carrying concealed deadly weapon.}

Sec. 10. That any person or persons who shall carry any firearms or deadly weapons of any kind in a concealed manner within the corporate limits of the city...(p. 328)

\section{Penalty.}

Sec. 10. cont. ....shall upon conviction thereof before the Police Court, be fined nor less than ten nor more than fifty dollars, or imprisoned not more than twenty days, provided, That peace officers shall be exempt from the provisions of this section (p. 328). ${ }^{8}$

individual's person was unclear. Perhaps, Chinese were subjected to periodic searches.

Chinese filed complaints of assault and battery against white residents but more often against other Chinese. It is unclear what issues or actions precipitated persistent confrontations between Chinese persons. They occupied living quarters that were confining, so, perhaps the lack of privacy caused personal eruptions. In addition, while there was conflict when seeking employment between Chinese workers and white workers, there was also conflict among Chinese when competing for similar jobs (Chen, p. 75). Also, with few women in the Chinese community, there was continuous rival among the men for their attentions. In subsequent arrest records, Chinese men were accused of kidnapping Chinese wives/sweethearts of other Chinese men. 
Chinese living quarters were cramped, as discussed in Chapter X. ,The Portland City Council enacted an Ordinance to discourage Chinese from sharing living quarters under the premise of preventing the spread of disease. See APPENDIX VIII, pp. 16-21. Over fifty Chinese were arrested for violating Ordinance 1347.

\section{AN ORDINANCE FOR PRESERVATION OF HEALTH AND THE PREVENTION OF DISEASE \\ No. 1347.}

The City of Portland does ordain as follows: Space to each person.

Section 1. That for the purpose of preventing disease and preserving health, it shall be unlawful for any person or persons to use any tenement house or other building used as a sleeping apartment within the city of Portland, which contains less than five hundred and fifty cubic feet of air or space for each and every person lodging in such house or apartment (p. 300)

Penalty

Sec. 2. Every person violating section 1 of this ordinance shall be deemed guilty of a misdemeanor, and upon conviction thereof, shall be punished by a fine of not less than five nor more than fifty dollars for each offense, or by imprisonment in the city jail not exceeding ten days (p. 300 ). Police to make examination.

Sec. $3 . \quad$ It shall be the duty of the Chief of Police and the members of the police force to make examination of premises, where they have reason to believe that persons are living in overcrowded houses in violation of this ordinance; and upon examination, if persons should be found violating this ordinance, to arrest any person violating the same and take the person or persons before the police Judge for trial (p. 300).

When observing arrest records, the legality of this Ordinance was not enforced against any other racial/ethnic group. Considering the limited space of most homes during that period, it is doubtful if any family could comply to the required 550 cubic foot of air space per individual. It should be noted that this requirement pertained to apartments or tenements only. Those dimensions measure approximately, 8" x 8" x 8," or a space that is about eight feet wide by eight feet long by eight in height per individual occupying the room. 


\section{POLICE ARREST RECORDS \\ JANUARY 1875 - MARCH 1878 \\ MISDEMEANORS AND FELONIES}

Chinese arrests during this time period reflect the same violations as in previous years. The Recorder added a new category to the books: gender, $M$ for male, or $F$ for female. The gender of a Chinese individual was not readily recognizable prior to the addition of this column. However, just as was the case with Native Americans and African Americans, few Chinese women were arrested. See APPENDIX IX.

Most Chinese males were arrested and charged with committing felonies and misdemeanors. One type of crime did not dominate the status of charges filed against Chinese. Yet, when observing this period of arrest, Chinese men appeared to be fighting not only among themselves but progressively with white men. There was little interaction between Chinese and identifiable Native Americans and identifiable African Americans.

There is one particular case that warranted discussion. See APPENDIX IX, p. 5. On March 17, 1876, a Corcoran (first name not indicated) was arrested for disorderly conduct, on First Avenue and Stark Street. During that period there was a policeman, J. Corcoran; it was assumed they were one in the same person. There were specific laws governing the conduct and actions of a police officer. See the following: 


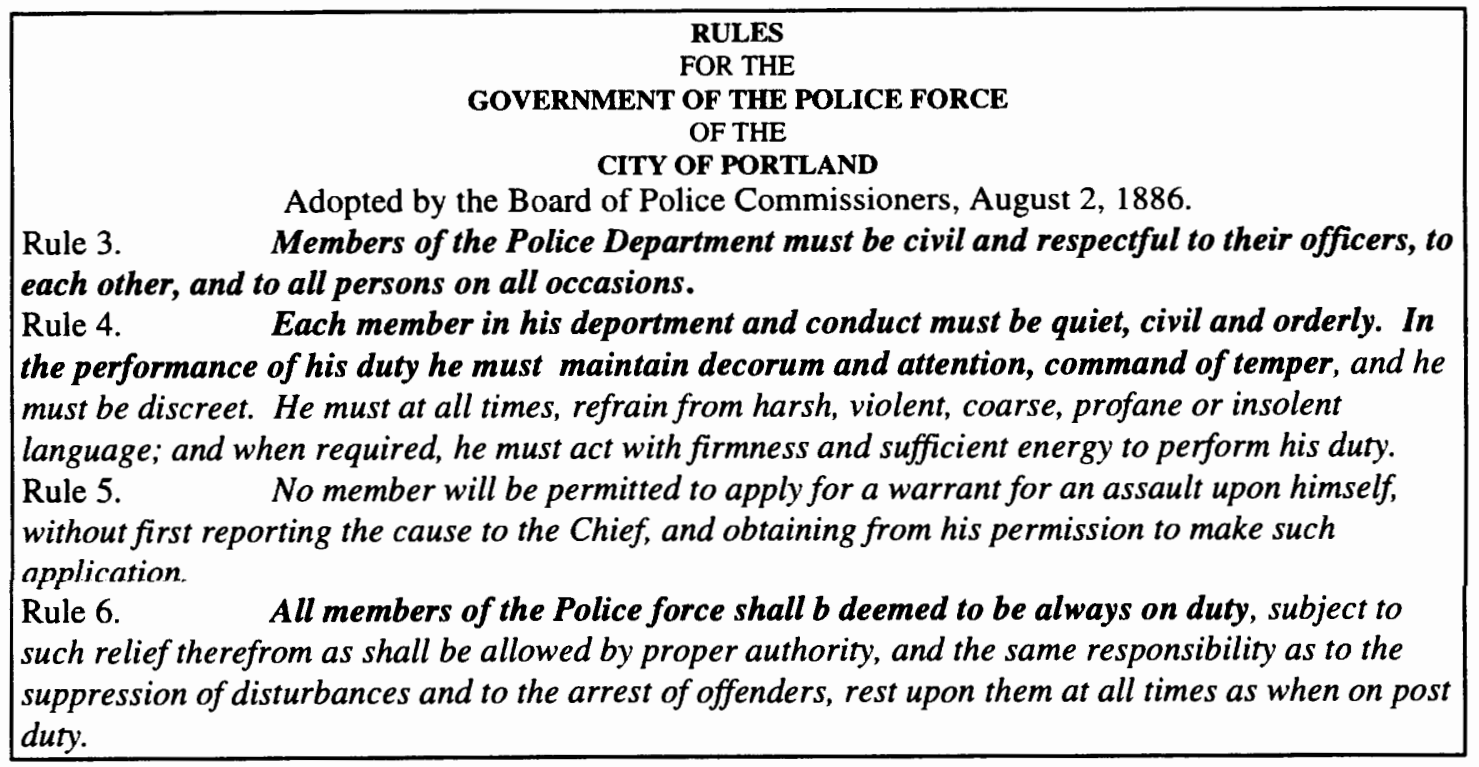

On June 11, of the same year, Corcoran filed a complaint of assault and battery against Fay Yon, a Chinese, at 3 o'clock in the morning. The arrest was made by Officer J. L. Hamilton, but Corcoran filed the complaint. An on duty police officer performed two functions, he made the arrest and filed the charges. Refer to arrest records, APPENDICES VIII-XXI. Corcoran was not the arresting officer.

There was also another unusual arrest on the same page as the case above. See APPENDIX IX, p. 6. On July 15, 1876, Ah Chum, was arrested by Officer Hamilton. He was declared insane in the arrest record, and remanded to the asylum.

He was not the beneficiary of a required hearing. Also see the following:

September 21, 1876, a Chinaman, p. 9.

October 24, 1876, Sep Hulah, p. 9

July 21,1877 , Chinaman (it was indicated that he was sent to an asylum) 
There were specific laws relative to the treatment of those considered to be mentally incapacitated.

\section{CHAPTER XXVI.}

OF THE CUSTODY AND TREATMENT OF THE INSANE.

September 27, 1862

Who not to be sent to asylum.

$\$ 4 . \quad$...That no insane or idiotic person shall be sent to an insane asylum, under the provisions of this act, who has friends that can, or desire to provide for their safe keeping and medical treatment...(p. 621).

If the individual who has been declared insane, has friends who will provide for his or her care, then those friends may elect to do so. However, as was the case with the insanity of Native Americans, Chinese, by Oregon law, were to be granted a guardian and a hearing to determine the degree of their derangement, if any.

\begin{tabular}{l} 
OF THE DOMESTIC RELATIONS. \\
TITLE II. \\
Of guardians and wards. \\
$\begin{array}{l}\text { December 15, 1853 } \\
\text { Guardian for insane person. } \\
\text { W13. When the relations or friends of any insane person, or any other persons, inhabitants of the } \\
\text { county in which such insane person resides, shall apply to the county by petition in writing, to have a } \\
\text { guardian appointed for him, the judge shall cause notice, to have a guardian appointed for him, the } \\
\text { judge shall cause notice to be given to the supposed insane person, of the time and place appointed } \\
\text { for hearing the case, not less than ten days before the time so appointed; and if, after a full hearing, it } \\
\text { shall appear to the judge that the person in question is incapable of taking care of himself, the judge } \\
\text { shall appoint a guardian of his person and estate, with the powers and duties hereinafter specified (p. } \\
\text { 555). }\end{array}$ \\
\hline
\end{tabular}

During this time period, Chinese continued to be arrested for violating

Ordinance No. 1431. See APPENDIX IX, pp. 7-9. The same two officers arrested each of the alleged perpetrators. Again, it was not clear what the Chinese were doing.

$1431 \quad$ Prevent obstruction and injury sidewalks. Approved February 5, 1874. 
Chinese continued to be arrested for violating Ordinances No. 1073 and No.

165. See APPENDIX IX, pp. 13. See the following:

\begin{tabular}{|cl|}
\hline 2073 & Amending Ordinance No. 475 (offences and disorderly conduct) Approved Nov. 9, 1877. \\
475 & $\begin{array}{l}\text { Concerning offences and disorderly conduct. Approved March 6, 1868. Amended by } \\
\text { Ordinance Nos. } 907 \text { and 1080. }\end{array}$ \\
1465 & Prevent nuisances and obstruction streets. Approved April 6,1874.
\end{tabular}

On December 15, 1877, five Chinese men were arrested for violating City

Ordinance 1357. This Ordinance was related to Ordinance 1347. See above. The

City continued to have authorities enforce the 550 cubic feet of air per occupant in a sleeping quarter.

1357 Appropriation; General Fund; to suppress and prevent infectious diseases. Approved August 1, 1873. 


\section{POLICE ARREST RECORDS \\ JULY 1877 - JANUARY 1879 \\ MISDEMEANORS AND FELONIES}

Arrests records during this period included additional categories not required in previous years. The following columns were added:

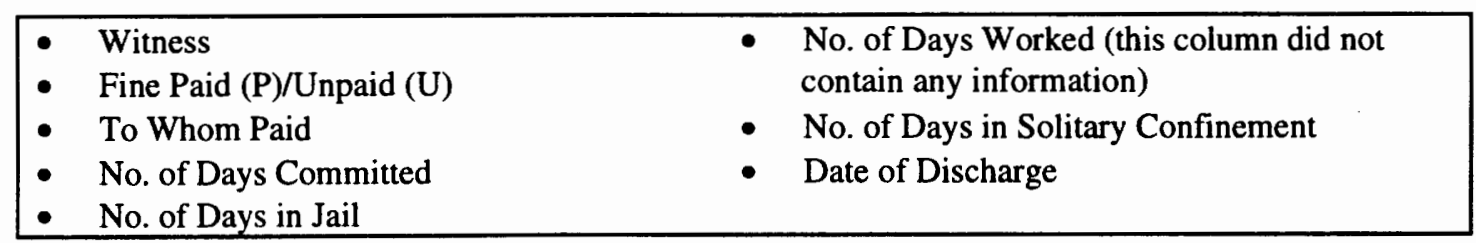

The columns for Complainant and Arrest Time were eliminated.

Arrest charges during this period were repetitious of previous periods observed. However, there were a few cases involving Appeals. See APPENDIX X, p. 2. On November 14, three Chinese women were arrested and charged with keeping a bawdy house. They were each fined fifty dollars, but failed to pay their fines. The Remarks column indicated that they appealed their charges and their Appeal was taken.

This period of arrest records provided information related to the cost of fines. The usual cost of a fine was five dollars. The Police Judge in some cases would impose a fine of ten dollars for the same type of violation. In those situations, the differences in the amount of fines were not indicated.

Most arrest charges were ordinary for that period of time according to laws enforced, whether equitable or inequitable. A case concerning a John Chineman, on March 23, 1878, was not common. See APPENDIX XI, p. 5. John Chineman was arrested and charged with attempt at sodomy. He was held to answer (meaning his 
case was bound over to a higher court), under a bond of $\$ 600$. Of the arrest observed, charges involving sexual misconduct were most uncommon during this period in history.

Many Chinese were arrested for violating Ordinance No. 2177, and fined at above average amounts. The essence of this law was not clear.

2177 Prevention and removal of nuisances. Approved May 2, 1878.

Chinese continued to be arrested for violating Ordinance 1347.

\section{AN ORDINANCE FOR PRESERVATION OF HEALTH}

AND THE PREVENTION OF DISEASE

No. 1347.

The City of Portland does ordain as follows:

Space to each person.

Section 1. That for the purpose of preventing disease and preserving health, it shall be unlawful for any person or persons to use any tenement house or other building used as a sleeping apartment within the city of Portland, which contains less than five hundred and fifty cubic feet of air or space for each and every person lodging in such house or apartment (p. 300)

See APPENDIX X, pp. 8-12. Over 130 Chinese men were arrested for violating this Ordinance. The arrests were conducted by approximately seven officers. Each arrested Chinese man was fined five dollars, jailed for a minimum of one day and possibly committed to a work day. The extent of sentencing depended on whether he paid his fine.. If he paid his fine, he was jailed for one day and released. If he failed to pay his fine, he was jailed for three days, and sentenced to work for one day.

Chinese were also arrested on charges of keeping (an) opium house. See APPENDIX X, pp. 13-16. The amount of fines for allegedly violating this Ordinance varied from one Chinese individual to another Chinese individual. Fines 
ranged in costs from five dollars to $\$ 200$ and were paid and unpaid. Fines that were unpaid resulted in a sentence of approximately twelve days. The following

Ordinance was observed.

To suppress gaming and gambling houses and punish gambling.

6. To prevent and suppress gaming and gambling houses or places where any game, in which chance predominates, is played for anything of value; and to punish any person who engages in such game, or keeps or frequents such a house; to prevent and suppress bawdy house or places where fornication is enacted and to punish any keeper, inmate frequenter thereof; to prevent and suppress opium smoking, and houses or places kept thereof. and to punish any keeper of such house or place, or person who smokes therein or frequents the same (pp. 14-15).

Introducing intoxicating liquor or opium into city jail excepting with permit or on physician's prescription..

Sec. 13. If any person or persons shall introduce or take into the City Jail, or deliver to any prisoner confined therein, any wine, spirituous or malt liquor, or any opium, except by permission of the chief of Police, or upon the prescription of a practicing physician, they shall be guilty of a misdemeanor, and ...(p. 328)

Penalty.

Sec. 13. cont. ...upon conviction thereof before the Police Court shall be fined not less than ten dollars nor more than fifty dollars or imprisoned in the City Jail not less than five nor more than twenty days, or both at the discretion of the Court (p.328). ${ }^{9}$

Any form of gaming and/or gambling was illegal. Chinese were arrested for

this offense. However, arrests observed during this period resulted in dismissals by

the court. There were no explanations. See APPENDIX X, pp. $16 \& 17$. Playing the

lottery was a form of gambling. See p. 19. Ah Put and Ah Ock were arrested on

September 29, 1877, and charged with lottery. These men did not appear to be fined,

but were sentenced to two days in jail.

Gaming and gambling and keeping or setting up gambling houses prohibited.

Sec. 14. It is hereby forbidden and declared unlawful for any person, either as owner, proprietor, manager, employer or lessee, or otherwise to play, deal, set up, open or cause to be carried on,...

p. 329)

Games enumerated.

Sec. 14. cont....or engage in any game of faro, monte, roulette, rogue et noir, rondo, twenty-one, poker, draw poker, bluff, brag, tan, tan tan, or fan fan, for or with anything of value, or for or with anything the

representative of value, whether the said games or any of them be played, dealt, set up, or carried on with cards, checks or any other device,...(p. 329)

Gambling house defined.

Sec. 14. cont. ....in any store, shop, building, hotel or in any room, park, street, or public or private yard or place and it shall be unlawful for any person to bet at or upon any such game or games, and any store, shop, hotel, room or building within which is played, dealt, opened, set upon or carried on in any game mentioned in this section, is to be deemed a gaming and gambling house...(p.329)

9 Ibid., see Ordinance 2959, Section 13, Introducing liquor \&c. in the city jail. 


\section{POLICE ARREST RECORDS \\ December 1879 -October 1881 \\ MISDEMEANORS AND FELONIES}

The categories recorded during this period did not change from the prior

period. Arrest charges remained routine with few exceptions. Sawing wood on the sidewalk was a violation of a City Ordinance. See APPENDIX XI, pp. 1 and 2.

\section{Cutting, splitting and sawing wood on sidewalk.}

Sec. 24. If any person or persons shall cut or split any wood upon the sidewalk of any public place, they shall, upon conviction thereof before the Police Court, be fined not less than five dollars nor more than one hundred dollars (p. 331). ${ }^{10}$

Chinese men were often arrested and charged with violating this Ordinance.

Fines were not stipulated in the record, but offenders were sentenced to time in jail ranging from one to two days. While the cost range of fines was often indicated within the applicable ordinance, failure to pay resulted in the discretion of the Police Judge regarding alternative punishment. This approach resulted in inconsistent fines for violations of the same ordinance.

Chinese, by law could not slaughter nor butcher meat within city limits. In addition, they could only haul swill (garbage) during certain hours of the day. 


\section{Baskets, buckets, bags, etc. suspended from poles carried on side walks.}

Sec. 34. If any person or persons shall carry any basket or baskets, bucket or buckets, bag or bags, or any other thing, suspended from or attached to poles across or upon the shoulders, or shall carry any rubbish, garbage, swill or filth so as to be offensive to pedestrians upon any sidewalk, they shall be deemed guilty of a misdemeanor,...(p. 334)

\section{Penalty.}

Sec. 34. cont. ....and upon conviction thereof before the Police Court, shall be punished by a fine of not less than five dollars not more than fifty dollars (p. 334). ${ }^{11}$

Transporting swill not in tightly covered box or apparatus.

Sec. 38. If any person or persons shall remove, transfer or transport through any of the public streets of the City of Portland any swill or garbage, except it be in a tightly covered box or apparatus, or in such manner as will prevent the contents thereof from being deposited in the public streets, or from being exposed in the open air during such process of transportation, he shall be guilty of a misdemeanor,..(p. 335)

Penalty.

Sec. 38. cont. . ...and upon conviction thereof, shall be fined not less than five (\$5) nor more than (\$25) twenty-five dollars (p. 335). ${ }^{12}$

\section{Transporting swill prohibited during certain hours within certain limits.}

Sec. 39. If any person or persons shall remove, transfer or transport any swill or garbage through any public street of the city north of Harrison street, east of Ninth street and North Tenth street, and south of $H$ street, except between the hours of $9 o^{\prime}$ 'clock evening and $8 o^{\prime}$ clock forenoon during the months of April, May, June, July, August and September, and between the hours of 7 o'clock evening and $9 o^{\prime}$ 'clock forenoon during the months of October, November, December, January, February and March, they shall be deemed guilty of a misdemeanor,...(pp. 335-336). ${ }^{13}$

Penalty.

Sec. 39. cont. ...and on conviction thereof before the Police Court, shall be punished by fine not less than five dollars not more than fifty dollars (p. 336).

This Ordinance and related sections were enacted to target Chinese. The Chinese were the only group to transport goods with the use of yeo ho poles. The law changed from season to season including hourly changes. Chinese immigrants unable to read, or understand the structure and application of such laws must have been clearly confused. The enforcement of this Ordinance was observed throughout arrest and court data.

11 Ibid., see Ordinance 2959, Section 34, Carrying baskets, buckets, \&c. on poles; and rubbish, filth, \&c., on side walks, Penalty.

12 Ibid., see Ordinance 2959, Section 34, Carrying baskets, buckets, \&c. on poles; and rubbish, filth, \&c., on side walks, Penalty.

13 Ibid., see Ordinance 2959, Section 39, Hauling swill through the streets within certain hours, and Penalty. 
Chinese owned and operated numerous laundries. However, such facilities

were not allowed within Portland city limits.

\section{To tax and license slaughter and wash houses.}

24. To license, tax, control and regulate slaughter houses, wash houses and public laundries, and to provide for their exclusion from the city limits or any part thereof (p. 17).

To punish by fine or imprisonment.

37. To provide for the punishment of a violation of any ordinance of the city by fine or imprisonment not exceeding three hundred dollars, or ninety days, or both, or by a forfeiture as penalty not exceeding three hundred dollars, and for working any person sentenced to such imprisonment upon the streets, public squares, work-house or house f correction during the term thereof, and to provide for the punishment of any person sentenced to imprisonment who shall refuse to work when ordered (p. 19).

Sec. 37. The Council has power and authority within the City of Portland-

However, in 1881 , Chinese were allowed to operate a laundry provided they

were licensed. See APPENDIX XI, p. 12. Several Chinese merchants were arrested

for failing to purchase a license. Upon purchasing a license their cases were

dismissed.

To tax and license slaughter and wash houses.

24. To license, tax, control and regulate slaughter houses, wash houses and public laundries, and to provide for their exclusion from the city limits or any part thereof (p. 17).

To punish by fine or imprisonment.

37. To provide for the punishment of a violation of any ordinance of the city by fine or imprisonment not exceeding three hundred dollars, or ninety days, or both, or by a forfeiture as penalty not exceeding three hundred dollars, and for working any person sentenced to such imprisonment upon the streets, public squares, work-house or house fcorrection during the term thereof, and to provide for the punishment of any person sentenced to imprisonment who shall refuse to work when ordered (p. 19).

Sec. 37. The Council has power and authority within the City of Portland-cont.

To license all trades and callings not prohibited by State law.

38. To license and regulate, for the purpose of city revenue, all such business, callings, trades and employments as the Common Council may require to be licensed, and are not prohibited by the laws of the State (p. 19).

Chinese arrested and convicted of felony offenses were sent to County Jail or

held to answer to a higher court. Few offenders were sent to the Penitentiary. See

APPENDIX I. On January 10, 1881, Ah Gee and Ah Sing were arrested, turned over 
to a Sheriff Twombley and taken to the penitentiary. The nature of their offense was not indicated. The records note that a European American was also arrested and taken to the penitentiary. 


\section{POLICE ARREST RECORDS \\ May 1894 - April 1895 \\ MISDEMEANORS AND FELONIES}

Arrest records during this period provided additional information. Several new columns were entered into the record book. However, while the inclusion of this information was insightful, the exclusion of the gender column was not.

- the hour of the arrest

- the recorded no. of the arrest and the page number on which the arrest was recorded.

- the name of the complainant

- where the arrest took place

- the age of the defendant
- the personal property the defendant had in his/her possession

- the amount of money the defendant had in his/her possession

- If bail was set the amount of bail

- the defendant's nativity

Arrest records examined during this period indicated the ages of thoose

arrested. Most of the Chinese men were in their early to mid thirties. There were also several more cases in which the defendant was declared insane. See APPENDIX XII, p. 1.

May 11, 1894, Ah Lin, sent to asylum

May 14, 1894, Chung Koi, sent to asylum at Salem - ran away from poor farm

September 14, 1894, Jim Sing, Held to Sheriff Sears'

September 24, Wo Sing, declared sick and sent to Chinese Hospital

The majority of the arrest charges continued to be mostly routine, again with some exceptions. On October 20,1894, Jung Ching was arrested and charged with kidnapping. he posted bail and was discharged. Several Chinese men were charged with kidnapping throughout this period. See APPENDICES VIII-XII.

There also a few Chinese who were arrested for safety. It is unclear whose safety was being protected, the defendant, or the public. 
Several Chinese were arrested for violating Ordinance No. 2530.

2530. Prohibiting firing of fire crackers. Approved Oct. 2, 1879.

See APPENDIX X, p. 8. Chinese immigrants use firecrackers in many of their religious celebrations. The City Council banned the use of fire crackers. However, while the City Council did not rescind the Ordinance, they provided for special exceptions for Chinese festivities.

3377. Granting Chinese certain privileges. Approved Feb. 3, 1882.

3640. Granting Chinese certain privileges. Approved Dec. 8, 1882.

4129. Granting Chinese residents certain privileges. Approved Jan. 25, 1884.

4486. Granting certain privileges to Chinese residents. Approved Jan. 10, 1885.

4766. Granting Chinese residents certain privileges. Approved Jan. 21, 1886. 


\section{CHAPTER XII CHINESE IMMIGRANTS COURTS OF RECORD - POLICE COURTS ${ }^{1}$}

There were numerous court cases observed involving Chinese immigrants.

While the vast majority of Chinese appeared to receive equitable treatment by the courts, certainly the charges that brought them before the bench were not always just.

Due to the volume of Chinese court records, the following commentary will discuss court cases from a broad view, rather than specifically citing each case.

In felony cases, when found guilty of a crime, the defendant was usually fined and assessed court costs. In the absence of a guilty verdict, the plaintiff, including the State, was required to pay court costs as stipulated in Oregon law.

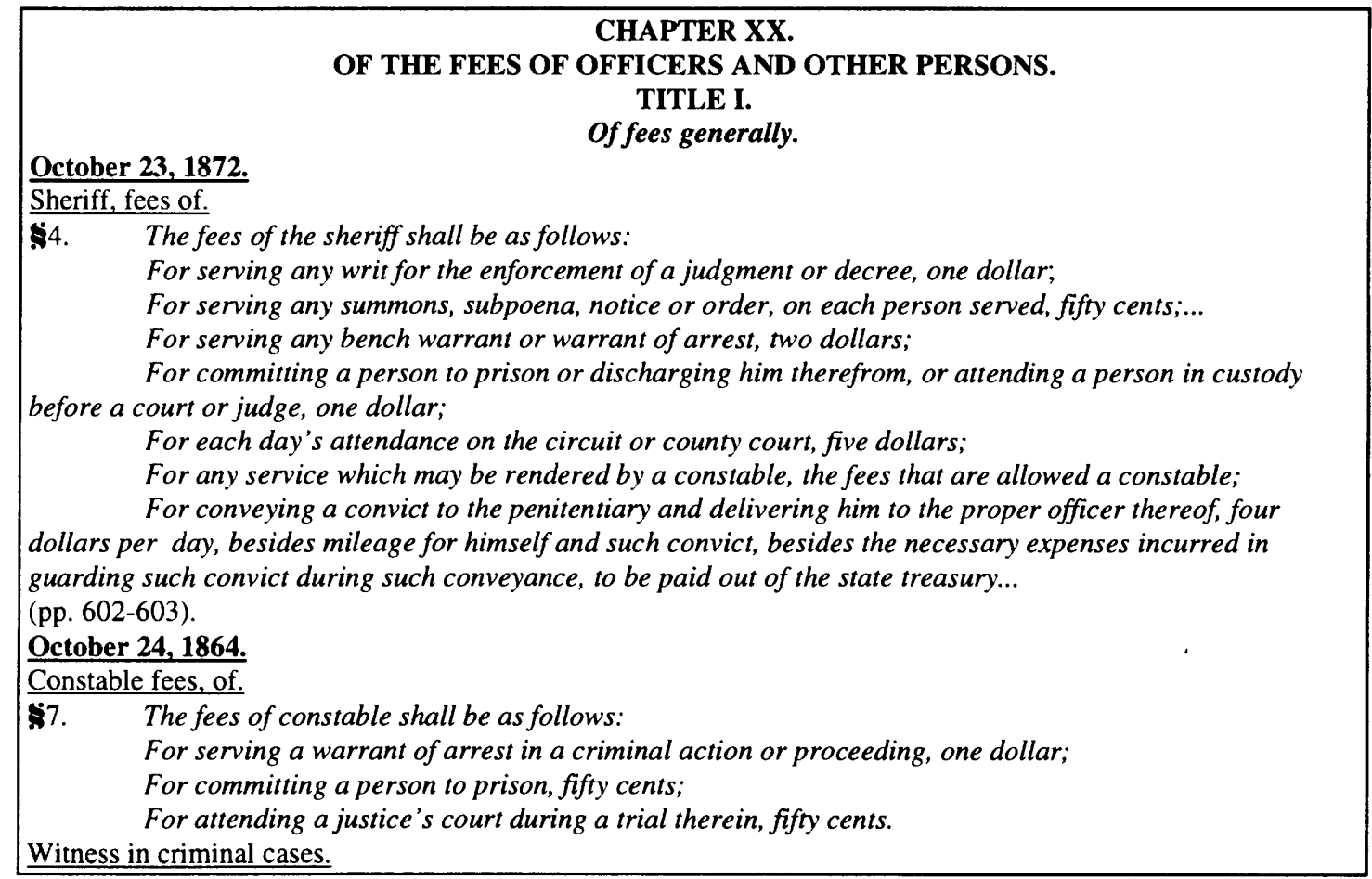

1 Portland was divided into several Precincts. However, which Precinct was involved in the a court case was not indicated in court records observed - see PRECINCTS, CHAPTER III, pp. 36-137. 


\section{CHAPTER XX. \\ OF THE FEES OF OFFICERS AND OTHER PERSONS. \\ TITLE I. \\ Of fees generally.}

October 23, 1872.

$\$ 20$. The county clerk, must, on the application of a witness in a criminal action or proceeding, enter in a fee book, under the title of the action in which the witness was subpoenaed or recognized, the number of days such witness has attended, and the number of miles he has necessarily traveled in consequence of such subpoena or recognizance, and shall swear such witness to the statement contained in such entry...(p. 606).

Fees of District Attorney.

$\$ 116$. The district attorney shall be allowed and receive for every criminal action prosecuted by him in a justice's court, if the defendant is convicted, ten dollars, or if acquitted one half thereof, but if the action is tried by a justice without the intervention of a jury, only one half of such fees...(p. 478).

\section{Expenses of court in certain counties.}

$\$ 14$. The counties having less than ten thousand white inhabitants shall be reimbursed, wholly or in part, for the salary and expenses of the county court, by fees, percentage, and other equitable taxation of the business done in said court, and in the office of the county clerk (p. 89).

Trial and district attorney fees.

$\$ 1031$. Parties to a judicial proceeding, are required to contribute towards the expense of maintaining courts of justice, or particular action, suit or proceeding therein, by the payment of certain sums of money, as provided in this title, which are denominated trial and district attorney fees (p. 313).

Trial fees, amount of, in the several courts.

$\$ 1032$. The trial fee in the several courts is as follows:

1. In the supreme court, upon each appeal heard and determined, six dollars;

2. In the circuit court, for every trial by jury, twelve dollars; for every trial by the court, six dollars, for every judgment or degree given without trial, three dollars;

3. In the county court, one half the amount required in the circuit court in like cases;

4. In justice's court, for every trial by jury, six dollars (p. 313).

District attorney fees.

$\$ 1041$. The district attorney, in addition to the salary and per diem allowed by law, shall receive the following fees:

1. In a criminal action, where the punishment is death or imprisonment for life, if the defendant is convicted, twenty-five dollars, or if acquitted, one-half thereof.

2. In a criminal action, where the punishment is imprisonment in the penitentiary for the term of years, if the defendant is convicted, fifteen dollars, or if acquitted, one half thereof ( $\mathrm{p}$. 314). 


\section{COURT DOCKET RECORDS \\ STATE OF OREGON \\ June 1867 to July 1868 \\ J. J. Hoffman - Recorder \\ FELONIES}

\section{Background 1867}

In 1867 , there were 50,00 Chinese in California, many would eventually migrate to Oregon (Columbia Encyclopedia, p. 540). Mayor Thomas Holmes of the City of Portland in his annual message to the Common Council offered the following recommendations to reduce government costs:

1. Contract with a low bidding hotel for board of prisoners

2. Use convicted prisoners as city laborers

3. Either remove, or heavily tax the Chinese bawdy houses (Tracy, p. 186)

Court cases during this period generally reflect the arrest charges discussed in

CHAPTER XI. In most cases involving Chinese immigrants resulting in a

conviction, fines and assessed court costs were usually paid. When observing the amount of fines levied against Chinese and their associated court costs, most rates appeared to be consistent with the amount of fines and court costs assessed to members of any other racial/ethnic group.

Assault and battery cases usually resulted in fines of five dollars and court costs totaling approximately, ten dollars. While fines and court costs appeared to be equitably applied, guilty verdicts were not. When an assault and battery charge involved a Chinese man assaulting another Chinese man, the verdict was usually, but not always, guilty. Fines spanned a range from five to twenty dollars.

When the assault involved a Chinese man assaulting a white man, the verdict was most often guilty. The fine was usually ten dollars or more. The defendant usually paid. 
However, when the assault involved a white man assaulting a Chinese man, the verdict was most often not guilty. When a white defendant was found guilty of assaulting a Chinese immigrant the fine was usually five to ten dollars. More often than not, however, the defendant failed to pay the fine (court costs were inconsistently indicated for cases resulting in this verdict) and was jailed. There were no notations regarding these inconsistencies. For examples, see APPENDICES XIII-XXI.

After reviewing available court records, there were other differences observed regarding posting bail. Most Chinese granted the offering of bail (language representative of the period), were assessed exorbitant amounts. Bail could be assessed from $\$ 200$ to over $\$ 500$. In many cases the Chinese individual involved posted the bail money. In addition, the court recorder usually indicated when bail moneys were returned. Such notations were often not indicated in the cases involving Chinese defendants.

Chinese immigrants were charged on numerous occasions with the following criminal violations:

\begin{tabular}{|ll|}
\hline - larceny & conducting a gambling device \\
- feloniously taking away material objects & - keeping a house of ill fame (bawdy house \\
- defacing property & - robbery, \\
\hline
\end{tabular}

However, the most prevalent charge was assault and battery. Most of these charges involved Chinese assaulting Chinese. On rare occasions Chinese were accused of assaulting white men (no notations to the contrary). For example, see 
APPENDIX XIII, p. 19. The case of the State of OR v. Sung Wa, April 23, 1868. Sung Wa was charged with assault and battery against David C. Layfield, he plead not guilty, was convicted, fined ten dollars plus court costs of nineteen dollars and ninety cents, for a total of twenty-nine dollars and seventy cents. 


\section{COURT DOCKET RECORDS \\ STATE OF OREGON \\ August 1868 to July 1870 \\ J. J. Hoffman Ex-Officio Justice of the Peace \\ FELONIES}

\section{Background - 1868}

The Burlingame Treaty with China guaranteed the right of Chinese immigration; it did not however, grant the right of naturalization (Columbia Encyclopedia, p. 540). In Portland, Oregon, over 600 arrest occurred in 1868, the majority for assaults, and disorderly conduct....Four additional policemen were employed to guard the quarantined Chinese ...(Tracy, pp. 199-200).

During 1868 the Chinese continue to be targets of assault both within their own racial group, and by whites (no notations to indicate the contrary). Chinese also continue to attack white men. Fines for such attacks appeared to equally applied to all groups. See APPENDIX XIV. 


\section{COURT DOCKET RECORDS}

STATE OF OREGON

August 1868 to July 1870

\section{J. J. Hoffman Ex-Officio Justice of the Peace}

FELONIES

\section{Background 1869}

Portland, Oregon's population was estimated to be between 9,000 to 10,000 inhabitants. The cost to operate the City's government was increasing and news ideas were needed to generate revenue. Yet, effort was made to establish a day and night police force (Tracy, pp. 201-209).

There was one unusual case during this time period. See APPENDIX XIII, $\mathrm{p}$.

11. In the case of the State of OR v. Sun Sing, May 5, 1869, the defendant was charged with larceny. Sing was accused of ...failing, refusing and neglecting to return on demand four towels which he had been entrusted to wash at one dollar each...(Court Record 21-05-38/2. Portland City Archives, p. 224).

The towels were the property of the Philharmonic Society. The charges were filed by Enno Cavelia, a negro. It was assumed Cavelia was employed by the Philharmonic Society. Sing plead not guilty, was convicted and fined twenty-five dollars. Court costs were not indicated. The defendant appealed his charges to the Circuit Court of Appeals.

On the same page as the Sing case, was the case of State of OR v. Lung, May 29,1869 . Lung was charged with larceny, by feloniously taking and carrying away one American flag and a number of preserve bottles, valued at ten dollars. Lung plead not guilty, was convicted and fined twenty-five dollars. Again, as in the former case, Court costs were not stipulated. Lung failed to pay the fine and was jailed for ...one calendar month. 
Chinese were often denied opportunity to purchase property. However, in State of Or v Wm. Husband, June 3, 1869, The defendant was accused of breaking glass in (a) building, the property of Hop Chung. Husband plead guilty, was fined ten dollars, paid the fine and court costs (which were not indicated) and was discharged. 


\section{COURT DOCKET RECORDS}

STATE OF OREGON

August 1868 to July 1870

\section{J. J. Hoffman Ex-Officio Justice of the Peace}

FELONIES

\section{Background 1870}

Portland, Oregon's Mayor Goldsmith, continued to acknowledge the need for additional police in his annual message. The crime problem was reported to be in need of emergency action (Tracy, p. 203).

The Board of Police Commissioners was established by the Common Council on October 15, 1870 (Tracy, p. 210).

Despite Mayor Goldsmith's warning regarding an increase in crime, there were an unusually low number of cases involving Chinese persons through July of 1870. Of the cases examined, none were particularly unusual. 


\section{COURT DOCKET RECORDS \\ STATE OF OREGON \\ December 1874-March 1880. \\ O. N. Denny, Police Judge \\ FELONIES}

\section{Background 1874}

See APPENDIX VII, of this document, p. 35, for specific information regarding the following case. On April 7, 1874, in Portland, Oregon, fifteen European American women were arrested for praying on a public street - 1 st and Morrision. These women were members of the Women's Temperance Prayer League. Their purpose was to rid the town of saloons (Tracy, pp. 252154). On April 17, six of the women were arrested, five failed to pay their fine and were sentenced to one day in jail. They were discharged late that night without escorts (Tracy, p. 253). The initial treatment by authorities of these assembled women was not the same as the treatment of assembled Chinese. The Chinese (men or women) were more vigorously pursued than their white counterparts for breaking essentially the same Ordinance. See CHAPTER XI, p. 260.

The use of an interpreter was observed during this time period. Interpreters were Chinese. This law was enacted in 1862, but was not indicated in records until the year 1874. There was an air of animosity among many Chinese inhabitants. This was evidenced in the number of assault perpetrators against each other. As such, the use of a Chinese as an interpreter of another Chinese was no assurance of fair representations. One defendant was at the mercy of the interpreter. The defendant had no means of knowing if his statements and best interest were accurately translated. In addition, the court had no valid means of determining if the information provided was factual.

TITLE VII.

October 11, 1862.

of the general rules of examination.

Interpreter sworn, when.

\$822. When a witness does not understand and speak the English language, an interpreter shall be sworn to interpret for him (p. 273). 
Oregon's provision was adopted in 1862, while Portland's Ordinance was not established until 1885 . See the following:

4731. Providing for appointment and compensation interpreter Police Court. Approved Nov. 20, 1885

AN ORDINANCE TO PROVIDE FOR THE APPOINTMENT AND COMPENSATION OF AN INTERPRETER IN THE POLICE COURT.

4731.

The City of Portland does ordain as follows:

Police Judge to appoint interpreter for Police Court.

Section 1. The Police Judge is hereby authorized to appoint an interpreter in all cases tried before him in which the city is a party, when the services of an interpreter are necessary (p. 346).

Compensation of Interpreter.

Sec. 2. Such interpreter shall receive the sum of one dollar and fifty cents (\$1.50) per day, for each day actually employed (p. 346).

Police Judge to make report of service monthly to council.

Sec. 3. The Police Judge shall make a report at the end of each month in the Common Council of the number of days any person have been employed as interpreter...(p. 346)

During this six year period, Chinese persons continued to be charged with felonious conduct. However, sentencing terms were gradually extending. It was not unusual, in lieu of payment, for an offender to be sentenced from thirty to sixty days in jail. See APPENDIX XV. See the following cases occurring in 1875. 


\section{COURT DOCKET RECORDS \\ STATE OF OREGON \\ December 1874-March 1880. \\ O. N. Denny, Police Judge \\ FELONIES}

\section{Background 1875}

Portland, Oregon's Population is estimated at 13,000 . The crime rate was reportedly stable. A policing system was firmly in place (Tracy, p. 216).

In the case of The State of Or v. Ah Gon, January 4, 1875, the defendant was accused of stealing one pair of pants valued at six dollars. While Ah Gon plead not guilty, he was convicted. However, while the amount of his fine was not indicated, he was jailed for a period of thirty days. See APPENDIX XV, p. 2.

In another case, State of Or v AH Pan, January 15, 1875, the defendant was accused of stealing a coat, valued at twenty dollars. Ah Pan plead not guilty, was convicted, but his fine was not indicated. He was committed to sixty days in jail. See APPENDIX XIV, p. 3.

In the case of the State of OR v. Ah Gee, March 29,1875, the defendant was charged with larceny. Gee was accused of stealing one box of raisins valued at one dollar and fifty cents. He plead not guilty, was convicted, fined twenty-five dollars. Gee failed to pay the fine (court costs were not indicated) and was jailed for twenty days. The fine for Guilt of assault and battery charges was usually five dollars and failing to pay resulted in less time in jail. See APPENDIX XV, p. 6.

Chinese were accused of feloniously taking many items of clothing and/or other personal objects not their own. While some charges were dismissed, many 
were not. In the case of the State of Or v. John Chinaman (Ah Ton), May 11, 1875, the defendant was accused of stealing an umbrella. See APPENDIX XV, p. 7. Ah Ton plead not guilty, was convicted and fined five dollars. He failed to pay and was sentenced to thirty days in jail.

The following data are inserted for reference - in all cases the defendant was convicted unless otherwise stated: See APPENDIX XV.

\begin{tabular}{|c|c|c|c|c|}
\hline NAME & DATE & PAGE & CHARGE & $\begin{array}{c}\text { FINE + COURT COSTS } \\
\text { /SENTENCE }\end{array}$ \\
\hline Ah Fook & $4 / 13 / 1875$ & 7 & stealing 5 bars of soap & dismissed \\
\hline Murphy (Chinaman) & $5 / 5 / 1875$ & 7 & $\begin{array}{l}\text { stealing } 10 \text { white shirts }(\$ 5) \text {, } \\
\text { I linen shirt }(\$ 2), 6 \text { pr. socks } \\
(\$ 3) 2 \text { pairs of pants ( } \$ 4) 6 \\
\text { handkerchiefs }(\$ 5)\end{array}$ & dismissed \\
\hline Ah Coon & (not indicated) & 8 & 35000 cigars & held for Circuit Court \\
\hline Ah Yen & (not indicated) & 9 & 3 sheets (bed linen) & $\$ 37.00 / 13$ days in jail \\
\hline Jim Chung & $10 / 7 / 1875$ & 11 & 1 pr. of boots $(\$ 10)$ & $\$ 17.40 / 90$ days in jail \\
\hline Ah Hock & (not indicated) & 12 & 1 coat $(\$ 8), \$ 52$ in US coins & dismissed \\
\hline Ah Lim & $11 / 4 / 1875$ & 12 & $\begin{array}{l}1 \text { satchel, } 1 \text { coat, } 1 \text { vest, } 1 \\
\text { parget, revolver, silver plate, } \\
\text { shirt, pr. socks, etc. }\end{array}$ & $\begin{array}{l}\$ 9.95 / \text { bail set at } \$ 250 \\
\text { held for Circuit Court }\end{array}$ \\
\hline Ah Chin \& Ah Pang & $11 / 10 / 1875$ & 13 & $\begin{array}{l}\text { basket, clothes, China shoes, } \\
\text { China slippers, China cigar }\end{array}$ & $\$ \$ 16.65 /$ Bail $\$ 200$ \\
\hline Sing Unpe & $12 / 6 / 1895$ & 15 & $\$ 5$ in silver coins & $\$ 32.40 /$ paid -discharged \\
\hline Toy Kum & (not indicated) & 16 & $\begin{array}{l}\$ 150 \text { in gold \& silver coins, } \\
1 \text { China blanket, } 1 \text { China } \\
\text { pillow }\end{array}$ & $\$ 12.60 /$ discharged \\
\hline
\end{tabular}




\section{COURT DOCKET RECORDS \\ STATE OF OREGON \\ December 1874-March 1880. \\ O. N. Denny, Police Judge \\ FELONIES}

\section{Background 1876}

There is a flood on front Street, in Portland. Oregon. Portland puts in public sewers and street lamps. Liquor is not permitting to be given to jailed offenders (Maddux, p. 57, and Laws of Portland, p. 461).

There was a case involving charges of murder. In the case of the State of Or v. Oung Sling, March 10 and 14, 1876, the defendant was accused of murdering Moy Chung. The state had five witnesses including two who were Chinese. The defendant had eight witnesses including no Chinese. The names of witnesses were used to decide race/ethnicity. Moy Hing was employed as interpreter. The defendant requested an examination and did not enter a plea. He was committed to jail until his trial.

There were additional cases involving the stealing of personal items with unusual jail terms. In the case of the State of Or v. Moy Foy, July 6, 1876, the defendant was accused of ...maliciously and wantonly injuring and destroying a kite by stomping, kicking, tearing and breaking it... Moy Foy plead not guilty, was convicted, fined fifty dollars and court costs of seventeen dollars and twenty-five cents, for a total of sixty-seven dollars and twenty-five cents. Moy Foy failed to pay and was sentenced to jail for twenty-five days. See APPENDIX XIV to observe additional cases. 


\section{COURT DOCKET RECORDS \\ STATE OF OREGON \\ December 1874-March 1880. \\ O. N. Denny, Police Judge \\ FELONIES}

\section{Background 1877}

In 1877 Chinese riots occurred in San Francisco and efforts were put in place to ban Chinese immigration. A tax of .005 was levied by Portland, Oregon by the City Council. Also. in Portland, there was a Physician's Report regarding infectious diseases and additional licensing was imposed (Laws of Portland, pp. 462-481)

Chinese persons continued to be accused of larceny and feloniously taking personal items. Assault and battery continued to be the most predominate violation. The use of an interpreter appeared to be firmly established. However, records did not indicate how effective interpreters were

In 1877, there was an increase observed in the number of court appeals. This was indicated by a request for examination. Chinese defendants were granted their requests by posting bail. Posted bail was usually about $\$ 400$ to $\$ 600$. 


\section{COURT DOCKET RECORDS \\ STATE OF OREGON \\ December 1874-March 1880. \\ O. N. Denny, Police Judge \\ FELONIES}

\section{Background 1878}

In Portland, Oregon, Ordinance No. 2116 was enacted by the City Council as a means to Preserve health and prevent disease. In addition, Ordinance No. 2121, aimed at Public health was also enacted and Ordinance 2177, Prevention and removal of nuisances (Laws of Portland, pp. 471-481). The enforcement of these Ordinance mostly targeted Chinese persons.

Court cases observed occurring in 1878 were not dramatically any different than Court cases observed occurring in prior years. The one difference observed is that more cases were being bound over to Circuit Courts. Jail terms continued to increase and bail posting were extremely costly - in the range of $\$ 300$ to $\$ 500$. Chinese defendants were usually able to post these bailed amounts.

Another murder case was observed during this year. In the case of the State of OR v Lee Chung and Lee Quang, (date not indicated), the defendant was accused of murdering Chin Toung. A Moy Chung was murdered in 1876 - see case previously cited in this chapter. The defendant was accused of chopping the victim with a hatchet and shooting with a pistol. The State had three witnesses each of whom were required to post $\$ 100$ bail to ensure their Court appearance as witnesses. There were no witnesses indicated for the defendant. An interpreter was not engaged. There was sufficient evidence to believe the defendant guilty and he was held in Multnomah County Jail for the Circuit Court. 
There were also cases where one person would file a complaint against another person on charges for example of assault. The accused could compensate the complainant for their injuries, or loss in the case of larceny. If the complainant was satisfied with the settlement, the Court would dismiss the charges. See for example, APPENDIX XV, p. 52, State of Or v. Ah Jack, October 18, 1878.

Other cases examined that occurred during 1878 were generally not unusual. 


\section{COURT DOCKET RECORDS \\ STATE OF OREGON \\ December 1874-March 1880. \\ O. N. Denny, Police Judge \\ FELONIES}

\section{Background 1879}

The United States Congress passed a Bill banning Chinese immigration. However, President Hayes vetoed the Bill on the grounds that it vetoed the Burlingame Treaty - see 1868, this Chapter (Columbia Encyclopedia, p.540). Portland, Oregon City Council enacted Ordinance No. 2364, Concerning offenses and disorderly conduct...and Ordinance No. 2364, Licensing and regulating barrooms and drinking shops ...Ordinance No. 2366, Prevention of removal of nuisances...Ordinance No. 2405, Authorizing contract to board prisoners... Ordinance No. 2417, the use of bean shooters was prohibited...Ordinance No. 2499 to Secure protection of property and provided for cleanliness and ornament of City...Ordinance No. 2509, prohibited bathing within City limits...Ordinance No. 2510, prohibited driving of swill carts certain hours (Laws of Portland, pp. 481-191).

There were no unusual cases observed during this period. 


\section{COURT DOCKET RECORDS \\ STATE OF OREGON \\ December 1874-March 1880. \\ O. N. Denny, Police Judge \\ FELONIES}

\section{Background 1880}

In 1880 , the United States entered into anew treaty with China. The treaty allowed the United States to regulate, limit or suspend the entry of Chinese labor but not to prohibit it (Columbia Encyclopedia, p. 540). In Portland, Oregon, the City Council enacted Ordinance No. 2678, to Protect public contagious or dangerous diseases..., Ordinance No. 2806, Prohibited from minors from roaming streets...Ordinance No. 2927, Prohibited suspension signs and transparencies over sidewalks (Law of Portland, pp. 491-509).

There was one circumstance that was somewhat different than most cases observed during this period. See APPENDIX XV, p. 74. In the case State of OR v. Long Ling Dow, (trial date not indicated), the defendant was charged with assault and battery. The complainant Ah Ding filed the charges, but failed to appear. The defendant was discharged. Of all the cases observed, there few cases where a complainant failed to appear. 


\section{PORTLAND COURT DOCKET RECORDS \\ JUNE 1867 TO AUGUST 1870 \\ J. J. HOFFMAN- POLICE JUDGE \\ MISDEMEANORS}

Most misdemeanor Court cases involving Chinese persons dealt with being

drunk and disorderly, disturbing the peace, or similar acts. Most of these charges

were a matter of discretion on the part of the arresting and complaining officer.

Fines ranged from five to ten dollars, with associated Court costs of approximately

ten to twelve dollars.

There were also cases involving peddling without a license. Initially, the City

allowed peddlers to sell their wares without the need to be licensed. However, as the

City's financial needs increased, there was pressure to license all merchants.

\begin{tabular}{|c|c|}
\hline 4. & $\begin{array}{l}\text { To impose license upon drinking places, taverns, shows, billiard tables, etc., Approved April } 20 \text {, } \\
\text { 1854. Repealed by Ordinance No. } 57 .\end{array}$ \\
\hline 5. & $\begin{array}{l}\text { To impose licenses on hawkers, peddlers, brokers and pawnbrokers. Approved April 20, } 1854 . \\
\text { Amended by Ordinance No. } 124 \text {. Repealed by Ordinance No. } 170 .\end{array}$ \\
\hline 170. & $\begin{array}{l}\text { To impose and regulate licenses. Approved January 13, } 1865 . \text { Amended by Ordinances Nos. } \\
312,334,393,395 \text { and } 722 \text {. Repealed by ordinance No. } 984 \text {. }\end{array}$ \\
\hline 312. & To amend Ordinance 170. Approved March 29, 1866. Repealed by Ordi \\
\hline 334. & $\begin{array}{l}\text { Too amend Ordinance No. 170, In force as per section } 45 \text { of Charter, may } 13,1866 . \\
\text { Amended by Ordinance No. } 361 \text {. Repealed by Ordinance No. } 387 .\end{array}$ \\
\hline 393. & To amend Ordinance No. 170. Approved Jan. 25, 1867. Repealed by Ordinance No. 984. \\
\hline
\end{tabular}

The previously cited Ordinances regulated licensing for most merchants.

Obstructing the side walk and cutting wood upon the sidewalk were other violations

for which Chinese were often accused. See APPENDIX XVI and the following:

22. To prevent and remove obstructions from the streets and sidewalks. Approved September 4, 1854. Superseded by Ordinance No. 142.

22. To prevent and remove obstructions from the streets and sidewalks. Approved September 4, 1854. Superseded by Ordinance No. 142.

To prevent and remove obstructions from streets and sidewalks. Approved June 13,

142. 1863. Amended by Ordinances Nos. 579 and 921 .

313. To prevent and remove obstructions to sidewalks. Approved March 29, 1866. 
Portland ordinances specifically stated what acts were prohibited. Most actions were targeted Chinese residents and their native customs.

\section{Cutting, splitting and sawing wood on sidewalk,}

Sec. 24. If any person or persons shall cut or split any wood upon the sidewalk of any public place, they shall, upon conviction thereof before the Police Court, be fined not less than five dollars nor more than one hundred dollars (p. 331). ${ }^{2}$

Baskets, buckets, bags, etc. suspended from poles carried on side walks.

Sec. 34. If any person or persons shall carry any basket or baskets, bucket or buckets, bag or bags, or any other thing, suspended from or attached to poles across or upon the shoulders, or shall carry any rubbish, garbage, swill or filth so as to be offensive to pedestrians upon any sidewalk, they shall be deemed guilty of a misdemeanor....(p. 334)

$2 \quad$ Ibid., As amended by Ordinance No. 4561, approved April 2, 1885. 


\section{COURT DOCKET RECORDS}

CITY OF PORTLAND

August 1870-April 1871

Sin Anderson-Recorder - Ex Officio Justice of the Peace MISDEMEANORS

Most Portland Court cases observed of the period were generally not unusual.

The same prevailing charges against Chinese were repeated., that is, being loud and boisterous, being drunk and disorderly, and assault and battery. See APPENDIX XVII.

The case of City of Portland v. Ah Fung, February 23, 1871, p. 5, was somewhat different. Ah Fung was accused of violating Ordinance No. 475, Concerning offense and disorderly conduct. However, the exact nature of the violation was not indicated. Ah Fung plead not guilty, was found not guilty and discharged. The complainant, Ah Jim, failed to appear at trial. This response was unusual for Chinese complainants. Records indicated if a Chinese individual filed a complaint, they appeared at trial, perhaps in pursuit of their day in court. 


\section{COURT DOCKET RECORDS \\ CITY OF PORTLAND \\ July 1871-October 1873 \\ O. N. Denny - Police Judge \\ MISDEMEANORS}

Most court cases observed during this period did not involve unusual

circumstances. The case of City of Portland v. China John, November 2, 1872,

involved unusual charges. See APPENDIX XVIII, p. 23. China John was accused of indecently exposing his person. There were several cases observed in which members of each studied racial/ethnic group were charged with this violation. It was unclear if this behavior was associated with being drunk and disoriented, having bladder difficulties, sexual misconduct, or if the individual was sexually deviant.

There were laws prohibiting minors from wandering the streets after nine o'clock in the evening.

\section{Minor wandering about streets after 9 o'clock at night without permission of guardian or parent, unless on necessary business. \\ Sec. 20. That no minor shall be permitted to go abroad upon or wander about the street of the city after the hour of nine o'clock at night, unless such minor shall have the permission of his or her guardian, or parent, or shall be accompanied by such parent or guardian, or unless such minor shall have necessary business upon such street or streets, and any minor who shall violate the provisions of this section shall be deemed guilty of a misdemeanor, and upon conviction thereof in the Police Court,..(p. 330) \\ Penalty. \\ Sec. 20. cont. ....shall be punished by fine not less than five dollars nor more than one hundred dollars (p. 330). ${ }^{3}$}

For example, see City of Portland v. John Chinaman, December 16, 1872.

See APPENDIX XV, p. 25. John was charged with wandering around the street after ten o'clock in the evening having no known occupation. He plead guilty, was

3 Ibid., see Ordinance 2959, Section 20, Minors on the street after 9 at night prohibited. 
convicted, and fined five dollars. He paid the fine and was discharged. It was assumed that John Chinaman was a minor since the Ordinance banning adults from roaming the streets did not do into effect until midnight.

Ordinance 3983, prohibited adults from roaming the streets after midnight.. It was unclear if this law was for the protection of the community, or the individual.

AN ORDINANCE CONCERNING OFFENSES AND DISORDERLY CONDUCT. No. 3983.

The City of Portland does ordain as follows:

Roaming about the streets after 12 o'clock at night without business prohibited.

Sec. 21. If any person or persons shall be found roaming about the streets at night, after the hours of 12 'clock, without having any lawful business upon the streets at that time, they shall be deemed guilty of a misdemeanor, and upon conviction thereof before the Police Court,...(p. 331)

Penalty.

Sec. 21. ...shall be punished by fine of not less than ten dollars nor more than one hundred dollars ( $\mathrm{p}$. $331)$.

In the case of the City of Portland v. Chinaman, November 19, 1872, the defendant was charged with wandering the streets after twelve o'clock midnight. The defendant plead guilty, was convicted, and fined five dollars. However, failing to pay the fine he was sentenced to the City Jail for three days.

During the winter when Chinese farm workers were unemployed, several Chinese men, without sleeping quarters and no means of income, often wandered the streets at night. Such individuals were not labeled vagrant, because while they had no means of support, they usually had some moneys, although not enough to rent an apartment. These men were arrested, convicted and fined for their lack of a residency. Perhaps these men would be classified as the homeless in the 1990's. See cases in the year 1882 regarding this same issue and violation. 
There were four cases involving Chinese charged with sleeping in a room having less than 550 cubic feet of air per person. See APPENDIX XV, p. 39. The case , City of Portland v. several Chinese individuals, June 27, 1873. There were approximate forty defendants. All four cases were tried on the same day. The defendants plead not guilty, were convicted and each fined five dollars. A few of the defendants paid their fines and were discharged. Those that failed to pay their fines were jailed for three days.

Portland residents were required to clean the street in front of their premises. Failure to do so, resulted in arrest and if convicted, a fine.

52. Providing for the cleaning of streets. Approved May 19, 1856. Amended by Ordinance No. 57. Superseded by Ordinance No. 302.

302. To provide for cleaning streets. Approved February 22, 1866. Repealed by Ordinance No. 936.

302. To provide for cleaning streets. Approved February 22, 1866. Repealed by Ordinance No. 936.

936. To provide for cleaning streets. Approved February 18, 1871.

936. To provide for cleaning streets. Approved February 18, 1871. 


\section{COURT DOCKET RECORDS \\ CITY OF PORTLAND \\ November 1873-June 1877 \\ O. N. Denny - Police Judge \\ MISDEMEANORS}

Most cases observed for this period did not involve any unusual

circumstances.

Sawing wood upon the side walk was a violation of a Portland City Ordinance

Cutting, splitting and sawing wood on sidewalk,

Sec. 24. If any person or persons shall cut or split any wood upon the sidewalk of any public place, they shall, upon conviction thereof before the Police Court, be fined not less than five dollars nor more than one hundred dollars (p. 331). ${ }^{4}$

There were several cases involving convicted violations of this Ordinance. It is assumed that charges levied in the winter involved individuals cutting wood for fire. The usual fine was five dollars and failing to pay, resulted in two to three days in jail. See APPENDIX XIX.

In the case of the City of Portland v. Ah Ching, April 25, 1874, p. 14, the defendant was charged with resisting arrest by Officer J. W. Kelly. Ah Ching plead not guilty, was acquitted and discharged.

Cases observed for the years 1876 and 1877 , did not reveal many unusual incidents. In the case of the City of Portland v. (forty different Chinese individuals), September 5, 1876, the defendants were charged with using s tenement house as a sleeping apartment which contained less than 550 cubic feet of air per person. They plead not guilty, were convicted and fined. Two of the defendants paid their fine and

$4 \quad$ Ibid., As amended by Ordinance No. 4561, approved April 2, 1885. 
were discharged. Three defendants failed to pay and were jailed. The remaining defendants paid two dollars and were jailed for three days. 


\section{COURT DOCKET RECORDS \\ CITY OF PORTLAND \\ August 1879-August 1881 \\ O. N. Denny - Police Judge \\ MISDEMEANORS}

Cases observed during this period reflected the same basic charges as seen in

previous periods. The Chinese were often arrested and charged with keeping an

opium house.

Introducing intoxicating liquor or opium into city iail excepting with permit or on physician's prescription..

Sec. 13. If any person or persons shall introduce or take into the City Jail, or deliver to any prisoner confined therein, any wine, spirituous or malt liquor, or any opium, except by permission of the chief of Police, or upon the prescription of a practicing physician, they shall be guilty of a misdemeanor, and ...(p. 328)

Penalty.

Sec. 13. cont. ....upon conviction thereof before the Police Court shall be fined not less than ten dollars nor more than fifty dollars or imprisoned in the City Jail not less than five nor more than twenty days, or both at the discretion of the Court (p.328). ${ }^{5}$

To suppress gaming and gambling houses and punish gambling.

$6 . \quad$ To prevent and suppress gaming and gambling houses or places where any game, in which chance predominates, is played for anything of value; and to punish any person who engages in such game, or keeps or frequents such a house; to prevent and suppress bawdy house or places where fornication is enacted and to punish any keeper, inmate frequenter thereof; to prevent and suppress opium smoking, and houses or places kept thereof. and to punish any keeper of such house or place, or person who smokes therein or frequents the same (pp. 14-15).

Sec. 37. The Council has power and authority within the City of Portland-.

Fines for this violation were higher than most fees, usually over thirty dollars, however, there were inconsistencies in assigning fines. See APPENDIX XX. For example, see APPENDIX XX, p. 3. In the case of the City Of Portland v. Ah Sing, September 1, 1879, the defendant was charged with keeping an opium house. Ah Sing plead not guilty, was convicted and fined two dollars. Ah Sing paid the fine and was discharged.

5 Ibid., see Ordinance 2959, Section 13, Introducing liquor \&c. in the city jail. 
However, in the case of the City of Portland v. Ah Yune, September 12, 1879, (just eleven days later), the defendant was also charged with keeping an opium house. Ah Yune plead guilty (reducing the court's time in trying the case) and was fined forty dollars. Ah Yune paid six dollars, but was committed to City Jail for seventeen days. 


\section{COURT DOCKET RECORDS \\ CITY OF PORTLAND \\ September 1881-August 1882 \\ O. N. Denny - Police Judge \\ MISDEMEANORS}

Members of the Chinese community practiced many traditional customs

acquired from their homeland. They carried many items in baskets attached to yeo-

ho poles, which they balanced across their shoulders. The Portland City Council

enacted an Ordinance banning this practice. Since Chinese were the major users, if

not the only users, of this routine, the following ordinance specifically targeted

members of their community.

\section{Baskets, buckets, bags, etc. suspended from poles carried on side walks.}

Sec. 34. If any person or persons shall carry any basket or baskets, bucket or buckets, bag or bags, or any other thing, suspended from or attached to poles across or upon the shoulders, or shall carry any rubbish, garbage, swill or filth so as to be offensive to pedestrians upon any sidewalk, they shall be deemed guilty of a misdemeanor,...(p. 334)

Penalty.

Sec. 34. cont. ....and upon conviction thereof before the Police Court, shall be punished by a fine of not less than five dollars not more than fifty dollars (p. 334). ${ }^{6}$

Transporting swill not in tightly covered box or apparatus.

Sec. 38. If any person or persons shall remove, transfer or transport through any of the public streets of the City of Portland any swill or garbage, except it be in a tightly covered box or apparatus, or in such manner as will prevent the contents thereof from being deposited in the public streets, or from

being exposed in the open air during such process of transportation, he shall be guilty of a misdemeanor,...(p. 335)

Penalty.

Sec. 38. cont. ...and upon conviction thereof, shall be fined not less than five (\$5) nor more than (\$25) twenty-five dollars (p. 335). ${ }^{7}$

For an example of the enforcement of this law, see APPENDIX XXI, p. 4.

The case of, City of Portland v. China Sam, October 31, 1881, the defendant was charged with carrying articles on poles on sidewalk. China Sam's plea was not

6 Ibid., see Ordinance 2959, Section 34, Carrying baskets, buckets, \&c. on poles; and rubbish, filth, \&c., on side walks, Penalty.

Ibid., see Ordinance 2959, Section 34, Carrying baskets, buckets, \&c. on poles; and rubbish, filth, \&c., on side walks, Penalty. 
indicated but he was required to post bail. China Sam posted bail of five dollars, failed to appear for his trial and therefore forfeited his bail.

On the same page, In the case of the City of Portland v. Lung Doro, October 15,1881 , the defendant was accused of the same violation. Lung Doro plead guilty, was fined five dollars, paid his fine and was discharged.

Another insightful case may be viewed in APPENDIX XXI, p. 13. The case of City of Portland v. Jim Chinaman, Ah Chia, Cham Jung, AH Young, Ah Juna, Joe China, Ah Wa, Ah Yon, Lee Lin, Ah Coon ${ }^{8}$, and Ah Ging, November 21, 1881, were charged with standing on the sidewalk in large and obstructing passage on the same. The defendants plead not guilty, were acquitted and discharged. However, there were three witnesses testifying against them who names appear those of white men (no indication to the contrary), at least one of whom was a policeman. The defendants were represented by an attorney, Badbars, esq. (no other name given). This policing response is still in practice in the 1990's. Often when several minorities convene in one area, there is an immediate concern about misconduct.

In 1872 , there were cases cited involving the arrest of adults roaming the streets after midnight without any lawful reason.

AN ORDINANCE CONCERNING OFFENSES AND DISORDERLY CONDUCT. No. 3983. The City of Portland does ordain as follows: Roaming about the streets after 12 o'clock at night without business prohibited. Sec. 21. If any person or persons shall be found roaming about the streets at night, after the hours of 12 'clock, without having any lawful business upon the streets at that time, they shall be deemed guilty of a misdemeanor, and upon conviction thereof before the Police Court,...(p. 331)

Penalty.

Sec. 21. ...shall be punished by fine of not less than ten dollars nor more than one hundred dollars (p. 331).

$8 \quad$ The word coon, was (and is) considered a racial slur within the black community. It was unclear if this was his exact name, a derivation of his name or a deliberate disparaging statement. 
In 1882 , several Chinese were arrested for sleeping on the property

of...premises without the owner's permission. For an example, see APPENDIX XX,

p. 27. In the case of the City of Portland v. Ah Lim, May 8, 1882, the defendant was

charged with violating the stated condition. The particular ordinance was not cited.

Ah Lim's plea was not indicated, however, he was convicted and fined ten dollars.

Ah Lim failed to pay the fine and was jailed for a maximum of five days. His

sentence could have been reduced upon payment of the fine or a portion thereof.

Baskets, buckets, bags, etc. suspended from poles carried on side walks.

Sec. 34. If any person or persons shall carry any basket or baskets, bucket or buckets, bag or bags, or any other thing, suspended from or attached to poles across or upon the shoulders, or shall carry any rubbish, garbage, swill or filth so as to be offensive to pedestrians upon any sidewalk, they shall be deemed guilty of a misdemeanor,...(p. 334)

Penalty.

Sec. 34. cont. ....and upon conviction thereof before the Police Court, shall be punished by a fine of not less than five dollars not more than fifty dollars (p. 334). ${ }^{9}$

Another prevalent violations was hauling swill through streets without proper

covering. See CHAPTER X, p. 244, this document for commentary.

\section{Transporting swill not in tightly covered box or apparatus.}

Sec. 38. If any person or persons shall remove, transfer or transport through any of the public streets of the City of Portland any swill or garbage, except it be in a tightly covered box or apparatus, or in such manner as will prevent the contents thereof from being deposited in the public streets, or from being exposed in the open air during such process of transportation, he shall be guilty of a misdemeanor,...(p. 335)

Penalty.

Sec. 38. cont. .... and upon conviction thereof, shall be fined not less than five (\$5) nor more than (\$25) twenty-five dollars (p. 335). ${ }^{10}$

$9 \quad$ Ibid., see Ordinance 2959, Section 34, Carrying baskets, buckets, \&c. on poles; and rubbish, filth, \&c., on side walks, Penalty.

${ }_{10}$ Ibid., see Ordinance 2959, Section 34, Carrying baskets, buckets, \&c. on poles; and rubbish, filth, \&c., on side walks, Penalty. 
In addition, there were specific laws restricting times that swill could be transported on public streets. Also see CHAPTER X, p. 244, for commentary.

\section{Transporting swill prohibited during certain hours within certain limits.}

Sec. 39. If any person or persons shall remove, transfer or transport any swill or garbage through any public street of the city north of Harrison street, east of Ninth street and North Tenth street, and south of $H$ street, except between the hours of $9 o^{\circ}$ 'clock evening and $8 o^{\circ}$ 'clock forenoon during the months of April, May, June, July, August and September, and between the hours of $7 o^{\prime}$ clock evening and 9 o'clock forenoon during the months of October, November, December, January, February and March, they shall be deemed guilty of a misdemeanor,...(pp. 335-336). ${ }^{11}$

Penalty.

Sec. 39. cont. ... and on conviction thereof before the Police Court, shall be punished by fine not less than five dollars not more than fifty dollars (p. 336).

$11 \quad$ Ibid., see Ordinance 2959, Section 39, Hauling swill through the streets within certain hours, and Penalty.. 


\section{CHAPTER XIII \\ PORTLAND JEWS}

The gold rush in California brought a vast migration of settlers to the west

coast. While thousands of pioneers ventured from eastern and midwestern states, thousands of immigrants also came from Europe. California soon became saturated with prospectors and adventure risk individuals. Seeking a slower life style while recognizing that valuable natural resources were available throughout the far west, many settlers started migrating into Oregon in search of silver and gold and a less hectic place to live.

Jews staring migrating into Oregon as early as 1840 's, with hopes of selling provisions to members of mining camps and other settlers residing in the state's rural and urban communities (Cline, pp. 2-3). The vast majority of Jews migrating to Oregon and subsequently Portland, were mostly immigrants from Germany (Cline, p. 6).

However, anxious to assimilate into American society, most Jews made an effort to speak English in addition to their native tongue (Cline, p. 8). As early settlers, many Jews were able to accumulate many acres of land and other valuable properties (Cline, p. 9). The Jewish community was largely responsible for building most of Portland's early brick structures (Cline, p. 10).

Herman Ehrenberg was credited with being one of the first identifiable members of the Jewish community to migrate into Oregon in 1844. In 1849, Jacob Goldsmith and Lewis May arrived in Portland and opened a general store 
(Lowenstein, p. 6). However, the United States Census data of 1850, only indicated one resident of Portland as being Jewish (Cline, p. 4) ${ }^{1}$. See POPULATIONS, APPENDIX IV.

Gradually, as Jews began to move into the Portland area and start families ${ }^{2}$, there was need for Jewish religious traditions (Cline, p. 10). One of the earliest needs, as a result of wide spread contagious diseases, was for an appropriate burial ground. However, Portland Jews experienced strong objections to this request from Portlanders at large. The reasons for objecting were unclear (Cline, p. 11). Eventually, burial grounds were developed.

Despite the rather large Jewish population in Portland it was not until 1859, that Beth Israel $^{3}$ evolved. Soon after, the First Hebrew Benevolent Association ${ }^{4}$ was founded by members and non members of Beth Israel (Cline, p. 16). Jews were rapidly becoming firmly rooted in Portland's community and emerging history. As the number of Portland inhabitants increased, the Jewish population also grew. Jews established many enterprises within the city to the extent that they eventually dominated the business community (Cline, p. 62). Jews also began to

1 That individual was identified as Isaac Stamper, age 32, a Prussian-born merchant (Cline, pp. 4-5). p. 49).

Simon Baum and Marjana Bettman were the first Jews to be married in Oregon (Lowenstein, 3 The Jewish community was composed of several denominations, as such there was not agreement on religious observance (Cline, pp. 13-14).

Although most Jews came from Germany, there were also Jews from Prussia, Bavaria, Poland, Austria, France, and Russia (Cline, pp. 23-25).

In addition, there was a need on the part of Jewish men to be married prior to joining the Jewish religious congregation (Cline, p. 15).

4 The Benevolent Association's main purpose was to care for the sick and berefted members of the Jewish community whether they were member of Beth Israel or not (Cline, p. 16). 
assume other leadership roles. Several of Oregon's and Portland's early administrative and justice officials were Jewish. See CHAPTER II, PORTLAND CITY OFFICIALS.

Prior to the presidential election of Abraham Lincoln, most American Jews belonged to the Democratic party. However, Northern Jews, opposed to slavery, switched their political allegiance to the Republican party soon after its emergence (Cline, p. 83). Portland Jews were not affiliated with just one party; some Jews were Democrats, while others were Republicans (Cline, p. 83). Jews viewed local politics and political office as a means of advancing the development of their adopted city (Cline, p. 84).

Jews were in opposition over the presence of Chinese in Portland. It was Mayor Wassermann, who in 1873, approved the health Ordinance that required 550 cubic feet of space for each occupant of an apartment (Cline, p. 85). However, within two days of approving that Ordinance, Wassermann vetoed the City Councils attempt to prohibit Chinese workers from being employed on City contracts (Cline, p. 85). Wassermann felt such actions should come from the United States Congress (Cline, p. 85). During that period, other Jewish residents, such as Ralph and Isaac Jacobs, felt Wassermann's concern should be with the City's white residents (Cline, p. 85). Other Jews were also uncomfortable with Wassermann's political position.

Nevertheless. Jewish business men employing Chinese workers held a business view against white workers based on profit. Jewish merchants theorized 
that they could not make profits if they were forced to employ white workers seeking higher wages than the substandard wages they paid Chinese workers. Jewish merchants knew that white consumers would not support their business right to seek workers willing to accept lower wages, most of whom were Chinese. At the same time, they felt their profits would be minimized if they were forced to employ white workers seeking higher pay. 1885, Rohn's Clothing Store featured the following rhyme in its advertisement in the Oregonian:

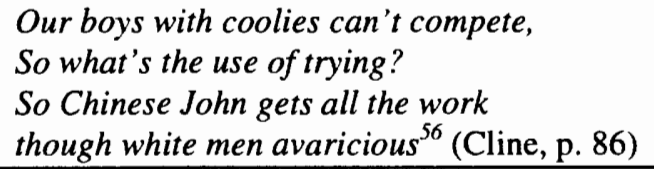

This statement was published during the height of anti-Chinese sentiments in the Portland area (Cline, p.85). Portland residents, including some Jews, felt the Chinese should be allowed to work since they were willing to do menial work at substandard pay. However, wanting to vent their anguish, a large gathering of Portland white residents assembled and made plans to physically expel Chinese from the community. Mayor John Gates and former Mayor Wassermann came to the defense of Chinese inhabitants (Cline, p. 86). They assembled a volunteer army of armed deputized men to quell the onslaught of the riot (Cline, 86).

Identifying members of the Jewish community was difficult. While it was forbidden, some Jews had mixed marriages (Cline, p. 110). Benjamin Cohen and

\footnotetext{
5 Avaricious - Greatly desiring money or property; greedy for wealth (World Book Dictionary, p. 139).

6 Coolie - an unskilled laborer in India or China; laborer who does hard work for very little pay (World Book Dictionary, p. 457).
} 
their religious identities (Cline, p. 110). As a result, while a name may have appeared to be of Jewish extraction, the mere name was not evidence of religious affiliation. Yet, the use of a Jewish name could evoke the same anti-Semitic treatment expressed to any practicing and affiliated Jewish person.

In their effort to blend into the meting pot, that is to assimilate into American society, some Jews joined Gentile faiths. While some families were successful in severing their ties with the Jewish community, others were not. David Wittenberg, joined the Unitarian church, but his children were still targets of anti-Semitic remarks perpetrated by other children (Cline, p. 111). Yet, a list of Jewish names was found.

H. W. Scott, as editor of, History of Portland..., included a list of names of Portland merchants identified as Jewish residing in the Oregon Territory prior to 1852. This list was developed by John M. Breck, George L. Story, Henry Failing and T. B. Trevett. See APPENDIX VII, JEWS IN OREGON STARTING IN $18544^{7}$

Scott and other historians in their research for information for the publication paid tribute to the business capability of these merchants and noted that they merited thanks from the publishers of this particular historical documentation and also for their interest and efficiency in making the historical work complete (Scott, p. 116).

This list provided the names of Jewish settlers residing and doing business in Oregon during the Territory period. The list was used to identify Jews who held public administrative and other political positions of authority in Portland.

7 Scott, H. W., editor, (1890), History of Portland, Oregon: With Illustrations and biographical Sketches of Prominent Citizens and Pioneers, D. Mason \& Co., Syracuse, New York, pp. 116-117. 
Yet, despite their contributions to the business and political growth of Portland, Jews were not as acceptable in the social circles of high society. For example, Jews were not invited to join the Arlington $\mathrm{Club}^{8}$, considered the most aristocratic club in Portland in the late 1800's (Cline, p. 100).

Anti-Semitism was not necessarily the result of just Jewish religious convictions. Thomas J. Dryer, founder and publisher of the Oregonian, accused the Jewish population of controlling the ballot box as a result of their significant presence in Portland. (Lowenstein, p. 151). Yet...Portland's Jewish merchants did not disproportionately enter the political area, though their representation exceeded other ethnic groups (Cline, p. 89). See CHAPTER II and APPENDIX VII. However, there was an incident cited by some historians as being anti-Semantic, having to do with the position of City Marshal.

A. Rosenheim, member of the Jewish community, was selected by majority vote of the Portland City Council to serve as Marshal of the City of Portland. Henry L. Hoyt, who held the position refused to give up the position to Rosenheim. Rosenheim took Hoyt to court resulting in the following:

8 The Arlington Club, founded in 1867, had a membership of business and professional men who spent much of their time strategizing Portland's future growth. The lack of presence during those discussion, denied Jewish businessmen the opportunity to contribute and benefit from those informal, but powerful, conversations (Cline, p. 100). 


\section{ROSENHEIN V. HOYT \\ SEPTEMBER 25, 1867 \\ W.S. CANTWELL \\ AUDITOR CLERK}

Whereas A. Rosenheim a member of this Council did on the 31st day of July received five votes and was disclosed elected Marshal of the City of Portland and whereas the then incumbent Henry L. Hoyt contested the right of A. Rosenheim to hold said office and said contested right has been decided by the Supreme Court of this State in favor of said Hoyt - therefore he is resolved.

\section{Resolved:}

1. There-by said contest the said Henry L. Hoyt was only exercising a legal right possessed by every citizen under our statutes, which right is one of the safeguards of a popular government.

2. This Council believes that in contesting the right to said office the said Hoyt was not actuated by prejudice or political motive but was merely doing what he believed to be his duty to himself and the public generally.

3. That this Council has never been interested in said contest except to know as soon as it was practicable to get the matter decided by the courts who was rightfully entitled to said office of Marshal since any person exercising the duties of that office illegally might involve the city in almost endless litigation.

4. This Council believe that the said Henry L. Hoyt has performed the duties of the office of City Marshal for the past three years and upwards to the satisfaction of all good citizens irrespective of party.

5. These resolutions to be spread upon the records ${ }^{9}$ (seconds) of this Council

George Townsend was appointed Deputy Marshal by Mayor J. A. Chapman, August 9, 1867 - City of Portland, while awaiting the decision of the Court.

Marshal's collected moneys for arresting the accused.

Hoyt retained the right to the position of Marshal. Reasons for the Court's resolution appeared to indicate that the Council should not have voted Hoyt out of the position. What originally perpetrated the vote was not indicated. However, the Court's decision was accepted as binding by the City Council as indicated in the above statement.

During the late 1800 's, Jews were often members of fraternal organizations including the Masons and Odd Fellows (Cline, pp. 55-60). Yet, as early as 1858,

$9 \quad$ Record, enter ..moved...that the foregoing resolutions be spread upon the minutes...(Webster's Third New International Dictionary, p. 2208). 
expressions of anti-Semitism gradually appeared. By the end of the nineteenth century, Jews would experience anti-Semitic name calling and witness the effects of bigotry by discovering acts of vandalism to their religious and social institutions.

Despite anti-Semitic sentiments, there were not any cases observed involving assault and battery upon or, by an identifiable Jew. Identifiable Jews were absence from the majority of arrest and court records observed. There were few criminal incidents involving identifiable Jews. In addition, of the few incidents observed...most citations were for minor fractions...(Cline, p. 87).

\section{POLICE ARREST RECORDS}

There was not sufficient arrest or court records observed involving an identifiable Jewish person to warrant the addition of separate chapters. Consequently, all observed arrest and court cases involving an identifiable Jewish person have been inserted for discussion in this chapter. 


\section{POLICE ARREST RECORDS \\ November 1870-January 1875 \\ MISDEMEANORS AND FELONIES}

\section{Background 1870-1875}

In 1870, In Oregon, the railroad was completed, stretching to Albany. Portland, Oregon, had twenty-two hotels, twelve boarding houses and nine restaurants. The Corbett building was built at a cost of $\$ 30,000$, the Glisan Building , $\$ 32,000$, and the A. P. Ankeny Building, $\$ 50,00$ (Scott, p. 156 ).

In 1871, In Portland, Oregon, Ankeny's Market Theater was built, at a cost of $\$ 100,000$.

In Portland, Oregon, in 1872, In Portland, Oregon, the Masonic Temple was built at a cost of $\$ 80,000$, The Good Templar's Hall, $\$ 10,000$ and the Clarendon Hotel (no figure indicated). The House of Destitute was built (Scott, p. 156).

In 1873, Leopold Damrosch, A Prussian Jew, became the first Jewish orchestra conductor in the U. S., as per his appointment as conductor of the New York Philharmonic Orchestra (Sloan, p. 10). Portland, Oregon, suffered a great fire, at a cost of $\$ 1,345,000$ (Scott, p. 157)

in 1874 , David Lubin, opened the first store in the U. S. , selling merchandise at retail with fixed prices marked on each item. He also established the first mail order house (Sloan, p. 10). Portland, Oregon, was continuing to re-build after the fire the previous year (Scott, p. 157).

In 1875, The Union of American Hebrew Congregation was founded by Rabbi Isaac M. Wise (Sloan, p. 11). There was a national economic depression underway. The Pacific Railroad was experiencing financial problems (Scott, P. 157).

There were no cases observed involving an identifiable Jew during this time

period. 


\section{POLICE ARREST RECORDS \\ January 1875-March 1878 \\ MISDEMEANORS AND FELONIES}

\section{Background 1875-1878}

In 1876, Portland, Oregon's economy started to prosper. Over seventy-two shipping vessels docked in Portland (Scott, p. 158).

There were no cases observed involving an identifiable Jew during this time 


\section{POLICE ARREST RECORDS \\ July 1877-January 1879 \\ MISDEMEANORS AND FELONIES}

\section{Background 1877-1879}

In 1877, in Portland, Oregon, The John Rhines Wharf was built at a $\$ 5,000$, and the P. W. D. Hardenburg building was built at a cost of $\$ 12,000$. Emile Berliner made the Bell telephone possible by inventing a microphone which was used a s a telephone receiver (Sloan, p. 11). The second open case of anti-Semitism in the U. S., involved the refusal of the Saratoga, New York Hotel, to admit Jewish guests (Sloan, p. 11). The first Kindergarten in the U. S. was established by Felix Adler (Sloan, p. 11).

In 1878, The Board of Delegates of American Israelites, operating under the Union of American Hebrew Congregations, and became the Board of delegates of Civil and Religious Rights (Sloan, p. 11).

There were no cases observed involving an identifiable Jew during this time period. 


\section{POLICE ARREST RECORDS \\ December 1879-October 1881 \\ MISDEMEANORS AND FELONIES}

\section{Background 1879-1881}

In 1879, in Portland, Oregon, Northwest Portland was beginning to be developed. Over ninety trading vessels continued to dock at Portland and sixty steamers also docked. The City had 276 dwellings of which 16 were brick. There were fifty-eight stores, fourteen shops, one brewery, eight hotels and fourteen stables (Scott, p. 155).

By 1880 , there 230,00 Jews in the United States (Sloan, p. 11). In Portland, Oregon, North Portland, South Portland, and East Portland had been developed. In addition, there were 103 liquor saloons and ten wholesale houses (Scott, p. 155).

In 1881, Adolpheus S. Solomon, founded the American Red Cross in Washington, D. C. (Sloan, p. 12). The was greater interest generated in Oregon mines (Scott, p. 158). Other business began to flourish in Portland, Oregon including: lumber, furniture, boots, shoes, wagons, iron, steel, hand. tools, machinery and preservation of fruit (Scott, p. 158).

There were no cases observed involving an identifiable Jew during this time period. 


\section{POLICE ARREST RECORDS \\ May 1894-April 1895 \\ MISDEMEANORS AND FELONIES}

\section{Background 1894-1895}

In 1894, Andrew Freedman purchased the New York Giants baseball club (Sloan, p. 13). In just the prior year, 1893, the National Council of Jewish Women was established in NYC (Sloan, p. 136).

The arrest records observed in 1894, reflected race/ethnicity, under the category Nativity. As a result, several cases were observed involving Jews.

\begin{tabular}{|c|c|c|c|c|c|c|c|c|c|c|}
\hline $\begin{array}{c}\text { date } \\
1894 \\
\text { Mo } \\
\text { Da }\end{array}$ & defendant & $\begin{array}{l}\text { arresting } \\
\text { officer }\end{array}$ & $\begin{array}{l}\text { com- } \\
\text { plainant }\end{array}$ & charge & $\begin{array}{l}\text { where } \\
\text { arrested }\end{array}$ & judgment & $\begin{array}{l}\text { discl } \\
\text { Mo. }\end{array}$ & $\begin{array}{l}\text { ged } \\
\text { day }\end{array}$ & age & $\begin{array}{c}\text { nativity } \\
*\end{array}$ \\
\hline $\begin{array}{l}\text { Sept } \\
14\end{array}$ & $\begin{array}{l}\text { Sam } \\
\text { Senosky }\end{array}$ & $\begin{array}{l}\text { WH } \\
\text { Duckworth }\end{array}$ & $\begin{array}{l}\text { WH } \\
\text { Duck- } \\
\text { worth }\end{array}$ & $\begin{array}{c}\text { Larceny } \\
\text { of } \\
\text { Oregonian }\end{array}$ & $\begin{array}{l}\text { 2nd \& } \\
\text { Hall }\end{array}$ & $\begin{array}{l}30 \text { days } \\
\text { sentence } \\
\text { suspended } \\
\& \\
\text { committed } \\
\text { to reform } \\
\text { school }\end{array}$ & Sept & 15 & 13 & Jew \\
\hline
\end{tabular}

The case above, involved Sam Senosky, arrested for larceny of the

Oregonian, convicted and sentenced to a thirty day suspended sentence and committed to reform school. It was assumed Senosky was a minor. The remain cases did not involve any unusual circumstances, but are presented here for reference. In the essence of space, information contained in all categories was not included. See APPENDIX XII, for complete review of each case. 


\begin{tabular}{|c|c|c|c|c|c|c|c|c|c|c|}
\hline $\begin{array}{l}\text { Nov. } \\
24\end{array}$ & $\begin{array}{l}\text { Chas } \\
\text { McCarthy }\end{array}$ & Gibson & $\begin{array}{l}\text { Elias } \\
\text { Haitom }\end{array}$ & $\begin{array}{l}\text { Malicious } \\
\text { injury to } \\
\text { personal } \\
\text { property }\end{array}$ & N. lst St. & $\begin{array}{l}\text { Dis } \\
\text { charged }\end{array}$ & Nov. & 26 & 10 & Jew \\
\hline \multicolumn{11}{|c|}{1894} \\
\hline $\begin{array}{l}\text { Dec } \\
7 \\
\end{array}$ & $\begin{array}{l}\text { Newby } \\
\text { Ochfield }\end{array}$ & Stewart & $\begin{array}{l}\text { Sam } \\
\text { Stewart }\end{array}$ & $\begin{array}{l}\text { Disturbing } \\
\text { by fighting }\end{array}$ & $\begin{array}{l}\text { No 3rd } \\
\text { St. }\end{array}$ & $\begin{array}{l}\begin{array}{l}\text { Dis } \\
\text { charged }\end{array} \\
\end{array}$ & Dec & 7 & 15 & Jew \\
\hline
\end{tabular}

\begin{tabular}{|l|l|l|l|l|l|l|l|l|l|l|}
\hline $\begin{array}{l}\text { Dec } \\
11\end{array}$ & S \\
Newman & Strow & $\begin{array}{l}\text { Geo } \\
\text { Strow }\end{array}$ & $\begin{array}{l}\text { violated City } \\
\text { Ord. } \\
\text { peddling no } \\
\text { license }\end{array}$ & $\begin{array}{l}\text { Front \& } \\
\text { Columbia }\end{array}$ & F & Dec & 17 & 4 & Jew \\
\hline
\end{tabular}

\begin{tabular}{|c|c|c|c|c|c|c|c|c|c|c|c|}
\hline $\begin{array}{l}\text { Dec } \\
15\end{array}$ & $\begin{array}{l}S \\
\text { Harris }\end{array}$ & Crouche & $\begin{array}{l}\text { CH } \\
\text { Daly }\end{array}$ & $\begin{array}{l}\text { Obstructing } \\
\text { sidewalk }\end{array}$ & $\begin{array}{l}\text { 2nd \& } \\
\text { Morrison }\end{array}$ & & $\begin{array}{l}\text { Dis } \\
\text { charged }\end{array}$ & Dec & 17 & 40 & Jew \\
\hline \multicolumn{12}{|c|}{1894} \\
\hline $\begin{array}{l}\text { Dec } \\
20\end{array}$ & $\begin{array}{l}\mathrm{J} \\
\text { Jacobs }\end{array}$ & $\begin{array}{l}\text { Sam } \\
\text { Goodman }\end{array}$ & $\begin{array}{l}\text { EM } \\
\text { Living- } \\
\text { ston }\end{array}$ & $\begin{array}{l}\text { Abusive } \\
\text { Language }\end{array}$ & 1st \& Jeff & $F$ & Dec & 21 & 18 & Jew & \\
\hline $\begin{array}{l}\text { Dec } \\
22\end{array}$ & $\begin{array}{l}\text { Isid } \\
\text { Smith }\end{array}$ & Wohlers & $\begin{array}{l}\text { GM } \\
\text { Griffith }\end{array}$ & $\begin{array}{l}\text { Petty } \\
\text { Larceny }\end{array}$ & 329 Wash & & $\overline{\mathrm{Dec}}$ & 22 & 10 & Jew & $\begin{array}{l}\text { Complaint } \\
\text { withdrawn }\end{array}$ \\
\hline
\end{tabular}

\begin{tabular}{|c|c|c|c|c|c|c|c|c|c|}
\hline $\begin{array}{l}\text { Jan } \\
1\end{array}$ & $\begin{array}{l}\text { Jake } \\
\text { Bernstein }\end{array}$ & Venable & $\begin{array}{l}\mathrm{C} \\
\text { Venable }\end{array}$ & Drunk & $\begin{array}{l}\text { 1st \& } \\
\text { Morrison }\end{array}$ & $\begin{array}{l}\text { Dis } \\
\text { charged }\end{array}$ & Jan & 45 & Jew \\
\hline
\end{tabular}

\begin{tabular}{|l|l|l|l|l|l|l|l|l|l|l|l|}
\hline $\begin{array}{l}\text { Jan } \\
2\end{array}$ & $\begin{array}{l}\text { H } \\
\text { Goodman }\end{array}$ & $\begin{array}{l}\text { G } \\
\text { Roberts }\end{array}$ & $\begin{array}{l}\text { G } \\
\text { Roberts }\end{array}$ & $\begin{array}{l}\text { Neglect to } \\
\text { register } \\
\text { purchased } \\
\text { goods }\end{array}$ & $\begin{array}{l}\text { Front \& } \\
\text { Main }\end{array}$ & $\begin{array}{l}\text { a } \\
\text { n }\end{array}$ & & Jew \\
\hline
\end{tabular}

\begin{tabular}{|c|c|c|c|c|c|c|c|c|c|c|c|}
\hline $\begin{array}{l}\text { Jan } \\
5 \\
\end{array}$ & $\begin{array}{l}\text { Jos } \\
\text { Myer }\end{array}$ & $\begin{array}{l}\text { Holsapple } \\
\text { \& Griffin } \\
\end{array}$ & $\begin{array}{l}\mathrm{JN} \\
\text { Minto } \\
\end{array}$ & Witness & Station & 5 & 30 & \multicolumn{2}{|c|}{ Jew } & & \\
\hline \multicolumn{12}{|c|}{1895} \\
\hline $\begin{array}{l}\text { Jan } \\
15 \\
\end{array}$ & $\begin{array}{l}\text { Ben } \\
\text { Berstein }\end{array}$ & Backstrom & $\begin{array}{l}\text { JW } \\
\text { Minto } \\
\end{array}$ & $\begin{array}{l}\text { Runaway } \\
\text { boy }\end{array}$ & $\begin{array}{l}\mathrm{Ja} \\
\mathrm{n}\end{array}$ & 16 & \multicolumn{3}{|c|}{ Hebrew } & \multirow{2}{*}{\multicolumn{2}{|c|}{$\begin{array}{l}\text { Released to } \\
\text { Parents } \\
\end{array}$}} \\
\hline \multicolumn{10}{|c|}{1895} & & \\
\hline $\begin{array}{l}\text { Jan } \\
19\end{array}$ & $\begin{array}{l}\text { Mark } \\
\text { Eller }\end{array}$ & Austin & $\begin{array}{l}J J \\
\text { Fitzgeral } \\
d \\
\end{array}$ & Larceny & \multicolumn{2}{|l|}{$\begin{array}{l}\text { 1st \& } \\
\text { Taylor }\end{array}$} & \multicolumn{3}{|c|}{ Jew } & & \\
\hline \multicolumn{12}{|c|}{1895} \\
\hline $\begin{array}{l}\text { Jan } \\
26\end{array}$ & $\begin{array}{l}\text { John } \\
\text { Lynch }\end{array}$ & $\begin{array}{l}\text { Davison } \\
\text { and } \\
\text { Endicott }\end{array}$ & $\begin{array}{l}\text { Davison } \\
\text { and } \\
\text { Endicott }\end{array}$ & $\begin{array}{l}\text { Defacing of } \\
\text { building }\end{array}$ & $\begin{array}{l}\text { 2nd \& } \\
\text { Alder }\end{array}$ & $\$ 10$ & Jan & $\begin{array}{l}2 \\
8\end{array}$ & 10 & $\begin{array}{l}\text { Hebre } \\
\text { w }\end{array}$ & \\
\hline $\begin{array}{l}\text { Jan } \\
30\end{array}$ & $\begin{array}{l}\text { Louis } \\
\text { Mozerty }\end{array}$ & Gibson & $\begin{array}{l}\text { HF } \\
\text { Gibson }\end{array}$ & $\begin{array}{l}\text { Vio Ord } \\
3983 \\
\text { Sec } 18\end{array}$ & $\begin{array}{l}\text { lst \& } \\
\text { G }\end{array}$ & $\$ 5$ & Jan & $\begin{array}{l}3 \\
0\end{array}$ & 36 & $\begin{array}{r}\text { Jew } \\
\text {. }\end{array}$ & $\begin{array}{l}\text { Released } \\
\text { by order } \\
\text { of judge } \\
\text { and chief }\end{array}$ \\
\hline
\end{tabular}

\begin{tabular}{|l|l|l|l|l|l|l|l|l|l|l|l|}
\hline $\begin{array}{l}\text { Jan } \\
30\end{array}$ & $\begin{array}{l}\text { Sid } \\
\text { Blumenthal }\end{array}$ & Quinton & $\begin{array}{l}\text { John } \\
\text { Quinton } \\
\text { by fighting }\end{array}$ & $\begin{array}{l}\text { Disturbing } \\
\text { blbina }\end{array}$ & $\begin{array}{l}\text { \$10 sent/ } \\
\text { suspend } \\
\text { on good } \\
\text { behavior }\end{array}$ & Jan & $\begin{array}{l}3 \\
0\end{array}$ & 14 & Jew & \\
\hline $\begin{array}{l}\text { Jan } \\
30\end{array}$ & $\begin{array}{l}\text { Lewis } \\
\text { Harris }\end{array}$ & $\begin{array}{l}\text { Davison } \\
\text { and } \\
\text { Endicott }\end{array}$ & $\begin{array}{l}\text { Davison } \\
\text { Endicott }\end{array}$ & Vagrancy & $\begin{array}{l}3 \text { rd \& } \\
\text { B }\end{array}$ & 90 days & Feb & 1 & 23 & $\begin{array}{l}\text { Hebr } \\
\text { ew }\end{array}$ & $\begin{array}{l}\text { Released } \\
\text { Feb } 1 \text { by } \\
\text { order } \\
\text { of judge }\end{array}$ \\
\hline
\end{tabular}




\section{COURTS OF RECORD - POLICE COURTS ${ }^{10}$}

There were no cases observed involving an identifiable Jew during the indicated time periods.

10 Portland was divided into several Precincts. However, which Precinct was involved in the a court case was not indicated in court records observed - see PRECINCTS, CHAPTER III, pp. 36-137 


\section{COURT DOCKET RECORDS}

STATE OF OREGON

June 1867 to July 1868

J. J. Hoffman - Recorder

FELONIES

There were no cases observed involving an identifiable Jew during this time period. 


\section{COURT DOCKET RECORDS}

STATE OF OREGON

August 1868 to July 1870

J. J. Hoffman Ex-Officio Justice of the Peace

FELONIES

There were no cases observed involving an identifiable Jew during this time period. 


\section{COURT DOCKET RECORDS}

STATE OF OREGON

December 1874-March 1880.

O. N. Denny, Police Judge

FELONIES

There were no cases observed involving an identifiable Jew during this time

period. 


\section{COURT DOCKET RECORDS \\ CITY OF PORTLAND \\ June 1867 to August 1870 \\ J. J. Hoffman- Police Judge \\ MISDEMEANORS}

To review the following cases, see APPENDIX XVI. There was an observed case involving a member of the Jewish community. S. Simon, was identified as being Jewish per the remarks provided regarding the case. In City of Portland v. L. Barman, September 16,1868 , the defendant is charged with conducting himself in an disorderly manner. Barman plead not guilty, was convicted and fined fifty dollars and court costs of seventeen dollars and fifty cents. The disposition of the case was not indicated.

In another case, City of Portland v. Solomon Kaffa, April 13, 1869, the defendant is charged with peddling without a license. Kaffa plead not guilty, was convicted and fined five dollars. Court costs were not indicated. Kaffa paid the fine and was discharged.

In the case City of Portland v. Rosenheim, August 17, 1869, the defendant was charged with assault, the alleged victim was not indicated. Rosenheim plead not guilty, was convicted, fined ten dollars and court costs of twelve dollars and sixty five cents. The defendant did not pay his fine or court costs until November 10 , 1869. There was no explanation for delay in payment or any stipulation that the defendant was jailed earlier for failure to pay. Also see the case of Rosenheim $\mathbf{v}$. Hoyt. 


\section{COURT DOCKET RECORDS}

CITY OF PORTLAND

August 1870-April 1871

Sin Anderson - Recorder - Ex Officio Justice of the Peace MISDEMEANORS

There were no cases observed involving an identifiable Jew during this time period. 


\section{COURT DOCKET RECORDS \\ CITY OF PORTLAND \\ July 1871-October 1873 \\ O. N. Denny - Police Judge MISDEMEANORS}

There were no cases observed involving an identifiable Jew during this time period. 


\section{COURT DOCKET RECORDS}

CITY OF PORTLAND

November 1873-June 1877

O. N. Denny - Police Judge

MISDEMEANORS

There were no cases observed involving an identifiable Jew during this time period. 


\section{COURT DOCKET RECORDS}

CITY OF PORTLAND

August 1879-August 1881

O. N. Denny - Police Judge

MISDEMEANORS

There were no cases observed involving an identifiable Jew during this time period. 


\section{COURT DOCKET RECORDS \\ CITY OF PORTLAND \\ September 1881-August 1882 \\ O. N. Denny - Police Judge \\ MISDEMEANORS}

There were no cases observed involving an identifiable Jew during this time period. 


\section{SUMMARY}

Racial and ethnic minorities are disproportionately represented in Portland, Oregon's criminal justice system. Laws, legal procedures and practices that excessively target minorities are not new phenomena. This study focused on a history of legal, political and social conditions in Oregon, and subsequently, Portland, from the 1840 's to approximately 1895 , that created unjust State laws and City ordinances that adversely impacted the presence of Native Americans, African Americans, and Chinese Immigrants and the conduct of their behavior while controlling their social interactions. Attention was also given to Portland's Jewish population.

The approach was to examine available arrest and court records from Oregon's and Portland's early beginnings to ascertain what qualitative information such records could provide regarding the treatment of minorities by the justice system. As an out growth of this observation, it was necessary to obtain a layperson's understanding of the legal environment related to the causes of arrests and dispositions of adjudication. Finally, it was essential to study the political and social atmosphere of the time period to become cognizant of the framework that shaped public attitudes and ultimately, civic actions.

The criminal justice system is composed of four distinct entities, legislation, law enforcement, judiciary and corrections, separate and unequal. Each department is unequal to any other because each performs a specific duty only as a consequence of each of the other areas. As such, the power and influence of departmental procedures 
and practices are not equally divided. Depending on circumstances, any one department may have more influential power on the justice system and clients within the system, than any other. These departmental differences were apparent during the time period studied.

A review and examination of Oregon laws disclosed legislation that skewed rights in favor of white settlers, at the expense of Native Americans, African Americans and Chinese immigrants. Many legislative acts were developed in response to public beliefs and mood. Public influence on the enactment of legislation was an attempt to monitor, control and direct the actions of Native Americans, African Americans and Chinese immigrants in the best interest of white inhabitants. Legislation was the product of white societal traditions, values, customs and prevailing attitudes.

The legislative process, while steeped in protocol, yielded authority to influential white community sentiment, resulting in laws that adversely affected indicated minorities. Oregon's and Portland's legislative process was used as a power to disenpower and deny rights to Native Americans, African Americans and Chinese immigrants. Some rights, flagrantly denied, were in opposition to provisions within the United States Constitution and even Oregon Law.

Legislation was designed to subtlety and/or overtly target Native Americans, African Americans and Chinese, because their racial identities and/or customs were deemed unacceptable to the white populace. For example, such actions denied 
members of these groups the right to vote, the right to just and appropriate legal and civic representation, the right to choose where they wanted to live and the right to pursue employment, and even freedom from illegal search and seizure.

Many customary practices indigenous to each group were declared illegal, often resulting in criminal charges, arrests, and when appropriate, adjudication and possible sentencing. The legislative branch of the justice system, often at the direction of elected public administrative officials, used and abused its authority by promoting the rights of whites over and above those of Native Americans, African Americans and Chinese immigrants. In hindsight, Oregon and Portland had affirmative action programs that worked against the best interests of racial/ethnic minorities. Inserted are examples of unjust legislation and consequently, law enforcement.

Laws denied these minority groups the right to free land offered to white residents, see Acts of Congress, ${ }^{I}$ Relating To Public Lands In Oregon (Territory), September 27, 1850, Grants of public land, the right to purchase land in Oregon. See September 18, 1857, Chinamen not to hold real-estate, or work mining claim...Minorities were also denied freedom of choice in interracial relationships; miscegenation was not permitted. See Code of Civil Procedure, Title VII, Suits to declare void or dissolve the marriage contract, Section 485 and CHAPTER VIII, Of crimes against public policy, Intermarriage with negro, etc. (included Chinese,

1 Deady, Matthew P. and Lafayette Lane, Organic and Other General Laws of Oregon: 18431872. 
Mulattoes and Kanaka ${ }^{2}$ blood, or any person having more than one half Indian blood), declared void. (p. 440), Section 689.

Oregon law included a provision under the State's Bill of Rights, Article 31, that extended rights and privileges to white foreigner born residents, but did not extend such rights to people of color. See Judicial Department, Article VII, Section 2.

Laws excluded Oregon residency to African Americans and for a period of time, Chinese immigrants, Native Americans were forced to live on reservations. African Americans, slaves and freepersons, and Chinese persons were legally denied equal opportunity to live and work in Oregon. See State Bill of Rights, Article 35 and Article XV, Miscellaneous, Section 8. Chinese immigrants, once accepting to a thriving community, were legally cast out and exiled from a place some had thought of as home. Even the right of suffrage extended to white foreign born residents was denied Chinese residents. See State Bill of Rights, Article II, Suffrage and Elections, Section 6 .

Subtlety, persons of color were denied an opportunity to be elected to an Oregon state office. The number of state justices allowed was based on the white population of the state. See Article VII, Judicial Department, Section 2. People of color were not recognized as residents of the state and were not legally considered for enumeration in census data. See Legislative Department, Article IV, section $5 .^{3}$

2 Kanaka - A native of Hawaii; A plantation worker on many Pacific Islands; coolie (World Book Dictionary, p. 1145).

3 Op. Cit., Deady. This provision was later revised. See Miscellaneous laws, Chapter II, Of the census of the inhabitants and products of the state., October 24, 1864, Enumeration of inhabitants, etc. once in ten years. 
Native Americans were rejected through legislation from their land, dismissed to live on reservations and forced to live under white laws. See CHAPTER XXV. of Indians and half-breeds belonging to the reservation. October 21, 1864 Indians or half breed, unlawful to entice from reservation or harbor, without written consent of agent. See White Code ${ }^{4}$ CHAPTER IV.

The Portland Common Council was less overt in enacting ordinances specifically denying minorities certain rights. Portland Ordinances were subtlety designed to interfere with the practices and habits of Chinese inhabitants. See Chapter $\mathrm{V}$, Of the organization and powers of the council, To prohibit use of firearms, firecrackers, etc. No. 23. Chinese used fire crackers when celebrating religious rites and for other festivities. Finally, the Council compromised and on a case by case basis, consented to allow Chinese special privileges in using fire crackers.

In addition, Chinese merchants operated most, if not all the laundry facilities in Portland. The Council enacted ordinances to regulate and prohibit such facilities from being located within City limits. See previously cited law, To regulate, etc., washhouses and laundries. Eventually, the City Council again compromised and while allowing laundry businesses to operate within City limits decided to license the operations of these establishments. See Laundries and wash houses $-\$ 5$ per quarter. Sec. 28. Public laundries and wash houses shall pay a quarterly license of five dollars.

4 Tracy, Charles Abbott, (1976), The Evolution of the Police Function in Portland, Oregon, 1811-1874, Dissertation, University of California, California State University campus, San Jose, California, pp. 55-56. Also see:

A. J. Allen (ed.), (1848), Ten Years in Oregon: Travels and Adventures of Doctor E. White and Lady, Mack, Andrus and Company, Ithaca, New York, pp. 189-190. 
The use of profanity and other forms of disorderly conduct were prohibited by City Ordinance No. 2959. This Ordinance was applied to all ethnic groups. However, records indicated, that this law was applied disproportionately to Chinese. In addition, it was assumed that most Chinese spoke in their native tongue during their private conversations. As a result, it was not clear how authorities determined the context of their discussions. See Concerning offenses and disorderly conduct, No. 2959, APPROVED DECEMBER 29, 1880, Violent, riotous, or disorderly conduct. Profane, abusive or obscene language. A violation of disorderly conduct is usually at the discretion of the arresting officer. As such, without additional information it was difficult to ascertain if an arrest for this charge was the result of justifiable probable cause, or was the decision of the officer acting out his biases.

Chinese arriving in this country were bound to practice many customs and habits derived from their culture. Chinese inhabitants used yeo-ho poles with attached baskets as an efficient means of transporting goods. Members of the City Council enacted laws prohibiting this practice. See Carrying baskets, buckets, \&c. on poles; and rubbish, filth, \&c., on side walks, Sec. 34 . This practice was not common among any other racial/ethnic group.

Oregon and Portland enacted laws restricting the behavior and practices of minorities based on discriminatory beliefs and out of fear of those who were perceived to be vastly different from the white majority. However, once an act became law, law 
enforcement was expected to uphold the legality according to its intent, be it just, or unjust.

Certain laws were enacted to rid the City of unacceptable activities, such as bawdy houses, gaming/gambling houses, opium dens and drinking establishments. However, the inconsistencies in enforcing such laws made these ordinances inequitable. It appears some laws were perhaps enforced based on administration decisions, public mood and/or the City's budgetary financial urgency.

This conclusion was based on inconsistencies in arresting alleged offenders. There were periods when several charges of violations were filed, but longer time periods when charges were not. It is possible that these businesses ceased to operate as the result of arrests, or application of fines, but unlikely.

During the period of study, Portland was undergoing tremendous growth in terms of population, public services and real-estate expansion. Elected officials cognizant of the need for additional funds to support and enhance these changes, were constantly considering legal means to raise additional funds. The City benefited financially from moneys received from levying fines for violating City ordinances and also from revenue derived from license fees charged for operating a business. Ordinances were often enacted by targeting unacceptable groups as a means of increasing revenue for the City and/or of controlling behavior deemed inappropriate from the same groups. 
Law enforcement had the task of exacting compliance to laws including identified laws. During this time period Portland ordinances had an extensive chronology. While some laws were changed or repealed, most laws remained active. With the increase in population, it gradually required additional staff to attentively enforce laws on the books. However, public administrators decided which laws had precedence over any other. In addition, administrators at the urgency of public mood, decided who and what groups to target for enforcement of such laws. ${ }^{5}$

An examination of police arrest records revealed that many arrests involving members of racial/ethnic groups ${ }^{6}$ were the result of the enforcement of unjust laws, especially, in the case of Chinese immigrants. Chinese immigrants had the largest minority presence in Portland.

Oregon white settlers and subsequently, Portland white residents, encouraged the arrest and detainment of Native Americans, African Americans (slaves or free blacks) and Chinese immigrants, thought to be violating City ordinances-ordinances that were just and unjust. Authorities arrested those they deemed in violation of such laws as a result of police complaints and complaint s from white settlers. All police

\footnotetext{
5 Dilulio, John J., (Fall, 1994), The Question of Black Crime, The Public Interest, No. 117, p. 30. Abstract:

Crimes against blacks do not elicit as much political response as those committed against whites...The majority of crime in America is interracial and blacks suffer a disproportionate amount of crime... 6 Schulberg, Pete, (9 March 1996), TV News, Nothing But Crime-Time Coverage, The Oregonian, p. E14. Abstract:

Visual images of crime stories tend to make a distinct impression...such distortion enables people to form stereotypes... a main component of prejudice... whites began to stereotype (who) is dangerous...
} 
officers were white. Circumstances leading to an arrest were usually at the discretion of the arresting officer.

Native Americans were repeatedly arrested for drunk and disorderly conduct. There was no way of determining if such charges were valid or at the convenience of the arresting officer as a form of harassment. Chinese persons were arrested for being loud and boisterous —a subjective decision. Throughout the period from which arrest records were examined, there were instances in which charges were dismissed. However, far more were sustained necessitating a trial.

Native Americans residing on reservations, were forced to police themselves based on white rule, again, referred to as the White Code. See Footnote 4, this CHAPTER. Away from the reservations, when suspected of having committed a violation, Native Americans were arrested by the Portland police, as were African Americans and Chinese.

A description of treatment by police officers during an arrest was not indicated. An examination of arrest records did not reveal any apparent negative treatment during arrests or bookings. ${ }^{7}$ Yet, given the hostile social and political environment prevalent during this period it is difficult to image that arrest were conducted civilly, absent of misconduct on the part of authorities. Yet, incidents surrounding arrests, without proof, is mere speculation. However, newspapers accounts of charges and subsequent

\footnotetext{
7 It was assumed that information recorded on arrest records was the written account of the arrest process.
} 
arrests, provided more insightful information. Articles related to African Americans may be reviewed. See APPENDIX II.

The nature of charges against Native Americans, mostly for being drunk and disorderly, while not much different from the broader population, were in some cases based on discriminatory laws. Native Americans were cited and required to testify against the perpetrators who sold them spirituous liquor, a violation of Oregon law. However, to testify against ones best interest appeared to also have been a violation of U. S. Constitutional law, specifically, the Fifth Amendment. ${ }^{8}$ Native Americans were the only racial/ethnic group subjected to this infantilized discipline. Native Americans were prohibited as adults from buying liquor freely available for purchase to white adult men.

Identifiable African Americans were not disproportionately represented in the arrest records examined. However, the means for identifying blacks was not scientific and therefore, the exactness of such information warrants additional study. While the population of African Americans during this time period was purportedly not extensive, there were blacks living in the Portland community. As such, it was difficult, given the animosities directed towards blacks and in recognition of the substance of articles (see APPENDIX II) printed in daily papers, that more arrest did not occur from public duress. However, an in-depth examination of the arrest, or lack of, of African Americans requires additional study.

$8 \quad$ Refer to the Bill of Rights, the Fifth Amendment: No person shall be...compelled in any criminal case to be a witness against himself...(World Book Encyclopedia, p. 1012). 
Other examples include harassment of Chinese. Chinese were often arrested based on charges resulting from unjust laws. Chinese persons were subjected to arrest, fined or sentenced for failure to pay, for violating laws whites were not expected to observe. The City Council enacted Ordinances 1431, prohibiting obstruction of sidewalks. On April 7, 1874, in Portland, Oregon, fifteen European American women were arrested for praying on a public street, at First and Morrision Streets . These women were members of the Women's Temperance Prayer League. Their purpose was to rid the town of saloons (Tracy, pp. 252-154). On that date they were not arrested. They also congregated a few days later, and on that day they were not arrested. Finally, out of a large congregation of women, on April 17, only six of the women were arrested, five failed to pay their fine and were sentenced to one day in jail. They were discharged later that night without escorts as an additional form of punishment (Tracy, p. 253). According to newspaper articles from that period, during ensuing weeks, the women continued to assemble, were ignored by authorities and eventually chose other means to bring attention to their causes.

However, when Chinese congregated, while their intent or purpose was not indicated in the arrest records, Chinese in attendance were arrested, convicted, fined or sentenced upon failure to pay. This charged was observed on several occasions in the arrest records. For example, there were over thirty arrests, over a period of just one week. It was not clear what lead to the Chinese gathering. However, it was evident 
that the Chinese were held to answer to a legal standard under stricter scrutiny than white women.

Chinese were also required to adhere to a City ordinance requiring 550 cubic feet of air space per person sleeping in a room. While this law was enforced only against Chinese, it was inconsistently enforced. Records reveal that the police would raid the apartment of a Chinese resident at odd hours of the night, check for violation of this Ordinance. Records indicate that as many as 130 occupants were arrested at one time. The men were convicted and fined on average, five dollars. Failure to pay a fine resulted in overnight sentencing. However, this law was only enforced once or twice a year. It was unclear why the law was inconsistently enforced. This law however, was not enforced against any other racial/ethnic group.

The judiciary reviews and passes judgments in response to charges filed against alleged violators, and when necessary imposes punishment. Native Americans in cases involving felonious charges, were sentenced to harsher punishment than their white counterparts for like charges and similar circumstances. Yet, in most cases involving drunk and disorderly conduct charges, their convictions, fines or sentencing were not much different from their white counterparts. The appearance of an identifiable African American before any court was rare. Additional research in this area could provided additional information.

Court cases involving Chinese were as prevalent as their arrests. There were many cases in which Chinese were charged with a felony for allegedly taking items 
with minimal value. In cases where allegedly stolen items were charged against Chinese, they were usually convicted and severely punished. Again, the punishment seldom fit the crime.

As entrepreneurs in the laundry business, they were often charged with failing to return a customer's cleaning. In some cases they were found guilty, but in other cases they were found not guilty. However, in cases where they were found Guilty, the punishment did not fit the crime. They were fined at higher rates or sentenced to longer sentences than their white counterparts found guilty on similar charges.

In addition, Chinese were required to post bail as the accused or as witnesses for a case. Bail was not usually required of white defendants serving as witnesses. Chinese were also required to post bail at extreme amounts. Cases requiring the appearance of a Chinese person in Court in which the individual failed to show were rare.

Many cases involving Chinese defendants necessitated the use of interpreters. Although the use of interpreters under Oregon law was not established until 1862, provisions for an interpreter as per a Portland ordinance was not enacted until 1885. Chinese were used as interpreters. It was unclear how fair and accurate Chinese interpreters were in representing Chinese defendants. Language was a barrier within the justice system and not all Chinese were accepting of each other.

Finally, corrections had the duty and responsibility of housing offenders. Corrections was usually the final option at the discretion of the judge. Some Native 
Americans, few identifiable observed African Americans, but a preponderance of Chinese, were often subjected to harsher sentencing by the Courts than their white counterparts.

An overview of Oregon's history demonstrated legal inequities that initially denied Native Americans and ultimately African Americans and Chinese immigrants not only the opportunity to obtain land in Oregon but to freely live in Oregon and subsequently, Portland. The United States Congress set the legal and political tone for the continuation of adverse laws seeking to regulate Native American rights in the land where they once controlled their own destinies.

Not only were Native Americans subjugated, they were subjected to insignificant roles with regard to decisions regarding practices related to their language, values and traditions. They were forced to acquiesce in white authority and white culture without equitable due process. The United States government, ultimately joined by Oregon legislators, enacted laws specifically denying Native Americans equal rights the Constitution was designed to acknowledge and respect for white inhabitants be they citizens or immigrants.

Oregon and subsequently Portland was established by missionaries who were Protestants and Catholics and later joined by members of the Jewish community. There were also independents not affiliated with any religion. Yet, these groups were bound by their abilities to assimilate into the broader society. An assimilation not available then or now to any racial minority. 
There was an examination of the Jewish community. There were few identifiable Jews observed as being arrested or brought to court. That does not mean they were not arrested or made to appear in front of the bench. However, unable to identify Jews by mere name, I was unable to identify many Jews involved in the criminal justice process.

I did however, obtain the names of Jewish businessmen residing in the Portland area prior to 1854 . From that list, name were matched with census data, city directories and Oregon State Directories to further determine the names of members of their families and descendants.

Jews were extremely prosperous during the time period researched and were also extensively involved in politics, public office and held judiciary and policing positions. Jews were respected for their business, civic and political contributions but were not accepted socially. They did not suffer from unjust laws, they were involved in enacting many laws. They did not suffer from the adversities directed at Native Americans, African Americans and Chinese initially. However, Jews later became the target of an intolerable society governing a system they helped to establish.

If the criminal justice system is to be successful in protecting the public from wrong doings then society must learn to define what wrong doings are outside belief based attitudes of superiority - control - and a fear of that which is different. Does a history of tolerated inequitable legal and illegal treatment of racial and ethnic 
minorities have adverse impact on contemporary practices and applications within Oregon's justice system?

The results of extensive research by an Oregon Supreme Court Task Force ${ }^{9}$ presented their findings after extensive research. Findings included the following:

- Many non-English speaking minorities appearing in court do not comprehend the proceedings:

- Interpreters are not present

- Interpreters are not qualified

- Too few lawyers speak/ understand non-English speaking clients

- Too few lawyers practice in Oregon - Efforts to recruit are inadequate

- Too few minorities called for jury duty - fewer serve on juries

- Preemptive challenges (without justifying objection of juror/without question) are usually based on race/ethnicity of perspective juror

- Judges handling family law cases lack an understanding of traditions/cultural practices of minority families. Too few minorities are employed in Oregon Courts $\longrightarrow$ of the forty-nine positions available - none are filled by a minority

COMPARED TO NON-MINORITIES - MINORITIES ARE:

- More likely to be arrested

- More likely to be charged with a crime

- Less likely to be released on bail
- More likely to be convicted

- Less likely to receive probation

- More likely to be incarcerated

The results of the Task Force study of the 1990's appear to be a reflection of my study conducted on the period from the 1850 's to 1895 . Not much has changed. Racial and ethnic minorities looked different - behaved differently - spoke differently and probably had different values and customs, as such they were seen as a threat to the stability of the white establishment, the majority. This continues to be true in the 1990's.

$9 \quad$ Report of the Oregon Supreme Court Task Force on Racial/Ethnic Issues in the Judicial System, (May 1994), Office of the State Court Administrator, Oregon Judicial Department, Office of the Secretary of State, Archives Division, Territorial Document \#3666, pp. 181-182. See APPENDIX II. 
In response to fear, ignorance and intolerance, laws continue to be enacted based on raw public opinion rather than valid studies. The four departments within the criminal justice system continue to be overworked and understaffed in attempts to monitor, admonish and correct the iniquitous of society; iniquitous that the justice system was not designed to manage.

For example, prostitution and substance abuse problems are not activities that the criminal justice system can efficiently or effectively correct. There are other institutions better equipped to deal with dysfunctional social problems using professionals proficient in that area. Time wise, other institutions could allocate the skills of a trained staff more efficiently, and considering the over use and often misuse of criminal justice personnel, ultimately, the trained personnel of such institutions may have a greater capacity to response more compassionately.

It should be noted however, that in response to need and having an improved understanding of social problems, the criminal justice system has attempted to professionally address these and other, defined as criminal, social issues. Yet, the question remains as to whether other institutions could more readily and effectively respond more appropriately to resolving such issues. Jails and other criminal sanctions has not and cannot change dysfunctional behavior.

Society continues to pressure legislators to enact, and police officers to enforce, laws that unjustly target groups who look different, act different, and speak different, because they are perceived to be negatively different. Laws and Ordinances 
during the time period of my research were enacted out of fear, ignorance, intolerance and attitudes of superiority. Laws in the 1990's are enacted in response to cries for action to control crime that most often are attributed to members of minority groups.

Legal practices and procedures in response to three strikes and you're out, Oregon's measure eleven and other federal mandatory sentencing laws have done little to combat dangerous criminal acts. Such mandates have demanded an unprecedented number of arrests, backlogged court calendars, and impaired correction facilities by dangerously overloading their personnel and physical capacities. The vast majority of such laws have targeted members of minority groups.

There appears to be a continuing pattern that has emerged from this research. Minorities continue to be disproportionately targeted for criminal activity based on laws that do not efficiently address society's crime problems. Laws, procedures, policies and practices overwhelmingly and adversely impact minorities because the majority feels comfortable in using its power to further disenpower the powerless.

Racial and ethnic minorities during the middle to late 1800 's were overwhelmingly employed in menial jobs at substandard wages. They were poor and subsequently, disenfranchised. A large percentage of minorities in the 1990's continue to have economic struggles and are therefore, not privy to adequate legal counsel. They continue to be threatened with deportation, deportation out of the country, the neighborhood, the community and the society. Most minorities are not given the same 
legal or social considerations given to members of the white middle or upper classes of society.

The findings of research conducted on the justice system in the 1990's has historic connection to practices stemming from Oregon and Portland's early social and political history, legislative actions, law enforcement, adjudication and sentencing. Just as many criminal justice actions are inequitable in the 1990's, in the 1880's these actions were also the result of biased views, were ineffective, and did not adequately control criminal activities. Yet, many laws did unjustly target diverse groups as a result of their racial and ethnic differences. Such actions continue to be as unjust and as ineffective in the 1990's. 


\section{BIBLIOGRAPHY}

Alexander, Wm. T., (1968), History Of The Colored Race In America, Negro Universities Press, New York, New York. (E 185 .A3 1867a)

Allen, A. J., (ed.), (1848), Ten Years In Oregon: Travels and Adventures of Doctor E. White and Lady, Mack, Andrus and Company, Ithaca, New York, pp. 289-290.

Atkinson, George H., (1876 Unpublished paper), Early History of the Portland Public School System of Oregon, Oregon Historical Society, Portland, Oregon.

Biskupic, Joan, (7 November 1995), High Court Will Hear Case On Mandatory Sentencing, Los Angeles Times, Washington Post Service

Bracey, John H., Jr., August Meier, and Elliott Rudwick, (July 1970), Free Blacks In American: 1800-1860, Wadsworth Publishing Company, Inc., Belmont, California.

Champagne, Duane, Editor, (1994), The Native North American Almanac: A Reference Work On Native North Americans In the United States and Canada, Gale Research, Inc., Detroit, Michigan, pp. 45-50.

Champion, Dean J., (1992), The Juvenile Justice System: Delinquency, Processing, and the Law, Macmillian Publishing Company, New York, New York,

Chen, Chia-Lin, (1972), A Gold Dream In The Blue Mountains, Thesis, Portland State University, Portland, Oregon.

Cline, Robert Scott, (1981), Community Structure On the Urban Frontier: The Jews of Portland, Oregon, 1849-1887, Thesis, Portland State University, Portland, Oregon,

Cole, Richard, (10 March 1996), 3rd Strike Scores In Wrong Cases, Study Finds, The Oregonian, Portland, Oregon, p. A20.

Columbia Encyclopedia, The, Barbara A, Chernow and George A. Vallasi, editors, (fifth edition 1963), Columbia University Press, United States of America. 


\section{BIBLIOGRAPHY}

Davis, Lenwood G., (October 1971), Blacks In The State of Oregon 1788-1971, Council Planning Librarians: Exchange Bibliography, Monticello, Illinois.

Oregon Spectator, (6 March 1851), Act Preventing Negroes Or Mulatoes Coming To or Residing In Oregon Passed By Territory Legislature in 1849, p. 3, col. 6 .

Oregon Spectator, (2 September 1851), Winslow Anderson Said To be Mulatto Responsible For Brave Among Oregon City Indians, p. 2, col. 2.

Pollard, Lancaster, (7 April 1963), Indians Consider Negro Slave Accompanying Lewis and Clark Expedition 'Big Medicine,' The Oregonian, p. 42.

Oregon Spectator, (7 January 1854), Oregon Territory Council Adopts Amendment To Witness Bill Preventing Negroes (including Mulattoes) From Testifying Against Whites, p. 1, col. 1)

Oregon Spectator, (2 September 1851), Winslow Anderson Declared Notorious, Ordered From Oregon Territory, p. 2, col. 2.

Deady, M. P., compiler and annotator, (1866), The Organic and Other General Laws of Oregon Together With the National Constitution and Other Public Acts and Statues of the United States: 1845-1864, Henry L. Pittock, State Printer, Portland, Oregon.

Deady, Matthew P. and Lafayette Lane, Compilers and Annotators, (1874), The Organic and Other General Laws of Oregon: Together With the National Constitution and Other Public Acts and Statutes of the United States. 18431872, Eugene Semple, State Printer, A. L. Bancroft \& Co., San Francisco, California.

DeBow, J. D. B., Superintendent of the United States Census, (1990), The Seventh Census of the United States: 1850, Norman Ross Publishing, Inc., New York, New York.

DiIulio, John J., (Fall 1994), The Question of Black Crime, The Public Interest, National Affairs, Inc., New York, New York, No. 117, p. 30. 


\section{BIBLIOGRAPHY}

Dobbs, G. B., (1986), The American Northwest: A History of Washington and Oregon, Biological Sketches of Prominent Citizens and Pioneers, D. Mason \& Co., Syracuse, New York.

Drimmer, Melvin, Editor, (1968), Black History: A Reappraisal, Doubleday \& Company, Inc., Garden City New York.

Carson, Clayborne, David J. Garrow, Gerald Gill, Vincent Harding, and Darlene Clark Hine, editors, The Eyes On The Prize: Documents, Speeches and Firsthand Accounts From The Black Freedom Struggle, 1954-1990, Penguin Books, New York, New York.

Chen, Chia-Lin, (1972), A Gold Dream In The Blue Mountains: A Study of the Chinese Immigration in the John Day Area Oregon, 1870-1910, Thesis, Portland State University, Portland, Oregon.

Clark, Robert Carlton, Robert Horace Down, George Verne Blue, (1926), A History f Oregon, Row, Peterson and Company, Chicago, Illinois.

Douglas, Jesse, (April 1950), Origins of the Population of Oregon in 1850, Pacific Northwest Quarterly, XLI, pp. 95-108.

Fenton, William D., (December 1901), Political History of Oregon from 1865 to 1876, Part I, Oregon Historical Quarterly, II, pp. 321-650.

Grumet, Robert Steven, (1979), Native Americans of the Northwest Coast, The Newberry Library Center for the History of the American Indian, Indiana University Press, Bloomington, Indiana. (SOC. SCT (Thesis)

Maddux, Percy, (1952), City on the Willamette: The Story of Portland, Oregon, Binfolds \& Mort, Portland, Oregon.

Hafen, LeRoy, (1961), The Mountain Men and the Fur Trade, Grolier Electronic Publishing, Inc.

Hagan, William T., (1966), Indian Police and Judges: Experiments in Acculturation and Control, Yale University Press, New Haven, Connecticut.

Handlin, Oscar, 1957), Race and Nationality In American Life, Doubleday Anchor Books, Doubleday \& Company, Inc., Garden City, New York. 


\section{BIBLIOGRAPHY}

Hewlett, Leroy, Editor, (1969), Indians of Oregon: A Bibliography of Materials In the Oregon State Library, Oregon State Library, Salem, Oregon.

Hiday, Mrs. Harry I., Compiler, (1972), United States Census of the City of Portland, Oregon: 1870, Genealogical Forum of Portland, Inc., Portland, Oregon.

Higham, John, (1955), Strangers In The Land, Rutgers Press, New Brunswick, New Jersey.

Hill, Daniel G., Jr., (1932), The Negro In Oregon: A Survey, Thesis, University of Oregon, Eugene , Oregon, (available through Oregon State University, Corvallis, Oregon).

Hornsby, Alton, Jr., (1973), The Black Almanac: From Involuntary Servitude (16191860 To The Age Of Disillusionment (1864-1972), Barron's Educational; Series, Inc., Woodbury, New York.

Ireson, Randall, Ph.D., (February 1994), Racial Disparities In Parole Revocation: Identifying Patterns and Possible Causes, Oregon Department of Corrections - Planning and Development - Research and Evaluation Unit, Salem Oregon.

Kennedy, Joseph C. G., Superintendent of Census, (1990), Population of the United States in 1860; Complied From the Original Returns of the Eighth Census Under the Direction of the Secretary of the Interior, Norman Ross Publishing, Inc., New York, New York.

Kessler, Lauren, (1993), Stubborn Twig: Three Generations of the Life of a Japanese American, Family, Random House, New York, New York.

Laws of Portland: Charter of the City of Portland and General Ordinances, In Force September 1886, Together With Rules of Order of the Common Council and Police and Fire Department Laws and Table of City Grades with Chronological Index of Ordinances, Passed by the Common Council of the City of Portland, from 1854-1886, (September 1886), Common Council of the City of Portland, R. H. Schwab \& Son, Portland, Oregon.

Lowenstein, Steven, (1987), The Jews of Oregon, Jewish Historical Society of Oregon, Portland, Oregon. 


\section{BIBLIOGRAPHY}

Lyman, H. S., (September 1900), Indian Names, The Quarterly of the Oregon Historical Society, City Hall, Portland, Oregon, vol. I, pp. 316-326.

Manzano, Phil, (19 November 1995), Case Challenges Tough-On-Crime Law, The Oregonian, Portland, Oregon,

McLagan, Elizabeth, (1980), A Peculiar Paradise: A History of Blacks in Oregon, 1788-1940, The Georgian Press, Portland, Oregon.

Mecklin, John Maffatt, Ph.D., (1963), The Ku Klux Klan: A Study of the American Mind, Russell \& Russell, Inc., New York, New York.

Meese, Edwin, (26 May 1995), Are Three Strikes Laws A Good Idea, Abstract, CQ Research, Congressional Quarterly Inc., Washington, D. C., vol. 5, No. 20, p. 481.

Merriam, Paul Gilman, (1971), Portland, Oregon, 1840-1890: A Social and Economic History, Dissertation, University of Oregon, Eugene, Oregon.

Merriam-Webster's Collegiate Dictionary, (Tenth Edition, 1993), Meriam-Webster, Inc., Springfield, Massachusetts.

Millner, Darrell, Professor, Lecture (Spring, 1991), Oregon Black History, Black Studies Department, Portland State University, Portland, Oregon.

Moreland, Kimberly S., et. al., (February 1993), History of Portland's African American Community (1805 to the Present), Portland Planning Bureau, Portland, Oregon.

Nokes, R. Gregory, (4 August 1996), The Return of the Nez Perce, The Oregonian, Portland, Oregon, p. C1)

Oregon State Directory 1881: A Business Directory of all Important Cities and Towns in Oregon: A General Directory of Portland and East Portland: Leading Business Firms In Eastern Washington: Abstract of the Census of 1880, Compared With That of 1870: And A Vast Amount of Other Matter, Religious, Educational, Commercial and Statistical, (1881), A. A. Byron, Compiler, J. K. Gill \& Co., Portland, Oregon. 


\section{BIBLIOGRAPHY}

Oregon Supreme Court Task Force on Racial/Ethnic Issues in the Judicial System, Report of the (May 1994), Chair, Honorable Edwin J. Petersen, Vice Chair., M. Khalil Zonoozy, Members, Kathleen Bogan, Honorable Nancy W. Campbell, Kathryn H. Clarke, Honorable Mercedes F. Diez, Marco A Hernandez, Douglas Hutchinson, Corine J. Lai, Honorable Jack L. Landau, Angel Lopez, Yvonne Martinez, Jeffery B. Millner, Jack L. Morris, Liliana E. Olberding, William A. Olsen, Nargress Shadbeh, H, Adunni Warren, Office of the State, Salem, Oregon.

Patterson, Lotsee and Mary Ellen Snodgrass, (1994), Indian Terms of the Americas, Libraries Unlimited, Inc., Englewood, Colorado.

Portland, Charter of the City of, As Amended, Together With the General Ordinances: 1880- 1881; Laws of Portland, (1881), A. G. Walling, Steam Primer and Bookbinder, Portland, Oregon.

Reddy, Marlita A., (1993), Statistical Record of Native North Americans, Gala Research, Inc., Detroit, Michigan.

Reynolds, Charles N., (December 1932), Portland Public Schools 1845-1871, Oregon Historical Quarterly, XXXIII, pp. 334-345.

Samuel, L., Newspaper Advertising Agent, (1873), Samuel's Directory of Portland and East Portland for 1873, Geo. H. Hines \& Co., Portland, Oregon.

Schulberg, Pete, (9 March 1996), TV News: Nothing But Crime-Time Coverage, The Oregonian, Portland, Oregon, p. E14.

Scott, H. W., Editor, (1890), History of Portland Oregon: With Illustrations and Biographical Sketches of Prominent Citizens and Pioneers, D. Mason \& Co., Syracuse, New York

Sloan, Irving J., Compiler and editor, (1971), The Jews In America: A Chronology and Fact Book, 1621-1970, Oceana Publications , Inc., Bobbs Ferry, New York.

Smith, Edward P., (1875), Annual Reports of the Secretary of the Interior, ser. 1680, p. 521. 


\section{BIBLIOGRAPHY}

Szasz, Margaret Connell, (1977), Education and the American Indian: The Road To Self-Determination Since 1928, University of New Mexico Press, Albuquerque, New Mexico.

Tracy, Charles A., (1976), Arrest and Crime Data: Portland, Oregon, 1868-1885, Portland Police Historical Society, Portland, Oregon, vol. $1 \& 2$.

Tracy, Charles A., (1976), The Evolution of the Police Function In Portland, Oregon, 1811-1874, Dissertation, University of California, Berkeley, California.

Turnquist, Kristi, Rob Eure and Kate Taylor, (23 June 1996), Many Blacks Say They Feel Sting of Racism Daily, The Oregonian, Portland, Oregon, p. A12.

Wood, Paul Adair, (1992), Urban Native American Educational Attitudes: Impact of Educational Background and Childhood Residency, Thesis, Portland State University, Portland, Oregon.

Woodward, Walter Carlton, (1913), The Rise and Early History of Political Parties in Oregon: 1843-1868, The J. K Gill Company, Portland, Oregon.

World Almanac and Book of Facts 1996, The, (1995), Funk \& Wagnalls, Mahwah, New Jersey,

World Book Dictionary, The, (1994), World Book, Inc., Chicago, Illinois, vol. one, A-K and vol. two, L-Z.

World Book Encyclopedia, The, (1995), World Book, Inc., Chicago, Illinois, Ci-Cz, vol. 4. 


\section{APPENDICES}


APPENDIX I

OREGON STATE PENITENTIARY

1853 - 1880 


\section{OREGON STATE PENITENTIARY ${ }^{1}$ \\ 1853-1880}

Oregon State Penitentiary was located one mile east of Salem. ${ }^{2}$ The section of the building made of brick housed the prison cells and administrative offices while the wooden section was used for workshops. Businesses within prison walls included:

chair factory; tannery; arness making; brick making, and; jute factory. ${ }^{3}$ The landscaping was elegant and spacious (Oregon State Directory, p. 78).

Convicts Received 1853 - September 7, 1880

\begin{tabular}{c|c|c|c|c|c|c|c} 
YEAR & \multicolumn{1}{c}{ INMATES } & YEAR & \multicolumn{1}{c}{ INMATES } & \multicolumn{1}{c}{ YEAR } & INMATES \\
\hline \hline 1853 & 2 & & 1863 & 17 & & 1873 & 59 \\
1854 & 7 & 1864 & 17 & 1874 & 45 \\
1855 & 5 & & 1865 & 30 & 1875 & 55 \\
1856 & 3 & 1866 & 23 & 1876 & 48 \\
1858 & 17 & 1868 & 29 & 1878 & 103 \\
1859 & 19 & & 1869 & 36 & 1879 & 127 \\
1860 & 18 & 1870 & 49 & & $9 / 7 / 1880$ & 171 \\
1861 & 22 & & 1871 & 58 & & & \\
1862 & 17 & & 1872 & 58 & & &
\end{tabular}

\begin{tabular}{c|c} 
OFFICERS - 1880 & OFFICE \\
\hline \hline A. Bush & Superentendent \\
W. P. Miller & Warden \\
J. A. Osborne & Assistant Warden \\
W. Stanley & Clerk and Turnkey $^{1}$ \\
T. B. Jackson & Commissary $^{1}$ \\
Rev. J. I. Parrish & Chaplain \\
Will L. Wade & Visiting Physician
\end{tabular}

1 Oregon State Directory 1881, (1881), A. A. Byron, Compiler, J. K. Gill \& Co., Portland, Oregon, pp. 77-79.

2 The Oregon State Penitentiary was orginally located in Portland from 1853 to 1867 , then moved to Salem. The facility was fully ocupied by 1871 , housing 200 inmates (Oregon State Directory 1881, p. 77).

3 An Asian plant used to make rope, twine and burlap. Obtained from the jute plant (American Hertiage Dictionary, SII, Seiko Instruments - electronic).

Appendix I

Oregon State Penitentiary 1853-1880

Boston 
APPENDIX II

OREGON SUPREME COURT TASK FORCE

REPORT

SUMMARY

RESEARCH \& FINDINGS 


\section{AREAS OF RESEARCH}

\begin{tabular}{|c|c|}
\hline $\begin{array}{ll}\text { - } & \text { Availability of Interpreters } \\
\text { - } & \text { Minorities Working In Oregon Courts } \\
\text { - } & \text { Minorities In Criminal Courts } \\
\text { - } & \text { Conduct of Trials Involving Minorities } \\
\text { - } & \text { Charging Decisions of Minorities } \\
\text { - } & \text { Sentencing Decisions of Minorities } \\
\text { - } & \text { Rate of Imprisonment of Minorities }\end{array}$ & $\begin{array}{ll}\text { - } & \text { Pretrial Release of Minorities } \\
\text { - } & \text { Plea Negotiations Among Minorities } \\
\text { - } & \text { Minorities In Juvenile Justice System } \\
\text { - } & \text { Minorities as Litigants } \\
\text { - } & \text { Minorities as Witnesses } \\
\text { - } & \text { Jury Selection } \\
\text { - } & \text { Jury Deliberations } \\
\text { - } & \text { Minority Lawyers }\end{array}$ \\
\hline
\end{tabular}

\section{FINDINGS}

- Many non-English speaking minorities appearing in court do not comprehend the proceedings:

- Interpreters are not present

- Interpreters are qualified

- Too few lawyers speak/ understand non-English speaking clients

- Too few lawyers practice in Oregon - Efforts to recruit are inadequate

- Too few minorities called for jury duty - fewer serve on juries

- Preemptory challenges (without justifying objection of juror/without question) are usually based on race/ethnicity of perspective juror

- Judges handling family law cases lack understand of traditions/cultural practices of minority families Too few minorities employed in Oregon Courts - of forty-nine positions available - none filled by a minority

\section{COMPARED TO NON-MINORITIES - MINORITIES ARE:}

- More likely to be arrested

- More likely to be charged with a crime

- Less likely to be released on bail
- More likely to be convicted

- Less likely to receive probation

- More likely to be incarcerated

Report of the Oregon Supreme Court Task Force on Racial/Ethnic Issues in the Judicial System, (May 1994), Office of the State Court Administrator, Oregon Judicial Department, Office of the Secretary of State, Archives Division, Territorial Document \#3666, pp. 181-182. See APPENDIX II. 


\section{APPENDIX III}

ARTICLES IN OREGON NEWSPAPERS CITING CRIMINAL, CIVIL RIGHTS VIOLATIONS AND OTHER ARTICLES OF INTEREST INVOLVING AFRICAN AMERICANS 1840'S TO 1880'S 
ARTICLES IN OREGON NEWSPAPERS CITING CRIMINAL AND CIVIL RIGHTS VIOLATIONS INVOLVING AFRICAN AMERICANS ${ }^{1}$ 1840'S TO 1810'S

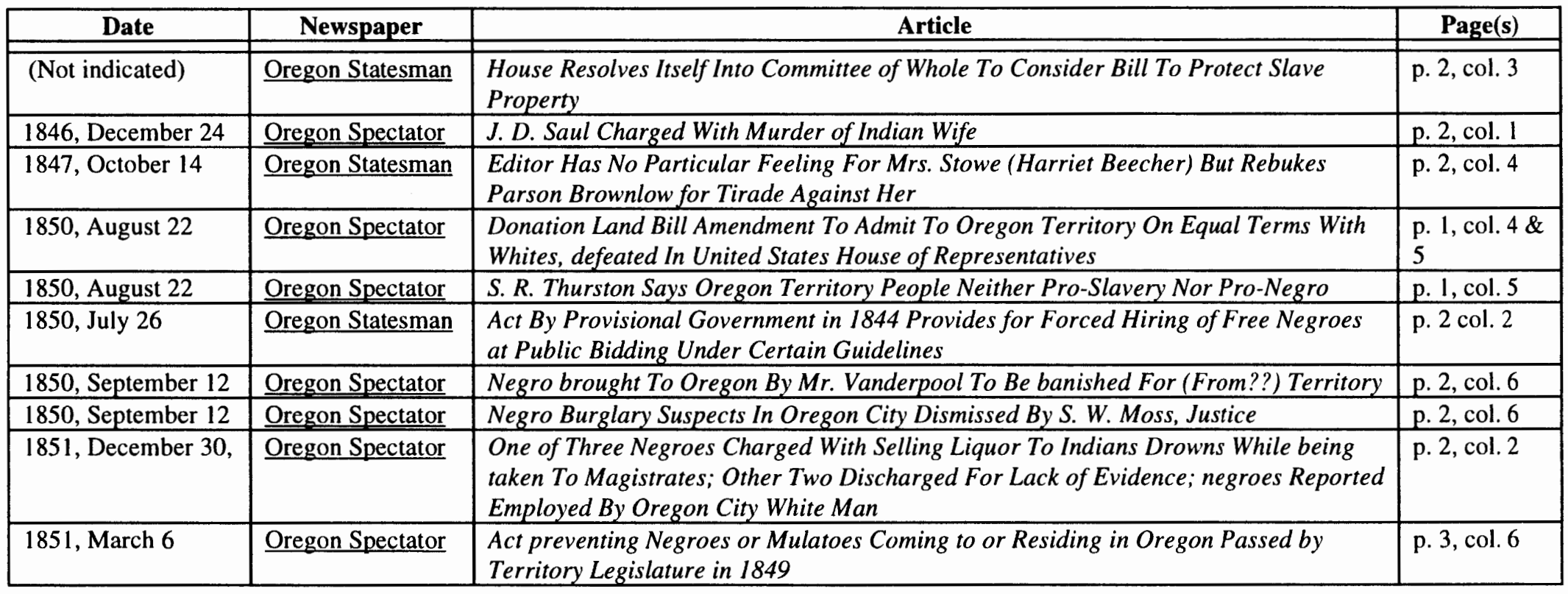

1 Bibliography - see Davis, p. 29

Appendix IIl

African Americans newspaper articles

1840 'S to 1810 'S

BOSTON 
ARTICLES IN OREGON NEWSPAPERS CITING CRIMINAL AND CIVIL RIGHTS VIOLATIONS INVOLVING AFRICAN AMERICANS ${ }^{2}$ 1840'S TO 1810'S

\begin{tabular}{|c|c|c|c|}
\hline Date & Newspaper & Article \\
\hline
\end{tabular}

The following two articles refer too the Cockstock Affair - see CHAPTER I, p. 45, footnote 26:

\begin{tabular}{|c|c|c|c|}
\hline 1851, September 2 & Oregon Spectator & Winslow Anderson Declared Notorious, Ordered From Oregon Territory & p. 2, col. 2 \\
\hline 1851, September 2 & Oregon Spectator & $\begin{array}{l}\text { Winslow Anderson Said To Be Mulatto reported Responsible For Brave Among } \\
\text { Oregon City Indians }\end{array}$ & p. 2, col. 2 \\
\hline 1851, September 9 & Oregon Spectator & 'S Urges Oregonians To Buy Negroes In South and Free Them In Oregon & p. 1, col. 3 \\
\hline 1853 , July 5 & Oregon Statesman & $\begin{array}{l}\text { Omitting Recognition of the Ordinance of } 1787 \text { In creation of Washington Territory } \\
\text { Leaves Territory Open To Slavery }\end{array}$ & p. 2 , col. 1 \\
\hline 1853 , July 5 & Oregon Statesman & $\begin{array}{l}\text { Habeas Corpus Proceedings In Oregon Supreme Court To Release Negroes At Dalles, } \\
\text { Polk County Who Were Once 'Held As Slaves In Mo.' }\end{array}$ & p. 2 , col. 2 \\
\hline 1853, October 20 & Oregon Spectator & Negro and White Man Fight Over Squaw & p. 3., col. 1 \\
\hline 1854 , January 7 & Oregon Spectator & $\begin{array}{l}\text { Oregon Territory Council Adopts Amendment To Witness Bill Preventing negroes } \\
\text { (Including Mulattoes) From Testifying Against Whites }\end{array}$ & p. 1, col. 1 \\
\hline 1854, November 14 & Oregon Statesman & $\begin{array}{l}\text { Presbyterian and Congregational Churches Hold Salem meeting and Discuss The } \\
\text { Nebraska Bill }\end{array}$ & p. 1, col. 5 \\
\hline 1854, October 17 & Oregon Statesman & $\begin{array}{l}\text { Luteshio Ceusar, Woman Slave In Missouri brought To Oregon, Sues Estate of Master } \\
\text { For Back Wages }\end{array}$ & p. 3, col. 1 \\
\hline 1855 , January 23 & Oregon Statesman & $\begin{array}{l}\text { Nebraska-Kansas Discussed In The House of representatives In relation To Slavery In } \\
\text { Oregon }\end{array}$ & p. 1, col. 5 \\
\hline 1856, December 23 & Oregon Statesman & Slavery Referred To By Delazon Smith In House On Oregon Statehood & p. 1, col. 3 \\
\hline
\end{tabular}

2 Bibliography - see Davis, p. 29

Appendix III

African Americans newspaper articles

1840 'S to $1810^{\prime} S$

BOSTON 


\section{ARTICLES IN OREGON NEWSPAPERS CITING CRIMINAL AND CIVIL RIGHTS VIOLATIONS INVOLVING AFRICAN AMERICANS ${ }^{3}$}

1840'S TO 1810'S

\begin{tabular}{|c|c|c|c|}
\hline Date & & Article & Page(s) \\
\hline 1856 , June 3 & Oregon Statesman & $\begin{array}{l}\text { Umpqua County Democrat Convention Passes Resolution Making Slavery A State or } \\
\text { territory Question --to the Effect That Slavery Is A Domestic Institution and Congress } \\
\text { has No Power To Establish It In Any State or Territory or Exclude It }\end{array}$ & p. 1, col. 7 \\
\hline 1856 , September 16 & Oregon Statesman & Leland States He Does Advocate Abolitionism For Standard; Editor Disagrees & p. 2, col. 2 \\
\hline 1857, April 21 & Oregon Statesman & $\begin{array}{l}\text { Debate Between Free State and Pro-Slavery Men Held In Eugene City During } \\
\text { Democratic Convention, Vote about } 30 \text { to Pro-Slavery }\end{array}$ & p. 2, col. 2 \\
\hline 1857, April 22 & Oregon Statesman & State Representative Convention Oppose Extension of Slavery & p. 2, col. 3 \\
\hline 1857, April 7 & Oregon Statesman & Letter From 'Young America' Objects To Making Slavery a Democratic Party Issue & p. 2, col. 4 \\
\hline 1857, August 4 & Oregon Statesman & Slavery Urged By F. B. martin To Increase Price of Real Estate & p. 3, col. 6 \\
\hline 1857, December 22 & Oregon Statesman & $\begin{array}{l}\text { Bill To Protect Rights of Slave Holders Indefinitely Postponed In House or } \\
\text { Representatives }\end{array}$ & (not indicated) \\
\hline 1857, July 28 & Oregon Statesman & G. H. Williams Sets Forth Reasons Why Oregon Should be Non-Slave State & p. 1, cols. $6 \& 7$ \\
\hline 1857 , July 7 & Oregon Statesman & Pro-Slavery Sentiment Reported Increasing & p. $2 . \operatorname{col} .7$ \\
\hline 1857, March 3 & Oregon Statesman & $\begin{array}{l}\text { Letter Signed 'Anti Niggerphobia' Says Let Democratic Conventions Nominate Good } \\
\text { and True Men Without Reference To Their Views Upon Slavery In Oregon }\end{array}$ & p. 2 , col. 5 \\
\hline 1857, May 19 & Oregon Statesman & County Democratic Convention To Put Slavery Question To Vote of People & p. 2, cols. $4 \& 5$ \\
\hline 1857, November 17 & Oregon Statesman & Slavery Rejected AT Election & p. 2 , cols. $3 \& 6$ \\
\hline 1857, October 13 & Oregon Statesman & Slavery, Pro-Slavery by J. Cooley & p. 1, col. 3 \\
\hline 1857, September 29 & Oregon Statesman & $\begin{array}{l}\text { Slavery Proposed Constitution Provides That Slavery Question Is to Be Decided By } \\
\text { Vote of People On Second Monday In November, I857 }\end{array}$ & p. 4, col. 2 \\
\hline 1858, February 9 & Oregon Statesman & $\begin{array}{l}\text { Bill To Protect Slavery Considered In Committee of Whole By House; After Debate } \\
\text { Committee Rose and Reported Adversely To Passage of Bill }\end{array}$ & p. 1, col. 7 \\
\hline
\end{tabular}




\section{ARTICLES IN OREGON NEWSPAPERS CITING CRIMINAL AND CIVIL RIGHTS VIOLATIONS INVOLVING AFRICAN AMERICANS ${ }^{4}$ 1840'S TO 1810'S}

\begin{tabular}{|c|c|c|c|}
\hline Date & Newspaper & Article & Page(s) \\
\hline 1858 , January 26 & Oregon Statesman & Petition Concerning Slavery Taken From Table and Referred To Committee of Whole & p. 2 , col. 1 \\
\hline 1858 , January 29 & Oregon Statesman & Slavery Bill For Protection of Slave Property In Oregon Introduced In House & p. 1, col. 4 \\
\hline 1858, May 15 & Oregon Statesman & Humorous Explanation of Dred Scott Decision Reportedly Made in Umpqua County & p. 1, col. 7 \\
\hline 1858 , November 9 & Oregon Statesman & $\begin{array}{l}\text { Views of Judge George H. Williams in } 1857 \text { Publication In His Reply To General } \\
\text { Adair's Letter }\end{array}$ & p. 1, col. 2 \\
\hline 1858, October 26 & Oregon Statesman & Entered Republican Opposition To Admitting Oregon Territory As A Free State & p. 1, col.. 4 \\
\hline 1859, December 6 & Oregon Statesman & Letter From 'Posted' Advocates Limited Form of Slavery For Training Indians & p. 1, col. 1 \\
\hline 1859, February 9 & Oregon Statesman & Moved To Take Up Bill Representing Slave Property; Motion Carried & p. 1, col. 5 \\
\hline 1859 , January 11 & Oregon Statesman & $\begin{array}{l}\text { Petition from James D. Southworth and Others For Recognition of Right of Protection } \\
\text { to Slave Property Presented To House of Representatives }\end{array}$ & p. 1, col. 4 \\
\hline 1859, January 18 & Oregon Statesman & Legislative Action on Bill For Protection of Slave Property & p. 1, col. 3 \\
\hline 1859, October 11 & Oregon Statesman & $\begin{array}{l}\text { Letter From F. B. Martin Says Slaves Can Be Freed Only By Being Taken Into and } \\
\text { Held In States By Their Owners In Violation of Law }\end{array}$ & p. 1, col. 4 \\
\hline 1859, September 12 & Oregon Spectator & S. R. Thurston Defends Law Excluding Free Negroes From Oregon & p. 1, col. 5 \\
\hline 1859 , September 20 & Oregon Statesman & $\begin{array}{l}\text { Session of Congregational Church Adopts Resolution To Deny Pulpit to Clergymen of } \\
\text { Other Sects Who Countenance Slavery }\end{array}$ & p. $2, \cos 3$ \\
\hline 1860, April 10 & Oregon Statesman & $\begin{array}{l}\text { Clackamas County Precinct Meeting Under Lane Influence Adopts Resolution for } \\
\text { Federal Control of Slavery }\end{array}$ & p. 2, col. 1 \\
\hline 1860, April 17 & Oregon Statesman & $\begin{array}{l}\text { Marion County Democratic Convention Favor Congressmen Who Will Resist Slave } \\
\text { Code In territories }\end{array}$ & p. 2 , col. 7 \\
\hline 1860 , August 28 & Oregon Statesman & $\begin{array}{l}\text { D. Smith and W. W. Chapman Omit Plank for Re-Opening African Slave Trade from } \\
\text { Breckinridge Platform }\end{array}$ & p. 2 , col. 5 \\
\hline
\end{tabular}

Appendix III

Bibliography - see Davis, p. 29

African Americans newspaper articles

1840 'S to $1810^{\prime} S$

BOSTON 


\section{ARTICLES IN OREGON NEWSPAPERS CITING CRIMINAL AND CIVIL RIGHTS VIOLATIONS INVOLVING AFRICAN AMERICANS ${ }^{5}$}

1840'S TO 1810'S

\begin{tabular}{|c|c|c|c|}
\hline Date & Newspaper & Article & Page(s) \\
\hline 1860, December 31 & Oregon Statesman & J. Lane In Letter Defines His views & p. 2, col. 3 \\
\hline 1860, March 13 & Oregon Statesman & $\begin{array}{l}\text { Letter From ' } G \text { ' Discusses stand Taken by Buchsnan and By Lane In } 1856 \text { and } 1860 \\
\text { on Slavery In Territories }\end{array}$ & p. 1, col. 3 \\
\hline 1860, March 6 & Oregon Statesman & J. Lane Says Congress Should Prohibit Slavery In Territories & p. 2. col. 2 \\
\hline 1860, May 15 & Oregon Statesman & J. Lane Votes for Pro-Slavery Resolutions In Senate & p. 2 , col. 5 \\
\hline 1860, October 21 & Oregon Statesman & $\begin{array}{l}\text { Gov. Whitaker in Message Says John Brown's Raid Hastens Settlement of Slavery } \\
\text { Question }\end{array}$ & p. 1, col. 3 \\
\hline 1860, October 21 & Oregon Statesman & Great Debate In United States On Question of Slavery In The Territory & p. 1, col. 1 \\
\hline 1864, August 29 & Oregon Statesman & M. Bride Votes For Fugitive Slave Law Repeal In Congress & p. 2 , col. 3 \\
\hline 1864, August 9 & The Oregonian & Resolution Adopted By general Conference M. E. Church In Regard To Freedom & p. 2 , col. 3 \\
\hline 1864, September 26 & Oregon Statesman & $\begin{array}{l}\text { Resolution Offered In Legislature Asks Congress To Amend Constitution To Forever } \\
\text { Prohibit Slavery }\end{array}$ & p. 2, col. 4 \\
\hline 1865, December 11 & Oregon Statesman & Oregon Legislature Casts Seven Votes Against Thirteenth Amendment & p. 3, col. 5 \\
\hline 1865, December 11 & Oregon statesman & Proceedings of Legislature Debate Upon Thirteenth Amendment Published & p. 3, col. 3 \\
\hline 1865, March 13 & Oregon Statesman & $\begin{array}{l}\text { Governor of Oregon Receives Proposed constitutional Amendment Prohibiting } \\
\text { Slavery }\end{array}$ & (Not indicated) \\
\hline 1865, March 20 & Oregon Statesman & Letter Fro Polk Attacks and Urges Passage of Amendment Prohibiting Slavery & p. 1 , col. 3 \\
\hline 1865, September 25 & Oregon Statesman & Legislature To Hold Special Session and Vote Re Abolition of Slavery & p. 3 , col. 6 \\
\hline 1866, January 8 & Oregon Statesman & J. S. Cartwright In favor of Ratification of Thirteenth Amendment Published & p. 1, col. 6 \\
\hline 1871, April 111 & The Oregonian & $\begin{array}{l}\text { School Meeting Taxes, Colored School-Enlargement of Buildings-Investigation of } \\
\text { reports and Accounts Ordered }\end{array}$ & p. 3 , cols. $2 \& 3$ \\
\hline
\end{tabular}




\section{ARTICLES CITING PARTICULAR EVENTS/INCIDENTS:}

The following article refers to George Washington and his attempt to pilot the ship when delivering food - see CHAPTER I, p. 34 , footnote 13.

\begin{tabular}{|l|l|ll|l|}
\hline 1846, August 6 & Oregon Spectator & Negro Living at Cape Disappointment Attempts To Pilot Shark To Astoria & p. 2, col. 3 \\
\hline
\end{tabular}

The following articles refer to organizations established by African Americans during the period of study:

\begin{tabular}{|l|l|l|l|}
\hline 1879, December 17 & The Oregonian & Organization of Colored Immigration Society & p. 3, col. 3 \\
\hline 1884, April 24 & The Oregonian & $\begin{array}{l}\text { Portland Colored Citizens Have A Public Meeting Pass Resolution Urging Greater } \\
\text { Union At The Polls }\end{array}$ & p. 3, col. 6 \\
\hline
\end{tabular}

\begin{tabular}{|c|l|l|l|l|}
\hline Date & \multicolumn{1}{|c|}{ Newspaper } & \multicolumn{1}{c|}{ Article } & Pages & \multicolumn{1}{c|}{ Reporter } \\
\hline 1963, April 7, & The Oregonian & $\begin{array}{l}\text { Indians Consider Negro Slave Accompanying Lewis and Clark } \\
\text { Expedition'Big medicine' }\end{array}$ & $\begin{array}{l}\text { p. 42 } \\
\text { Pollard }\end{array}$ \\
\hline
\end{tabular}




\section{APPENDIX IV}

\section{OREGON, PORTLAND AND COUNTY ${ }^{*}$ POPULATIONS 1850's TO 1890's}

The census data for specific Counties were included because of minority populations. 
OREGON, PORTLAND AND COUNTY ${ }^{1}$ POPULATIONS ${ }^{2}$

POPULATION OF PORTLAND - P

POPULATION OF OREGON - O

POPULATION BY RACE, ETHNICITY, OR NATIVE BORN COUNTRY

\begin{tabular}{|c|c|c|c|c|c|c|c|c|c|c|c|c|c|}
\hline YEAR & \multicolumn{2}{|c|}{1850} & \multicolumn{2}{|c|}{$1860^{3}$} & 1862 & 1863 & 1865 & 1866 & 1867 & 1868 & 1869 & \multicolumn{2}{|c|}{1870} \\
\hline PORTLAND & \multicolumn{2}{|c|}{1022} & \multicolumn{2}{|c|}{ 2874-2917 } & 4057 & 5819 & 6508 & N/A & 6717 & 7980 & 8928 & \multicolumn{2}{|c|}{ 8293-9569 } \\
\hline OREGON & \multicolumn{2}{|c|}{13294} & \multicolumn{2}{|c|}{52465} & & & & & & & & \multicolumn{2}{|c|}{90923} \\
\hline & $\mathbf{P}$ & $\mathbf{0}$ & $\mathbf{P}$ & 0 & $\mathbf{O}$ & $\mathbf{O}$ & $\mathbf{0}$ & 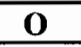 & $\mathbf{0}$ & $\mathbf{0}$ & 0 & $\mathbf{P}$ & 0 \\
\hline Foreign Born & 51 & N/A & 728 & 52465 & & & & & & & & 2578 & 11600 \\
\hline Great Britain ${ }^{4}$ & 18 & 313 & 97 & 939 & & & & & & & & 442 & 1978 \\
\hline Ireland & 13 & 156 & 242 & 1266 & & & & & & & & 787 & 1967 \\
\hline Norway & $\mathbf{0}$ & 1 & 2 & 43 & & & & & & & & & 76 \\
\hline Sweden & $\mathbf{0}$ & 2 & 8 & 56 & & & & & & & & 40 & 205 \\
\hline Denmark & $\mathbf{0}$ & 2 & 4 & 50 & & & & & & & & 20 & 87 \\
\hline Switzerland & 1 & 8 & 9 & 71 & & & & & & & & 20 & 160 \\
\hline France & 3 & 45 & 24 & 198 & & & & & & & & 80 & 308 \\
\hline Germany & 8 & 116 & 195 & 1078 & & & & & & & & 609 & 1874 \\
\hline Russia & $\mathbf{0}$ & 11.4 & 0 & 22 & & & & & & & & 5 & 67 \\
\hline Italy & $\mathbf{0}$ & 5 & 3 & 33 & & & & & & & & & --31 \\
\hline Canada & 3 & 293 & 45 & 663 & & & & & & & & 281 & 1168 \\
\hline China & $\mathbf{0}$ & & $20 / 27$ & 425 & 200 & & 324 & & & & & 487 & 3326 \\
\hline Civilized Indians & & & 6 & 177 & & & & & & & & 28 & 318 \\
\hline Free Colored & 4 & 207 & 16 & 128 & 52 & & & & & & & 147 & 346 \\
\hline
\end{tabular}

County census data was included for those counties having minority populations.

U. S. Bureau of Census (1892), Compendium of the Eleventh Census: 1890, Government Printing Office, Washington, D. C.

Scott, H. w. Editor (1890), History of Portland, Oregon: with Illustrations and Biographical Sketches of Prominent Citizens and Pioneers, D. Masco \& Co., Syracuse, New York.

3 Kennedy, Joseph C. G., Superintendent of Census, (1990), Population of the United States in 1860; Compiled From the Original Returns of the Eighth Census Under the Direction of the Secretary of the Interior, Norman Ross Publishing Inc., New York, New York, pp. 402-405.

Appendix IV

Great Britain includes England, Scotland and Wales.

Oregon \& Portland Populations 
OREGON POPULATION $1850^{5}$

BY AGE \& RACE/ETHNICITY

\begin{tabular}{|c|c|c|c|c|c|c|c|c|c|c|c|c|}
\hline \multirow[t]{2}{*}{ WHITES - AGES } & \multicolumn{2}{|c|}{ less than 1} & \multicolumn{2}{|c|}{1 to 5} & \multicolumn{2}{|c|}{5 to 10} & \multicolumn{2}{|c|}{10 to 15} & \multicolumn{2}{|c|}{15 to 20} & \multicolumn{2}{|c|}{20 to 30} \\
\hline & $\mathbf{M}$ & $\mathbf{F}$ & $\mathbf{M}$ & $\mathbf{F}$ & $\mathbf{M}$ & $\mathbf{F}$ & $\mathbf{M}$ & $\mathbf{F}$ & $\mathbf{M}$ & $\mathbf{F}$ & $\mathbf{M}$ & $\mathbf{F}$ \\
\hline Benton & 19 & 17 & 68 & 54 & 62 & 71 & 60 & 51 & 47 & 39 & 79 & 43 \\
\hline Clackamus & $=$ & 1 & 155 & 127 & 119 & 135 & 85 & 88 & 95 & 91 & 326 & 139 \\
\hline Clark & 1 & - & 15 & 20 & 28 & 17 & 16 & 13 & 17 & 7 & 293 & 22 \\
\hline Clatsop & 5 & 8 & 21 & 25 & 19 & 17 & 21 & 16 & 21 & 13 & 128 & 21 \\
\hline Lewis & 1 & 2 & 24 & 22 & 23 & 15 & 12 & 13 & 17 & 11 & 144 & 26 \\
\hline Linn & 16 & 14 & 76 & 75 & 80 & 82 & 65 & 60 & 57 & 37 & 126 & 87 \\
\hline Marion & 38 & 35 & 202 & 185 & 224 & 239 & 174 & 159 & 152 & 119 & 343 & 175 \\
\hline Polk & 18 & 14 & 93 & 93 & 91 & 81 & 71 & 63 & 40 & 56 & 107 & 71 \\
\hline Washington $^{6}$ & 39 & 28 & 143 & 126 & 144 & 158 & 119 & 129 & 156 & 81 & 621 & 132 \\
\hline Yam Hill & 24 & 30 & 105 & 108 & 117 & 119 & 94 & 100 & 75 & 71 & 208 & 86 \\
\hline TOTAL & 161 & 149 & 902 & 835 & 907 & 934 & 717 & 692 & 677 & 525 & 2375 & 802 \\
\hline WHITES - AGES & \multicolumn{2}{|c|}{30 to 40} & \multicolumn{2}{|c|}{40 to 50} & \multicolumn{2}{|c|}{50 to 60} & \multicolumn{2}{|c|}{60 to 70} & \multicolumn{2}{|c|}{70 to 80} & \multicolumn{2}{|c|}{80 to 90} \\
\hline & $\mathbf{M}$ & $\mathbf{F}$ & $\mathbf{M}$ & $\mathbf{F}$ & $\mathbf{M}$ & $\mathbf{F}$ & $\mathbf{M}$ & $\mathbf{F}$ & $\mathbf{M}$ & $\mathbf{F}$ & $\mathbf{M}$ & $\mathbf{F}$ \\
\hline Benton & 53 & 48 & 41 & 19 & 16 & 9 & 10 & 2 & 1 & 1 & - & - \\
\hline Clackamus & 173 & 88 & 93 & 36 & 43 & 20 & 14 & 5 & 2 & - & 1 & - \\
\hline Clark & 94 & 13 & 22 & 4 & 8 & 1 & 1 & - & - & - & - & - \\
\hline Clatsop & 63 & 9 & 39 & 8 & 13 & 5 & 5 & 1 & - & - & - & \\
\hline Lewis & 74 & 16 & 25 & 7 & 15 & 1 & 8 & - & - & - & 1 & - \\
\hline Linn & 80 & 39 & 32 & 29 & 19 & 7 & 5 & 6 & 1 & 1 & & \\
\hline Marion & 249 & 120 & 115 & 63 & 71 & 28 & 20 & 4 & 4 & - & - & - \\
\hline Polk & 83 & 46 & 33 & 26 & 25 & 14 & 12 & 7 & 2 & - & $\cdot$ & - \\
\hline Washington & 347 & 94 & 119 & 44 & 64 & 22 & 17 & 11 & 3 & - & - & $=$ \\
\hline Yam Hill & 127 & 73 & 64 & 38 & 33 & 12 & 16 & 4 & 3 & 3 & 1 & - \\
\hline TOTAL & 1343 & 546 & 583 & 274 & 307 & 119 & 108 & 40 & 16 & 5 & 3 & \\
\hline & & & & & & & & & & & & \\
\hline
\end{tabular}

5 DeBow, J. D. B., Superintendent of the United States Census, (1990), The Seventh Census of the United States: 1850, Norman Ross Publishing, Inc., New York, New York, pp. 988-995.

$6 \quad$ Washington County Oregon included the towns of Linn City, Milton City and Portland. 
OREGON POPULATION 1850

BY AGE \& RACE/ETHNICITY

\begin{tabular}{|c|c|c|c|c|c|c|c|c|c|c|c|c|}
\hline \multirow{2}{*}{$\begin{array}{c}\text { FREE COLORED } \\
\text { AGES } \\
\end{array}$} & \multicolumn{2}{|c|}{ less than 1} & \multicolumn{2}{|c|}{1 to 5} & \multicolumn{2}{|c|}{5 to 10} & \multicolumn{2}{|c|}{10 to 15} & \multicolumn{2}{|c|}{15 to 20} & \multicolumn{2}{|c|}{20 to 30} \\
\hline & $\mathbf{M}$ & $\mathbf{F}$ & $\mathbf{M}$ & $\mathbf{F}$ & $\mathbf{M}$ & $\mathbf{F}$ & $\mathbf{M}$ & $\mathbf{F}$ & $\mathbf{M}$ & $\mathbf{F}$ & $\mathbf{M}$ & $\mathbf{F}$ \\
\hline Benton & - & - & 1 & - & - & 1 & - & - & - & - & - & - \\
\hline Clackamus & & - & - & 2 & - & 1 & 2 & - & 1 & - & 7 & 3 \\
\hline Clark & - & - & 2 & -2 & 5 & 4 & 1 & - & 3 & 2 & 22 & 2 \\
\hline Clatsop & - & - & - & - & - & - & 1 & - & - & - & - & - \\
\hline Lewis & & - & 17 & 14 & 8 & 10 & 5 & 8 & 6 & 6 & 6 & 9 \\
\hline Linn & - & - & - & - & - & - & - & - & - & - & - & - \\
\hline Marion & & & 2 & - & & & - & 1 & 1 & - & 2 & 1 \\
\hline Polk & & - & 1 & - & - & 2 & - & 1 & - & $\mathbf{1}$ & - & - \\
\hline Washington & & - & - & - & & 1 & - & 1 & - & - & 1 & - \\
\hline Yam Hill & - & - & - & - & - & - & - & - & - & 1 & - & - \\
\hline TOTAL & & & 23 & 18 & 13 & 19 & 9 & 11 & 11 & 10 & 38 & 15 \\
\hline \multirow[t]{2}{*}{$\begin{array}{c}\text { FREE COLORED } \\
\text { AGES } \\
\end{array}$} & \multicolumn{2}{|c|}{30 to 40} & \multicolumn{2}{|c|}{40 to 50} & \multicolumn{2}{|c|}{50 to 60} & \multicolumn{2}{|c|}{60 to 70} & \multicolumn{2}{|c|}{70 to 80} & \multicolumn{2}{|c|}{80 to 90} \\
\hline & $\mathbf{M}$ & $\mathbf{F}$ & $\mathbf{M}$ & $\mathbf{F}$ & $\mathbf{M}$ & $\mathbf{F}$ & $\mathbf{M}$ & $\mathbf{F}$ & $\mathbf{M}$ & $\mathbf{F}$ & $\mathbf{M}$ & $\mathbf{F}$ \\
\hline Benton & - & 2 & - & - & - & - & - & - & - & - & - & - \\
\hline Clackamus & 4 & - & 1 & 1 & 1 & - & - & - & - & - & - & - \\
\hline Clark & 4 & 1 & 1 & 2 & - & - & - & - & - & 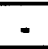 & - & - \\
\hline Clatsop & 2 & - & 1 & - & - & - & - & - & - & - & - & - \\
\hline Lewis & 6 & 4 & - & 1 & 1 & - & - & - & - & - & - & - \\
\hline Linn & - & - &. & - & - & & - & - & - & - & - & - \\
\hline Marion & - & 1 & - & 1 & - & - & - & - & - & - & - & - \\
\hline Polk & - & - & - &. & - & - & - & - & - & - & - & - \\
\hline Washington & 4 & 1 & 1 & - & $=$ & - & - & - & - & - & - & - \\
\hline Yam Hill & & - & - & - & - & - & - & - & - & - & - & - \\
\hline TOTAL & 20 & 9 & 4 & 5 & 2 & - & - & - & - & - & - & - \\
\hline & & & & & & & & & & & & \\
\hline
\end{tabular}

Oregon \& Portland Populations 
OREGON POPULATION 1850

\section{BY AGE \& RACE/ETHNICITY}

\begin{tabular}{|c|c|c|c|c|c|c|c|}
\hline & \multicolumn{3}{|c|}{ WHITES } & \multicolumn{3}{|c|}{ FREE COLORED } & \multirow{2}{*}{ AGGREGATE } \\
\hline & M & F & TOTAL & $\mathbf{M}$ & $\mathbf{F}$ & TOTAL & \\
\hline Benton & 456 & 354 & 810 & 1 & 3 & 4 & 814 \\
\hline Clackamus & 1106 & 730 & 1836 & 16 & 7 & 23 & 1859 \\
\hline Clark & 495 & 97 & 592 & 38 & 13 & 51 & 643 \\
\hline Clatsop & 335 & 123 & 458 & 4 & - & 4 & 462 \\
\hline Lewis & 344 & 113 & 457 & 49 & 52 & 101 & 558 \\
\hline Linn & 557 & 437 & 994 & - & $\cdot$ & - & 994 \\
\hline Marion & 1603 & 1137 & 2740 & 5 & 4 & 9 & 2749 \\
\hline Polk & 575 & 471 & 1046 & 1 & 4 & 5 & 1051 \\
\hline Washington & 1800 & 843 & 2643 & 6 & 3 & 9 & 2652 \\
\hline Yam Hill & 867 & 644 & 1511 & - & 1 & 1 & 1512 \\
\hline TOTAL & 8138 & 4949 & 13087 & 120 & 87 & 207 & 13294 \\
\hline
\end{tabular}

WASHINGTON COUNTY

\begin{tabular}{|c|c|c|c|c|c|c|c|}
\hline & \multicolumn{3}{|c|}{ WHITES } & \multicolumn{3}{c|}{ FREE COLORED } & AGGREGATE \\
\hline & M & F & TOTAL & M & F & TOTAL & \\
\hline Linn City & $\mathbf{6 6}$ & $\mathbf{5 8}$ & 124 & - & 1 & 1 & 125 \\
\hline Milton City & $\mathbf{4 5 8}$ & $\mathbf{2 3 1}$ & $\mathbf{6 8 9}$ & 3 & - & 3 & 692 \\
\hline Portland & $\mathbf{6 5 3}$ & 164 & $\mathbf{8 1 7}$ & 2 & 2 & 4 & 821 \\
\hline
\end{tabular}


OREGON POPULATION 1860

BY AGE \& RACE/ETHNICITY

COUNTIES

\begin{tabular}{|c|c|c|c|c|c|c|c|c|c|c|}
\hline \multirow[t]{2}{*}{1860} & \multicolumn{3}{|c|}{ WHITE } & \multicolumn{3}{|c|}{ FREE COLORED } & \multicolumn{3}{|c|}{ INDIAN } & \multirow[b]{2}{*}{ Aggregate } \\
\hline & $\mathbf{M}$ & $\mathbf{F}$ & Total & $\mathbf{M}$ & $\mathbf{F}$ & Total & $\mathbf{M}$ & $\mathbf{F}$ & Total & \\
\hline Benton & 1806 & 1253 & 3059 & 5 & 5 & 10 & 5 & - & 5 & 3074 \\
\hline Coos & 305 & 116 & 421 & - & - & - & 5 & 19 & 24 & 445 \\
\hline Clackamus & 1980 & 1484 & 3464 & - & 1 & 1 & 1 & - & 1 & 3466 \\
\hline Clatsop & 307 & 189 & 496 & 2 & - & 2 & - & - & - & 498 \\
\hline Columbia & 334 & 198 & 532 & - & - & - & - & - & - & 532 \\
\hline Curry & 287 & 89 & 376 & - & - & - & 6 & 11 & 17 & 393 \\
\hline Douglas & 1957 & 1210 & 3167 & 4 & 5 & 9 & 15 & 12 & 27 & 3203 \\
\hline Jackson & 2789 & 900 & 3689 & 26 & 16 & 42 & 2 & 3 & 5 & 3786 \\
\hline Josephine & 1288 & 321 & 1609 & 3 & 1 & 4 & 3 & 7 & 10 & 1623 \\
\hline Lane & 2735 & 2044 & 4779 & 1 & - & 1 & - &. & - & 4780 \\
\hline Linn & 3787 & 2976 & 6763 & 2 & 5 & 7 & 1 & 1 & 2 & 6772 \\
\hline Marion & 4004 & 3018 & 7022 & 12 & 8 & 20 & 14 & 32 & 46 & 7088 \\
\hline Multnomah & 2446 & 1680 & 4126 & 10 & 7 & 17 & 2 & 5 & 7 & 4150 \\
\hline Polk & 2104 & 1519 & 3623 & 2 & - & 2 & - & - & - & 3625 \\
\hline Tillamook & 61 & 34 & 95 & - & - & - & - & - & - & 95 \\
\hline Umpqua & 745 & 497 & 1242 & 1 & 2 & 3 & 1 & 4 & 5 & 1250 \\
\hline Wascoo & 1160 & 513 & 1673 & 7 & 2 & 9 & - & 7 & 7 & 1689 \\
\hline Washington & 1554 & 1226 & 2780 & - & - & - & 9 & 12 & 21 & 2801 \\
\hline Yam Hill & 1802 & 1442 & 3244 & 1 & - & 1 & - & - & - & 3245 \\
\hline TOTAL & 31451 & 20709 & $\overline{52160}$ & $\overline{76}$ & $\overline{52}$ & 128 & $\overline{64}$ & 113 & 177 & 52465 \\
\hline
\end{tabular}

MULTNOMAH COUNTY

\begin{tabular}{|c|c|c|c|c|c|c|c|c|c|c|}
\hline 1860 & \multicolumn{3}{|c|}{ WHITE } & \multicolumn{3}{c|}{ FREE COLORED } & \multicolumn{3}{|c|}{ INDIAN } & \\
\hline & M & F & Total & M & F & Total & M & F & Total & Aggregate \\
\hline Portland & 1701 & 1151 & 2852 & 9 & 7 & 16 & 1 & 5 & 6 & 2874 \\
\hline
\end{tabular}

\section{BENTON COUNTY}

\begin{tabular}{|c|c|c|c|c|c|c|c|c|c|c|}
\hline 1860 & \multicolumn{3}{|c|}{ WHITE } & \multicolumn{3}{c|}{ FREE COLORED } & \multicolumn{3}{c|}{ INDIAN } & \\
\hline & $\mathrm{M}$ & $\mathrm{F}$ & Total & $\mathbf{M}$ & $\mathrm{F}$ & Total & $\mathrm{M}$ & $\mathrm{F}$ & Total & Aggregate \\
\hline Corvallis & $\mathbf{7 0 0}$ & $\mathbf{5 2 0}$ & $\mathbf{1 2 2 0}$ & $\mathbf{4}$ & $\mathbf{5}$ & $\mathbf{9}$ & $\mathbf{2}$ & - & $\mathbf{2}$ & 1231 \\
\hline
\end{tabular}


OREGON POPULATION 1860

BY AGE \& RACE/ETHNICITY

COUNTIES

\section{COOS COUNTY}

\begin{tabular}{|c|c|c|c|c|c|c|c|c|c|c|}
\hline 1860 & \multicolumn{3}{|c|}{ WHITE } & \multicolumn{3}{c|}{ FREE COLORED } & \multicolumn{3}{|c|}{ INDIAN } & \\
\hline & $\mathrm{M}$ & $\mathrm{F}$ & Total & $\mathrm{M}$ & $\mathrm{F}$ & Total & $\mathrm{M}$ & $\mathrm{F}$ & Total & Aggregate \\
\hline Coyville & 64 & $\mathbf{3 0}$ & $\mathbf{9 4}$ & - & - & - & 2 & 2 & 4 & 98 \\
\hline Empire & 126 & 44 & 170 & - & - & - & - & 6 & 6 & 176 \\
\hline Johnson & $\mathbf{4 5}$ & $\mathbf{1 0}$ & $\mathbf{5 5}$ & - & - & - & 2 & 4 & 6 & 61 \\
\hline Randolph & $\mathbf{7 0}$ & $\mathbf{3 2}$ & 102 & - & - & - & 1 & 7 & 8 & 110 \\
\hline
\end{tabular}

JACKSON COUNTY

\begin{tabular}{|c|c|c|c|c|c|c|c|c|c|c|}
\hline 1860 & \multicolumn{3}{|c|}{ WHITE } & \multicolumn{3}{c|}{ FREE COLORED } & \multicolumn{3}{|c|}{ INDIAN } & \\
\hline & M & F & Total & M & F & Total & M & F & Total & Aggregate \\
\hline Applegate & 433 & 79 & 512 & - & 2 & 2 & - & - & - & 514 \\
\hline Ashland & 215 & 112 & 327 & - & - & - & - & - & - & - \\
\hline Butte Creek & 192 & 109 & 301 & 13 & 13 & 26 & - & - & - & 327 \\
\hline Dardanelles & 275 & 55 & 330 & 1 & - & 1 & - & - & - & 331 \\
\hline Forestville & 111 & 10 & 121 & 3 & - & 3 & 1 & 1 & 2 & 126 \\
\hline Jacksonville & 657 & $\mathbf{2 2 2}$ & $\mathbf{8 7 9}$ & 9 & 1 & 10 & 1 & 2 & 3 & 892 \\
\hline
\end{tabular}

MARION COUNTY

\begin{tabular}{|c|c|c|c|c|c|c|c|c|c|c|}
\hline 1860 & \multicolumn{3}{|c|}{ WHITE } & \multicolumn{3}{c|}{ FREE COLORED } & \multicolumn{3}{|c|}{ INDIAN } & \\
\hline & M & F & Total & M & F & Total & M & F & Total & Aggregate \\
\hline Champoag & 230 & 141 & 371 & - & - & - & 8 & 19 & 27 & 398 \\
\hline Fairfield & 474 & 348 & 822 & - & - & - & - & 2 & 2 & 824 \\
\hline Labish & 151 & 117 & 268 & 1 & - & 1 & - & - & - & 269 \\
\hline Northern & 373 & 251 & 624 & - & - & - & - & 2 & 2 & 626 \\
\hline North Salem & $\mathbf{3 6 3}$ & 237 & 600 & 8 & 8 & 16 & 4 & 5 & 9 & $\mathbf{6 2 5}$ \\
\hline Santiam & $\mathbf{2 2 6}$ & 183 & 409 & - & - & - & - & 3 & 3 & 412 \\
\hline Silverton & $\mathbf{3 5 0}$ & 262 & 614 & - & - & - & 1 & - & 1 & 490 \\
\hline Southern & 269 & 220 & 489 & 1 & - & 1 & - & - & - & 902 \\
\hline Sublimity & $\mathbf{6 4 6}$ & $\mathbf{5 7 3}$ & 1219 & 1 & - & 1 & 1 & - & 1 & 1221 \\
\hline
\end{tabular}


OREGON POPULATION $1870^{7}$

BY AGE \& RACE/ETHNICITY

\begin{tabular}{|c|c|c|c|c|c|c|}
\hline \multicolumn{4}{|c|}{ BORN IN U.S. } & \multicolumn{3}{c|}{ PLACE OF BIRTH IN U. S. } \\
\hline White & Colored & Chinese & Indian & White & Colored & Indian \\
\hline 78711 & 301 & 4 & 307 & 31 & 1 & 2 \\
\hline
\end{tabular}

\begin{tabular}{|c|c|c|c|c|c|c|}
\hline \multicolumn{2}{|c|}{ BORN IN FOREIGN COUNTRIES } & \multicolumn{3}{|c|}{$\begin{array}{c}\text { FOREIGN COUNTRY OF } \\
\text { BIRTH } \\
\text { NOT STATED }\end{array}$} \\
\hline White & Colored & Chinese & Indian & Whitc & Colored & \\
\hline 8218 & 45 & 3326 & 11 & - & - & - \\
\hline
\end{tabular}

\begin{tabular}{|c|c|c|}
\hline \multicolumn{3}{|c|}{ BORN IN CANADA } \\
\hline White & Colored & Indian \\
\hline 12138 & 254 & 2 \\
\hline
\end{tabular}

7 Francis A. Walker, Superintendent of Census, (1990), Ninth Census, Volume I, The Statistics of the Population of the United States, Embracing The Tables of Race, Nationality, Sex, Selected Ages and Occupations..., Norman Ross Publishing, Inc., New York, New York, pp. 243, 319, 328 and 336. Appendix IV 


\section{OREGON, PORTLAND AND COUNTY ${ }^{8}$ POPULATIONS 9 \\ POPULATION OF PORTLAND - $P$ \\ POPULATION OF OREGON - O \\ POPULATION BY RACE, ETHNICITY, OR NATIVE BORN COUNTRY}

\begin{tabular}{|c|c|c|c|c|c|c|c|c|c|c|c|c|c|}
\hline YEAR & 1871 & 1872 & 1873 & 1874 & 1875 & 1876 & 1877 & 1878 & 1879 & \multirow{2}{*}{\multicolumn{2}{|c|}{$\begin{array}{c}1880 \\
17577\end{array}$}} & \multicolumn{2}{|c|}{1890} \\
\hline PORTLAND & 11103 & & 12959 & & 13470 & 13802 & 15099 & 19128 & & & & \multirow{2}{*}{\multicolumn{2}{|c|}{$\begin{array}{c}46385 \\
313767 \\
\end{array}$}} \\
\hline OREGON & & & & & & & & & & \multicolumn{2}{|c|}{174568} & & \\
\hline & & & & & & & & & & $\mathbf{P}$ & 0 & $\mathbf{P}$ & $\mathbf{O}$ \\
\hline Foreign Born & & & & & & & & & & 6312 & 30503 & 17323 & 57317 \\
\hline Great Britain & & & & & & & & & & N/A/ & 4190 & 2065 & 8284 \\
\hline Ireland & & & & & & & & & & N/A & 3659 & 1638 & 4891 \\
\hline Norway & & & & & & & & & & N/A & 574 & 704 & 2271 \\
\hline Sweden & & & & & & & & & & N/A & 983 & 1312 & 3774 \\
\hline Denmark & & & & & & & & & & N/A & 385 & 300 & 1288 \\
\hline Switzerland & & & & & & & & & & N/A & 730 & 403 & 2093 \\
\hline France & & & & & & & & & & N/A & 514 & 305 & 842 \\
\hline Germany & & & & & & & & & & N/A & 5034 & 3652 & 12475 \\
\hline Russia & & & & & & & & & & N/A & 379 & 359 & 2583 \\
\hline Italy & & & & & & & & & & N/A & 167 & 267 & 589 \\
\hline Canada & & & & & & & & & & N/A & 3019 & 1238 & 6463 \\
\hline China & & & & & & & & & & 1668 & 9472 & 4438 & 9465 \\
\hline Nat. Amer. & & & & & & & & & & & & & \\
\hline Free Coolored & & & & & & & & & & 192 & 487 & 480 & 1186 \\
\hline
\end{tabular}

$8 \quad$ Op. Cit., County census.

Appendix IV

Op. Cit., U. S. Bureau of Census (1892).

Oregon \& Portland Populations 


\section{APPENDIX V}

\section{CHARACTERISTICS OF PERSONS ARRESTED BY YEAR ${ }^{1}$ 1868-1885}

Tracy, Charles A., (1976), Arrest and Crime data: Portland, Oregon, 1868-1885, Portland Police historical Society, Portland, Oregon, vol. 1 \& 2. 


\section{CHARACTERISTICS OF PERSONS ARRESTED BY YEAR}

1868-1885

\begin{tabular}{|c|c|c|c|c|c|c|c|c|c|c|c|c|c|c|c|c|c|c|}
\hline \multirow{2}{*}{$\begin{array}{c}\text { Racial, Ethnic } \\
\text { and/or } \\
\text { National Group }\end{array}$} & \multicolumn{18}{|c|}{ NUMBER OF PERSONS ARRESTED } \\
\hline & 1868 & 1869 & 1870 & 1871 & 1872 & 1873 & 1874 & 1875 & 1876 & 1877 & 1878 & 1879 & 1880 & 1881 & 1882 & 1883 & 1884 & 1885 \\
\hline $\begin{array}{l}\text { Anglo-Saxon - } \\
\text { General } \\
\end{array}$ & 464 & 415 & 591 & 1622 & 1285 & 1516 & 1145 & 873 & 972 & 1434 & 1167 & 1880 & 2 & $\mathbf{5 0}$ & 78 & 192 & 110 & 61 \\
\hline $\begin{array}{c}\text { Anglo-Saxon } \\
\text { American }\end{array}$ & & & & & & & & & & & & & 969 & $\mathbf{7 8 0}$ & 1215 & 1936 & 1427 & 865 \\
\hline $\begin{array}{c}\text { Anglo-Saxon } \\
\text { British }\end{array}$ & & & & & 2 & & & & $\mathbf{1}$ & 2 & & & 336 & 232 & 223 & 234 & 117 & 114 \\
\hline $\begin{array}{c}\text { Anglo-Saxon } \\
\text { Irish }\end{array}$ & 3 & 1 & 2 & & 7 & 11 & 8 & & & & 182 & & 655 & 662 & 899 & 1535 & 881 & 462 \\
\hline $\begin{array}{c}\text { European } \\
\text { General }\end{array}$ & 65 & 21 & 12 & 88 & 227 & 157 & 137 & 37 & 84 & 127 & 433 & 338 & 294 & 307 & 351 & 728 & 390 & 287 \\
\hline $\begin{array}{c}\text { European } \\
\text { Scandinavian } \\
\end{array}$ & & & 1 & 1 & 4 & 8 & 3 & 1 & 2 & 1 & 57 & 2 & 151 & 124 & 123 & 125 & 91 & 64 \\
\hline $\begin{array}{c}\text { Indian/Native } \\
\text { American }\end{array}$ & 20 & 20 & 10 & 10 & 16 & 16 & 11 & 6 & 2 & 9 & 2 & 7 & 14 & 15 & 21 & 13 & 2 & 2 \\
\hline
\end{tabular}

'Tracy, Charles A., (1976), Arrest and Crime data: Portland, Oregon, 1868-1885, Portland Police historical Society, Portland, Oregon, vol. 1 \& 2.

Appendix $\mathrm{V}$

Characteristics of Persons Arrested By Year

1868-188

Boston 


\section{CHARACTERISTICS OF PERSONS ARRESTED BY YEAR}

1868-1885

\begin{tabular}{|c|c|c|c|c|c|c|c|c|c|c|c|c|c|c|c|c|c|c|}
\hline \multirow{2}{*}{$\begin{array}{c}\begin{array}{c}\text { Racial, Ethnic } \\
\text { and/or } \\
\text { National Group }\end{array} \\
\end{array}$} & \multicolumn{18}{|c|}{ NUMBER OF PERSONS ARRESTED } \\
\hline & 1868 & 1869 & 1870 & 1871 & 1872 & 1873 & 1874 & 1875 & 1876 & 1877 & 1878 & 1879 & 1880 & 1881 & 1882 & 1883 & 1884 & 1885 \\
\hline & & & & & & & & & & & & & & & & & & \\
\hline Middle East & & 1 & & 1 & & & & & & & & & & & & & & \\
\hline & & & & & & & & & & & & & & & & & & \\
\hline Negro - Blacks & & & & & & 2 & & & & & & & 23 & 27 & 35 & 19 & 2 & 14 \\
\hline & & & & & & & & & & & & & & & & & & \\
\hline Oriental - Asian & 48 & 25 & 20 & 114 & 108 & 207 & 144 & 76 & 110 & 101 & 303 & 224 & 133 & 232 & 132 & 852 & 478 & 475 \\
\hline & & & & & & & & & & & & & & & & & & \\
\hline Polynesian & 1 & & & 2 & & & & 1 & & & & 2 & 2 & 1 & & 1 & 2 & \\
\hline & & & & & & & & & & & & & & & & & & \\
\hline Other & & & & & & & & & & & & & 1 & 1 & & & & \\
\hline & & & & & & & & & & & & & & & & & & \\
\hline Totals & 601 & 483 & 636 & 1838 & 1649 & 1917 & 1448 & 994 & 1171 & 1674 & 2144 & 2453 & 2581 & 2432 & 3077 & 5634 & 3500 & 2344 \\
\hline
\end{tabular}




\section{APPENDIX VI}

CITY DIRECTORY

NAMES, ETHNIC DERIVATIONS, AND VOCATIONS OF THE MINORITY

RESIDENTS OF PORTLAND IN 1870 AND 1872

INCLUDING WHITE CITY OFFICIALS, ATTORNEYS AND THE CLERGY 


\section{CITY DIRECTORY 1 \\ NAMES, ETHNIC DERIVATIONS, AND VOCATIONS OF THE MINORITY RESIDENTS OF PORTLAND IN 1870 AND 1872}

The first City Directory was printed in 1863 . The names, ethnic derivation, and vocation of the minority residents of Portland in 1870 and 1872 are provided in this APPENDIX. The names of apparent racial/ethnic minorities have been replicated for insertion in this document.

\section{CITY DIRECTORY ${ }^{2}$ \\ PORTLAND AS OF JANUARY 1, 1870}

\section{Population of Portland}

\begin{tabular}{|c|c|c|c|c|c|}
\hline 1860 & 2917 & \multicolumn{2}{|r|}{1869} & \multirow{2}{*}{\multicolumn{2}{|c|}{ East Portland }} \\
\hline 1862 & 4057 & total males & 4182 & & \\
\hline 1863 & 4794 & total females & 3389 & males & 300 \\
\hline 1864 & 5619 & transient & 500 & females & 500 \\
\hline 1865 & 6068 & colored males & 90 & & \\
\hline 1866 & 6508 & colored females & 47 & & \\
\hline 1867 & 6717 & Chinese males & 500 & & \\
\hline 1868 & 7980 & Chinese females & 220 & & \\
\hline & & & 8928 & & 800 \\
\hline
\end{tabular}

Grand Total

9428

$1 \quad$ Polk Directory, Publisher, (8th year of publication) - General Directory of Residents Directory of Citizens, Portland, Oregon, pp. 33-101. 2 Ibid.

Appendix VI

General Directory of 


\begin{tabular}{|c|c|c|c|}
\hline Name & Occupation & Address & $\underline{\text { Race }}$ \\
\hline Ah Jack & Laundress & 26 Stark & Chinese \\
\hline Boyce, A. & Jobber & 13 Front & colored \\
\hline Carr, Mrs. M. H. & $\begin{array}{l}\text { Boarding } \\
\text { House }\end{array}$ & First \& Pine & colored \\
\hline Carr, Albert* & $\begin{array}{l}\text { Saloon } \\
\text { groceries }\end{array}$ & Second \& Alder & colored \\
\hline Dixon, Robert & barber & 16 Morrison & colored \\
\hline Douglas, John & cook & N. Third cor. C & colored \\
\hline Duck, Loung \& Co. & merchants & & Chinese \\
\hline Fook Sing & laundress & 212 Front Street & Chinese \\
\hline Graham, C. J. ** & barber & Taylor btw 3d \& 4th & colored \\
\hline Height, Mrs. E. & & 143 Second & colored \\
\hline Hill, Cornelia & & 2nd btw Wash/Alder & colored \\
\hline Ho Lee & laundress & E s Front nr Madison & Chinese \\
\hline Hon Song & laundress & $8 \mathrm{~N}$. Front & Chinese \\
\hline Hong Sing & laundress & 24 Washington & Chinese \\
\hline Hop Kee & laundress & E s N front & Chinese \\
\hline Hop Wa & laundress & 14 Morrison & Chinese \\
\hline Hop Chung & laundress & Yamhill btw Front/1st & Chinese \\
\hline Johnston, Andrews & cook & N. First Cor A & colored \\
\hline Kam Wah & laundress & 58 Front & Chinese \\
\hline Kinsland, $M$. & $\begin{array}{l}\text { barber (19 } \\
\text { Front) }\end{array}$ & 5th btw Taylor/Salmo & colored \\
\hline Long Sing & laundress & 199 Front & Chinese \\
\hline Loong Sing & laundress & 46 Front & Chinese \\
\hline Lodge, Rev. J. & minister & NE cor Pine \& N 6th & colored \\
\hline May Hin & restaurateur & Alder btw 1st \& 2nd & Chinese \\
\hline Mercier, C. H. & $\begin{array}{l}\text { hair dresser } \\
\text { (Alder- } \\
\text { Front/1st) }\end{array}$ & btw 2nd \& 3d & colored \\
\hline Monchow & $\begin{array}{l}\text { (Chinese) } \\
\text { physician }\end{array}$ & Alder btw 2nd \& 3d & Chinese \\
\hline Mung Sing & laundress & 9 Taylor & Chinese \\
\hline OAES (not Oaes) & $\begin{array}{l}\text { Chinese } \\
\text { doctor (not } \\
\text { physician) }\end{array}$ & 24 Stark & Chinese \\
\hline $\begin{array}{l}\text { O'Hagan, Isaac } \\
\text { Prescott, William H. } \\
\text { Stopped p. 83-7/19/95 }\end{array}$ & $\begin{array}{l}\text { bootblack } \\
\text { jobber }\end{array}$ & $\begin{array}{l}12 \text { Washington } \\
\text { C btw N 3d \& 4th }\end{array}$ & $\begin{array}{l}\text { colored } \\
\text { colored }\end{array}$ \\
\hline Public School & $\begin{array}{l}\text { (for colored } \\
\text { children) }\end{array}$ & 266 Fourth & colored \\
\hline $\begin{array}{l}\text { Robinson, } \mathbf{N} \text {. } \\
\text { Canvasser City }\end{array}$ & $\begin{array}{l}\text { saloon } \\
\text { - A. Bushwi }\end{array}$ & Alder - btwn 1st \& 2nd & colored \\
\hline
\end{tabular}




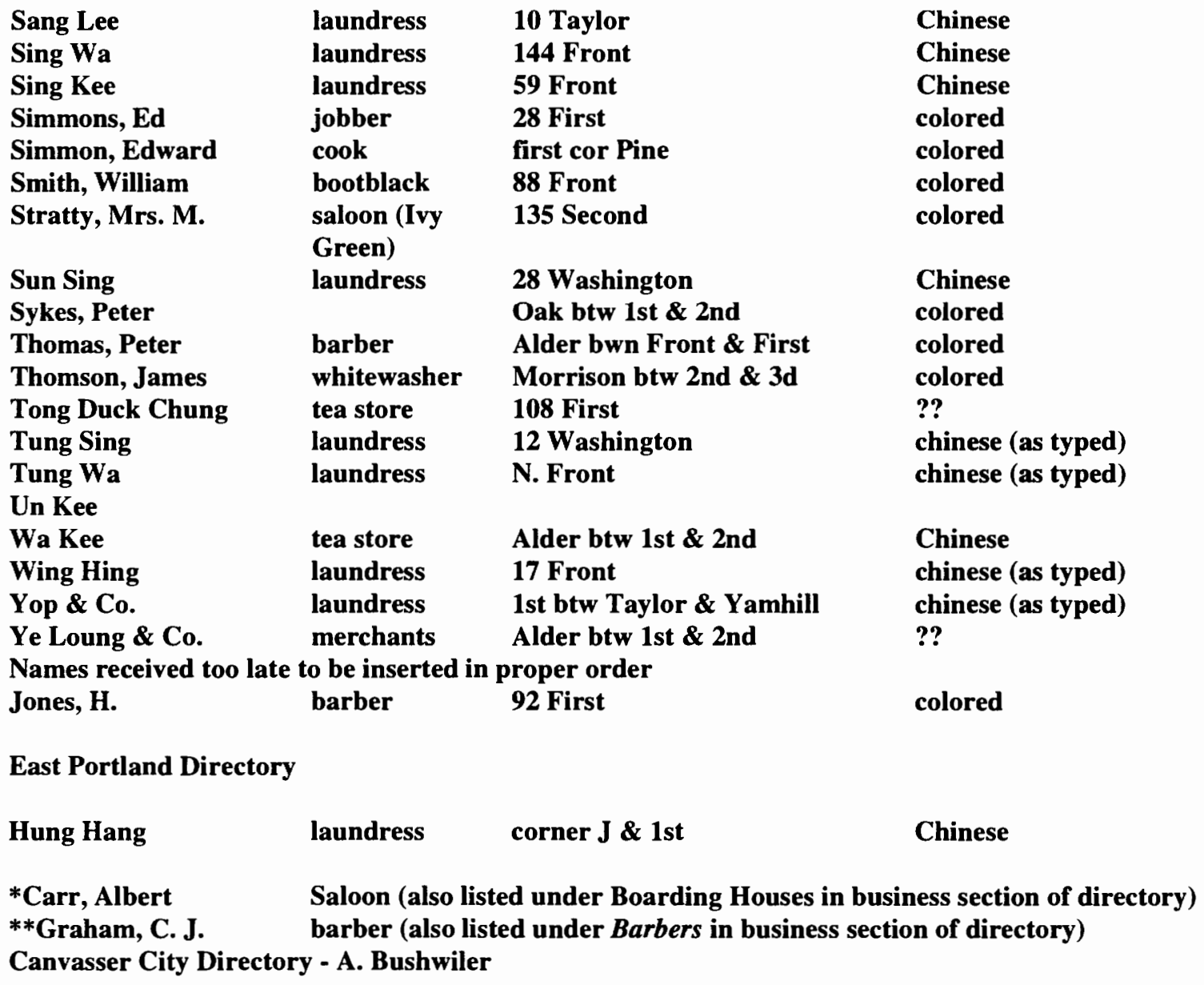


PORTLAND CITY OFFICIALS, POLITICIANS, CLERGY AND LAWYERS

First Ward

Councilmen:

Second Ward

Councilman:

Third Ward

Councilman:

POLICE

Marshall

Deputy Marshals:
North of Washington Street

C. Bills, William Cree, A. C. Ripley

Between Washington and Main Street

J. M. Breck, R. Porter, W. Moffett

South of Main Street

D. C. Lewis, L. Besser, Charles Hopkins

Philip Saunders

J. Donovan

William C. Blake or (W. P. Blake)

A. P. Brannan or (A. B. Brannon)

William Clink

H. M. Hudson

B. O'Hara

FIREMAN

D. E. Jones

James Wall

DUPTY SHERIFF

J. P. Ward

SHERIFF OF MULTNOMAH COUNTY

Al Zieber

JUSTICES OF

THE PEACE

\section{J. A. Waterman (N. Portland Precinct) \\ B. Trainor (near Ferry Landing) \\ M. P. Bull, (Washington Precinct)$$
\text { Constable: Philip Saunders }
$$ \\ John C. Work, (Central Portland Precinct)
Constable:
A. B. Brannan

US SENATORS

H. W. Corbett

George H. Willaims

CITY RECORDER -

Levi Anderson (Also served as Police/Court Recorder)

CITY AUDITOR

W. S. Caldwell 


\section{U.S. DISTRICT JUDGE - \\ COUNTY JUDGE - \\ JUDGE FOURTH \\ JUDICIAL DISTRICT \\ CITY TREASURER - \\ COUNTY TREASURER - \\ COUNTY COMMISSIONER \\ COUNTY COMMISSIONER \\ DEPUTY COLLOECTOR \\ OF CUSTOMS - \\ CITY ATORNEY'S OFFICE - \\ CHIEF PAY MASTER - \\ DEPT OF COLLECTIONS - \\ US DISTRICT \\ ATTORNEY'S OFFICE:}

Editor of Oregonian -

Editor of P. C. Advocate -

Editor of Hearld -

Proprietor - Oregonian -

\section{Attorneys at law -}

1. Beal

2. Octavius Bell (editor - The Hearld)

3. E. Bybee (Also served as a police office)

4. C. Bronaugh (notary public)

5. F. Caples

6. M. Carter

7. John Catlin

8. W. Chapman

9. A. Cronin

10. H. Durham

11. A. Dolph (Also served as a police officer)

12. Milton Elliot

13. W. Fechheimer

14. David Freidenrich

15. Hamilton

16. B. Hanna

17. F. Hensel

18. Lair Hill

19. J. Hoffman (Also served as Justice of the Peace)
M. P. Deady

P. A. Marquam

W. W. Upton

D. E. Backentos

W. P. Doland

E. L. Quimby (East Portland)

H. Boyd

H. L. Hoyt (Also served as Police Recorder)

C. A. Dolph (Also served as policeman)

P. M. Gibson

John C. Cartwright

C. P. Crandall

I. Dillion

F. Elsworth

Henry L. Pittock

20. James. K. Kelly (Also served as a police officer

21. Killin (Killen)

22. David Logan

23. F. McCoy

24. A. Moreland (Also served as Justice of the Peace)

25. W. Page

26. H. Reed

27. Thomas Smith

28. John H. Stinson

29. Lansing Stout

30. Robert Stott (law student)

31. F. Trimble

32. Upton

33. E. Wait

34. W. Whalley

35. John C. Work

36. H. Mitchell Name received too late to be inserted properly:

37. Attorney - East Portland

38. Charles Gardner 


\begin{tabular}{|c|c|}
\hline $\begin{array}{l}\text { Pastor - } \\
\text { Pastor } \\
\text { Priest }\end{array}$ & $\begin{array}{l}\text { G. H. Atkinson (Congregational Church) } \\
\text { J. F. DeVore } \\
\text { John F. Fierrens (Catholic Church) } \\
\text { (Chinese Church) }\end{array}$ \\
\hline Priest & Cornilius Delahunty (Catholic Church) \\
\hline Rabbi & Dr. Julius Eckman (Synagogue Ahabi Sholam) \\
\hline Pastor & T. L. Eliot (Untarian Church) \\
\hline Pastor & A. L. Lindsley (Presbyterian Church) \\
\hline Bishop & B. Wistar Morris (Protestant Episcopal) \\
\hline Pastor & A. Myers(Lutheran Church) \\
\hline Pastor & $\begin{array}{l}\text { William Roberts (M. E. Church) } \\
\text { A. C. Fairchild (M. E. Church) }\end{array}$ \\
\hline $\begin{array}{l}\text { Pastor } \\
\text { Beth Isreal }\end{array}$ & W. H. Stoy (Trinity Church) \\
\hline School - & $\begin{array}{l}\text { H. R. Phillips } \\
\text { (Beth Israel Synagogue) } \\
\text { (Ahabi Shalom Synagogue) }\end{array}$ \\
\hline & James Wilbur (Methodist Church) \\
\hline
\end{tabular}

Proprietor - Washington Hotel -

Proprietor - Pioneer Hotel -

Proprietor - Brooklyn Hotel -

Proprietor - Orient Hotel -
Jacob Koenig

P. Morrissey

J. Petty

J. Barker (East Portland) 
PORTLAND CITY DIRECTORY JANUARY $1,1^{3}{ }^{3}$

POPULATION OF PORTLAND

\begin{tabular}{|c|c|c|c|}
\hline 1861 & 2917 & \multicolumn{2}{|l|}{$\underline{1871}$} \\
\hline 1862 & 4057 & white males & 5,831 \\
\hline 1863 & 4794 & white females & 3,729 \\
\hline 1864 & 5819 & colored males & 837 \\
\hline 1865 & 6068 & colored females & 206 \\
\hline 1866 & 6508 & transients & 500 \\
\hline 1867 & 6717 & total & 11,103 \\
\hline 1868 & 7980 & & \\
\hline 1869 & 8928 & & \\
\hline 1870 & 9565 & & \\
\hline
\end{tabular}

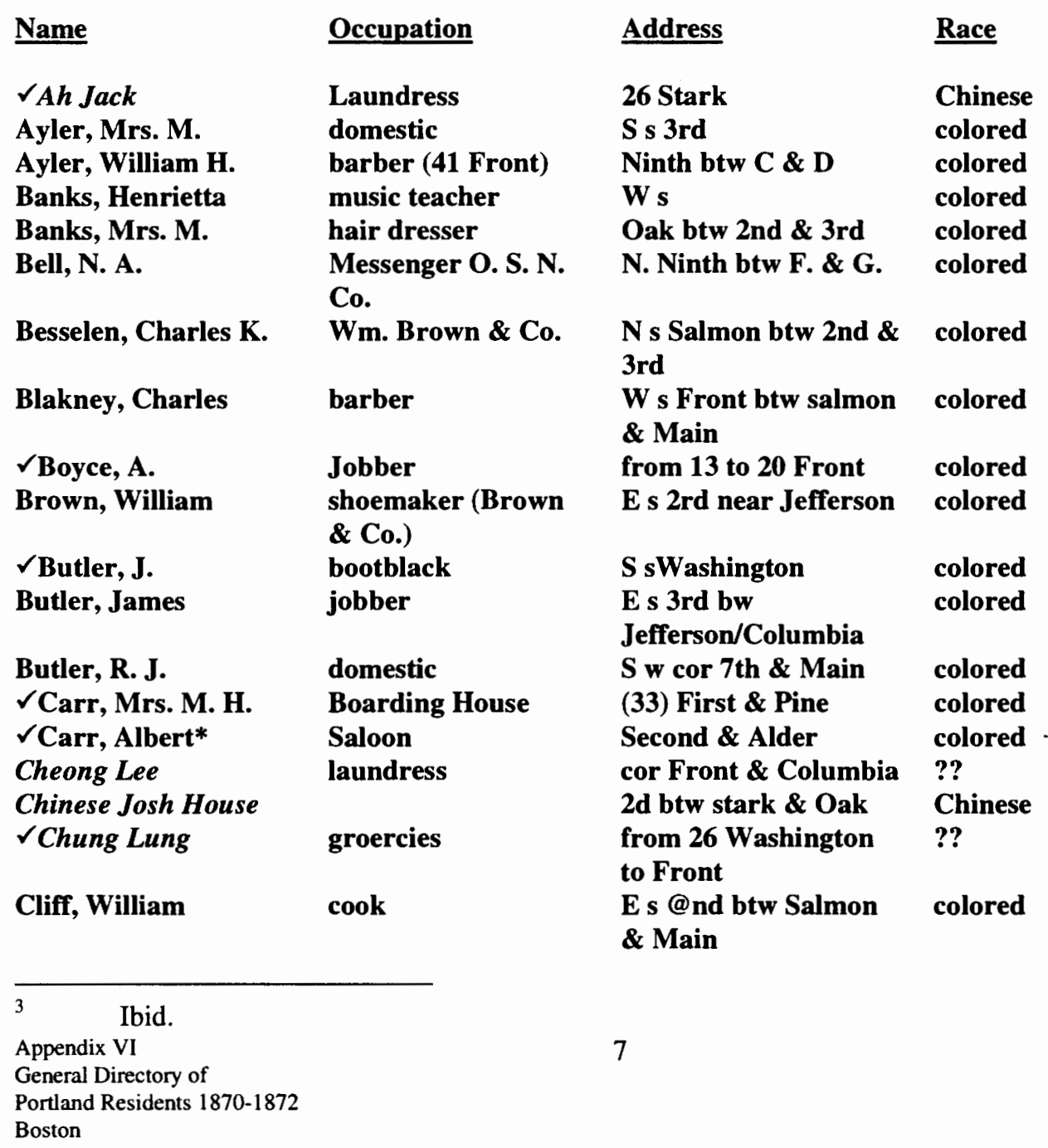




\begin{tabular}{|c|c|c|c|}
\hline $\begin{array}{l}\text { Crawford, Reuben } \\
\text { Debois, Andrew }\end{array}$ & $\begin{array}{l}\text { caulker } \\
\text { barber }\end{array}$ & $\begin{array}{l}\text { 32 N 3rd } \\
\text { W S front btw Salmon } \\
\text { \& Main }\end{array}$ & $\begin{array}{l}\text { colored } \\
\text { colored }\end{array}$ \\
\hline Dixon, Robert & barber & 16 Morrison & colored \\
\hline Douglass, John & cook & N. Third cor. C & colored \\
\hline Duck Loung \& Co. & $\begin{array}{l}\text { merchants (fm } \\
\text { Loung toLung) }\end{array}$ & 99 Alder & Chinese \\
\hline Flowers, Allen & house cleaner & $\begin{array}{l}\text { N E cor 2nd and } \\
\text { Jefferson }\end{array}$ & colored \\
\hline Francis, P. J. & calsomining & $\begin{array}{l}\text { SS Washington btw } \\
\text { 4th \& 1st }\end{array}$ & colored \\
\hline $\begin{array}{l}\checkmark \text { Fook Sing } \\
\text { Gibson, Wm Henry }\end{array}$ & $\begin{array}{l}\text { laundress } \\
\text { barber }\end{array}$ & $\begin{array}{l}212 \text { Front Street } \\
\text { S Taylor btw 3rd and } \\
\text { 4th }\end{array}$ & $\begin{array}{l}\text { Chinese } \\
\text { colored }\end{array}$ \\
\hline Graham, C. J. ** & $\begin{array}{l}\text { from barber to hair } \\
\text { dresser }\end{array}$ & $\begin{array}{l}12 \text { Alder S Taylor bw } \\
\text { 3rd/4th }\end{array}$ & colored \\
\hline Hang Yek & butcher & $\begin{array}{l}\text { S s Alder btw 1st \& } \\
\text { 2nd }\end{array}$ & $\begin{array}{l}\text { chinese } \\
\text { (as typed) }\end{array}$ \\
\hline Harris, Arthur & $\begin{array}{l}\text { cook (St. Charles } \\
\text { Hotel) }\end{array}$ & cor A \& N Street & colored \\
\hline $\begin{array}{l}\text { Harrison, Phillip } \\
\text { Hee Kee }\end{array}$ & $\begin{array}{l}\text { bootblack } \\
\text { laundress }\end{array}$ & $\begin{array}{l}\text { Front btw A \& Ash } \\
\text { E s 1st btw Main \& } \\
\text { Madison }\end{array}$ & $\begin{array}{l}\text { colored } \\
\text { Not } \\
\text { indicated } \\
\text { (Chinese) }\end{array}$ \\
\hline Height, Mrs. E. (A.) & $\begin{array}{l}\text { (not listed as colored } \\
\text { in 1972) }\end{array}$ & $\begin{array}{l}\text { 143 Second } \\
\text { (restaurant) }\end{array}$ & colored \\
\hline Hill, Cornelia (C.M) & $\begin{array}{l}\text { (not listed as colored } \\
\text { in 1972) }\end{array}$ & $\begin{array}{l}\text { 2nd btw Wash/Alder- } \\
\text { boarding }\end{array}$ & colored \\
\hline$\checkmark$ Ho Lee & $\begin{array}{l}\text { laundress (172 } \\
\text { Front) }\end{array}$ & E s Front nr Madison & Chinese \\
\hline $\begin{array}{l}\checkmark \text { Hon Song (Hong } \\
\text { Song) }\end{array}$ & laundress & $\begin{array}{l}\text { from } 8 \mathrm{~N} \text {. Front to } 2 \\
\text { Front }\end{array}$ & Chinese \\
\hline Hong Ong & shoemaker & 26 washington & $\begin{array}{l}\text { Not } \\
\text { Indicated } \\
\text { (Chinese) }\end{array}$ \\
\hline Hong Sing & laundress & $\begin{array}{l}\text { from } 24 \text { Washington } \\
\text { to } S \text { Morrison }\end{array}$ & Chinese - \\
\hline Hop Hing & laundress & 42 Front & $\begin{array}{l}\text { Not } \\
\text { Indicated } \\
\text { (Chinese) }\end{array}$ \\
\hline$\checkmark$ Hop Kee & laundress ( & $\begin{array}{l}\text { from E s N Front to } 37 \\
\text { Washington }\end{array}$ & Chinese \\
\hline
\end{tabular}


PORTLAND CITY DIRECTORY JANUARY 1, 1872

COMPARED TO CITY DIRECTORY OF 1870

$(\checkmark$ - SEEN IN 1870) (X - NOT SEEN IN 1870)

$\checkmark$ Hop Wa
$\checkmark$ HopChung
Hop Fung
Issac, --.
Jackson, J.
X Johnston, Andrews
$\checkmark$ Kam Wah
Dr. Kee
Kingsland, Marshall
Kiung, Ming (note ,)
X Kinsland, M.
Kong Duck Kee

Koong Tai

Lee Yune

stopped 7-20-95

Long Sing

Loong Sing

Lodge, Rev. J.

May Hin

Mercier, C. H.

Monchow

Mung Sing

OAES (not Oaes)

O'Hagan, Issac

Prescott, William H.

Stopped p. 83-7/19/95

\author{
laundress \\ laundress (8 \\ Yamhill) \\ butcher
}

boot black

boot black

(N E cor 1st \&

(Alder

cook

laundress

Chinese physician

barber

Chinese physician

barber (19 Front)

cigar manufacturer

Chinese grocers

laundess

laundress

laundress

minister

restauranter

hair dresser

(Alder- Front/1st)

(Chinese) physician

laundress

Chinese doctor

(not licensed

physician)

bootblack

jobber

\author{
14 Morrison \\ Chinese \\ Yamhill btw Front/1st Chinese \\ S s Alder btw 2nd \& Not \\ 3rd \\ Indicated \\ (Chinese) \\ 72 Front \\ colored
}

E s front btw Ash and

A.

N. First Cor A colored

58 Front Chinese

55 2nd Chineses

front btw Vine \& Ash colored

48 First Chinese

5th btw colored

Taylor/Salmon

S E cor 2nd \& Alder Not

indicated

(Chinese)

S s Alder Btw 2nd and Chinese

3rd

W s front btw Not

Madison \& Jefferson Indicated

(Chinese)

199 Front Chinese

46 Front Chinese

NE cor Pine \& N 6th colored

Alder btw 1st \& 2nd Chinese

btw 2nd \& Third colored

Alder btw 2nd \& $\quad$ Chinese

Third

9 Taylor Chiness

24 Stark Chinese -

12 Washington colored

C btw $N$ Third \& 4th colored 


\begin{tabular}{|c|c|c|c|}
\hline Public School & $\begin{array}{l}\text { (for colored } \\
\text { children) }\end{array}$ & 266 Fourth & colored \\
\hline Robinson, N. & saloon & $\begin{array}{l}\text { Alder - btwn 1st \& } \\
\text { 2nd }\end{array}$ & colored \\
\hline Sang Lee & laundress & 10 Taylor & Chinese \\
\hline Sing Wa & laundress & 144 Front & Chinese \\
\hline Sing Kee & laundress & 59 Front & Chinese \\
\hline Simmons, Ed & jobber & 28 First & colored \\
\hline Simmon, Edward & cook & first cor Pine & colored \\
\hline Smith, William & bootblack & 88 Front & colored \\
\hline Stratty,Mrs. M. & saloon (Ivy Green) & 135 Second & colored \\
\hline $\begin{array}{l}\text { Sun Sing } \\
\text { Sykes, Peter }\end{array}$ & laundress & $\begin{array}{l}28 \text { washington } \\
\text { Oak btw 1st \& 2nd }\end{array}$ & $\begin{array}{l}\text { Chinese } \\
\text { colored }\end{array}$ \\
\hline Thomas, Peter & barber & $\begin{array}{l}\text { Alder bwn Front \& } \\
\text { First }\end{array}$ & colored \\
\hline Thomson, James & whitewasher & $\begin{array}{l}\text { Morrison btw 2nd \& } \\
\text { Third }\end{array}$ & colored \\
\hline Tong Duck Chung & tea store & 108 First & \\
\hline Tung Sing & laundress & 12 Washington & $\begin{array}{l}\text { chinese } \\
\text { (as typed) }\end{array}$ \\
\hline Tung Wa & laundress & N. Front & $\begin{array}{l}\text { chinese } \\
\text { (as typed) }\end{array}$ \\
\hline Un Kee & & & \\
\hline $\begin{array}{l}\text { Wa Kee } \\
\text { Wing Hing }\end{array}$ & $\begin{array}{l}\text { tea store } \\
\text { laundress }\end{array}$ & $\begin{array}{l}\text { Alder btw 1st \& 2nd } \\
17 \text { Front }\end{array}$ & $\begin{array}{l}\text { Chinese } \\
\text { chinese } \\
\text { (as typed) }\end{array}$ \\
\hline Yop \& Co. & laundress & $\begin{array}{l}\text { 1st btw Taylor \& } \\
\text { Yamhill }\end{array}$ & $\begin{array}{l}\text { chinese } \\
\text { (as typed) }\end{array}$ \\
\hline Ye loung \& Co. & merchants & Alder btw 1st \& 2nd & $\begin{array}{l}\text { Not } \\
\text { indicated } \\
\text { Chinese }\end{array}$ \\
\hline \multicolumn{4}{|c|}{ Names received too late to be insertd in proper order: } \\
\hline Jones, $\mathbf{H}$. & barber & 92 First & colored \\
\hline \multicolumn{4}{|c|}{ East Portland Directory: } \\
\hline Hung Hang & laundress & corner J \& 1st & Chinese \\
\hline
\end{tabular}


FIRST WARD

Councilmen:

SECOND WARD

Councilman:

Councilman:

POLICE

SHERIFF OF

MULTNOMAH COUNTY

MARSHAL

Deputy Marshals:
THIRD WARD

North of Washington Street

C. Bills, William Cree, A. C. Ripley

Between Washington and Main Street

J. M. Breck, R. Porter, W. Moffett

South of Main Street

D. C. Lewis, L. Besser, Charles Hopkins

Thomas Burke

William Hickey

H. M. Hudson

William Kelly

\section{Al Zieber}

Philip Saunders

J. Donovan

Wiliam C. Blake or (W. P. Blake)

A. P. Brannan or (A. B. Brannon)

William Clink

H. M. Hudson

B. O'Hara

D. E. Jones (Also served in 1870)

James Wall (Also served in 1870)

Paul Kingston

J. P. Ward

SHERIFF OF

MULTNOMAH COUNTY

County Sheriff

Al Zieber

Cincinnatus Bills

JUSTICES OF

THE PEACE

CONSTABLE

J. A. Waterman (N. Portland Precinct)

B. Trainor (near Ferry Landing)

M. P. Bull, (Washington Precinct)

Constable: Philip Saunders

John C. Work, (Central Portland Precinct)

Constable:

A. B. Brannan

C. C. Crich (South Portland)

Thomas J. Dryer (North Portland Precinct)

J. S. Allen

PORTLAND CITY OFFICIALS, POLITICIANS, CLERGY AND LAWYERS

Appendix VI

General Directory of

Portland Residents 1870-1872

Boston 
SCHOOL

SUPERINTENDENT

G. H. Atkinson (Also Paster - First Congregational Church)

CITY TREASURER

E. D. Backenstos

US SENATORS

H. W. Corbett

George H. Willaims

STATE SENATOR

William Church

CITY RECORDER -

Levi Anderson

$\checkmark$ CITY AUDITOR -

W. S. Caldwell
U. S. DISTRICT JUDGE -
$\checkmark$ M. P. Deady
COUNTY JUDGE -
P. A. Marquam
E. Hamilton

JUDGE FOURTH

JUDICIAL DISTRICT

W.W. Upton

CITY TREASURER -

D. E. Backentos

COUNTY TREASURER -

W. P. Doland

COUNTY

COMMISSIONER

E. L. Quimby (East Portland)

COUNTY

COMMISSIONER

H. Boyd

Deputy COLLECTOR

OF CUSTOMS -

H. L. Hoyt

City Atorney's Office -

C. A. Dolph

CHIEF PAY MASTER -

DEPT OF COLLECTIONS -

P. M. Gibson

US DISTRICT

ATTORNEY'S OFFICE:

John C. Cartwright 


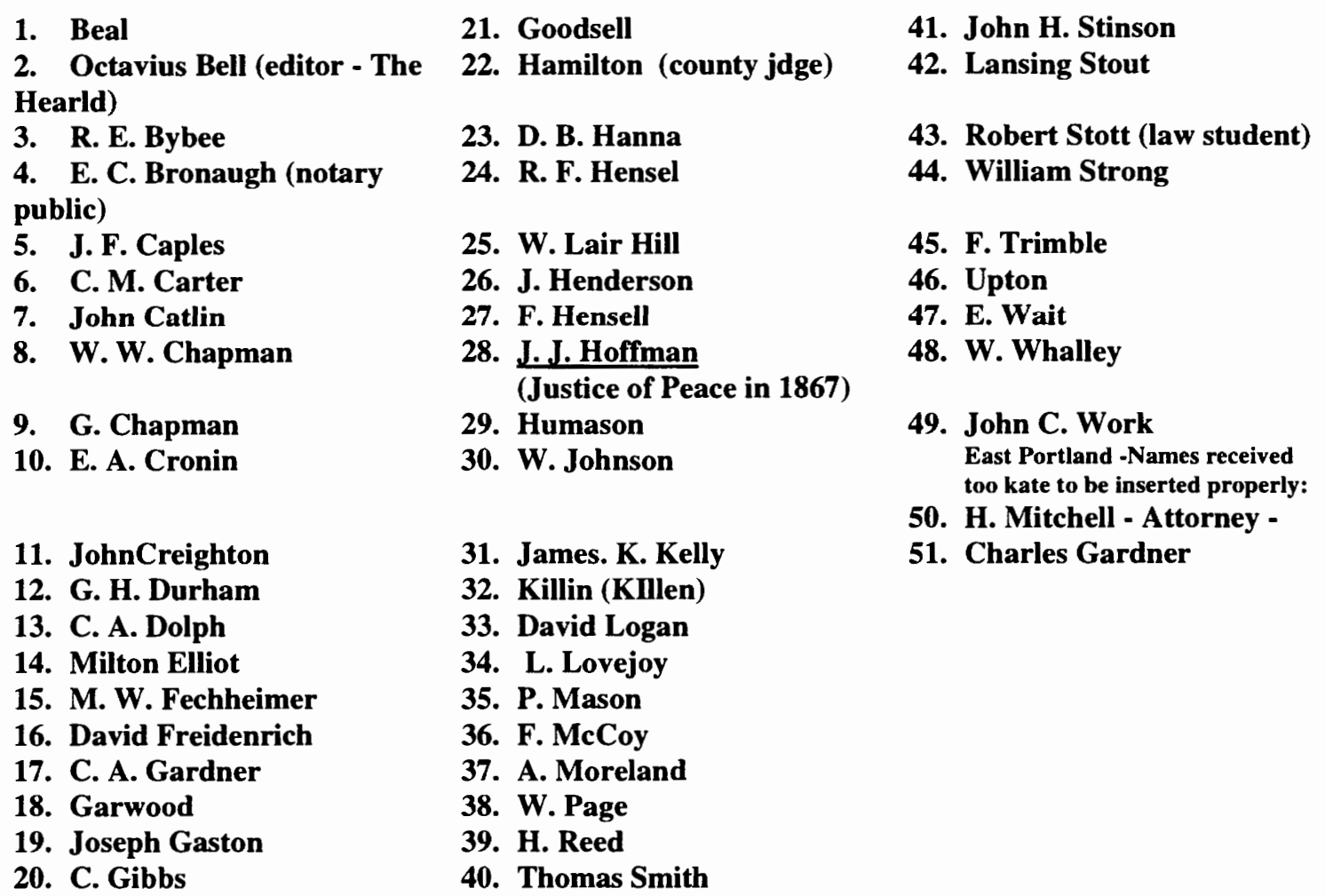




\begin{tabular}{|c|c|}
\hline $\begin{array}{l}\text { Pastor - } \\
\text { Paster }\end{array}$ & $\begin{array}{l}\text { G. H. Atkinson (Congregational Church) } \\
\checkmark \text { J. F. DeVore }\end{array}$ \\
\hline Roman Catholic & \\
\hline Archbishop & $\begin{array}{l}\text { F. N. Blanchet } \\
\text { Rev. H. H. Bories }\end{array}$ \\
\hline Priest & $\begin{array}{l}\checkmark \text { John F. Fierrens (Catholic Church) } \\
\text { (Chinese Church) }\end{array}$ \\
\hline Priest & $\checkmark$ Cornilius Delahunty (Catholic Church) \\
\hline Rabbi & $\checkmark$ Dr. Julius Eckman (Synagogue Ahabi Sholam) \\
\hline Paster & $\checkmark$ T. L. Eliot (Untarian Church) \\
\hline Paster & A. L. Lindsley (Presbyterian Church) \\
\hline Bishop & B. Wistar Morris (Protestant Episcopal) \\
\hline Paster & $\begin{array}{l}\text { A. Myers (Lutheran Church - 1870)) } \\
\text { Henry Gans (Lutheran Church - 1872) }\end{array}$ \\
\hline Paster & $\begin{array}{l}\text { William Roberts (M. E. Church) } \\
\text { A. C. Fairchild (M. E. Church) (not seen in 1872) } \\
\text { M. E. Izer (M. E. CHurch }\end{array}$ \\
\hline Paster & $\begin{array}{l}\text { W. H. Stoy (Trinity Church) } \\
\text { (Beth Isreal Synagogue) } \\
\text { (Ahabi Shalom Synagogue) } \\
\text { James Wilbur (Methodist Church) }\end{array}$ \\
\hline Paster & Lames L. Daly (Episcopal Church) \\
\hline
\end{tabular}

Proprietor - Washington Hotel - Jacob Koenig

Proprietor - Pioneer Hotel - $\quad$ P. Morrissey

Proprietor- Brooklyn Hotel - J. Petty

Proprietor - Orient Hotel - $\quad$ J. Barker (East Portland) 


\section{APPENDIX VII}

PORTLAND JEWISH RESIDENTS

STARTING IN 1854 


\section{PORTLAND JEWISH RESIDENTS STARTING IN 1854'}

\begin{tabular}{|c|c|c|c|}
\hline Anderson, Levi & $\begin{array}{l}\text { Apperson, Mrs. \& Family } \\
\text { (boardinghouse) }\end{array}$ & Abbott, Dr. Moses & Abrams, W. P. \\
\hline Ayres, Capt. & Bacon, Chas. P. & Adams (?) & Allen, Lucius $\mathrm{H}$. \\
\hline Backenstos, E. D. & Barnhart, William H. & Babcock, Deveaux & Backenstos, J. B. \\
\hline Baker, Capt. Wm. & Blackistone, Wm. & Baker, D. S. & Barnes, A. M. (general sture) \\
\hline Baldra, R. C. & Breck, John M. & Balch, Danforth & Barnes, Geo. A. \\
\hline Birdseye, C. G. & Brown, Natherial & Bennett, $\mathrm{Wm}$. (livery stable) & Barnes, Hiel \\
\hline Boise, R. P. & Campbell, Alexander & Berry, (printer) & Bell, Sam \\
\hline Broy, Dr. L. C. & Carson, John C. (sash \& door factories) & Birdseye, David & Bennett (?) \\
\hline Caldwell, Wm. S. & Caruthers, Finice (schoolhouse) & Blumauer, J. B. & Butler, J. B. V. \\
\hline Camp, Frank D. & Cater, T. Jeffferson (store having 2 floors) & Bonnell, A. C. & Chapman, W. W> \\
\hline Carer, Thos. & Cleaver, Jos. W. & Camp (?) & Chappellier, M. \\
\hline Cheney, (?) & Coffin, Stephen & Carter, D. M. & Clinkenbeard (?) \\
\hline Coe, Eugene F. & Colburn, Barrell & Chambreau, Ed. & Coleman. D. C. \\
\hline Coe, Henry & Corbett, Henry W. (general store) & Comfort, E. B. & Cook, Richard Kissard, \\
\hline Coe, Lawrence W. & Crawford, Dobbin & Davis, Anthony $\mathrm{L}$. & Couch, John H. (general store) \\
\hline Coe, Nathaniel & Croke, Rev. Father* & Davis, Thomas. A. & Couch, John P. \\
\hline Erpelding, Peter & Crosby, Nathaniel & Davis, Warren (photographer) & Dauline, (?) \\
\hline Fackler, Rev. St. Michael* & Elliott, John & Day, Lewis & Davenport, Dr. Issac A. \\
\hline Fitch, A. D. & Failing, Henry (general store -- son & Dennison, A. P. & Davidson, Elijah B. \\
\hline Fitch, Wm. & Failing, John W. (gen. store - son) & Dimmick, Otis J. & Dewitt, Peter \\
\hline Fuller, David & Failing, Josiah (gen. store - father) & Doubleblower, W. B. & DeWitt, Thos. \\
\hline Gladwell, Thomas & Francis, A. L. & Drew, John & Donner, John \& Family \\
\hline Ham, Nelson & Francis, F. B. & Elliott, George & Dryer, Thos. J. \\
\hline Hardenberg, Peter D. & Frush, Col. & Ettlinger (?) & Field, F. M. \\
\hline Harris, Jack & Gall, Capt. O. M. & Fleming Family & Flanders, George $\mathrm{H}$. \\
\hline Harris, Uriah & Grooms, Wm. & Frazar, Thos. (general store) & Fruit, Jas \\
\hline
\end{tabular}

1 Scott, H. W., editor, (1890), History of Portland, Oregon: With Illustrations and biographical Sketches of Prominent Citizens and Pioneers, D. Mason \& Co., Syracuse, New York, pp. 116-117.

Appendix VII

Portland Jewish Residents

Starting in 1854

Boston 


\section{PORTLAND JEWISH RESIDENTS \\ STARTING IN 1854 cont.}

\begin{tabular}{|c|c|c|c|}
\hline Holcomb, Samuel R. & Guild, Peter & Griffin, Dr. E. H. & Fulkerson, Peter \\
\hline King, Col. Wm. M. & Harlow, John & Hallock, A. B. & Goldstein, E. L. \\
\hline Kingsley, Rev. C. S.* & Hobbs, Thoma, J. & Harley, McDonald & Hendee, B. H. (photographer) \\
\hline Kittridge, Geo. & Johnson, A. H. & Hartness, Thos. & Henderson (?) \\
\hline Kohn, J. & Long, Edward & Hastings, L. B. & Hibert, P. \\
\hline Loring, George & Loring, Col. & Higgins, George W. & Higggins, Wm. L. \\
\hline Lownsdale, D. H. & Louis, French & Hooper, Dr. Saml. & Holmes, Thos. J. \\
\hline Lyman, Rev. Horace* & Markly, John C. & Hoyt, Richard & Irving, Capt. \\
\hline McBride (?) & Marye, W. B. & King, A. N. & Jewitt , (?) (general store) \\
\hline Molthrop, Capt. & May, Sam E. & Lawrence, Charles & Kamm, Jacob \\
\hline Naylor, William & McLaren, Finley & Lewis, Jewitt & Kelly, Clinton \\
\hline Northrup, Nelson (gen. store) & McLaren, Robt. N. & Love,Lewis & Ladd, W. S. (livery stable) \\
\hline Parrish, Chas. W. & McNamee, Richardd & Lovejoy, A. J. & Lewis, C.H. (Allen \& Lewis gen. store) \\
\hline Peterson, Knute & McNight, Orlando & Lucas, M. M. & Marsh, Samuel \\
\hline Prettyman, Dr. Perry & Norris, Shubrick & Matthias, Frank & May, Lewis \\
\hline Roberts Family & O'Bryant, Hugh D. & Murphy, John M. & McKay, John W. W. \\
\hline Robinson, Thomas G. & Ogden, Wm. Seton & Otway, W. B. & Mears, John \\
\hline Sargent (Sargent \& Ricketson) & Owens, N.H. & Parrish, Norman & Northrup, Nehemiah \\
\hline Simonds (?) (general store) & Parrish, J. L. & Pettigroove, F. W. & Norton, Capt. Zachariah (small store) \\
\hline Skidmore, (?) & Potter, L. C. & Pillow, C. B. & Parrish, Samuel B. \\
\hline Slater, S. S. & Ross, Sherry (livery stable) & Redman, C. C. & Pritchard, Thos. (grocery) \\
\hline Stephens, B. & Salisbury, Dr. & Reed, C. A. & Reese, R. R. (saddler) \\
\hline Stephens, Jas. & Simpson, L. M. & Ross (?) & Ricketson, John \\
\hline Stephens, Thomas & Skidmore, Stephen G. & Sherlock, Wm. & Robbins, G. C. \\
\hline Stephens, Wm. & Smith, F. M. & Silver, C. S. & Savier, Thos. A. \\
\hline Story, George L. & Smith, Thos. H. & Simonsfield (?) & Sherman, George \\
\hline Tallentire (?) & Starr, A. M. (stove \& tin store) & Smith, Joseph S. & Smith, Capt. B. F.. \\
\hline Thompson, John & Starr, L. M. (stove \& tin store) & Snell, Geo. W. (drug store) & Smith, Hiram (\#1 Smith - general store) \\
\hline Tibbetts, Gideon & Terwillger, James & Snow, Lucien (dry goods) & Smith, I. B. \\
\hline Tilford, Frank & Thompson, James & Southmayd, (printer) & Smith, Samuel D. \\
\hline
\end{tabular}

Appendix VII

Portland Jewish Residents

Starting in 1854

Boston 


\section{PORTLAND JEWISH RESIDENTS STARTING IN 1854 cont.}

\begin{tabular}{|l|l|l|l|}
\hline Trevett, T. B. & Thompson, Robert & Stewart, Eli & Stark, Benj. \\
\hline Tucker, Major & Wells, Capt. & Stuart, A. B. & Stewart, Dan \\
\hline Vaughn, G. W. (hardware-flour mill-mayor) & Wheeler, James & Thomas, John & Talbot, John B. \& Family \\
\hline Weil, David & White, Allen (livery stable) & Wasserman, Herman & Travalliot, Capt. O. (owned horse - Siskiyou \\
\hline Wilbur, Rev. J. H. ${ }^{*}$ & Wilbur, Hiram & Waterman, Orvis & Walker, John P. (sash \& door manufacturer) \\
\hline Wilson, Dr. R. B. & Wiley, Richard (livery stable) & Wilson, A. V. & Webster, Frank E. \\
\hline Wimple (?) & Williams, Capt. Richard & Zenas, Webber & Wilcox, Dr. Ralph \\
\hline
\end{tabular}

\section{THE JEWS OF PORTLAND, OREGON, 1849-1887 ${ }^{2}$}

(Additional Names)

\begin{tabular}{|c|c|c|}
\hline Blumaumer, Simon & Blumauer, Simon & Ackerman, Henry (Bd of Comm) \\
\hline Ehrenberg, Herman & Bergman, Joseph (butcher) & Arch, Henriatta \\
\hline Goldsmith, Jacob & Bergmanm Issac (butcher) & Levy, Sam \\
\hline Hirsch, Edward (general store) & Elfelt, A. B. (dry goods) & Baum, Simon \\
\hline Hirsch, J. B. (general store) & Mayer, Jacob (wholesale merchant) & Baum, Leopold \\
\hline Hirsch, Leopold (general store) & Meier, Aaron ${ }^{3}$ (merchant) & Wolf, $\mathrm{H}$. \\
\hline Hirsch, Maier (general store) & Oppenheimer, Marcus & Simon, Joseph (state senator) \\
\hline Hirsch, Soloman (general store) ${ }^{4}$ & Sellers, Moses & Mitchell, John H. (US Rep) \\
\hline May, Lewis & Weil, Abram (dry goods) & Wasserman, Henry \\
\hline Stamper, Isaac (merchant) & Weil, Moses (dry goods) & \\
\hline
\end{tabular}
Aaron Meier, founder of Meier and Frank department Store (Cline, p. 7)

4 Solomon Hirsh, a member of the Oregon State Senate from 1874-1885. He also served as senate president. (Cline, p. 89). Appendix VII

Portland Jewish Residents

Starting in 1854

Boston
} 